\title{
Wilhelm Breitschuh
}

\section{Die Feoptija V. K. Trediakovskijs}

\section{Ein physikotheologisches Lehrgedicht im Russland des 18. Jahrhunderts}

Verlag Otto Sagner München · Berlin · Washington D.C.

Digitalisiert im Rahmen der Kooperation mit dem DFG-Projekt „Digi20“

der Bayerischen Staatsbibliothek, München. OCR-Bearbeitung und Erstellung des eBooks durch den Verlag Otto Sagner:

http://verlag.kubon-sagner.de

( $)$ bei Verlag Otto Sagner. Eine Verwertung oder Weitergabe der Texte und Abbildungen, insbesondere durch Vervielfältigung, ist ohne vorherige schriftliche Genehmigung des Verlages unzulässig.

«Verlag Otto Sagner» ist ein Imprint der Kubon \& Sagner GmbH. 


\section{SLAVISTISCHE BEITRÄGE}

BEGRÜNDET VON

ALOIS SCHMAUS

HERAUSGEGEBEN VON

JOHANNES HOLTHUSEN - HEINRICH KUNSTMANN · JOSEF SCHRENK

REDAKTION

PETER REHDER

Band 134

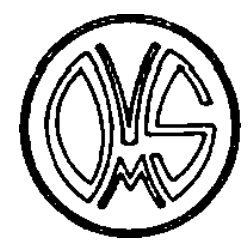

VERLAG OTTO SAGNER

MÜNCHEN 


\section{WILHELM BREITSCHUH}

\section{DIE FEOPTIJA V. K. TREDIAKOVSKIJS}

\section{EIN PHYSIKOTHEOLOGISCHES LEHRGEDICHT IM RUSSLAND DES 18. JAHRHUNDERTS}

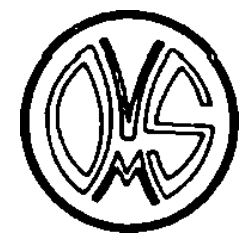

\section{VERLAG OTTO SAGNER - MÜNCHEN 1979}


ISBN 3-87690-167-7

Copyright by Verlag Otto Sagner, München 1979 Abteilung der Firma Kubon \& Sagner, München Druck: Alexander Grossmann

Fäustlestr. 1, D-8000 München 2

Bayerische
Staats:ibliothek
München 
Vorbemerkung

Diese Untersuchung geht auf eine Anregung meines verehrten Lehrers, Herrn Professor Dr. Dietrich Gerhardt in Hamburg zurūck. Ihm danke ich herzlich für die nachhaltige wissenschaftliche Betreuung und Förderung meiner Arbeit. Ohne die großzügige Unterstützung der Joachim Jungius-Gesellschaft der Wissenschaften in Hamburg wăre diese unfangreiche Studie nur schwer zu veroffentlichen gewesen.

An dieser stelle danke ich auch meiner Frau für viel Verstăndnis und Anteilnahme an meinen wissenschaftlichen Bemühungen der letzten Jahre.

Der Verfasser 

Vorwort

1. Kapitel

Voraussetzungen und Uberlieferung

der Feoptija

Leben und Werk V.K. Trediakovskijs

Geistesgeschichtlicher Hintergrund

Uberlieferungsgeschichte der Feoptija

2. Kapitel

Textbegleitende Interpretation

I.Epistel: Philosophische Beweise fur die Existenz Gottes

II.Epistel: Die Beschaffenheit der Erde und der Gestirne setzt die Existenz des Schöpfers voraus

III.Epistel: Macht und Weisheit Gottes werden an der Tierwelt aufgezeigt

IV.Epistel: Das Wunder des menschlichen Organismus

weist auf den Schöpfer hin

V.Epistel: Das Zusammenwirken von Geist und Korper

offenbart Gottes Weisheit und Gute

VI.Epistel: Die Eigenschaften Gottes

Die Notwendigkeit des 'Fürsprechers'

Die Notwendigkeit der offenbarung durch Christus

Zusammenfassender Textvergleich:

Feoptija - Démonstration

3. Kapitel

Die Feoptija als Lehrgedicht

Einleitung

1. Aufbauelemente

Epistelform und Apostrophen 
2. Beschreibungs formen .

Der kosmische Bereich

Der Mensch

Naturkundliche Inhalte

3. Bildformen 459

Metaphern

460

Beispiele

464

Vergleiche 465

Gleichnisse 466

4. Beweis formen 467

Physikotheologische Argumente 467

Traditionelle Gottesbeweise 469

Syllogismen 470

Definitionen 472

Berufung auf Autoritäten und Lehrmeinungen 474

Bibel und Kirchenlehre 476

Bibelzitate und biblische Anklange 478

\section{Kapitel}

Zur Metrik und Sprache der Feoptija

Metrik

Sprache

Lexik

Syntax

stil 
VORWORT

V.K.Trediakovskif hat an der FEOPTIJA in den Jahren 1750-54 gearbeitet. Zu der zeit hatte die Bewunderung für A.Popes 'Essay on Man' (1734) in Europa ihren Hohepunkt erreicht. Der 'Essay' war in viele Sprachen ubersetzt und als glănzendes Vorbild des philosophisch-theologischen Lehrgedichts oft nachgeahmt worden. In RuBland ist der 'Essay' zuerst 1753 von N.Popovskif, einem Schüler Lomonosovs, in Versen übersetzt worden. Tred. hat das Poem aber schon früher aus franzosischen Ubersetzungen, deren erste 1737 erschienen war, kennengelernt. Wie er selber sagt, ist er durch den 'Essay on Man' zu seiner Feoptija angeregt worden. Es liegt deshalb nahe, dem EinfluB Popes auf Tred. nachzugehen und zu prüfen, wie sich die Gattungsmerkmale des Lehrgedichts, das zwischen 1730 und 1760 in Westeuropa in Blute stand, in der Feoptija ausgeprăgt haben. Das geschieht im 3.Kapitel der vorliegenden Arbeit.

Bei der Untersuchung des Textes in seinem geistesgeschichtlichen Zusammenhang habe ich eine enge Beziehung zwischen den in der Feoptija dargestellten Inhalten und dem physikotheologischen Schrifttum festgestellt, das darauf zielt, die Existenz und das Wesen des Schöpfers an den Erscheinungen der Schőpfung nachzuweisen. Dabei bin ich auf den Traktat Fénelons, 'Démonstration de l'existence de Dieu, tirée de la nature'(1713) gestoßen, der Tred. offenkundig als Vorlage, z.T. als quelle gedient hat. Der Hinweis kam durch eine Stelle in dem Buch von Paul Hazard, 'Die Krise des europaischen Geistes'. Er führt u.a. aus dem Traktat Fénelons das Bild vom obstbaum an, der seine Àste unter der Last der Früchte niederbeugt, als wolle er dem Menschen die Ernte erleichtern. ${ }^{1}$ Dies Bild findet sich auch in der Feoptija, Ep.II,293ff. Nun begann ich, den Text der Feoptija mit dem Traktat Fénelons zu vergleichen und fand eine fülle von Parallelen, die beweisen, daB Tred. den Traktat Fénelons benutzt hat.

Durch diese Entdeckung hat die Arbeit einen anderen Schwerpunkt bekommen. Nun muBte das Verhăltnis zwischen den beiden Texten im einzelnen untersucht werden. Hier bot sich die textbegleitende Intexpretation als die Methode an, mit der die Abhăngigkeit am deutlichsten gezeigt werden kann. Um zu zeigen, wie Tred. mit dem Text seiner Vorlage umgegangen ist, ihn verkürzt, erweitert oder sonst modifiziert hat, ist ausgiebig zitiert worden.ther den Fund habe ich mit ausfuhrlichen Belegen am 17.0kt.1975 berichtet. ${ }^{2}$ 
Nachdem das Manuskript der Interpretation abgeschlossen war, ist in der 'Russkaja literatura' 1976/2, ein Aufsatz von E.N.Lebedev erschienen, in dem gleichfalls auf den Traktat Fénelons als Vorlage der Feoptija hingewiesen wird. 3

Die Feoptija ist jedoch nicht durchgehend von der 'Démonstration' Fénelons abhãngig. In allen Episteln stammen wesentliche Passagen- etwa die Hålfte der 4720 Verse- von Tred. selber. Die vI.Epistel enthălt hauptsãchlich scholastisches Gedankengut und kirchlich-orthodoxe Lehren. Die Verbindung von physikotheologischen, scholastischen und dogmatischen Elementen ist charakteristisch fur die Feoptija, die damit eine singulare Erscheinung unter den Lehrgedichten der Zeit darstellt. Schlieblich ist die Versifikation das eigene Werk Tred.s, der als bedeutendster russischer Metriker des 18.Jahrhunderts der Versbildungslehre eine neue Grundlage gegeben hat. 


\section{Kapitel}

\section{Voraussetzungen und tberlieferung}

der Feoptija

Leben und Werk Trediakovskijs

Vasilif Kirillovic Trediakovskif wurde als Sohn eines Popen am 22. Febr. 1703 in Astrachan' geboren. Auch sein GroBvater war orthodoxer Geistlicher. Schon im Elternhaus hat Tred. die biblischen und liturgischen Bücher kennengelernt. Nach seinen Worten hat er Kirchenslavisch nicht nur lesen und schreiben gelernt, sondern auch gesprochen:'Не только я им писывал, но и разговаривал со всеми. ${ }^{1}$ Ex bemerkt aber in diesem Zusammenhang, daB viele heutzutage (1730) die kirchenslavische Sprache nicht mehr verstunden, und daß sie sich jetzt auch für ihn 'hart anhore': 'Язык славенский в нынешнем веке у нас очењ темен, и многие его наши, читая, не разумеют... язык славенский ныне жесток моим ушам сльшится. ${ }^{2}$ In spateren Jahren hat Tred. das ihm von frühauf gelăufige Kirchenslavisch zur Bereicherung seines Wortschatzes herangezogen. Die Feoptija ist dafür ein Beispiel.

Das südrussische, provinzielle Astrachan' bot dem Jungen Tred. eine sprachliche Umwelt von anregender Vielfalt. Hier horte er das 'npoctoe pyccкое слово', die Sprache der Handlex und Schiffsleute, der Fischer und Hirten, Handwerker und Soldaten, der 'Glücksritter' aller Art, die von der Stadt, in dex es sich frei und bequem leben lieB, angelockt wurden: 'Actpaхань привлекала к себе и торговый люд и разных искателей счастья своим привольем, дешевизчо1 и легкостьр добывать там средства к суиествованио. ${ }^{3}$ Bе 1 dem letzten denkt man etwa an Feopt. Ep.III,150f., wo von Fischschwămen die Rede 1st, die vom Meer aus flußaufwărts ziehen, 'so daß man sie fast mit der Hand fangen kann.'

In Astrachan' lebten damals viele Auslăndex: Tataren, Georgier, Griechen, Perser und vor allem Armenier, die von der Regierung, die den Bandel mit dem Osten fordern wollte, mancherlel vergünstigungen erhielten. ${ }^{4}$ Zur kirchlichen Betreuung dex rómisch-katholischen Armenier hatten sich am Anfang des 18.Jahrhunderts Kapuzinermonche angesiedelt. Sie erhielten im Jahre 1720 vom Gouverneur Volynskif die Erlaubnis zum Bau einer Holzkirche in der armenischen Vorstadt. Als die katholischen Monche dann noch eine Schule gründeten, die auch von Kindern orthodoxer Eltern besucht wurde, beschwerte 
sich der russische Bischof Ioakim beim Gouverneur, hatte aber damit keinen Erfolg. Bei den 'römischen Mơnchen' hat der junge Tred. auf Wunsch seines Vaters Latein gelernt: 'Я... учивчись, по желеланию моего, покойного ныне, родителя, словесным наукам на латинском языке, еще в молодых момх летах, 8 Астрахани, где моя и родина, у Римских живущих там Монахов... 5 Mit zwanzig Jahren war Tred. so weit fortgeschritten, daB er in die Rhetorik-klasse der 'slaveno-greko-latinskaja Akademija' in Moskau aufgenommen wuxde. Pekaxskij zitiert eine Notiz, in der Tred. seinen Fortgang von Astrachan' als 'Flucht aus Lernbegierde' bezeichnet: '...nо охоте моей к учению, оставил природный город, Аом, и родителей, и убежал в Москву... ${ }^{6}$ Für unglaubwürdig hălt Pekarskij die von dem Akademie-Historiographen Muller dargebotene Version, Tred. sollte von seinem Vater gezwungen werden, Geistlicher zu werden und sich zu verheiraten, darum sei er mit Hilfe der Kapuziner am Tage vor der Hochzeit 'geflohen'. 7

In der 'Slaveno-greko- latinskaja Akademija', die im 'Zaikonospasskij'Kloster in Moskau untergebracht war, studierte Tred. von 1723-25 auBer Kirchenslavisch die klassischen Sprachen und Literaturen. Er hat an Kursen in Rhetorik und Verskunst, wahrscheinlich auch an theologischen Vorlesungen teilgenommen. Die Akademie wurde von dem Archimandriten Višnevskij geleitet, die Lehrer waren Mönche. Tred. hat in der Klosterbibliothek dieselben Bucher benutzt, in denen wenige Jahre danach (seit 1731) Lomonosov, wie er sagt, 'gewült' hat: '...рылся в монастырской библиотеке. 8 Der Bestand der Klosterbücherei war düftig, wie man aus den 'Materialien zur Biographie Lomonosovs' weiB: neben einigen Chroniken, Werken von Kirchenvatern und anderen theologischen Büchern gab es eine kleine Anzahl philosophischer, physikalischer und mathematischer Schriften. Sie veranlassen den Herausgeber der 'Materialien', Biljarskij, zu der Anmerkung: 'Заиконоспасская библиотека не могла насытить жадность его к наукам. 9 Das gilt auch für Tred.

Wahrend seines Studiums in Moskau hat Tred. seine ersten Gedichte in dem damals găngigen 'polnischen Versmaß' verfaBt. Die 'stichotvorcy', seine Lehrer in den Regeln der Verskunst, beurteilt er respektlos: '. они не много мне могут пользы ученить чрез свое освидетельствование в мере стоп, в количестве слогов, в пресечении, и в роде стихов, яля того что они излагая свои рацеи на те правила не смотрят... 10 Eines der frühesten syllabischen Gedichte Tred.s ist eine Elegie auf den Tod Peters d.Gr. (8.2.1725). Der Anfang lautet: 
Что за печаль повсюду сльиится ужасно?

Ах! знать Россия плачет в многолюдстве гласно! 11

Anfang 1726 bot sich Tred. 'die Gelegenheit, nach Holland zu reisen' ('noлучил я... окказию выехать в Голландиь') ${ }^{12}$, und zwar auf dem Seewege, wie Pekarskif anmerkt. ${ }^{13}$ Sein Hauptziel war Paris. Tred. hat das Motiv zu seiner Auslandsreise so dargestellt: 'Проходя мои науки в Москве в Спасском Заиконном монастыре,...превеликое я, нимеименованный, имел мелание, чтоб окончить в Европских краях, а особливо в Париже: яля того, как всему свету известно, что в оном наиславнейшия нахояятся... 14 Die begeisterten Berichte einiger Studenten, die aus Paris kommend, in die Heimat zuruckkehrten, werden ihn in seinem Wunsch bestărkt haben. ${ }^{15}$ Von der Geistlichen Akademie wurde inm vorgeworfen, er habe sein studium eigenmächtig abgebrochen, ein Vorwurf, der lange an ihm hăngenblieb und ihm sehr geschadet hat.

In Holland fand Tred. die Unterstützung des russischen Gesandten Graf Ivan Gavrilovic Golovkin. ${ }^{16}$ Er nutzte den Aufenthalt zum Lernen der französichen Sprache, zugleich studierte er die neue Umgebung. Vor kurzem noch zogling einer geistlichen Akademie, muB Tred. sich in tolland wie auf einem anderen Stern vorgekommen sein. 'Dort' diskutierte man noch ernsthaft darūber, in welcher Sprache sich wohl die Engel unterhielten, oder ob im Paradies die Rose ohne Dornen gewesen sei, ${ }^{17}$ hier dagegen wurde in 'Journalen' wie in den seit 1686 von Pierre Bayle veroffentlichten 'Nouvelles de la Republique des lettres', die biblische offenbarung für unbeweisbar erklăt. Die Anschauungen der Deisten, Epikureer, Pantheisten und Atheisten, mit denen sich Tred. in der Feoptija auseinandersetzt, sind ihm wahrscheinlich schon in Holland begegnet. Man kann vermuten, daB ihm von den Entdeckungen der hollandischen Naturforscher, die damals Aufsehen erregten, einiges bekannt geworden ist. Das Staunen Tred.8 uber die Kleinlebewesen, die wir 'in großer Menge durchs Mikroskop betrachten'(Feopt.III,301ff.), scheint auf die Entdeckungen Leeuwenhoeks anzuspielen. Die folgenden Worte Paul Hazards beleuchten die geistige situation, in die Tred. unversehens geraten war: "In Holland sind sich die Menschen, die Bücher, die Ideen der verschiedenen Lănder begegnet, und ein geistiger Austausch hat dort stattgefunden, wie man ihn in Jener Epoche nirgendwoanders finden kann." 18

Trotzdem war Holland für Tred. nur eine Station auf der Reise nach Paris. Er ist den Weg zu FuB gegangen, well er kein Geld hatte: '0rтудy, шедши newb 
за крайнер уме своер бедности:, пришел в Париж... ${ }^{19}$ Der Umstand zeigt, wie dringlich es ihm war, sein ziel zu erreichen. Die ersten Briefe Tred.s aus Paris sind, so berichtet P.Berkov, schon vom Januar 1727 datiert. Er beruft sich dabei auf Dokumente im Archiv des sv. Sinod, t.X,SPb. 1901, die Pekaxskij noch nicht kannte. 20

In Paris findet Tred. reiche Gonner: Furst Boris Kurakin und dessen Sohn Aleksandr Borisovic. Im Dezember 1727 wendet sich Tred. mit der Bitte um ein Stipendium an den Synod in Moskau. Er versichert, daß er nicht aus jugendlicher Neugier ins Ausland gegangen sei, sondern, '...4т06 усneвatb B науках, К которым я такуо имею охоту.' Mit Hilfe eines Jahresstipendiums könne er in Paris seine theologischen und philosophischen Studien zum Abschlub bringen:'... такме и науки мои богословския и философския привесть $k$ окончанио. 21 Das Gesuch Tred.s wird abgelehnt, da die vom synod uber ihn bei der Geistlichen Akademie eingeholte Auskunft ungünstig lautete: der Bittsteller sei aus der Akademie im Jahre 1725 'davongelaufen'. Darüber sind seine ehemaligen Vorgesetzten noch immer verăgert. Es heiBt, daB er '... Париж для въиих наук ни по какому указу из оной Академии отправлен не 6 wn. 22

Seine Wohltăter ermöglichten ihm aber den weiteren Aufenthalt in Paris, den er zu fleibigen Studien genutzt hat. Darüber schreibt Tred. 1754: '..npu щедром благодетелей моих солержании, обучался математическим и философским Наукам, а богословским тамше в Сорбоме. ${ }^{23} \mathrm{Ex}$ hebt hervor, daB er dort am Mazarin-Kolleg auch offentliche Disputationen gehalten habe. 24

Die drei Jahre in Paris von Anfang 1727 (nach P.Berkov) bis zum Frühahr 1730 haben Tred.s geistige Entwicklung fūr sein ganzes Leben geprăgt und sind aus seinem schriftstellerischen Werk nicht wegzudenken. In dieser Zeit hat sich Tred. zum hervorxagenden Kenner der französischen Sprache entwikkelt, was selbst der inm nicht wohlgesonnene Aistoriograph Muller zugeben mußte:'Тредиаковский, будучи в Париже, изучил Французский язык, который он знал лучше, нежели прочие . 25 bestätigt Müller. Tred. hat seine Kenntnisse der Scholastik und der Philosophie Descartes', die in der Feoptija an den Tag kommen, wahrscheinlich an der Sorbonne erworben. Besonders stolz war er darauf, die Vorlesungen des seinerzeit berühmten Historikers Rollin gehört zu haben, dessen vielbandige Geschichte der Antike von ihm spater ins Russische übersetzt worden ist. In engen Beziehungen stand Tred. in Paris mit dem abbé Gabriel Girard, seinem 'überaus wohlwollenden Freund', (самий 6ла- 
госклонный приятель). Der abbé führte den Titel eines 'Secrétaire-interpréte du Roy pour les langues eslavonne et russe.' Als solcher hat er z.B. das 'слово на погребение Петра Великого' des Feofan Prokopovic ins Französische ubersetzt. Auf den abbe Girard hat sich Tred. in seinem 'cnoso o 6oraтом, различном, искусном и несходственном витийстве', das er am 12 .August 1745 in einer Sitzung der Akademie in Petersburg vorgetragen hat, berufen. Der abbe hatte ăhnliche studien uber die 'Justesse de la langue françoise' und die 'Synonymes françois' veroffentlicht. ${ }^{26}$ Der Umgang mit dem gelehrten abbe hat den Studenten Tred. besonders auf philologischem, wohl auch auf theologischem Gebiet gefordert. P.N.Berkov unterstreicht die Bedeutung, die der Aufenthalt in Paris für Tred. selber und für die russische Literatur gehabt hat: '...c'est alors que Tred. a découvert en même temps la vie et la littérature françaises. .27

Der gereimten Aufstellung, die Tred, in der 'Эпистола от российския поззии к Аполлину' seinem 'Cnoco6' vom Jahre 1735 angefügt hat, sind u.a. die Namen der ihm bekannten französischen Schriftsteller zu entnehmen. Mit den meisten von ihnen wird sich Tred. schon in Paris beschaftigt haben. Er nennt Boileau(1636-1711), dessen L'art poétique einer ganzen Dichtungsepoche die Regeln geliefert hat. Ferner werden in der 'Onистолa' die Klassiker des 17.Jahrhunderts, Corneille, Racine und Lafontaine aufgeführt. Von den zeitgenössischen Autoren nennt Tred. Voltaire und Fontenelle. Zum ersten Mal im Russischen -so Pumpjanskij- wird auch Rousseau erwăhnt, dessen Epigrame Tred. besonders gut gekannt habe:'Когда Тред. был студентом в Париже, как раз эти зпиграммы он, вероятно, знал лучше всего... 28 Die Aufzăhlung der franzósischen Autoren, die er bewundere, sei nicht vollstăndig, bemerkt Tred. ausdrücklich:

Про Аругих упоминать, право, нет им счету, особливу всяк в стихе показал доброту...29

Pumpjanskif weist darauf hin, daB Tred. sich in der 'querelle des anciens et des modernes' auf die Seite der Modernen gestellt habe. Gemeinsam mit Fontenelle und anderen, aber im Gegensatz zu Boileau, hat Tred. die Auffassung vertreten, daB die franzosische Dichtung der griechischen und lateinischen nicht nachstehe. Er lobt die franzosischen Dichter:

Песен их что может быть лучше и складнее?

Ей! ни Греция, ни в том мог быть Рим умнее.

Галлия имеет в том, ейl толику славу,... 30 
Eine Vorliebe hat Tred. für moderne Autoren wie Tallemant und Fénelon. Zwei seiner wichtigsten Ubersetzungen, die 'Езда 8 остров Лю6ви' (1730) und die 'Тилемахида' (1766) haben Bücher dieser Verfasser zum Gegenstand. Fénelons 'Traité de l'existence et des attributs de Dieu, Première Partie: Démonstration de l'existence de Dieu, tirée du spectacle de la nature et de la connaissance de l'homme', ist von Tred. als Vorlage für die Feoptija benutzt worden.

In dem angeführten $\mathrm{Zitat}$ gibt P.Berkov $\mathrm{zu}$ verstehen, daB Tred. in Paris auch 'das französische Leben entdeckt' habe. Er hat in diesen Jahren die Blütezeit des Rokoko miterlebt. Da Tred. in Hause des Fürsten Kurakin wohnte, kam er mit Kreisen der höheren Gesellschaft zusammen, die der galanten Mode folgten, sich als Schăfer und Schaferinnen mit der Flote und dem Schäfchen am rosa Band bei ihren Festen auführten und ein scheinbar naives Landleben nachahmten. Das Pariser Leben hat Tred., der aus der strengen Zucht des Klosters kam, begeistert. 31 In den 'Стихи похвальные Парижу' besingt ex das 'liebe Ufer der Seine', das milde Klima, die duftenden Blumen, die singenden und spielenden 'Nymphen', ein Hinweis auf die Rokokoszene. zuletzt ruft der Dichter aus:

Красное место! арагои берег Сенски! кто тя нелюбит? разве был аух зверски! 32

Timofeev sieht in den 'стихи nохвальные Парижу' Proben der 'Landschaftslyrik' (пейзажной лирики) Tred.s. 33

Damals hat Tred. auch Gedichte in französischer Sprache geschrieben, von denen manche ihm so gut gelungen sind, daB man ihn einen 'poète français' genannt hat. Darunter sind auch mehrere Liebesgedichte. Vielleicht enthalt das eine oder andere ein Stūck 'Autobiographie seines Herzens', vermutet Pekarskij. 34 So spricht der Dichter іш 'Промении при разлучении со всякой милой' wie ein französischer Kavalier zur 'Dame seines Herzens':

Divin objet d'un feu pur et celeste,

a qui mon coeur adressoit tous ses voeux,

ce jour funeste, mais prétieux,

ou je fais mes eternels adieux

est le seul prix, le seul bien qui m'en reste -35

Die Liebe des Dichters zur fernen Heimat kommt in den 'Стихи похвальныя 
Poссии' zum Ausdruck:

Начну на флеите стихи печальны

зря на Россию чрез страны дальнн...

Mit dem Gedenken erhebt sich der Stolz auf den Reichtum und die Kraft der 'мать Россия':

\author{
Чада достойны таковой мати, \\ везде готовы за тебя стати. \\ Чем ти,Россия, неизбильна? \\ где т山, Россия, не была сильна?
}

SchlieBlich vertreibt die patriotische Begeisterung den Klageton:

\title{
Виват Россия! 8иват арагая! \\ Виват надежда! Виват благая. \\ Скончу на флейте стихи печальны, Зря на Россио чрез страни дальны -36
}

Nach Timofeev eroffnen diese Verse die Tradition der patriotischen Lyrik in RuBland. 37

Auf der Rückreise von seinem ertragreichen Studium in Paris macht Tred. in Hamburg Station. Nach seinen Worten hat er sich dort 'einige Zeit' im Sommer 1730 aufgehalten. Uber seinen Aufenthalt gibt es nur wenige Daten. In hamburg hat ex zur Feier des Krönungstages der Zarin Anna Ioannovna (10.August 1730) ein Gedicht verfaBt. Die Uberschrift lautet: 'Mecmb counнена в Гамбурге К торжественному празднованию коронации Ея Величества Государыни Императрицн Анны Иоанновны Самодержицш Всероссийския... 38 Ferner hat Tred. In Hamburg den Roman Paul Tallemants 'Voyage d l'Ile d'amour' ubersetzt. Im Vorwort des bald nach seiner Heimkehr im selben Jahre in Petersburg gedruckten Buches schildert Tred., wie es zu der Ubersetzung gekommen ist:"Когаз я был в Гамбурге послучар чрез несколькое время, гае не имея никакова дела со скуки я пропадал", da sei er von dem Fürsten A.B.Kurakin in einem Briefe aufgefordert worden, 'tirgendein franzósisches Buch ins Russische zu übersetzen': "...nовелел мне ирез одно свое письмо из Москви перевесть какую нибудь книжку Французскую на наш язык, И то Аля того, Аабы всуе мое время нетратилось. 139 Er habe sich beellt, fahrt Tred. fort, den Wunsch seines 'Wohltăters' zu exfülen. Dabel sel ihm das Buch Tallemants in den Sinn gekommen. Es sei fedoch in Hamburg 'nicht ohne Muhe aufzutrei- 
ben gewesen'. Schließlich habe er es entdeckt und in 'weniger als einem Monat' übersetzt: "Torда впала мне на разум сия, которую я там не без трудноСти Сыскал У ОАной девицЫ Очонь Охотницы АО КниГ, И СТал Онуо переводить С так великим прилежанием, что в месяц еще и меньше я совсем ея окончал..."140 Es kann dahingestellt bleiben, ob Tred. die Schilderung vielleicht geschmũckt und für den Geschmack des Petersburger Publikums hergerichtet hat; es ist die einzige, die wir von ihm selber über seinen Aufenthalt in Hamburg haben. Wichtige Fragen, Tred.s Beziehungen zu Hamburg betreffend, bleiben offen, z.B.: hat Tred. damals Barthold Heinrich Brockes kennengelernt, den Dichter des physikotheologischen Kreises? Brockes war seit 1720 Ratsherr in Hamburg und hat in seiner Vaterstadt bis zu seinem Tode 1747 einfluBreiche Amter ausgeubt. Seine seit 1721 erscheinende Gedichtsammlung 'Irdisches Vergnügen in Gott, bestehend in physikalisch- und moralischen Gedichten' (9 Bănde,1721-48), ist typisch für die Geisteshaltung der Physikotheologen. $\mathrm{Zu}$ verschiedenen Gedichten von Brockes gibt es Parallelen in Fénelons 'Démonstration' und in der Feoptija. P.N.Berkov hat darauf hingewiesen, daB in den Примечания к Ведомостам, Т.102-03 vom 25.XII.1735,S.405f. Prosaübersetzungen aus den 'книги немецкого позта r.Брокс, загл.Ird. Vergnügen III, S.692 und $662(!)$ enthalten sind, die vielleicht von Tred. selbst ubersetzt worden sind. 41 In der oben zitierten 'Эnистола.... Anoллину' von 1735 wird in der Liste der deutschen Autoren auch Brockes aufgeführt:

Брокса, Триллера, кому 6 выше можно знати,

Что в вещах природных есть аля стиха изрядно,... 42

Pumpjanskif interpretiert die stelle so: "т.e. (оставляя в стороне ученика Броккесса, неинтересного Триллера): кто лучше Броккеса знал, что в мире природы может быть предметом поззии? Очевиано, Тредиаковский знает, что Броккес натурфилософский поэт пейзажа." 13 Das Problem ist: wie konnte Brockes in eine Liste aufgenommen werden, in der sonst die Autoren des 'vernünftigen Stils' den Ton angeben: Juncker, König, Besser, Neumeister, Neukirch und Günther? Pumpjanskij erwăhnt, daB z.B. König in seiner Komödie 'Die verkehrte Welt'(1725)'den verdorbenen Brockesischen und seiner Anhänger üblen Geschmack' verunglimpft hatte. Den Vertretern der 'Schule der Vernunft' erschien Brockes wie 'ein neuer Hofmannswaldau', dessen spătbarokker Schwulst als Gipfel des schlechten Geschmacks galt. 44 Folgt man der Auffassung Pumpjanskijs, so ist Tred. bei der Auswahl der deutschen Auto- 
ren besonders von dem Professor an der Petersburger Akademie und Hofdichter Juncker beeinfluBt worden. Unter dessen Anleitung habe Tred. nach seiner Rückkehr aus dem Ausland in den Jahren 1732ff. deutsche Literatur studiert:"С :нкером он знаком, конечно, уже с его приезда, с 1731 г., но теперь, в 1732 и 1733 rr., он с ним сближается и изучает немецкую литературу под его руководством. "45 Juncker hat inm nicht nur Autoren der "немецкая школа разума', denen er nahestand, empfohlen, sondern ihn auch auf 'Nebenrichtungen' dex deutschen Literatur hingewiesen, meint Pumpjanskif: "Юнkep же указал ему и на Аругие побочные направления, приемлемые яля его позиции (Гюнтер, Шмольк, даже Броккес)..." 46 Bei Tred. ist eine deutliche Vorliebe für Brockes zu exkennen, die in der physikotheologischen Einstellung der beiden Autoren begründet ist. Beide sind offenkundig von der 'Démonstration' Fénelons inspiriert worden. DaB Tred. die Gedichte von Brockes gekannt hat, kann, wie oben dargelegt, als erwiesen angesehen werden. Es labt sich aber nicht belegen, ob ex inn in Hamburg auch personlich kennengelernt hat.

Im September 1730 ist Tred. In Petersburg. ${ }^{47}$ Dort veroffentlicht er sein erstes Buch, das den in Hamburg übersetzten Roman 'Езда в остров Любви' und eine Sammiung eigener Gedichte enthielt. Timofeev hebt hervor, daB es die erste gedruckte Gedichtsammlung eines Autors in der russischen Literaturgeschichte darstellt. Von den 32 Gedichten sind 16 in franzosischer, eines 1st in lateinischer Sprache geschrieben. Der Autor reprăsentiert damit 'e1nen neuen Typ der russischen Kultur, der souverăn und kompetent Beziehungen zur Kultur des Auslands angeknüpft hat. ${ }^{48}$ Das Bemūhen Tred.s, europãisches Denken von der Antike bis in seine Gegenwart 'ins Russische zu ubersetzen', 1st in dex Feoptija im hơheren stil verwirklicht.

Der Roman 'Eзда...' hat Tred. auf einen Schlag berühmt gemacht. Das Thema der Liebe zwischen Mann und Frau war mit solcher offenheit, obwohl teilweise allegorisch verschlüsselt, bis dahin in RuBland noch nicht behandelt worden. Auf diesem Geblet herrschten noch die Auffassungen des aus dem 16 . Jahrhundert stammenden 'Домострой'. 49 So wurde der Roman in hofischen kreisen begeistert aufgenomen, von der Geistlichkeit hingegen, abgesehen von einigen Ausnahmen, scharf verurtellt. Uber das Echo, das sein Buch hervorgerufen hat, aubert sich Tred. In einem Bxief an den einfluBreichen Akademierat schumacher: "Я могу сказать по правде, что моя книга входит здесь В моду и К несчастью, я также вместе с ней. Честное слово, мсье, я не знар, что делать: меня ищут со всех сторон, повсоду просят моп книгу...При:'в: 
ные ею вำлне довольны. Среди принадлежащих $\mathrm{k}$ духовенству есть такие, кто благожелательны ко мне, аругие, которые обвиняют меня, как некогда обвиняли Овияия за его прекрасную книгу,...говорят, что я первый развратитель русской молодежи...Что вы, сударь, думаете о ссоре, которую затевают сомноі эти ханжи?...они не принадлежат К иислу тех, кто может мне вредить. Ведь это - сволочь, которую в просторечии называют попами...Но посмотрите, суАарь, на бесстыдство последних, оно, несомненно поразит вас. Ведь они винят меня в нечестии, в нерелигиозности, в деизме, в атеизме, наконец во всякого рода ересы...Да не прогневаются зти невежи, но мне наплевать на них, тем более что они люяи очень незначительные..."150 Tred. hat die Anschuldigungen seiner Gegner $z u$ leicht genomen und ihren EinfluB unterschatzt. Das MiBtrauen gegen ihn, durch sein erstes Buch geweckt, verfolgte ihn zeitlebens. Es hat auch die Veroffentlichung der Feoptija verhindert. Pekarskij berichtet von einem Zusammentreffen Tred.s mit dem Archimandriten Platon Malinovskij in Moskau im Jahre 1731. Dabei habe Malinovskif inn nach seinen Studien im Ausland gefragt. "И Тред.-де сказывал, что слушал он филозофию. И по разговорам о объявленной филозофии во окончании пришло так, яко бы бога нет."151 Daraus habe Malinovskij gefolgert, "4то и оншй Тред. по слушанию той филозофии, может быть во оном не без повреждения... 152 Platon Malinovskij wurde als Gegner der Reformen Peters unter Anna Ioannovna nach Sibirien verbannt, dann aber von der zarin Elisabeth begnadigt. Spater wurde er Erzbischof in Moskau(1748-54). Er war Tred. feindlich gesonnen und soll ihm bei einer anderen Gelegenheit gedroht haben:'Пролется ваша еретичесеая кровь. 53

Zwischen 1730 und 1740 stand Tred. auf der Hohe des Ruhmes. Der Roman 'Езда...' wurde nicht nur von vielen gelesen, die darin enthaltenen Liebesgedichte wurden auch vertont und gesungen: "Почти все они стали русскими кантами и вошли в рукописные сборники, будучи записанными вместе с музыкой. $1{ }^{54}$ Tred. wurde zum Hofdichter ernannt und durfte sich am 3 .Febr. 1732 mit einem panegyrischen Gedicht der Zarin Anna Ioannovna persönlich vorstellen. Er hatte die Aufgabe, $z u$ den verschiedensten festlichen Anlăssen des Hofes wie zum Geburtstag und Krönungstag der Zarin, zum Neujahrsfest, zu Hofballen oder aus $A n l a B$ von staatsbesuchen und siegesfeiern dithyrambische Verse anzufertigen und meist auch selber vorzutragen. Dabei sind ihm Jedoch manchmal auch Demütigungen nicht erspart geblieben. Von einem derartigen Vorfall berichtet Pekarskif: "...когда при торжественном 
случае Тред. подносил императрице Анне свор оду, он должен был от самых Аверей залы до трона ползти на коленях!"155 Ein andermal wurde er von dem Minister Volynskif aus nichtigem AnlaB so brutal geschlagen, daB er auf dem rechten ohr taub wurde: "...начал...меня бить пред всеми толь немилостиво... что правое мое ухо оглушил..."156

Aus der Dutzendware panegyrischer Gedichte auf Bestellung hebt Timofeev die zur Feler der Eroberung Danzigs durch russische Truppen 1734 verfaBte 'Oда тормественная о сдаче города Гданска' hervor. Mit ihr hat Tred., so meint Timofeev, prinzipiell ein neues Genre in die russische Literatur eingeführt: "Приниипиально зто было очень важным и безусловно новаторским шагом в развитии тогдашней поззии, но шагом, естественно, самым первоначальным, робким и неуверенным." 57 тred. hat spăter (bei der Veroffentlichung seiner Werke 1752) zugegeben, daB er Bolleaus Ode uber die Eroberung von Namur als Muster benutzt habe:"...признаюсь необиновенно, сия самая 0да подала мне весь план к сочиненио моея о здаче города Гданска... 58 Die Ode wurde von Juncker ins Deutsche Ubersetzt: "Оау, которуо я сочинил,...Госпояин Юнкер, В Санктпетербургскои Императорскои Академии Наук публичнои профессор, благоволил перевесть на немецкои язык..."159 Tred. hat die zunăchst im syllabischen VersmaB verfaBte ode später syllabo-tonisch umgedichtet.So steht sie in den Gesammelten Werken von 1752. Charakteristisch fü den stil der Ode ist das Oxymoron des ersten Verses, der in der ursprünglichen, syllabischen Fassung lautet:

Kое трезвое мне пианство -

In den Gedichten von Brockes sind solche Figuren, die einander sich ausschlieBende Begriffe vereinigen, hăufig zu finden. Als Beispiel fuhrt K.Richter an: 'helligs Grauen', 'frohe Angst', 'bange Lust' aus Brockes' Gedicht 'Die himmlische Schrift'. ${ }^{60}$ Dieses Stilmittel, von der Theorie im 18. Jahrhundert 'gemischte Gefüle' genannt, kennzeichnet nach K.Richter die auf das 'Erhabene' bezogene neue Lyrik von Brockes bis Klopstock. 61 Festzuhalten ist, daß sich Tred. schon in seiner ersten Ode der Ausdrucksmittel bedient hat, die inm in der europaischen Dichtung begegnet waren.

Se1t 1732 stand Tred. als Ubersetzer im Dienst der Petersburger Akademie der wissenschaften. Am 14.0kt.1733 wurde er mit dem Titel eines Akademiesekretars zu einem Jahresgehalt von 360 Rubeln fest angestellt. Sein Vertrag verpflichtete ihn, 'nереводить с Франиузского языка на русской язык все что ему дастся. 62 So nehmen die Ubersetzungen aus dem Franzorsichen im Werk 
Tred.s großen Raum ein. Erwăhnt seien: Boileaus L'Axt poêtique (1735 übersetzt), die 16băndige'Römische Geschichte' des Historikers Rollin (1761-67 übersetzt) und die 'История о римских императорах' des Rollin-Schülers Crêvieu (1767 übersetzt). Von den Schriften Fenelons veroffentlichte Trd. die folgenden Ubersetzungen: 'Нстинная политика знатных и благородных осо6' (Lа veritable politique des personnes de qualité) und das Gedicht 'Правила благоразумия и добронравия человеческого' (La sagesse humaine, ou le portrait d'un honnête homme). Den 'Télémaque' Fênelons hat Tred. in seiner 'Tилемaхида' 1766 in russische Hexameter übertragen. Timofeev schreibt, damit habe Tred. den Weg zur Ubersetzung der 'Ilias' und 'Odyssee' gewiesen: "TpeA. таким образом, стоит у истоков не только традиции русского гекзаметра, но и гомеровской традиции в России." 63

Anders als sein poetisches Talent, sind Tred.s Leistungen als Ubersetzer niemals angezweifelt worden. Sie beruhen auf der Beherrschung mehrerer Sprachen und auf seinen umfassenden Kenntnissen in einer Reihe von Wissenschaften. Tred. ist wahrscheinlich einer der belesensten und kenntnisreichsten Autoren des 18.Jahrhunderts in RuBland gewesen. Welches Ansehen er wegen seiner tbersetzungskunst hatte, geht aus einem Schreiben der Akademie an den Senat im Jahre 1745 hervor:"...во0бще можно сказать, что по отбытии проФессора Тр.ого, если какия книги о мауках с иностранных европейских языков переводить надобно будет, то трудно сыскать, чтобы кто имел довольную способность оныя без погрешности перевести и так, чтобы их без дального свидетельства в печать выдать...

Tred. hat das Verhaltnis zwischen Autor und Ubersetzer so beschrieben: "...nереводиик от творца только ито именем рознится. Еще донесу вам больше, ежели творец замысловат был, то переводчику замысловатее надлежит быть (я неговорю о себе, но о добрых переводчиках)". 65

Durch seine Ubersetzungen aus den verschiedensten Gebieten der Literatur, Philosophie, Geschichte, Naturwissenschaft und Technik, die Tred. teils im dienstlichen Auftrag, teils aus eigenem Antrieb herstellte, ist er im 18. Jahrhundert $2 u$ einem der bedeutendsten Vermittler europãischen Geistesgutes in RuBland geworden.

Als Dichter hat sich Tred. in beinahe jeder Gattung seiner Zeit versucht: in der Anakreontik, in der Landschaftslyrik und der patriotischen Lyrik, in der Panegyrik und in der Ode. Selbst das Drama fehlt nicht. Tred. hat die 'Деидамия' 1750 geschrieben. Das Stũck wurde erst nach seinem Tode gedruckt. 
Sein anspruchvollstes Poem ist aber wohl die Feoptija(1750-54), die im Mittelpunkt der vorliegenden Untersuchung steht. Tred. wollte mit der Feoptija, angeregt durch A.Popes 'Essay on Man', eine Literaturgattung in RuBland vorstellen, die im 18.Jahrhundert trotz antiker Vorbilder auch in Westeuropa als neu empfunden wurde und starke Resonanz fand, das Lehrgedicht. Seine deutsche Ausprăgung wird von Chr.siegrist so charakterisiert:"... der strenge methodische Anspruch, die erzieherische Aufgabe, die 'hohe' Thematik waren -mehr oder weniger- neu. Die Spezies, welche diesen Forderungen sehr genau zu entsprechen vermochte und damit eine neue Epoche der deutschen Dichtung eroffnete, war das Lehrgedicht, dessen plotzliche vitalität und Beliebtheit in den Jahrzehnten zwischen 1730 und 1760 nur in diesem Kontext erklarlich werden."66 Die Intention Tred.s war also vollig zeitgemäB.

Neben den Ubersetzungen und den poetischen Werken bilden die sprachwissenschaftlichen Arbeiten die dritte Gruppe im Schaffen Tred.s, der als 'Tрудолюбный филолог ${ }^{67}$ bekannt war. In dem vortrag, den er in der ersten sitzung des von Baron Korff am 14.Mărz 1735 gegründeten 'Poссийское Собрание' hielt, umriB Tred. die wichtigsten Aufgaben der neuen Einrichtung:"... оратор высказал здесь взгляд свой на цель вновь учрежденных собрании именно, что там должно заниматься составлением Грамматики, Реторики и словаря. 168 Für Tred.s Interesse an der Sprache gab es keine Grenze: er hat sich mit den Fragen der Grammatik ebenso beschaftigt wie mit der Rechtschreibung, Phonetik, Lexik und Etymologie. Nach Meinung von Fachgelehrten -Timofeev nennt G.O.Vinokur, 'Орфографическая теория Тредиаковского'-gehort Tred. zu den Wegbereitern der russischen Phonetik. ${ }^{69}$ Timofeev erwăhnt ferner, daB Tred. als erster das Phănomen der sogenannten volksetymologie erkannt und untersucht hat. 70 In seinem Eifer, slavische Wurzeln in anderen Sprachen, z.B. im Deutschen zu entdecken, ist Tred. nicht selten zu kuriosen Behauptungen gekommen. ${ }^{71}$ Anzumerken ist, daB Puskin den Philologen Tred. gelobt hat: 'Ero филологическая и грамматическая изыскания очень замечательны. 72

Um das Jahr 1735 hat Tred. den Hơhepunkt seiner Laufbahn erreicht. Er gehorte $z u$ den angesehensten Mitgliedern der Akademie und war offiziellex Hofdichter. Zu seinen măchtigsten Gönnern zăhlte er den Minister Biron und den Prăsidenten der Akademie, Baron Korff; nicht zuletzt besaB er das Wohlwollen des damals in der orthdoxen Kirche tonangebenden Geistlichen, Feofan Prokopovič. Von reichen Măzenen erhielt Tred. in diesen Jahren des ofteren Ge- 
schenke, so daB auch seine materiellen Verhaltnisse, über die er spăter oft zu klagen hatte, befriedigend waren. Einen Hinweis auf solche zuwendungen enthalt ein Brief des Grafen S.A.Saltykov an seinen Sohn aus dem Jahre 1732/33: "Когда он, Тред., такие книжки подавал тамошним кавалерам, то дарили ль его чем или нет, и буде дарили то,ито наялежит, -и ты подари что мадобно. "73 Die Stelle hat folgenden AnlaB: Tred. hatte dem Grafen sein Buch 'Панегирик, или Слово похвальное императрице Анне Иоанновне' geschenkt. Das Geschenk oder die Widmung eines Buches an einen Mazzen war als diskrete Bitte um eine Spende zu verstehen. Dies war für einen Autor im 18.Jahrhundert oft die einzige Möglichkeit, aus seiner Arbeit finanziellen Gewinn zu ziehen, da es noch keine Buchverlage gab. D.D.Blagoj weist auBerdem darauf hin, daß der Kreis der Leser sehr begrenzt war. Er beschrănkte sich "B ocновном $к$ представительям вышей дворянской знати... да К очень еще тонкому слою разночинцой интеллигенции, складшвавшейся вокуг Академии наук и Московского университета. 174

Seit dem Ende der 30er Jahre wurde das Leben für Tred. schwieriger. Damals begann der jahrelange streit zwischen ihm und Lomonosov um die Prioritat bei der Versreform. Jeder von beiden bestand darauf, als erster den entscheidenden Schritt zur Neubildung der russischen Verslehre getan zu haben. Es ist jedoch erwiesen, daß Lomonosov den 'Новый и краткий способ к сломеню российских стихов...' Tred.s bald nach der Veröffentlichung im Jahre 1735 gelesen hat. Er hat den 'Cnoco6' 1736 mit ins Ausland genommen, um sich weiter damit zu beschăfigen. DaB Lomonosov den 'Cnoco6' aufmerksam studiert hat, verraten die kritischen Anmerkungen, die er in dem noch vorhandenen Exemplar notiert hat. Sie betreffen einzelne Formulierungen, Pleonasmen u. $a$. "В 1736 году, уежая за границу, Ломоносов взял с собой 'Спосо6'Тред.ого и внимательно изучал его, что показывает ряд заметок, покрываюиих его страницы. Пометки эти имеют явно недобромелательный характер и касахтся частностей."175 Im Jahre 1739 schickte Lomonosov aus Freiberg in Sachsen der Petersburger Akademie seine studie 'O nравилах российского стихотворства', in der ex mit einigen Erweiterungen den Grundgedanken des 'Cnoco6' vertritt, ohne diesen mit einem Wort zu exwăhnen:"...nисьмо '0 правилах...', в котором обосновывалась та же по сути дела система стихослотения и ни звука не говорилось о 'Cnособе' Tред.ого."176 Die dem Schreiben an die Akademie beigefügte 'Ода на взятие Хотина' fand großen Beifall und stellte den 'Cnосо6' in den Schatten. Die Ode ist das erste Beispiel für den vierfuBigen Jambus in der russischen Dichtung. Tred. sah seine Urheberschaft gefahrdet und re- 
agierte darauf gereizt in einem Brief an Lomonosov, den er inm durch die Akademie zuschickte in der Absicht, seinem Einspruch mehr Gewicht zu geben. Der Brief wurde jedoch von der Akademie zurückgehalten mit der Begründung, "сего учеными ссорами наполненного письма аля пресечения дальних, бесполезmux $и$ напрасных споров к Ломоносову не отправлять и на платеж за почту деher напрасно не терять..." 77

AuBere Bedrăngnisse kamen für Tred. hinzu. Bei einer Feuersbrunst verbrannte 1736 seine gesamte Einrichtung, und er muBte notgedrungen ein Darlehen $z u$ hohen $z i n s e n$ aufnehmen. In einer an die Akademie gerichteten Bittschrift schildert er seine Lage: "Прошлаго 1736 года учинияшимся на мытном Аворе... потаром разорился я до основания, того раяи Аля исправления моих крайних тогАа нужд принумден я бил занять себе денег с великими прочентами." 78 Aus diesem Grunde bittet er um die vorauszahlung eines Jahresgehalts von 360 Rubeln. Dies Gesuch steht am Anfang einer Reihe von ahnlichen Eingaben. Immer wieder hat Tred. einen AnlaB, seine bedruckten Verhaltnisse darzulegen und flinanzizile Hilfe, sei es als VorschuB oder als Gehaltserhohung zu erbitten. Dabel läbt er manchmal durchblicken, daB er für seine Leistungen eine bessere Besoldung verdient habe. Er ging so weit, in einem Gesuch vom 18.August 1743 den Senat um seine Ernennung zum Professor der Rhetorik zu bitten. Seine Eingabe begrundete er teils mit wirtschaftichen Schwierigkeiten, teils mit dem Hinweis auf seine wissenschaftliche Befahigung, die ex seit zehn Jahren im Dienste der Akademie bewlesen habe. DaB Tred. mit seinem Gehalt nicht auskam und wiederholt uber seine Geldknappheit klagte ("не могу я содержаться окладом моим не имея ни двора ни кола как говорится"19), lag sicher nicht an einer zu aufwendigen Lebensfuhrung. Wahrscheinlich haben ihn die Druckkosten für seine Bücher finanziell ruiniert. Die meisten seiner Bücher muBte er auf eigene Rechnung veroffentlichen. Bei einer Auflage von 500 Exemplaren waren die Kosten meist hoher als das Jahresgehalt des Autors. Der Verkauf zog sich über Jahre hin und brachte kaum Gewinn.

Das erwăhnte Gesuch läbt auch darauf schlieben, dab sich Tred.s Stellung in der Akademie im Laufe der Jahre verschlechtert hatte. Auf Grund seiner Leistungen und Făhigkeiten hatte man ihn langst befordern müssen. DaB dies ausblieb, deutet auf die inzwischen eingetretene Minderung seines Ansehens hin. Bereits im Jahre 1740 schreibt der oben genannte Graf Saltykov an Tred., nachdem er von dessen Demutigung durch den Minister Volynskif erfahren hat- 
te: "Я ведаю, что друзей вам почти нет и никто с добродетелю об имени вашем и упомянуть не захочет." 80 spatestens seit der Thronbesteigung dex zarin Elizaveta im Jahre 1742 begann 'der Stern Tred.s zu sinken'. Nun war ex dadurch belastet, daB er Hofdichter der Zarin Anna und ein Schützling ihres Ministers Biron gewesen war. Hinzu kam, daB der unter der Regierung der za$r$ in Anna nach Sibirien verbannte Archimandrit Platon Malinovskij, von Elizaveta begnadigt, nach Moskau zurückgekehrt war, wo er 1748 Erzbischof wurde. Durch ihn bekam die reformfeindliche Richtung in der orthodoxen Geistlichkeit wieder die Oberhand, in deren Augen Tred. ein Freigeist und Atheist war. - Es vergingen fast zwei Jahre, bis die Zaxin Elizaveta Tred. auf Vorschlag des 'Правительствующий Сенат' am 25. Juli 1745 zum Professor 'как латинския, так и российския элоквениии' exnannte. 81 Sein jăhrliches Gehalt wurde von bisher 360 auf 660 Rubel erhöht. ${ }^{82}$ zum gleichen zeitpunkt wie Tred. wurde auch Lomonosov zum Professor berufen. Er war im Unterschied zu Tred. von der Akademieversammlung vorgeschlagen worden. In der Akademie hat man es Tred. nachgetragen, $d a B$ er sich direkt an den Senat gewandt und seine Berufung selber betrieben hatte. Dies hatte zur Folge, meint Pekarskij, daB er von Anfang an von seinen Kollegen nicht sehr freundlich aufgenommen wurde: "Это обстоятельство...было причиною, что с начала вступления Тред.ого в среду академиков, его там приняли не совсем друмелюбно. 83 Nachdem Lomonosov vom Studium in Deutschland heimgekehrt war, gab es zwischen ihm und Tred. eine Kette von Meinungsverschiedenheiten uber Fragen der Metrik, der Grammatik, der Rechtschreibung und der Entwicklung der Literatursprache. Die gelehrten Streitfragen wurden oft im gereizten Ton diskutiert. An die Stelle von Argumenten traten dann auch Spottverse, mit denen einer den anderen verunglimpfen wollte. Im Verhalten Tred.s gegenuber Lomonosov wurde die Eifersucht auf den erfolgreicheren Rivalen zur treibenden Kraft. Der folgende Vorfall macht deutlich, wie Tred. reagierte, wenn seinem widersacher eine Auszeichnung zuteil wurde. So erhielt Lomonosov am 1. Mărz 1751 den Titel eines Kollegienrates und die damit verbundene Gehaltszulage. Schon am 8.Mårz schreibt Tred. flehentlich an den Präsidenten der Akademie: "слезно прошу вашу ясневельмомность, припадая к ногам вашим,... повелеть прибавить мне годовое малованье...дабы я хотя несколько еще ободрился слукить мог без дальныя печали и сокрушения, и пребедную мою Фамильишку питать не растворяя хлеб плачем. "84 Das Gesuch war erfolglos.

In Konkurrenz mit Lomonosov veroffentlichte Tred. im Jahre 1752 seine ge- 
sammelten Werke in zwei Bănden, nachdem auch die Werke Lomonosovs kurz vorher erschienen waren. Tred. muBte für die Auflage von 604 Exemplaren 376 Rubel aus eigener Tasche bezahlen und geriet aufs neue in Schulden. So muBte ex im Februar 1753 wieder um einen Gehaltsvorschuß bitten, "понеже данные мне ...деньги триста рублей от Ея Императорского Величества, мною издержаны, а из продажи книжек ничего еще не выбрано, так что я теперь отнюды не имею денет. 185 In den Gesammelten Werken von 1752 ist u.a. die Neufassung des 'Cnoco6' enthalten. Tred. hat darin seine Verslehre erweitert und der tatsăchlichen Entwicklung, die vor allem von Lomonosov gefordert worden ist, angepaBt. Nach den Regeln des 'Cnoco6' von 1752 sind auch die verse in der Feoptija gebildet worden.

In den Jahren 1750-54 hat Tred. an seinem 'доказательство о Божием бытии' gearbeitet und gleichzeitig den Psalter in russische verse ubertragen. 86 Er bezeichnete das Poem mit dem aus griechischen Elementen bestehenden Kunstwort 'Feoptija', dessen Bedeutung dem russischen 'бorosperne' entspricht, wie der vollstăndige Titel zeigt. Es hat den Autor schwer getroffen, daß die Veroffentlichung seines Poems verhindert wurde. Năheres uber das Schicksal der Feoptija wird spater ausgeführt. Im Jahre 1754 wurde die weitere Herausgabe der von Tred. übersetzten 'Geschichte der Antike' Rollins durch die Akademie eingestellt, ohne daB dafür ein stichhaltiger Grund genannt wurde. 87 Dies war für Tred., dem viel daran lag, das Werk seines ehemaligen Lehrers in RuBland bekanntzumachen, eine herbe Enttauschung. Als mehrere fertiggestellte Bănde des umfangreichen Werkes bei einem zweiten Brand in seiner Wohnung im Jahre 1747 vernichtet worden waren, hat Tred. sie noch einmal übersetzt. Manches weist darauf hin, daB Tred. literarisch mundtot gemacht werden sollte. So hatte er nur in den ersten Heften der neu gegründeten Zeitschrift 'Ежемесячныя Сочинения' noch einige kleine Aufsăze unterbringen kơnnen, dann wurden seine Manuskripte nicht mehr angenommen: "... тиился маленькими пиесами, вносимыми в Ежемесячныя Сочинения, казать мой труа. Но Г.Конференц Секретарь Миллер разгласил, что от меня ничего не велено принимать, а тогожде ради и Ролленовы Истории печатание остановлено. 1188 .

In dem Gefül, ausgeschlossen und von einer Atmosphăre der Feindseligkeit umgeben zu sein, kămpfte Tred. gegen verschiedene Widersacher: Lomonosov, Müller und andere Mitglieder der Akademie. Auch Sumarokov hatte ihn mit satirischen Versen angegriffen. Zornig uber die Verspottung, schreckte Tred. 
nicht davor zurück, Sumarokov beim Synod zu denunzieren:"Тред., раздраженный и осмеянный, придумал иной спосо6 к отмещению: 13. октября 1755 года он решился подать донос на Сумарокова в синод." 89 In der Anzeige hat Tred. eine nach seiner Ansicht hăretische Auslegung des 106.Psalms in den 'OAM AYховные' Sumarokovs aufgedeckt. Dieser hat von der Anschuldigung bald darauf Kenntnis bekommen und war emport:"... пн прислал 1 ноября 1755 года бумагу в академическое собрание, в которой было много яростных выходок против Тредиаковскаго..."190 Lomonosov stellte sich auf die Seite Sumarokovs, indem er Tred. als 'безбомник и ханжа' 91 in einer satire blobstellte. Es dauerte nicht lange, bis dieser eine Gelegenheit fand, zurückzuschlagen. Anfang 1757 hatte Lomonosov ein satirisches Gedicht gegen die rückstăndige Geistlichkeit, den 'Гимн бороде' verfaßt. Die kühne sprache gegen die 'Bărte', die an dem Verbot der russischen Ubersetzung des 'Essay on Man' schuld waren, löste einen Skandal aus. ${ }^{92}$ Tred. nahm für die kritisierten 'Bărte' Partei, indem er den 'Гимн бороде' parodierte und es sich nicht versagen konnte, eine persōnliche Schwăche Lomonosovs aufzuzeigen:" 8 'Переодетой 6ороде, или имне пьяной голове' Тред. осмеивает известную слабость Ломоносова к вину..."93 Der Streit zwischen den beiden unversర̌hnlichen Gegnern wurde mit spitzen und verletzenden Epigrammen fortgesetzt.

Seit August 1757 lieB sich Tred. nicht mehr in der Akademie sehen. Man forderte von ihm eine Erklărung für sein Verhalten und lieB sein Gehalt vorlăufig sperren. In einem ausführlichen Bericht begründet Tred. dem Prăsidenten der Akademie das Fernbleiben vom Dienst mit seinen Krankheiten 'remontoзис и ипохондрия'. Der Brief gibt einen erschutternden Einblick in seine Verbitterung und Vereinsamung. Er spricht von 'Schlăgen, die ihm unertrăgliche Wunden zugefügt' hatten und meint damit, daB man die Veröffentlichung seiner Arbeiten verhindere. Die Erregung bricht in folgende Worte aus: "ненавидимый в личе, презираемый в словах, уничтожаемый в делах, охуждаемый в искусстве, прободаемый сатирическими рогами, изображаемый чудовищем, еще и во нравах (что сего безсовеснее?) ог лашаемый..!94 Im selben Schreiben berichtet Tred., daB er seine Ubersetzungen $z u$ Hause fortführe, z.B. Rollins 'Geschichte der Antike', "...и6о хотя Ролпень и не продолжается печатию, но мне не повелено покинуть сей перевод..."95 Darüber hinaus studiere er lateinische, französische polnische und altrussische Autoren nicht zum Privatvergnügen, sondern - Аля пользы всей России'96. Als Ergebnis seiner studien nennt er drei Aufsătze, die er inzwischen fertiggestellt habe: 'O nерөенстве Славнскаго 
языка пред Тевтоническим', 'O родоначалии Россов' und 'O Bapяrax Pуссах, Славенскаго зөания, рода и языка. 97 Am Ende seines Schreibens beklagt sich Tred. daruber, daB inm kein Gehalt gezahlt werde, obwohl er seine Arbeit zu Hause weitergeführt habe. Er müsse vor Hunger und kalte zugrunde gehen, wenn er kein Geld erhalte: "я несправедливо осумден буду, ежели осужден чрез удержание жалованья умирать голодом и холодом... у меня нет ни подушки в доме, ни сухаря хле6а, ни Аров полена."98 Anscheinend hat Tred. auf diesen Bericht keine Antwort bekomen, denn am 3.und 15. November wiederholt er mit dringenden Worten seine Bitte um Zahlung des Gehalts. Darauf ergeht an Ihn die Verfugung, unverzüglich seinen Dienst wiederaufzunehmen und nachzuweisen, was er zwei Jahre lang 'zum Nutzen der Akademie' getan habe. Andernfalls werde ihm kein Gehalt gezahlt werden. Nun bat Tred. um seine Pensionierung. Ex sei infolge langjahriger tberarbeitung schwer erkrankt und durch verschiedene Schlcksalsschlage in Armut, Kumber und dauernde Depressionen geraten, "...так что сделался крайне неспособным к продолжению службш... "99 Dies Gesuch 1st am 23.Marz 1759 bei der Kanzlei der Akademie eingetragen worden. Schon am 30.márz verfügte die Behơrde die Entlassung Tred.s mit sofortiger wirkung aus dem Dienst der Akademie. Pension wurde inm nicht gewahrt. Pekarskif bezeichnet das Verhalten der Behơrde als groBe Hărte gegen 'den verdienten Schriftsteller', der zweifellos für die Aufklarung in RuBland von Bedeutung gewesen ist. Die personliche Feindschaft Lomonosovs und Tauberts, die damals in der Leitung der Akademie den Ausschlag gaben, sel die Ursache, so hebt Pekarskif hervor, daB Tred. und seine Famille ohne versorgung zurückblieben. 100

Nach diesem Abgang ist es um so erstaunlicher, daB der von Krankheiten geplagte Tred. im letzten Jahrzehnt seines Lebens u.a. noch die 16băndige 'Geschichte der Antike' abgeschlossen, die 'История о римских императорах' von Crévieu übersetzt und die 'Thлемaxияa' In Bexameter abertragen hat.

In seiner letzten biographischen Notiz vom April 1768 schreibt Tred.: "я, упадая еще с самого начала года сего из болезни в болезнь, как от Харибд в Сииллы, во все $ш$ тяжкие и опаснше, лишился межау тем употробления Hor: так что ни по хижине моей не могу пробресть без заемныя помоци, имея, однако, еще несколько дейстөительны голову, глаза и руки."101

Tred. starb am 6.August 1769 in Petersburg. 
Der geistesgeschichtliche Hintergrund

Auf ihn wird bereits im Titel der Feoptija hingıwiesen: 'Фeonrия или Аоказательство о Богозрении по вещам созданного естества...' Damit ist das Programm einer theologisch-religiosen Bewegung bezeichnet, "die den 'Erweis' Gottes von den Wundern der Schöpfung unternimnt." 1 Die Trăger dieser Bewegung, die Physikotheologen, erhielten ihren Namen nach der Methode, mit der sie die Existenz Gottes beweisen wollten. So wandte sich einer ihrer frühesten Vertreter, Samuel Parker, in den 'Tentamina physico-theologica de Deo' (1669) gegen die scholastischen Gottesbeweise a priori und setzte sich für die aposteriorische Beweisführung ein: die ganze Welt sei ein Spiegel der Herrlichkeit Gottes. Aus der Vielfalt, Zweckmåigkeit und Schönheit der Kreaturen müsse man notwendig auf einen weisen, gütigen und allmăchtigen Urheber schlieBen. Dies Argument ist der Grundgedanke der physikotheologischen Bewegung, der in vielen Variationen verarbeitet worden ist. Er wurde von den Physikotheologen in der Auseinandersetzung mit den Vertretern des naturwissenschaftlichen Weltbildes energisch verfochten. Diese sahen im Kosmos einen riesigen Mechanismus, der sich nach mathematisch bestimmbaren physikalischen Gesetzen bewegt. In dieser mechanistischen Auffassung blieb kein Raum für die Vorstellung einer 'geschaffenen Welt' oder für das Einwirken geistiger Krafte auf den Weltlauf. Die Welt war 'entstanden' aus der Zusammenballung von Atomen, die sich im leeren Raum nach den Gesetzen der Mechanik bewegten. So hatten bereits Demokrit und Epikur die Entstehung der Welt erklărt. ${ }^{2}$ Die moderne Naturwissenschaft schien ihre Theorie bestätigt zu haben.

Durch die Entdeckung des Kopernikus war das ptolemăische Weltgebăude ins Wanken geraten. Die Erde war nicht lăger Mittelpunkt der Welt, sondern ein Stern unter vielen Sternen. Auch der Mensch muBte auf seine zentrale Stellung m Kosmos verzichten. Diese Erkenntnis, von Kopernikus schon 1543 in 'De revolutionibus orbium coelestium' dargelegt, hat sich erst im 17 . und 18.Jahrhundert voll ausgewirkt. H. Blumenberg hat darauf hingewiesen, daB die 'geschichtliche Potenz' des kopernikanischen Ereignisses erst durch die von Giordano Bruno daraus gezogenen Konsequenzen wirksam geworden ist. Das kopernikanische Prinzip ist von G.Bruno auf den Fixsternhimmel übertragen worden und hat die Vorstellung von der Unendlichkeit des Kosmos begründet, der "als Produkt einer unendlichen schöpferischen Kraft...die adăquate Dar- 
stellung des Gottlichen selbst" sei. B.Blumenberg fügt hinzu: "Für dieses metaphysische Pathos, nicht für eine astronomische Theorie ist G.Bruno den Feuertod gestorben." ${ }^{3}$ Der Tod G.Brunos im Jahre 1600 markiert den Wendepunkt einer neuen Epoche. Das dreistöckige ptolemăische Welthaus, in dem die scholastische Theologie ihre wesentlichen vorstellungen unterbringen konnte, war von der Dimension der Unendlichkeit gesprengt worden. W.Philipp formuliert:"(die) Relation der Unendlichkeit lăbt keinen Raum mehr für das gottliche goldene Empyreum aber dem blauen Welthimmel der scholastischen Kosmik." 4 Dies muBte zu einer tiefgreifenden Verănderung des Gottesgedankens führen. Entweder wurde dem unendlichen Universum selbst religiose Qualitat beigelegt (pantheistische Konsequenz), oder Gott rückte in kosmische Ferne, 'vor die Tore des Al $18^{\circ}$ (deistische Konsequenz). Wo aber der unendliche leere Raum und die in ihm sich bewegenden Atomschwărme zur letzten Wirklichkeit erklăt wurden, in der das Prinzip der Mechanik regiert, trennte man sich ganz vom Gottesgedanken(atheistische Konsequenz). Selbst die orthodoxen Verteidiger des christlichen Theismus konnten sich dem Eindruck der neu entdeckten Dimension des Unendlichen nicht entziehen. "Die neue Dimension transponiert sich dem Christen $[$ in der zeit des Hochbarock $T$ zum schrecklichen zorn und zum zermalmenden Grimm, zur eisigen Diastase, zux totenden Ferndimension seines Gottes." 6

Nicht weniger tief wirkten die metaphorisch als 'kopernikanische Wende' bezeichneten Vorgånge auf das BewuBtsein des Menschen. H.Blumenberg betont, daB die erste wirkung der kopernikanischen Reform nicht in einem 'BewriBtsein der Erniedrigung des Menschen bestand, sondern im Bewubtsein seiner zugehorigkeit zur Welt der Gestirne'. "Kopernikus hatte auf die kosmische Mittelpunktstellung des Menschen verzichten kőnnen, well er gerade durch diesen Verzicht die zentrale stellung der menschlichen Vernunft behaupten bzw. bestatigen konnte." 8 Aber der Hochstimung folgte eine lang andauernde Depression. Der Mensch sah sich einem unendlichen Kosmos mit unzahligen Welten gegenüber. Jeder Fixstern bildet, so hat G.Bruno gelehrt, den Kern eines Sonnensystems. Die Erde 1st nur ein Punkt im Weltall. Das Prinzip der Mechanik, dem, wie Galilei und Newton entdeckt und nachgewiesen hatten, alle Bewegungen im Universum unterworfen sind, der 'fallende Apfel hier und der kreisende Komet dort', 9 diente nicht nur zux Erklarung der astronomischen und physikalischen Erscheinungen. Wie durch die galileische Mechanik der Unterschied zwischen der irdischen Welt und den 'himmlischen Sphăren' 
aufgehoben wurde, so auch der zwischen der unbelebten Materie und den Organismen. Descartes hat die Tiere grundsătzlich als komplizierte Automaten angesehen und ihnen, wenn auch nicht eindeutig, seelisches Leben abgesprochen. 10 Den Menschen hat er als unbegreifliche vereinigung zweier verschiedenartiger Substanzen verstanden, dex răumlichen und der bewubten. Die Frage, wie Geist und körper bei dem vorausgesetzten Substanzendualismus aufeinander wirken können, hat Descartes nicht eindeutig beantwortet. Die Funktionen des Körpers hat er aber als mechanische Prozesse gedeutet. ${ }^{11}$ Bestătigt wurde diese Auffassung z.B. durch die Entdeckung des Mechanismus des Blutkreislaufs, die Harvey 1626 gelungen war. SchlieBlich fiel dem mechanischen Prinzip Galileis auch der Unterschied von Körper und Seele zum Opfer, den Descartes beharrlich behauptet hatte. Diese Konsequenz ist von Bacon und Hobbes gezogen worden. Für sie gehort die Sphăre des Bewritseins wesentlich zur kơrperwelt hinzu. Nach ihrer Auffassung sollen "Vorstellungen und willenstatigkeiten, wie sie durch die Erfahrung bekannt sind,... im Grunde auch Tătigkeiten des Leibes sein." 12 Geistige Funktionen wie Gedāchtris und Denken kommen nach Hobbes dadurch zustande, daB sich die sinnesempfindungen, die als einzige Elemente des BewuBtseins gelten, von Lust bzw. Unlust motiviert, verknüpfen und umbilden."13 so hat die mechanistische Naturerklărung alle Bereiche der Wirklichkeit erfaBt und am Ende sowohl zum kosmischen wie zum anthropologischen Materialismus geführt. Von Bacon und Hobbes geht eine direkte Linie zu de Lamettrie, der seinen schroffen anthropologischen Materialismus in dem viel genannten Buch L'homme machine(1748) dargelegt hat. Nach inm besteht zwischen Mensch und Tier nur ein gradueller Unterschied. Die geistigen und seelischen Tătigkeiten des Menschen werden als Funktionen der erregten Gehirnfasern erklät.

Die Krise des menschlichen Selbstverstăndnisses, durch den 'kopernikanischen Schock' hervorgerufen, äußert sich in einem pessimistischen und melancholischen Lebensgefühl, wie es z.B. aus der Titelzeichnung A.Popes zum 'Essay on Man' spricht. 14 Sie zeigt vor der Ruinenkulisse der 'Roma aeterna' neben einer zerbrochenen Saule einen Mann, der Seifenblasen in die Luft blăst. Im Vordergrund ist das zerstorte Standbild eines 'unsterblichen' Feldherrn zu sehen. Die Inschrift am Sockel lautet: Sic transit gloria mundi. So zeichnet Pope das Lebensgefühl der hinter ihm liegenden Epoche, zu dessen Uberwindung der 'Essay' beitragen soll. w.Philipp schreibt: "Ausweglosigkeit ist das Kennzeichen barocker Weltanschauung.... Verzweiflung da- 
rüber, daß alles Schōne Beute des Todes 1st...selbst der Zugang zur Ewigkeit ist nicht zu finden, die Ewigkeitsvorstellung ist 'nihilistisch'." 15 Hăufig wiederkehrende Metaphern in der Zeitdichtung lauten: "Ein Nichts ist die Welt, Rauch, Staub, Grab, ein Blitz in der Nacht grenzenloser 'Ewigkeit'. "16 W.Philipp widerspricht der landlăfigen Auffassung von der 'herrlichen barocken Hochkultur" des 17.Jahrhunderts und weist auf den "kompensatorischen Charakter des barocken kulturellen Pathos" hin, das "ein Oberflăchenerbe der Renaissance darstellt über der Tiefe der Weltangst." 17 Die "qualvolle kosmologisch-anthropologische situation des Barock" 18 spricht aus den philosophischen Schlagwortern der Zeit: Nihilismus, Materialismus, Atheismus, Deismus, Skeptizismus, Epikureismus, Atomismus u.a., in denen zumeist 'hellenistische Philosopheme' wieder auftauchen. Im apologetischen und polemischen Reflex werden diese Lehren bzw. die Namen ihrer Vertreter auch in der Feoptija sichtbar, z.B. 'arenct' $(I, 471)$, 'пантеист' $(I, 460)$, ' сцептики неверные' (I, 116), 'безбожные люди' (I, 134), 'Эпикур' (I, 446), Спиноза' (I, 455). Неftig wird auch das Zufallsprinzip bestritten, das bei Epikur eine betonte Rolle spielt (z.B.I,212ff.).

Der Kampf gegen die Deisten und die genannten 'destruktiven Ideen' 19 hat im Zeichsn eines neu begründeten Glaubens an den Schopfergott in England begonnen. Worum es geht, zeigt einprăgsam das Titelblatt der 'Religio medici' von Thomas Browne(1643). "Mit verzerrtem Gesicht stürzt der Mensch von einsamex Felsnadel rücklings ins unendliche Meex (dex kosmisch-anthropologische Schock). Eine Hand aus den Wolken ergreift den Stürzenden zwischen Himmel und Erde", 20 sinnbild für eine neue sicherung des Menschen durch den theistischen Gottesglauben. Von England aus hat sich die physikotheologische Bewegung schnell nach Holland und Frankreich ausgebreitet. In Deutschland war Hamburg in ersten Drittel des 18.Jahrhunderts ein physikotheologisches Zentrum. Hier unterhielt der Kreis um Joh.Albert Fabricius enge Kontakte mit den englischen Physikotheologen. 21

Der Schopfungsglaube der Physikotheologen ist nicht an ein bestimmtes Weltbild gebunden. In den Schriften der führenden britischen, hollandischen und deutschen Physikotheologen wird das kopernikanische vorausgesetzt. Wie Fénelon und Tred. darüber denken, wird an den Texten zu zeigen sein. Der britische Physikotheologe William Derham gibt in seiner hăfig aufgelegten 'Astrotheologie' -die 5.deutsche Auflage erschien 1765 in Hamburg-"eine do- 
xologische astronomische Demonstration der Existenz und Eigenschaften Gottes." 22 Selbst die erschreckende Dimension des Unendlichen wird von den Physikotheologen positiv gedeutet. So schreibt Chrstian Huygens im 'Kosmotheoros' (1698): "Zu Gott aber, dem Urheber aller dieser großen Welten, wie anders als im Geiste tiefster Ehrfurcht wird er zu ihm aufzuschauen haben?" 23 Die Vielzahl der Welten ist also kein Argument mehr für den kosmischen Nihilismus. Die Majestăt des Schŏpfers wird durch sie um so größer.

Der scholastische Wunderbegriff, der besagt, daB Gott von Fall zu Fall die Trennwand zwischen Himmel und Erde wunderbar aufhebt, erscheint klein gegenuber der physikotheologischen Auffassung vom Nunder, wie sle z.B. von Mathias Hale in seinem Buch 'Vom Ursprung des Menschengeschlechtes' (deutsche Ubersetzung 1683) ausgesprochen wird: "Ich aber unterstehe mich dagegen zu sagen, daB in der Tat selbsten soviel manderwerke sind, ...als Werke in der Natur oder soviel als Creaturen selbst gefunden werden." 24 W.Philipp urteilt: "Damit wird die Bewegung der Physikotheologie weithin zur Theologie des Wunders in einem spezifischen sinne und begegnet der bisher schwersten anthropologischen Katastrophe." 25

Wie ihre materialistischen Gegner bejahen auch die Physikotheologen die induktive Methode. Sie studieren die Natur im GroBen wie im Kleinen. Allerdings kommen sie zu den entgegengesetzten Folgerungen. In ihren Hănden werden Teleskop, Mikroskop und Seziermesser Hilfsmittel, mit denen sie die Wunder der Schöpfung entdecken und betrachten. Es ist bezeichnend, daB sich unter den Physkotheologen auffallend viele Physiker, Optiker, Naturforscher und Arzte befinden. Der Optiker und Physiker Nicolaus Hartsoeker in Paris polemisiert in seinen 'Principes de Physique'(1696), gestützt auf eigene Beobachtungen der Gestirne, gegen das zufallsprinzip: "... nie kann ein gesunder Mensch davon überzeugt werden, daB sich der Kosmos durch zufalliges Zusammentreffen einer unendlichen $\mathrm{Zahl}$ von Atomen gebildet habe..." 26 Von der Gesetzmåigkeit und Harmonie des Universums leitet W.Derham in der 'Astrotheologie' den Glauben an den Schöpfer her und fahrt fort: "Denn es ist ein Kennzeichen, daB einer ein recht mutwilliger, boshafter und gottloser Atheist sei, der ein so herrlich Werk, wie die Schopfung ist, viel lieber einem andern, wer weiB was, ja einem bloßen Nichts (dergleichen der blinde Zufall ist) zuschieben will als dem groBen Gott." 27

Neben dem Fernrohr wurden Mikroskop und Seziermesser zu 'Devotionalien' der neuen Bewegung. Th.Browne lehrte in seiner 'Religio medici'(1643) die 
Andacht zum Kleinen: die Bienen, Ameisen und Spinnen seien gröBere Wunder als die Giganten der Tierwelt. ${ }^{28}$ M.Hale "berichtet ergriffen uber den Feinbau der winzigen Wesen unter dem Mikroskop." 29 Die Physikotheologen beobachten die Fische und Frösche, die Heuschrecken und Grashüpfer, die Insekten, den Seidenwurm und die Bienen. Aus dem Beobachten komen sie ins 'Betrachten' und 'Erwăgen' und zum Lobpreis des Schopfers. Die Titel ihrer Schriften -w.Philipp führt einen Katalog an- muten vielfach kurios an: es gibt eine Ichthyo-, Rana-, Akrido-, Locusta-, Insecto-, Bombyco- und Melittotheologie. ${ }^{30}$ Nichts ist zu gering oder zu ausgefallen, als daB es nicht die Herrlichkeit des Schopfers reflektierte. Gott ist gerade 'in minimis maximus', bekennen die Verfasser dieser Schriften.

Mit den Wundern der Tierwelt befaBte sich Hexmann Samuel Reimarus in dem Buch 'Programina de instinctu brutorum, existentis del eiusdem sapientissim1 indice' (Wismar,1725). Die Wunder der Pflanzenwelt zeigte Bernhard de Rohrs in seiner 'Phytotheologie'. Joh.Albert Fabricius(1688-1736), der Funrer des Hamburger Kreises der deutschen Physikotheologen, hat, durch die Axbeiten W.Derhams angeregt, die 'Ocular-Theologie', eine 'Hydro- und PyroTheologie verfaßt und andere physikotheologische Werke ubersetzt und eingeleitet.

Im Mittelpunkt des Interesses der Physikotheologen steht jedoch der Mensch. Seine von den Materialisten geleugnete Würde als Geschópf Gottes wollen sie herausstellen. Darum suchen sie bel der Betrachtung der kreaturen den 'Nutzen' aufzuzeigen, den diese für den Menschen haben. Die Teleologie der Schopfung, so meinen die Physikotheologen, 1st auf den Menschen bezogen. Diese anthropozentrische sinndeutung der Welt kann, wie das physikotheologische Schrifttum nicht selten erkennen laBt, zum Utilitarismus ausarten. Neben dem materiellen wird aber vielfach auch der moralische und padagogische 'Nutzen' hervorgehoben, den Tiere, Pflanzen und Naturerscheinungen fur den Menschen haben.

Die Materialisten hatten den Menschen als eine zufallige Gruppierung von Atomen angesehen und seine Seele als mechanische Funktion der Gehirnfasern erklart. Was ist der Mensch wirklich? Der fürende Anthropologe des 17.Jahrhunderts, M.Hale, kommt in seinem 'Ursprung des Menschengeschlechtes' (1683) zu dem Ergebnis, das von w.Philipp so zusammengefaBt wird: "...der Mensch ist nach Seele und Leib ein Beweis von Gottes Sein und Leben. Ex 1st nicht Zufallsstăubchen auf dem Staubkorn eines geringen Sterns, sondern der Ab- 
glanz gottlicher Wundermacht..." 31 Das ist der Grundgedanke dex verschiedenen anthropologischen Arbeiten. Uber den Korperbau des Menschen und seine Physiologie veroffentlichen Joh.Christoph Hebenstreit und Anton Wilhelm Platz inre 'Dissertatio de corporis humani machina, Divinae sapientiae teste' (Leipzig,1725). Ein Jahr darauf erscheint in Marburg die 'Dissertatio de existentia Dei ex stupenda mentis cum corpore unione demonstrata' von Franz Ulrich Ries, 32 die das seit Descartes viel diskutierte Problem der Vereinigung und Wechselwirkung von Leib und Seele zum Gegenstand hat. -Wie verhalt es sich mit der Anatomie des Magens oder des Herzens? Solchen Untexsuchungen widmet sich der hollandische Arzt Bernhard Nieuwentyt in seinem 1715 in Amsterdam veroffentlichten Buch 'Die Erkenntnis der Weisheit, Macht und Güte des göttlichen Wesens aus dem rechten Gebrauch dex Betrachtungen aller irdischen Dinge dieser Welt zur Uberzeugung der Atheisten und Unglăubigen'. 33 In den dreiBig Betrachtungen nehmen die anthropologischen Themen breiten Raum ein. Es geht u.a. un die Anatomie und Physiologie der Speiseröhre, des Magens, der Eingeweide und des Herzens. Ferner werden die Vereinigung von Leib und Seele, das Gedăchtnis und die Phantasie 'betrachtet'. In demselben Werk werden Wasser, Exde und Feuer, auch die Tiere, vogel und Fische unter physikotheologischem Blickwinkel geschildert. Es ist dieselbe Thematik, die uns in der Feoptija begegnet.

Das Buch B.Nieuwentyts ist dem 1712 veroffentlichten 'Traite de l'existence et des attributs de Dieu' Fenelons in seiner Thematik und Tendenz unmittelbar benachbart. Im ersten Teil des 'Traite' bietet der Autor, Francois de Salignac de la Mothe-fénelon, eine 'Demonstration de l'existence de Dieu, tirée du spectacle de la nature et de la conaissance de l'homme', die Tred. als quelle für die Feoptija benutzt hat. Die 'Démonstration' Fenelons exschien bereits 1714 in Hamburg in deutscher Ubersetzung. sie wird in der Bibliographie von H.Fromm, Bd.3,S.25 untex dex Nr.8995 aufgeführt: 'Demonstration de L'existence de Dieu -Augenscheinlicher Beweis, daB ein Gott sey', Hamburg 1714. Dex Name des Ubersetzers ist nicht angegeben.

Deutliche Anklánge an verschiedene Passagen der 'Démonstration' lassen sich in den Gedichten von B.H.Brockes nachweisen. So bewundext 2.B. Brockes in einem seiner Gedichte die schönheit und den Nutzen der Gebirge, die damals im allgemeinen noch als unheimlich und wild angesehen wurden. Fenelon schreibt: "L'inégalité meme des terroirs, qui paxalt d'abord un defaut, se 
tourne en ornement et en utilite." 34 Darauf schildert er die Bergwelt von den Rebhügeln im Vorland bis hinauf zu den Gletschern. Ein ăhnliches Bild zeichnen die folgenden Verse aus dem 'Irdischen Vergnügen...' :

Ob nun gleich der Berge Spitzen

Oed' und grausam anzusehn;

sind sie doch, indem sie nützen,

Und in ihrer GroBe schön... 35

Der Vergleich Fénelons, "Les rochers...soutiennent la terre des montagnes, comme les os du corps humain en soutiennent les chairs" 36 findet sich auch bei Brockes. Er sagt von der Erde:

Ihres Körpers Fleisch aus Leimen,

Ihre Knochen, Fels und Stein. -37

Die Erwăgung, was wăre, wenn die Erde hărter oder weniger hart wăre, als sie ist, findet sich sowohl in der 'Démonstration' wie im 'Irdischen Vergnūgen'. Fénelon schreibt: "Si elle était plus dure, l'home ne pourrait en ouvrir le sein pour la cultiver; si elle etait moins dure, elle ne pourrait le porter; il enfoncerait partout..." 38 Brockes stellt die Erwăgung so an:

Denn das ganze Rund der Erden

Konnt ohn' ihre Festigkeit

Nicht von uns bewohnet werden.

Ohne die Beschaffenheit

MüBten wir zu Grunde sinken...

wăre sie zu fest hingegen

Und nicht kornicht, feucht und naB;

Wüchsen solcher Hărte wegen

Weder Băume, Laub noch Gras. 39

Auch Brockes' Gedicht 'Dex Regen' erinnert an eine Stelle der 'Demonstration'. Die Betrachtung geht von der Frage aus, wie es zugehe, daB sich die schweren Wolken in der Luft halten. Fénelon schreibt: "S'ils tombaient tout a coup par de grosses colonnes d'eau... ils submergeraient et detruiraient tout dans l'endroit de leur chute." Darauf folgt die bewundernde Frage: "Quelle main les tient dans ces reservoirs suspendus, et ne leur permet de tomber que goutte a goutte..." 40 Ahnlich heiBt es in dem Gedicht von Brockes: 
Alles aber ward ersaufen,

Brechen und $z u$ trümern gehn,

Wenn der Wolcken Fluht mit Haufen

Von den ungeheuren $\mathrm{B}$ ohn,

Als ein' allzuschwere Bürde,

Unzertheilet fallen würde; -

Drum schafft Gott, daB sich der Regen

Durch die Luft nux tröpfelnd drăngt.-

Nimm, o Mensch, in uns in Acht

Gottes Lieb' und weise Macht. 41

Die Beispiele lieben sich vermehren durch Gedichte im 'Irdischen Vergnūgen', die 'das Wasser', 'das Feuer', 'die Luft', 'die fünf sinne', die wăchserne Anatomie' U.a.m. zum Gegenstand haben. Hierzu finden sich Parallelen sowohl in der 'Demonstration' wie in der Feoptija. Die Themen gehoren, wie es scheint, zum Repertoire der Physikotheologen, da sie auch von anderen Autoren behandelt worden sind. In den angeführten Beispielen ist aber die Ahnlichkeit mit bestimmten Passagen der 'Demonstration' nicht nur thematisch bedingt. Interessant ist, daB auch Verse der Feoptija, die von der 'Demonstration' unabhängig sind, in Gedichten von Brockes anklingen. So z.B. Feoptija, Ep.II, 285f.:

\section{0! промысл, стужа гае несноснейше ярится, \\ В тех более странах густых лесов и зрится.}

In dem Gedicht 'der Winter' von Brockes heiBt es:

Gott hat, o weise Wunder-Macht!

Die man onn Ehrfurcht nicht ermiBt,

$\mathrm{Da}$, wo das meiste Holtz vonnothen ist,

Das meiste Holtz hervorgebracht. -42

D.F.Strauß hat "die ganze Brockes'sche Naturpoesie...einen gereimten physico-theologischen Beweis" genannt. " 43 Die Auffassung von StrauB, Brockes sei ein Wegbereiter des Deismus, wird jedoch durch den Lobpreis der creatio continua in der Brockes'schen Lyrik widerlegt. Das zeigen folgende Verse:

Ein heller Andacht-Strahl begeistert mein Geblüte....

Es flammt in meiner seelon

Ein Trieb, was herrliches vom Schopfer zu erzălen, 
Der alle Dinge wirckt, belebt, regiert, erhalt,

DeB Wesen ich mit Lust in seinen Werken sehe. 44

Der preisende Ton dieser Verse ist für Brockes bezeichnend. W.Philipp hebt hervor, daB bel Brockes "das Lichterlebnis uber der Schopfung....eine kennzeichnende Brillanz" zeige. 45 Das zentrale Anliegen der Physikotheologen 1st, den Schópfer zu verherrlichen. W.Philipp exklărt: "Da Sinn und Sein der Geschópfe allein darin besteht, Reflex der Doxa zu sein, ist das (bewundernde, beschreibende, statistische, naturforschende) Bemühen der Bewegung Doxologie im engsten Sinne." 46

Zum Glauben an den allmăchtigen, weisen und gütigen Schöpfer gehơrt für die Physikotheologen die GewiBheit, daB alles Geschaffene dem Wohl des Menschen dient. Diese teleologische sicht schliebt aber das mechanische Prinzip der Naturwissenschaft nicht aus. Der Kausalzusammenhang des Naturgeschehens ist vielmehr so angeordnet, daB er den von Gott gesetzten Weltzweck erfullt. Leibniz hat mit seiner Lehre der 'harmonie prétablie des substances' die metaphysische Begründung für die optimistische Weltanschauung der Physikotheologen gegeben. Der Leitgedanke seiner Philosophie besteht darin, mechanische und teleologische Weltanschauung, wissenschaftliches und religioses Interesse in Einklang $2 u$ bringen. 47

wie laBt sich jedoch der Optimismus, wie ihn die Formeln von der 'besten unter den möglichen Welten' (Leibniz), oder 'whatever is, is right' (Pope) zum Ausdruck bringen,mit der Tatsache des Ubels vereinbaren? Ist die Welt denn so vollkommen, daB sie den physikotheologischen Beweis für die Existenz eines allmăchtigen, weisen und gütigen Schơpfers trăgt? Pope hat sich im 'Essay on Man' auf die Antwort berufen, die Shaftesbury auf die Frage der Theodizee gegeben hat. Nach seiner Auffassung verschwindet alle Unvollkommenheit des einzelnen in der Vollkommenheit des Universums, jeder MiBklang 18st sich in der Harmonie der Welt. ${ }^{48}$ Diese Anschauung spricht aus den Versen Popes:

All Discord, Harmony, not understood;

All partial Ev1l, universal Good. 49

Die Physikotheologen haben sich hăufig auf die Gedanken der Theodizee Leibnizens berufen. Er hat so argumentiert: Aus den dunklen und verworrenen Vorstellungen der niedersten Monaden, die die Materie bilden, folgen notwendig die verworrenen Sinnentriebe, welche die Motive der Sünde sind. In einer 
sittlichen Weltordnung haben die moralischen thel die physischen zur Folge. Aus der Sünde folgt das Leid, das als Strafe für die sünde zu verstehen ist. Das moralische Ubel ist aber in der Endlichkeit und Begrenztheit der Geschöpfe begründet. Es bleibt nur die Frage, weshalb Gott das moralische Ubel zugelassen hat. Darauf antwortet Leibniz: Die Endlichkeit gehört zum Begriff des Geschópfes, das damit zugleich unvollkommen ist. "Eine Welt, die aris lauter vollkommenen Wesen bestünde, ist eine contradictio in adiecto." 50 Eine Welt ohne Ubel ist deshalb undenkbar. Gott hat aber in seiner Gute dafür gesorgt, daB es so wenig Ubel wie möglich gibt. Wenn Gott aus einer unendlich großen Zahl von möglichen Welten diese wirkliche Welt geschaffen hat, so kann ihn wegen seiner Güte nur die Wahl des Besten geleitet haben. Daraus folgt: diese Welt ist die Welt der kleinsten Ubel. In diesem Sinne ist sie die 'beste unter den möglichen Welten'. 51

Einen Bundesgenossen, der ebenfalls für die theonome Weltdeutung eintrat, hatten die Physikotheologen in Isaac Newton(1642-1727). Auf der einen Seite hat Newton durch die Entdeckung des Gravitationsgesetzes das mechanische Prinzip des Weltzusammenhanges hervorgehoben. Andererseits hat er den Weltmechanismus als Ganzen auf den Schöpfer zurückgefuhrt, indem er ihn analog zu den von einem menschlichen Techniker gebauten Maschinen oder Uhren verstanden hat, die sich durch ihre kunstvolle und zweckmäBige Konstruktion als Werk einer überlegenen Intelligenz ausweisen. So nimmt Newton am SchluB seiner 'Mathematischen Prinzipien der Naturphilosophie'(1686) das Argument auf, das G.Bruno als schărfste waffe gegen den Glauben benutzt hatte. Newton schreibt: "Und wenn jeder Fixstern Mittelpunkt eines dem unsrigen āhnlichen Systems ist, so muB das Ganze, da es nach einheitlicher Absicht konstruiert erscheint, das Reich ein und desselben Herrschers bilden. Es folgt daraus, daB Gott ein lebendiger, einsichtiger und allmãchtiger Gott ist, $\mathrm{daB}$ er uber das Weltganze erhaben und durchaus vollkommen ist. Es ist klar, daß der hochste Gott notwendig existiert, und kraft derselben Notwendigkeit existiert er uberall und $2 u$ jeder zeit." 52 Damit hatte die vorstellung von einer 'Vielzahl der Welten' ihren Schrecken verloren.

Der anthropologische Nihilismus der Materialisten füht zur vereinzelung des Menschen und wird vom Gefühl der Einsamkeit des einzelnen begleitet. Wenn sich der Mensch als zufällige Anhăufung von Atomen verstehen muB, geht die persönliche Beziehung zum anderen verloren. Mit dem neuen Selbstverstăndnis des Menschen als Geschöpf Gottes entsteht ein neues menschliches Mitein- 
ander. W.Philipp weist auf die Bedeutung hin, die der Begriff der Menschheit in den physikotheologischen Schriften hat: "Nun erst tritt die Menschheit als echtes Gegenüber in den Gesichtskreis mit ihren eigentümlichen Werten, ihrem religiosen und ethischen Besitz." 53 Der Gedanke der 'Brudergeschöpfe auch in den Naturvolkern', 54 z.B. bei den Indianern (Essay on Man, I.99ff.) wird aktuell. In der Feoptija zeigt etwa der Abschnitt über den völkerverbindenden Ozean in diese Richtung. Der Ozean ist dazu bestimmt, "4то6 меж со6ой весь род был человеч собщенный"(II,411). Gott will, daß die Menschen im gegenseitigen Geben und Nehmen freundschaftlich zusammenleben: "не явно ль хочет бог нам меж собой жить аружно?'(II,198). Die Wertschătzung des 'o6щестBO', veranschaulicht durch den Vergleich mit dem Bienenstaat (Feopt.III, 210ff.), bringt die 'sozialethische Valenz'(Philipp) des anthropologischen Selbstverstăndnisses der Physikotheologen zum Ausdruck. Dem korrespondiert auf der anderen Seite die Geringschatzung des kriegerischen Heldentums:

II,133f. Един сей плод всегда от славных всех героев, От Аействий громких тех и от несчетных воев.

Bauer und Hirt sind für die Menschen von gröBerem Nutzen als der nur auf eigenen Ruhw bedachte 'Held' (II,135ff.)

In der theozentrischen Naturauffassung haben auch die Tiere einen Platz als Mitgeschöpfe, in denen sich ebenfalls die Herrlichkeit des Schópfers widerspiegelt. Ihre Kunst und Geschicklichkeit wird dem Menschen hăufig als Vorbild vorgestellt. P.Hazard zitiert aus einem Brief Lafontaines an Mme de la Sablière: "Ich erblicke bel den Tieren nicht eine Vernunft nach unserer Art....aber doch viel mehr als einen blinden Antrieb." 55 In der Feoptija ist die III.Epistel ausschließlich den Tieren gewidmet, denen im widerspruch zu der These Descartes' eine Seele zuerkannt wird, wenn diese auch nicht von menschlicher Art ist. Die Mechanismustheorie wird verworfen:

III,921f. Против Декарта весь наш општ вопиет, Что мысли Он и чувств животным не дает.

Das Gottesbild der Physikotheologen trăgt väterliche Züge, ohne daB die Majestăt des Schopfers zurückstănde. Dem kosmischen Nihilismus entsprach das numen tremendum. Im physikotheologischen schrifttum begegnet uns dagegen die biblische Aussage von Gott, dem Vater und allmăchtigen Schopfer, der den Menschen $z u$ seinem Bilde geschaffen hat. Das angemessene Verhalten Gott ge- 
genuber besteht nicht in Furcht und zittern, sondern in Liebe und Lobpreis:

$$
\begin{aligned}
& \text { IV, } 5 \text { ff. Возвеличим силу всемогущего твориа } \\
& \text { И возлюбим сердчем чадолюбного отца; } \\
& \text { ОН, Евсевий, сотворил нас себе собразно, } \\
& \text { По подобию создав своему, не разно. }
\end{aligned}
$$

Zum geistesgeschichtlichen Hintergrund der Feoptija gehören schlieBlich scholastische Denkformen, die in den apriorischen Gottesbeweisen der I.Epistel, in den Syllogismen und Definitionen, sowie in der Ableitung der Attribute Gottes aus metaphysischen Prämissen(vorwiegend in der VI.Epistel) vertreten sind. Elemente der orthodoxen Kirchenlehre finden sich ebenfalls zum gröBten Teil in der VI.Epistel. Hier geht Tred. uber die Thematik des Schöpferglaubens hinaus, die in der physikotheologischen Literatur sonst vor allem behandelt wird. In der Passage über den 'ходатай' (Ep.VI,600-615) erscheint das zentrale Thema der Christologie in der Feoptija.

\section{Die Uberlieferungsgeschichte der Feoptija}

Tred. hat das Poem wegen seines im wesentlichen philosophischen und theologischen Inhalts der geistlichen Zensurbehörde des Synod in Moskau vorgelegt und un die Druckerlaubnis gebeten. Auf Grund eines von Bischof Gabriel von Kolomna verfaBten Gutachtens stellte das Synodalbūro am 24.Februar 1755 ein 'imprimatur' aus, in dem bescheinigt wird, daß in der Feoptija "...никакой противности Церкви святой не присмотрено..."' Seiner sache nunmehr sicher, wandte sich Tred, an 17.Mărz 1755 an den Prăsidenten der Akademie, Graf Razumovskij, und bat un die Erlaubnis, die Feoptija und den ebenfalls von der geistlichen zensur gepruften Psalter auf eigene Kosten in der Typographie der Akademie drucken zu lassen. 2

Darauf antwortete ihm die Akademiekanzlei, die Būcher könnten erst dann gedruckt werden, "...когда начатыя в типографии книги будут окончены печатанием." ${ }^{3}$ Gleichzeitig wurde dem Autor nahegelegt, die Būcher in der synodaltypographie in Moskau drucken zu lassen. Tred. reagierte verargert: wenn seine Bücher erst an die Reihe kommen sollten, nachdem alle anderen, die in der Druckerei lägen, fertig seien, "... иего ни мне, ни внукам моим не домдаться..." ${ }^{4}$, so möge man ihm seine Bücher gleich zurückgeben. Das sollte nichts anderes heiBen, als daB der Autor es mit der veroffentlichung eilig 
habe. Er wiederholte deshalb sein Anliegen, die Feoptija in 600 Exemplaren auf eigene Rechnung in Petersburg drucken zu lassen und gab die gewinschte Papiersorte, das Format und die Drucktypen an. 5 Die Akademiekanzlei griff jedoch nur das Stichwort 'Rückgabe' auf. Scheinbar korrekt, kam man dem Wunsch des Autors nach und schickte inm das Manuskript am 22. August 1755 zurück. Tred. erhob vergebens Einspruch gegen die falsche Auslegung seines Briefes. Dabei beanstandete er, daB das Siegel, mit dem er seine Bücher dem Prăsidenten zugeschickt hatte, bel der Rückgabe nicht mehr vorhanden war und auBerte den Verdacht, das Manuskript konnte ohne seine Erlaubnis abgeschrieben worden sein:"... имею nо сему подозрение, что не списал ли их кто, и буде они списаны сверх моего позволения, то Канцелярия вияит, ито сиё мне весьма предосудительно. 16 Die beseitigten Siegel lassen vermuten, daB das Manuskript der Feoptija, wathrend es sich in der Akademie befand (vom 17.Mărz bis zum 22.August), geprüft worden 1st. Die kaum verhüllte Ablehnung der Publikation paBt in eine Reihe ahnlicher Manipulationen, mit denen es Tred. schwer gemacht wurde, seine Arbeiten herauszubringen: schon 1754 war die Veroffentlichung der 'Geschichte der Antike' eingestellt worden. Seit dem Sommer 1755 nahmen die von der Akademie herausgegebenen 'Ежемесячния Сочинения' keine Beitrăge Tred.s mehr auf. Seine Gegner in der Akademie wollten ihn literarisch zum Schweigen bringen. 7 Ein abermaliges Gesuch vom 29.Sept.1755 an den Prăsidenten der Akademie wegen der Veröffentlichung der Feoptija hatte gleichfalls keinen Erfolg.

Im April 1757 schlug Tred. einen anderen Weg ein: er wandte sich an den Synod mit der Bitte, die Feoptija und den Psalter in Moskau 2 drucken. Geschickt brachte er vor, daB viele fromme Leute diese Bücher $z u$ lesen und abzuschreiben wünschten. Ex habe aber die Sorge, die Abschreiber kónnten Irrtüer in das von der kirchlichen Zensur gepruft original eintragen und AnstठBiges hinzufügen: "...опасаясь, чтоб преписатели не внесли в списки важных каких погрешности и тем не нанесли в предосуждения. 8 Еx appelliert also an das Interesse der Geistlichen Behörde, keine Verwirrung in Glaubensfragen aufkommen $z u$ lassen. AuBerdem weist Tred. auf den geistlichen Inhalt der beiden Werke hin, so daB kirchliche Drucktypen angemessen seien: "Cии причины возбудили во мне желание ныне, чтоб помяненные книти напечатать иерковным тыпом, как по всему ауховные...19 Am Schluв seines Bittschreibens verpflichtet sich Tred., die Kosten für den Druck von 600 Exemplaren zu ubernehmen, bittet jedoch um die stundung der summe,"...и6о я человек весьма не- 
богатый, так ито не продав книг, не могу иметь подлежащия тоя суммы..."10

Der Synod erklärte sein Einverstădnis und wies die Symodaltypographie an, das Manuskript Tred.s zu drucken. Dem Erscheinen der Feoptija und des Psalters schien nichts mehr im Wege zu stehen. Schon hatte sich Tred. mit den Korrektoren der 'московская древняя типография' wegen der Verwendung der kirchlichen Lettern in Verbindung gesetzt. Da kamen unerwartet neue Schwierigkeiten: "Несмотря, однако, на разрешение синода, судьбе не уродно било, чтобы Псалтырь и Феоптия Тредиаковскаго были напечатаны."11 Die Texte blieben mehr als ein Jahr ungedruckt liegen. Dann reichte die Druckerei dem Synod einen von dem stellvertretenden Direktor Afanasij Pel'skij und dem Korrektor Grigorif Kondakov verfaBten Bericht ein, dem eine Liste der von ihnen beanstandeten Stellen der Feoptija beigefugt war. Offensichtlich erregte die 'Выписка о сумнительствах, в Феоптии находящихся', in der eine Anzahl von Versen von den Zensoren als 'противоречащие священному писанию' 12 bezeichnet worden waren, die Bedenken des Synod, so daB die Feoptija nicht gedruckt wurde.

Man fragt sich, was die Druckerei veranlaBt haben mag, ein Manuskript, dem das kirchliche Imprimatur bereits erteilt worden war, nochmals zu prüfen. Waren die beiden Zensoren ubereifrig, oder sind sie von bestimmter Seite beauftragt worden, 'zweifelhafte' Anschauungen Tred.s in der Feoptija aufzuspuren? Es ist bekannt, daB die Furcht vor atheistischen und materialistischen Irrlehren damals im orthodoxen Klerus akut war. Das Verbot der VerOffentlichung des ins Russische ubersetzten 'Essay on Man' im Jahre 1756 ist ein Anzeichen dafur. In dieser Lage wurde jede literarische Neuerscheinung beargworhnt. Dies galt in besonderem MaBe für ein Manuskript aus der Feder Tred.s.

Im Laufe von 200 Jahren konnten nur einzelne Fragmente der Feoptija veroffentlicht werden. So hat Tred. In seinem Aufsatz ' 0 древнем, среднем $n$ новом стихотворении российском'(1755) 10 Verse aus seinem Poem als Beispiel für den 6 füBigen Chorăus und Jambus verwendet. ${ }^{13}$ weitere 12 verse aus der Feoptija hat Tred. In seiner Tragödie 'Aеидамия'(1750) zitiert, die erst nach seinem Tode gedruckt wurde (1775). ${ }^{14}$ Durch eine Abhandiung von M.P. Pogodin 'O Феоптии B.K.Tреяиаковскаго', die im 'Москвитянин' 1851, N19-20, стр.536-552 erschien, wurden insgesamt 104 verse aus der Feoptija bekannt. ${ }^{15}$ Das Poem wurde von N.I.Novikov in seinem 'Опыт исторического словаря' (1772) 
unter den unveroffentlichten Werken Tred.a aufgefüht, die anscheinend von 'seiner Witwe und seinem Sohn L.V.Trediakovskif aufbewahrt wurden'. ' 16 zur Feoptija heibt es bei Novikov: "Феоптия и богозрение. Сия книга сочинена стихами, состоит из шести зпистол, из которых пред камдою описана сила ее прозор; но сила всей книти объяснена рассуждением, служащим вместо предисловия."17

Die Feoptija galt seitdem als verschollen. Im Jahre 1959 entdeckte I.Serman unter den Akten der Synodaltypographie in 'Государственном архиве древних актов'(f.381) die Manuskripte der Feoptija und dex Psalmenubersetzung Tred.s. Eine weitere Abschrift der Feoptija wurde von I.Serman im 'apxивe Ленинградского отделения Института истории АН СССР (в коллекции автографов Н.П. Лихачева) 18 gefunder.

Von seinem Fund berichtet I.Serman: "...нам удалось обнаружить три идентичных рукописи Феоптии. Все они имеют следуоций титульный лист:

"ФЕОПТЯ

или

ДОКАЗАТЕЛЬСТВО

0

БОГОЗРЕНИИ

ПО ВЕЩЕСТВАМ СОЗДАННОГО ЕСТЕСТВА, СОСТАВЛЕННОЕ СТИХАМИ

В ШЕСТИ ЭПИСТОЛАХ К ЕВСЕВИЮ

OT

ВАСИЛИЯ ТРЕДИАКОВСКОГО

B CAHKTIETEPEYPIE

$1754^{119}$ 


\section{Kapitel}

\section{Textbegleitende Interpretation}

\section{I.Epistel: Philosophische Beweise für die Existenz Gottes}

Tred. hat der Feoptija das Wort aus dem Römerbrief des Apostels Paulus, Kap.1,20 in kirchenslavischer Fassung vorangestel1t:

Невияимая бо его от создания мира твореньми помышляема, видима суть, и присносущная сила его и божество, во еже им безответным.

К римлянам. Глава 1, ст. 20

Es ist die Kernstelle fur die theologische Lehre der revelatio generalis, der zufolge dex Mensch ein ursprüngliches Wissen um Gott hat. Gott ist zwar unsichtbar, aber er hat die Welt geschaffen, "und in dieser seiner Schöpfung zeigt er sich seither dem Auge des Geistes als der allmăchtige und überweltliche Herr. Das Werk bezeugt den Wirker. So läBt sich des Menschen Gottlosigkeit durchaus nicht entschulaigen." 1 Die Schuld des Menschen besteht darin, daB er Gott, dessen ewige Macht und Majestät er aus den Werken der Schöpfung erkennen kann, in seinem selbstherrlichen willen nicht als seinen Herrn anerkennen will.

Die Physikotheologen haben sich auf dieses Wort des Apostels haufig berufen. In dem Gedicht ' $Z u$ viel und $z u$ wenig' beklagt z.B. B.H.Brockes, daB 'fast alle Menschen' ihre Sinne für die offenbarung Gottes in den Kreaturen verschlossen haben und făhrt mit der gereimten stelle des Römerbriefes fort:

Giebt uns Sanct Paulus dieB nicht deutlich gnug zu lesen?

Er saget: DaB man weiB, daB Gott sey, ist ja klar, Und allen Menschen offenbar.

Gott offenbahrt' es selbst, und gab es $\mathrm{zu}$ verstehn, DaB Gottes unsichtbares Wesen,

Das ist, Sein ew'ge Kraft und Gottheit wird ersehn, So man dieb wahrnimmt an den Wercken, Wie von der Welt Erschaffung an zu mexcken, So daß sie keinen Grund, sich zu entschuld'gen haben. 2

In der Feoptija wird gleich am Anfang der I.Ep. das physikotheologische 
Glaubensbekenntnis verkündigt, das in vielen Variationen ihren Hauptinhalt bildet. Jedes Glaubensbekenntnis schlieBt die Abgrenzung gegen den Unglauben ein, die hier in heftiger Polemik gegen die 'Gottlosen' zum Ausdruck kommt. In einer Apostrophe, die gerade in Eingang zur Briefform gehort, wird der Adressat nachdracklich aufgefordert:

\section{I,1 Прокляни, Евсевии, нечестивых слепоту...}

Verdammenswert ist die Blindhelt der Gottlosen, weil sie nicht sehen wollen, daB die Welt thre Schonheit und Grobe dem allmăchtigen Gott verdankt. Der Weg zum Glauben führt uber das Sehen, sagen die Physikotheologen. Sie me1nen damit ein Sehen, bel dem die auBeren Augen die Erschelnungen aufnehmen, die von den 'Inneren Augen" betrachtet werden. Die Gründe zum Glauben sind nach ihrer Meinung so augenfallig, daB man sich schon bewuBt gegen sie verschlieben muB. Diesen Vorwurf macht der Autor den Gottlosen:

\section{I,69f. Разве вы нарочно восхотите затворить \\ Очи внутрь душевны, света 6 правды вам не зрить.}

Einen ahnlichen Gedanken auBert Fernelon: "Alnsi vivent les hommes. Tout leur pressente Dieu, et ils ne volent nulle part... Souvent meme 118 ne veulent pas les ouvrir / (Demonstr.,S.2). Dabei ist der Glaube so lelcht jedermann zugănglich. Fenelon sagt: "Je ne puis ouvrir les yeux sans admirer l'art qui eclate dans toute la nature: le moindre coup d'oell suffit pour apercevoir la main qui fait tout." (Demonstr., s.1)

Die Geisteshaltung der Gottlosen wird mit der Metapher 'Finsternis' bezeichnet, die zu demselben Bildbereich gehort wie 'cлenota'und 'затворить очи внутрь аушевны.' Das 'lumen naturale' (природный свет,I,42), mit dessen Hilfe die Vernunft Gott erkennt, lst erloschen; denn die Vernunft der Gottlosen ist durch Irrtümer verblendet (ослепленный грубых заблумдений тымой, I,41), hingerissen von Leidenschaften (гнусными...страстьми сердча восхищенншй, I, 43), durch Laster verdorben (пороками...развращенный, I, 44). Fênelon führt es ebenfalls auf 'Vorurteile und Leidenschaften' zurück, daB die Menschen die Augen vor dem 'groBen Schauspiel' verschließen: "...les faux prejugés qui naissent des passions ont fermé leurs yeux d ce grand spectacle" (Demonstr.,S.2). Im Gegensatz dazu wird Evsevif aufgefordert, seine Augen aufzumachen und die schopfungstat Gottes zu preisen (виждь и проповедуй, I, 7). 
An einen Gedanken der Theodizee Leibnizens erinnert die Aussage:

\section{I,9f. Неисчетны ми́ры по всемуарию бог знал, Но состав сей точно благостию предшзбрал.}

Der deistischen Irrlehre, Gott habe sich von der Welt zurückgezogen, wird die fortdauernde Herrschaft Gottes uber seine Schopfung gegenubergestellt:

\section{I,11f.Bсе хранит, всем правит сам: будем же покорны Изволениям святим, а не богоборнш.}

Die Apostrophe -als Eroffnungsform eines epistolarisch aufgebauten Lehrgedichts 'unumgănglich' ${ }^{3}$ - ist hier an 'Evsevij' gerichtet. E.N.Lebedev vermutet, es handle sich um eine konkrete Person, wăhrend I.Serman an einen fiktiven Adressaten denkt. ${ }^{4}$ Für Sermans Meinung spricht, daB der Name Evsevij

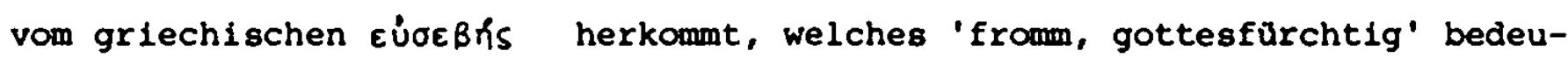
tet. 'Evsevij' könnte also ein 'redender Name' sein und den Idealtyp des Frommen und Gottesfürchtigen meinen, dem der Autor seine Briefe schreibt.

Die ganze Schöpfung, so weit und mannigfaltig sie ist, verkündigt den Schöpfer. Im Kleinsten wie im Grobten, in der Materie wie im Reich der pflanzen und Tiere, vor allem aber im Menschen, in seiner wunderbaren Verbindung von Körper und Geist, offenbart sich Gottes Weishelt, seine alleinige Vollkommenhe1t. Das 1st der Inhalt des Abschnitts I,13-38, der eine Art Vorschau auf das Programm der Feoptija enthălt.

Mit der Aufzăhlung von gottlichen Elgenschaften, die in der VI.Epistel ausführlich dargestellt werden, wird das Blld des ewigen, unverănderlichen, relchen und autonomen Herrschers gezelchnet, der das Sein aus sich selber hat und allen Geschopfen ihr Sein und Wesen schenkt. Hier hăufen sich kirchenslavische Wörter. Der Schð̋fer ist ' само6ытный' (s.Miklosich,a.a.0.819). Dem entspricht im scholastischen Vokabular die 'aseitas Dei'. Gott ist 'npeудобренный' $(I, 15)$. Das Adjektiv ist von ksl. 'удобриити' abgeleitet, das Miklosich(1040) mit 'decorare' wiedergibt. Auch in I, 16:

\section{Всем владыку, ни чией длани покоренна -}

werden gottliche Attribute mit ksl. Termini bezeichnet: 'владыка' (Mikl.66= 'dominus') und 'Aлань'(Mikl.162='palma manus').

Da Gott alles geschaffen hat, weist auch alles auf ihn hin. Dieser Zusammenhang erscheint den Physikotheologen 'sonnenklar':

\section{I,20 Ясность истины сея солнца есть светлейша.}


Fenelon stellt fest: "...toute la nature montre l'art infini de son auteur " (Demonstr.,S.3).

Unter dem Stichwort 'всё являет Gora' $(1,21)$ zeigen zwel Reihen von Beispielen, daB die Welt einen Schöpfer hat. Die erste Reihe beginnt beim 'Allerkleinsten' (сама вещь малейша, I,19), und nennt die Welt der materie -Gott allein kennt die zahl der sichtbaren und unsichtbaren Dinge- fugt der Autor hinzu. Am SchluB der Reihe steht das 'riesige Universum', das wir nicht einmal mit den Gedanken erfassen können:

\section{I,23f. Верно камет обиий круг мислей сверьх обширншй,} Что зижаитель есть ему и что сей премирный -

Mit der Betonung der Uberweltlichkeit Gottes wird der Pantheismus abgewiesen, die Lehre Spinozas, das Universum sei identisch mit Gott.

zur zweiten Reihe von Beispielen setzt der Autor von neuem an mit der Formel 'ace ero $ш$ являет' $(I, 25)$. Vom Allgemeinen geht es zum Besonderen, vom Universum zu den Pflanzen und Tieren in aufsteigender Linie zum Menschen.

Gottes Weisheit wird slchtbar in allem, was grünt und bluht. Das 'angenehme' verschiedene Grün wird besonders erwăhnt:

I,25f. Всё его ж явяет развиваясь, что цветет И, приятну зелень различая толь, растет.

Die physikotheologische Betrachtung nimmt in der Schopfung nicht nur das Erhabene und ZweckmäBige, sondern auch das Angenehme und Schóne wahr.

Auch in den Lebewesen bezeugt sich der Schópfer. Nach der Art der Fortbewegung wird aufgezdhlt:

I,27f. Всё, что, с чувствием Анша, ходит иль летает, Ползает, или себя, плавая, питает.

Der höchste Rang unter den Lebewesen kommt dem Menschen zu. Er lst sozusagen der 'Zar' der Welt (миру как 6 4арь, I,30). Diese Stellung entspricht der biblischen schópfungsgeschichte (Gen.1,26), der zufolge der Mensch im zusammenhang mit den Tieren und zugleich mit dem Auftrag, uber sie zu herrschen, geschaffen worden 1st. In dem Doppelwesen des Menschen, das aus der munderbaren Vereinigung von koxper und Geist besteht, offenbart sich Gottes höchste Weisheit:

I,35f. Человек, А говоро, весь являя бога,

Проявляет, что ЕСо и Премуарость много. 
Mit den Formeln 'ввусоставншй человек' $(I, 29)$ und 'coюз дивнейший'(тела C умом), I, 33, werden die Stichworte der Anthropologie Descartes' ins Russische übersetzt. "Dieses Thema wird in der V.Epistel ausführlich behandelt. Dort erortert Tred. auch das in der Philosophie der Cartesianer viel diskutierte Problem der psychophysischen Kausalitat. Hier beschrănkt er sich darauf, die These von der alleinigen Kausalitat Gottes, wie sie von den Schülern Descartes' vertreten wurde, hervorzuheben:

\section{I,37f. Так что бесконечно совершен есть бог един, И причина перва к действию вторых всех вин.}

In den folgenden Abschnitten geht Tred. auf die apriorischen Gottesbeweise ein, die von den Physikotheologen sonst abgelehnt wuxden. Er schopft, wie er sagt, 'из самшх глубокостей...метафизики'. 6 Die apriorischen Beweise, die von der 'theologia naturalis' ins Feld gefuhrt wurden, beruhen auf einer Methode des Denkens, von der sich die Physikotheologen bewrit distanziert haben. Der Unterschied zwischen Physikotheologie und Theologia naturalis wird von W.Philipp so beschrieben: "SchlieBt jene a posteriori aus der Fülle der Welt auf Gott, so will diese auf dem Wege apriorischer Vernunftschlüsse Existenz und Eigenschaften Gottes erweisen...Mit ihren begrenzten apriorischen Mitteln versuchen die Vertreter der Theologia naturalis festzustellen, ob der Mensch aus einem angeborenen natürlichen Licht erkennen könne, daB ein Gott sei, ob man mittels vernünftiger Gründe das Dasein Gottes gegen die Atheisten erweisen konne." ${ }^{7}$ Tred. hatte keine Bedenken, beide Beweisformen, die induktive wie die deduktive, in der Feoptija anzuwenden.

Die Vernunft, so führt er aus, hat mittels des natürlichen Lichtes unmittelbare Gotteserkenntnis, sofern sie nicht durch Leidenschaften des Herzens und Laster verdunkelt ist. Es heiBt von der Vernunft:

\section{I,42 Весь в природном свете пребшваюций собой-.}

Darum: I,45 Не возможет тотчас бога жива не познать -.

Die Vernunft enthålt den Begriff Gottes als des vollkommensten Wesens, das darum auch notwendig existiert. Dahinter steht der ontologische Beweis, der, von Anselm ausgebildet, von Descartes und Leibniz übernommen, von der Idee auf die Existenz schliebt. Das allervollkommenste Wesen muB zugleich 'ens realissimum' sein, das höchste Sein kann unmöglich als nichtseiend gedacht 
werden. 8 Auf diesem Gedankengang beruhen die folgenden Verse:

$$
\begin{aligned}
& \text { I,47ff. Он понятие в себе бомества имеет, } \\
& \text { Кое И довольным толь называть он смеет, } \\
& \text { Что им познавает совершенств всех сумество } \\
& \text { И что в нем вседолжно бытность купно естество - }
\end{aligned}
$$

Hier wird der apriorische Gedankengang unterbrochen und erst in I,75 fortgesetzt. In dem dazwischen liegenden Abschnitt setzt sich der Autor in heftiger Polemik mit den Atheisten auseinander. Solche Abschweifungen verschiedenen Inhalts, in der zeitgenossischen Poetik Digressionen genannt, haben den Zweck, die Aufmerksamkeit des Lesers, etwa nach einer abstrakten Passage, neu zu beleben. Im vorliegenden Fall geschieht dies durch eine affektgeladene Rede. Die Atheisten werden angeklagt, sie seien vermessen, scheuten sich nicht vor dem Gewissen und trăten die Wahrheit mit FüBen:

$$
\begin{aligned}
& \text { I,55f. 0! вы, кои, буйно мчась в дерзости проклятой, } \\
& \text { Страхом совести, ниме правдог за пятой - }
\end{aligned}
$$

Sie hăten sich nicht nur selber von dem heiligen Gott abgewendet, sondern trieben auch noch Propaganda fur den Unglauben, indem sie das 'Gift verspeien', die Welt bestehe von Ewigkeit her aus sich selber:

$$
\begin{aligned}
& \text { I,59f. Говорите, что сей мир, с чином, с красатор, } \\
& \text { Вечен состоит и есть искони собою. }
\end{aligned}
$$

Was hat die Atheisten dazu getrieben, diese 'lügnerische und unmogliche Behauptung' aufzustellen? Die Antwort kann nur sein: die 'Leidenschaften und Laster' (vgl.I,43f.):

$$
\begin{aligned}
& \text { I,61ff. Тьма ли вас прегустая, беззаконий ли всех сласть, } \\
& \text { Гордость ли безумна, затвердела ль коя страсть } \\
& \text { К утверждению сему побуждает ложну - }
\end{aligned}
$$

Mit dem vorwurfsvoll wiederholten 'можно ли' soll den Gegnern noch einmal vorgehalten werden, wohin sie sich verrannt haben:

$$
\begin{aligned}
& \text { I,65ff. Рассмотрите, можно ли от доводов устоять } \\
& \text { И еще упорно лжею адскою зиять; } \\
& \text { Можно ль, коль бш вам во мрак слепо ни стремиться, } \\
& \text { Чтоб от истинншх зарей в том не просветиться }
\end{aligned}
$$

Es bleibt nur die Erklarung: die Atheisten haben boswillig ihre Augen ver- 
schlossen, um das Licht der Wahrheit nicht zu sehen. Sonst ware es unmoglich, die Aufforderung zum Glauben zu miBachten, die der Anblick der Welt darstellt:

1,71f. Инако преодолеть не́льзя всем предлога, Кой доказмвает вам присносуина бога -

Der Abschnitt I,55-74 ist rhetorisch gepragt durch affektbetonte Anredeformen: "0! вw, кои буйно мчась... (I,55), рассмотрите, можно ли... (I,65), разве ви нарочно восхотите затворить очи внутрь Аушевны...(I,69f.)" und durch rhetorische Fragen: "Тьма ли...горяость ли...(I,61f.), мотно ли... (I,65 u.67)." Im Unterschied zu der abstrakten Darlegung in I,39-54 1st die polemische Einblendung I,55-74 mit bildhaften Wendungen geschmückt, z.B. "Страхом совести, ниже правдор за пятой $(I, 56)$ ", das in den Примечания mit "не страшась совести не следуя правде" umschrieben wird. Auch die bekannte Licht-Finsternis Metapher wird verwendet. Das Verhalten der Atheisten wird durch die metaphorisch zu verstehenden Verbformen 'буйно мчась'(55) und 'во мрак слеno...стремиться'(67) gekennzeichnet. Den Gegensatz dazu bildet die Metapher von der 'Erleuchtung durch die wahre Morgenröte' "पтоб от истинншX зарей в том... просветиться" (68).

In I,75ff. setzt dex Autor die apriorische Beweisfunrung fort. Er geht von der Prămisse aus, daß die Dinge das Ergebnis einer Tat sind:

\section{I,75 Действом ншне вещи суть есть и пре6швают -.}

Dies wiederum setzt voraus, daß etwas da war, das von Ewigkeit her seine Wirksamkeit hatte:

1,76ff. Но что действом суть теперь, то предполагают

Нечто бшвше прежде от превечности всея,

Aля Аействительныя бштности своея.

Andernfalls wăren die Dinge entweder aus dem Nichts oder aus sich selber hervorgegangen. Was könnte absurder seln, gibt der Autor den Atheisten zu bedenken:

\section{I,80ff. Момет ито ж безместней бшть, если 6 вш сказали, Что Ничто пустое вещи все произвело, \\ В коем сил и средствий никаких бшть не могло?}

Ebenso unsinnig wăre es zu behaupten, die Dinge wăren aus sich selbst entstanden, da sie sowohl sein als auch nicht sein kónnten: 


\section{1,83f. Как им бить $и$ от себя, всем вельми пресломним \\ И К небытию притом всячески возможншм?}

Sie existieren nicht notwendig, darum sind sie von einem in sich notwendigen Wesen geschaffen, das wix Gott nennen:

$$
\begin{aligned}
& \text { I,87f. И сие т то обме мы называем богом, } \\
& \text { В почитании твориа всяческих премногом. }
\end{aligned}
$$

Der Name des Schöpfers aller Dinge wird in 'großer Ehrfurcht' genannt.

Die Verse I,75-88 enthalten den kosmologischen Beweis fü die Existenz Gottes in gereimter Form. Angemerkt sei, daB Tred. den philosophischen Beweis dadurch erweitert hat, daB er die Meinung der Gegner in die logische Argumentation einbezogen und Punkt für Punkt widerlegt hat. Die I,81 verurteilte Behauptung, das 'Nichts' habe alle Dinge hervorgebracht, bzw. sie seien 'von selbst' entstanden (I,83), 1st Im Altertum von Epikur (341-270 v.Chr.) vertreten und von seinen Epigonen im 17./18. Jahrhundert wiederholt worden. 10

Der Abschnitt enthät die ksl. Worter 'действо' und 'безместьн', die bel Miklosich belegt sind: 'Аейство'= gr. energeia, lat. efficacia (186); '6езMестьн' = gr. atopos, lat. absurdus (15).

Die Ausfuhrungen in $I, 89-114$ beruhen auf dem zuerst von Descartes entwikkelten anthropologischen Beweis für die Existenz Gottes. ${ }^{11}$ Am Anfang steht das unmittelbare Selbstbewubtseln des menschlichen Geistes. Descartes benutzt die Formel 'cogito, sum':

$$
\text { I,89 Человеч ум сведом, что он есть и состокт - }
$$

Der menschliche Geist hat einen Begriff der Vollkommenheit, die er in sich nicht verwirklicht sieht:

I,90ff. Совершенств от смысла многих добрих не таит, Коих сам в себе тогда жинтрь не обретает, 06 изрядстве их хотя достоверно знает.

Woher hat der Mensch das wissen von der Vollkommenheit? Die Antwort lautet: nicht aus sich selber, sondern von elnem 'andern':

$$
\begin{aligned}
& \text { I,93f. От сего ль не ясно, что не от себя ум есть, } \\
& \text { И другой, Что долмен в бытность оного известь? }
\end{aligned}
$$


Der menschliche Geist hătte sich, wăre er dazu făhig gewesen, alle Vollkommenheiten selbstherrlich beigelegt, um sich zu exhöhen:

$$
\begin{aligned}
& \text { I,101f. Произвел бы оны совершенства в красоту } \\
& \text { И чрез те } 6 \text { умножил собственнур высоту. }
\end{aligned}
$$

Ein weiteres Argument spricht gegen die Annahme, der menschliche Geist habe seinen Ursprung aus sich selber:

$$
\begin{aligned}
& \text { I.103f. И когаа } 6 \text { ум стал собой, то } 6 \text { не сорзился } \\
& \text { С телом человечим он: в тело } 6 \text { не варузился - }
\end{aligned}
$$

Der menschliche Geist weiB ein Lied $z u$ singen von der Unruhe und den Nachteilen, die ihm der korper zufugt. Aus freien stücken hăte er sich nicht mit inm 'angefreundet', wirde er es nicht eine Stunde, ein Jahr, ein Leben lang in ihm aushalten:

$$
\begin{aligned}
& \text { I,105f. В коем терпит много неспокойств и невыго́д; } \\
& \text { С час терпеть бы сии не всхотел, не с век, не с год. }
\end{aligned}
$$

Aber angenommen -der Autor läBt sich einen Augenblick lang auf die These der Gegner ein- der Geist hăte die Vereinigung mit dem korper selbst gewollt, so kơnnte er sie auch wieder rũckgăngig machen:

$$
\begin{aligned}
& \text { I,107f. Положите ж: волей сам тот союз имеет, } \\
& \text { Как же волек раздрать он уж не умеет? }
\end{aligned}
$$

Da der menschliche Geist dies nicht kann, folgt:

$$
\text { I,109 Человечь ум сделан, следовательно другим. }
$$

So schliebt sich die Argumentation, belebt durch eingestreute Fragen, direkte Anrede der Widersacher und Schilderung der Last, die der körper dem Menschen aufládt. Der 'andere', dessen Existenz a priori bewiesen werden sollte, ist der Schöpfer. Im Unterschied zum geschaffenen menschlichen Geist heiBt es vom schöpfer:

$$
\begin{aligned}
& \text { I,110E. Ho другой сей здатель, сотворен наш ум каким, } \\
& \text { Mor себе дать бытие всячески со6о1- }
\end{aligned}
$$

Er ist, wie es I,13 heiBt, ' самобытный творе4'.

Am SchluB des Beweises wird der Name Gottes feierlich genannt:

I,113f. Кто сам быть вседолжно с вечности всея возмог, Нами тот преславно нарицаемый есть бor. 
Nicht zu den herkömmlichen Gottesbeweisen gehort der folgende, I,115-34, der aus einer Prămisse der Philosphie Descartes' entwickelt wird. Nach Descartes ist die Materie von sich aus vollig unbewegt und "empfangt ihre Bewegung von einer ihr nicht immanenten Ursache." 12

An der Existenz der Materie, aus der alle Korper bestehen, zweifeln selbst die 'ungläubigen Skeptiker'nicht (сцептики неверны,I,116), so leitet Tred. den neuen Gedanken ein und fahrt fort:

$$
\begin{aligned}
& \text { I,117f. В веществе том самом, из которого весь свет, } \\
& \text { Праздность токмо грунтом, Аейственности сродУ нет. }
\end{aligned}
$$

Aus der 'Trăgheit' der Materle folgt nach Meinung des Autors unbestreitbar, daB sie nicht aus sich selbst entstanden sein kơnne:

$$
\begin{aligned}
& \text { I,119f. Oт cего я навожу слеаствие бесспорно, } \\
& \text { Что собой стать вещество было непроворно. }
\end{aligned}
$$

Weil zwischen dem 'Nichtsein' und dem 'Sein' ein unendlicher Abstand besteht, muB die Kraft, die die Materie ins Sein gerufen hat, ebenfalls unendilch sein:

$$
\begin{aligned}
& \text { I,122ff. Ей притом всемерно бесконечной должно быть: } \\
& \text { Тем что от Небытия К Бытип, не пречно, } \\
& \text { Расстояние лежит также бесконечно. }
\end{aligned}
$$

Daß aber viele Dinge aus dem bloB Möglichen, 'aus. der. leeren Nacht' (nз nyстых нощей, I, 130), ins wirkliche Dasein gekommen sind, hat seinen Grund nicht in der Materie und auch nicht im menschlichen Geist. Folglich liegt die Ursache dafür in elnem schaffenden(беспраздном существе,I,131), allmăchtigen, von der Welt verschiedenen Wesen. Das Bild des persónlichen, uberweltlichen Schopfers(от света разном, I,132) richtet sich gegen die Pantheisten, die Hervorhebung des 'schaffenden Wesens' gegen die Deisten. Der Beweis schlieBt wie I,87 und $114 \mathrm{mit}$ der Verküdigung des gottlichen Namens. Warnend fügt der Autor hinzu, daB Gott seine Rache an den Atheisten vorbereitet:

I,133f. Вся есть содержима, кое самый боr и есть,

Всем безбожним подам приуготовляяй месть.

Im Gegensatz zur trăgen Materie ist der Mensch wesentlich durch Tatigkeit gekennzeichnet (действо есть сущеe co MнOю, I,136). Also kónnte der Mensch sich selbst geschaffen haben. Diesen SchluB lehnt der Autor sofort als falsch ab: 
I,135 Буде 6 я был от себя...-

I,137f. То мой ум, как сведом обо всем, что есть во мне, Ведал 6 , что сделал и себя сам не извне -

Aus dem Prinzip des menschlichen SelbstbewuBtseins, dem Ausgangspunkt der Philosophie Descartes' (человечь ум сведом, что он есть, I,89), folgt unmittelbar:

I,142 Что во мне не мног сделано есть бытие.

AuBerdem weiß ich (mit rationaler Evidenz), daB das 'leere Nichts' (Hичто nустое, I, 143) kein Wesen hervorbringen kann. Daraus folgt:

I,145f. Заключаіо твердо, что был некто предо мной, Кой есть мне зиждитель и предсуаствует собой.

Denn es gilt die Regel:

I,147f. Кто Аругих производить в бытие умеет, Тот конечно от себя оное имеет.

Auch diese Argumentation mündet wie die vorangehenden in der proklamation des Namens Gottes. Wir heiBen ihn unseren Schopfer und gelten mit Fug und Recht als seine Geschöpfe:

I,149f. Ho cero mы точно ботом и твориом зовем, И по правде са̀мой тварио его слывем.

Die Gegner werden einwenden, daB wir von unseren Eltern abstammen und diese von ihren Eltern und so endlos weiter zurück. Aber die unendliche Kausalităt der zeugung, wie sehr Ihr sie auch bewundert, ist vernunftwidrig, entgegnet der Autor:

I,155f. Бесконечный сей возврат, коль он вам ни Аивен, Есть всемерно по себе разуму противен.

Gäbe es keinen Anfang a se, dann müBte alles aus dem 'leeren Nichts' hervorgegangen sein. Was wăre sinnloser?

I,157ff. Буде нет Начала самобытного того, То всему быть должно от пустого Ничего.

Hier appelliert der Autor an die Einsicht der Gegner: 


\section{I,159f. Что ж безумней утверждать? Видите вы сами:}

Я свидетельствуюсь в том всенадежно вами.

Die Auseinandersetzung mit den Gegnern ist verschiedenartig. Sie wechselt zwischen zorniger Verurteilung (прокляни...I,1), Drohung mit der gottlichen Rache (всем безбожным людям приуготовляяй месть,I,134), logischer Argumentation (тщетно возразили 6 вы, что...I,151ff.) und behutsamem Zureden wie im obigen Zitat.

Die trăge Materie bildet den Ausgangspunkt für einen weiteren Beweis in I,161-190 (vgl.I,115ff.) .

Die Materie kann nicht die Ursache fur die Bewegung sein, aber die Bewegung kann auch nicht von selbst entstehen. Bewegung gibt es nur als Eigenschaft von Materie. Eine Eigenschaft kann aber nicht vor der Sache, zu der sie gehort, da sein:

I,163f. Hо движених собой такме быть не момно:

Свойство 6 было тем честняй вещи, что есть ломно.

Daraus folgt:

$$
\begin{aligned}
& \text { I,165 Есть затем Начало, разное от вещества - } \\
& \text { I,167 Кое в вещество сие Авиги впечатлело - }
\end{aligned}
$$

Der menschliche Geist kann ebenfalls nicht die prima causa der Bewegung sein. Er kann wohl etwas in Bewegung setzen, aber ex konnte nicht die weisen Gesetze der Bewegung in Kraft setzen, um durch sie die Materie nach ihrer Art zu unterscheiden. Dahinter steht der Gedanke Descartes', daB sich die elnzelnen Körper ausschlieBlich durch die verschiedenen 'Modi der Raumlichkeit' wie Gestalt, Grobe, Lage und Bewegung voneinander unterscheiden. ${ }^{13}$ Die Weisheit der Gesetze zeigt sich auch darin; daB sich die Korper 'durch so lange zeiten unverănderlich nach diesen Gesetzen drehen' (ирез многи веки толь твердо o6pamarbca, I, 172). Was der menschliche Geist vermag, und wozu er nicht imstande ist, wird so beschrieben:

$$
\begin{aligned}
& \text { I,169f. Ум наш хоть имеет силу в двиг вещь приводить, } \\
& \text { Но не мог законов авигам мудрых утвердить. }
\end{aligned}
$$

Dies alles führt zu dem 'unausweichlichen' SchluB:

$$
\begin{aligned}
& \text { I,173f. Всё то полагает, и необходимо, нам, } \\
& \text { Что Правитель вышний и безмерный есть в том сам. }
\end{aligned}
$$


In dieser Passage begegnet uns ein Stück Descartes'scher Philosophie. Die entsprechenden Aussagen Descartes' werden von R.Specht so erlautert: "Die von Gott entworfenen Gesetze der Bewegung... sind so vollkommen, daB sie allein die Welt in ihre gegenwărtige ordnung bringen könnten, wenn Gott die Materie im wilden Chaos beließe... Die Bewegung ist von Gott erschaffen, und Gott halt ihre Gesamtmenge im Universum konstant." 14

Der sich anschlieBende Beweis nimt Elemente des vorhergehenden noch einmal auf. Der Autor stellt fest:

\section{I,177 Двиг есть только свойством в праздном оном веществе -}

Er schließt daraus, daB die Bewegung nicht zum Wesen der Materie gehört. Selbst wenn man annimmt, die Materie sei ewig, von der Bewegung labt sich dies keineswegs sagen:

I,179f. Но хотя 6 и положить - вещество превечно, 0 движении сказать не́льзя толь конечно.

Ähnlich argumentiert Fénelon in der Auseinandersetzung mit den Epikureern: "Supposons donc que les atomes sont éternels, existants par eux mêmes,... Faudra-t-il supposer encore qu'ils ont par eux-mêmes le mouvement? Le supposera-t-on à plaisir, pour réaliser un systême plus chimérique que les contes des fées (Démonstr.,S.85)? Neben der inhaltlichen ist die formale Ubereinstimmung der beiden stellen beachtenswert.

DaB die Bewegung nicht zum Wesen der Materie gehort, sagt Tred. übereinstimmend mit Fénelon:

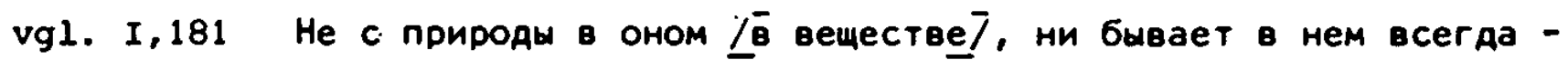
und I,178 Случаем бывает оного $n$ в естестве -

mit Démonstr., S.86f.: "Ce qui est essentiel à un être est toujours le même en lui...Je dois donc conclure que les corps sont parfaits dans leur essence, sans qu'on leur attribue aucun mouvement: $s^{\prime}$ ils ne l'ont point par leur essence, ils ne 1 'ont que par accident..."

Woher kommt dann aber die Bewegung? Tred. antwortet: Es gibt einen 'freien Beweger', einen Beweger, der nicht selber eine Korpuskel in dem mechanischen System der Bewegungen ist. Innerhalb dieses Systems bewegt ein Körper den anderen durch Druck und StoB und wird von anderen korpern in Bewegung gesetzt. Der 'freie Beweger' ist davon zu unterscheiden:

\section{I,182 Есть Авизатель вольный,...}


Ahnlich heiBt es in der Demonstr.,s.88: "...1l faut trouver le premier atome ébranle, et le premier moment de cette premiere motion, avec le premier moteur dont la main a fait ce premier coup."

Den Einwand, die Materie könnte durch einen Zufall in Bewegung geraten sein, labt Tred. nicht gelten:

\section{I,187f. Что припадком в веществе иногда бывает, То припадком-также в нем всё и пропадает.}

GesetzmäBige, konstante Bewegungen lassen sich nicht auf einen zufall zurückführen:

$$
\begin{aligned}
& \text { I, 185f. Ежели ж припадком в двиги вещество пришло, } \\
& \text { Сохранить законов долго } 6 \text { оных не могло. }
\end{aligned}
$$

Die Gesetze der Bewegung stammen also weder aus dem menschlichen Geist (ym наш... не мог законов двигам мудрых утвераить,I,169f.), noch aus dem Zufall, sondern aus gottlicher Weisheit. Auch dieser Beweis schliebt wie die vorigen mit dem Bekenntnis zu Gott/vgl. I,37;72;87;114;133 und 149):

I,189f. Посему премудрый некто те уставы дал:

Сей премуарый богом и зово́м от нас быть стал.

In der apologetischen Tendenz der Feoptija ist es begründet, daB in inr jeweils die Anschauungen der ideologischen Antipoden erkennbar werden. In dem Abschnitt I,191-200 wird die Meinung, dex Kausalzusammenhang sei unendlich, als vernunftwidrig zurückgewiesen:

\section{I,191f. Бесконечный вспять возврат есть непонимаем, Как противный весь уму...}

Gegen diese Anschauung hat sich der Autor schon in I,155f. ausgesprochen:

Бесконечный сей возврат, коль он вам ни Аивен,

Есть всемерно по себе разуму противен.

Er vertritt, auf Descartes und die Scholastik zurückgreifend, den Standpunkt, daB die Kausalordnung mit der ersten Ursache beginnt:

$$
\begin{aligned}
& \text { I,193f. Закпючая прямо, что порядок есть причин, } \\
& \text { Так что есть меж ними первейший пределов чин. }
\end{aligned}
$$

Dies wird durch das Beispiel des Ahnherrn, von dem ein Geschlecht abstanmt, veranschaulicht: 
I,195f. Например, есть человек самый первый в роде, А по нем вторый, и так далей в производе.

Von der Erstursache sind nach der Lehre Descartes' und der Cartesianer die Zweitursachen (causae secundae), auch 'dispositions' oder 'occasions' genannt, zu unterscheiden. $\mathrm{Zu}$ den $\mathrm{Zweitursachen} \mathrm{gehören} \mathrm{z.B.} \mathrm{die} \mathrm{Gesetze} \mathrm{der}$ Bewegung, aber auch das biologische Gesetz der Zeugung. R.Specht erklät: "Dispositionen dieser Art, die hăufig als occasiones bezeichnet werden, verursachen zwax indirekt, jedoch infolge einer von Gott gesetzten hypothetischen Notwendigkeit, mit naturgesetzlicher Prazision." ${ }^{15}$ Die Entwicklung des Cartesianismus-ist dadurch gekennzeichnet, daB in zunehmendem MaBe den zweitursachen die Aktivităt abgesprochen wird. Das läBt sich bei Geulincx und Malebranche beobachten, den führenden vertretern des Occasionalismus, in deren Texten, wie R.Specht anmerkt, "geradezu ein Pathos geschopflicher Ohnmacht" erscheint, das "wahrscheinlich aus der theologischen Gnadenlehre herrührt." 16 Das theologische Interesse der Occasionalisten an der Passivität der Zweitursachen, wenigstens an ihrer begrenzten Wirksamkeit, scheint die folgenden Verse der Feoptija beeinflußt zu haben:

I,197f. Но вины вторые, опыт как то учит нас, Все имеют явно долоные границы враз.

Das Vorhandensein begrenzter Ursachen schließt aus dieser Sicht die Anerkennung einer vornehmsten Ursache ein. Diese Ehre gebührt aIlein Gott:

I,199f. Тем граничащу их признают причину, Благороднейшу себя: та есть бог по чину.

Der letzte in dieser lose aneinandergefügten Reihe apriorischer cottesbeweise geht aus von der Prämisse, daß die Welt nicht mit absoluter Notwendigkeit, sondern als ein komplexes Gebilde 'zufallig' existiert:

I,201f. Hе простый мир, сложный. От сего как не навесть, Что не необходно, да случайно оный есть?

Das heiBt, die Welt könnte auch nicht sein, oder anders sein, als sie ist:

I,203 Сиречь, mor не быть, и быть неиссиетно разно...

Aus der Kontingenz der Welt folgt, daB sie eine Ursache haben muB, die sie so gemacht hat, wie es ihr (der Ursache) gefiel: 


\section{I,207f. Следует, что мир вины требовал природно,}

Дa его так изведет, как самой угодно.

Diese Ursache ist Gott, der hier am SchluB der Reihe apriorischer Beweise in seiner trinitarischen wüde vorgestellt wird:

I,209f. Та есть 6оr премуарый, всеблагий в нем произвол, Преисполнен мочи, содеваяиий Глагол.

Die Trias scheint auf Augustin zurückzugehen, nach dem die Gottheit in Allmacht, Allweisheit und Allgute das Universum umspannt. ${ }^{17}$ Mit der Wendung ' содевающнй Глагол' wird das Schöpfungswort Gottes bezelchnet, das nach der Lehre der Bibel alle Dinge geschaffen hat. Es erscheint, mehrmals wiederholt, in der Formel 'und Gott sprach' in der Schöpfungsgeschichte Gen.1,Kap.1 und am Anfang des Johannes-Evangeliums, der sich deutlich auf die Schopfungsgeschichte bezieht:

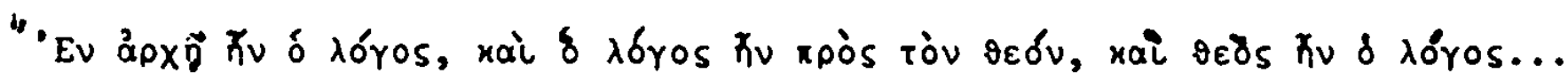

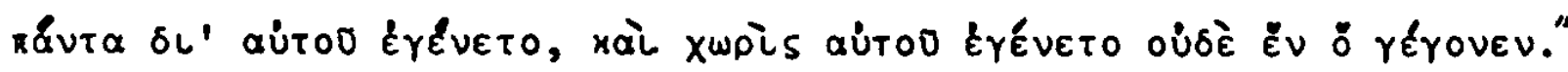

Eine Betrachtung über das 'schaffende Wort' findet sich in dem Gedicht von B.H.Brockes, 'Schönheit der Felder im Frühling':

Betrachte, wie sein grobes wort

Allein die Quelle dieser Welt,

Und dab dasselbe fort und fort

Sie unaufhorilich schafft, indem ex sie exhalt. 18

Der Abschnitt I,211-232 unterscheidet sich von der rationalen Argumentation der vorangehenden Ausführungen durch dramatische Elemente. Der Wechsel der Tone ist im Lehrgedicht, besonders im philosophischen, nicht bloB erwinscht, sondern notwendig, um Monotonie zu vermeiden. 19

In I,211ff. werden dieselben Gegner wie in I,55ff. angeredet. Der Autor fragt sie, wieso sie die Materie ewig und den Zufall 'Schopfer aller Dinge' nennen kơnnen:

\section{I,211f. Се ум как вам называть вещество всевечным, А припадок всех вещей здателем вдруг өстречным?}

Die beiden Behauptungen ergeben sich aus der Kosmogonie Epikurs. 20

Dann wird in den Versen 213-22 der zufall entmythologisiert. Er labt sich nur negativ kennzeichnen: 
I,213f. पто припадок в деле? Сама суща слепота, Скудная причина и недосточна та.

Der Zufall hat weder Intelligenz noch freien willen (нет в ней смысла и ума, I,215; весь беспроизвольный,I, 218). Er kann weder planen noch auswăhlen (ни намерения нет, ни избраний точных, I,216). Der Zufall bereitet nichts vor und bringt nichts zustande (не готовит случай и не учреждает он, I, 217). Was bleibt also vom Zufall, in dem die Gegner den 'Schopfer aller Dinge' sehen wollen? Beinahe 'ein Nichts' (почитай ничто, I,221). Seine Merkmale sind:

I,221f. Cлеп, глух и бесчувствен, почитай ничто, так хил, Да $и$ не имущий особливых к действу сил.

Die angefuhrten Verse geben in erweiterter Form einen Satz der Démonstr., 5.3 wieder: "Le hasard est, tout au contraire, une cause aveugle et nécessaire, qui ne prépare, qui n'arrange, qui ne choisit rien, et qui n'a ni volonté ni intelligence..." Fénelon kommt zu dem Ergebnis "...que le hasard... ne peut avoir forme ce tout." Angesichts der GroBe, Mannigfaltigkeit und schónheit der Welt ist es deshalb absurd zu behaupten, der 'armselige zufall' habe sie hervorgebracht:

\section{I,223f. Как ему сей произвесть Мир в таком пространстве,} Мир в различии таком и в таком убранстве?

Vielmehr werden in der Welt nicht allein die Kraft, sondern auch die Weisheit und Güte einer unendlichen Ursache sichtbar (сила, мудрость, благость...бесконечныя вины, I,225f.). Die Schönheit und Harmonie der Welt, in der alles nach 'Maß, Zahl und Gewicht' geordnet ist, erweisen sie als ein Werk, das seines Schopfers würdig ist:

I,227f. Где толико красота, где и чин толь стройный, Мера, вес, иисло, округ весь творца достойный.

Die Dreiheit von 'MaB, Zahl und Gewicht' erscheint in der Weisheit Salomos, Kap. 11,21 als Lobpreis Gottes: "Sed omnia in mensura, et numero, et pondere disposuisti." H.-P.Herrmann weist darauf hin, daB die Formel im Mittelalter eine betráchtliche Rolle gespielt hat. Die Zahlenmystik greift immer wieder auf den Vers zurück. Der mittelalterliche ordo-Begriff stützt sich auf dieses wort. Es ist dem protestantischen 17.Jahrhundert gelăufig und wird von Leibniz zitiert. 21

Nach physikotheologischer Uberzeugung erkennt die Vernunft den Schöpfer, sobald sie die Geschopfe betrachtet: 
I,229f. Всяк, едва на твари с примечанием воззрит,

То твориом премуарым разум свой и озарит.

Der vertreter der Zufallstheorie wird dagegen als 'dumm und ekelhaft' bezeichnet (rлyn n гадок, I, 232).

In I,211-32 wird deutlich, wie.Tred. aus einem Satz uber den Zufall in Démonstr.,S.3 (s.oben) einen gegliederten, dramatisch akzentuierten Abschnitt entwickelt hat. Zuerst personalisiert er die Aussage, indem er die Vertreter der Zufallstheorie apostrophiert: "Се уж как вам называть...nрипадок всех вещей здателем...? (I,211f.). Dann laßt er vor ihren Augen das. Prinzip Zufall zu einem bloßen Schemen werden $(1,213-22)$. Er fordert sie auf zu erkláren, wie denn die Welt durch den Zufall entstanden sein solle (I,223). Die GroBe und Vielfalt der Welt, ihre asthetische und rationale Gestalt (kpacora... n чин стройный, I, 227) - kōnne doch nicht vom zufall herrüren. Der armseligen Zufallstheorie wird das Bekenntnis zum allmächtigen, allweisen und gutigen Schópfer entgegengesetzt (I, 224-30). Am Ende wird der unbelehrbare Anhănger des zufalls verspottet:

I,231f. Если ж кто 6 сказал ему: сделайте припадок, Bдpуг покажется такой сам и глуп, и гадок.

Von I, 233-424 schließt sich eine Reihe von Beispielen an, in denen die Analogie zum menschlichen Schaffen veranschaulichen soll, daB die Welt ihre Existenz keinesfalls dem Zufall, sondern dem Schopfer verdankt. Die meisten dieser Beispiele stammen aus der Demonstration, einige hat Tred. hinzugetan. Die übernommenen Beispiele sind gegenüber der Vorlage z.T. verkürzt, erweitert oder auf andere Weise verădert worden.

Fenelon hat, wie er anmerkt, seine Vergleiche aus antiker Uberlieferung. Er nennt als Quellen Cicero und Gregor von Nazianz (Demonstr.,S.4). Die Reihe der Vergleiche wird von Fënelon so eingeleitet: "C'est ici qu'il est bon de rappeler les célebres comparaisons des anciens (Démonstr.,s.3). Diese Uberleitung fehlt in der Feoptija. .

Niemand wird daran zweifeln -so das erste Beispiel- daß die Verse Homers in der Ilias von einem großen Dichter geschaffen worden sind:

I,233ff. Кто когаа поверит, что Гомеровы стихи, Кои в 'Илаиде', глупости где нет крохи, Не великим счинены смшслом стихотвориа, - ? 
Wer wollte annehmen, dẹ zufall habe eine Mischung aller Buchstaben so zusammengefügt, daß daraus ein Kunstwerk ohne Fehl (rлynoctи где нет крохи, I, 234), mit måchtig klingenden versen geworden sei (громогласнейшими...стихами, I, 240):

\section{I,237f. Кто поверить может, что припадок всех букв смесь В тот привел порядок и союз составил весь?}

Das adj.comp. 'rромогласнейший' (I,240) soll andieser stelle wohl absichtlich eine Eigentümlichkeit der Sprache Homers nachahmen. Es ist aber nicht eigens von Tred. gebildet worden. Nach D. Tschižewskij ist 'rромогласный' bei Sreznevskij (25) belegt. ${ }^{22}$ Zu den Komposita in der Sprache Tred.s bemerkt D.Tschižewskij allgemein: "Der Gebrauch der Doppelepitheta ist keine Neuerung von Trediakovskij, sondern vielmehr ein Zug seines Stils, der ihn mit der russischen Literatur des 17.Jahrhunderts verbindet." 23 Auch in der liturgischen Sprache kommen solche Komposita häufig vor.

Tred. hat in diesem Falle den detaillierten: Text der Démonstr. gekürt und nur den folgenden Satz in Versform gekleidet: "Qui croira que l'Iliade d'Homère, ce poème si parfait, n'ait jamais été composé par un effort du génie d'un grand poète, et que les caractères de l'alphabet ayant été jetés en confusion, un coup de pur hasard...ait rassemblé toutes les lettres précisément dans l'arrangement nécessaire...,pour les placer et pour les lier si biens tous ensemble...? (Démonstr.,s.3)

Im chapitre III, Uberschrieben "Réponse aux objections des épicuriens", verwendet Fénelon das Beispiel der Ilias noch einmal, um die Zufallstheorie zu entkraften: "Je suppose un nombre infini de combinaisons de lettres de l'alphabet formées successivement par le hasard... Or est-il que I'Iliade d'Homere n'est qu'une combinaison de lettres?" (Démonstr., S.82)

Es liegt auf der Hand, was mit dem Beispiel der Ilias Homers im Hinblick auf den Ursprung der Welt gesagt werden soll. Dies wird jedoch erst in I,259 bis 266 ausgeführt. Zunăchst werden zwei weitere Beispiele aus der Dichtkunst eingeschoben.

Die Aeneis Vergils kann man nicht dadurch hervorbringen, daB man alle Buchstaben, des Gedichts-auf einen Haufen schüttet und damit wärfelt. Ob jemand viele Male, ja sein Leben lang wirfelt, es wird ihm nicht gelingen:

I,249f. Не укинет трудник и ни первых всех стишков, Не укинет токмо и ни маленьких клочков. 
Dabel ist es durchaus moglich, daß der zufall eine Reihe von Buchstaben zusammenwirfelt, die in der Aeneis vorkommen. Wer aber die ganze Dichtung als Werk des Zufalls ansăhe, muß ohne Verstand sein:

\section{I,253f. Без ума быть должно, если так то утверждать И состав стиховный случах то отдавать.}

In der Demonstration gibt es für dieses Beispiel keine Parallele. Tred. hat es sich aber auch nicht selber ausgedacht. In seinen 'Principes de Physique' (Paris 1696) fuhrt der damals beruhmte Optiker und Physiker Nicolaus hartsoeker das Beispiel der Aene1s in einem AnalogieschluB an: "...nie kann ein gesunder Mensch davon überzeugt werden, daß sich der Kosmos durch zufalliges Zusammentreffen einer unendlichen Zahl von Atomen gebildet habe. Es ist tausendmal unwahrscheinlicher, als wenn alle Buchstaben der Aeneis Vergils geschüttelt das Poem ergeben hatten." 24 Das soll nicht heiBen, daB Tred. das Beispiel in dem Buche Hartsoekers gefunden hatte. Wohl aber ist $2 u$ vermuten, daB Anschauungsmittel dieser Art unter,den Physikotheologen verbreitet waren.

Mit rhetorischen Mitteln verdeutlicht Tred. seine Absicht, am Beispiel der Aeneis die Zufallstheorie ad absurdum $z u$ führen. In fünf mit 'nycto' eingeleiteten Konzessivsătzten schildert er Schritt für schritt das vergebliche Unternehmen. Zuerst das zahlen der Buchstaben: "Пусть в Енеиде сиислил ктонибуаь все буквн сам"(I,241). Dann das Zusammenschutten der Zeichen des Abc auf einen Haufen:

$$
\begin{aligned}
& \text { I.243f. Пусть наделает себе столько ж всех их точно } \\
& \text { И в одну смешает их кучку все нарочно. }
\end{aligned}
$$

Darauf der exste Wurf:

$$
\text { I,245 Пусть потом Он кинет совокупно всех из рук - }
$$

Schlieblich das unaufhörliche weiterwirfeln:

$$
\text { I,248 Пусть же мечет много крат, пусть всо жизнь упрямо - }
$$

Die Wiederholungsfigux 'не укинет' (I,249f.) stellt das endgũltige Scheitern des Unternehmens fest.

Auf der Linie der skizzierten Beispiele liegt auch der Ausspruch Ciceros uber die Annalen des Ennius: der zufall kơnne keine zelle davon zustande bringen, geschweige denn die ganze Dichtung:

$$
\begin{aligned}
& \text { I,255ff. Цицеріон "Летописей" Энниевых только } \\
& 06 \text { одном стинке сказал, не о всех в них столько, }
\end{aligned}
$$


Что не мог припадок сочинить там и того,

A не стихотворства совериенного всего.

Fênelon nennt als Quelle des Cicero-zitats 'De Nat. Deor., lib.II, ${ }^{\circ}{ }^{\circ} 8^{\prime}$ und schreibt: "Cicéron en disait autant des Annales d'Ennius; et il ajoutait que le hasara ne ferait jamais un seul vers, bien loin de faire tout un poeme" (Démonstr.,S.4).

Aus diesen Beispielen folgt die vorwurfsvolle Frage:

$$
\begin{aligned}
& \text { I,259ff. Так почто ж безумно толь утверждать о челом, } \\
& \text { Благолепотнейшем сем мире, в буйстве смелом, } \\
& \text { Что его припадок не нарочно сотворил...? }
\end{aligned}
$$

In 'kūhner Vermessenheit' (в буйстве смелом; ksl. bouist' = audacia, impietas, Mikl.48) behaupten die Widersacher, der Zufall habe diese 'herrliche Welt unabsichtlich geschaffen'. $\mathrm{Zu}$ 'благолепотнейший' verweist D.Tschizewsk1j auf ksl.'благолепный' bei Sreznevskij (7) und im worterbuch von Lavxentyj zyzanij (=оздобный), sowie bei simeon Polockij (381).

Die Welt sei vom Zufall geschaffen, behaupten die Gegner, wo der gesunde Menschenverstand doch verbietet, dies von einem Gedicht zu behaupten:

\section{I, 263f. Смысл когда и о стихах мнить не попуцает И всемерно верить тем ставших запрещает?}

In diesen Versen ist die Vorlage zu erkennen, in der es heiBt: "Pourquoi donc cet homme sensé croirait-il de l'univers, sans doute encore plus merveilleux que l'Iliade, ce que son bon sens ne lui permettra jamais de croire de ce poème?" (Démonstr., S.4)

Eine andere Art von Beispielen, als Dichtungen es sind, kündigt sich in den folgenden Versen an:

\section{I,265f. Hе стихами только можно доказать все то; \\ Тысящи прилогов утверждают, а не сто.}

Tred. neigt, wie Vers 266 zeigt, zu Ubertreibungen.

In 1,267-302 folgt der gelungene und interessante orgelvergleich, den Tr., angeregt durch den auf Gregor von Nazianz zurückgehenden vergleich mit der Violine, selbstăndig gebildet hat. In der Démonstr. lesen wir: "Si nous entendions dans une chambre, derriere un rideau, un instrument doux et harmonieux, croirions-nous que le hasard, sans aucune main d'homme, pourrait avoir formé cet instrument? Dirions-nous que les cordes d'un violon seraient venues d'elles-mêmes se ranger et se tenare sur un bois...Soutiendri- 
ons-nous que l'archet,... serait pousse par le vent pour toucher chaque corde si diversement et avec tant de justesse? quel esprit raisonable pourrait douter serieusement si une main d'home toucherait cet instrument avec tant d'harmonie?" (Démonstr.,S.4, unter Hinweis auf Gregor v.Nazianz, Orat.XXVIII, Or.XXXIV, $n \circ 6$ ). Von diesem Muster hat Tred. auBer dem Grundgedanken (ein Musikinstrument wird nicht vom Zufall gemacht oder gespielt, sondern von einem Künstler) die Darstellungsform (Verwendung rhetorischer Fragen) entlehnt. DaB Ihm der Text der Demonstr. vorlag, verrat ein Detail: bei fenelon erklingt die Geige "derrière un rideau". So soll auch die orgel "за завесом" (I, 268) zu hören sein. Die Orgel 'hinter einem Vorhang' ist fedoch "in Nordwesteuropa seit dem Ausgang des Mittelalters nicht mehr ublich". In Norditalien gab es sie noch im 18.Jahrhundert. ${ }^{25}$ Da Tred.s Vorstellungen uber die Orgel im ubrigen recht deutlich und zutreffend sind, ist anzunehmen, daB er sich diese Kenntnisse wăhrend seines Aufenthalts im Ausland, in Holland, in Paris und Hamburg angeeignet hat. 26 Dort gab es aber im 18.Jahrhundert keine Orgeln 'за завесом'. Der Ausdruck wird aus dem Text der Demonstr. in den orgelvergleich der Feoptija hineingekommen sein.

Der Vergleich ist in vier strophenăhnliche Abschnitte eingeteilt. In I,267272 wird die Szene kurz beschrieben: In einer dunklen Kirche ist orgelspiel zu hơren. Wer kăme wohl auf den Gedanken, sie spiele von selber:

\section{I,267ff. Как не зрим органа мы сладостно гудуща, иль за за́весом, или́ в темном храме суща, Можно ль нам подумать, что орган собой поет -?} Ein Mensch, ja sogar ein Künstler läbt auf ihr bald eine frôhliche, bald eine traurige Melodie erklingen:

\section{I,271f. А что то не человек, и еще искусный, Кой глас то веселый в слух, то влагает грустный?}

Der Autor versteht etwas vom Orgelspiel. Er weiB z.B., daB sich mit drei Klăngen (drel Harmonien) der Eindruck des achten Tones'vermitteln laBt:

\section{I,270 В с тремя гласами в сходстве звон осмый дает -}

Mit dem 'achten Ton' ist die hypomixolydische Kirchentonart gemeint, die in der seit dem frühen Mittelalter bis heute gebrăuchlichen zăhlung der acht Kirchentóne die Nr.8 erhalten hat.

Der nachste Teil des Vergleichs ist wohl so zu verstehen, daB man aus dem 
dunklen Kirchenraum an die Orgel herangetreten ist. Man sieht, wie 'einer die Tasten schlăgt' und 'ein anderer mit den FüBen die Bălge tritt'. Die Tastatur bringt ja nicht von selbst b-Moll und Dur hervor. Die Bălge bewegen sich ja nicht von selbst auf und ab. Der Autor fragt:

I,269 Можно ль нам подумать...

I,273 Так что тот руками не биет там клавитур,

274 Что согласность, бе́мол делается сам в дур,

275 И что там не дует тот ни мехо́в ногами,

276 Но что ме́хи вверьхи вниз движутся те сами?

Nun fallt der Blick auf die orgel als Ganzes. Kann man im Ernst meinen, das wohlproportionierte Werk sei durch Zufall entstanden? Zwei rhetorische Fragen sollen bewubt machen, wie grotesk eine solche Annahme ist:

$$
\begin{aligned}
& \text { I,277ff. Можно ль верить дельно, видя самый тот орга́н, } \\
& \text { Что состав весь в оном, и что весь его тот стан } \\
& \text { Стройно так располомен случаем бездумным? } \\
& \text { Ненарочным и слепым и совсем безумным? }
\end{aligned}
$$

Das Orgelwerk ist so konstruiert (махина органа, 285), daß es seinen musikalischen zweck exfüllt; nämlich wohlklingende, unzăhlig verschiedene und liebliche Töne zu erzeugen. Davon handeln die Verse I,281-90. Auch hier verwendet der Autor als Stilmittel rhetorische Fragen, um die Meinung zu verspotten, der Aufbau des Werkes habe sich zufallig ergeben und sei nicht das Ergebnis vorausgehender tberlegungen:

$$
\begin{aligned}
& \text { I,281є. А однак припало, без предмысливших причин, } \\
& \text { Что распорядилось прямо всё в свой долоный чин -? }
\end{aligned}
$$

Hat sich denn das Werk selbst so gemacht, wie es sein soll? Hat sich etwa jede Pfeife an den richtigen Platz gestellt? Haben sie sich verschiedenen Klang gegeben? Um die Ironie komplett zu machen, fragt der Autor, ob etwa auch die Băge unten in der orgel ihren eigenen weg gingen:

$$
\begin{aligned}
& \text { I, 289f. Сделали и мехи на низу себе свой путь, } \\
& \text { Чтоб им в тру6ки трубкой, надобно когда, ветр дуть? }
\end{aligned}
$$

Im vierten Abschnitt des Orgelvergleichs beschreibt Tred., wohl als erster in der russischen Literaturgeschichte, die Mechanik der orgel (I.291ff.). Daraus ergibt sich, daB ex die orgel aus eigenex Anschauung gekannt haben 
muB. Die einzelnen Teile werden sachkundig bezeichnet: das Geblase (Mexи,289), der Windkanal und die Pfeifen (fux beides steht das wort tpy6ka,290), die windladen (лады,292), die Ventile (аакришечки,292). Die Tastatur wird mit einem gemeineuropischen Fredwort benannt (клавитура,291, statt kлавиатура, "das nach dem Crоварь /C̄oвp. русск. лит. я3.1951-63/ erst 1845 für Russisch belegt ist"). 27 Die Funktion des Mechanismus wird ebenfalls zutreffend dargestellt. Man drückt die Tasten. Dadurch werden die Ventile unter den windladen, an denen der Mechanismus mit Draht befestigt ist, nach unten gezogen, d.h. geoffnet. Durch den freigemachten windkanal strónt die Luft zu den pfeifen:

I,291ff. Клавиту́ры наверху рядом сочетались

И к закришечкам ладо́в стрункой привязались,

4тоб им, опускаясь, кршшечки те открывать,

Но не все вдруг, только долшно кои подымать -

Von einem so sinnreichen und kunstvollen Mechanismus schliebt jeder sofort auf einen erstklassigen orgelbauer und organisten (механист и музыкант, 300), der die orgel erdacht und gebaut hat. "Orgelspieler waren in alter zeit mit den orgelbauern identisch." 28

Im Bilde der Orgel sind die Komponenten des Mechanismus und des Kunstwerks vereinigt. Darum erscheint dem Autor dies Bild besonders geeignet als Analogie für das Weltall, das sich ebenfalls durch Zweckmäbigkeit und Schönheit auszeichnet. Kann schon eine orgel nicht durch zufall entstanden sein von dew 'Weltgebăude' kann dies erst recht nicht behauptet werden, schliebt der Autor a minore ad maius. Zornig apostrophiert er die Anhănger der zufallslehre, die sich einbilden, weise zu sein:

$$
\begin{aligned}
& \text { I,307ff. То ум вам, оl мудрецы, только ж мудрым мнимо, } \\
& \text { Мира здание сие, обще всеми зримо, } \\
& \text { С разумом как можно дерзновенно утвермдать, } \\
& \text { Что оно припадком возмогло в порядок стать? }
\end{aligned}
$$

Mit einer den Zweifel ausschlieBenden Suggestivfrage schlieBt der Orgelvergleich:

I,311f. Можно ль сомневаться впрямь, что свет не всесильним, Не всемуарьм сотворен, не всеизобильным?

Die sorgfaltig aufgebaute, anschaulich dargestellte Analogie verfolgt die Absicht, den Leser $z u$ dem Bekenntnis zu bewegen, daB die Welt von dem all- 
măchtigen, allweisen und ewigreichen Gott geschaffen ist.

Der folgende Vergleich aus der bildenden Kunst ist zu einer kleinen Geschichte ausgeweitet, die Tred. von Fénelon übernomen hat: I,313-352. Der Erzăhler berichtet, daß jemand auf einer unbewohnten, den Menschen von alters her unbekannten Insel eine Marmorstatue (in der Feoptija handelt es sich um ein marmornes Gotzenbild 'истукан', 313;'кумир', 317) entdeckt habe und daraus schlieBt, die Insel müsse einst von Menschen bewohnt gewesen sein:

I,313ff. Если кто увидит марморный весь истукан

На пустом конечно острове с четырех стран

И давно-давно уже лидям не знакомом,-

I,317f. Тот необходимо скажет, оный зря кумир:

Тут живал всемерно человечий прежде мир -

In der Démonstr. lautet der Eingang: "Qui trouverait, dans une Ile déserte et inconnue a tous les hommes, une belle statue de marbre, dirait aussitót: Sans doute il $y$ a eu ici autrefois des hommes..." (Demonstr. , S.4). Im Selbstgesprãch ăußert der Entdecker sein Entzücken über den glücklichen Fund:

\section{I,319f. Здесь ваятелево зро мастерское дело \\ И дивлось, коль нежно он вырезал всё тело!}

Fénelon schreibt: "...je reconnais la main d'un habile sculpteur; j'admire avec quelle delicatesse il a su proportionner tous les membres de ce corps...' (Démonstr., S.4).

Der Entdecker betrachtet das Werk des unbekannten Meisters mit den Augen des Kenners und beschreibt es bewundernd:

\section{I,323f. Он прицель различил, купно действий живность; Oн аругое всё привел в совершенну яивность -}

Die Reihe der Substantive in der Vorlage: "...il a su...leur donner tant de beauté, de grâce, de majesté, de vie, de tendresse, de mouvement et d'action" (Démonstr.,S.4) ist von Tred. durch Verbformen ersetzt worden, die die Handlung betonen. Die Beschreibung der Gesichtszüge des Marmorbildes geht über die Vorlage hinaus:

I,325f. Наконец, представил живо все в лице черты, Бодрость, и осанку, похвальны красоть!

Nun nimmt wieder der Autor das Wort und fragt: Was meint Ihx, warde dieser 
Kunstkenner Jemandem antworten, der dreist behauptete, das Gotzenbild hatte nicht ein Bildhauer mit dem MeiBel, sondern der zufall ohne zutun eines Menschen so naturgetreu gemacht:

I,327ff. Сей ответствовал 6ш что, мните ви, Аругому, Кой, в противность бы его мнению такому, Burоворил смело, что болван не резчико́м Сделан сей здесь зримшй, но припадок ни при ком Ненароком учинил статуу так власно, -?

In der Démonstr. wird die Behauptung des Anhăngers der Zufallstheorie in direkter Rede vorgebracht: "Que repondrait cet home si quelqu'un s'avisait de lui dire: Non, un sculpteur ne fit jamais cette statue...c'est le hasard tout seul qui l'a faite." (Démonstr., S.4) In der Feoptija wird dem Anhanger des Zufalls eine grobe Abfuhr erteilt: I,335f. Он не назвал ли 6 того прямо сумасбродом, Иль из глупых всех людей страннейшим уродом?

Diese Verse fehlen in der Quelle. Offenbar liegt dem aristokratischen FeneIon solche Grobheit nicht. Sie entspringt aber nicht bloB dem cholerischen Temperament Tred.s. Affektausbrüche gegen die Atheisten scheinen im physikotheologischen Schrifttum nicht selten zu sein. W.Philipp zitiert aus der 'Physikotheologie' (1714) von W.Derham: "Dahero kann man einen Atheisten... für ein rechtes Monstrum, MiBgeburt und Ungeheuer unter den vernünftigen Geschopfen halten..." 29 Auch in der 'Vorrede des Ubersetzers' zur deutschen Fassung der Demonstration werden die Unglaubigen als 'Monstra und Ungeheuer' tituliert. ${ }^{30}$ Mit beiBender Ironie malt Tred. aus, was alles die Unglaubigen dem Zufall zutrauen. So unterstellt er ihnen die absurde Behauptung:

$$
\begin{aligned}
& \text { I,338ff. Сльша так твердяща, что та камня часть, от гор } \\
& \text { Отделившись, там собой сделалась толь стройно; } \\
& \text { Истуканом от себя, Как ей быть пристойно. }
\end{aligned}
$$

Dann wird das Gotterbild vom Sturm an diesen Ort getragen, und ohne daB sich eine Hand rühren mübte, fest auf sein Podest gestellt. Fénelon hat sich uber den Zufallsglauben folgendermaBen moquiert: "Parmi tant de morceaux de marbres, il $y$ en a eu un qui s'est forme ainsi de lui-meme; les pluies et les vents l'ont detache de la montagne; un orage très-violent l'a jeté tout droit sur ce piedestal, qui s'etait préparé de lui-même dans cette place." 
(Demonstr.,S.4f.). Tred. setzt hinzu, daß dies natürlich alles nur 'leere Reden' sind:

$$
\begin{aligned}
& \text { I,345f. И конечно зная, что то быть не может быль } \\
& \text { И что все те речи только пустота иль пыль. }
\end{aligned}
$$

In der Démonstr. wird die ironische Rede fortgeführt, indem die vom zufall gebildete statue den berühmten Vorbildern an die Seite gestellt wird: "C'est un Apollon parfait comme celui du Belvédère; c'est une vénus qui égale celle de Médicis; c'est un Hercule qui ressemble a celui de Farnèse." (Démonstr., S.5). Fénelon treibt die Parodie auf die Spitze: "Vous croiriez, il est vrai, que cette figure marche, qu'elle pense, et qu'elle va parler: mais elle ne doit rien a l'art, et c'est un coup aveugle du hasard qui l'a si bien finie et placée." (Démonstr., S.5)

Tred. hat den Ton schon in 1,345f. gewechselt. Er stellt nach der Aufzăhlung der Meisterwerke der bildenden Kunst nüchtern fest:

I,351f. Без искусныя руки и не заложились,

А не то чтоб сами все дивно совершились.

Außer den in der Demonstration genannten Werken wird in der Feoptija noch die Statue der 'Bepa' erwăhnt. Den 'Примечания' zufolge hat zar Peter I. sie 1722 im Garten des Sommerpalais aufstellen lassen. Auf den feinen aus Marmor gebildeten Schleier vor dem Gesicht der statue wird eigens hingewiesen: "Особо тонкой работы было покрывало (мраморное), закрывавшее лицо статуи. 131 Tred. führt folgende Werke an:

$$
\begin{aligned}
& \text { I,347ff. Бельведерский Аполлин и Венера славна, } \\
& \text { Медичейской что слывет, в статуах как главна, } \\
& \text { Наконец, Фарнезский оный дивный Геркулес, } \\
& \text { Статуа и Веры, кою Петр в свой сад привез,- }
\end{aligned}
$$

Die Verse I,353-364 haben in der Démonstr. keine Parallele. Hier werden aufs neue die widersacher angeklagt, daB sie sich erdreisten, den Zufall anzupreisen:

I,354ff. Кои дерзновенно не стыдитесь так кричать, Что припадком весь сей свет и собою стался, А премудрым он никем в чин не созидался?

Sie werden eindringlich ermahnt, ihre stimme nicht mehr für den zufall zu erheben, sondern von Herzen Gott zu bekennen: 
I,357ff. Буде есть хоть капля разума природно в вас,

То вам догоно вскоре пременить нелепый глас

И от сердца признавать бога купно с нами, -

Scheinbar ratlos gegenuber dem Starrsinn der Unglăubigen hat der Autor in Vers 353 gefragt:

Как же, по примеру, можем вам мы отвечать,-?

Jetzt antwortet er innen mit dem physikotheologischen Credo:

$$
\begin{aligned}
& \text { I,361f. Всяка тварь во свете проявляет вам его, } \\
& \text { Камет всё, что стало бытием от самого. }
\end{aligned}
$$

Es folgt, knapp formuliert, der AnalogieschluB a minore ad maius: Wenn nicht einmal ein Gotzenbild durch zufall entstanden sein kann, wie kơnnte man dies von der Welt behaupten:

$$
\begin{aligned}
& \text { I,363f. ибо утвераить чего не́льзя о кумире, } \\
& \text { Как возможно то с умом говорить о Мире? }
\end{aligned}
$$

Im Mittelpunkt des năchsten Vergleichs steht ein Gemålde, das den Durchzug der Israeliten durch das Rote Meer darstellt (Exod., Kap.14,21ff.).Dieses Thema war, wie in den Примечания angemerkt wird, in der europaischen Malerei des 16.-18. Jahrhunderts sehr verbreitet. Als Beispiel wird auf das Bild des franzósischen Malers Nicolas Poussin (1594-1665) hingewiesen. 32 Fénelon kōnnte dieses Bild im Sinn gehabt haben, als er schrieb: "Si on avait devant les yeux un beau tableau qui representat, par exemple, le passage de la mer Rouge, avec Moise..." (Démonstr.,S.5). Tred. hat diese Stelle erweitert. Er denkt an einen Kunstliebhaber, der in einer Gemaldesamnlung an der Wand Bilder erblickt, die ihm wegen ihrer auBergewornnlichen Kunst besonders auffallen:

$$
\begin{aligned}
& \text { I,365ff. Напоследок: буде некто обходя везде } \\
& \text { В лобопытстве хвальном, на стене усмотрит где } \\
& \text { Преизряднуо во всем мивопись картины, } \\
& \text { Мечуциеся в глаза с своея холстины, - }
\end{aligned}
$$

Nun faBt er ein spezielles Bild ins Auge:

I,369ff. Я кладу, на коей проведение лодей

Всех израилетских по пучине без ладей

Моисеем иногаа, написан худомник, -

Es folgt in $1,373-84$ die Beschrelbung des Bildes: 
Es stellt das Volk Israel dar, das voller Freude auf dem Grund des Meeres geht, die Hănde zum Schópfer erhoben, der es aus der ăgyptischen Plage errettet hat. Der zug des befreiten Volkes wird durch die Verwendung von Verbformen im Präsens lebendig geschildert:

$$
\begin{aligned}
& \text { I,373ff. Там одних увидит, в радости по глубине } \\
& \text { Шествуоцих сонмон и на самом бездны дне } \\
& \text { Воздеваощих к твориу в выспренняя руки, } \\
& \text { 0т египетския их спасшему всех муки, } \\
& \text { И благодарящих за избаву ту себе, } \\
& \text { бывших прежде в лютой у мучителей гоньбе - }
\end{aligned}
$$

Auf der anderen Seite sieht man den Untergang der Ägypter im Meer:

$$
\begin{aligned}
& \text { I,379ff. Но с другой там стороны узрит он тристатов } \\
& \text { Фараона самого, всех же супостатов, } \\
& \text { Колесмицы, коней и всё войско без иисла, } \\
& \text { Гнавшее за теми, но пришедшее до зла } \\
& \text { Потопления в водах - }
\end{aligned}
$$

Auch der Schrecken der Ägypter angesichts der sie verschlingenden Wellen wird gezeigt:

$$
\text { I, 383f. }
$$$$
\text { - И затем всех в страхе, }
$$

Видящих, что волны их пог лощают в махе.

In der Démonstration sieht die Bildbeschreibung so aus: "...on verxait d'un côté cette multitude innombrable de peuples pleins de confiance et de joie, levant les mains au ciel; de l'autre côté, on apercevrait Pharaon avec les Égyptiens, pleins de trouble et d'effroi à la vue des vagues qui se rassembleraient pour les engloutix." (Démonstr.,s.5)

Tred. hat diesen Text durch die aus der biblischen Erzăhlung bekannten Einzelheiten 'Wagen, Pferde und das ganze Heer' (vgl. Exod.14,28) erweitert.

Auf die Bildbeschreibung folgt, ahnlich wie im vorigen vergleich, eine groteske Theorie der Entstehung des Bildes aus der Sicht der Zufallsglaubigen. Hat etwa eine Magd die Leinwand mit ihrem Besen getüncht? "... ou serait l'homme qui osat dire qu'une servante barbouillant au hasard cette toile avec un balai...?" (Démonstr.,S.5). Absurd anzunehmen, daB auf diese Weise Farben, Figuren, Mienenspiel, Licht und Schatten, "...enfin tout ce que le plus beau génie d'un peintre peut rassembler... (ebd.) zustande gekommen sei. 
In der Feoptija ist diese Passage nur wenig verăndert worden. So ist an die Stelle der Magd mit dem Besen die wăscherin mit dem Schlegel getreten:

$$
\begin{aligned}
& \text { І,385 Скажет ли тот некто, живопись сио смотря,- } \\
& \text { I,387f. Что вальком то полотно прачка поражавши, } \\
& \text { И из оного всо нрязь при реке где жавши, - }
\end{aligned}
$$

Konnte wohl unter ihren Hăden ein Kunstwerk entstehen?

$$
\begin{aligned}
& \text { I,389ff. Варуг там усмотрела что собон краски все } \\
& \text { Прибрались различно, да и в самом том часе } \\
& \text { Лица вмиг на полотне те изобразили, } \\
& \text { Тень и свет в местах своих чинно сомзили; } \\
& \text { Словом, все что может живописец учредить, } \\
& \text { Чтоб ему картину совершенством расцветить? }
\end{aligned}
$$

Ferner fragen sich unsere Autoren, ob etwa der Schaum am Maul eines Pferdes -es geht um das Bild vom Durchzug der Israeliten durchs Rote Meer- durch einen Klecks vom Pinsel des Malers zufăllig entstanden sein kơnne. Der Maler habe vielleicht den Pinsel argerlich ausgeschüttelt. Man muß zugeben, sagen sie, daß es solchen Zufall, wenn auch sehr selten, gibt:

$$
\begin{aligned}
& \text { I,395ff. Если } 6 \text { наша пря была, силь ж не в премене, } \\
& 06 \text { одной явленной там в Конской морде пене, } \\
& \text { Коя ненарочным случаем произошла... } \\
& \text { I,399 То } 6 \text { возмог признать и сам делом я возможным,... } \\
& \text { I,401ff. Что там живописец с сердца кистио тряхнул, } \\
& \text { Коер он краски преизлишно зачерпнул } \\
& \text { И чрез то однажды в жизнь, самому на диво } \\
& \text { Конскую изобразить пену смог и живо. }
\end{aligned}
$$

In der Demonstration hat die Stelle diesen Wortlaut: "Encore s'il n'etait question que d'un peu d'écume a la bouche d'un cheval, j'avoue, suivant l'histoire qu'on en raconte....qu'un coup de pinceau jete de depit par le peintre pourrait, une seule fois dans la suite des siecles, la bien représenter." (Demonstr. ,S.5)

In Feoptija I,405ff.ist eine Anekdote eingeschoben, die von dem griechischen Maler Protogen handelt, der im 4.Jahrhundert v.Chr. auf Rhodos gelebt hat. Sie steht nicht bel Fenelon. Darin wird erzăhlt, der maler habe bei der Arbeit an seinem Bilde 'Jalis mit dem Hunde' nach vielen miblungenen Versuchen, eine Schaumflocke an der Schnauze des Hundes zu malen, die Geduld ver- 
loren und den Schwamm, mit dem er die Farben abwischte, zornig auf das Bild geworfen. Dabei habe er aber nicht etwa das Bild beschmutzt, sondern gexade jene Schaumflocke wunderbar zum Ausdruck gebracht:

I,410ff. А броском не токмо живописства не смарал, Но еще впрямь изразил ону пену чудно, Кон мастерством ему сделать было трудно.

So schlieBt die lebendig erzăhlte Anekdote. Der Autor fügt aber sofort hinzu, daB man aus diesen Beispielen, in denen es um ein biBchen schaum geht, nicht den Schlub ziehen dürfe, die Welt sei ebenso durch zufall entstanden;

I,413ff. Пен же ль сих примером заключить возможно нам, Что сей мир припаяком так же сделаться мог сам?

Mit dem Ausruf 'коль различно то с Аругим!' (415) wird der gewaltige unterschied zwischen einem zufalligen Farbspritzer auf der Leinwand und 'dieser Welt' hervorgehoben. Im folgenden schließt sich Tred. wieder an seine Vorlage an. Selbst beim 'Schaum' hat der npunapok fast nichts geleistet: der Maler hatte ja schon vorher die Farbe gemischt:

\section{I,415f. - Краски улж составил}

живописец сам себе, лица все представил, -

Die Leistung des Zufalls ist also minimal: nur ein biBchen Schaum hat er zustande gebracht, der in der Vorstellung des Künstlers schon da war:

I,419f. Пенку посему одну там свершил припадок,

Коя от искусных уж начата догадок.

Die Stelle lautet in der Demonstration: "Mais au moins le peintre avait-il dejà choisi, avec dessin, les couleurs les plus propres à représenter cette ecume... Ainsi ce n'est qu'un peu de hasard qui a acheve ce que $I^{\prime}$ art avait dejà commencé." (Démonstr., s.5)

Kann nicht einmal ein biBchen Schaum am pferdemaul vom Zufall allein gemalt werden, wie sollte er dann ein ganzes Bild schaffen kơnnen?

I,421f. Hо картину ль целу без всего свершить он мог, Как всегаa бессмыслен и всега во всем убог?

Hier klingen die Attribute des Zufalls aus I,213ff. wieder an: 'скуяная причина' (214), 'нет в ней смысла и ума'(215), 'не готовит случай и не учреждает OH' (217). 
In den Versen 421f. hat Tred. den Text seiner Vorlage reduziert. Fenelon schreibt: "Quelle comparaison de cette ecume avec tout un dessin d'histoire suivie, ou l'imagination la plus feconde et le génie le plus hardi... suffisent a peine pour executer ce qui compose un tableau excellent?" (Dem., S.6)

Tred. führt die Analogie konsequent zu Ende. Der Schaum ist bei weitem nicht das ganze Bild, stellt ex fest. Mag dex Zufall auch beim Zustandekommen der Schaumflocke ein wenig im Spiel gewesen sein, mit der riesigen Welt hat er nichts zu tun. So sind wohl die folgenden Verse zu verstehen:

I,423f. И от целой далека той картинки пена,

А с огромним тором всем нет в ней ни примена!

An dieser Stelle ist ein Einschnitt im Aufbau der I.Epistel. Der Abschnitt I,233-424 stimmt, von den erwăhnten Ausnahmen abgesehen, weitgehend mit dem Text der Démonstration überein. Ex enthălt vor allem Analogien aus dem künstlerischen Schaffen des Menschen, die den Schluß auf die Existenz des Schöpfers nahelegen. Zugleich sollen diese Beispiele den Zufall in seiner Nichtigkeit blobstellen und låcherlich machen. In der Feoptija wie in der Demonstration geht es in dem besprochenen Abschnitt um die anschauliche Widerlegung des 'nрипадок' bzw. des 'hasard'. Darüber hinaus hat Tred. auch die Vertreter der Zufallstheorie personlich angegriffen:

$$
\begin{aligned}
& \text { I,307ff. То уж вам, оl мудрецш, - } \\
& \text { Мира здание сие... } \\
& \text { С разумом как можно дерзновенно утверждать, } \\
& \text { Что оно припадком возмогло в порядок стать? } \\
& \text { I,353ff. Как же, по примеру, можем вам мы отвечать, } \\
& \text { Кои дерзновенно не стидитесь так кричать, } \\
& \text { Что припадком весь сей свет и собох стался -? }
\end{aligned}
$$

Solche polemischen Einschübe, in denen der Autor als Anwalt des Schopfungsglaubens die Anhănger der Zufallslehre anklagt, sind emotional gefărbt und beleben die Ausfürungen durch dramatische Elemente.

Das gilt in besonderem Maße von dem durch starke Erregung gekennzeichneten Abschnitt I, 425-468.

Die vorgebrachten Beispiele mübten eigentlich genügen, meint Tred., um jeden vernüftigen Menschen von der Existenz des lebendigen Gottes, des Schopfers, zu überzeugen. Aber die Gegner bleiben ungerührt. Das bringt den Autor aus 
der Fassung. Er überschūttet sie mit vorwurfsvollen Fragen. Woran fehlt es denn noch, ihnen Gott zu beweisen?

$$
\begin{aligned}
& \text { I,425f. Что уме оскудно к доказанию вообще } \\
& \text { Бога суща, жива и зиждителя еще? }
\end{aligned}
$$

Was muB noch geschehen, um die Finsternis und Gottlosigkeit zu vertreiben?

I,427f. Что к разгнанию в вас тьмы? Мрака что густого? Что нечестия? Что - локи? Мнения пустого?

Das Stakkato der Fragen veranschaulicht die Erregung, mit der sie gestellt werden. Die Stelle erinnert an I,55ff. Die geistige Verfassung der Unglaubigen wird dort mit denselben Metaphern bezeichnet: 'Tbma nperycrag'(61), 'mpak' (67), ' ложь' (64 und 66).

Die Irrlehre, die sie 'beharrlich herunterleiern', ist hier wie dort ein und dieselbe :

$$
\begin{aligned}
& \text { I,433f. Как и быть в упрямстве блядословствуя всё тож, } \\
& \text { Јварь что самозданна? вияите вы всо в том ложь. }
\end{aligned}
$$

Die Form 'баядословствуя' ist vom ksl. 'блядословати' abgeleitet, das Mikl. (33) mit lat. 'nugari' wiedergibt. In I,59f. wird den Ungläubigen die Auffassung in den Mund gelegt:

\section{Говорите, что сей мир, с чином, с красотою, Вечен состоит и есть искони со6о1 -}

Der Autor verurteilt diese Meinungen als 'nлeтни', d.h. als 'Klatschereien', 'Gefasel' (Pawlowski, 1062f.). Sie sind durch das 'Schwert der Wahrheit' schon 'weggehauen' $(I, 430)$. Nachdem die Irrlehren widerlegt sind, fragt der Autor die Gegner, woran es denn noch fehle, daB sie durch das licht erleuchtet werden?

I,429f. Кой есть недостаток, просветиться 6 вам лучом?

Все ум плетни ваши правды ссечены мечом.

Er wirft den Anhängern der Zufallstheorie vor, ihre Beahuptungen seien nur unnützes Gerede. Sie kümmerten sich nicht um die stichhaltigkeit der Argumente, sondern erzăhlten gottlose Fabeln:

I,439f. Токмо говорить на ветр басни толь злобожны, Басни нечестивы толь, да и невозможны -

In der Démonstration wird die Meinung der Gegner als 'le roman de la philo- 
sophie épicurienne' (S.83) abgewertet. Fénelon spricht geringschătzig von "les epicuriens dans leurs suppositions les plus fabuleuses" (S.89). Tred. hat sich diese Beurteilung zu eigen gemacht. Energisch fordert er die zufallsglăubigen auf:

1,435ff. Перестаньте: полно вам в бреде утверждаться

И мечтами, как вещьми, мнимо усламдаться;

Вымынлять доводн, а о твердости сих всех

Не радеть нимало, не хотеть гои видеть в тех.

Im folgenden richtet sich die Polemik gegen eine Gruppe von Gegnern, die sich nach Meinung des Autors nicht wesentlich von denen unterscheiden, die ex bisher im Visier hatte. Wahrend die Zufallsanhănger ihren Unglauben offen verkünden, bekennen sich die neuen Gegner scheinbar zum Glauben an die Existenz Gottes. Ihre Einstellung wird so charakterisiert:

I,443f. Утверждать, что бог хоть есть, но не промышляет

И создание свое просто оставляет.

Damit verbergen sie aber, 'listig wie die Schlange', nur ihre wahre Meinung:

I,442 И по-змийски хитро в мнениях своих таясь, -

Mit dieser metaphorischen Wendung verbindet sich die Erinnerung an die verhăngnisvolle Rolle, die die Schlange in der biblischen Geschichte vom Sündenfall spielt (Gen.Kap.3). Im Neuen Testament wird die Wendung 'klug wie die Schlangen' von Jesus mit der Aufforderung seid 'ohne Falsch wie die Tauben' verbunden. Von Natur aus kann der Mensch beldes zusammen nicht durchhalten. Jesus meint ein Verhalten, zu dem die Jünger erst in seiner Nachfol-

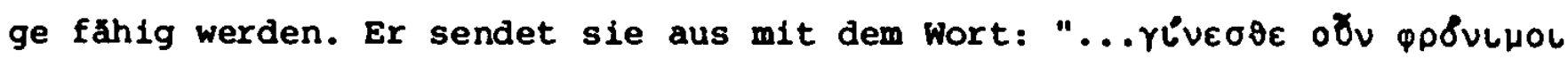
is oi öpels xal \&xépalol is ai neplotepal."(Matth.K.10,16)

Die Existenz Gottes behaupten und zugleich sein Elnwirken auf die Welt verneinen, darin besteht nach den Worten Tred.s die altbekannte List Epikurs:

I,445ff. Мнение такое с первых по всему одно,

То нам в Эпикуре хитрость ведомо давно:

Кто не хочет в боге знать действа ни едина, -

Zum exsten Mal taucht hier der Name des griechischen Philosophen Epikur (341-270 v.Chr.) auf, zu dessen Anhăngern im 17./18.Jahrhundert die Deisten und Atomisten gerechnet werden. Fénelon nennt diese kurzerhand 'les épicu- 
riens', z.B. in der Uberschxift zu 'chapitre III' der Demonstration, in dem er sich mit den 'objections des épicuriens' auseinandersetzt. (Demonstr.,s.77) Die Auffassung von E.N.Lebedev, im Mittelpunkt der I.Epistel der Feoptija stehe die Kritik an der Lehre Descartes' von den 'occasiones', scheint im Text nicht begründet zu sein: "...здесь иентральное место занимает критика картезианской 'системы случайных причин'." 33 vielmehr geht es um die widerlegung des 'Zufalls' (припадок=hasard) im Sinne des 'ursachlosen Geschehens', das durch Epikur zum ersten Mal in der Geschichte der Philosophie "zu einem metaphysischen Prinzip" gemacht worden ist. 34 Im System Descartes' sind die 'occasiones' die von Gott gesetzten 'causae secundae' des Geschehens.

Wer das Wirken Gottes leugnet, verweigert ihm die Anerkennung als 'Herr der Welt', folgert Tred.:

\section{I,448 Самым тем не признает свету господина.}

Wesen und wirken Gottes sind miteinander identisch. Gott ist, wie die alten Dogmatiker sagten, 'semper ubique actuosus'. Verneint man sein Wirken, so leugnet man ein wesentliches Attribut Gottes und dichtet der 'geistigen Gottheit' menschliche Züge an:

\section{I,449ff.Существительное свойство отрицая так, Суиества самого не приемлет тот никак Oн Ауховну боместву образ причитает Человеческий и взор...}

Damit verwirft man den 'uberweltlichen Gott'. Es ist pure Heuchelei, wenn man seine Existenz mit dem Munde anerkennt:

\section{I,453f. Сим премирна бога, неописанна притом,} Признавая только лицемерствуюиим ртом.

Auch Spinoza - für Tred. der zweite Reprăsentant des philosophischen Atheismus- ist mit List in seinen Worten vorgegangen, aber nur scheinbar unterscheidet er sich von Epikur:

\section{I,455f. И Спиноза поступил хитростию ж в слове, А от эпикурской в вид как иною внове.}

Nach seiner Lehre ist kein Wesen imstande, ein anderes zu erschaffen. Folglich muß die Welt von selbst entstanden sein: 
I,457f. По его: не можно суиеству Аругое здать, Следственно, собоп долино зданиям всем стать.

Spinoza wollte aber in bezug auf die Ethik kein Epikureer sein:

I,459 Не хотя, за сласти' речь, быть зпикуристом, -

Die Wendung 'за сласти ре4ь' soll wohl das ethische Prinzip des Epikureismus andeuten, das in der 'Lust', der hoovh́=cлactb, gesehen wurde. Die Epikureer richteten ihx Interesse auf die individuelle Glückseligkeit. "Der asthetische Selbstgenuß des gebildeten Menschen 1st... das höchste Gut fur den Epikureer." 35 Das Wort 'cласть' ist im Text der Feoptija kursiv gedruckt und vermutlich auch im Manuskript Tred.s hervorgehoben worden, um es als Schlüsselwort der epikureischen Ethik kenntlich zu machen. So sehr es dem Autor recht gewesen sein mag, daB Spinoza sich von der 'cracto' distanziert hat, ex macht inm einen schweren Vorwurf:

\section{I,460 Стал злобожнейшим еще жид сей пантеистом.}

Der Vers ist interessant als erster Beleg für das Wort 'пантеист' im Russischen. Nach Gerta Hüttl-Worth hat Tred. das Wort eingeführt, "das nach dem Slovar' erst seit 1847 für Russisch belegt ist." ${ }^{36}$ Der Name Pantheist scheint durch den Titel einer Schrift von John Toland,'Pantheisticon' (1710), "wenn nicht geschaffen, so jedenfalls üblich geworden" zu sein."

In Tred.s Augen ist Spinoza ein 'ganz gottloser Pantheist'. Das demonstrative 'сей жид' scheint antisemitisch gefarbt zu sein.

Gegen die These Spinozas (I,457f.) erhebt Tred. den Einwand, was denn das 'allervollkommenste Wesen' daran hindern kơnne, ein anderes, begrenztes Wesen zu schaffen. Der Begriff des 'allervollkommensten Wesens' schliebt zwar die Erschaffung gottgleicher Wesen aus, aber Gott hat die Macht, alle inm nicht gleichen Wesen nach seinem gnădigen Ratschluß zu schaffen:

I,465f. Исклочает равных, но неравных всех себе Произвесть бог мощен, по своей благой суаьбе.

Im letzten Verspaar des polemischen Einschubs bricht noch einmal die emotionale Erregung des Anfangs durch:

I,467f. Долго ль блядословить вам? Наше слово твердо. Бог вас сам да просветит правдой милосердо!

So ist der polemische Einschub geplant und in sich geschlossen aufgebaut. 
'Gott selbst wird Euch erleuchten', weist darauf hin, daB die Făhigkeit, andere in Glaubensdingen $z u$ überzeugen, begrenzt ist. Alles Argumentieren und Polemisieren wird die Unglăubigen nicht zum Glauben bringen, aber 'Gor сам вас просветит...'

Es scheint, als habe der Autor langst vergessen, daß er einen 'Brief' schreibt. Außer in einigen Versen am Anfang hat er sich noch nicht wieder an den Adressaten gewandt. Jetzt bittet er Evsevij un Entschuldigung, daB er sich, statt dem Freund zu schreiben, mit den Atheisten auseinandergesetzt habe:

$$
\begin{aligned}
& \text { I,469ff. Извини, Евсевий, устремление мое, } \\
& \text { Что начертавая к другу я письмо сие, } \\
& \text { К атеистам обратил дело в ней и речи, - }
\end{aligned}
$$

Das Fremdwort 'arenct' findet sich im Russischen seit Prokopovic. 38

Geschickt fährt Tred. fort, er habe damit zugleich den 'wohlgesinnten Freund' zum Zeugen der Auseinandersetzung gemacht:

$$
\text { I,472 А те6я варуг судией сделал после встречи. }
$$

Der Vers gehört zur 'Captatio benevolentiae', wie sie in der klassischen Briefform nach der 'Salutatio' üblich ist. Dies wird in den folgenden Versen noch deutlicher:

I,473ff. Ты, как благосклонный, в Аружестве отнюдь не льстив, K богуж весь усерден и к нему благочестив, По приятству не причтешь мне сего в погрешность.

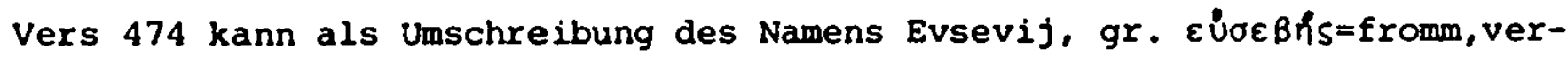
standen werden. Das Adj. 'благочестивый', abgeleitet von ksl. 'благочьстивъ', heißt 'gottesfürchtig, fromm' (Pawl.61). Wenn die Annahme richtig ist, daß es sich bei dem Namen Evsevij um einen 'redenden Namen' handelt, dann hătte der Autor damit den idealtypischen Leser gemeint, der die in der Feoptija behandelten Dinge sachverständig beurteilen kann.

Der Anrede an Evsevij und der 'captatio benevolentiae' folgt eine Zusammenfassung des Inhalts der I.Epistel. In ihr hat der Autor gegen Atheisten und Deisten gekämpft. Die einen leugnen die Existenz Gottes, die anderen wollen nicht, daß er der Schópfer der Welt sei: 
I,477f. Свел борьбу я с теми, кои бога быть не мнят

Иль, чтоб был зимаитель миру, всяко не хотят.

'Klipp und klar' -der Autor gebraucht den volkssprachlichen Ausdruck 'Brs8b'habe er die Ansichten der Gegner dargestellt und sie geradeheraus mit der Wahxheit bekămpft:

1,479f. Пред собой представил их, въявь изображая

И как прямо и в личе истиной сражая.

Evsevif hat als Augenzeuge gesehen, daß die Gegner nicht standhalten konnten: I,481 Вияел ты, как зритель, что стоять не можно вм -

Seiner Sache gewiB und in dem BewuBtsein, noch viele Argumente zu haben, fragt der Autor:

I,483f. Чем еще я не могу доказать им бога?

Что не объясняет нам твердого предлога?

Es gibt noch viele Beweise für die Existenz Gottes, will er sagen und nennt als Beispiel die schon I,47 angeführte Gottesidee der Vernunft, aus der Descartes seinen Beweis entwickelt hat:

\section{I,485 Существа такого разум наш в идее зрит, -}

Nach Descartes ist die Idee Gottes eine 'idea innata', die ebenso 'klar und deutlich' wie das selbstbewuBtsein, d.h. unmittelbar evident, ist. ${ }^{39}$ zum Beweis a priori, den die Vernunft aus sich selbst hat, kommt der physikotheologische Beweis. Zwei verschiedene Denkformen, die sich gegenseitig das Lebensrecht absprachen, hat Tred. ohne philosophische Bedenken in der Feoptija für den Gottesbeweis herangezogen:

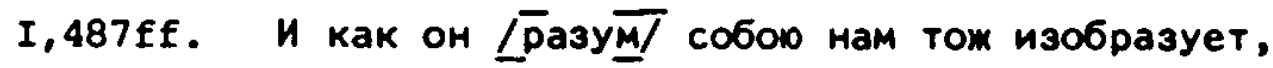 Так и целость мира вся равно показует: \\ Чин и строй являют вышня существа извол -}

Als Schopfung Gottes gekennzeichnet ist die Welt vor allem durch die Merkmale 'чин и строй' (489), 'чин толь стройный' (227) und 'nорядок' (310). Gerade die Entdeckungen der modernen Physik und Astronomie hatten die 'Ordnung und Harmonie' aufgezeigt, so daB die Physikotheologen im streit mit den Gegnern darauf hinweisen konnten, daB sie die neve wissenschaft auf ihrex seite hatten.

Bel der Frage "чем еще я не могу доказать им 6ora?" (483) hat Tred. wohl 
auch den Beweis im Sinn, den er im folgenden Abschnitt I,491-542 ausführlich darstellt. Darin wird aus der allgemeinen Verbreitung des cottesgedankens bei allen Völkern (e consensu gentium) auf die Existenz Gottes geschlossen. Die Stichhaltigkeit dieses Beweises braucht in unserem Zusammenhang nicht geprūft zu werden.

Der Autor führt aus, daB zu allen Zeiten und an allen orten die Menschen, so verschieden ihre sitten und Gebrăuche auch sein mögen, sich darin gleichen, daß sie irgendeine Religion haben:

$$
\begin{aligned}
& \text { I,491f. Роды всех веков и мест, коль они аруг аругу } \\
& \text { Ни противны по себе и страны по кругу; - } \\
& \text { I,495ff. Все однак согласны в том, чтоб сердец внутрь к богу } \\
& \text { Почитание иметь, объявлять честь многу } \\
& \text { Оному снаружи действием покорства в вия } \\
& \text { И его звать в помощь от напастей и обид. }
\end{aligned}
$$

Die universale Verbreitung der Religion wird in I,534 noch einmal hervorgehoben:

\section{Всіод отдается божеству вседолжна честь.}

Der universalen Verbreitung der Religion entspricht ihre Bedeutung für das private, kultische und gesellschaftliche Leben. Ein bewegendes Bild des menschlichen Schicksals wird gezeichnet, in dem sich der einzelne, Hilfe und Schutz suchend, an seinen cott wendet, angesichts von Unglück und Unxecht (от напастей и обия,498), in Ungewißheit vor der zukunft (неспособны ведать буаущу себе судьбу,505), in besonderen Anliegen, bei der Eheschließung, auf dex Reise (в особливых нуждах, в сочетаниях, в пути,513), in Bedrăngnissen (в бедствия ль nonaת,515) : bei alledem wird Gott angerufen (в том всем божество зовется,515). Welche Gelübde werden ihm nicht dargebracht, damit man unter seinem Schutz ohne Anschuldigungen leben kann:

$$
\begin{aligned}
& \text { I,507f. Под его покровом быть, да и без наветов, } \\
& \text { Коих не приносят где божеству обетов? }
\end{aligned}
$$

Man ruft zu Gott, und seine Hilfe kommt bald:

I,516 Да пособство от него вскоре низведется.

Die Erscheinungsformen des religiösen Kultes sind in allen Lăndern zu finden: Priester, Altăre, Gotteshäuser, Feste und herrliche Zeremonien: 
I,499ff. Кто ни станет гАе из стран, всоду обрящет

Богу посвященных слуг, жертвенники срящет,

Узрит купно жертвы, храмы, празднований ряд

И великолепный, по богатству там, обряд.

Gottesdienst und Gottesfurcht sind aberall verbreitet; in diesem Gefuhl sind die Menschen einander ahnlich:

1,503f. Cлуm6а всоау божеству, страх повсоду божий;

Каждый человек с другим в чувствии сем схожий.

Besonders erwăhnt wird der nationale Dankgottesdienst, etwa nach dem Sieg über die Feinde, in dem kostbare Beute zum opfer dargebracht wird:

\section{I,523ff. Слава ж за успех всегда, с чувствием природным, Восписуется ему гласом всенародным, Купно благодарством и приносом предрагих Всяческих корыстей, полученных от других.}

$\mathrm{DaB}$ diese Verse auf den Dankgottesdienst nach siegreichem $\mathrm{Krieg}$ anspielen, scheint wegen 1,518 nahezuliegen:

Божеством воюют, божеством и славят мир.

Auch im gesellschaftlichen Leben wird der Religion eine bedeutende Rolle beigemessen. So heiBt es, $d a B$ von jeher Bündnisse zwischen den verschiedenen 'Gesellschaften' im Namen des Horchsten besiegelt werden:

$$
\begin{aligned}
& \text { I,509f. Печатлеют сею преверьховнол они } \\
& \text { Властио союзы обществ разных искони - }
\end{aligned}
$$

Es fragt sich, ob 'о6щество' hier in privatrechtlichem oder staatsrechtlichem Sinn gemeint ist. Wahrscheinlich ist an Bundnisse zwischen Staaten gedacht.

Ferner wird auf die Wichtigkeit der Religion in der Rechtsprechung hingewiesen, bei der Eidesleistung und beim Urteilsspruch der staatlichen oder kirchIichen Gerichte:

\section{I,511f. Обещания присаг ер утверждарт,}

Ей в казнь оставляют злых, коих проклинают.

Gemeint ist das Todesurteil, das mit der Kirchenstrafe der Exkomunikation verbunden ist.

Kein Bauwerk wird begonnen (нет строений,519), kein wichtiges Unternehmen 
angefangen (нет отнодь предприятий важных,519), kein Geschăft abgeschlossen (купли, ни товаров нет без того продажных,520), nichts geschieht ohne Gott. Tred. faBt die Bedeutung der Religion für das zusammenleben in der Gesellschaft zusammen:

$$
\begin{aligned}
& \text { I,521f. Словом, ни малейших, в обществе полезных, дел, } \\
& \text { Чтоб без бога оны начинать когда был смел. }
\end{aligned}
$$

Der Autor hebt hervor, daB weder Leidenschaften noch trügerische Spekulationen, noch die Gewalt etlicher Tyrannen es fertiggebracht haben, eine so universale Ubereinstimmung wie die Religion zunichte $z$ machen:

$$
\begin{aligned}
& \text { 0бщего толико, неразрывного нигде } \\
& \text { И единовидна сходствия сего везде, } \\
& \text { Польза ни страстей, ниже умствований ложных } \\
& \text { Мнима твердость, И ни власть некоих вельможных } \\
& 8 \text { слабость, в разность мнений, не могли никак привесть. }
\end{aligned}
$$

Woher kommt der consensus gentium?

$$
\begin{aligned}
& \text { I,535f. Отчего ж сие взялось сходствие толико } \\
& 8 \text { подах, коих есть число в свете превелико -? }
\end{aligned}
$$

Der 'consensus' wird damit erklărt, daß der Schöpfer selbst sein Bild den Menschen ins Herz geprägt hat:

I,539f. Как и не от чувства внутрь в сердце положенна

И создателем его в том изображенна?

Die altesten Spuren der religiosen Uberlieferungen sind so alt wie die Welt, fügt Tred. hinzu:

$$
\begin{aligned}
& \text { I,541f. И как не от первых самых тех преданий след, } \\
& \text { Столько ж точно аревних, сколько есть и самый свет? }
\end{aligned}
$$

Das Verspaar exinnert an den Titel der Schrift des englischen Deisten Matthews Tindal(1656-1733) 'Christianity as old as the creation'(1730), dessen These, das wahre Christentum sei mit dem Deismus identisch, Tred. nicht zugestimmt hat.

In gewăhlten Worten unterstreicht Tred. das Ergebnis; Der Glaube an die Existenz Gottes ist so gewiB wie der 'Hall einer Posaune':

I,543f. Bepy, бora 6uть, к тому ж са́ma безопасность Утверждает, как трубы громка велегласность -

Die 'Stimme der Posaune' kommt in der Bibel an betonten Stellen vor, z.B. 
bei der Gottesoffenbarung am Sinai (Exod.Kap.19,16), bei der Eroberung der Stadt Jericho(Jos.Kap.6,4ff.), in verschiedenen Psalmen, insbesondere dort, wo die Thronbesteigung Jahves bzw. das Kommen der Gottesherrschaft verherrlicht wird (Ps.47,6; Ps.98,6; Ps.150,3-Lutherbibel).

Unser Autor wird des Beweisens nicht müde, er fügt noch einen Beweis e contrario hinzu. Angenommen, es gäbe keinen Gott und Schopfer der Welt, gibt er zu bedenken, dann wăre unser Glaube, der die Existenz Gottes behauptet, unwahr. Wer wurde uns aber dann 'wegen dieser Luge' als gerechter Richter in der Ewigkeit bestrafen?

$$
\begin{aligned}
& \text { I,545ff. Положив, что бога и зижаителя всему } \\
& \text { Нет и не бывало, вера наша, посему, } \\
& \text { Утверждающая быть, ложна непреречно. } \\
& \text { Правосудный кто ж за ложь показмит нас вечно? }
\end{aligned}
$$

Andererseits sollen aber auch die Unglaubigen die Folgen bedenken: ihnen wird die Tür zur Barmherzigkeit endgültig verschlossen:

$$
\begin{aligned}
& \text { I,549f. Hо противну веру положа во люи теперь, } \\
& \text { К милости всемерно заключается уж дверь. }
\end{aligned}
$$

Das Bild der 'verschlossenen Tur' erinnert an das Gleichnis Jesu von den klugen und torichten Jungfrauen(Matth.25,10). Dort heiBt es in Ton einer

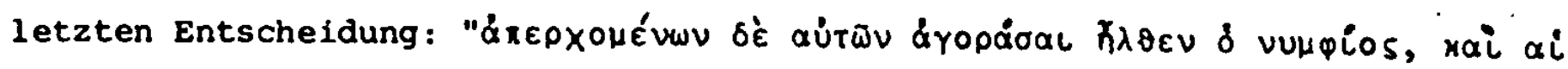

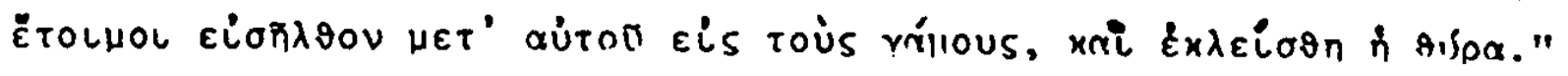

Der Autor hat keinen zweifel, daß der Unglaubige wegen seiner Leugnung der Existenz Gottes und wegen der Verfahrung anderer zum Unglauben die Strafe Gottes empfangen wird:

I,552ff. Ясно, веруяй не быть, так и утверждаяй, восприимет казни за локесловие и лесть:

Бог, кой правосудный, не отмстит ли, ибо есть?

Die Epistel schlieBt mit dem physikotheologischen Credo im hymnischen stil. Der Grundgedanke,'Gott ist', wird dem Evsevif aberschwenglich (5mal in zwei Verspaaren) bezeugt:

$$
\begin{aligned}
& \text { I,555ff. Есть всеведый! Всеблагий! Есть бог өсемогуиий! } \\
& \text { Без начала, без конца, есть везде присущий! } \\
& \text { Есть бот, оा Евсевий: всяка проявляет төарь, } \\
& \text { Что он есть создатель и верьховный мира царь. }
\end{aligned}
$$


Die Verse gehōen zu den wenigen aus der Feoptija, die Tred. zu seinen Lebzeiten als Beispiel für das von ihm geschaffene Metrum des 'Гекзаметръ хореический' veroffentlichen konnte. Sie sind in seiner schrift ' 0 Аревнем, среднем и новом стихотворении Российском' (В.P.,S.447) zitiert.

Ir.Epistel: Die Beschaffenheit der Erde und der Gestirne setzt die Existenz des Schopfers voraus

Wie es in seinem Plan vorgesehen ist, geht der Autor den Weg vom Allgemeinen zum Besonderen, von dem Beweis der Existenz Gottes "из самих метафизических внутренностей"(I.Epistel) zum Beweis "no вещам созданного естества". Diese Absicht wird am Anfang der Ir.Epistel ausgesprochen:

\section{II,1f. Вообще, что утвердил и в веки утверждаю,}

В особности о том теперь здесь рассуждаю.

Damit wird zugleich einem pădagogischen Interesse Genüge getan, denn der Autor räumt ein, daB die apriorische Beweisführung der I.Epistel nicht für jedermann einfach $z u$ verstehen sei:

II,3f. Не всякому легки доводы, признаю, Читающиму ту эпистолу мою.

Nicht jeder ist wie Evsevij, dem in der folgenden Apostrophe vortreffliche Geistesgaben bescheinigt werden:

II,5f. Но твой, Евсеиий, смысл толико просвещенный

От тонкости вещей не мог быть воспященный -

Ex läßt sich von philosophischen Feinheiten nicht abschrecken, sondern verfügt ubex natürlichen Scharfsinn, um in sie einzudringen und sie zu beurteilen. Ihm genuggen die Argumente der Vernunft, und er hat sie zweifellos schon mit denselben Worten vertreten, wie es der Autor getan hat:

II,11f. Довольны Аля тебя тебе ум показал;

Не сомневаюсь я, ты ж словом то ж сказал.

Evsevij wird die Wahrheit, die er erkannt hat, auch anderen mitteilen:

II,13f. Однак, как весно мне, аругим то всё собщаешь, Что истинным себе и твераым ощущаешь.

Individuelle zugge treten in dieser Apostrophe nicht hervor. Ein Charakter80 
portxat des Evsevij wird nicht gezeichnet. Wohl wird er von 'den anderen' unterschieden, denen es an Urteilskraft und Făhigkeit zur Begriffsbildung fehlt:

$$
\begin{aligned}
& \text { II,17ff. Поистине из них не все с тобор равны } \\
& \text { И быть не возмогли рассудком толь исправны, } \\
& \text { Ни столько ж о вещах понятия иметь, } \\
& \text { Чтоб вещи без труда им суие разуметь. }
\end{aligned}
$$

Aber Evsevif steht 'den anderen' nicht als einzelner gegenuber, sondern innerhalb einer elităren Gruppe:

$$
\begin{aligned}
& \text { II,15f. Но всяк ли из Аругих тебе подобен есть, } \\
& \text { Хотя И мноГим в том я отдар всі честь? }
\end{aligned}
$$

Die Wahrheit ist jedoch nicht nux denen zugănglich, die es gelernt haben, begrifflich zu denken. $\mathrm{Zu}$ philosophischem Hochmut besteht kein Grund. Der Autor verspricht 'den anderen', ja auch 'den Schwăchsten', ex werde sie auf einem leichteren Wege, der långst für sie gebahnt sei, zu eben jener Wahrheit führen:

$$
\begin{aligned}
& \text { II,21ff. Аля сих теперь пойду гладчайшею стезею } \\
& \text { И поведу с собой их к той ме правде ео. } \\
& \text { Всем сла́бейшим в себе способнейша она } \\
& \text { И точно аля таких давно проложена - }
\end{aligned}
$$

Die Wahrheit, die jedem offen steht, ist die Exkenntnis cottes, des Schöpfers:

$$
\begin{aligned}
& \text { II,25f. Но равно приведет } k \text { создатело и } k \text { бory, } \\
& \text { Как и идущих всех в ту перөуо дорогу. }
\end{aligned}
$$

Tred. kennt wie Fénelon einen zweifachen Weg zur Erkenntnis Gottes, einen durch die Vernunft, die den Gottesbegriff a priori in sich enthalt, den anderen durch die Betrachtung der Natur. Ihre ordnung ist ein Abbild der Weisheit Gottes. Wohin man auch blickt in der Welt, Jberall hat man ihren allweisen Schöpfer, den allgütigen und allmăchtigen Baumeister vor Augen, der alles nach seinem Ratschluß regiert:

$$
\begin{aligned}
& \text { II,31ff. Еава кто всех вещей воззрил на өсак конец, } \\
& \text { Не может не узреть, что их премудр творец, } \\
& \text { Что купно он всеблаг, что всемогущ, строитель } \\
& \text { И есть он по судьбам своим всему правитель. }
\end{aligned}
$$


Diese Weisheit ist keinem Menschen verborgen, es sei denn, er vergibt sie in der Hitze der Leidenschaften:

II,29f. Такая мудрость всем всегда есть не закрита, Да разве от страстей в жар может быть забыта.

In der Demonstration wird dex 'zweifache Weg' zur Wahrheit so aufgezeigt: "...les hommes accoutumés d méditer les verités abstraites, et a remonter aux premiers principes, connaissent la Divinite par son idee; c'est un chemin sor pour arriver a la source de toute verite. Mais plus ce chemin est droit et court, plus il est rude et inaccessible au commun des hommes qui dépendent de leur imagination...

Mais il $y$ a une autre voie moins parfaite, et qui est proportionnee aux hommes les plus mediocres. Les hommes les moins exerces au raisonnement... peuvent, d'un seul regard, decouvrir celui qui se peint dans tous ses ouvrages." (Demonstr., S.1f.)

Auch der Gedanke, daB die Leidenschaften den Menschen an der Erkenntnis Gottes aus der Natur hindern, geht auf die Démonstration zurück: "Si un grand nombre d'hommes d'un esprit subtil et pénetrant n'ont pas trouve Dieu par ce coup d'oeil jete sur toute la nature, il ne faut pas s'en étonner: les passions qui les ont agités...ont fermé leurs yeux a ce grand spectacle." (Démonstr., s.2)

Wăhrend Fênelon den zweiten Weg als 'weniger vollkommen' bezeichnet (...il y a une autre voie moins parfaite, Demonstx.,s.1), hat Tred. die beiden Wege nicht unterschiedlich bewertet. Beide Autoren stimmen aber darin überein, $\mathrm{daB}$ es einen ' $z$ weifachen Weg' $z$ u ein und derselben Wahrheit gibt. Man darf vermuten, daB sie sich damit der Lehre von der 'zweifachen Wahrheit' bewubt entgegenstellen, die damals von Pierre Bayle(1647-1706) in den vielgelesenen Artikeln des 'Dictionnaire historique et critique' (1695 und 1697) in aller Schăfe vertreten wurde. P.Bayle leugnete die Beweiskraft der philosophischen Argumente fur das Dasein Gottes und die Unsterblichkeit der Seele. "Religion ist deshalb für ihn nur als positive offenbarung im widerspruch mit der philosophischen Erkenntnis möglich." 1

Füx unsere Autoren steht beides miteinander in Harmonie. Man braucht nicht besonders scharfsinnig zu sein, erklät Tred., um die schóne Gestalt der Welt wahrzunehmen. Es genügt die einfache, aber aufmerksame Betrachtung: 
II,35ff. Не долг уж тонку быть вещей зря на убор,

Единственно простый доволен токмо взор,

При чем однак всегда потребна есть прилежность.

Was mit der 'einfachen Betrachtung' gemeint ist, wird aus der entsprechenden Stelle der Demonstration deutlich: eine Betrachtung, die kein gelehrtes, z.B. physikalisches Wissen voraussetzt: "Je ne pretends meme entrer dans aucune discussion de physique...je ne veux leur proposer que le simple coup d'oeil de la face de la nature; je ne veux leur parler que de ce que tout le monde sait, et qui ne demande qu'un peu d'attention tranquille et sérieuse." (DEmonstr., (S.7)

In II,41-50 wird die Gliederung der Epistel angegeben. Als Gegenstănde der Betrachtung werden genannt: das Universum, das 'Erdental', das Bimmelsgewölbe, die 'Fülle' der Luft und des wassers und schlieBlich die Gestirne. Es sind dieselben Themen wie in der Demonstration: "Oгромность света,...весь okpyr ero" = "la structure génerale de l'univers"; "дол земли" = "cette terre"; "воззрим выспрь к небесам на толь далеки своды" = "regardons cette volte immense des cleux": "воззрим на полноту и воздуха и вод" = "ces abimes d'air et d'eau"; "воззрим...на звезды" = "ces astres".

Tred. hat den Themenkatalog der Vorlage in alexandrinische Verspaare ubertragen. Das Versmaß ermöglichte es $1 \mathrm{hm}$, die Aufzăhlung der Themen durch bezeichnende Zusătze $z u$ veranschaulichen. So wird z.B. die GröBe des Universums durch den vom Versmaß abhăngigen Zusatz 'so weit der Blick reicht' sinnfallig gemacht:

II,41f. Воззрим сначала мы на всю огромность света, На весь округ его, достигнет сколь примета.

Die Metapher 'Erdental' wird durch die Aussagen, daB wir hier 'leben, gehen und sterben' amplifiziert:

II,43f. Воззрим на дол земли, на коей ми живем, По коей ходим все, где смертними слывем.

Die Demonstration sagt von der Erde nur, daß sie uns trăgt: "Jetons les yeux sur cette terre qui nous porte." (S.7)

Der Blick zum Himmelsgewölbe erweckt die Vorstellung von einem Dach, das sich so viele Jahre hoch über uns ausbreitet:

II,45f. Воззрим выспрь к небесам на толь далеки своды, Которы кровом нам ирез толь премноги годы. 
Man sieht, die bergende Vorstellung des Welthauses ist trotz der astronomischen Wende noch da. Das 'Dach' der Welt ist noch nicht abgedeckt. Das Verspaar erhălt durch das wiederholte 'толь' (толь далеки... толь премноги') еinen emphatischen Beiklang.

In der Démonstration heiBt der Satz: "...regardons cette voate immense des cieux qui nous couvre." (S.7)

Das Verspaar über Luft und Wasser unterscheidet sich nicht wesentlich von der vorlage.

Den Satz "ces astres qui nous eclairent" (Demonstr.,S.7) hat Tred. erweitert und hervorgehoben:

II,49f. Воззрим мы, наконец, на звезды, на светила

И узрим, что зарей сих неисчетна сила.

Am stārksten unterscheidet sich dieser Abschnitt der Feoptija von der Vorlage durch seine rhetorische Stilisierung. Durch die regelmäBig an den Anfang eines jeden Verspaares gesetzte Wiederholungsfigur 'воззрим' wird aus der Aufzăhlung von Themen ein emphatischer Aufruf zur gemeinsamen Betrachtung.

Aus der Aufforderung zum 'Sehen' folgen im nāchsten Abschnitt II,51-84 das 'Erwăgen' (рассуждать, 63), die 'Bewunderung' (Аивиться,78) und der Lobpreis des Schöpfers (в том восклицает: кто сие все...создал? 81f.).

Zwei Typen von Menschen werden unterschieden. Die einen leben in den Tag hinein, ohne sich Gedanken zu machen. Sie denken nur an den Lebensunterhalt. Von der ganzen großen Erde kennt ein solcher Mensch nur den Platz, auf dem sein Haus steht:

$$
\begin{aligned}
& \text { II,55f. Он из всея Земли ту знает токмо часть, } \\
& \text { На коей дом его и где ему вся власть. }
\end{aligned}
$$

Von der Sonne weiB er nur soviel, daB sie am Tage scheint, so wie er des Nachts von der Kerze genügend Licht bekommt:

$$
\begin{aligned}
& \text { II,57ff. Сей знает по тому о солнце и с зарями, } \\
& \text { Что от него светло ему бывает днями; } \\
& \text { Так равно, как себе, во мраке и в нощи, } \\
& \text { Он получает свет довольный от свещи - }
\end{aligned}
$$

Daß einem 'не рассужяаяй' (51) das Licht der Sonne im Grunde nicht mehr bedeutet als sein Nachtlicht, illustriert die Dumpfheit, in der er dahinlebt. Sein Denken ist auf alltăgliche Dinge beschrănkt und kann sich nicht aufschwingen: 
II,61f. Eго мысль за места, на коих пребывает

И ходит он куда, отнодь не залетает.

Die Typisierung des "home qui vit sans reflexion" ist in der Demonstration vorgegeben und weicht von dieser nur in wenigen Punkten ab. So kennzeichnet Fénelon den engen Horizont dieses Typs mit dem Vergleich: "...il ne regarde la terre entière que comme le plancher de sa chambre". (Demonstr.,S.7) Tred. hat dafü: "Он...зинет токмо часть, на коей дом его"(55f.). Fénelon formuliert prăgnant: (il regarde)"...le soleil qui l'eclaire pendant le jour que comme la bougie qui l'eclaire pendant la nuit". (Demonstr.,s.7) Die kerkerhafte Enge des Denkens, "...ses pensees se renferment dans le lieu étroit qu'il habite", ist in der Feoptija durch den zusatz unterstrichen: "... OTHOAb не залетает". Ist jemand schon mit seiner körperlichen Existenz an einen engen Raum gebunden, so sind doch seine Gedanken frei und könnten sich 'aufschwingen', aber "отниды не залетает".

Anders der Mensch, der sich seines Verstandes zu bedienen weiB, (человек, обыкший рассуждать,II,63). Er unterscheidet sich von dem vorher geschilderten durch die Weite und Beweglichkeit seines Denkens. Tred. umschreibt die Tătigkeit des analysierenden Verstandes mit den Begriffen 'Bejahung' und 'Verneinung', in denen der Satz vom Widerspruch aus der aristotelischen Logik anklingt:

II,63ff. Но каждый человек, обыкший рассуждать

И разбирая всё о правде утверждать,

Иль отрицать ему покажется что ложным,

Невероятным что или и невозможным, -

Die Verse sind von Tred. selbständig eingefügt worden.

Der "не рассуждаяй" denkt nux an die 'nahen, notwendigen und bekannten' Dinge:

\section{II,52ff. Здесь мыслит о вещах единственно таких, Которы, суть к нему иль ближе, иль на нужды Зрит кои быть себе потребны и не чужаы.}

Der 'denkende Mensch' hingegen richtet seine Gedanken in die Weite und bemüht sich, alles zu erkennen, was ihn umgibt und sich ringsum in dem weiten Raum befindet, dessen Ende auch die Gedanken nicht kennen: 
II,67ff. Весь простирает вдаль в себе сам помысл свой

И тиится рассмотреть и все познать собой

Те виды, что его отвспду окружают, -

II,71f. И зрятся пребывать в пространстве вкруг таком,

Которого конец ни мыслям не знаком.

Diese Charakterisierung geht auf die folgende stelle der Demonstration zurück: "Au contraire, l'homme accoutume à faire des réflexions etend ses regards plus loin, et considère avec curiosité les abimes presque infinis dont il est environne de toutes parts." (S.7)

Vor diesem Horizont schrumpfen die irdischen GroBenverhătnisse zusammen. Wer sich in seinem Denken mit dem Universum befaßt, dem erscheint das größte Imperium nur als eine 'kleine Ecke' der großen Erde und die ganze Erde als ein Stäubchen oder wolkchen im Weltall:

II,73 Не момет он тогда пространнейшего царства, -

II,75ff. He положить в уме за малый уголок

Обширныя Земли; а Землю вск за клок

Или за облачко во всем пространстве круга.

In Metaphern der Winzigkeit (Tred. hat hier, abweichend von der Vorlage, 'kлok' = Flocke, Stăubchen und 'облачка' = wölkchen) außert sich der Rangverlust der Erde in einem Raum, 'dessen Grenzen selbst den Gedanken nicht bekannt ist'. Solche Vergleiche sind hăufig im Lehrgedicht der Aufklärung vertreten. Chr.Siegrist zitiert als Beispiel Verse von Brockes:

So find' ich, daß der Raum so ungeheuer groB, $\mathrm{DaB}$ gegen ihn die Welt ein kleiner Erden-KloB; Ein Erbs', ein Senf- ein Sand-Korn scheint. 2

Ännlich bezeichnet Genest die Erde als "grain de sable et de poussiere". 3 In der Démonstration lautet die entsprechende stelle: "Un vaste royaume ne lui paraft alors qu'un petit coin de la terre; la terre elle-même n'est a ses yeux qu'un point dans la masse de l'univers." (S.7)

Der nachdenkliche Mensch (человек, обыкший рассукдать,II,63) nimmt es nicht als selbstverstăndlich hin, daB er und seinesgleichen auf dieser Erde leben. Es erregt bei inm Staunen. Er sucht zu verstehen, wie er in diese Welt gekommen ist: 
II,78ff. Аивится, зря себя и зря прдобна аруга, Что жителем Он с ним находится на ней, Старается понять, в мир как введен есть сей.

Diesen Versen entspricht in der Vorlage der Satz: "...il admire de s'y voir place, sans savoir comment 11 y a eté mis." (Demonstr., S.7)

Die physikotheologische Klimax fürt vom Sehen,Erwagen und Bewundern zum Lobpreis des Schopfers. Hăufig auBert sich der Lobpreis in ehrfüchtigen Fragen, die nicht selten formal und inhaltlich von der Bibel beeinfluBt sind:

$$
\begin{aligned}
& \text { II,81f. В том воскличает: кто сие всё, что поемлю, } \\
& \text { Соэдал? и на вода́х кто всі повесил Землю? }
\end{aligned}
$$

Die erste Frage erinnert an Hiob Kap.34,13(Lth.): "...wer hat den ganzen Erdboden gesetzt?" In der zweiten Frage wird die Vorstellung vorausgesetzt, daB die Erde auf dem Wasser schwimt. "Ha Boдax" hat Tred. hinzugefügt, ebenso Vers II,84 И кто водами ж ту отвсіау окружил?

Fénelon denkt an das freie Schweben der Erde im Weltraum: "Qui est-ce qui a suspendu ce globe de la terre, qui est immobile?" (Demonstr.,5.7) Die Erwahnung 'der Wasser' in der Feoptija scheint auf den Schöpfungsbericht der Priesterschrift (Gen.Kap.1) zurückzugehen. Nach diesem Bericht ist die Welt aus dem Chaosmeer hervorgegangen. Der Schopfer teilt das Chaosmeer durch die Errichtung des Himmelsgewolbes in die oberen Wasser, "den Himelsozean, dessen Blaue durch das Firmament leuchtet", und in die unteren wasser, aus denen sich die auf innen ruhende und von ihnen umgebene Erdscheibe erhebt. 4

II,83 stammt aus der vorlage:

\section{Заклепы кто ее толь твердо положил?}

In der Démonstration heiBt es: "...qui est-ce qui en a posé les fondements?" (S.7)

Tred. hat die zwel Fragen der Démonstrations zu vier aneinandergereihten Fragen erweltert, wohl in der Absicht, den Lobpreis zu steigern.

Die folgenden Ausfürungen der II.Epistel sind nach den vier 'Elementen' gegliedert, wie sie schon von Empedokles aufgestellt worden sind: Erde, Wasser, Luft und Feuer. Daran schlieBt sich die Betrachtung des Firmaments.

Die Erde hat zwar in astronomischer Sicht ihre Sonderstellung im Weltall 
verloren. Unter physikotheologischem Aspekt ist sie jedoch voller wunder, die sich dem nachdenklichen Betrachter offenbaren. Das gilt schon für die Materie, aus der sie besteht. Unsere Autoren verwenden hypothetische Uberlegungen -sozusagen eine Vorform der Verfremdung- um den Schleier, den die Gewöhnung über die Augen legt, zu beseitigen. Z.B.: Was wăre, wenn die Erde überall steinhart wäre? Es găbe weder Saat noch Ernte:

\section{II,85 Когда 6 Земля была везде претвердый камень, - II,88 Нам сеять бы нельзя, а ей бы клас родить.}

Die Metapher in Vers 87, "(не можно)...в недра $k$ ней входить", findet sich in der Démonstration: "Si elle était plus dure, l'homme ne pourrait en ouvrir le sein pour la cultiver..." (S.7)

wäre die Erde dagegen weicher, oder bestünde sie aus losem Sand, so könnte sie weder Menschen noch Lasten tragen. Wir würden versinken:

\section{II,89ff. Но если 6 вещество в ней магче некак было, Иль только 6 ито песок и сыпко также плыло, То не могла 6 она носить поверьх людей, Нельзя 6 и никаким быть тягостям на ней: Повсоду 6 мы в нее и грузы 6 все тонули, -}

Tred. hat den Text der Vorlage durch die Erwăhnung der Lasten erweitert. In der Démonstration heiBt es: "...si elle etait moins dure, elle ne pourrait le porter; il enfoncerait partout, comme il enfonce dans le sable."(S.7) Das Gedankenexperiment soll deutlich machen, daß die Erde so beschaffen ist, daß sie den Menschen ernährt und trägt. In der Feoptija wird dies durch einen Zusatz noch unterstrichen. Die Erde ist weder $z u$ hart noch $z u$ weich. Sie enthălt beides im richtigen Maße. So ist sie für uns die 'Mutter', die uns jeden Ertrag bringt:

\section{II,95f. Се ж равномерна в том есть обоем она, Притом и всех выго́д та мать есть нам одна.} Das Bild der 'Mutter Erde', die ihre Schätze austeilt und es fertigbringt, selbst Schmutz und staub in Reichtum zu verwandeln, steht auch hinter den folgenden Versen:

$$
\begin{aligned}
& \text { II,97f. Сокровища свои нам все она собщает } \\
& \text { И грязь и пыль свою в богатство превращает. }
\end{aligned}
$$

Bei der Beschreibung der Fruchtbarkeit und Vielgestaltigkeit der Erde folgt 
Tred. im ganzen der Demonstration. Der eben zitierte Vers 97 entspricht dem Satz Fénelons: "C'est du sein inepuisable de la terre que sort ce qu'il y a de plus precieux." (S.7) In Vers 98 wird die paradoxe Tatsache hervorgehoben, die im franzósischen Text so lautet: "...cette boue si sale se transforme en mille beaux objets..."(S.8) Wie in der Demonstration wird auch in der Feoptija herausgestrichen, daB die Exde gibt, was wir nur winschen, nicht nur das Notwendige, sondern im Uberfluß:

II,101f. Земля нам подает чето ни нелаем, Как всё что нужно есть, так мы и чем играем.

Diese Verse beziehen sich auf den Satz der Demonstration: "...elle seule devient tour a tour tous les biens que nous lui demandons." (5.8)

Die năchste Passage hat Tred. nicht aus der Demonstration. In II,103f. werden Landschaftsformen genannt, die eher für Rubland als für Frankreich charakteristisch sind: Sümpfe, steppen, undurchdringliche wălder und schluchten:

\section{II, 103f. Болотна где она и также где пуста,}

Гае непроходны суть от дебрей в ней места, -

Der Autor schildert etwa eine Reise, die ihn zunăchst durch unbewohnte Gegenden führt; aber die Landschaft andert sich und bietet dort einen reizenden Anblick. Bald sieht man Felder und wiesen mit 'saftigem Gras', bald Blüten und Früchte, Gebüsch und Băume. Der Reisende făhrt durch kultiviertes Land:

II, 105ff. Bсё пременяет то и скоро и чудесно,

И делает уж там видение прелестно:

Tо с полем зрятся луг и сочная трава,

То чве́ты и плоды, то рочи и арева.

Dies alles sind nur die außeren züge im Antlitz der 'Mutter' Erde. Ihr Wesen ist Güte und Freigebigkeit. Sie überschüttet ihre Bewohner mit Wohltaten:

II, 109f. Везде являет та всем только что доброты,

На жителей своих премноги лья щедроты.

Im folgenden halt sich rred. wieder an den Text der Demonstration. Aus der Metapher 'Muttex' (II,96) wird in der Feoptija eine Personifikation der Exde. Die 'Mutter Exde' 1st gut und freigebig, jung und unermudilich tatig: 
II,117f. Не стареется вся, ни убывая тлеет, Bcerá млада в себе и бодрость всі имеет.

Die Personifikation wird jedoch nicht năher ausgeführt. Der Autor wendet sich wieder dex realen Erde $z u$ und beschreibt bildhaft, daß ihre Quellen unerschöpflich sind. Je mehr dex Mensch beim Bergbau den 'Leib' der Erde zerreiBt, um so gröBere Reichtümer bringt sie ihm:

\section{II,115f. Утробу мы ее терзаем болей чем, Богатства больше мам она приносит тем -}

Das Bild ist aus der Démonstration genommen: "Rien ne l'épuise: plus on déchire ses entrailles, plus elle est liberale."(S.8)

Alles auf Erden wird altersschwach und vergeht. Die Erde selbst aber ersteht in jedem Frūhling neu. Tred. verwendet hier das Wort 'Bockpecaet'. Da man dies von der Erde eigentlich nicht sagen kann, schwãcht er die Aussage durch 'будто' ab:

II,119ff. Bсе чезнет из нее, под старость всяк в нас хил, Еяина токмо та вся не теряет сил:

При каждой и весне в жизнь будто воскресает, -

In der Démonstration lautet die stelle: "...tout vieillit, excepté elle seule; elle se rajeunit chaque annee au printemps."(S.8)

Die Erde macht den Menschen so reich, daß er niemals Mangel zu haben brauchte

II, 123f. 06илен человек так от нее всегда,

Что недостатка нет ни в чем ему когда.

Fénelon betont: "Elle ne manque jamais aux hommes." (Démonstr.,S.8)

Woher kommt dann aber der tatsăchlich vorhandene Mangel? Unsere Autoren geben zwei Ursachen an, die Trăgheit und den Unfrieden:

II,125 От лености его приходит недостаток, -

Es liegt an der Faulheit, wenn die Vorratskammern leer sind, wenn Kleidung fehlt und auf dem Felde Dornen und Disteln wachsen, exklăxt Tred. freiheraus:

II,127f. Нетщание людей причина пустоты, И терний, и волчцов, и гнусны наготы.

Ahnlich ist es in der Démonstration ausgedrückt: "...c'est par leur paresse et par leurs désordres qu'ils laissent croltre les ronces et les épines en 
la place des vendanges et des moissons." (S.8)

Eine 'Weinlese' wird es in RuBland im 18.Jahrhundert kaum gegeben haben, so daB Tred. den Passus ausgelassen hat.

Die Wortverbindung 'Dornen und Disteln' geht wahrscheinlich auf Gen.,Kap.3,18 zurück(Lth.). Dort heiBt es in der hintergründigen Erzăhlung vom Sündenfall, Gott habe um Adams willen auch den Acker verflucht, daB er Dornen und Disteln tragen und Adam sich 'mit Kummer' sein Leben lang von ihm nahren solle. Der Acker, hebr. 'haadama', ist von dem Wortstamm 'adam' = Mensch abgeleitet. Die sprachliche Beziehung der beiden Begriffe ist der Ausdruck für die enge Verbindung, die zwischen Mensch und Erde besteht.

In der Feoptija wie in der Demonstration fehlt, kennzeichnend für die Aufklarung, das Fluch-Motiv. Die 'Dornen und Disteln' werden rationalistisch erklărt als Folge der mangelnden Bodenbearbeitung und der menschlichen Trăgheit. AuBerdem verwisten 'BlutvergieBen und $\mathrm{Krieg}$ ' die Erde:

\section{II,129 Еще ту пустошат и кроволитны 6рани, -}

Zu dem Doppelepitheton 'кроволитный' merkt Tschižewskij an: "...ich finde keinen Beleg für 'кроволитный und кровопивный', kenne aber 'krv-litie' (Sr.I,1338). 5 skeptisch beurteilt Tschizewskij die Auffassung von A.Malein, das die Doppelepitheta Tred.s "meist griechische Entsprechungen haben". 6

In diesem Zusammenhang denkt Tred. an den Einfall fremder Heere, welche 'die Grenzen an sich reiBen'. Das vergossene Blut verbessert den Boden nicht, sondern läbt ihn verdorren:

\section{II,131f. А вместо чтоб ее доброте споспешить,} Кровь тем лодей смогла и весь тук иссушить: Mit diesem recht drastischen Bild gibt Tred. den Gedanken der Demonstration wieder: "Les conquerants laissent en friche la terre pour la possession de laquelle ils ont fait périr tant de milliers d'hommes." (S.8)

Die Vorstellung der bluṭgetrănkten Erde veranlaBt Tred. zu einer Digression, in der er seine affektbetonte Ablehnung des Krieges und des kriegerischen Heldentums und seine Achtung vor der Arbeit des Bauern und Hirten ausspricht, ohne deren Dasein Ldyllisch zu verklăren (II,133-144). Das zur steppe gewordene Ackerland ist die einzige 'Frucht' des ruhmreichen, kriegerischen Heldenlebens, bemerkt der Autor sarkastisch:

II,133f. Един сей плод всегда от славных всех героев, От действий громких тех и от несиетных воев. 
Der 'Held' kămpft nur für sich selber und noch dazu mit fremder Hilfe, heiBt es mit bitterem Unterton:

$$
\text { II,137 Герой всяк Аля себя, и то с чумим, воюет, - }
$$

Im Gegensatz zu der einzigen, und zwar todbringenden Frucht, die der Kriegsheld hervorbringt, preist der Autor die vielen Früchte der friedlichen Arbeit. Sein gröBter Wunsch ist, daB alle aufhörten, Krieg zu führen und jeder mit Sorgfalt das eigene Land bestellte. Emphatisch ruft er aus:

II,139f. 0! коль плодов, когАа 6 престали быть бойцы, А токмо 6 нежил всяк своих земель концы!

Mit einer für die Verhăltnisse in RuBland im 18.Jahrhundert -und nicht nur dort- erstaunlichen offenhelt klagt der Autor die 'Ungerechtigkeiten der Măchtigen' an:

II,141f. Но лотая уже, оружий толь обильных, Вражда ворет в казнь за все неправды сильных!

Mit diesen Worten ordnet er zugleich die 'grausame Feindschaft', mit der die Menschen Krieg führen, in sein religiöses Weltverstăndnis ein. Darin wirkt sich die Strafe Gottes für die 'Ungerechtigkeiten' aus.

Der Autor beklagt, daß im Kriege 'den Lastern und Leidenschaften Tür und Tor geoffnet ist', und daB bei allen die 'Einfachheit' verdirbt:

II, 143f. Порокам и страстям отверзла та ж врата, отнеле же во всех погибла простота!

Im Kontrast zum kriegerischen Helden, der nur für sich kămpft, werden Bauer und Hirt geschildert, deren Arbeit allen zugute kommt:

II,135f. Полезней людям всем оратай и пастух, Неж вознесенный тот граблений лотых Аух -

Der Arbeit, zumal wenn sie der Allgemeinheit nützt, wird ein hơherer ethischer Wert zugesprochen als den ruhmreichen Heldentaten, hinter denen sich nach Meinung des Autors ein hochmüiger, egoistischer Geist verbirgt:

$$
\text { II,137f. Герой всяК Аля себя, и то с чужим, воюет, }
$$

Аа всех земли делец трудясь, себе горюет.

Der Wertschătzung der Arbeit entspricht, wie II,125 und 127 zeigen, die MiBbilligung der Trăgheit.

Von einer idyllischen Verklarung des Landlebens ist hier nicht die Rede. 
Eher deutet die Stelle die Not des leibeigenen Bauern an, der sich für andere abplagt und selber kümmerlich lebt.

Die antiheroische Sinnesart, die Tred. In diesem Abschnitt, unabhăngig von der Demonstration zum Ausdruck bringt, ist im Lehrgedicht der Aufklarung des ofteren zu finden. Chr. Siegrist zitiert zum Beleg Verse von Haller und Dusch. 7 Auch A.Pope kritisiert die 'Helden'. Im 'Essay on Man', Ep.IV,219ff. heibt es:

$$
\begin{aligned}
& \text { Heroes are much the same, the point's agreed, } \\
& \text { From Macedonia's madman to the Swede; } \\
& \text { The whole strange purpose of their lives, to find } \\
& \text { Or make, an enemy of all mankind! }
\end{aligned}
$$

Fénelon stellt das widersinnige Verhalten derer bloB, die um eines 'Winkels' dieser Exde willen die ganze Menschheit umstürzen: "Les hommes ont devant eux des terres immenses qui sont vides et incultes; et ils renversent le genre humain pour un coin de cette terre si negligee." (Demonstr.,s.8)

Nach diesem Exkurs făhrt Tred. mit der Beschreibung der Landschaftsformen fort. Er stellt uns schildernd und betrachtend die Gebirge vor Augen. Man meint, sie seien nicht 'nützlich', sondern unwirtlich und unheimlich, so gibt ex die damals vorherrschende Auffassung wieder. In Wahrheit sind sie aber notig, weil sie der Schŏnheit der Erde und unserem Nutzen dienen:

$$
\begin{aligned}
& \text { II,145f. Неравности Земли быть мнятся не услужны, } \\
& \text { Но те к ее красе, а к пользе нашей нумны. }
\end{aligned}
$$

Die Verse stimen mit dem Text dex Demonstration (S.8) Ubereln: "L'inegalité même des terrois, quil paralt d'abord un defaut, se tourne en ornement et en utilite."

Das 'Schóne' und das 'Nützliche' schlieBen sich in der physikotheologischen Weltbetrachtung nicht gegenseitig aus. Es wird auch nicht dem einen vor dem anderen der Vorrang gegeben. Der Schopfer hat in seiner Güte beide Bedürfnisse des Menschen, das asthetische wie auch das praktische, materielle, ernstgenommen. Auch in der Darstellung wird beides nicht voneinander getrennt. So entsteht ein Bild von den Bergen und Tålern mit ihrem 'herrlichen Gras' für die Tiere:

$$
\text { II, } 148 \text { На пицу в них трава преславная скотам. }
$$

Dahinter wogen und reifen ringsum gelbe Kornfelder: 
II,149f. За ними вкруг поля И нив бразды желтеют, Богатых класы жатв волнуртся и спект.

Das Vorland ist reich an Blumen, Gras und Obstbäumen, die Luft gesund und rein:

II,151f. С одной страны их край и цветен и травист, $n$ древом плодовит, $и$ аухом здрав и чист; -

Auf der anderen Seite erheben sich die Gipfel der Berge bis an die Wolken und setzen uns durch ihre Hohe in Erstaunen:

II,153f. С другой - верьхи свои до облак взносят горы, Аивят нас өысотой, увеселяя взоры.

In der Démonstration(S.8) wird die Bergwelt ăhnlich geschildert: "Dans ces profondes vallees on voit croitre l'herbe fraiche pour nourrir les troupeaux: auprès d'elles s'ouvrent de vastes campagnes, revêtues de riches moissons." Die von 'Weinbergen bekrănzten' Hơhen(couronnés de vignobles) fehlen in der Feoptija, weil es sie damals in RuBland wahrscheinlich nicht gab. Die Schilderung der 'arbres fruitiers' und der mit Eis bedeckten hohen Berge(de hautes montagnes vont porter leur front glace jusque dans les nues, 5.8 ) ist von Tred. erweitert und poetisiert worden.

Eine Anmerkung zu den geologischen Verhăltnissen ergănzt die Beschreibung der Gebirgslandschaft. Sie weist darauf hin, das die Felsen und die wilden Schluchten die zwischen ihnen liegenden Exdschichten fest zusammenhalten. Der Vergleich mit den Knochen und Sehnen des menschlichen korpers soll die geologische Belehrung veranschaulichen:

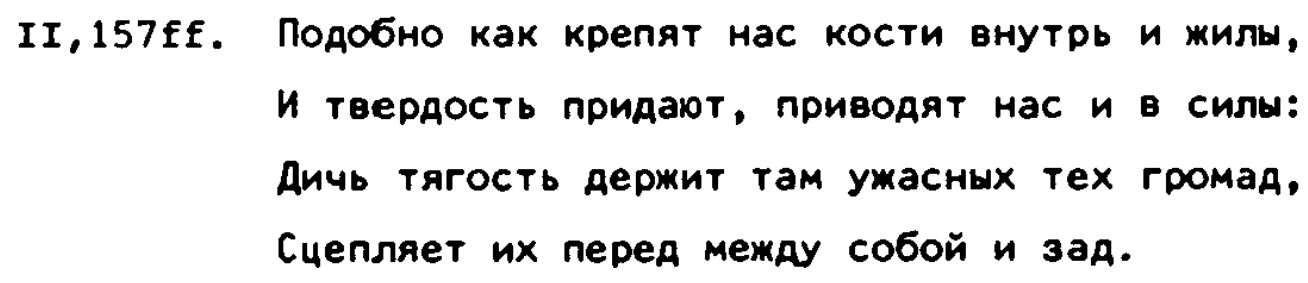

In der Démonstration ist dieser Gedanke prăgnanter gefaBt: "Les rochers, qui montrent leux cime escarpée, soutiennent la terre des montagnes, come les os du corps humain en soutiennent les chairs." (S.8f.)

Am SchluB der Betrachtung wird noch einmal hervorgehoben, daB die Erde durch ihre Vielgestaltigkeit verschönert wird, und daB die Berge uns zugleich von Nutzen sind (vgl.II,146). Tred. erinnert daran, daB die Hôhlen bei Hitze und Unwetter Schutz bieten, und daB man auf den Bergen zuflucht findet vor der 
'Grausamkeit der Menschen':

$$
\begin{aligned}
& \text { II,163f. Убежище в вертеп от зноя и дождей, } \\
& \text { убежище на холм от наглости подей. }
\end{aligned}
$$

Mit diesem Zusatz konkretisiert Tred. den allgemeinen Hinweis im Text der Demonstration(S.9): "Cette variets fait le charme des paysages, et en meme temps elle satisfait aux divers besoins des peuples." Erinnert sei hier an das oben (S.29) zitierte Gedicht uber das Gebirge von B.H.Brockes, der ebenfalls die schönheit und den Nutzen der Berge hervorhebt. Die ersten Verse lauten:

Ob nun gletch der Berge Spitzen

Oed' und grausam anzusehn;

Sind sie doch, indem sie nützen, Und in ihrer Grobe, schón - ${ }^{8}$

Tred. versichert, es gibt überhaupt in der ganzen Welt keinen einzigen Akker, der nicht seine Frucht bringt, vorausgesetzt, daB 'wir nicht faul sind':

II,165f. Во всей вселенной нет, ниме́ едины, нивы,

Без некоих доброт, когау не ленион.

Die Ermahnung zum FleiB ist inm, wie auch die Verse II,125ff. zeigen, wichtig. sie steht nicht in der Vorlage: "Il $n$ ' $y$ a point de terroir si ingrat qui n'ait quelque propriete." (Demonstr.,s.9) Nicht nur die Tăler und die Schwarzerde, sondern auch Sumpf- und Sandboden lohnen dem Bauern seine Mühe:

$$
\begin{aligned}
& \text { II,167ff. Не только долы те, не только чернозем, } \\
& \text { Но и болотный низ, но и пески по сем } \\
& \text { Оратаю за труд мзду воздают напольну, - }
\end{aligned}
$$

Die Verse stimmen mit dem französischen Text überein: "Non seulement les terres noires et fertiles, mais encore les argileuses et les graveleuses,

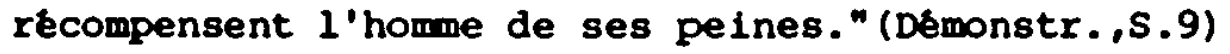

Wir horen von der Trockenlegung des Moores, das danach reiche Frucht trăgt (роскошстеует плодом, 172) und von der Melioration von Sandboden, wie sie schon im Altertum vorgenomen wurde. Fênelon bezieht sich an dieser stelle auf Xenophon, 'Oeconom.' Danach wurde zunăchst die Sandschicht beseitigt und der darunter liegende Boden freigelegt. Dieser wird dann umgegraben und den Sonnenstrahlen ausgésetzt. So entsteht allmahlich fruchtbarer Boden. Fenelon stellt den Vorgang so dar: "Les sables ne couvrent d'ordinaire que 
la surface de la terre: et quand le laboureur a la patience d'enfoncer, il trouve un terroir neuf, qui se fertilise a mesure qu'on le remue et qu'on l'expose aux rayons du soleil." (Demonstr.,s.9)

Tred. beschreibt die Melioration als einen ProzeB, der zwei Jahre in Anspruch nimmt:

II,174ff. Kогда делец земель в одном очистит лете Всіо земло под песком, лежащу впусте там, И силу солнца даст очищенным местам, То на другое он, Как пойдет полосами, Увидит весь тот грунт играющ колосами.

Er fügt hinzu, daß das Colland, wenn es regelmăßig gedüngt wird, dem Kulturland an Fruchtbarkeit nicht nachsteht:

II,179f. Удо́бренный чредом кряж всякий мест пустых Не хуже будет сам плодами нив густых.

Jeder Boden hat seine besondere Eignung:

II,182 Грунт на пшеницу есть, грунт на ячмень особен.

Selbst in den Schluchten zwischen den Felsen gibt es ebenso gute Weiden wie in den waldern. Da sind Lichtungen, in die die Sonnenstrahlen eindringen und die des Nachts ausdünsten, so daB der Boden locker wird und wiesen entstehen, auf denen das Vieh im Sommer weidet:

II, 183ff. Среди расселин гор, на каменных горах

Бывает пажить так яобра, как и в борах.

Есть скважины и там, чтоб солниу в них лучами

Проникнуть и чтоб быть испарине ночами.

II,189f. Там производит корм и паству летобытну,

Которая творит собой скотину сытну.

In der Démonstration(S.9) heiBt es ăhnlich: "Au milieu des pierres et des rochers on trouve d'excellents paturages; il y a, dans leurs cavités, des veines que les rayons du soleil pénètrent, et qui fournissent aux plantes, pour nourrix les troupeaux, des sucs très savoureux."

Der Gedanke, daß kein Feld ohne Frucht, kein stück Erde für den Menschen ohne Nutzen ist(II,165f.), wird am SchluB des Abschnitts noch einmal eingeschärft. Selbst der unzugăngliche Berghang (Ab6pb, bei Sr.I,766 belegt, wird von Gerta H.-Worth mit торный склон' wiedergegeben) ${ }^{9}$ und die von jeher unfruchtbare Steppe haben für den Menschen ihr Gutes. Hier wachsen süBe Früch- 
te und Heilkxaluter, die es sonst auch an den fruchtbarsten orten nicht gibt. In der Demonstration(5.9) ist dies so ausgesprochen: "Les côtes mêmes qui paraissent les plus stêriles et les plus sauvages offrent souvent des fruits delicieux, ou des remedes très salutaires, qui manquent dans les plus fertiles pays." Diesen Text hat Tred. durch zwei Zusatze erweitert. Im ersten Zusatz spricht er im Blick auf die geographische Lage RuBlands von dex Steppe in dex heiBen und in der kalten zone. AuBerdem fügt er hinzu, daB die 'Lehrbucher' uns davon Kenntnis geben, daB dort Heilpflanzen wachsen:

II,191ff. Henроходимо дебрь, неплодна с века степь,

Лежит ли в знойншх та, в краях ли мразных цепь, -

Родят, как книти нам знать подарт учебны,

То сладкии плоян, то зелия врачебнм,

Которшх инде нет в обильнейших местах, -

Die Beobachtung, daB die Beilkrauter oft gerade an schwer zugănglichen oder unfruchtbaren Orten wachsen, wird auch in den folgenden Versen von Brockes verwertet:

Merckt, wie sehr der Berge Spitzen,

Durch der Krăuter Menge nützen,

Welche nirgends so voll kraft

Und gesunder Eigenschaft. 10

Tred. faBt den Inhalt des Abschnitts II,165-197 in den Satz: es gibt auf der Erde alles, was die Menschen brauchen, aber nicht alles an allen orten:

II,197 Всё есть, но не во всех землях, что люяям нуино!

Dem Einwand, ob dann nicht jedem etwas fehle, entgegnen unsere Autoren: Gerade dies ist Gottes Absicht, denn so sind die Menschen aufeinander angewiesen. Die Verteilung der Güter uber die ganze Welt ist gewissermaBen ein Kunstgriff des Schopfers, der den Zweck hat, daB die Menschen zueinanderfinden. Fénelon hat diesen Zusammenhang belehrend dargelegt: "D'ailleurs, c'est par un effet de la Providence divine que nulle terre ne porte tout ce qui sert a la vie humaine; car le besoin invite les hommes au commerce, pour se donner mutuellement ce qui leur manque." (Demonstr., S.9)

Tred. tragt diesen Gedanken mit rhetorischer Eindringlichkeit vor:

II,198ff. Не явно ль хомет бог нам меж собой жить Аружно?

Не сим ли нас всхотел к собщенио привесть,

Аабш взаммно брать кому в чем нумда есть? 
Der Ton wechselt unvermittelt von der Darlegung, die den Abschnitt II,165196 kennzeichnet, zur Exklamation (197) und zu den erregten Fragen der Verse $198-200$.

Aus einer Beschreibung der Bodenverhăltnisse in den verschiedenen Landschaften wird unversehens eine sozialethische Digression. Der physikotheologische Betrachter sieht in den regionalen Unterschieden der Vegetation ein Mittel der gottlichen Pădagogik, das die Menschen zur Gemeinschaft erzieht. Es ist der Mangel, der die Menschen, die in weit voneinander entfernten Lăndern wohnen, miteinander verbindet:

\section{II,201f. Се нужда, коих край далекий разделяет,} Тех в Общество оАно путем Совокупляет -

Ohne den Mangel hătten wir die volker der Erde nicht kennengelernt, noch wăre jemals ein 'kühnes Boot' über den Ozean gefahren:

II,203f. Без ней не знать бы нам людей Земли всея, Ниже 6 за океан шла дерзка ладия.

Hier hat Tred. den Text der Démonstration mit einem einprăgsamen Bild ausgeschmückt. Fénelon schreibt: "...ce besoin est le lien naturel de la société entre les nations: autrement tous les peuples du monde seraient reduits a une seule sorte d'habits et d'aliments; rien ne les inviterait a se connaltre et a s'entrevoir." (Demonstr.,s.9)

In diesen Sătzen ăuBert sich (wie vorher in der Ablehnung des Kxieges,129ff.) die philanthropische Gesinnung der Physikotheologen. Von dem neu erwachten Interesse an der Menschheit und von der 'sozialethischen Valenz' (Philipp) der physikotheologischen Weltanschauung war schon weiter oben in dem Abschnitt über die geistesgeschichtlichen Voraussetzungen die Rede. Auf die Gemeinschaft stiftende Funktion des Mangels und der Bedurfnisse hat auch A.Pope im 'Essay on Man' hingewiesen:

But as he $\bar{G}$ God fram'd a whole, the whole to bless, On mutual Wants built mutual Happiness. (Ep.III,111f.)

Das Thema 'Fruchtbarkeit der Erde', durch die sozialethische Digression kurz unterbrochen, wird in II,205ff. wiederaufgenomen. Jetzt wird der biologische Kreislauf von Werden, Vergehen und neuer Frucht zum Gegenstand der Betrachtung gemacht.

Was immer die Erde uns gibt, nimmt sie wieder in sich hinein; aber nur, um es uns zurückzugeben, so skizziert Tred. den Kreislauf: 
II,212f. Земля что нам ни даст, в себя ж приемлет вдруг, Приемлет, но затем, чтоб нам подать то паки, -

Der Autor bewundert die Gesetzmaßigkeit, mit der die Erde aus vermoderten, toten Stoffen frische Pflanzen hervorbringt und uns 'zehnmal mehr Früchte' zukommen läbt:

II,214ff. A как подать? оI чин, из стнивших свеки-злаки, Из всех ум как совсем умерших тех родов

В десятерииу $\mathrm{K}$ нам шлет более плодов.

Tred. hat die Bewunderung für den 'unaufhorlichen Kreislauf' der Natur im Unterschied zur Demonstration besonders akzentuiert:

II,211 Предивен есть весьма сей непрестанный круг: -

Im ubrigen stimmen die beiden Texte inhaltlich uberein. Fénelon fuhrt aus: "Tout ce que la terre prodult, se corromant, rentre dans son sein, et devient le germe d'une nouvelle fécondite. Ainsi elle reprend tout ce qu'elle a donné, pour le rendre encore." (Demonstr., S.9)

Im selben Zusammenhang wird nüchtern vermerkt, daB das Vieh mit seinen Ausscheidungen den Boden 'ernăhrt' und damit seine Fruchtbarkeit erhöht:

\section{II,219f. Питает земло сам изверженным своим \\ И помощь подает К обилир он сим.}

So übersetzt Tred. die zugrunde liegende stelle der Demonstration,s.9: "...les excréments des animaux qu'elle nouxrit, la nourissent elle-même et perpetuent sa fertilite."

In den beiden Texten erscheint die Erde als ubermenschliche Mutter wie in einem Mythos. Aus inrem 'SchoB' wird reiches Leben geboren: "rout sort de son sein", sagt Fénelon(Demonstr.,S.10). In der Feoptija werden die Metaphern 'недро' (205) und 'yтроба' (225) verwendet:

\section{II,225 Исходит из ее обильно всё утробн -}

Die Fruchtbarkeit der Erde wird 'unerschöpflich' genannt. Fénelon nennt die Erde "cette mère féconde" (Démonstr.,s.10) und sagt von ihr: "...elle ne s'epuise jamais" (ebd.).

Tred. verbindet das Motiv der Fruchtbarkeit mit dem der mütterlichen Füsorge, 'damit wir ja keinen Mangel haben': 
II,223f. И никогда ни в чем не может оскудеть,

Лишения чтоб нам ни в чем же не иметь.

Ferner wird der 'Leib der Erde' mit einem Grab verglichen, in das alles 'eingeht' :

II,226 И так же өходит өсё к ней внутрь, как буато в гробы. An dieser Stelle hat 'rpo6' wohl die alte ksl. Bedeutung 'Grab', 'Gruft' (Pawl.273).

Vom biologischen Kreislauf (непрестанный круг,211) ist auch im 'Essay on Man', Ep.III,15ff. die Rede:

See dying vegetables life sustain,

See life dissolving vegetate again:

All forms that perish other forms supply,

(By turns we catch the vital breath, and die) -

Am Beispiel des Samenkorns macht Tred. deutlich, welche Kraft zur Vermehrung in der Erde liegt:

II,227f. Зерно в нее вложи - от одното зерна, Как любяща мать чад, даст десять зерн она.

Der Vergleich mit der 'kinderliebenden Mutter' geht auf die Démonstration (S.10) zurück: "...cette mère féconde vous rend avec usure plus d'épis qu'elle n'a recu de grains."

Zur 'Fruchtbarkeit' der Erde gehört auch ihr Reichtum an Bodenschătzen. 'Man offne ihr Inneres', so findet man Steine und Marmor zum Bau von Palăsten. In der sprachlichen Form (Imperativ, 2.sg. Im Sinne eines Konditionalsatzes), sowie in der Metapher stimmen die Verse 229f. mit der Vorlage genau überein. Des Reimes wegen erwăhnt Tred. bei der Aufzählung der Mineralien zusătzlich 'зnaтo':

$$
\begin{aligned}
& \text { II,229f. Разверзи чресла в ней - обрящешь камни, злато, } \\
& \text { Обрящешь мармор внутрь на здание богато, - }
\end{aligned}
$$

Vergl.: "Creusez dans ses entrailles, vous y trouverez la pierre et le marbre pour les plus superbes edifices." (Demonstr., S.10)

In II,231 werden die Metalle einzeln aufgefüht:

Железо, медь, свинец и с оловом сребро, -

Fénelon unterscheidet sie nur im allgemeinen(métaux précieux et utiles,s.10).

Der Reichtum der Erde löst die Frage aus: "Mais qui est-ce qui a renfermé tant de trésors dans son sein, a condition qu'ils se reproduisent sans 
cesse?" (Demonstr., S.10)

Nur aus Gründen der Anschaulichkelt war bisher von einer Art Mutterwesen die Rede. In Wahrheit bringt aber die Erde nichts aus sich selber hervor. Alles ist zuvor in sie hineingelegt worden.

Tred. hat die Frage Fénelons zu einem rhetorisch-emotional getönten Abschnitt erweitert, der zwolf Verse umfaBt (II,233-44). Im ersten Teil fragt der Autor mit wachsender Eindringlichkeit: Wer hat einen so groBen Reichtum in der Exde verwahrt? Wer vermehrt inn dermaBen, daB er niemals erschöpft wird, so viel man auch wegnimmt? Wen setzt es nicht in Erstaunen, wenn er sieht, wie die Erde alles im therflub hervorbringt?

II,233f. Kто $w$ скрыл в нее то всё толикое богатство?

Кто умножает в ней сие всё толь изряаство, -?

II,237f. Кого не уаивит на всё сие смотряща,

И как и что земля обильно есть родяща?

Diese Fragen sind im Sinne des Autors nichts anderes als eine ehrfürchtige Form seines Bekenntnisses zum Schöpfer. (vgl.II,81-84)

Ihnen korrespondieren in zweiten Teil der Passage bewundernde Exklamationen. Was empfăngt der Mensch nicht alles von der Erde: Nahrung und Arznei, unzăhlige Güter und Gaben, wohlschmeckende Früchte und -auch an das asthetische Bedürfnis ist gedacht- duftende Blumen aller Art! Bezeichnend für die Stelle ist der anthropozentrische Blickwinkel: alles Nützliche und Schöne auf Erden wird auf den Menschen bezogen. Formal fallt die viermal wlederholte Anapher auf :

\section{II,241ff. Коль многи корни суть! Колики трав всех роды! \\ Коль неисчетны их доброты и пригоды! \\ Коль благовонных тех в различии цветов! \\ Коль сладостнейших мы вкушаем и плодов!}

Inhaltlich sind diese Verse aus der Demonstration hergeleitet, aber von Tred. selbstandig gestaltet worden. Fenelon schreibt: "Admirez les plantes qui naissent de la terre; elles fournissent des aliments aux sains, et des remèdes aux malades. Leurs especces et leurs vertus sont innombrables: elles ornent la terre; elles donnent de la verdure, des fleurs odoriferantes et des fruits delicieux." (Démonstr.,s.10)

Die năchste Betrachtung richtet sich auf den Wald. Der Autor denkt an einen 'dichten Wald', den Urwald, der ihm, wie er ubertreibend hinzufügt, so 
alt wie die Welt zu sein scheint:

II,245f. Как на дремучий лес по случаю взираем,

За старость сверсным мы тот миру полагаем: -

Genau so steht es in der Démonstration(S.10): "Voyez-vous ces vastes forêts qui paraissent aussi anciennes que le monde?"

Aber nicht der riesige Urwald im ganzen zieht das Interesse des Betrachters an, sondern 'der Baum'. Der Baum und was in ihm geschieht, wird eingehend geschildert: der Weg des Saftstromes von der Wurzel bis zum wipfel und in die zweige und Blătter. Das botanische Gemălde beginnt bei den Wurzeln, die sich in eine 'fast unendliche Tlefe senken', wie Tred. übertreibend bemerkt:

II,247f. Аревес всех корни в нем, все ж углубившись $к$ ану, В безмерную почти спустились глубину: -

In der Démonstration lesen wir(S.10): "Ces arbres s'enfoncent dans la terre par leurs racines, comme leurs branches s'élèvent vers le ciel."

Die Wurzeln erfüllen einen doppelten Zweck. Sie halten den Baum durch ihr Geflecht und ihre Länge, so $d a B$ er bei starkem wind nicht fällt und verfault:

$$
\begin{aligned}
& \text { II,249ff. Сплетением своим, потом же и Алиною, } \\
& \text { Как держит корень всяк всё дерево собою } \\
& \text { И не дает ему от сильных ветров пасть, } \\
& \text { Чтоб падшему не сгнить и вскоре не пропасть; - }
\end{aligned}
$$

Ferner suchen sie unter der Erde die geeigneten Safte und leiten sie durch den Stamm bis zum Wipfel hinauf, "nicht nur einen viertel und nicht nur einen ganzen Arschin", setzt Tred. scherzhaft hinzu (ein 'Arschin'=0,711 m).

$$
\begin{aligned}
& \text { II,253ff. Так равно тем же он и ищет под землею } \\
& \text { Пристойных соков там, а трубкою своею } \\
& \text { Втянув в себя внизу, шлет в верьх те до вершин } \\
& \text { Не на четве́рть одну, ни на один аршин. }
\end{aligned}
$$

In der Démonstration wird die Funktion der Wurzeln so beschrieben (S.10): "...leurs racines les défendent contre les vents, et vont chercher, comme par de petits tuyaux souterains, tous les sucs destinés a la nourriture de leur tige."

Die Vorstellung vom Steigen des Saftstromes viele Arschin hoch erweckt die Bewunderung des Autors: 
II,257f. Предивный механизм сей в милках всяка листа

Предивного всем нам являет механиста!

Der wunderbar funktionierende Mechanismus weist auf einen bewandernswerten 'Konstrukteur' hin. Für den nachdenklichen Betrachter wird die botanische Exscheinung unmittelbar zu einem physikotheologischen Argument. Er macht sich auch darüber Gedanken, daB die Blatter auf beiden Seiten grūn sind. Daran erkennt ex die dem Menschen zugewandte Fursorge des 'Baumeisters', denn die grüne Farbe stäkt unsere Augen und erfreut uns durch ihren Anblick:

\section{II,259ff. Но и раяящий сей в строителе совет, Что на листах вобще зеленый токмо цвет, Сей зренир очей цвет наших споспешает, Те w бoлеe, неж взор, со601 утешает.}

Die grüne Farbe der Blatter ist, wie alles in der Welt, dazu bestimnt, dem Menschen zu nutzen und ihn zu erfreuen, zumal das 'eine Grūn' nicht eintónig. sondern sehr verschieden aussieht:

\section{II,265f. А зелень кто ж одну, которая толь слична, Исчислит, коль есть та, по зелени, различна?}

Nach diesem exbaulichen Einschub(II,257-66), der in der Vorlage keine Parallele hat, fahrt der Autor mit der Beschreibung des Baumes fort, wobei er den Text der Demonstration z.T. erweitert.

Der Saft ernahrt den Baum. Seine Zweige und Aste wachsen in die Hohe und Breite und werden dicker:

II,267f. Pacпростирает сок все ветви в вышину И в широту собой, и такме в толиину.

Warum sich der Stamm mit einer Rinde bekleidet, wird in der Demonstration so erklart: "...la tige elle-meme se revet d'une dure écorce, qui met le bois tendre a l'abri des injures de l'air." (S.10)

Tred. verdeutlicht die Notwendigkeit der Rinde mit dem Hinweis auf die starken Temperaturgegensatze des russischen Klimas:

II,269ff. Hо дередуб от стуж и жара защититься,

Или 6 от сильних тех в себе не повредиться,

Корой одето всё от низа до верьха.

AuBerdem schützt die Rinde die zweige vor dem Vertrocknen, fügt Tred. hinzu. Durch die Rinde ist der Saft im Innern des Baumes 'wie im Mutterleib geborgen':

II,273f. Иауиий сок наверьх, по внутренности в древе, Содержится корой в нем равно как во иреве; - 
Die Bedeutung von ksl.' 4peso' = uterus ist bei Miklosich (1123) belegt. Mit einem weiteren Bild wird die Funktion der Rinde veranschaulicht. Sie umschlieBt das Innere des Baumes, wie die Ufer einen FluB einfassen:

II,275f. Иль сераце в ареве том ему реке как ров,

А оная кора вкруг вместо берегов.

Im folgenden ist vom Nutzen der Băume die Rede. Sie geben uns im Sommer Schatten vor der Hitze. Tred. vergleicht die nach allen Seiten ausgebreiteten Aste mit einem Zelt, untex dem nicht allein die Menschen kuhlung finden. Auch die Vögel können sich dort ausruhen. Diese Bemerkung zeigt, daB der Autor nicht nur anthropozentrisch denkt:

II,277ff. Раскинувшись на все страны древа суками

И сделавшись чрез то как некими шатрами,

От зною подают прохладнуо нам сень,

А птицам на отдох насести в оных лень.

In der Démonstration(S.10) steht hiex der Satz: "En été, ces rameaux nous protègent de leur ombre contre les rayons du soleil."

Ein weiterer Nutzen dex Băume: ihr Holz ist der Brennstoff, mit dem wir im winter heizen. Die Stelle hat in der Feoptija Lokalkolorit. Der 'krachende Frost des trostlosen Winters' gehört zur Umwelt Tred.s:

II,281ff. Что ж вещество дерев горит огнем природно,

То нас зимоп греть весьма оно пригоано

И теплоту хранить естественнуо в нас

Печальныя зимы в трескучий самый мраз.

Die entsprechende stelle lautet in der vorlage(S.10): "...en hiver, ils nourissent la flamme qui conserve en nous la chaleur naturelle."

Tred. unterbricht die Darlegung mit einem Ausruf des Staunens. Er rühmt die Vorsehung, die es so eingexichtet hat, daß gerade in den Lăndern, in denen der Frost 'wutet', die dichtesten wälder zu finden sind:

II,285f. O! промшсл, стужа гАе несноснейше ярится,

В тех более странах густых лесов и зрится.

Dieser Gedanke stammt nicht aus der Démonstration. Ex ist aber in einem Gedicht von B.H.Brockes, 'Der Winter', enthalten:

Gott hat, o weise Wunder-Macht!

Die man ohn' Ehrfurcht nicht ermisst,

Da, wo das meiste Holtz vonnöthen ist, 
Das meiste Holtz hervorgebracht:

Wie denn von je und je im kalten Norden

Es mehr als andernwerts gefunden worden. ${ }^{11}$

Tred. hat seine Bekanntschaft mit Brockes in der 'Эпистола.... Аполлину' (1735) ausdrücklich erwăhnt. Es ist daher möglich, daß die Verse II,285f. von dem Brockes'schen Gedicht beeinflubt sind.

In II,289-292 erinnert Tred. an die vielseitige Verwendbarkeit des Bolzes und nennt besonders die Verwendung beim Baus- und Schiffbau:

II,291f. Мы делаем из древ себе в жиличе дом

И строим ладии и кора6ли притом, -

Es wird hervorgehoben, daß das Bolz eine feste und dauerhafte Materie ist, die sich trotzdem auf jede Weise gut bearbeiten laBt:

II,289f. Но вещество аубрав, хоть твердо есть и тельно,

Выделмваем всяк вид из того мы чельно: -

Fénelon beschreibt die Sache so: "...c'est une matiére douce, quoique solide et durable, a laquelle la ma in de l'homme donne sans peine toutes les formes qu'il lui plaft, pour les plus grands ouvrages de l'architecture et de navigation." (Demonstr.,S.10)

Bel dem Thema 'Wald', 'Baum', 'Holz' (eines folgt dem anderen durch Assoziation), stellt sich auch die Vorstellung eines Obstgartens ein(II, 293-96): Es ist kurz vor der Ernte. Die Băume sind mit Früchten beladen, so daB die Zwelge sich herunterblegen. Der Autor boschreibt aber nicht nur das schöne Bild. Er kommt ins Betrachten: es 1st, als reichten die Băume absichtlich den Menschen ihre Früchte hin, solange diese frisch, reif, schmackhaft und noch nicht alt sind. Tred. schildert den Garten nach dem Muster der Demonstration, hat es aber erganzt:

II,293ff. А красный взору сад, плодом обремененный, Тем самым есть на низ довольно наклоненный, Чтоб, Как нарочно, Он плод подносил свой в дар, Пока тот свеж и спел, и вкусен, и не стар.

Vgl. Démonstr.,S.10: "De plus, les arbres frultiers, en penchant leurs rameaux vers la terre, semblent offrir leurs fruits a l'home."

Das Bild hat nicht nur poetischen Reiz. Im Zusammenhang soll es deutlich machen, wie sinnvoll der schöpfer es eingerichtet hat, dab die obstbăume ihre Zweige zux Ernte herunterbiegen, damit der Mensch sie leicht erreichen kann. 
In II,297-302 wixd der Gedanke des 'неnрестанный круг'(211ff.) am Beispiel der Früchte konkretisiert: auch die Früchte, die nicht geerntet werden, sondern abfallen und verfaulen, sind im Haushalt der Natur nicht verloren:

II,298f. У матери ж земли на лоне согнивая, От семени опять свой омивляют род -

Die Metapher 'SChOB der Mutter Erde' fehlt an dieser Stelle in der Demonstration: "Les arbres.... en laissant tomber leurs fruits,...se préparent autour d'eux une nombreuse postérité." (S.10)

Die Betrachtungen uber die Erde schließen in beiden Texten mit der Feststellung: alles, was die Erde $2 u$ sich nimmt, bewahrt sie so, daB sie es verwandelt. Sie selber verändert sich nicht:

II,301f. Всё примет что земля, В себе так сохраняет, Что, пременяя то, себя не пременяет!

Fénelon schreibt: "La terre, qui ne change jamais, fait tous ces changements dans son sein." (Démonstr.,s.11)

II,303-312 sind der Form nach eine Apostrophe an Evsevif. Ihm legt der Autor felerlich ans herz, alles noch einmal sorgfătig zu bedenken:

II,303f. Прилежно рассуждай, Евсевий, и внемли, Что вся земля собой и всё, что из земли, -

Inhaltich bilden die Verse ein physikotheologisches Credo, in dem der Autor bekennt, daB die ganze Erde den Schöpfer selber allen sichtbar macht. Hierbei wird die bisherige Betrachtung in Stichworten wiederholt:

II, 303ff.
Что вся земля собой и всё, что из земли,
И что растет на ней, и коль ме всё богатно
И как то тлеет всё, выходит и возвратно,
И сколько пользы нам бывает из всего,
Показывает всем сотворша самого, -

Im Werk des Schopfers offenbart sich sein Wesen: seine Weisheit, Güte und Allmacht, seine Fürsorge für uns Menschen, die uns mit allem versorgt. Der letzte Satz dieses Credo macht vollends deutlich, daB es aus dem biblischen Schopfungsglauben stammt: der schopfer ist in Wahrheit unser barmherziger Vater :

II,311f. Что обо всех из нас печется, наконеи,

И ито премилосерд нам в истине отец. 
In II,313-471 wird als zweites der Elemente das Wasser zum Gegenstand der Betrachtung gemacht.

Einleitend ladt der Autor den fiktiven Brieffreund ein, sich mit ihm zusammen dem neuen Objekt zuzuwenden:

II,313f. К Аругой уж обрати стихии взор со мною, Которуо зовем по-нашему водоо.

Hierwit schaltet er sich wieder in den Text der Demonstration(S.11) ein: "Regardons maintenant ce qu'on appelle l'eau..."

Zunarchst werden die physikalischen Eigenschaften des Wasser vorgestellt:

II,315 Прозрачен жидкий сей и зыбок ест́́ состав, -

Es fliebt und past sich jeder Form an, von der es umschlossen wird, ohne eine eigene spezifische Gestalt zu haben:

II,317ff. С одной страны течет и быстро уплывает,

С Аругой - во все себя он виды изгибает, Обходят коИ вне с сторон весь тот кругом,

А нет ни одного в нем образа самом.

Die Verse entsprechen genau der Vorlage: "...c'est un corps liquide, clair et transparent. D'un côté, il coule, il echappe, il s'enfuit; de l'autre, il prend toutes les formes des corps qui l'environnent, n'en ayant aucune par lui meme." (Demonstr., S.11)

Daran schliebt sich (II,321-28) die schon bekannte (vgl.II,85ff.) hypothetische Erwăgung: "was wăre, wenn..." Wenn das Wasser 'etwas flüssiger' wăre, so wirde es der luft ahnlich:

II,321f. Kогда 6 вода была пожиже и не сдобна,

То 6 сделалась она вся воздуху подобна.

Die Folgen wăren katastrophal. Die Erde wirde austrocknen und unfruchtbar werden:

II,323 Bезде 6 иссохла ум в бесплодности земля, -

Menschen und Tiere müBten zugrunde gehen. Auch die Fische fanden nirgends eine 'Bleibe':

II,327 Хилища 6 не нашлось и рыбам ум нигде, -

Als einzige kőnten vielleicht die vögel uberleben:

II,325 Одним бы разве жить возможно было птицам, -

Schiffahrt, durch die die Menschen zusammengeführt werden, wăre unmöglich:

II,328 Съежаться 6 не могли взаимно мы везде. 
Wenn das Wasser nur ein wenig 'flüssiger' wăre, könnte es große Schiffe nicht tragen, und auch eine kleine Last würde sofort untergehen:

II,335f. Великих тех судов сдержать не возмогла

И мала 6 тягость $K$ Ану, вдруг погружаясь, шла.

Tred. hat dieses Gedankenexperiment von Fenelon übernommen und nur wenig verandert: "Si l'eau était un peu plus raréfiée, elle deviendrait une espèce d'air; toute la face de la terre serait seche et stérile; il n'aurait que des animaux volatiles; nulle espece d'animal ne pourrait nager, nul poisson ne pourrait vivre; il n'y aurait aucun commerce par la navigation...si l'eau était un peu plus raréfiee, elle ne pourrait plus soutenir ces prodigieux edifices flottants qu'on nomme vaisseaux..." (Demonstr.,S.11)

Vor dem drohenden, wenn auch hypothetischen Hintergrund, erscheint die wirkliche Beschaffenheit des Wassers bewundernswert. Das Staunen auBert sich in einer Reihe von rhetorischen Fragen (II,329-32; 338-43): Wer hat das Wasser so gleichmabig 'dicht' gemacht und in der Welt zwei verschiedene 'flüssige' Substanzen (Wasser und Luft), geschaffen?

$$
\begin{aligned}
& \text { II,329ff. Кто ж густу сотворил толь равномерно воду? } \\
& \text { Кто жидких в свете двух составов сих разводу } \\
& \text { Дал меру, их между собоо различив, -? }
\end{aligned}
$$

Wie II,95 ist 'равномерно' auch hier ein Merkmal der gottgegebenen ordnung der Dinge. Vor allem staunt der Betrachter darüber, daB ein flüssiges, durchsichtiges Element wie das Wasser, das ganz und gar keine Festigkeit besitzt, riesige Lasten $\mathrm{zu}$ heben imstande ist:

II,342f. Кто, твердости в себе отнияь ту не имущу,

А бремена поднять огромные могущу?

Die Stelle geht auf zwei komplexe rhetorische Fragen in der Démonstration (S.11) zurūck: "Quelle main industrieuse a su épaissir l'eau en subtilisant l'air, et distinguer si bien ces deux espèces de corps fluides?...Qui est-ce qui a pris le soin de choisir une si juste configuration de parties, et un degré si précis de mouvement, pour rendre l'eau si fluide, si insinuante, si propre a echapper, si incapable de toute consistance, et néanmoins si forte pour porter et si impétueuse pour entrainer les plus pesantes masses?" Tred. hat die Fragen aufgeteilt und sie in eine rhetorische Klimax umgeformt.

In II,344-367 folgt eine Besinnung über den Nutzen des Wassers. Der Autor denkt zuerst an die Wasserkraft, die sich der Mensch zunutze macht: 
II,344f. Помысли, сколько нам послушна есть вода:

Мы можем ону взвесть в прилежности труда, -

Der Imperativ 'помысли' ist an Evsevif gerichtet. Er möge bedenken, wie erstaunlich es ist, daB eine so elementare Gewalt dem Menschen 'gehorcht' wie ein Tier. Fénelon nennt das Wasser 'gelehrig' und 'folgsam': "Elle est docile; l'homme la mène, comme un cavalier méne un cheval sur la pointe des rênes..." (Demonstr.,s.11)

Dann wird geschildert, wie das Wasser, das man von einem Berg in die Tiefe stüren läbt, wieder zur ursprünglichen Hơhe aufsteigt:

II,348ff. Спускаем и велим ей так вниз упадать, Чтоб в стольку ж высоту самой ей возлетать, Со сколькия на низ мы онуо пустили

Tred. fügt hinzu: $И$, разводя концш, тем под гребло сводили.

Der letzte Vers 1aBt, Je nachdem wie 'nop rpe6ro' ubersetzt wird, zwei Deutungen zu. 'Гре6ло' heiBt 'Streichbrett' und 'Ruder' (Pawl.270). Mit dem Streichbrett wurde z.B. früher das Korn in dem uberfullten MaB glattgestrichen, so daB sich ein volles, 'gestrichenes MaB' ergab. Geht man von dieser Bedeutung aus, dann hieBe "die strömung teilen und unter das Streichbrett führen" soviel wie das tosende Wasser 'glätten'. Ubersetzt man 'rpeблo' mit 'Ruder', dann denkt der Autor daran, daB die Stromung des herabsturzenden Wassers verteilt und z.B. zum Antreiben von Wasserrádern ausgenutzt wird.

In der Démonstration(S.11) wird der Hergang so beschrieben: "... (1'home) l'élève sur les montagnes escarpêes, et se sert de son polds même pour lui faire des chutes qui la font remonter autant qu'elle est descendue."

Tred. nennt es 'uberaus wunderbar', daB der Mensch die gewaltige Kraft des Wassers so gebrauchen kann, als wăre es seine eigene. Er verfügt über sie zu seinem Nutzen und bewaltigt mit ihrer Hilfe Jede Last:

\section{II,355ff. Не может быть, как мно, сего ничто дивняе,}

Что сила она вся испитана ея

Есть человеку так, Как собственна своя:

На пользу он себе той так повелевает,

Что всяку тягость тем, И скоро, премогает.

Durch ihren subjektiven Tenor unterscheidet sich diese Passage von der lehrhaften Art, in der Fênelon die Wasserkraft schildert: "L'eau est une des plus grandes forces mouvantes que l'homme sache employer, pour suppleer a ce que lui manque, dans les arts les plus nécessaires, par la petitesse et 
par la faiblesse de son corps." (Démonstr..S.11)

In II, 360-367 gibt Tred., unabhăngig von der Vorlage, noch zusătzliche Beispiele für die Verwendung des Wassers.

Mit Wasser beseitigt man Gestank und Schmutz:

II,360f. Прибавь, на есякий смрая, на всю нечистоту,

Да смоются они, употребляем ту: -

Das năchste Verspaar gibt einen Hinweis auf den Stand der Körperpflege im RuBland des 18.Jahrhunderts:

II,362f. Водор иногда всё омшваем тело,

Но частее личе, от сна встая на дело; -

Man spült den Mund, wenn er vor Hitze trocken geworden ist:

II,364 Полощем ею мы, как нагорят, уста, -

Der năchste Vers bezieht sich auf die zubereitung der spetsen:

II,365 Разводим ею ж смесь, которая густа -

So hilft uns das Wasser auf vielfache Weise, bemerkt der Autor zusammenfassend. Wir erkennen es auch im Saft der Früchte:

II.366f. Премного от воды пособия имеем,

Чрез соки и в плодах мы воду ж разумеем.

Nach diesem Einschub, der von der alltăglichen Verwendung des Wassers handelte, kehxt Tred. zum Gedankengang der Démonstration zurück. In einzelnen Bildern, unterbrochen von Betrachtungen physikotheologischen Inhalts, wird der Weg des Wassers von den Wolken zu Regen und Tau, zu den Quellen, Bächen und Flüssen bis zum Meer geschildert. Schlieblich richtet sich der Blick wieder auf die 'schwebenden wasser' hoch uber uns, aus denen die 'weise vorsehung' es 'von Zeit zu Zeit auf Erden regnen läBt'. In der Feoptija endet der Abschnitt mit einem Lobpreis des Schöpfers.

Der Autor macht darauf aufmerksam, daB die alltăgliche Naturerscheinung der Wolken keineswegs selbstverständlich ist. Man bedenke: wenn das Wasser auch ursprünglich flüssig ist, so ist es doch recht schwer. Trotzdem steigt es in die Hơhe und hăngt als ein 'bunt gefărbter Abgrund' uber uns:

II,370f. И в тяжести своей, вздымаясь вверьх, над нами

Огромными висит преиспещренно днами.

Der Flug der Wolken wird mit einem biblischen Bild bezeichnet (Ps.103,3 und Ps.17,11; beide Stellen nach LXX). Begeistert fordert der Autor seinen Partner auf, das große Wunder zu sehen, wie die Wolken 'auf den Flügeln des Windes am Himmel dahinziehen: 
II,372f. Воззри на облака: оl чудо из чудес,

Как ветров на крилах летают у небес, -

Das Psalmwort, das in der Demonstration, S.12,Anm.1 lateinisch zitiert wird ("Super pennas ventorum",Ps.CIII,3), lautet in der Septuaginta:

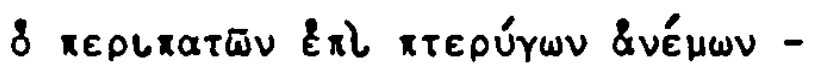

Im Psalm ist es Gott, 'der auf den Fittichen der Winde einhergeht'. Unsere Autoren haben das Bild auf das Ziehen der Wolken angewendet. Tred. hat die Stelle durch eine emphatische Apostrophe(372) akzentuiert. In der Demonstration heiBt es: "Mais ces eaux qui, nonobstant leur fluidite, sont des masses si pesantes, ne laissent pas de s'élever au-dessus de nos têtes, et d'y demeurer longtemps suspendues. Voyez-vous ces nuages qui volent comme sur les ailes des vents?" (S.11/12)

staunend merkt Tred. an, daB die Wolken trotz ihres Gewichts nicht herunterfallen. Sie verschmelzen, wenn sie sich begegnen:

II,374f. А в тяжести такой на низ не упадают, Aа только Аруга Аруг, сливаясь там, сретают -

Dem Bild der ruhig dahinziehenden wolken wird eine apokalyptische vision gegenubergestellt: Was wăre, wenn die Wolken plotzlich wie Wassersăulen auf die Erde stürzten? Eine neue Sintflùt wăre die Folge:

II,376f. Kогда 6 столпами те на низ упали враз,

То 6 потопили край весь тот земли у нас -

Mit einem Schlage würden sie das fruchtbare Land verderben. Nur die hoch gelegenen Geblete blieben ubrig; aber anstelle von Ackererde gabe es dort nux Düre und Sand:

II,379ff. Но повредили 6 всо ту земло тем уааром,

А прочих бы частей край сделался высок

И принял 6ы за тук как сухость, так песок.

Wieder labt der Autor vor der dunklen Folie einer hypothetischen Erwăgung die Wohltat der bestehenden Naturordnung in einem hellen Licht erscheinen. Tred. hat das Gedankenexperiment im wesentlichen aus der Demonstration(S.12) ubernommen: "S'ils tombaient tout a coup par de grosses colonnes d'eau,... ils submergeraient et detruiraient tout dans $l^{\prime}$ endroit de leur chute, et le reste des terres demeurerait aride."

Der Alparuck einer neuen Sintflut kommt auch in dem oben(S.30) z1tierten Gedicht 'Der Regen'von B.H.Brockes zum Ausaruck, das vielleicht auf die Demonstration zuruckgeht. 12 
In II, 382-399 wird die GewiBheit ausgesprochen, daB der Schöpfer überall das Wasser in seiner beständigen ordnung erhălt. Auch hier dienen rhetorische Fragen zum Ausdruck des physikotheologischen Bekenntnisses (vgl.329ff.). Wessen Hand hält die wolken in der Luft und macht, daß es nur in Tropfen regnet?

II,382f. Чья ж держит их рука на воздухе висящи, А каплями весь низ в потребности росящи?

Fast gleichlautend heiBt es in der Demonstration(S.12): "Quelle main les tient dans ces réservoirs suspendus, et ne leur permet de tomber que goutte à goutte...?"

In dem genannten Gedicht 'Der Regen' schreibt B.H.Brockes:

Drum schafft Gott, daB sich der Regen

Durch die Luft nur tröpfelnd drängt - 13

Wie kommt es, fragt der Autor weiter, daB dort, wo fast das ganze Jahr kein Regen fällt, der Tau in der Nacht so reichlich ist, daB er wie Regen das Land tränkt?

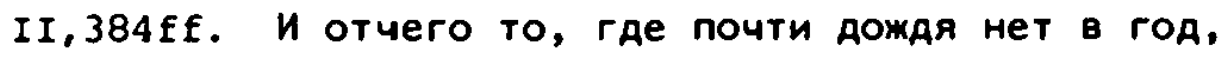

Там силный толь росы бывает ночью род, Что сливным как дождем всю землю наводняет -?

Ebenso fragt Fènelon: "D'ou vient qu'en certains pays chauds, ou il ne pleut presque jamais, les rosées de la nuit sont si abondantes qu'elles suppléent au défaut de la pluie...?" (Démonstr.,S.12)

Das jährliche Hochwasser des Nils, das nach dem Abschwellen den fruchtbaren Schlamm zurückläBt, ruft die andächtige Frage hervor:

II, 388f. Египетскому кто так Нилу повелел, Чтоб разливался он в назначенный предел?

Der physikotheologische Betrachter begnügt sich nicht mit einer natürlichen Erklärung des Naturereignisses. Wer hat dem Nil geboten, fragt er, um klarzumachen, daß in der Natur nichts ohne den Schöpfer geschieht.

Die Démonstration nennt auBer dem Hochwasser des Nils noch das des Ganges. Tred. hat den Ganges unerwähnt gelassen, weil er auBerhalb seines Blickfeldes lag, während der Nil durch die biblische Geschichte allgemien bekannt war. In der Démonstration(S.12) lesen wir an dieser Stelle: "(d'oul vient), qu'en autres pays, tels que les bords du Nil et du Gange, l'inondation règulière des fleuves en certains saisons pourvoit, à point nommé, aux besoins des peuples pour arroser les terres?" 
Dank dieser 'Einrichtung' braucht man sich in diesen Lăndern nicht vor Unfruchtbarkeit zu fürchten, făhrt Tred. fort. Das Staunen darüber kommt in der Frage zum Ausdruck:

II,392f. Строения cего что может дивней быть, Бесплодием везде дабы землям не ныть?

So steht es auch in der Vorlage: "Peut-on imaginer des mesures mieux prises pour rendre tous les pays fertiles?" (Demonstr.,S.12)

Der Schöpfer hat das Wasser 'von einem Ende der Erde zum anderen fließen lassen', denn es wird überall gebraucht. So gleicht die Erde einem bewăsserten Garten:

\section{II,396ff. Тещи пустил водам премудрый всех творец \\ От края по земле на самый в ней конец, \\ Подобно как в саду, особенном и малом, \\ Пускается та вкруг ископанным каналом.}

In diesen Versen scheint die biblische Vorstellung vom Garten Eden anzuklingen. Gen.Kap. 2,6 und v.10 heiBt es im Text der LXX:

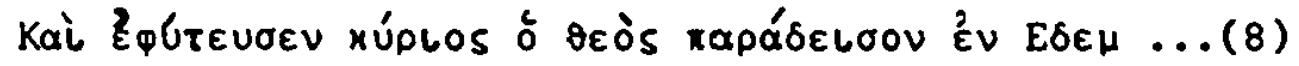

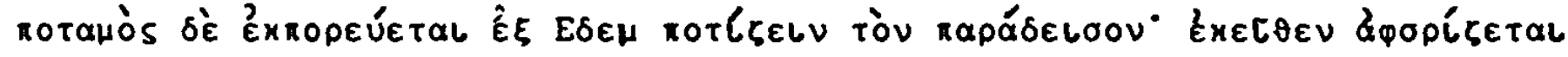
Els téooapas ápxás. (10)

In der Démonstration heiBt es: "...celui qui nous a donné ce corps fluide l'a distribue avec soin sur la terre, comme les canaux d'un Jardin."(S.12)

Den Weg des Wassers von der Quelle zum Meer schildert Tred. in II,400405 lebendig und anschaulich.

Die Quellen fließen von steilen Felsen herab. Das Bild des Wasserfalls wird angedeutet, der 'ohrenbetáubend' rauscht, dessen Anblick uns aber erfreut:

II, 400f. Клочи гремящи, вниз с крутшх стекая гор,

Наш поражая слух, а веселя тем взор, -

Unten im Tal sammeln sich die Quellen zum Bach, aus dem die Tiere trinken können:

II,402f. Сбирахтся внизу в разложистой долине, Способно тае уи пить возможно есть скотине.

An Stăten und Feldern vorbel strebt der FluB in schneller strömung zum Meer:

II,404f. Протекши реки близ градов и по полям,

Струями в бистрине стремятся ум К морям.

Die Passage hat in der Demonstration diesen Wortlaut: "Les eaux tombent des hautes montagnes ou leurs réservolrs sont placés; elles s'assemblent en gros 
ruisseaux dans les vallees: les rivières serpentent dans les vastes campagnes pour les mieux arroser; elles vont enfin se précipiter dans la mer." (S.12)

Im Vergleich zur Démonstration entsteht in der Feoptija durch die reichliche Verwendung von Adjektiven stärker der Eindruck des 'Malerischen'. Es wird aber keine konkret-individuelle, sondern eine ideale Landschaft dargestellt.

Im năchsten Abschnitt II,406-443 richtet der Autor sein Augenmerk auf das Meer. Er denkt an das Weltmeer, das die Erde umfaßt und die Kontinente voneinander trennt. Diese Vorstellung erweckt seine Bewunderung:

\section{II,406f. Великий Океан - дивлюсь, как то поемлю, -}

0бъемльщий вокруг и на́полы всю земли, -

Man könnte meinen, überlegt der Autor, es habe alles überflutet, um die Erde für immer aufzuteilen, aber statt dessen verbindet es die Menschheit:

II,410f. Но напротив мы зрим, то способ сокращенный, Чтоб меж собой весь род был человеч собщенный.

Ohne das Meer könnte der Mensch nicht so schnell von einem Ende der Erde zum anderen gelangen. Es würde ihm vieles fehlen, was er braucht. Auch könnte er wegen der Schwierigkeiten nicht mit fernen volkern verkehren:

II,412f. От края человек не мог без моря в край

Земли дойти по свой, толь скоро, нужный пай.

Die kosmopolitische Einstellung unserer Autoren, die Neigung zum Reisen(wie P.Hazard anmerkt, typisch für die Zeit), ${ }^{14}$ das Interesse am Kennenlernen fremder Völker, am wechselseitigen Austausch durch Handel und Verkehr, tritt hier ähnlich wie in II,197ff. hervor. Verglichen mit den Hindernissen, die sich dem Reisenden damals zu Lande in den Weg stellten (Gebirge, Flüsse, schlechte und unsichere Straßen, mangelhafte Verkehrsmittel, Grenzen und zollschranken), erscheint die Seereise als schnell und ungehindert. Zur Neuen Welt, nach Amerika, gibt es nur den Weg über das Meer. Auf dem Seewege ist die 'Neue Welt' entdeckt worden, von der wir viele Güter erhalten. Umgekehrt führen wir unsere Waren dorthin aus:

II,416ff. Еаиным сим путем есть найден Новый свет,

К Америке пловцам лег океаном след,

Из коея богатств мы много получаем, -

II,420 Взаимно ж мы туда привозим и свои - 
Von dem emphatischen Ausruf 'Великий Океан' abgesehen (406), hălt sich Tred. an den Text der Demonstration: "Cette Océan, qui semble mis au milieu des terres pour en faire une eternelle séparation, est au contraire le rendezvous de tous les peuples, qui ne pourraient aller par terre d'un bout du monde a l'autre qu'avec des fatigues, des longueurs et des dangers incroyables. C'est par ce chemin.... que l'ancien monde donne la main au nouveau, et que le nouveau préte a l'ancien tant de commodités et de richesses." (S.12)

In II,422-25 wird die unaufhorliche Bewegung des Meeres mit dem Blutkreislauf des menschlichen Körpers verglichen:

\section{Разлитием своим вода в земном сем круге \\ В подобном действе есть и в равњой ме услуге, Как в теле нашем кровь, кружащая всегда, -}

Hier wie dort darf der 'Kreislauf' nicht stillstehen, fügt Tred. hinzu:

$$
\text { II.425 И не могуща в нем без крайня стать вреда. }
$$

Der Vergleich stammt aus der Demonstration: "Les eaux distribuees avec tant d'art font une circulation dans la terre, come le sang circule dans le corps humain." (S.12)

In II,426-39 geht es um den geheimnisvollen Rhythmus von Ebbe und Flut:

$$
\text { II,428f. Урочный ко брегам прилив есть от пучин }
$$

И от брегов отлив в известный час И чин.

Der Autor beschrănkt sich darauf, das Phănomen der Gezeiten aufzuzeigen, ohne die Ursache dafūr angeben zu kơnnen. Er hat ja im voraus bemerkt (II,35f.), daß der 'einfache Anblick' (nростый взор, 36) genüge, um die wunder der Schöpfung zu erkennen. Ihm geht es weniger darum, die Ursache zu erforschen, als den Urheber zu bewundern, der Flut und Ebbe in solcher ordnung kommen laßt:

II,432 Премуарости того и власти я аивлось -

II,434f. Который в таковом пораяке то приводит

И в равном же назад отливн те отводит.

Die Weisheit der bestehenden Ordnung wird durch das schon bekannte Gedankenexperiment ins rechte Licht gerückt: was wăre, wenn die Bewegung des Wassers grơßer wăe:

II,436f. Движения воде немного болей Аать,

Tо от вреда сего Земле 6 всей проподать: -

Der Abschnitt uber Ebbe und Flut entspricht der Darstellung dieser Naturerscheinung in der Demonstration. Fenelon nennt die Gezeiten "le flux et reflux de la mer." (Demonstr.,S.12) Er kann und will ihre Ursache nicht ergrün- 
den: "Ne cherchons point les causes de cet effet si mystérieux"(ebd.).Statt dessen fragt er nach dem Urheber der RegelmäBigkeit und betont, daB eine geringfügige Stơrung des Gleichmaßes der Gezeiten verderbliche Folgen hătte: "Qui est-ce qui la fait se retirer, et puis revenir sur ses pas avec tant de régularité?...un peu plus de mouvement dans les eaux qui remontent inonderait des royaumes entiers." (Démonstr.,S.13) Von neuem stellt sich das Bild einer groBen Flut ein, von der die Erde überschwemt wird.

Aus den Fragesătzen II,440-43 spricht die Uberzeugung, daB der Schöpfer dieses Verhăngnis verhindern wird. Er hat dem Ozean eine feste Grenze gesetzt, die dieser 'nicht $z u$ überschreiten wagt', wenn er auch manchmal 'kocht':

II,441ff. Границей Океан кто твердой оградил,

За ко1 преступить он никогда не смеет, Хоть грозно иногда волна́ми сам и вреет?

In der Démonstxation lautet diese Stelle: "Quel doigt a marqué à la mer...la borne immobile qu'elle doit respecter.... en lui disant: Là vous viendrez briser l'orgueil de vos vagues?"(S.13) Hier bezieht sich Fénelon in der Anmerkung auf Hiob XXXVIII,11. Die Bibelstelle hat in der LXX diesen Wortlaut:

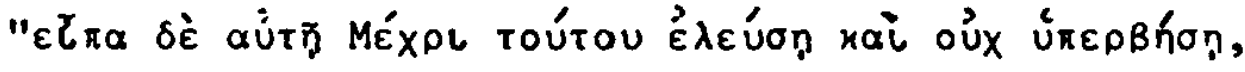

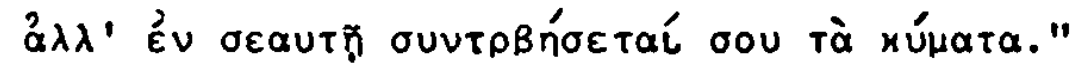

Der Abschnitt II,444-471 handelt von den Aggregatzuständen des Wassers. Das flüssige Wasser verwandelt sich im Winter $z u$ ' $K r i s t a l 1 '$. Der Autor hat $z u-$ nächst das Eis der Flüsse und Seen vor Augen, auf dem ohne Floß Lasten verfrachtet werden können:

II,444f. Текущая вода зимой кристалл тверд есть И может без плотов все бремена понесть.

Ferner sieht man zu jeder Jahreszeit Eis und Schnee in großer Menge auf den Gipfeln der Berge, obwohl diese in der Sonne liegen:

II,446f. Ho rop верьхи лучам хоть солнечным открыты, Во всяко время льдом и снегом зрятся СЫтЫ.

Von dort flieBt das Wasser bei starker Hitze ins Tal, trănkt die Weiden und wird zum Fluß, der dem fernen Meer zuströmt. Das Bild der Verse $402 \mathrm{ff}$. erscheint noch einmal:

$$
\begin{aligned}
& \text { II,450f. Тем пажити поит и производит реки, } \\
& \text { Влекущие струю к морям в кониы далеки. }
\end{aligned}
$$

Tred. hat in dieser Passage den Text der Démonstration durch eigene Zusătze erweitert, 2.B. durch die Bemerkung, daB das Eis der Flūsse und Seen den 
Transport schwerer Lasten ermoglicht(445). Sie weist auf die Verhaltnisse des strengen russischen Winters hin. In der Vorlage steht: "Mais ces eaux si coulantes deviennent tout a coup, pendant l'hiver, dures comme des rochers."(S.13) Der Satz "...les sommets des hautes montagnes ont meme en tout temps des glaces et des neiges, qui sont les sources des rivières"(vgl.II,446f.), wird in der Feoptija weiter ausgeführt:

II,448f. С них в непряженный зной течет шумящий ток

И, чистясь по кремням, стекает в Аол глубок: -

Auf den Unterschied zwischen dem SüBwasser der Flüsse und dem Salzwasser des Meeres weisen die Verse II,452-55 hin:

II,452f. Здесь вся пресна вода и здрава $K$ питию,

Тут растворила соль, и круто уж сио.

Der Autor betont jedoch, daß auch das ungenieBbare Salzwasser dem Menschen unentbehrlich ist:

II,454f. Однак Аля пользы ж нам, Аля нашей и выго́ды,

Мы солио крепим слаяя всех ядей роды.

Die Verse stimmen mit der Vorlage uberein: "Ici les eaux sont douces pour désaltérer l'homme; là elles ont un sel qui assaisonne et rend incorruptibles nos aliments." (Démonstr.,s.13) Auch im Alltăglichen erkennen die Physikotheologen die Weisheit der Vorsehung.

Die Verse 456-59 hat Tred. In den Zusammenhang eingeschoben. Sie sagen, daB uns das Wasser 'überall mit lauter stimme verkündigt', daB es in der Natur unentbehrlich ist:

II,458f. Провозвещает всем повсюау велегласно,

Что в естестве вещей она есть не напрасно.

Nachdem er den Lauf des Wassers von den Wolken $2 u$ den Quellen, Băchen und Flüssen bis hin zum Meer beschrieben hat, richtet der Betrachter den Blick wieder nach oben. Anknüpfend an II,372 schildert er:

II,460f. Hо возвому как выспрь мои глаза и зрю

Там плавающих вод громады, (говорю), -

Angesichts der 'Massen schwebender Wasser' bekundet er 'andăchtig', daß wir nicht genug darüber staunen können:

II, 463 Всем надивиться нам тому отноды не можно.

Die Vorsehung hat 'das Wasser, bedrohlich wie es scheint, uber mir aufgehăngt', schreibt der Autor, aber sie hat damit nur gute Absichten: 
II,465f. ПОвесил вОАУ ОН, В вИА ГрОзнО НадО Мной, Не в том, чтоб злесь меня так придавить мог ею, -

Die bedrohlich erscheinenden Wolkenmassen sollen uns nicht erdrūcken, sondern sind dazu da, die Luft gleichmăBig feucht zu machen, die glühenden strahlen der Sonne $z u$ mildern und es $a b$ und $z u$ regnen $z u$ lassen. Die guten Absichten des Schopfers werden in aneinandergereihten Finalsătzen beschrieben:

II,468ff. Чтоб в мерность воздух весь вокруг нас приводить, Чтоб на землю еще по временам дождить

И чтоб зной прохлаждать лучей толь раскаленный, -

Die Verse sind vom Text der Démonstration(S.13) abhängig. Fénelon bezeichnet die Wolken als "des espèces de mers suspendues", vom Schōpfer dazu bestimmt, "pour temperer l'air, pour arreter les rayons enflammés du soleil, et pour arroser la terre quand elle est trop seche."

Der Abschnitt II,472-535 behandelt als zweites der Elemente 'die Luft'. Das neue Thema wird ohne Ubergang mit den Versen eingeleitet:

II,472f. Оставим водный род; на воздух уж воззрим:

0 благости твориа и в нем поговорим.

Im Unterschied zur Démonstration erklärt Tred, ausdrücklich, daß es ihm auch bei diesem Thema darum geht, von der Güte des Schōpfers zu reden. Fénelon beginnt den neuen Abschnitt so: "Apres avoir consideré les eaux, appliquonsnous a examiner d'autres masses encore plus étendues." (Démonstr.,S.13)

In II,478-485 referiert Tred. unabhăngig von der Démonstration, was die damalige Naturwissenschaft über die Zusammensetzung der Luft lehrte. Danach besteht sie aus drei Stoffen: aus feinstem Atherstaub,

$$
\text { II,479 Эфир, тончайши те пылинки и крупицы, - }
$$

aus Wasserdampf:

II,480 Пары, а сии все суть сродственны воде, -

und aus 'Rauchteilchen', die aus dem Exdinneren kommen und, wenn sie sich verdichten, Gasstürme verursachen:

II,482f. Курения, извнутрь земли происхояящи,

Сгустевши $w$, разны 8 нем мете́оры плодящи. -15

In diesem Zusammenhang wird auch das damals aktuelle Problem der Elektrizität angesprochen. Der Autor sagt, es sei umstritten, ob sie eine besondere Art von Materie darstelle, oder ob sie durch Reibung entstehe:

II,484f. Эле́ктрических сил особо ль вещество, Иль трением, в том спор, родит их естество. 16 
In II,486-489 gibt Tred. ubereinstimmend mit der Desmonstration die physikalischen Eigenschaften der Luft an, auf denen inxe Durchlássigkeit für das Licht beruht:

II,486f. Bесь воздух тонок, чист и так есть проницаем, Что шлемый от планет легко свет созерцаем, Von den Eigenschaften der Luft heiBt es in Demonstr.,s.13: "...c'est un corps si pur, si subtil et si transparent, que les rayons des astres situes dans une distance presque infinie de nous le percent tout entier sans peine, et en un seul instant, pour venir eclairex nos yeux."

Auch Tred. spricht in Ausdrucken, die dem neuen Weltbild entsprechen, von der 'ungeheuren Hơhe', in der sich die Himmelskorper befinden und davon, daB sie ihre Strahlen 'in einem Augenblick' zur Erde schicken:

$$
\text { II,487ff. } \quad \text {...ot nланет легко свет созерцаем, }
$$

Поставленншх от нас в ужасной вишине,

А шиот лучи свои в мгновение оне.

In der Wendung 'ужасная вьшина' klingt der kaum uberwundene 'kopernikanische Schock' ${ }^{17}$ nach. Die realistische vorstellung von der Geschwindigkeit des Lichtes ist beiden Autoren gemeinsam.

Unabhăngig von der Démonstration geht Tred. auch auf das Phănomen des Luftdrucks ein. Die Luft labt sich zusammendrücken, aber sobald der Druck aufhort, dehnt sie sich sofort wieder aus:

II,490f. ОАнак в себе упруг, как сматый он стеснится, Но то,что жмет, лишь прочь - тотчас распространитыя. Der physikalische Vorgang ist hier in volkstümlicher Redeweise prăgnant bezeichnet worden.

AuBer dem experimentell darstellbaren Luftdruck nennt der Autor den in der Natur vorhandenen. Die Luft drückt mit ihrem Gewicht von oben und von allen Seiten 'in ihrem Kessel' auf die Erde:

\section{II,492f. Притом тяжел и сам: с верьхов в своем котле}

И равно со сторон всё Аавит он К земле.

Hier schlieBt sich in II,494-503 die hypothetische Erwăgung an: was wăre, wenn die Luft dûnner, bzw. dichtex wăre. Dasselbe Gedankenexperiment ist auch bei der Erde(II,85ff.) und beim Wasser(II,321ff.) gemacht worden. Tred. uberlegt zuerst, wie eine dünnere Luft sich auswirken wĩrde. Wir erhielten dadurch ein trubes, blasses Tageslicht: 
II,494ff. Kогда 6 тончае был состав сей хоть немного,

Сияние планет к нам шло 6 в лучах убого:

Мы получали 6 тем себе примрачный свет,

Который бы өсегда не ясен был, но блед.

Diese Wirkungen erwartet Fénelon gerade umgekehrt von einer gröBeren Dichte der Luft. Er beginnt seine Uberlegungen mit den Worten: "Un peu moins de subtilité dans ce corps fluide nous aurait dérobe le jour, ou ne nous aurait laissé tout au plus qu'une lumière sombre et confuse..." (Démonstr.,S.13) Tred. hat an dieser stelle den ausführlicheren Text der Démonstration gekürzt. Er geht gleich der entgegengesetzten Uberlegung nach: wenn die Luft dichter wäre, fiele uns das Atmen schwer, und wir wärden in einer Art Schlamm versinken:

II,498ff. Kогда ж бы гуще был наш воздух и сыряе,

То бы задыхаться нам чрез то пришло скоряе.

Как в тине 6 мы какой уж углебали в нем, -

Die Verse gehen auf die vorlage zurück: "...s'il devenait plus épais et plus humide: alors nous nous noierions dans les flots de cet air épaissi..." (S.14) Von der Démonstration scheint auch das Gedicht 'Die Luft' von B.H.Brockes beeinflußt zu sein:
Wenn die Lüfte dünner wăren;
Könnt' die Dün- und Seltenheit
Unsre Lunge nicht ernăhren,
Durch die linde Feuchtigkeit.
Könnte sie sich sehr verdicken,
Müsten Vieh und Mensch ersticken,
Ja der Sonnen Lebens-Schein
würd' uns dann geraubet seyn. 18

Die hypothetische Erwägung ist, wie sich von neuem gezeigt hat, ein Mittel zur Rechtfertigung des bestehenden Zustandes der Welt, der einem weisen Urheber zu verdanken ist. Diese Uberzeugung auBert sich in der physikotheologischen Frage:

$$
\begin{aligned}
& \text { II,504f. Кто ж воздух весь привел в умеренность сию, } \\
& \text { Что продолжаем в нем, дьша тем, жизнь свою? }
\end{aligned}
$$

Tred. hat sie aus der Démonstration(S.14): "Qui est-ce qui a purifie avec tant de justesse cet air que nous respirons?" 
Die Verse II,506-535 handeln von der Bewegung der Luft, d.h. vom Wind und sturm.

Die Stürme entstehen, so erklărt Tred., durch eine 'starke Gewalt', die sie 'ermutigt', die aber auch făhig ist, sie zu 'zăhwen':

\section{II,506f. Какая сильна власть в нем бури ободряет}

\section{И буйность оныХ вско способно усмиряет?}

Die rhetorische Frage hat theozentrischen Sinn. Der Autor meint mit 'сильна өласть' den Schöpfer. Er hat die Winde 'aus verborgenen Ortern' genomen, heibt es in einer mythisch anmutenden Metapher. Er hat ihnen geboten, aus den vier Himmelsrichtungen zu wehen. Die Passivformen im russischen Text dienen ebenfalls zur Umschreibung der theozentrischen Aussage:

\section{II,512f. В сокровинах каких все ветры взяты суть, \\ С четырех коим стран повелено здесь ауть?}

Die Macht des Schöpfers wird daran sichtbar gemacht, daß er den Winden befiehlt, die doch mit ihrer Urgewalt das Meer aufwihlen:

\section{II,510f. Волнение в морях есть следство ветров сильных И наглых тех погоя и вихрей неумильных.}

Das geheimnisvolle und unfaBbare Phănomen des windes dient auf GeheiB des Schöpfers dem Menschen. Den Winden ist 'geboten', 'die Luft zu reinigen', 'den Grimm des Winters zu mildern', 'die Wolken zu zerstreuen und zusammenzufügen'. Tred. hălt sich an die Ausführungen Fénelons, hat sie aber deutlicher theozentrisch formuliert und $z . T$. erweitert. In der Demonstration(14) wird ausgefuhrt: "Mais quelle puissance invisible excite et apaise si soudainement les tempetes de ce grand corps fluide? Celles de la mer n'en sont que les suites. De quel tresor sont tirés les vents qui purifient l'air, qui attiedissent les saisons bralantes, qui temperent la rigueur des hivers, et qui changent en un instant la face du ciel? Sur les ailes de ces vents volent les nuees d'un bout de l'horizon a l'autre."

Um eine bestimmte Art von winden geht es in II,526-535. Der Autor hat fur sie keinen speziellen Namen. Sie sind, sagt er, 'erst jetzt bekannt geworden'. Gemeint sind die Monsun- und Passatwinde:

\section{II,526ff. Суть ветры на морях, уж ныне нам известных, Которы ялятся там, как 6ы в границах местных, Чрез несколько не дней, но месячов самих, Сменяемы потом на столько м от аругих.} Fénelon hat diese Naturerscheinung so beschrieben: "On sait que certains 
vents règnent en certaines mers dans des saisons précises: ils durent un temps réglé; et il leur en succède d'autres..."(Démonstr.,S.14)

Damit hat die Vorsehung gūnstige Bedingungen fūr die Seefahrt geschaffen, so deuten die Physikotheologen das Phānomen:

II,530f. Не промысл ли есть в сем, для плаваний податных, чрез полгода в страну, чрез столько ж вспять обратных?

Diese freundliche Vorsorge kommt aber nur denen zugute, die Geduld genug haben, die günstige Windrichtung abzuwarten:

II,532f. Kогаa 6 те возмогли, случилось коим плыть, Коль постоянен ветр, толь терпеливы быть, -

Dann würden sie eine weitere Fahrt machen und mehr Ladung zurückbringen:

II,534f. То 6 далей ход морский произвели пловуии

И болей бы плода везли назад идущи.

Der physikotheologisch denkende Autor versteht die meteorologische Naturerscheinung der Monsun- und Passatwinde als Wink der Vorsehung, auf den der Mensch achten soll. Es gereicht ihm zum Nutzen, wenn er geduldig die rechte Zeit erwartet. Das ist wohl der Sinn dieser kurzen moralischen Digression. In der Démonstration(S.14) hat sie diese Form: "(ils durent un temps régle), comme tout exprès, pour rendre les navigations commodes et régulières, pourvu que les hommes soient patients et aussi ponctuels que les vents, ils feront sans peine les plus longues navigations."

Als năchstes Element wird in II,536-593 das Feuer zum Gegenstand der Betrachtung gemacht.

Das neue Thema wird mit der Aufforderung 'laBt uns das Feuer anschauen' genannt. Es hat seinen Ursprung in der Sonne. Dort lodert es und gibt der ganzen Welt seine Strahlen:

II,536f. Посмотрим и на огонь, в Аневном светиле кой

Пылает, подая вселенной всей луч свой.

In der Démonstration beginnt der Abschnitt ăhnlich: "Voyez-vous ce feu qui parait allumé dans les astres, et qui répand partout la lumière." (S.14) Auf der Erde ist das Feuer in den Vulkanen gespeichert, wird vom Schwefel der Erde genāhrt, bis es plötzlich durch den ZusammenstoB mit anderen Körpern ausbricht: die Berge 'blasen Feuer aus', sagt Tred.:

II,538f. И возведем еще мы лобопытны взоры

На дышущи огнем и пламенисты горы. 
Wie es $2 u$ einem Vulkanausbruch kommt, schildern diese Verse: II,540 Питаясь сей огонь н них серой от земли, -

und II,544f. Пока, столкнувшись с ним, других тел тверд укрух Ударом тем его не взбудит вспихнуть вдруг.

Diese Theorie des Vulkanismus hat Tred. In der Demonstration gefunden(S.14): "Voyez-vous cette flame que certaines montagnes vomissent, et que la terre nourrit de soufre dans ses entrailles? Ce même feu ...y attend a eclater jusqu'd ce que le choc d'un autre corps l'excite..." Wie das Feuer in den Berg gekommen ist, weiB der schópfer allein, der es dort entzundet und gewissermaBen in einer 'engen Grube' verwahrt hat:

II,546f. Огонь сей, естеству единому известный, Зиокиителем зажокен и скршт как в ров кой тесний -

Die Verse II,546-55 hat Tred. selbstandig eingeschoben. Sie handeln vom Ursprung des vulkanischen Feuers. Ex denkt daran, wie das Feuer unter der Erde unbewegt ruht und, obwohl es von Natur schnell ist, nicht zu den 'feurigen Sphăren' auffăhrt, in denen sein ursprung ist:

\section{II,548ff. Бездвижностио там покой его таит;}

Тем К сферам выспрь огней, хоть быстрый,не парит, Начало гае его и собственно родство -

Von einem StoB getrieben(vgl.544f.), fliegt das unterirdische Feuer aus seiner 'Gruft'. Der Autor sieht darin ein Gleichnis für die Auferstehung der unsterblichen Seele:

\section{II,553ff. Ho сшибкон когда бывает устремленнын, То вспархивает светл из гроба своего, \\ Бессмертныя Ауши как образ от того.}

Um den Nutzen des Feuers für den Menschen geht es in II,556-587. Einleitend wird festgestellt, daB wir es gelernt haben, das 'drohende Element' zu beherrschen und für unsere zwecke anzuwenden:

$$
\text { II,556 Но мы и грознщм сим составом овладели, - }
$$

So steht es auch in der Defionstration(S.14): "L'homme a su l'allumer et l'attacher a tous ses usages..." Darauf schildert Fénelon den vielfaltigen Gebrauch des Feuers. Es dient dem Menschen, "...pour plier les plus durs métaux.... pour nourrir avec du bois... une flamme qui lui tienne lieu du soleil quand le soleil s'éloigne de lui...Cette flame se glisse subtilement dans 
toutes les semences...elle consume tout ce qui est impur, et renouvelle ce qu'elle a purifie. Le feu...enleve tout a coup les édifices et les rochers. ...il réchauffe l'homme, et il cuit ses aliments." (Démonstr.,s.14f.)

Tred. hat diese Aufzăhlung benutzt, sie teilweise erweitert und ihre Reihenfolge geändert, hier und da auch etwas ausgelassen. Er stellt es so dar:

Das Feuer schmilzt das Harte und härtet das Weiche:

$$
\begin{aligned}
& \text { II,562f. Умеет человек им твердость умягчать } \\
& \text { И мягкость иногда огнем ожесточать. }
\end{aligned}
$$

Es dient dem Menschen im winter als wärmequelle:

II,564f. Возжегши аров костер, себя он жаром греет, Как удаленный луч греть силы не имеет.

Eine Entsprechung für "cette flamme se glisse...dans les semences" fehlt. Mehrmals wird die verzehrende Kraft des Feuers hervorgehoben, z.B.:

II,566 Bсё поглощает сей возжоенный так огонь, -

und II,575 Не разрешит чего 2 собой иль не скует?

Wie in der Démonstration wird auch die reinigende und erneuernde Wirkung des Feuers erwähnt:

II,573f. С того, очистив грязь, в чвет поновляет. Пришедшим в слабость нам огнь силу придает; -

Fénelon ergänzend, schildert Tred., wie sich das Feuer ausbreitet, 'als hätte es Flügel', und wie es durch Erz und stein dringt:

II,568f. Oн разливает свой, как крилами, весь пламень,

Проникнет и в крушец и в твердый самый камень.

Von der verschiedenartigen Wirkung des Feuers auf die Stoffe ist in den Versen 570ff. die Rede:

Так, проницая, огнь иное пепелит,
Иное ж, проходя, совсем не попалит;
Другое только тем на части раздробляет, -

Im Hausgebrauch schlieblich, bedient sich der Mensch des Feuers zum wärmen des Wassers (orнb pasorpeet воду,577), zur Zubereitung der speisen und zur Beleuchtung:

II,578ff. Hе здраву в пище нам он сырость растворит, И, растворяя ту, как хочет, так варит.

всего аражайше огнь зимоі, равно летом,

Единственным всегаа всем пребывает светом; -

Wie nötig wir das Feuer haben, läBt sich nicht mit Worten erfassen, fügt der 
Autor hinzu. Es könnten noch viele Beispiele genannt werden; genug, dab es eine fur alle 'wohltatige Sache' ist. Gott hat uns in seiner Weisheit mit dem Feuer ausgerüstet, sonst wirde alles in der Welt erfrieren:

II,586f. Премудро нас огнем снабдило бомество:

Замерзло 6 без него всё на́ все естество.

Mit diesem Zusatz hat Tred. die physikotheologische Absicht, die er bei den naturkundlichen Beschreibungen nicht aus dem Auge verliert, ausdrucklich bezeugt.

In II,588-593 wird der Prometheus-Mythos skizziert.

Die Heiden haben das Feuer als grobten Schatz angesehen, den ein Mensch im Himmel rauben und ins 'Erdental' bringen konnte. Es war ohne das Feuer zu 'armselig' :

\section{II,588ff. Язшиники затем Арагим огнь полагали,}

Что лучшим аля себя сокровинем познали,

Какое человек похитить выспрь возмог

И В АOЛ земний унесть: был без огня убог.

Die Anspielung auf den Mythos verdankt Tred. der Vorlage: "Les anciens, admirant le feu, ont cru que c'etait un tresor celeste que l'home avait derobe aux dieux." (Demonstr.,s.15)

Die emotionale Nuance, von Tred. mit dem Wort 'язынники' anstelle von 'les anciens' angedeutet, kommt verstarkt in dem Zusatz "weg mit der heidnischen Sage" zum Ausdruck. Wir wissen in Wahrheit, daB das Feuer ein unvergleichlich kostbarer Schatz ist:

II,592f. Hо баснь поганска прочь; по правде, несравненно Сокровище сие и есть неоцененно!

In dem vielfach unterteilten Abschnitt II,594-869 ist 'der Himmel' (He6eca) das beherrschende Thema.

Mit wenigen Worten, die nur leicht auf das vorige hinweisen, kundigt der Autor an, daB es noch 'andere Wunder' gibt, die uns ins Auge fallen:

II,594f. Довольно о6 огне: другие чудеса

Bsop nopawawt naw; a те суть - нeбeca.

In der Demonstration beginnt das neue Thema mit der einfachen Ankündgung:

"Il est temps de lever nos yeux vers le ciel."(s.15)

Der Grobe des Themas entspricht in der Feoptija die Tonalitat der Darstellung: Tred. spricht in der 1.Pers.sg. wie jemand, der ein Exlebnis in Worte 
faBt, das ihn gerade jetzt bewegt. Angesichts des ungeheuren Raumes verkündet er im Ton ehrfürchtigen Staunens: Ich erkenne in ihm eine allmăchtige Hand, die das Himmelsgewolbe in einer solchen Rundung über uns gesetzt und wie eine Schale niedergelassen hat. Mein Verstand kann diese Dimension nicht fassen:

II,596ff. Огромностям аивясь пречудным, познаваю

Всесильну руку я: ту в них усмотреваю,

Которая свод сей в окружности такой,

Что равную понять не может здесь ум мой,

Ная нашими с верьхов главами утверяила

И чашею к бокам в пространстве ж ниспустила; -

In diesen von gehobener Sprache geprăgten Versen spiegelt sich einerseits das neue Weltbild mit seinen riesigen Räumen ('огромностям аивясь', 'в окружности такой', 'равную понять не может здесь ум мой', 'в пространстве'). Andererseits sind darin bekannte vorstellungen aus der biblischen schöpfungsgeschichte (Gen.Kap.1) enthalten. Die Wendungen ' познаваю всесильну руку' und 'которая свод сей...утвердила' exinnern an den Anfang der Bibel:

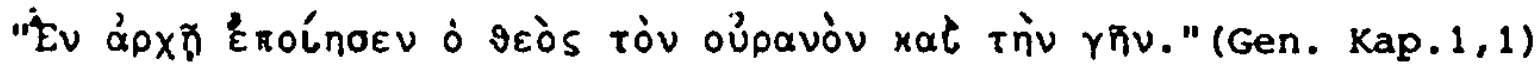

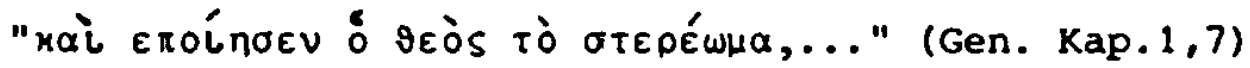
Durch das Vertrauen auf die 'allmächtige Hand', die den unendlichen Raum geschaffen hat, ist das Grauen davor überwunden. An seine Stelle ist die Bewunderung getreten. Tred. bekennt, daß beim Anblick der Himmelskörper, ihrer Zahl, Entfernung, Verschiedenheit und Größe 'der Verstand sich verwirrt'. Die Darstellung ist von begeisterten Ausrufen gekennzeichnet, die die Erregung des Autors zeigen:

$$
\begin{aligned}
& \text { II,602Еf. Мятется разум наш, к сим высота́м паря, } \\
& \text { На множество и тел и на далекость зря. } \\
& \text { Се вияы каковы и зрим мы их колики! } \\
& \text { Различные те коль! и разно коль велики! }
\end{aligned}
$$

Der französische Text, mit dem Tred. hier frei ungegangen ist, bringt im Vergleich zur Feoptija die Bewunderung verhaltener zum Ausdruck: "Quelle puissance a construit au-dessus de nos têtes une si vaste et si superbe voote? Quelle étonante variété d'admirables objets! c'est pour nous donner un beau spectacle, qu'une main toute-puissante a mis devant nos yeux de si grands et de si éclatants objets." (Demonstr.,s.15)

Einen ahnlichen Ton wie in der Feoptija finden wir in dem Gedicht 'Das Firmament' von B.H.Brockes, wie die folgenden zeilen deutlich machen: 
Es schwindelte mein Aug', es stockte meine Seele

Ob der unenalichen, unmäig-tiefen Höle - 19

In II,606-611 wird die aufrechte Korperhaltung des Menschen teleologisch gedeutet.

Gott hat den Menschen so geschaffen, daB er seine Augen leicht zum Himmel aufheben kann, um seine Schönheit zu betrachten. Dies zeichnet den Menschen vor allen Kreaturen aus. Ein Zitat -Fenelon gibt an, daB es von Cicero stammt- bestátigt diese Auffassung:

II,606ff. Поистине на то, как Аревный муж сказал,

Бог человека сам единственно создал,

От прочих тварей всех отменна и отлична, Чтоб красоту небес ему, зря, знать коль слична,

Свободно очи внспрь возможет он возвесть

И видеть над его главою, что́ там есть.

Die Passage geht auf die Démonstration(S.15) zurück: "C'est pour nous faire admirer le ciel, dit Ciceron, que Dieu a fait l'homme autrement que le reste des animaux. Il est droit, et léve la tête, pour être occupê de ce quil est au-dessus de lui." (Fénelon verwelst in der Anmerkung auf 'De Nat.Deor.II,56)

Es folgt in II,612-631 eine Beschreibung des Firmaments bei Tage und in der Nacht.

Die Beschreibung des Taghimmels deckt sich im wesentlichen mit dem Text der Vorlage: Manchmal sehen wir den Himmel in einem 'dámmerigen Blau', das vom Licht des 'himmlischen Feuers' glănzt:

$$
\begin{aligned}
& \text { II,612 Мы видим иногаа там синету примрачну, - } \\
& \text { II,614 В которой блещет свет небесного огня - }
\end{aligned}
$$

Bei fenelon heiBt es: "Tantot nous voyons un azur sombre, ou les feux les plus purs etincellent." (Demonstr.,s.15)

Manchmal sehen wir einen reinen Himmel uber uns mit solchen wolkenmustern, wie kein Maler sie malen kann:

II,616ff. Зрим небо иногда толь чистое над нами,

С узорными еще толико облаками,

Что никакой зограф того изобразить

Не может так отнодь, глаз столь же 6 поразить, -

Die Demonstration(S.15) hat hier einen etwas anderen Text: "...tantôt nous 
voyons dans un ciel temperé les plus douces couleurs, avec des nuances que la peinture ne peut imiter..."

Zuletzt wird ein buntwolkiger Himel beschxieben, der sich stăndig verăndert:

$$
\begin{aligned}
& \text { II,620ff. А иногда зрим там мы виды озаренны } \\
& \text { И разно в облаках цветами испещренны, } \\
& \text { Которы образ свой меняют повсегда, - }
\end{aligned}
$$

Diese Schilderung ist der Vorlage nachgebildet: "...tantot nous voyons des nuages de toutes les figures et de toutes les couleurs les plus vives, qui changent a chaque moment cette décoration..." (Démonstr.,S.15)

In der Feoptija heben sich die 'malenden' Verse 612-23, denen die Freude an den verschiedenen Himmelslandschaften, dem Licht, den Farben und den wechselnden Formen der Wolken anzumerken ist, deutlich von der dithyrambischen Passage 596-605 ab.

Ein neuer Kontrast ergibt sich durch die von Tred. selbstăndig eingeschobene Schilderung des năchtlichen Sternhimmels. Von seinem Anblick ist der Autor so ergriffen, daB er ihn nicht mit ruhigen Worten beschreiben kann. Seine Bewunderung der năchtlichen Pracht kommt in rhetorischen Fragen und Ausrufen zum Ausdruck. LaßBt sich etwa der herrliche Anblick, den uns der Himel in klaren Năchten gibt, mit Worten erkläen, fragt der Autor:

$$
\text { II,624f. Возможно ль изъяснить прекрасный вид речами, }
$$

Кой мы на небе зрим немглистыми ночами?

Hierauf folgt ein Ausruf der Bewunderung über das Glänzen der 'goldenen Sterne' aus ihren, wie es uns scheint, 'unbeweglichen Nestern':

\section{II,626f. Коль неиссчетный лик златых блистает звезд,}

Являіющихся нам как неподвижных гнезд!

Wird uns nicht schwindelig, wenn wir den bernsteinfarbenen Schimmer der Milchstraße sehen? Durch die Frage soll das ehrfürchtige Staunen geweckt werden :

$$
\text { II,628f. Ум не мятется ль наш, зря млечную дорогу, }
$$

А блеск янтарный в ней чрез искру варуг премногу? Wir bewundern diesen 'Schmuck' nicht weniger, seit wir wissen, daB die Milchstraße aus unzăhligen sternen besteht, so endet diese aus einem bewegten Wechsel von rhetorischen Fragen und Exklamationen bestehende Schilderung des Sternhimmels:

II,630f. Чудимся превесьма и видя сей убор; Но как? Что знаем уж, коль тот непраздно хор! 
Bemerkenswert ist, daB das astronomische Wissen der ehrfürchtigen Bewunderung nicht im Wege steht, sondern sie herausfordert.

Der Wechsel von Tag und Nacht steht im Mittelpunkt von II,632-667. Die Aufeinanderfolge der Tageszeiten erscheint dem Physikotheologen als 'wunderbare ordnung', die auf die 'hơchste Weisheit' hinweist:

II,632f. Чин Аивный смену Аня и ночи уставляет, Премуарость винно тем довольно проявляет: -

Fénelon hat hier keinen ausärücklichen tinweis auf die 'wunderbare ordnung' des Schopfers. Ex fragt: "La succession régulière des jours et des nuits, que fait-elle entendre?" (Démonstr.,S.15)

Die Frage zielt auf den Sinn, den die Tageszeiten für den Menschen haben. Davon handelt der Abschnitt II,644ff. Zuvor wird ausgefuhrt, daB die Tageszeiten von der Sonne abhăngig sind (II,634-43).

Von jeher haben die Menschen das Licht von dex Sonne, ohne die die Welt keinen Augenblick bestehen kann:

II,634f. Чрез многи веки свет от солнца аля людей, Без солнца и побыть не может весь мир сей.

In der Démonstration(S.15) heiBt es: "Le soleil ne manque jamais, depuis tant de sieccles, a servir les homes, qui ne peuvent se passer de lui." Im folgenden ist vom Aufgang und Untergang der Sonne die Rede, wie sie sich dem Augenschein darbieten, ohne daB unsere Autoren sich damit zum alten Weltbild bekennen wollen. Die Sprache, besonders die poetische, bleibt ptolemåisch auch nach der 'kopernikanischen Wende'. H.Blumenberg meint zu diesem Problem: "Es ist also nicht unbedingt die Sprache, in der sich die ungeheure Verănderung des BewuBtseins durch Kritik und Wissenscahft reflektieren muB, im Gegenteil, die neu gewonnene Souverănităt des Menschengeistes liegt gerade auch in der Objektivierung der Sprache." 20 Ex zitiert eine Bemerkung von L.C.Lichtenberg: "Unsere Sprache darf aber in diesem Sinne nicht philosophisch sein, so wenig sie in Rücksicht auf das Weltgebăude kopernikanisch sein darf." 21 Mit einem aus der Demonstration entlehnten Bild beschreibt Tred., wie die Morgenrote der Sonne vorhergeht und sie zur richtigen Zeit 'herausführt', ohne daB sie es in Tausenden von Jahren einmal vergessen hătte, sie anzukündigen:

II,636f. Чрез тысящи ум лет заря пред солнца ходит И в свой исправно срок она его выводит; 
II,638f. А ни однажды та его ж превозвещать

He позабыла нам и өдруг себя собщать.

Die Verse stimmen mit der Demonstration (S.15) überein: "L'aurore, depuis des milliers années, $n^{\prime a}$ pas manqué une seule fois d'annoncer le jour: elle le commence a point nommé au moment et au lieu réglés."

Für den Untergang der Sonne benutzt Fénelon eine Wendung aus Ps.103,19: "Le soleil, dit l'Ecriture, sait ou il doit se coucher chaque jour."(S.15)

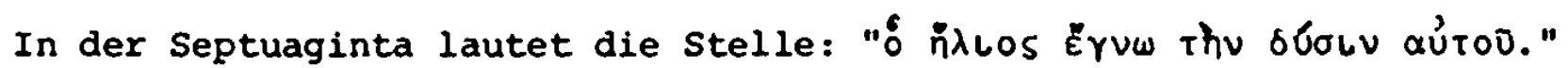
Tred. hat zwar die Bibelstelle übernommen, sie aber nicht als zitat gekennzeichnet:
II, 640
С Полудня солнце сшед свой Запад познавает,

Dann beginnt bei anderen Menschen der Tag und bei uns die Nacht. Auf diese Weise schenkt die Sonne der ganzen Welt ihr 'hellstrahlendes' Licht:

II,642f. Сим образом оно вселенной подает

Луч сөетозарный свой, Как тут и там встает.

Den Gedanken hat Tred. aus der Démonstration, in der er so formuliert ist: "Par-là il éclaire tour à tour les deux côtés du monde..."(S.15)

In der ordnung der Tageszeiten offenbart sich die göttliche Weisheit, die auf die Bedürfnisse des Menschen Rücksicht genommen hat. Der Mensch braucht die Gemeinschaft mit anderen Menschen. Dazu ist uns der Tag gegeben. Die Physikotheologen messen dem menschlichen Gemeinschaftsleben, wie schon gesagt hohen Wert bei:

$$
\begin{aligned}
& \text { II,644f. В собщение взаем приводит день живущих, } \\
& \text { Взаимны, сей в другом, потребности имущих. }
\end{aligned}
$$

Fénelon erklärt: "Le jour est le temps de la societé et du travail..."(S.15) Zahlreich sind die Wohltaten der Nacht, 'die mit ihrem Dunkel die Erde zudeckt'. Sie erscheint wie eine mütterliche Gestalt, 'die den Mühen ein Ende setzt und uns wieder stărkt' :

\section{II,646f. Всі Земль темнотой своей покрывши, нощь Коне́ц творит трудам, нас ободряя в моць; -}

In den nachfolgenden Versen scheint ein Stūck Lebenserfahrung Tred.s, seine rastlose Arbeit(man nannte ihn 'труженник'), seine nicht aufhörenden Sorgen und Verwicklungen, anzuklingen:

II,650f. Нощь өводит сладкий сон, покой и тишину, Аает вещей забыть нам низ и вышину, -

Die Wendungen vom 'süBen Schlaf' der Nacht, die uns 'die Dinge vergessen 
labt', hat Tred. eigens eingefügt. Die Nacht hat für den Menschen noch eine weitere Wohltat: wăhrend sie uns alles aus der Hand nimmt, und der Körper ohnmăchtig auf dem Lager ruht, gibt sie den Schlafern neuen Mut und neue kraft zu inrem Tagewerk:

\section{II,652ff. Отьяөши в те часы у нас из рук өсё дело, Ha ложах наших всё ж приводит в слабость тело, Но ободряет аух тогда ж в нас спящих так И силы отдает встаячим утра в зрак.}

DaB die Erneuerung 'gerade dann' (TorAa $w$ ) vor sich geht, wenn wir passiv und schwach daliegen, ist für den Autor ein Merkmal der 'wunderbaren Ordnung' . Bei der Beschreibung der Nacht hat sich Tred. im wesentlichen an die Demonstration gehalten, den Text der Vorlage aber in einigen Punkten besonders akzentuiert. Was die Nacht fūr den Menschen wert ist, wird von Fenelon so beschrieben: "...la nuit, enveloppant de ses sombres la terre, finit tour a tour toutes les fatigues, et adoucit toutes les peines: elle suspend, elle calme tout; elle répand le silence et le sommeil; en délassant les corps, elle renouvelle les esprits. Bientôt le jour revient pour rappeler l'home au travail, et pour ranimer toute la nature." (Demonstr.,S.15f.)

In II,656-667 hat Tred. das Thema 'Tageszeiten' amplifiziert. Er führt aus, daß jede einzelne der vier Tageszeiten 'die Mutter' der folgenden ist. So wird aus dem Morgen der Tag und aus dem Abend die Nacht 'geboren'. Der Schopfer hat es um des Menschen willen so geordnet, well der plotzliche Wechsel von Licht und Finsternis 'unseren Augen schaden würde', hebt der Autor hervor:

\section{II,658ff. Родится утром день, от вечера уж тьма, \\ Без утра варуг мы Аня, без вечера весьма \\ Не можем вдруг же снесть и темныя толь ночи: \\ В том сильный свет, в той мрак вредили 6 наши очи.}

In der Absicht, das Zweckvolle und dem Menschen Nüzliche in allen Erscheinungen aufzuzeigen, führen die Physikotheologen hăufig Beispiele an, die uns naiv oder seltsam vorkommen. Gegen eine ubertriebene Teleologie erhebt aus theologischer Sicht P.Althaus den Einwand: "(Die Natur) zeugt von Gott nicht nur durch das für unseren Blick Zweckvolle, sondern auch durch das erhabenoder seltsam-, ja lăcherlich-Zwecklose. Sie labt sich nicht aufrechnen in Zwecke, die uns einsichtig wăren. Sie verkündet, daß die Gedanken des Schöp- 
fers höher sind als unsere... An der Natur lernt man Gott auch fürchten. Diese Seite hat die Aufklärung in ihrer Naturfrommigkeit nicht gesehen. Weil sie überall nur Telos, Sinn, Vernunft fand, wurde ihr Naturerlebnis und mit ihm ihr Gottesgedanke flach." 22 zum Anthropozentrismus in der Schopfung nimmt P.Althaus wie folgt Stellung: "Die Unendlichkeit I $A$. merkt an, daB er damit 'die ungeheure Weite' meint/, Fülle, Rátselhaftigkeit des Kosmos widersetzt sich jeder rein anthropozentrischen Sinndeutung seiner Wirklichkeit. Zum christlichen Glauben gehort allerdings die GewiBheit: Gott hat den Menschen als sein höchstes irdisches Geschöpf geschaffen und den Kosmos so eingerichtet, daB er dem Menschen gibt, was er zum Leben bedarf." 23

Die physikotheologischen Betrachtungen der Natur -wir wenden uns wieder den Tageszeiten in der Feoptija zu- illustrieren die Uberzeugung: Gott sorgt für uns Menschen. Wir erfahren seine Fursorge u.a. auch in der regelmäBigen Aufeinanderfolge, im 'Аивный чин' der 'vier Teile' von Tag und Nacht. Eindringlich fragt der Autor: Ist Gott nicht in allem unser 'Behüter und vater'?:

II,662f. Hе пекся ль сим о нас премудрый всех творец?

Не по всему ль нам есть хранитель и отец?

Diese GewiBheit wird auch in II,311f. und II,675 ausgesprochen. 'Хранитель' wird von Mikl. mit gr. 'фú $\lambda \alpha \xi$ ', lat. 'custos' (1096) übersetzt.

Tred. vergleicht in II,664-67 den Wechsel von Tag und Nacht mit den 'Stufen' des menschlichen Lebens:

II,664f. Дивна премена дней с ночами в нощеденстве:

Так стар, так прежде муж, так отрок, пчак в младенстве, Ksl. 'нощедьнство' ist bei Mikl. (455) belegt und mit 'nox et dies' ubersetzt. 'Schrittweise' (im wörtlichen und übertragenen Sinne) geht der Mensch durch das Leben bis an sein Ende:

II,666f. Степенями идущ, бывает человек И провождает свой весь до кончины век.

In II,668-723 befaBt sich Tred. mit dem Wechsel der Jahreszeiten, der ihm nicht weniger wunderbar erscheint als die Aufeinanderfolge der Tageszeiten. Das Jahr wird durch die Sonne in vier Teile geteilt. Sechs Monate 'bewegt sie sich zum Warmen' -wieviele Male schon-gibt der Autor staunend zu bedenken, darauf zieht sie sich 'schrittweise zum Kalten zurück' :

II,668f. Ho и времен дивна не меньше есть премена: Делится солнцем год весь на четире члена. 
II,670f. Шесть месячев идя $\mathrm{k}$ теплу, и сколько ж крат!

Творит и К хладу свой степенями ж возврат.

So steht es im wesentlichen auch in der Vorlage: "Mais outre ce cours si constant qui forme les jours et les nuits, le soleil nous en montre un autre par lequel il s'approche pendant six mois d'un pole, et au bout de six mois revient avec la même diligence sur ses pas poưr visiter l'autre." (Démonstr.,S.16)

Die 'Bewegung' der Sonne wird nach dem Augenschein beschrieben, was wieder (s.oben,S.129) kein Bekenntnis zum ptolemaischen Weltbild bedeutet. Tred. unterscheidet 'четыре члена' des Jahres: außer somer und winter auch die Ubergangszelten Frühling und Herbst. Er hebt gerade den 'schrittwe1sen', allmählichen Ubergang von einer Jahreszeit zur anderen hervor. Der Gedanke ist ahnlich wie bei den Tageszeiten. Der plotzliche Wechsel von Frost und Hitze wăre fūr uns 'unertrăglich' :

II,672ff. Так Есень, не Зима, сперва Весна, не Лето, Да вдруг ни мраз сразит, ни жаром разогрето, Несносным обоим в нас будет естество: Der allmăhliche Ubergang der Jahreszeiten ist ein Zeichen der gottlichen Fürsorge: II,675 Bсегá о всех и всём печется божество.

Fénelon sieht im Wechsel der Jahreszeiten vor allem den Zweck, daß 'eine einzige Sonne fũr die ganze Erde genũgt': "Ce bel ordre fait qu'un seul soleil suffit a toute la terre."(Demonstr.,S.16)

In seiner Neigung zur Redundanz hat Trod. auch diese Sinndeutung der vorigen noch hinzugefügt:

II,676ff. Толь постоянный ход толикого в том чина

Есть несомненна всем и видами причина, Что есть довольно так светила одного, Чтоб освещать Земли шар круга в ней всего.

Hieran schließt sich die hypothetische Erwăgung, "was wăre, wenn die Sonne (dieselbe Entfernung von der Erde vorausgesetzt), gróBer bzw. kleiner wăre". Vgl. die entsprechenden Erwăgungen bei der Erde(II,85ff.), beim Wasser (II,321ff.) und bei der Luft(II,494ff.) wăre die Sonne grober, so hătte sich durch inre Glut alles auf der Erde langst in Asche verwandelt:

II,680ff. Ho в расстоянии сем когаa 6 то больше было, То пламенем бы всё, что на Земле уж плыло,

$И$ в пепел бы сама давно обращена

И так бы жаром тем была поглощена. 
Wäre die Sonne aber kleiner, so würde die ganze Erde vereisen und wegen der Kălte unbewohnt sein. Dann kămen, fügt Tred. ein, die Absichten des Schopfers nicht zum Ziel:

II,684ff. А если 6 меньше то окружности имело,

То 6 и земля и всё ж на ней оледенело:

Ненаселенной бы при том быть хладе ей,

Намерений твориа не полнил бы вред сей.

Diese Erwägungen beruhen auf dem Text der Démonstration(S.16): "S'il était plus grand, dans la meme distance, il embraserait tout le monde; la terre s'en irait en poudre: si, dans la même distance, il était moins grand, la terre serait toute glacée et inhabitable..."

Auch in diesem Falle führen die hypothetischen Erwägungen zur Rechtfertigung der gegebenen Weltordnung. Die Sonne bringt allen Bewohnern der Erde Nutzen, auch dann, wenn sie sich von uns entfernt:

II,688f. Хотя ж когаа и вдаль зрим Солнце мы ияущим,

Однак не меньше польз есть и тогда живущим: -

Fénelon weist darauf hin, daB die Sonne sich von einem Teil der Erde entfernt, um sich dem anderen zu nähern. So kommt dem einen das gemäßigte $\mathrm{Klima}$ zugute und dem anderen die kraft der Sonnenstrahlen: "Cet astre ne fait pas moins de bien a partie dont il s'éloigne pour la tempérer, qu'a celle dont il s'approche pour la favoriser de ses rayons."(Demonstr.,S.16)

In beiden Texten wird abschließend festgestellt, daB die Sonnenstrahlen das Land fruchtbar machen:

II,690f. Лучи его в местах которых ни горят, ТО пЛодовитым весь тОт КРяЖ ОнИ творят, -

In der Démonstration(S.16) heiBt es: "Ses regards bienfaisants fertilisent tout ce qu'il voit."

Die Verse II,692-699 haben in der Demonstration keine Entsprechung. Sie zei gen, daB Tred. den astronomischen Kausalzusammenhang von Ekliptik und Jahreszeiten gekannt hat. Er hat ja bei seinem Auslandsaufenthalt in Paris in den Jahren 1727-30 u.a. Mathematik studiert. ${ }^{24}$ Tred. führt aus, daB die Punkte der Tag- und Nachtgleiche und die beiden Wendepunkte 'vierfach die Ekliptik schneiden'. Es sind die Schnittpunkte der größten (scheinbaren) Sonnenbahn mit dem Himmelsäquator. Sie bezeichnen den Beginn der Jahreszeiten:

$$
\text { II.694f. Что ж начетверо те зклиптику секут, }
$$

То растворенны к нам тем времена текут, - 
Das Fremdwort 'эклиптика' ist hier vermutlich zum ersten Mal im Russischen gebraucht worden.

Ohne die erwăhnten astronomischen Punkte, d.h. ohne die Ekliptik, warden auf einem Dreiviertel der Erdoberfăche 'die Knospen nicht aufbluhen', formuliert Tred. anschaulich:

\section{II,692f. Без равной той Аля аней и без возвратной точки}

В трех на земле 6 частях не процветали почки.

Zwei Punkte (der Ekliptik)'bringen Tag- und Nachtgleiche herbei'. Die beiden Wendepunkte aber bringen mäBige Hitze und mäBigen Frost, damit unsere walder nicht umkommen und Menschen und Tiere nicht bei extremen Temperaturen verderben. An dieser Stelle ist bemerkenswert, daB der Autor auch am Wohlergehen von Tieren und Pflanzen interessiert ist:

\section{II,696ff. Приводят в равность две - и дни и также ноци,}

Две 2 в мерность зной и мраз, не стибли 6 наши рощи,

$И$ не погибли 6 мы от сильных тех притом,

И кои на земле животны ймут дом.

In der Passage II,692-99 1st die Verbindung des kausalen mit dem teleologischen Gesichtspunkt kennzeichnend für die Weltanschauung des physikotheologisch denkenden Autors.

In II,700-723 werden die einzelnen Jahreszeiten betrachtet.

Zunăchst führt Tred. die typischen Kennzeichen auf: Der Frühling bringt milde Luft, Blutenpracht, 'verspricht uns Früchte', zeigt uns 'die Aihren einer reichen Ernte'. Der Sommer erfreut uns durch seine 'Fulle'. Der Herbst teilt freigebig aus, was der Frühling versprochen hat:

II,700f. Весна студеный ветр и холод умягчает,

Роскошствуя ж в цветах, плоды нам обещает,

Зернистих класы жатв пред наш представив глаз,

Всех Лето веселит обилием тем нас.

Плод Есень раздает прещедроп рукоп,

Кой обеща́н был нам прохладною весною.

Die knappe Charakterisierung der Jahreszeiten -bei einem sonst sehr wortreichen Autor auffallend- stimmen mit denen der Demonstration(S.16) uberein: "Le printemps fait taire les vents glaces, montre les fleurs et promet les fruits. L'ete donne les riches moissons. L'automne répand les fruits promis par le printemps..."

Der Winter wird in den Versen 706-713 geschildert. Tred. vergleicht ihn mit 
der Nacht:

$$
\text { II,706 Подобна ночи есть бесплодная зима, - }
$$

Im Ablauf des Jahres ist der Winter dem Alter und seiner Schwăche vergleichbar: II,707 Погод как старость тех, Так Аряхлость их сама: -

Nur den ersten Vergleich hat Tred. aus der Démonstration(S.16) genommen: "...l'hiver, qui est une espèce de nuit ou l'homme se délasse."

Als weitere Kennzeichen des Winters erwăhnt Tred. die Entlastung von der Arbeit auf dem Felde und die MuBe:

II,708f. Свободен человек в ней от трудов напольных

Покоен по большой есть части и в довольных, -

Im Winter 'verschwendet' der Mensch alles, was er im Herbst geerntet hat und hofft, daß es das Frühjahx wieder reichlich wachsen 1aßt. Tred. fügt hinzu, im Winter sei der Mensch nur darum bemüht, 'sich im Frost zu wármen', was besonders für den harten russischen winter gilt. Die winterliche Lebensweise wird deshalb etwas geringschătzig beschrieben:

$$
\begin{aligned}
& \text { II,710ff. То расточает всё, что в Есень приобрел, } \\
& \text { И только прилежит, чтоб в мраз себя согрел, } \\
& \text { А иждивает всё толь больше и скоряе, } \\
& \text { Что уж, в надежде быть, весна велит щедряе. }
\end{aligned}
$$

Dieser Unterton fehlt in der Démonstration: "...l'hiver... ne concentre tous les trésors de la terre qu'afin que le printemps suivant les déploie avec toutes les grấces de la nouveauté." (S.16)

Welchen Sinn hat die Abwechslung in der Natur? Fénelon sieht ihn darin, daß sie, 'verschieden geschmückt', immer wieder einen schönen Anblick bietet, so daB der Mensch niemals den Geschmack an dem, was er besitzt, verliert: "Ainsi la nature diversement parée donne tour à tour tant de beaux spectacles, qu'elle ne laisse jamais a l'homme le temps de se dégooter de ce qu'il possede." (Démonstr. ,s.16)

Tred. hat diese Stelle erweitert. Auch er betont zunăchst den ásthetischen Reiz des Wechsels:

$$
\text { II,714 Красуясь естество различием времен - }
$$

Der winderbare Wechsel der Jahreszeiten (Аивна премена времен,II,668) verschönert nicht nur die Natur. Er macht auch das menschliche Leben abwechslungsreich. Alles dient dem Zweck, daB wir uns nicht wegen der Einformigkeit des Lichtes oder des Dunkels langweilen: 
II,718f. Сие ж нарочно всё, без скук чтоб были мы От одновидна в жизнь иль света, иль и тьмы; -

Der Wechsel der Jahreszeiten bringt ferner die dem Menschen nötige Abwechslung von Arbeit und MuBe, von warme und kalte mit sich:
II, 715
И то веля в делах, то бить нем без бремен, -
II, 720
Хладок чтоб прохлаждал, тепло 6 нас согревало.

Die Verănderung ist dazu bestimmt, uns wohlzutun, der tberfluß hat den Zweck, uns zu erfreuen, und die Ruhe soll uns Lust zu neuen Muhen machen:

II,721ff. Различие везде 6 приятность подавало,

Чтоб веселила нас обильность по чредам

И самий чтоб покой всех возбумдал $к$ трудам.

Im năchsten Abschnitt II,724-763 wird dargelegt, daB die Sonne, gleich ob man sie dem alten oder dem neuen Weltbild einordnet, ein Beweis für die Macht und Weisheit des Schopfers ist.

Wie kommt es, daB die Sonne so bestăndig ist, obwohl sie einem Feuermeer gleicht? Der Gegensatz zwischen der 'Bestăndigkeit' der Sonne und ihrer ewig bewegten, flackernden Glut ruft die Frage hervor, wer denn diese Wellen in ihren Grenzen hălt:

II,724 Hо Солнце отчего в себе толь постоянно?

II,726ff. Оно как море есть, как зњбкий и состав.

Кто * тверашй толь ему преднаписал устав,

Что волны то свои вклочило свет в границн? -

Die Stelle ist in der Demonstration vorgegeben(S.16): "Mais comment est-ce que le cours du soleil peat etre si rêgulier? Il paralt que cet astre n'est qu'un globe de flame três subtile, et par consequent très fluide. Qui estce qui tient cette flamme, $s i$ mobile et $s i$ impetueuse, dans les bornes precises d'un globe parfait?"

Beim Nachdenken uber die Sonne meldet sich eine Frage nach der anderen. Wer fürt diese 'Kugel' auf einer so regelmaBigen'kreisbahn und labt nicht $2 u$, daB sie plotzlich vom Wege abweicht?

II,730f. Кто водит шар его в порядочншй толь круг?

И сбиться кто $⿻$ с путей не Аопускает вдруг?

Fenelon hat ahnlich gefragt: "Quelle main conduit cette flame dans un chemin si droit, sans qu'elle s'echappe jamais d'aucun côté"' (Démonstr.,S.16) Die zitierten Verse setzen das ptolemăische Weltbild voraus. In Vers 732 
liegt, wie in den 'Примечания'(S.515) angemerkt wird, eine Anspielung auf das heliozentrische System des Aristarch von Samos (geb. um 310, gest. um $230 \mathrm{v}$. Chr.) vor. Der Autor fragt, ob etwa die Sonne im Weltraum 'an irgend etwas befestigt sei':

$$
\text { II,732 Иль прикреплен к чему зад у сего светила? }
$$

Das ist aber nach seiner Meinung unmöglich, denn 'welche Kraft könnte die Sonne festhalten'? Würde sie nicht jede Befestigung zerreiBen und ganz und gar verzehren?

II,733ff. Но чья ж и прикрепить превозмогла так сила?

Твердыно всяку то могуще есть раздрать

И всяку сокрушить и до конца пожрать, -

Die Frage in Vers 732 ist hypothetisch gemeint und kann, da sie keine năheren Angaben enthălt, wohl auch nicht als Anspielung auf das astronomische system des Aristarch von Samos verstanden werden. Die Stelle stammt aus der Demonstration(S.16f.): "Cette flamme ne tient a rien, et il n'y a aucun corps qui pot ni la guider, ni la tenir assujettie. Elle consumerait bientôt tout corps qui la tiendrait renfermée dans son enceinte."

Die folgende Frage hãngt ebenfalls mit dem ptolemäischen Weltbild zusammen:

II,738f. Кто ж научил ходить пространнейшим путем,

Людей всех освещать и множество греть тем?

Das Verspaar unterscheidet sich durch gröBere Bildhaftigkeit vom Text der Vorlage: "Qui lui a appris a tourner sans cesse et si regulierement dans des espaces ou rien ne la gêne? Ne circule-t-elle pas autour de nous tout exprès pour nous servir?" (Demonstr.,S.17)

Die kopernikanische Position wird in Form eines Konditionalsatzes vorgebracht: Nimmt man dagegen an, 'daß wir uns um die Sonne drehen', so muß wan auch darüber 'grenzenlos staunen':

II,740f. Но буде, напроти́в, мы вкруг его вертимся, Чему, поемля то, безмерно мы чуаимся, -

Sofort erhebt sich die Frage: durch wen ist denn die Sonne in diesen Mittelpunkt gestellt worden?

$$
\text { II,742 То кем в средине той поставлено оно? }
$$

Ein Flammenmeer wie die Sonne lasse sich nicht irgendworan festmachen, hat der Autor in den Versen 734ff. erklărt. Das wird nochmals bekraftigt:

II,743f. И равно так к чему ж собой прикреплено?

И как? есть жидко всё и пламенно с природы. 
Diese Uberlegungen gehen auf die Demonstration(S.17) zurück: "Que si cette flame ne tourne pas, et si au contraire c'est nous qui tournons autour d'elle, je demande d'ou vient qu'elle est si bien placée dans le centre de l'univers...? Je demande d'ou vient que ce globe, d'une matiere si subtile, ne s'echappe jamais d'aucun côté dans ces espaces immenses qui l'environnent?"

Aus der These, daB sich die Erde um die Sonne dreht, ergeben sich weitere Probleme. Wie kommt es, fragt Tred. in Anlehnung an die Demonstration, daB ein fester Korper wie die Erdkugel sich in einem so großen Raum um die Sonne bewegt, ohne jemals auf ein Hindernis zu stoßen?

II,745ff. Вот сам и круг земный, не жидок, как то воды,

Aa гру6 собой и твера, вертится отчего

В пространстве таковом светила вкуг того,

А твердый никакой состав ему препоны

Не сделал никогда ни встречу, ни в нагоны?

Fénelon stellt die Frage: "Enfin je demande d'ou vient que le globe de la terre, qui est si dur, tourne si regulierement autour de cet astre, dans les espaces ou nul corps solide ne le tient assujetti, pour régler son cours?"(S.17)

Unsere Autoren kommen zu dem Ergebnis: alle Argumente der Physik reichen nicht aus, um die Bewegung der Sonne un die Erde bzw. der Erde um die Sonne zu erklăren. Dex Schlüssel zum Verständnis ist in jedem Falle die Existenz Gottes. Fenelon formuliert die physikotheologische Uberzeugung, auf die die rhetorischen Fragen des Abschnitts hinweisen: "Qu'on cherche tant qu'on voudra, dans la physique, les raisons les plus ingénieuses pour expliquer ce fait: toutes ces raisons, suppose même qu'elles soient vraies, se tourneront en preuves de la Divinite." (Demonstr.,s.17)

Tred. hat diese Aussage noch erweitert. Er braucht sich weder für das alte noch für das neue Weltbild zu entscheiden. Ex labt es dahin gestellt sein, ob die Bewegung der Welt durch einen 'Mechanismus' oder durch 'plastische Natur', durch 'Anziehung' oder durch eine Art 'Schubkraft' bewirkt wird. Alle Theorien setzen eine hochste Kraft und Intelligenz voraus:

II,750ff. Пусть будет механисм, пусть пла́стический Аух,

Кой постоянно толь наш обращает круг;

Пусть что влечет спереди, пусть с тыла подвигает,-

Верьховну силу всё и ум предполагает.

Hier werden verschiedene zeitgenössische Theorien angedeutet -Descartes' Mechanismus- und Newtons Gravitationstheorie- denen wir nicht nachgehen konnen. 
Den Begriff 'пластический Аух' verdankt Tred. wohl dem 'Essay on Man'. In Ep.III, 7-12 heiBt es:

\author{
"Look round our World; behold the chain of Love \\ Combining all below and all above. \\ See plastic Nature working to this end, \\ The single atoms each to other tend, \\ Attract, attracted to, the next in place \\ Form'd and impell'd its neighbour to embrace."
}

Diese Verse scheinen in Feoptija II,750ff. anzuklingen. $\mathrm{Zu}$ 'plastic Nature' führt Maynard Mack in den Anmerkungen zum 'Essay on Man'(S.93) aus: "The informing and forming power of God, as manifested in the creativity of na- . ture: cf. the natura naturans of the Schools. The term was variously used in the 17th century, but usually to emphasize...the breath of the Divine in every part of the nature." 25

In II,754-60 legt Tred. dar, daB die Kraft, die die Welt bewegt, aus der Allmacht des Schōpfers stamint. Der Gedanke ist aus der Demonstration ubernommen und von Tred. amplifiziert worden. Die in den angedeuteten Theorien mit verschiedenen Namen bezeichnete Kraft beschreibt Tred. folgendermaBen: Sie bewegt die Welt ("...сила та, весь движущая свет,"754. Sie ist unverănderlich ("в которой ни следов к непостоянству нет," 755). Sie ist der Welt und allen Lebewesen von Nutzen ("полезна миру есть, живущим всем выгодна," 756). Sie ist ubberall dieselbe, aber im einzelnen vielfältig fruchtbar ("noвcijay грунте та ж, но в розни многоплодна," 757). Weil diese 'Kraft' so viel für den Menschen schafft, folgt, daß sie als Werk des Schöpers und als Allmacht, die die Welt regiert, verstanden werden soll:

\title{
II,758ff. Tо больше человек есть должен познавать \\ Создание твориа, его разумевать \\ И предержавну власть в правлении всем света.
}

Fénelon denkt hier ausschlieblich an die Mechanismustheorie und argumentiert: "Plus le ressort qui conduit la machine de l'univers est juste, simple, constant, assuré, et fécond en effets utiles, plus il faut qu'une main trèspuissante et très-industrieuse ait su choisix ce ressort, le plus parfait de tous." (Demonstr.,s.17)

Tred. beendet diesen Abschnitt mit einem Ausdruck menschlicher Selbstbescheidung: was wir nicht verstehen kơnnen, wollen wir dem weisen RatschluB Gottes uberlassen. Er hat whlweislich bestimmt, was wir wissen, und was wir nicht 
wissen sollten:

II.762f. Ero премуарым то да отдаем судьбам:

бог зная восхотел, что знать, не знать ль нам.

Es folgt in II,764-820 die Betrachtung des Sternenhimmels. Sie beginnt im Gesprăchston: "Verweilen wir noch ein wenig, das blaue Gew $1-$ be anzuschauen, an dem die sterne funkeln":

II,764f. Eще помедлим зреть на голубыи своды,

На комх блешут звезд бесиисленные роды.

Die Abhăngigkeit von der Vorlage ist deutlich: "Mais regardons encore une fois ces voltes immenses, ou brillent les astres, et qui couvrent nos tetes." (S.17) - Dann wird die Frage exörtert, ob das Himmelsgewolbe aus einer festen oder aus einer flüssigen Substanz bestehe. Bildet das Himmelsgewolbe eine feste Kuppel, so muB man an den 'Baumeister' denken. Fénelon benutzt diese Metapher: "Si ce sont des voltes solides, qui en est l'architecte?"(S.17) Tred. gibt den Satz so wieder:

II.766f. Kогаа суть твераы все огибы те собой,

ТО ОнЫ СОтворил кто плотными суАьбой?

Die Kette der folgenden Fragen bringt das ehrfüchtige Staunen des Betrachters der Himmelskuppel zum Ausdruck:

II,768ff. Кто легионам звезд места дал пригвожденны?

А ниже вкруг послал планеты учрежденны?

Измерил точно всё, как оным расстоять?

от злата тем велел, сим от сребра сиять? -

Wer anders als der Schópfer, will Tred. sagen, hat den 'Leglonen' von Sternen (diesen Ausdruck für eine sehx große zahl hat Tred. hinzugefugt) ihren festen Platz zugewiesen, sie 'angenagelt' (пригвожденны)? Unterhalb der Fixsternsphare sind die planeten in vorbestimter ordnung vom Schopfer 'ausgesandt' worden. Dieser Vers hat in der Demonstration keine Parallele. Dasselbe gilt für Vers 771: (der Schopfer) "hat jenen befohlen golden und diesen silbern zu scheinen". Die Stelle hat in der Demonstration diesen Wortlaut: "Qui est-ce qui a attache tant de grands corps luminieux à certains endroits de ces voltes, de distance en distance?" (S.17)

Nur der Schopfer vermochte diese Sphăren in Bewegung zu setzen, so daB sie sich wie ein riesiges Gewolbe um uns herum drehen. Das bringen die folgenden Fragen zum Ausdruck: 
II,772f. Кто чашам оным двиг разложистым собщает?

И свод огромный весь кругом нас обращает?

In der Démonstration(S.17) lautet die zugrunde liegende Frage: "Qui est-ce qui fait tourner si réguliexement ces voltes autour de nous?" Gegen die Annahme, der Himmel sei von flüssiger, luftformiger Beschaffenheit werden in den Versen 774-89 verschiedene Gxünde vorgebracht. Wäre der Himmel von flüssiger Substanz, so fănden feste körper an ihm keinen Halt, sondern müBten herunterfallen:

\section{II,774ff. Hо буде не6о есть состав из жидких тел, \\ Какой в родстве себе наш воздух возымел, \\ То твердые тела на чем там пре6ывают? \\ Как в тягости своей ко ану не утопаNт?}

In einer flüssigen Substanz würden die Korper schwimmen. Die Strömung triebe sie aufeinander zu. Von einer solchen Verănderung ist aber nichts zu bemerken. Mit Bewunderung konstatiert der Autor die GleichmāBigkeit, mit der die Gestirne ihre Bahn ziehen und kleidet das in die rhetorische Frage:

II,778f. И меж собоо как не токмо не сплылись, Но ни от стезь своих намало подались?

Zur Hypothese einer flussigen Beschaffenheit des Himels nimmt Fénelon so Stellung: "Si au contraire les cieux ne sont que des espaces immenses remplis de corps fluides, comme l'air qui nous environne, d'ou vient que tant de corps solides y flottent sans s'enfoncer jamais, et sans se rapprocher jamais les uns des autres?" (Demonstr., s.17)

Zum Beweis werden die Beobachtungen der Astronomen herangezogen. Diese haben nicht die geringste Unordnung in den Bewegungen der Gestirne festgestellt. Im Gegenteil, fügt Tred. hinzu, die RegelmäBigkeit hat stets die Bewunderung des Beobachters erregt:

II,782ff. От набподений всех, от первых их начал, блоститель никакой отнюяь не примечал, Чтоб беспорядок в чем малейшем там явился, Но, напроти́, всегда исправности дивился; Die Berufung auf die empirische Wissenschaft, eine moderne Argumentationsform, macht deutlich, wie unsere Autoren bestrebt sind, diese ihrem physikotheologischen Weltverstandnis zu integrieren. Die Demonstration hat hierzu Tred. den Weg gewiesen: "Depuis tant de siecles que nous avons des observations astronomiques, on est encore a découvrir le moindre dérangement dans 
les cieux." (S.17)

Schlieblich sagt uns 'der gesunde Menschenverstand', daB eine flüssige Substanz unmöglich feste Körper auf gleichbleibenden Bahnen füren kann, ohne daB sie auf ein Bindernis stoBen:

II,786ff. А смнсл нам говорит, что невозможно есть, Чтоб жиякость возмогла в себе чиновно весть

Тверанн, ту 2 в округ одним путем плывуцу И беспрерывно так и без препон идущу.

Die Wendung 'смысл нам говорит' ist in der Demonstration nicht vorgegeben. Sie besagt, daß der 'Verstand' von sich aus, ohne Bilfe von außen, urteilsfăhig ist.

Auch Fénelon wendet sich, ohne diesen Begriff zu nennen, an den 'gesunden Menschenverstand', wenn er die Frage stellt: "Un corps fluide donne-t-il un arrangement si constant et $s i$ regulier aux corps solides qui nagent circulairement dans son enceinte?" (Demonstr.,s.17f.)

Welchem Zweck dient die 'unzăhlbare Menge' der Sterne? Davon handelt der Abschnitt II,790-821. Die Frage nach dem Zweck ist für die Physikotheologen charakteristisch. Sie beschranken sich nicht auf die Feststellung und Beschreibung der Exscheinungen, sondern suchen den Sinn zu finden, den der Schöpfer in sie hineingelegt hat. Die Suche nach dem sinn ist für sie die Spur, die auf den schopfer hinführt.

Angesichts der Pracht des Sternenhimmels fragt Tred.: Wozu die unzahlbare Menge, 'dieses Strahlen von Diamanten, dieser Schmuck von Bernsteinen', 'das ganze Heer', das der Schopfer mit offener Hand uber den Himmel verstreut hat?

II,790ff. Да и к чему огней бесчисленный собор, Тот адамантов блеск, тот йлектров убор, Тот весь полк, кой творец толь щедрою рукою

Рассыпал по лицу небес, смотримых мноо?

In seinem Gedicht 'Die Bewegung der Sternen' hat B.H.Brockes den Glanz des Sternenhimmels mit einem Diamantring an der Band des Schöpers verglichen:

Indew ein Diamant aus viel polierten Spitzen

viel Lichter läbt auf einmahl blitzen,

Als wår' der gantze Raum voll Glantz, ein Diamant

An unsers Schöpfers Allmachts-Hand. 26 
Kostbarkeits- und Edelsteinmetaphern, in der Dichtung des Barock oft im Ubermaß verwendet, werden von den Poetikern des 18.Jahrhunderts "als eine Art Quintessenz des 'schwilstigen'...stils betrachtet" und aus diesem Grunde abgelehnt. 27 Solche $\mathrm{Kritik}$ erscheint jedoch nur gegenüber dem mechanischen und maBlosen Gebrauch dieser Metaphern gerechtfertigt, dort, wo "der Ornatus... mit seinem kostbaren Gewande... den zu vermittelnden Inhalt" verbirgt. ${ }^{28}$ In der zitierten Stelle der Feoptjja sind die Metaphern dem Inhalt durchaus angemessen, wăhrend der Vergleich des Sternenhimmels mit dem Diamanten am Fingerring des schơpfers etwas kūnstlich wirkt.

Tred. hat sich nach dem Text Fénelons gerichtet, der angesichts des sternenhimmels den Schöpfer mit einem Füsten vergleicht, der mit vollen Hănden Silbermunzen austeilt, und dessen Gewand mit Juwelen besetzt ist: "Mais que signifique cette multitude presque innombrable d'étoiles?...la main de Dieu les a répandues sur son ouvrage... Il en a semé les cieux, come un prince magnifique répand l'argent à pleines mains, ou comme il met des pierreries sur un habit." (Demonstr.,S.18)

Die năchste Passage befaßt sich mit der maBgeblich von G.Bruno vertretenen Theorie, nach der im unendlichen Raum jeder Fixstern als Sonne und Zentrum eines Weltsystems zu gelten hat. Die Diskussion uber diese Vorstellung war gegen Ende des 17.Jahrhunderts durch das populäre Buch von Fontenelle, 'Entretiens sur la pluralité des mondes'(1686) neu entfacht worden. Ohne den Namen zu nennen, skizziert Tred. die These von G.Bruno:

\section{II,794ff. Мнят камду! из звезд, лучей их по оrнw, Подобну солнцу быть и солнечному ані, А каждую притом подобному ж светящу Tу миру там сему и такме свой плодящу.} Wăhrend viele Zeitgenossen bei dieser Vorstellung in geistige Bedrăngnis gerieten und sie als unvereinbar mit dem biblischen Weltbild und dem christlichen Gottesglauben ansahen, begegneten die Physikotheologen dem neuen Weltbild positiv. Sie folgerten daraus, daß die Herrlichkeit des Schópfers groBer sei, als man sie sich bisher vorstellen konnte. In tiefer Ehrfurcht schauten sie auf "zu Gott,... dem Urheber aller dieser großen Welten." 29 Fénelon, der Erzbischof von Cambrai, und Tred., unter den Augen der geistlichen Zensurbehorde, muBten ihre Meinung über das neue Weltbild verschleiern. Sie konnten höchstens sagen: Nehmen wir einmal an, es sei wahr, was die Anhănger dieser Theorie behaupten: 
II,798f. То правдой положив, не удивится ль ум?

И не смятется ль он от собственнах внутрь аум, -

Der Verstand steht vor Bewunderung still, fahrt Tred. fort, wenn er die Macht, Weisheit und Gute dessen bedenkt, der 'Erden ohne Zahl' geschaffen und sie mit denselben Wohltaten beschenkt hat wie unsere Erde:

II,799ff. И не смятется ль...
Приемля в помысл свой толь силу превелику,
Премудрость такову и благость в нем толику,
Которий без числа Земель толь сотворил
И равным благом те, сей нашей, одарил?

Das Eingestăndnis der 'Verwirrung' angesichts der Herrlichkeit des Schopfers gibt diesen Versen, die inhaltlich auf die Demonstration(S.18) zurückgehen, die besondere Note. Dort heiBt es: "Que quelqu'un dise, tant qu'il lui plaira, que ce sont autant de mondes semblables a la terre que nous habitons; je le suppose pour un moment. Combien doit etre puissant et sage celui qui fait des mondes aussi innombrables que les grains de sable..." Fénelon vergleicht die groBe Zahl der Sterne mit dem Sand am Meer und den Schopfer, der die Sterne lenkt, mit einem Hirten, der seine Schafe hütet. Beide Vergleiche fehlen in der Feoptija.

Tred. hat an dieser Stelle einen Hymnus eingeschoben. Die Verse II,804-13 bilden eine Kette von enthusiastischen Ausrufen (16mal). Der Autor außert seine Begeisterung über die große zahl von 'Sonnen, Erden und Geschopfen':

II,804f. Колико зримых Солнц! Земель колико нижных!

Колико тварей всех! родов коль непостижных!

Mit 'Geschopfen' und 'unerreichbaren Arten' sind in diesem Zusammenhang wohl Sterne jeder Art, GroBe und Helligkeit gemeint. Hinzu kommt die groBe Zahl von 'Kombinationen':

\section{II,806 Сиетаний коль взаем! колик исправный чин!}

Der Autor meint damit wohl die sternbilder, die in ihrer Mannigfaltigkeit und Ordnung sein Entzücken hervorrufen. Im Rausch der großen Zahlen vergiBt er nicht, daß allem ein einheitlicher Plan zugrunde liegt:

\section{II,808 Всему един чертеж! но коль по еияу разно!}

Hier zeigt sich wieder, daß Tred. die găngigen Begriffe seiner Zeit kennt. Wie Chr.Siegrist anmerkt, aktualisiert das Bild "die Lieblingsvorstellung der Zeit, daß zunăchst ein Plan ausgedacht, der anschließend in der Schopfing verwirklicht worden sei." ${ }^{30}$ Er zitiert aus einem Lehrgedicht C.M.Wielands, in 
dem über Newton gesagt wird, er habe "der Schopfung Bau im ersten Plan gesehn. " 31

Tred. preist die Vorsehung, die in allen Dingen unablassig am Werk ist:

$$
\text { II,809 } 0 ! \text { промысл, всё } * \text { со всем не втуне и не праздно! }
$$

Ex ist überwaltigt von dem 'UberfluB' und der 'Pracht', des Firmaments:

$$
\text { II,812 Разлитие то всё! прекрасне убранство! }
$$

Er gesteht, daß er mit dem Verstande den Weltraum nicht begreifen kann. 'Das Licht des Verstandes erlischt' beim Anblick dessen, was am Himmel an einem einzigen Tage geschieht:

$$
\begin{aligned}
& \text { II,810f. A пОА ОАНО⿴囗 всё тО хлубио на вэгляа! } \\
& \text { 0бъемлется ОАним тОт О́бндом весь ряд! } \\
& \text { II,813 Темнеет свет ума: нет сил обнять пространство! }
\end{aligned}
$$

Der hymnische Uberschwang hơrt plotzlich auf. Im Stil der Erwăgung făhrt Tred., den Gedanken der Demonstration aufgreifend, fort:Wenn die Sterne nur dazu da sind, auf die Erde zu scheinen, nicht aber, wie G.Bruno meinte, die Sonnen anderer Welten darstellen, so verkündigen sie dennoch die Macht des Schópfers.Die Astronomen mögen sich darüber streiten, ob die Sterne nux himmlische Lichter für die Exde, oder ob sie Sonnen anderer Welten sind. Für unsere Autoren offenbart sich an den Sternen in jedem Falle die Macht und Herrlichkeit des Schópfers. Darum fordern sie den Menschen zur Doxologie auf:

II,814ff. Но буде звезды все имеют только свет,

$$
\begin{aligned}
& \text { А множества Земель, подобншх нашей, нет; } \\
& \text { и если токмо круг земншй сей освещают, } \\
& \text { И силу и совет творца провозвещаот, }
\end{aligned}
$$

То яолжен всяк и в том его власть признавать

И славу здесь ему приличну воздавать,

Зря в малом уголке толь зрелище прекрасно,

А всё учреждено не просто, не напрасно.

Fénelon hat âhnlich argumentiert: "Si au contraire ce sont seulement des flambeaux allumés pour luire a nos yeux dans ce petit globe qu'on nome la terre, quelle puissance...! Quelle profusion, pour donner a l'home, dans ce petit coin de l'univers, un spectacle si etonnant!" (Démonstr.,S.18)

In der Feoptija schließt sich eine Doxologie an:II,822-827.

$$
\text { II,822 Кто велий толь иншй, коль велий есть наш бог! }
$$

Der Vers hat biblische Anklange. In Psalm 112,5(LXX) heibt es: 


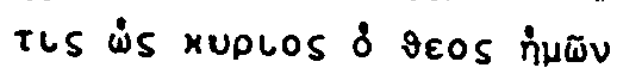

$\delta$ Ev S\&niols xatolxüv -;

Im sog. 'Lobgesang des Mose' (die Septuaginta bezeichnet ihn als 'Ode':

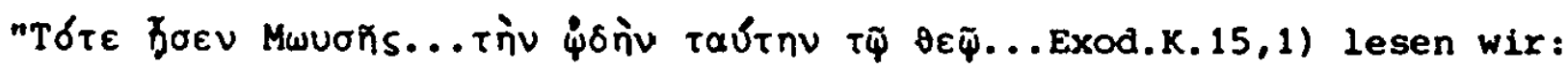

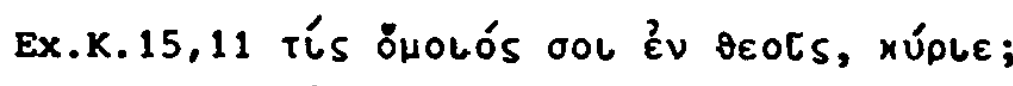

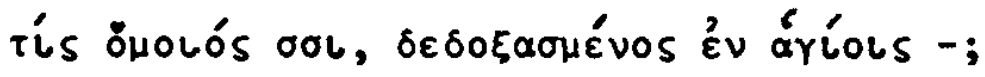

Tred. fahrt mit preisenden Worten fort: Gott, du tust Wunder aus dem einen Grunde, uns zum Lobpreis zu bewegen:

$$
\text { II,823 0! боме, чудеса творишь еАин в преялог: - }
$$

Auch dieser Vers erinnert an ein Psalmwort (Ps.76,15):

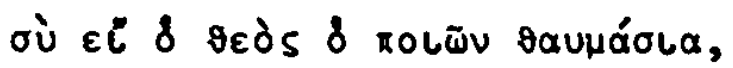

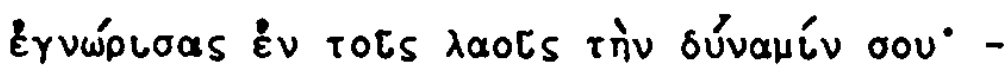

Dem Lobpreis Gottes korrespondiert das Elngestăndnis des menschlichen Unvermögens, die wunderbaren Werke des Herrn recht $2 u$ verstehen und sie so, wie es ihnen gebührt, zu verkündigen:

$$
\begin{aligned}
& \text { II,824ff. Нет слова, нет речей в язи́ке земнородных, } \\
& \text { Ни мыслей нет у нас пристойно благородных } \\
& \text { К понятию всему пречудных дел твоих, } \\
& \text { Дабы изобразить довольно силу их! }
\end{aligned}
$$

Die Verse sind in liturgische Sprache gefaBt. Psalm 105,2 scheint anzuklingen:

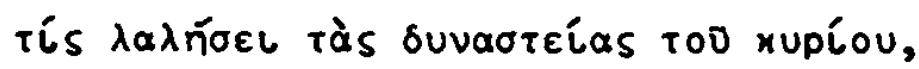
\&xovotàs rouńoel ráoas tàs alvéoels aúrõ;

Den feierlichen Gebetsversen $1 \mathrm{aBt}$ Tred. unvermittelt eine unpathetische Betrachtung uber den Mond folgen:II,828-847.

Zunăchst wird nüchtern festgestellt, daß der Mond von allen Himmelskorrpern der Erde am năchsten ist.Er 'geht hinter der Erde her', empfăngt sein Licht von der Sonne, um es uns in der Nacht zu schenken:

$$
\begin{aligned}
& \text { II,828ff. Небесных мы светил в числе Луну зрим 6лиже, } \\
& \text { Ходяиу за Землей, стояшу прочих ниже. } \\
& \text { Как силоо сия отъемлет свет Луна } \\
& \text { У Солнца, чтоб тот в нощь нам подала она. }
\end{aligned}
$$

Die Verfasser der "Выписки О сумнительствах в 'Феоптии' находящихся" haben diese Verse beanstandet, weil sie nach ihrer Auffassung 'der Heiligen Schrift widersprăchen' ("... священному писанио противно"). 32 DLe Korrektoren sahen in dieser Stelle ein Bekenntnis zum kopernikanischen Weltbild. Wenn der Mond 
'hinter der Erde hergeht', misse diese sich ja ebenfalls bewegen, folgerten die 'cправщики'. Tred. ging es aber nicht um die stellungnahme für ein bestimmtes astronomisches System. Er will sagen, daB es die Aufgabe des Mondes ist, des Nachts zu scheinen, damit die Erde auch dann nicht ganz ohne Licht ist. Die Passage hat ihren Skopus in dem Finalsatz "4то6 тот в ноць нам подала она" (831). Das wird im folgenden unterstrichen: Der Mond geht auf, "wenn die Nacht mit ihren Schatten den Erdkreis bedeckt", damit es auch in den Năchten niemals ganz finster wird:

\section{II,834f. В конечном мраке так не быть чтоб в ночам,}

Луна приятнй свет в нощь нашим шлет очам.

Der Mond bekommt sein Licht von der Sonne, steht also, wie Tred. anmerkt, mit inr 'auf freundschaftlichem FuBe' :

\section{II,836 От Солнца емлет тот, с ним Аружески собщаясь, -}

Von dieser Anmerkung abgesehen, stimmen die Ausführungen uber den Mond in der Feoptija im wesentlichen mit denen der Dewonstration (S.18) uberein: "Mais parmi ces astres $j$ 'apperçois la lune, qui semble partager avec le soleil le soin de nous éclairer. Elle se montre a point nommé, avec toutes les etoiles, quand le soleil est obligé d'aller ramener le jour dans l'autre hémisphère. Ainsi la nuit même, malgré ses ténèbres, a une lumière, sombre a la vêrité, mais douce et utile. Cette lumière est empruntée du soleil, quoique absent."

Den von Fénelon übernommenen Text hat Tred. durch die Beschreibung der Mondphasen in II, 837-43 ergănzt.

Zunăchst wird ausgeführt, daß die Mondphasen von der Konstellation der Sonne und des Mondes zueinander abhăngig sind. Tred. beschreibt den astronomischen Zusammenhang recht ansprechend. In der ersten Phase 'lernt' der Mond gewissermaßen erst das Scheinen. Er 'hellt sich nux ein wenig auf' und geht 'halbbedeckt davon'. In der Ferne, gegenuber der Sonne, zeigt er dann das ganze Gesicht: es ist vollmond:

\section{II,837ff. И, как учась светить, помалу просвещаясь, Идет полскрыта прочь, вдали ж проти́в него Уж кажет всё лице округа своего.} Wiederum 'schleicht' er sich nahe an die Sonne heran, bis wir ihn nicht mehr sehen:

II,840f. Hо и опять $к$ нему ж подкрадываясь близко И престая́ ходить над нами в понте низко, -

Für den zunehmenden bzw. den abnehmenden Mond gebraucht der Autor das Bild 
von Sichel und Horn. So hat es den Anschein, als sel der Kreis nur noch ein 'Bogen' :

\section{II,842f. Показывает серп и на обрат рога:}

Так и́s kpyra eщé no виay есть Ayra.

Auf diese reizvolle Digression folgt der physikotheologische AbschluB: In allem sehen wir die weise ordnung der Welt, in der sich der Ratschlub des Schopfers offenbart:

II,844f. Bо всем премудрий чин сего мы вияим света, Являжиий творца великого совета!

Wie sehx die naturliche Ordnung der Dinge auf den Menschen bezogen 1st, wird durch die Aussage beleuchtet, daB sich der Mond sein Licht borgen muB, und wir dadurch immer in seiner Schuld stehen:

II,846f. Луна, как и Земля, толста есть и тверда,

Свет взявши в долг сама, далюит нас тем всегда.

Die Verse der Feoptija sind hier pointierter als der zugrunde liegende Text der Démonstration: "Ainsi tout est ménage dans 1 'univers avec un si bel art, qu'un globe volsin de la terre, et aussi ténébreux qu'elle par lui-même, sert néanmoins d lui renvoyer par réflexion les rayons qu'il reçoit du soleil; et que le soleil eclaire par la lune les peuples qui ne peuvent le voir, pendant qu'il doit en eclarer d'autres." (S.18)

In II,848-869 setzt sich Tred. mit der These auseinander, die Planeten bewegten sich ohne Einwirkung Gottes nach dem Naturgesetz.

Die Physikotheologen haben immer wieder behauptet, daB an der Regelmabigkeit, mit der sich die Himmelskorper bewegen, die Macht und Weisheit des Schopfers offenbar werde. Sie setzten voraus, daB Gott sich der allgemeinen Naturgesetze bediene, um die Ordnung im Kosmos zu erhalten. Im Unterschied zur traditjonellen Concursuslehre haben sie Gott nicht als die unmittelbare Ursache alles Geschehens angesehen. Die Naturgesetze sind nach lhrex Meinung die von Gott gesetzten 'Zweitursachen', die das Geschehen notwendig bestimmen. An diesem Punkt haben die Gegner des theistischen Weltverstăndnisses den Hebel angesetzt: Ist das 'unerschüterliche Naturgesetz' die Ursache aller Bewegungen der Gestirne, so werden diese eben nicht von der Hand Gottes gelenkt. Die 'Widersacher', sagt Tred., pochen stăndig auf das Naturgesetz und meinen in ihrer Hybris, Gottes Vorsehung dadurch 'niederwerfen' zu können:

II,848ff. Авижение планет есть чин необходимый, Устав претвердый то и непоколебимый, - 
II,850f. Противники сие на всякий час твердят,

Божественный чрез то сбить промысл Гордо мнят.

In der Démonstration wird dieser Standpunkt kurz und sachlich bezeichnet:

"Le mouvement des astres, dira-t-on, est réglé par des lois immuables." (S.18) Fenelon nimmt die These auf und benutzt sie für seinen $Z$ weck, indem er nach dem Urheber dieser einfachen, beständigen und wirkungsvollen Naturgesetze fragt:"Je suppose le fait; mais c'est ce fait meme qui prouve ce que je veux etablir. Qui est-ce qui a donné a toute la nature des lois tout ensemble si constantes et si salutaires, des lois si simples,...et si fecondes en effets utiles..." (Demonstr.,S.18f.) Ferner fragt Fénelon nach dem Konstrukteur der 'Maschine des Universums', deren reibungslosen Gang er mit der Prăzision eines Uhrwerks vergleicht.

Tred. argumentiert zunăchst anders als Fénelon. Er bestătigt zwar, daß das Naturgesetz bestăndig und fest ist, wendet sich aber gegen die Auffassung, es sei völlig unzerstörbar:

II,852f. Не споря, говоро: устав тот тверд беспречно, Но ненару́шим есть он так не всеконечно.

Er weist auf die komplizierte Weltordnung hin, die 'nicht von allein lăuft': II,854f. Избранный чин вещей и купный оных слог Не может, данных сверьх, иметь себе дорог -

Diese Auffassung ist der von Malebranche ăhnlich. In der Philosophie Malebranches entsteht, so führt R.Specht aus, "durch die Verbindung der göttlichen providenz mit den allgemeinen Gesetzen und den occasionellen Ursachen... die Auffassung von der Verkettung der Ereignisse...alle wirkungen sind so miteinander verbunden, daß die geringste Bewegung der Materie unzăhlige Ereignisse mitbestimmt, da jedes von unzăhligen subordinierten Ursachen abhăngig ist." 33 Vor diesem Hintergrund ist die Bemerkung Tred.s $z u$ verstehen, daß die Naturgesetze nicht 'völlig' stabil seien. (853)

Der These der Gegner,

II,848 Движение планет есть чин необходимый -

setzt Tred. entgegen;

$$
\text { II,856 Движение планет есть посему подвластно -. }
$$

Nach diesem Alleingang schliebt sich der Autor wieder seiner Vorlage an. Die charakteristischen Fragen nach dem Urheber sind der Demonstration nachgebildet : 
II,860f. Я напротив спрошу: кто ж ОН, толико сильный, Который естеству закон дал толь обильный?

Weitere rhetorische Fragen gehen in dieselbe Richtung:

II,862f. Толь постоянный тот? и нужный толь закон?

Да сказывают мне, премудрый кто есть он?

Tred. vermeidet an diese Stelle das von Fenelon gebrauchte Bild der 'Weltmaschine'. Ex stellt staunend fest: das 'Gesetz' axbeitet zu unserem Nutzen, ohne daB wir daran denken:

II,864f. Устав, которым всё чиновно толь вертится,

Без наших мислей сам на пользу нам трудится!

Dahinter steht die Frage Fenelons: "D'ou nous vient la conduite de cette machine universelle, qui travaille sans cesse pour nous, sans que nous y pensions?" (Demonstr.,s.19)

Das wird an einem Gegenbeispiel demonstriert: brăche irgendwo im Weltall auch nur ein Teilchen $a b$, so wirde es die Erde mit einem Schlage in den Abgrund stürzen:

II,866f. Хотя 6 частича где отторглась от шаров, Низвергла 6 Земло всо ударом бездны в ров.

Den Ideologischen Gegnern, die sich allzu sicher auf das Naturgesetz verlassen, gibt Tred. damit zu bedenken: Weltall und Erde sind nicht geschützt vor kosmischen Katastrophen.

Auch Fenelon weist darauf hin: "Le moindre atome de cette machine, qui viendrait a se deranger, demonterait toute la nature." (Demonstr.,s.19)

Im Blick darauf fragt Tred. eindringlich, wem wir die Erhaltung der Welt zuschreiben, und wen wix als den Urheber des Naturgesetzes verehren wollen:

II,868f. Хранение кому жы всех вещей присвоим?

Кого началом всех уставом удостоим?

Den SchluB der II.Epistel bilden hymnische Verse (870-77), in dener. die Weisheit des Schopfers, Erhalters und Regenten der Welt gepriesen wird, die sich am Himmel wie auf Erden offenbart.

wie in der gottesdienstlichen Liturgie werden alle aufgefordert, gemeinsam mit dem Kơnig David den Schópfex zu preisen: 'Die Himmel verkündigen die Ehre Gottes': Die Doxologie nennt zu Anfang nochmals die Hauptthemen der Epistel:

II,870f. Премуар в Земле, в воде, в воздухе, в небесах, В огне, в растуием всем, премудр во всех красах. -

Dann werden die Wüdenamen Gottes zum Gegenstand des Lobpreises gemacht: 


\section{II,872ff. Которшй произвел все естество зижяитель И продолжает бшть тому един правитель, Прекрасное подав позорище вшспрь всем!}

Der von Tred. selbstandig gestaltete Hymnus schliebt mit dem Wort aus einem dem König David zugeschriebenen Psalm $(18,2)$ :

\section{II,875ff. Достойно восклицать в восторге нам затем, По одному с царем, то ж возгласившим, праву: Вещают небеса божественнул славу!}

Tred. hat das Psalmwort passend zum letzten Thema der Epistel ausgewăhlt. Es lautet in der Septuaginta:

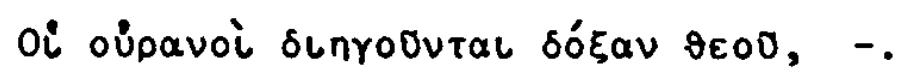

Fénelon zitiert am SchluB seiner Betrachtung des Himmels ein wort aus den alttestamentlichen Apokryphen, Baruch, Kap.3,35:"Je ne crains donc pas de dire, avec l'Ecriture, que chaque étolle se hate d'aller ou le seigneur l'envoie; et que, quand il parle, elles répondent avec tremblement: Nous volci:Adsumus." (Demonstr.,S.19)

III. Epistel: Macht und Weisheit Gottes werden an der Tierwelt aufgezeigt

In dieser Epistel will Tred., wie er in der einleitenden Apostrophe an Evsevij ankündigt, sein Augenmerk auf die verschiedenen Tierarten richten:

$$
\begin{aligned}
& \text { III,7ff. Итак, Евсевий, здесь я делом постарахсь, } \\
& \text { К чему, коль момно мне, толь с силами сбираюсь, } \\
& \text { Различный род живых и вия их примечать, } \\
& \text { А третие письмо к тебе тем и начать. }
\end{aligned}
$$

Gleich zu Anfang weist der Autor darauf hin, daB auch die Tiere (wie vorher die Elemente, der Himmel, die Pflanten und Băume) aus physikotheologischer Sicht -und nicht etwa aus der des zoologen-betrachtet werden sollen. An den Tieren, sagt der Autor, kónnen wir das Werk des Schópfers nicht weniger erkennen als am Sternenhimmel. Darum 'laBt uns die Tiere ansehen':

III,3ff. Посмотрим уж на всё, что с чувством есть животно, Не меньше от сего строение добротно

Создавшего во всем, кой бштствует везде, Возмомем мы узреть, коль и от зарь в звезде.

Fenelon leitet das neue Thema so ein: "Mais tournons nos regards vers les animaux, encore plus dignes d'admiration que les cieux et les astres."(S.19) 
Unsere Autoren haben nicht vor, ein zoologisches Lehrbuch zu schreiben. Die zoologischen Details werden von innen physikotheologisch interpretiert. Sie heben Einzelheiten dex Anatomie und des Verhaltens dex Tiere hervor, andenen nach inrer Auffassung die Weisheit und Kunst des schopfers sichtbar wird. Ferner berichten sie Legenden und Kuriositaten aus der Welt der Tfere, die sich, so meinen sie, nux teleologisch deuten lassen. Vor allem beschaftigt sie die Frage, ob die Tiere eine Seele haben. Băufig bringen sie damals lăngst bekannte zoologische Kenntnisse vor, denen sie aber eine tiefere Bedeutung beilegen. DaB die verschiedenartigen Tiere genau für die Uwwelt ausgerüstet sind, in der sie leben, verstehen unsere Autoren als Beweis für das Wirken des Schopfers.

In III,11-104 werden die in der freien Natur lebenden Tiere betrachtet.

Nach inrer Fortbewegung unterscheidet Tred. Lauftiere (zweibeinige: 'AByножны',11; Vierfußer: 'Aругие...четыре у се6я имеют ноги',13 und Vielfüer: 'в иных и больше ног',14), ferner kriechende, schwimmende und fliegende Tiere. Manche können sich, fügt er hinzu, auf mehrfache Art fortbewegen:

III,15ff. Te идут, те ползут, те пресмыкаться знают;

Te плавают в водах, те в воздухе летают;

Инuе как летать, так могут и ходить, -

Fénelon zăhlt dieselben Fortbewegungsarten auf: "Les uns marchent, les autres rampent, d'autres volent, d'autres nagent, d'autres volent, marchent et nagent tout ensemble." (Demonstr.,S.19) Die Kombination 'fliegen'. 'laufen' und 'schwimen' hat Tred. zu 'schwimmen' und 'laufen' verkürzt.

In den Versen 21-40 werden die vogel und Fische miteinander verglichen. Die Flügel der Vögel sind den Flossen der Fische vergleichbar: mit jenen wird die Luft, mit diesen das Wasser 'zerteilt':

III,27f. 0 воздух опершись, те оны разделяют,

А си́и то ж с водой чинят, что населают; -

Die Flossen der Fische vergleicht Tred. mit den Rudern eines Bootes:

III,25f. Как весла у ладей, так точно те с боков.

И ХоA у них у всех бшвает в даль таков.

Die Verse gehen auf die franzósische Vorlage zurück: "Les ailes des oiseaux et les nageoires des poissons sont des rames qui fendent la vague de l'air ou de l'eau, et qui conduisent le corps flottant de l'oiseau ou du poisson, dont la structure est semblable a celle d'un navire." (Demonstr.,s.19)

Tred. macht außerdem noch auf die symetrische Anordnung der Flügel bzw. der 
Flossen aufmerksam. So sind sie nicht allein zweckmāBtg, sondern auch schön. Die Verbindung des Schónen mit dem Nützlichen wird als bedeutsam angesehen:

III,21ff. Всем птицам два крила $K$ летению даны;

А перия у рыб с обоея ж страны.

Но что с двух сии стран, то столько есть услумно,

Что им и на красу и на потребность нузно: -

Zwischen den Flügeln der Vögel und den Flossen der Fische gibt es ater auch wichtige Unterschiede: Die Federn sind hohl. Das ist für das Fliegen durchaus kein 'Nachteil'. Im Wasser werden sie dagegen schwer, aber das Wasser ist nicht das Element der vögel. Ganz anders die Fischflossen. Sie werden vom Wasser nicht durchtrånkt, sondern zerteilen es mühelos:

III,31ff. У nтиц перо в крилах не только что есть густо, Но и притом еще во всо длину там пусто,

На воздухе оно надуто без вреда,

Oтягонает же не сродна то вода.

А рыбие перо есть птичьему противно, -

Dem Autor erscheint dieser Unterschied 'höchst wunderbar':

III,36 Как $и$ во всем другом различие предино:

Daß die Federn des Vogels und die Flossen eines Fisches genau für das Element in dem sie leben, passen, versteht er als deutlichen Hinweis auf den Schopfer Tred. hat den Vers 36 eigens eingefügt. In der Demonstration (S.19) lautet die stelle: "Mais les ailes des oiseaux ont des plumes avec un duvet qui s'enfle a l'air, et qui s'appesantirait dans les eaux: au contraire les nageoires des poissons ont des pointes dures et sèches.... qui ne s'appesantissent point quand on les mouille."

Tred. setzt noch eine eigene Metapher hinzu: Die Fische sind 'kleine Schiffer', denen das wasser mehr gehorcht als den vogeln die Luft:

III,39f. И так послушен в плывь малейшим есть плотицам, Как воздух никогда непрекословен птицам.

Die Passage III,41-54 handelt von den Wasser- und Tauchvögeln. Als besonderes Merkmal der Vögel, 'die auch auf dem Wasser leben', (als Beispiel werden in der Démonstration 'les cygnes', die Schwāne,genannt) führt Tred. an, daß ihre Flügel oben am Rücken, 'über der strómung', sitzen, so daB sie niemals ins Wasser eintauchen:

III,41f. Которые из птиц живут и ма водах, у оных кри́ла зрим струй выше при хребтах; - 
Tred. hat an dieser stelle den Text der Demonstration gekurzt. Dort wird z.B. noch angemerkt, daB die schwane ihre Flügel als segel benutzen ("...il leur serve comme de volle." S.20).

Be1 den Wasservögeln, zu deren Art das Tauchen gehört, wird hervorgehoben, dab sie ein wasserdichtes Gefieder besitzen:

\section{III,45ff. Но коим в глубину природно есть нырять, \\ Тех плотности перу дана особа прядь \\ И масляная толь, что сквозь ее пробиться \\ Не может мокрота, ни сверху некак влиться.}

Durch diese Besonderheit hat Tred. die Beschreibung der 'Taucher' ergănzt. Fénelon weist darauf hin, daß diese vögel Schwimmhăute an den FüBen haben, damit sie am Flubufer nicht im Schlamm versinken: "Les oiseaux aquatiques, tels que les canards, ont aux pattes de grandes peaux qui s'etendent...poux les empêcher d'enfoncer dans les bords marécageux des rivières." (S.20)

Auch in der Feoptija wird dieses Merkmal beschrieben. Unsere Autoren wollen darauf aufmerksam machen, daß die Tiere mit allem, was sie für ihre Lebensweise benotigen, ausgestattet sind. Uber die Schwimmhăute bei den Wasservogeln lesen wir:

III,49ff. Есть в лапках у других и кожица еще,

В промежках коя тех простерта не вотще:

На самой держит их мест тонких та средине,

На всяких и грязях, на жиякой такме тине:

Чрез то способно им по тем везде ступать, -

III,55-74 handelt von den Raubtieren und Raubvogeln.

Als hervorstechende Eigenschaft der Raubtiere nennt Tred. ihre Grausamkeit: III,55 Есть много и зверей, в них лотости немилы, -

AuBerdem sind sie schrecklich anzusehen und ungewöhnlich stark:

\section{III,56 Сөирепы рожи их и чрезвычайны силы -}

Fenelon gibt ein weniger abstoBendes Bild von den Lowen: sie sind nicht nux sehr starke, sondern auch geschmeldige Tiere: "...les betes feroces, telles que les lions,... ont les muscles les plus gros aux epaules, aux cuisses et aux jambes: aussi ces animaux sont-ils souples, agiles, nerveux, et prompts à s'elancer." (Démonstr., S.20)

zu den Merkmalen der Raubtiere gehoren ferner ein 'furchterregendes GebiB', der große Rachen und die scharfen Krallen, mit denen sie ihre Beute reiBen und fressen: 
III,57ff. Иx челости весь зев велик и грозен есть.

Иx пазногти остры в орумие и в месть;

Терзарт те аругих зверей бессильных ими,

A пожирают ум зубами их сооими.

Diese Schilderung beruht auf dem Text der Demonstration (S.20): "Les os de leurs machoires sont prodigieux...Ils ont des dents et des griffes, qui leur servent d'armes terribles pour dechirer et pour devorer les autres animaux."

Im folgenden werden die Raubvögel beschrieben. Ihnen stellt Tred. zunăchst die 'herrlichen Sănger' gegenüber und macht damit auf den großen Kontrast aufmerksam: kaum zu glauben, daß Singvögel und Raubvógel zur selben Gattung gehoren:

III,61f. В парящих много есть преславных как певиц,

Так мног же видим сонм и хищных лото птиц; -

Die typischen Kennzeichen der Raubvögel sind der scharfe Schnabel und die scharfen Krallen. Sie sind 'Sicheln' ähnlich, fügt Tred. mit einer eigenen Metapher hinzu:

III,63f. У камдой сих нос остр, остры весьма и когти, Подобныи серпам, на них еще и ногти.

Fénelon führt als Beispiel den Adler an und schreibt: "Par la mesme raison, les oiseaux de proie, comme les aigles, ont un bec et des ongles qui percent tout." (Démonstr.,S.20) Uber die Démonstration hinausgehend, nennt Tred. als typische Merkmale der Raubvögel die harte, kahle stelle uber dem Schnabel und ihr wildes, blutgieriges Aussehen:

III,66f. Тверда у них вельми и вся ножная лысть.

Их также взгляд свиреп, их кровопивна рожа, -

Zu dem Doppeladjektiv "krovopivnyj" bemerkt D.Tschižewskij, daB er zwar keinen Beleg angeben kơnne, daB aber Adjektive und Substantive gleicher Bildung (kr-vopiv's' und krv-pitije bei Sr.I,1338, sowie kr-vopivyi im Codex Supr.) belegt seien. 1

Die Flügel der Raubvögel, făhrt der Autor fort, sind mit einer lederartigen Haut uberzogen. Dadurch kơnnen sie sich zwar schwerer als andere vögel in die Luft erheben, aber auch schneller auf ihre Beute herunterstürzen:

III,68ff. А кры́лам их дана в покршику толста кожа, Что6 их полету 6ыть на воздухе ярчай

И опускаться 6 им на лов свой в Аол шибчай; - 
III,71f. Пояъемлотся они вверьх хоть аругих тямеле,

Но ки́дартся вниз бшстрее тех при деле.

Diese Darstellung unterscheidet sich nur formal vom Text der Demonstration: "Les muscles de leurs ailes sont d'une extreme grandeur, et d'une chair très dure, afin que leurs alles aient un mouvement plus fort...Aussi ces animaux, quoique assez pesants, s'elévent-ils sans peine jusque dans les nues, d'ou ils s'elancent comme la foudre sur toute proie..."(s.20)

Beide Autoren stimmen in der teleologischen Deutung der anatomischen Merkmale der Raubvögel überein.

Das Verspaar 73f. paBt nicht ganz in den Zusammenhang der Raubtiere und Raubvogel. Es geht um Tiere, die ein Horn tragen, mit dem sie sich verteidigen, manchmal aber auch angreifen konnen:

III,73f. Скоты и звери суть, даны которым в часть

Pora аля оборон, случится как напасть.

In der Vorlage heibt es: "D'autres animaux ont des cornes... Chaque espece a ses armes offensives ou defensives." (Demonstr.,S.20)

In III,75-88 ist von Nestern und Hơhlen die Rede.

Die Passage beginnt mit der uberraschend klingenden Feststellung: es gibt Tiere, die das 'Nest', in dem sie geboren wurden, stăndig mit sich herumtragen, als wăren sie dazu 'verurteilt':

III,75f. Суть, кои то гнездо, в котором породились, Носить всё на себе как будто осудились.

Der Vergleich mit der Demonstration zeigt, daß 'rнездо' metaphorisch gemeint 1st: Fenelon hat an die schildkrote gedacht: "L'un porte, come la tortue, sa maison dans laquelle il est né." (S.20)

Nester und Höhlen werden von den vogeln und Tieren an verschiedenen orten angelegt: 'на ropax'(77), 'на вершинах древ', 'в подземных норах' (78), 'в густой траве','в густом листе'(80). Die Tiere 'flechten', 'bauen' oder 'graben' Ihre 'Behausungen': 'вьют, строят, роют гнезда' (79), oder sie verstecken diese im dichten Gras und Laub. In jedem Falle sind sie bemüh, sich vor Angriffen zu schützen und ihre Jungen ungefăhrdet aufzuziehen:

III,81f. Чтоб от нападок те злодейских их спасти

И без вреда 6 и зла там молодых взвести.

DaB der Nest- und Hôhlenbau diesen Zwecken dient, hat Fénelon so dargestellt: "...l'autre batit la sienne $/ \overline{m a} i s o n \bar{J}$, comme $l^{\prime}$ oiseau, sur les plus hautes 
branches des arbres, pour préserver ses petits de l'insulte des animaux qui ne sont pas ailés. Il pose même son nid dans les feuillages les plus épais, pour le cacher a ses enemis." (Démonstr.,S.20)

Als bemerkenswertes Beispiel wird der unter Wasser befindliche Bau des Bibers beschrieben:

III,83f. Бобр в водной глубине творит себе жилище, То осыпьр от волн хранит он логови́ще.

Tred. hat das Beispiel aus der Démonstration (S.20) übernommen: "Un autre, comme le castor, va bâtir jusqu'au fond des eaux d'un étang l'asile qu'il se prépare, et sait élever des digues pour le rendre inaccessible par l'inondation." Den Hinweis auf den unterirdischen Bau des Maulwurfs, den die Démonstration an dieser Stelle hinzufügt, hat Tred. ausgelassen. Er übernimmt aber die Bemerkung, daB manches Tier seine Höhle mit zwei రffnungen baut, so daB es im Notfall entkommen kann:

III,85f. Два устья у иных в гнезде или в норе, Не тем, ин чтоб Аругим уйти от бед в поре.

Fénelon hat an den Fuchsbau gedacht: "Le renard sait creuser un terrier avec deux issues, pour n'être surpris..." (Démonstx.,s.21)

Nicht in der Vorlage enthalten ist die Anmerkung Tred.s uber Tiere, die sich einen Vorrat fūr den Winter anlegen und ihn wie die Menschen in 'Kornkăsten' legen:

$$
\begin{aligned}
& \text { III,87f. Суть многи из живых, что так, как человеки, } \\
& \text { Корм на зиму себе пасут, кладя в сусеки. }
\end{aligned}
$$

Von den Reptilien handelt der Abschnitt III,89-94. Zuerst wird darauf hingewiesen, daB die Reptilien 'anders' sind als alle übrigen Tiere:

III,89f. Отменно сотворен весь ползањщий гад;

Отлично их родство других живых от стад: -

Auch Fénelon betont ihre 'Andersartigkeit': "Les animaux reptiles sont d'une autre fabrique." (Démonstr., S.21)

Vielleicht wirkt darin eine Erinnerung an die biblische Erzahlung von der Schlange nach (Gen.Kap.3,1ff.). Dort wird die Schlange deutlich von allen Tieren auf Erden abgesondert:

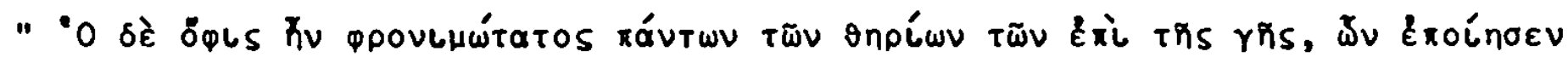
xúplos \& veós..."

Tred. sieht das Andersartige der Reptilien darin, daB sie sich kriechend auf 
der Erde fortbewegen:

III,91f. Сгибаются они, землек пресмыкаясь,

И Каут Так өперед, улиткой разгибаясь.

Die Bewegung des $k r i e c h e n s$ wird in der Vorlage noch genauer beschrieben: "Ils se plient, ils se replient; par les évolutions de leurs muscles, ils gravissent, ils embrassent, ils serrent, ils accrochent les corps qu'ils rencontrent; ils se glissent subtilement partout." (Demonstr.,S.21) Eine Eigentümlichkelt bel den Reptilien wird besonders erwăhnt: ihre abgetrennten Glieder bewegen sich weiter:

III,93f. Составы у иных толь все оживлены, Что Авижутся особ, когда разделены.

Fénelon schreibt: "Leurs organes sont presque independants les uns des autres: aussi vivent-ils encore après qu'on les a coupes." (Demonstr.,S.21)

In III,95-104 geht es um die Proportion von Tierbeinen und -hălsen. DaB Tiere mit langen Beinen auch einen langen Hals haben, wird von unseren Autoren teleologisch gedeutet: solche Tiere brauchen einen langen Hals, um das Futter zu erreichen. Darin sieht Tred. die wunderbare Weisheit des Schöpfers:

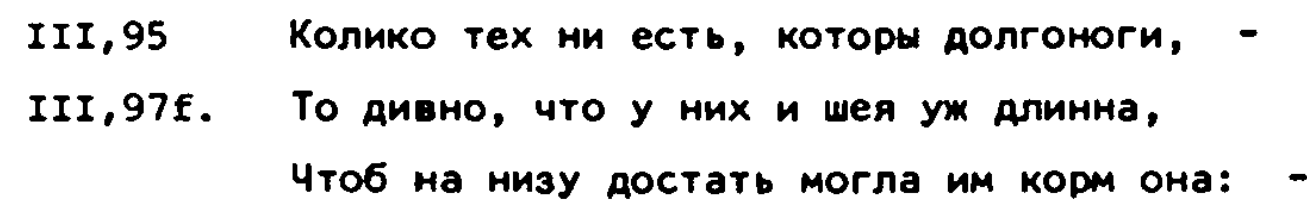
Die Verse sind von Fénelon abhăngig, der an dieser stelle anmerkt, daB die gleiche Beobachtung schon Cicero zum Staunen veranlaBt habe: "Les oiseaux, dit Cicéron, qui ont des jambes longues, ont aussi le cou long a proportion, pour pouvolr abaisser leur bec jusqu'd terre, et y prendre leurs aliments." Fenelon verweist auf Cicero, 'De Nat.Deor.,lib.II, $\mathrm{n}^{\circ} 47$, und fügt hinzu: "Le chameau est de meme." (Démonstr.,s.21) Tred. nennt als Beispiel den Kranich und ebenfalls das Kamel:

$$
\text { III,99 Хуравль есть и вер6пор в пример тому со6010. }
$$

Der Elefant hingegen ist von der Vorsehung anders geschaffen worden. Ware sein Hals so lang wie der des Kamels, so wirde er ihn belasten. Darum ist ihm statt dessen ein Russel 'gegeben' worden, mit dem er wie mit einer Hand alles aufsucht, was für thn gut ist:

III,100ff. ОАнак произееден слон инако судьбоо:

В нем шее так себя когда 6 распространить,

Tо 6 ra morлa собой его обременить; - 
III,103f. Затем то дан ему тот хобот от природы,

Он сыскивает им все, как рукой, выгоды.

Tred. hat sich auch hier an seine Vorlage gehalten: "L'éléphant, dont le cou serait trop pesant par sa grosseur, s'il était aussi long que celui du chameau, a été pourvu d'une trompe...pour saisir les corps...aussi les Latins ont-ils appelé cette trompe une main." (Démonstr.,s.21) Die Metapher 'pyka' fü den Russel des Elefanten stammt aus dem Lateinischen. Das Lexikon bestătigt die Behauptung Fẻnelons: 'manus data elephanto' = Rūssel (Stowasser, $1969,5.308$ ).

Der Abschnitt III,105-268 entfaltet die These: der Schöpfer hat die Tiere zum Nutzen des Menschen geschaffen.

III,105-152 handelt vom materiellen Nutzen der Tiere für den Menschen. Für die Physikotheologen spielt der anthropozentrische Gesichtspunkt bei der Betrachtung der Tierwelt eine wesentliche Rolle. Dies erklārt sich, wie W.Philipp ausführt, durch die Bedeutung, die der 'ideengeschichtliche Rückbezug' auf die Anthropologie des katalanischen Physikotheologen Raimund von Sabunde für die Aufklărung gehabt hat. Dieser hat in seinem Hauptwerk, dem 'liber creaturarum'(1436), eine Stufenleiter der Geschópfe aufgestellt. Sie werden so eingeteilt:

Klasse I: 'Ist' (lebt nicht, empfindet nicht). Dazu gehören die vier Elemente, Steine und Erze, Himmel und alle Himmelskörper.

Klasse II: 'Ist und lebt' (Botanik).

Klasse III:'Ist, lebt und empfindet' (Tiere).

Klasse IV: 'Ist, lebt, empfindet, versteht und hat Freiheit' (Mensch).

Es scheint, daß diese Einteilung auch unsere Autoren beeinflußt hat. Auf der Stufenleiter der Geschöpfe steht der Mensch auf der obersten Sprosse. Sabunde hat, so faBt W.Philipp zusamen, "die Einzigartigkeit des Menschen mit dem Gedanken unterbaut, alles in der Welt sei um des Menschen willen da." 2 In unseren Texten herrscht weitgehend dieselbe Auffassung. Was die Feoptija angeht, wurde schon gezeigt, daB die Naturkrafte: das wasser $(I I, 358)$ und das Feuer (II,558) für den Menschen von Nutzen sind. Jetzt heiBt es von vielen Tieren, sie seien 'gleichsam eigens für uns geschaffen':

III,105 Премножество зверей мы видим и скотов, -

III,107f. Аля нас сотворены те будто как нарочно

И на работы нам как подданы оброчно. 
Tred. vergleicht diese Tiere mit 'zinspflichtigen Untertanen', ein Vergleich, der den sozialen Verhătnissen im RuBland des 18.Jahrhunderts entnommen ist. Von Fénelon wird das neue Thema so eingeleitet: "Certains animaux paraissent faits pour l'home." (Demonstr., S.21)

Unter den Tieren, die dem Menschen am meisten nützen, werden zuerst die Haustiere vorgestellt. Von diesen stehen der Hund und das Pferd in einer nahen Beziehung zum Menschen, die über den bloB materiellen Nutzen hinausgeht. Der Hund dient dem Menschen mit seiner Wachsamkeit und seinew Gehorsam. Er ist der unentbehrliche Helfer des Menschen bel der Jagd: mit Eifer verfolgt und apportiert er das Wild:

\section{III,117f. Различных бы зверей с охотоо ловил \\ И что ни приобрел, то нам же уступил.}

Gepriesen wird die enge Beziehung des Hundes zu seinem Herrn. Es ist, als ob der Hund nur dazu da ist, den Menschen 'zu liebkosen, in Hitze und Frost bei Ihm auszuharren, ihn zu beschützen, seine Befehle auszuführen und ihm Treue und Freundschaft zu erweisen', schreibt Tred.:

III, 109ff. Пес будто Аля того, Чтоб нам всегАа ласкать, Терпел бы зной и хлая, хранить и ночь не спать Приказы 6 исполнять все наши научился, ZusammengefaBt: der Hund ist der treue Diener und Freund des Menschen:

III,115f. Чрез верные свои и чрез усердны службы, К хранениі всегда и верности и Аружбы, -

Fénelon hat das Verhalten des Hundes gegenuber dem Menschen ganz ahnlich geschildert: "Le chien est ne pour le caresser, pour se dresser comme il lui plait....pour garder tout ce qu'on lui confie, pour prendre a la course beaucoup d'autres betes avec ardeur, et pour les laisser ensulte d l'home, sans en rien retenir. Le chien est nêT pour lui donner une image agréable de societe, d'amitie, de fidelite et de tendresse..."(Démonstr.,s.21)

Das Pferd (Tred. nennt außerdem den Maulesel) ist dazu bestimmt, dem Menschen als Arbeitstier zu dienen. Es trăgt bzw. zieht die Lasten, damit der Mensch sich ausruhen kann:

$$
\begin{aligned}
& \text { III,125ff. На то он / КоньТ сотворен, чтоб тягости носил } \\
& \text { Не легкие всегАа, чтоб клади нам возил } \\
& \text { И дал 6н отдыхать толь слабым нашим силам, - }
\end{aligned}
$$

Fenelon hat die Dienstleistungen des Pferdes für den Menschen so beschrieben: "Le cheval et les autres animaux semblables se trouvent sous la main de 
l'home, pour le soulager dans son travail, et pour se charger de mille fardeaux. Ils sont nés pour porter, pour marcher, pour soulager l'home dans sa faiblesse, et pour obeir a tous ses mouvements." (Démonstr.,s.21)

Die Schilderung ist von Tred. durch einige Bemerkungen ergănzt worden, die einen emotionalen Unterton $z u$ haben scheinen. So sagt er, daß die pferde 'unter schweiBbedecktem Joch' für uns arbeiten:

III,119f. Конь, меск и всякий скот, зовущийся работншм, Наш облегчал бы труд, под игом был бы потным, -

Er fügt hinzu, daB das Pferd immer 'den Riemen der Peitsche unterworfen ist', und daß wir es mit unzufriedenem oder ermunterndem zuruf antreiben:

III,128ff. Подверженный всегда бича ременным жилам,

Как лености его наш недоволен глас

Иль тихий и простый взбуждения приказ.

In der Reihe der Haustiere, von denen der Mensch greifbaren Nutzen hat, folgen der Ochse, die Kuh und das Schaf.

Der Ochse ist mit seiner Kraft und Geduld aufs beste geeignet, den Pflug zu ziehen:

III, 131f. Bол в крепости своей труаится терпеливо:

Употреблен от нас он к плугу особливо.

Vgl. Démonstr.,S.21: "Les boeufs ont la force et la patience en partage, pour trainer la charrue..."

Schon für geringes Futter bekommen wir von den Kühen Milch, hebt Tred. hervor:

III,133f. Насытивши в полях иль снопиком где трав,

Мы получаем уж за то млеко́ от крав.

Der Armvoll Gras steht in keinem Verhăltnis zum Wert der Milch, die wir dafür bekommen. Tred. will darauf hinweisen, daß der schöper es so eingerichtet hat. Ihm ist es $z$ danken, daB aus dem Gras des Feldes 'Băche von Milch' fließen, wie es Fénelon ausdrūckt: "Les vaches donnent des ruisseaux de lait." (Démonstr., S.21)

Zum Nutzen des Menschen wăchst den Schafen jedes Jahr soviel Wolle, daß sie sie für sich selber nicht nötig haben. Der Mensch soll sie zu seinem Bedarf scheren, um daraus Kleidung für sich herzustellen:

III,137f. В потребность нашу то должны мы остригать,

А из прядей уже в одежду сукна ткать.

Die Stelle stamt aus der Demonstration: "Les moutons ont, dans leur toison, un superflu qui n'est pas pour eux, et qui se renouvelle pour inviter l'homme 
a les tondre toutes les années." (S.21)

Aus den Fellen der Tiere werden Pelze zum Schutz gegen die kălte genăht. Die Tiere nūtzen also auch nach ihrem Tode noch dem Menschen. So hat es der Schópfer gewollt und bestimmt:

\section{III,141f. Зижаитель повелел и так расположил, \\ Чтоб и по смерти зверь полезно нам служил.}

So hat Tred. es in der Démonstration gelesen: "Ainsi l'auteur de la nature a vetu ces betes selon leur besoin: et leurs dépouilles servent encore ensuite d'habits aux hommes, pour les réchauffer dans ces climats glaces." (S.22) Die anthropozentrische Auffassung vom Nutzen der Tiere wurzelt im Glauben der Physikotheologen an die Fürsorge des Schöpfers für den Menschen. So banal die genannten Beispiele uns vorkommen mogen, sie sollen zeigen, wie gut es der Schópfer mit dem Menschen meint. Darum haben unsere Autoren sie aufmerksam und ehrfürchtig festgehalten.

Der Schöpfer hat jedoch auch für alle anderen Geschöpfe gesorgt und ihnen alles 'gegeben', was sie in ihrer Umwelt brauchen (vgl. die Formel 'AaH', 'Аана', 'Ааны' in III,21; 46; 68 und 103). Er hat z.B. Jene Tiere, die weder ein Fell noch Federn haben, mit einer dicken Haut oder einem Panzer gegen Hitze und Kålte geschützt:

\section{III,143ff. Јез шерсти, как без пер тварь коя, то примета, Вся толстоз вельми та кожею одета, Иль черепом каким снабдена есть она, Во вред ей не была 6 жаров и стуж страна.}

Hier und da scheint Tred. über die enge anthropozentrische Deutung der Natux hinauszugehen. Man denke an vorsichtige Wendungen : "Пес буато аля того, чтоб нам всегда ласкать" (III,109) und "Для нас сотворены те будто как нарочно" (III, 107). Im Kontrast dazu steht aber die anthropozentrische Sentenz: III,147f. Bсё, что живет и Аух что жизненный имеет, На пользу нашу тем создатель мам радеет.

Hierin folgt Tred. seiner französischen Vorlage, nach der auch die Dickhăuter und Panzertiere zum Nutzen des Menschen geschaffen sind: "Les animaux qui n'ont presque point de poil ont un peau très épaisse et très dure comme des ecailles... Ces peaux et ces ecailles servent aux besoins des hommes. Ainsi, dans la nature, non seulement les plantes, mais encore les animaux, sont faits pour notre usage." (Demonstr.,S.22)

Tred. unterstreicht diese These noch durch seine anthropozentrische Erklărung 
dex Fischschwărme, die vom Meer her flußaufwăts ziehen, "damit man sie fast mit bloBer Hand fangen kann":

III,149ff. При мнотих тьмах примет, сия будь в образ нам:

Рцет? Рыбы из морей станицами к рекам

Плывут, чтоб их ловить тотда почти рукор,

Как в пресной там воде стеснятся густотом.

In III, 153-268 wird ausgeführt, daB die Tiere dem Menschen zum Vorbild und zur Lehre gesetzt sind.

Eine Tierart scheint nicht in das anthropozentrische Bild der Natur zu passen: die Raubtiere. Dem halten unsere Autoren jedoch entgegen, daB selbst das wildesete Tier dem Menschen unterworfen ist, wenn es auch manchmal gegen inn 'revoltiert:

III,153f. Зверь литый самый нам поделастен есть всегда, Хотя и восстает как будто иногда; -

Mag es anfangs auch noch so wild gewesen sein, allmăhlich wird es zahm:

$$
\text { III, } 156 \text { И, коль ни аик сперва, потом бывает Аворен. }
$$

Uber das Verhalten der Raubtiere zum Menschen sagt Fénelon: "Les betes farouches même s'apprivoisent, ou du moins craignent l'homme." (Démonstr. ,s.22)

An diesem Punkt verläbt Tred. seine Vorlage, dex ex sich erst in III,179ff. wieder anschliebt.

In III,157-178 wird eine moralische Digression eingeschoben, in der manche Eigenschaften der Tiere dem Menschen zum Vorbild, andere inm als abschreckendes Beispiel vor Augen gestellt werden.

Obwohl wir gut und böse unterscheiden können, führt Tred, aus, hat uns der Schopfer am Beispiel der Tiere verschiedene Eigenschaften und Tugenden vorgezeigt, damit wir innen nacheifern sollen:

III, 159ff. Хивотным свойства дал и склонности различны

И предложил нам всем в них образы приличны

Премногим, жизни сей пристойным, долоностям,

Чтоб нам те исполнять всегда не по страстям; -

Der Schöpfer hat den Tieren aber neben guten auch schlechte Eigenschaften beigelegt, die wir meiden sollen:

III, 163f. Вложил, при добрых, в них и качества худые,

Да убегаем мы от тех, которы злые.

So dient uns das Lamm als Vorbild der Einfachheit (npoctora,165) und des 
friedfertigen Wesens (Thxoctb,166). Der Hund bringt uns Liebe und Treue entgegen (лобовь и искренняя верность,167). Dagegen finden wir beim Löwen 'maBlose Raubgier und Grausamkeit' neben vielen anderen bosen Eigenschaften. Das gleiche gilt vom Wolf, Tiger und anderen Raubtieren:

III, 168ff. Но, напротив, во льве хищения безмерность И потость и еще зол множество таких, То $w$ в волке, в тигре то $w$, в подобных то $w$ других. Hier fallt auf, daB der Lowe negativ charakterisiert wird und die ubliche Idealisierung seiner Kraft und seines Mutes als des 'Königs der Tiere' fehlt.

Der Schópfer wollte uns auf diese Weise lehren, die zuerst genannten Eigenschaften $z u$ lieben und die anderen $z u$ verabscheuen. An den guten wie an den abschreckenden Beispielen hat uns der schöpfer gezeigt, wie wir sein sollen. So hat der 'Nutzen' der Tiere für den Menschen außer der materiellen auch eine pădagogisch-moralische Komponente. Diese wird gerade an den Raubtieren besonders deutlich und rechtfertigt nach physikotheologischem verstăndnis z.T. deren Existenz:

III, 171 Наставить восхотел он тем нас чрезвыяайно -

Tred. schliebt die Digression mit einem Satz, der ein fast emotionales Verhaltnis zu den Tieren verrăt:

III,177f. Все разумеем сей, коль ни немый, язык, И чувствия сего прегромок в сердче зык!

Die Einstellung Tred.s zu den Tieren wird bei der Erorterung der Frage, ob sie eine Seele haben, năher dargestellt werden.

In III, 179-198 folgen weitere Erwăgungen zum Thema 'Raubtiere'. Tred. hat sich in dieser Passage wieder dem Gedankengang der Démonstration angeschlossen.

Unsere Autoren haben das Vorhandensein von 'schälichen Raubtieren' in einer dem Wohle des Menschen dienlichen Welt mit verschiedenen Gründen zu rechtfertigen versucht. DaB die Raubtiere durch ihre Bosartigkeit den Menschen abstoBen und ihn dadurch indirekt zum Guten veranlassen sollen, ist schon ausgefüht worden. Im AnschluB an die Vorlage weist Tred. weiter darauf hin, daB die Raubtiere von Natur aus den Menschen meiden. Daraus folgt: wenn die Erde dicht besiedelt wăre, 'von Menschen wimmelte', găbe es keine Raubtiere, auBer in menschenleeren, wilden Gegenden und waldern: 
III,179ff. C другой страны, когда 6 везде сельбу имела

Земля вся на себе и жительми кипела,

То не было 6 нигде, Аля множества людей,

На всем лице Земли вредительных зверей,

Кроме что превесьма в дубравах отдаленных,

Иль в Аиких гае местах, еще не населенных, -

Diese Erwăgung ist von Fénelon so formuliert worden: "Si tous les pays étaient peuplés et policés comme ils devraient l'être,... on ne trouverait plus d'animaux féroces que dans les forêts reculées..." (Démonstr., S.22)

Vielleicht sind die Raubtiere zu dem 2 wecke da, den Mut des Menschen herauszufordern, fragen sich unsere Autoren. Wenn die Menschen bei der Jagd auf wilde Tiere ihre Tapferkeit beweisen können, brauchen sie sich nicht in endlosen Kriegen gegenseitig zu zerreiBen:

\section{III,185ff. И разве * 6ы на то, могли чтоб оказать \\ В забаве храбрость мы: нужд не было терзать \\ Войной себя и весть брань меж собой несносну, \\ Долгопротяжну ту и обще смертоносну.}

Die Doppelepitheta 'долгопротяжный' und 'смертоносный' sind keine Neuschöpfungen Tred.s. Nach D.Tschižewskij ist 'смертоносный' bei Hamartolos(108) zu treffen. ${ }^{3}$ Zum Kompositum 'долгопротяжный' gibt Tschižewskij zwar keine Parallele an, betont aber, dies "bedeutet...keinesfalls, daB /solche Kompositä wirklich Neuschöpfungen Tred.s sind." 4

Tapferkeit, Stărke und Gewandtheit solle der Mensch im Kampf gegen die wilden Tiere bewăhren, aber nicht gegen seine Mitmenschen, meint Fénelon: "...on les réserverait pour exercer la hardiesse, la force et l'adresse du genre humain, par un jeu qui représenterait la guerre, sans qu'on eat jamais besoin de guerre veritable entre les nations." (Demonstr.,S.22) Hier zeigt sich der im Lehrgedicht der Aufklărung häufig vorkommende Topos der Ablehnung des Krieges, 5 der uns schon in der Feoptija II,129-39 begegnet ist.

SchlieBlich braucht die Existenz der wilden Tiere den Menschen auch deshalb nicht an der guten Weltordnung zweifeln zu lassen, weil ihre zahl begrenzt ist: III,189f. Но долюно примечать, в чем есть не без выго́́, Что вредных нам зверей не преобильный род: -

Zwar werden mehx Schafe, Bठcke, Ziegen und Ochsen geschlachtet als Tiger,Lסwen, Băren und Wölfe zur strecke gebracht. Trotzdem sind diese viel seltener 
zu sehen als jene:

III,193ff. Бырт более ове4, овнов, коз и быков,

А нежель тигров, львов, медведей и волков,

Однак последних сих повсоду меньше зрится -

Dieser Gedanke geht auf Fénelon zurück: "Mais observez que les animaux nuisibles a l'home sont les moins féconds... On tue incomparablement plus de boeufs et de moutons qu'on ne tue d'ours et de loups: 11 y a néanmoins incomparablement moins d'ours et de loups que de boeufs et de moutons sur la terre." (Démonstr.,S.22)

Tred. fügt noch die Uberlegung hinzu, ob etwa eine Anzahl von wilden Tieren durch Hunger oder 'Verhängnis' zugrunde gingen. Er neigt aber zu der Annahme, die Vorsehung habe sie weit von uns entfernt und in die 'tiefe Nacht' (der wălder, Dschungel und Steppen) 'verbannt':

III, 196ff. Oт голода ль число, от рока ль то морится, Иль промысл их от нас всех уалляет прочь, В глубокуш от глаз ссылая жить их ночь. Die auf Cicero hinweisende Anmerkung Fénelons, daB die Muttertiere im allgemeinen so viele zitzen haben, wie sie Junge zur Welt bringen, fehlt bei Tred.

III, 199-268 beschreibt die Insekten als Lehrmeister des Menschen Den Leitgedanken des Abschnitts hat Tred. in den Versen 251f. ausgesprochen:

То всё, что в мире мне творец ни представляет,

Смотрящего меня безмерно уаивляет

So wird die 'wundervolle Făhigkeit' der Seidenraupe gerühmt: wăhrend die Schafe uns nur den alltaglichen 'Bedarf', die wolle, liefern, 'wetteifert sie gleichsam mit ihnen' und gibt uns die weichste Seide:

III,199ff. Как овцы нам дарт в потребность нашу во́лну,

Так, будто напрерыв пред ними, черви полну

Чудес способность всю к мягчайшим тем шелкам,

Достаточну весьма, оказывают нам.

Dem Leitgedanken (251f.) entspricht der begeisterte $\mathrm{Zwischenruf}$ des Autors: III,203 Предивно! какову в себе являют силу!

Er denkt an die unansehnliche Raupe, die sich in ihrem Kokon ein 'reiches Grab' bereitet, aus dem sie als Schmetterling wiedergeboren wird. Vielleicht sieht Tred. darin ein Gleichnis für die Unsterblichkeit der Seele. -Danach nimmt der Seidenspinner wieder das Aussehen eines Wurmes an. Diese Verwandlung wird mit Ausrufen des Staunens beschrieben: 


\section{III, 204ff. Готовят как свон богатую могилу! \\ Oт семени опять рожда:отся те как! \\ И на себя потом берут червиный зрак!}

Ist es nicht zum Staunen: eine häBliche Raupe versteht die Kunst, feine Seide für den Luxus zu machen:

\section{III, 207f. Червяк co6ow тот нам кажется толь гнусен,}

А делать нежный шелк на щегольство искусен!

Tred. will sagen, daß auch die hăßlichen Geschöpfe, und machmal gerade sie, die Herrlichkeit des Schöpfers reflektieren. Die Passage unterscheidet sich vor allem durch ihre enthusiastische Tonalităt von dem zugrunde liegenden Text der Démonstration: "Pendant que les moutons font croftre leur laine pour nous, les vers à soie nous filent, à l'envi, de riches etoffes, et se consument pour nous les donner. Ils se font de leurs coques une espèce de tombeau, ou ils se renferment dans leur propre ouvrage; et ils rênaissent sous une figure étrangère, pour se perpétuer." (S.22f.)

In III, 209-220 werden die Bienen betrachtet.

Tred. schildert, wie die Biene mit 'unaufhörlicher Mūhe' (всечасными трудами,211) den Nektar der Blüten einsammelt und ihn in die Waben fült. Für 'Wabe' gebraucht er die Metapher 'восковый прудок' (212). Am Fleiв der Bienen solle sich der Mensch ein Beispiel nehmen, will Tred. sagen. In der Demonstration wird die musterhafte ordnung im Bienenstock hervorgehoben. Im ubrigen hat sich Fénelon an dieser stelle nicht aber die Bienen ausgelassen: "...elles...rangent $\underline{\bar{l} e}$ miel $\bar{T}$ avec un ordre qui nous peut servir de modele." (S.23) -

In der Feoptija schlieBt sich hier eine Digression über den Bienenstaat als Muster sozialethischen Verhaltens an:

\section{III,213f. Премуаро вышня власть саружает пчельный рой}

Как в общество, иль в град единый меж собой: -

Das Gemeinwesen hat eine monarchische Verfassung. Jede einzelne Biene arbeitet für das Gemeinwohl. Die Schmarotzer werden ausgemerzt:

\section{III,215ff. Имеет и царя себе сие гражданство \\ И знает наблюдать послушное подяанство; \\ Произдодя ж особь Аля общей пользы труА, \\ На тунеядцев в них казнь Аелает и суА.}

Tred. kann das Verhalten der Bienen nicht genauer erforschen, stellt aber zusammenfassend fest, daB sie 'wie mit Vernunft' zu Werke gehen: 
III,219f. Исследовать всего подробнейше не можно, Что действует пчела, как с разумом, не ложно.

Das Exempel des Bienenstaates ist im 18.Jahrhundert in verschiedenem Sinne sozialethisch ausgewertet worden. So liegt der bekannten Schrift 'The Fable of the Bees' (1715) von Bernard de Mandeville (1670-1733) die "Maxime /zugrunde $\bar{T}$, daß die verfolgung des Eigennutzes das allgemeine Wohl fơrdere." 6 "In abgewandelter Form findet sich diese Auffassung auch im 'Essay on Man' von A.Pope. Er vergleicht in Ep.III,184ff. die Bienen mit den Ameisen und hebt zunăchst den Unterschied zwischen der monarchischen Ordnung des Bienenstaates und der republikanischen Gesellschaft der Ameisen hervor. Wăhrend diese aus allem, was sie an Nahrung finden, einen gemeinsamen Vorrat ansammeln, behaupten fene ihr 'Privateigentum'. Im 'Essay' steht die Fabel unter dem Motto:

Ep.III,171f. Thus then to Man the voice of Nature spake "Go, from the creatures thy instructions take: -"

Als eines der Beispiele folgt der Vergleich zwischen dem 'Staat' der Ameisen und dem der Bienen:

Ep.III,183ff."Learn each small People's genius, policies, "The Ant's republic, and the realm of Bees; "How those in common all their wealth bestow, "And Anarchy without confusion know;

"And these for ever, tho' a Monarch reign,

"Their sep'rate cells and properties maintain. -"

Anders als Pope hat Tred. die Akzente gesetzt. Er unterstreicht im Blick auf die Bienen ihre 'gehorsame Unterordnung' unter die Konnigin (III,216), die Arbeit des einzelnen für das gemeinsame Wohl (III,217) und die Vernichtung der Schmarotzer (III,218). Die Arbeit für das Gemeinwohl schliebt aber das Eigentum des einzelnen nicht aus. Heute würde man dies die 'soziale Verpflichtung' des Eigentums nennen.

Die Ameisen werden von Tred. lediglich als Muster fleiBiger Arbeit angefuhrt. DaB sie in einer Art Republik zusammenleben, in der 'Anarchie ohne Durcheinander' herrscht, und daB sie nur gemeinsames Eigentum kennen, wie Pope entwickelt hat, läBt Tred, beiseite, weil diese zuge nicht in sein Konzept passen. Die fleiBigen Ameisen und die klugen Spinnen hat uns Gott als Lehrmeister für unsere wissenschaft vorgestellt. Von ihnen sollen wir lernen, fleiBig zu arbeiten und gegen den MüBiggang, 'die Mutter aller Ubel' zu kămpfen, wie Tred. in sprichworthaf ter kurze hinzufügt: 
III,221ff. Коль в муравье труда! коль мудр есть и паук!

Бог не явил ли их яля наших здесь наук?

Смотря на обои́х, труаиться 6 научились

И, как на мать всех зол, на праздность ополиились.

Mit der Bemerkung, daB wir die weisheit des Schöpfers nicht nur an den bisher besprochenen, allgemein bekannten Tieren wahrnehmen kơnnen, sondern auch an den vielen, die noch nicht erforscht worden sind (III,225-28), wendet sich Tred. wieder dem Text der Vorlage zu.

Der Abschnitt III,229-268 handelt von den scheinbar unnützen Insekten, die aber doch in mancher Hinsicht für den Menschen von Nutzen sind.

Die unzăhligen Würmer, Schmetterlinge und Mücken im Sommer sind, so scheint es, von jeher nutzlos gewesen. Fragt man, wodurch sie dem Menschen nützlich sein sollten, so hat Tred. mehrere Antworten: Sie wecken unsere wiBbegierde ("к побопытстөу нам причину подают",233), ihr Anblick erfreut uns, sie "nageln unseren Fleiß fest" ("A взор наш веселя, прилежность пригвождают",235). Sie regen uns an, über sie nachzudenken (" $И$ рассуждать о всех внутрь мысли возбумдают", 236). Daraus folgt, daß nichts in der Welt nutzlos ist:

III,237f. Мы заклочений сих не можем произвесть, Что зримое то нам во свете втуне есть: -

Auf den Einwand, daB viele Insekten, Fliegen und würmer unnütz seien, erwidert Fénelon: alles, was 'zum großen Schauspiel der Natur gehöt und zu seiner Vielfalt beitrăgt' ist für stille und aufmerksame Beobachter niemals ohne Nutzen: "...ce qui fait partie du grand spectacle de la nature, et qui contribue à sa varieté, $n$ 'est point sans usage pour les hommes tranquilles et attentifs." (Démonstr.,S.23) Er făhrt fort mit der rhetorischen Frage, was es denn Schöneres und GroBartigeres geben könne, "que ce grand nombre de républiques d'animaux si bien policées, et dont chaque espece est d'une construction différente des autres?" (S.23)

An dieser Stelle hat Tred., von der Demonstration abweichend, in III,239252 das Bild der 'Kette' des Seins erörtert, das er aus dem 'Essay on Man' kannte. Das Bild dient ihm zur Erlăuterung der These, 'daß nichts in der Welt nutzlos ist' (238). Auch Würmer, Schmetterlinge und Mücken sind demnach notwendige Glieder der 'Kette'. Wir wissen nicht, legt Tred. dar, wie die Welt 'durch ihre Kette zusamengenietet ist', und wie alle Glieder ineinanderhaken und auf das letzte, allgemeine ziel zugehen, das der Schöpfex gesetzt hat: 
III,239ff. He знаем, склепан как мир цепив своер

И как краи всех звен впреде и заде ео

Сцепляются с собой по слогу своему

И йаут все $\mathrm{K}$ кониу последнему тому,

Которшй положил всеобщим бшть создатель.

Die Versreihe wird von der Vorstellung bestimmt, daB der Aufbau der Welt einer Kette gleicht, die aus vielen Gliedern besteht. Diese Vorstellung, die auf Homers Ilias zurückgeht, hat sich in einer langen Tradition entwickelt und war, wie B.Fabian bemerkt, "das găngige ontologische ordnungsschema des frühen achtzehnten Jahrhunderts." 7 In A.Popes 'Essay on Man' ist 'the chain of being' "das zentrale gedankliche Element." 8 Danach besteht die Welt aus einem "Kontinuum dex Existenzformen" 9 , das vom Nichts uber eine vielstufige Hierarchie geschaffener Wesen bis hinauf zu Gott reicht. "In statischer Gliederung" -so B.Fabian- "steigen die Schichten des Seins zu immer höherer Vollkommenheit auf, und jedes Wesen hat den ihm vorbestimmten Platz in der kosmischen Hierarchie." 10 Das ontologische, 'lineare' Schema der 'chain of being' ist von Pope dichterisch reich entfaltet worden. Ein Beispiel für die aufsteigende Linie findet sich im 'Essay', Ep.I,43ff.:

of Systems possible, if 'tis confest

That wisdom infinite must form the best,

Where all must full or not coherent be,

And all that rises, rise in due degree;

Then, in the scale of reas'ning life, 'tis plain

There must be, somewhere, such a rank as Man; -

Den lückenlosen Zusammenhang schildert der Dichter auch in umgekehrter Richtung:

Ep.I,237ff. Vast chain of being, which from God began, Natures aethereal, human, angel, man, Beast, bird, fish, insectl what no eye can see, No glass can reachl from Infinite to thee, From thee to Nothingl - On superior pow'rs Were we to press, inferior might on ours: or in the full creation leave a void, Where, one step broken, the great scale's destroy'd: From Nature's chain whatever link you strike, Tenth or ten thousandth, breaks the chain alike. 
Beidemal ist der Mensch das Mittelglied, in dessen Wesen Geistiges und Animalisches vereinigt sind. M.Mack kommentiert die eben zitierte Stelle des 'Essay on Man' mit folgenden Worten: "The conclusion is that in the part of the ladder which embraces rational existents (e.g. man and angel) there could no more be a gap than elsewhere: there had to be a creature which combined the rational nature with an animal one, for such a creature... was certainly one of the conceivable possibles." 11

B.Fabian hat in seinem Aufsatz 'Pope und die Goldene Kette Homers' dargelegt, daß die 'chain of being' im 'Essay on Man' nicht nur, wie oben gezeigt, die Bedeutung eines linearen, ontologischen Ordnungsschemas hat. Für Pope scheint die Kette, so führt Fabian aus, "auch eine dichterische Formel für ein Weltbild zu sein, das zuvơrderst durch Kreislăufe und Bewegungsvorgănge bestimmt ist." 12 Seine These, A.Pope habe das Bild der 'Kette' im Sinne des modernen physikalischen Weltbildes neu gedeutet, stūtzt B.Fabian vor allem auf die Verse der kosmischen Vision am Beginn des 'Essay on Man':

Ep.I,23ff. He, who thro' vast immensity can pierce, See worlds on worlds compose one universe, Observe how system into system runs, What other planets circle other suns, What vary'd being peoples ev'ry star, May tell why Heav'n has made us as we are. But of this frame the bearings, and the ties, The strong connections, nice dependencies, Gradations just, has thy pervading soul Look'd thro'? or can a part contain the whole? Is the great chain, that draws all to agree, And drawn supports, upheld by God, or thee?

Zu Vers 30f. gibt M.Mack die Erlăuterung: "...connections, dependencies, gradations... were key terms of the new sciences with respect to the hierarchies both of being and the stellar systems. "13 In diesen Versen geht es -labt man den Gedanken der 'Vielzahl der Welten' einmal beiseite- vornehmlich um das dynamische Verstănanis der 'Großen Kette', die das Universum zusammenhălt (draws all to agree,Vers33f.). Mit dieser universalen physikalischen Kraft hat der Dichter -so die einleuchtende Interpretation B.Fabians- die von Newton entdeckte und in ihren Wirkungen beschriebene Gravitation gemeint. Mit der Neudeutung des Bildes der 'Goldenen Kette', die das Verdienst A.Popes 
1st, hat aber das traditionelle Verstăndnis nicht aufgehort, stellt B.Fabian fest: "Die Goldene Kette blieb zuvorrderst das Symbol für das Kontinuum der Existenzformen. Aber neue Vorstellungen traten hinzu, und der Dichter des achtzehnten Jahrhunderts konnte unter dem gleichen Bild auch uber die kosmologischen Vorstellungen seiner Epoche sprechen. "14 AbschlieBend erklart B.Fabian, man mũsse bei den Autoren des 18.Jahrhunderts, besonders bei den Dichtern, "bestăndig damit rechnen, daß sie die coldene Kette nicht traditionellneuplatonisch verstehen, sondern 'newtonisch' als poetisches symbol für die Gravitation, für die ordnung im planetarischen Raum, ja für den gesamten kosmos der klassischen Physik." 15

In der Feoptija wird die 'Kette' (uenb,III,239) als Sinnbild für das 'Kontinuum der Existenzformen' (Fabian) nicht nux in der Digression III,239ff. ausdrücklich dargestellt. Die Vorstellung einer stufenweise aufsteigenden Ordnung bestimmt den Aufbav des gesamten Poems, in dem nacheinander die unbelebte Materie, die Pflanzen, die Tiere und der Mensch behandelt werden. Jedes Wesen hat innerhalb der geschaffenen Welt seinen bestimmten Rang und ist für den Zusammenhalt des Ganzen unentbehrlich. Das gilt, wie wir gesehen haben, auch für die scheinbar unnützen Insekten. Die Rangordnung wird durch die Kategorie der 'stufen' bezeichnet, so z.B. in Feopt.III,514f.:

Мы в совершенствах зрим степени толь различны, И каждой вещи те, по сродству их, приличны; -

Zu diesem Vorstellungsbereich gehoren auch die haufig in der Feoptija vorkommenden Begriffe ' порядок', 'связь', 'чин' und die davon abgeleiteten Adjektiva.

DaB der Wegfall selbst einer kleinen Partikel die kosmische ordnung durcheinanderbrachte, hat Tred. im Hinblick auf die Bewegung der Planeten ausgesprochen:

II,864ff. Устав, которым всё чиновно толь вертится,

Без наших мыслей сам на пользу нам трудится!

Хотя 6 частица гае отторглась от шаров,

Низвергла 6 Земло всо ударом бездны в ров.

Die Aussage entspricht dem ontologisch verstandenen Bild der 'Kette' im 'Essay', Ep. I, 245f.:

From Nature's chain whatever link you strike,

Tenth or ten thousandth, breaks the chain alike.

Es ist zu fragen, ob sich in der Feoptija auch die von A.Pope eingefühte Neudeutung des Bildes der 'Kette' findet, nach der es als poetische Formel für die Gravitation zu verstehen ist. Wir werden darauf bel der Besprechung 
des Abschnitts III,576ff. zu sprechen kommen, in dem der Begriff 'uenb' zentrale Bedeutung hat.

In III, 239-252 handelt Tred. von dem Zusammenspiel der Ursachen, das kein Mensch, und sei er noch so scharfsinnig, je durchschauen wird:

III.244f. Никто из человек, хоть коль ни остр снискатель,

Постигнет здесь когда всех действие причин, -

Gott bedient sich allex Ursachen in seinem unerschopflichen wirken. Er hat jedem Wesen Zweck und ziel bestimmt. Was auch imer der Schopfer uns in der Welt vor Augen fuhrt, veranlaBt uns $2 u$ unbegrenztem staunen, auch wenn wir es nicht begreifen:

\section{III,249ff. Когда * мой разум мал к познаниі кониа, \\ Кой в каждой твари вкруг предписан от твориа, \\ То всё, что в мире мне творец ни представляет, \\ Смотрящего меня безмерно удивляет}

Mit III,253 knüpft Tred. wieder an die Demonstration an. Beim Stichwort 'уаивляет' fahrt er fort: es ist zu bewundern, wie der schopfer in seiner Weisheit die grobe Materie in zartes Leben verwandelt, das sich hin und her bewegt. Er macht es 'wie winziges Spielzeug', fügt er hinzu:

$$
\begin{aligned}
& \text { III,253ff. Премудростию как он грубость вещества } \\
& \text { В тончайшую ту жизнь меняет существа; } \\
& \text { Дая ж им двиги все, творит их как игрушки. }
\end{aligned}
$$

Selbst die kleinen Fliegen sind für das Auge wunderbar anzuschauen:

$$
\text { III,256 Чудесно оку зреть и малие те мушки! }
$$

In der Démonstration heiBt es: "Tout montre combien la facon de l'ouvrier surpasse la vile matiere qu'il a mise en oeuvre: tout m'etonne, jusqu'aux moindres moucherons." (S.23)

Auch wenn sie uns låstig werden, gibt uns dex Schópfer durch sie zu verstehen, daB wir nicht müBig sein sollen:

III, 257ff. Hо некие из них что беспокоят нас,

То помнить должно всем на всякий твердо час,

Что нам повелено́ иметь, и при покое,

Подвижный труА всегда, чтоб не лежать, как в гное, -

Tred. hat diese Stelle zu einem moralischen Exkurs über den Nutzen fleiBiger Arbeit erweitert. Die Fliegen storen den Menschen bei der Ruhe und exinnern inn daran, daB er immer tatig sein und nicht 'wie verfault' daliegen soll. Tred. verwendet drastische Ausdrücke: wir wirden ohne Arbeit 'verschimmeln' 
(Заплесневши без дел и без стремлений быть,261). Wir wärden 'erschlaffen und verkommen', wenn wir alle Tage 'herrlich und in Freuden ohne Kummer lebten'. Auf diese Weise wirden wir alt und hătten unser Leben unnütz verbracht:

III,262ff. Могли 6 мы ослабеть иль и себя забыть,

Роскошствуя все Ани в сей жизни без печали,

А так бы живучи, без всех польз изветшали, -

Die Arbeit bringt doppelten Lohn -so schliebt der Autor die moralische Lektion- wir werden 'das Ubel' los (gemeint sind wohl die vorher genannten Folgen des MüBiggangs) und 'schmücken uns mit Gutern'. So erfreut sie doppelt das Herz:

III,267f. Избывши ж тем от зол, красуемся благими

И веселимся ууж сугубо в сераце ими.

Den Grundgedanken des Abschnitts hat Tred. in der Demonstration vorgefunden: "Si on les /moucherons/ trouve incommodes, on doit remarquer que l'home a besoin de quelques peines mêlées avec ses commodités. Il s'amollirait et il s'oublierait lui-même, s'il n'avait rien qui modérat ses plaisirs, et qui exerçat sa patience." (S.23)

Es făllt aber auf, daß Tred. die Mahnung zu fleißiger Arbeit und die Warnung vor einem nutzlosen Luxusleben mit eigenen Worten nachdrücklich formuliert hat. Die Aufforderung zum FleiB hat bei ihm fast die Form eines gottlichen Gebotes: "нам повелено́ иметь...подвижный труд всегда"(259f.) Die Verse bringen zugleich die personnliche Lebensauffassung Tred.s zum Ausdruck und lassen die pådagogische Absicht deutlich erkennen. Uber den Luxus am Hofe der Zarin Anna Ivanovna schreibt V.Gitermann u.a.: "...Auslăndische Diplomaten, die schon manche Residenz...gesehen hatten, stellten fest, daB Petersburg durch seine Verschwendung jede andere europăische Hauptstadt bei weitem übertreffe. ...Unter der Kaiserin Anna wurde die russische Aristokratie erstmals vom Taumel eines raschen, sensationshungrigen Modewechsels erfaBt... Um die zahlreichen Empfănge, Bålle, Maskeraden, Illuminationen, Jagden und vor allem die prunkvollen Palastbauten zu bezahlen, bürdete man dem Volk immer grởere Steuern auf."16 - Die Mahnungen der Feoptija werden auch zur zeit, als Tred. an dem Poem arbeitete, einen aktuellen Hintergrund gehabt haben.

III, 269-322 handeln von der Weisheit Gottes im Makrokosmos und im Mikrokosmos.

Im ersten Verspaar fordert der Autor zum Nachdenken uber die gottliche Weisheit auf, die im Großen wie im Kleinen zu beobachten ist: 
III, 269f. Размыслим 060 всей премудрости, что здесь

Мы вияим как в большом, так в малом не ирез смесь.

Tred. will über die 'Премуарость', Fénelon über die 'merveilles' nachdenken: "Considérons maintenant les merveilles qui éclatent également dans les plus grands corps et dans les plus petits." (Démonstr.,s.23)

Unsere Autoren schildern ein Weltall von atemberaubender GröBe. Wir sehen die Sonne, die gröBer als die Erde ist, in einer solchen Entfernung (Tred. spricht von vielen Millionen Werst), daB sie als ein kleiner Kreis erscheint. Die damals heikele Frage, 'ob sie geht oder steht', labt er offen:

III,271ff. Мы Солнце зрим, оно(в колико ж верст мильонов?)

Есть более Земли и обществом законов

Иль ходит, иль стоит в пространствии таком,

При коем то в себе есть маленьким кружком.

Chr.Siegrist macht darauf aufmerksam, daB man sich in der Lehrdichtung hăufig des Mittels der Zahl bedient hat, um "diese fūr die Dichtung neue und unerhörte Thematik / $\overline{d e s}$ neuen Weltbildes/ darzustellen...Diese abstrakte GröBe soll eine wenn auch ungenügende,... Ahnung von der UnermeBlichkeit dieser Dimension vermitteln." 17 Fénelon hat den GröBenunterschied zwischen der sonne und der Erde in einer Zahl ausgedrückt: "...tant de milliers de fois plus grand que la terre."(Demonstr.,S.23) Nach seinen Worten 'kreist die Sonne in Răumen, im Vergleich zu welchen sie nur ein glănzendes Atom ist': "...qui circule dans des espaces en comparaison desquels il n'est lui-même qu'un atome brillant." (Demonstr.,s.23)

Die GroBe des Weltraumes wird weiter verdeutlicht durch die Menge der Sterne, die, grober als unsere Sonne, so weit von uns entfernt sind, daB wir ihre Entfernung nicht messen kōnnen:

$$
\begin{array}{ll}
\text { III,275 Мы множество зрим звезд; - } \\
\text { III,277f. Те расстоят от нас в далекостях таких, } \\
\text { Что меры положить не можно есть до них. }
\end{array}
$$

Auch bei ihnen endet der Weltraum noch nicht:

III,279f. Сих выне звезды зрим еще, хотя и мрачно,

Затем и различать не можем их удачно.

In diesen Versen hat Tred. die Schilderung der Démonstration (23) nachgeahmt: "Au deld de tous ces espaces, qui échappent déja a toute mesure, j'aperçois encore confusement d'autres astres qu'on ne peut plus compter ni distinguer." In einem so großen Universum ist die Erde nur ein kleiner Punkt: 
III,281f. Пред всем, что зрим, земля есть точечко уже

И в ней с тем мер почти нет никаких ниже́.

Vg1. Démonstr.,S.23: "La terre...n'est qu'un point, par proportion a ce tout ol l'on ne trouve jamais aucune borne."

Diese Diskrepanz wăre für die winzige Erde bedrohlich, wenn nicht das unendliche Weltall von einer wunderbaren Ordnung zusammengehalten würde. Kein Teil darf fortfallen, ohne daß 'die Reihe der richtigen Bahnen zerbrăche' und die Welt unterginge:

III, 283E. Всё ж то сопряжено толь чинно меж собом, Что меньше стать в себе ни частиы одною, -

III,287f. Hе момет 6ез того, что6 варуг не сокрушился Исправнах бегов ряд и свет не низложился.

Von dieser katastrophalen Folge war schon II,866f. (vgl.Demonstr.,S.19) die Rede. Die vorliegende stelle entspricht dem Satz Fénelons: "Ce tout est si bien arrange, qu'on $n^{\prime} y$ pourrait déplacer un seul atome sans déconcerter toute cette immense machine..." (Demonstr.,s.23)

Die kosmische Betrachtung führt zu dem Ergebnis, daB in der unermeBlichen GröBe und gesetzmåBigen Ordnung des Weltalls 'die Hand' des Schópfers sichtbar wird:

III,289f. Поистине, рука содержит весь одна

Зимдителева мир, с оисот его АО дна; -

Eigentümlich ist die folgende Wendung, daB 'seine / $\overline{\mathrm{d} e s}$ schöpferş $\bar{T}$ Finger uberall in der Welt spielen':

III,291f. Eго повсюау толь в нем персты всем играют, Что, разбирая всё, в союз тверя собирают.

Dies Bild stamnt aus der Demonstration, wo es als zitat aus den proverbien, Kap.8,31 angegeben wird: "Il faut qu'une main a qui rien ne colte ne se lasse point de conduire cet ouvrage depuis tant de siecles, et que ses doigts se jouent de l'univers, pour parler comme l'Écriture." (S.23f.) In Anmerkung hierzu steht: "Ludens in orbe terrarum",Prov.VIII,31. (S.24)

Nach dem hebraischen Text spricht an dieser Stelle die 'chokma', die Weisheit, die, wie in Prov., Kap.8,22-31 ausgefüht wird, als Erstling von cott geschaffen worden ist und "dann der weiteren eigentlichen schopfung beigewohnt hat -nicht als Helferin, sondern wie ein kind, das in der Werkstatt seines Vaters spielt. Als cottes...'Liebling' (hebr.'amin', 30) hat sie mit der Schopfung und dem Menschen gespielt." 18 In der Septuaginta ist Vers 31 
in dew Sinne geăndert worden, daß Gott selber an die Stelle der Weisheit getreten ist:

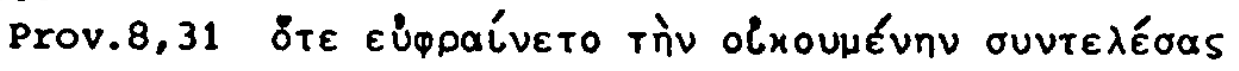

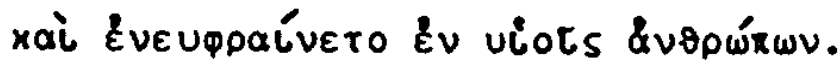

In III, 293-322 folgt nach dem Ausblick in den Makrokosmos die Betrachtung der kleinsten Lebewesen.

Die kleinsten Wesen sind nicht weniger wunderbar als das groBe Ganze der Natur. An ihnen erweist sich der 'Allmăchtige' nicht weniger als im riesigen Universum:

III,293ff. Но челого сего ж и обиа естества

Не меньше аивн суть малейши существа;

Всесильный и по сих не менее нам зрится,

Коль по огромном всем наш ум им светл творится.

Fénelon beginnt das neue Thema mit dem Bekenntnis, daB die Schōpfung im GroBen wie im Kleinen bewundernswürdig ist: "D'un autre coté, l'ouvrage n'est pas moins admirable en petit qu'en grand." (Démonstr.,S.24)

Tred. veranschaulicht seine Behauptung am Beispiel der 'kleinen Mücke'. Fénelon nennt 'le ciron' (Made bzw.Milbe). Diese Insekten haben in winzigem Format dieselben Korperteile und Organe wie die grobten Tiere, z.B. wie der Elefant:

III,297f. То ж в малой мошке есть, что в ките и слоне;

Есть голова, глаза и тела слог отвне.

Auch die inneren Organe des kleinen Insekts, Herz, Blut und Adern, auch seine Kraft entsprechen im Verhăltnis zur Größe denen eines großen Tieres. Der Text der Vorlage ist von Tred. etwas gekürzt worden. Dort wird der organismus der 'lebendigen Atome' ausführlicher beschrieben: "Il y a, dans chaque partie de ces atomes vivants, des muscles, des nerfs, des veines, des artères, du sang; dans ce sang, des esprits, des parties rameuses et des humeurs." (S.24)

In der Feoptija äuBert sich die motion des Autors bei der Betrachtung des Kleinen in ahnlicher Weise wie beim Nachdenken über die makrokosmischen Dimensionen. So erklärt er im Hinblick auf den organismus einer Mücke:

III,301f. Но в малости такой, что всё сие наш ум

Поемлощий мятет и весь мрачит от Аум.

Mit ahnlicher Betroffenheit reagierte der Autor angesichts der Sterne:
II, 798f. -
не уаивится ль ум?
И не сматется ЛЬ ОН От СОБственныХ внУтрЬ АУм?
II,813 Темнеет свет ума: нет сил обнять пространство! 
Ein neuer Bereich der Wirklichkeit ist durch das Mikroskop entdeckt worden, von dem A.v.Haller sagt, es habe "mehr zur VergröBerung des Reichs der Wissenschaften /getan], als der schopferische Geist Des Cartes.... des Aristoteles, als...Gassendi." 19 Unsere Autoren haben die Begeisterung der Zeitgenossen über dieses Instrument geteilt. So erklart sich thre übertriebene Vorstellung von der Leistung des damaligen Mikroskops. Tred. erklărt, der Démonstration folgend,

III,303f. Чрез микроскоп живых мы тьмы усмотреваем, Которих чрез простий глаз зреть не возмогаем, Fénelon schreibt: "Le microscope nous découvre, dans chaque objet connu, mille objets qui ont èchappe à notre connaissance." (Demonstr.,S.24) Von dem Mikroskop Leuwenhoecks (gest.1723), der die Kleinstlebewesen entdeckt hat, berichtet P.Hazard, es sei von inm nach unzăhligen Versuchen so weit entwickelt worden, daB es die Gegenstănde $270 \mathrm{mal}$ vergroberte. 20 Auch die Mikroorganismen bestehen aus Teilen, fahrt Tred. fort. Diese sind jedoch so klein, daß man sie selbst durch das Mikroskop nicht wahrnehmen kann: III, 305ff. Hо в каждом и из сих премноги ж части суть, И малм толь они, что не лежит К ним путь Ниже́ чрез микроскоп, чтоб видеть их раздельны; DaB zu unzăhligen Mikroorganismen 'kein Weg führt', hat die Demonstration ahnlich gesagt: "Combien y a-t-il, en chaque objet decouvert par le microscope, d'autres objets que le microscope lui-même ne peut decouvrirl"(S.24) Erwartungsvoll sehen unsere Autoren der Weiterentwicklung des Instruments 'zu letzter Feinheit' entgegen. Was konnten wir dann noch alles sehen!

III,309ff. А что ж бы мы еще увидеть возмогли, По счастио когда 6 здесь способы нашли

Оруаия привесть в последно тонкость исто -?

Tred. hălt es für sicher, daß wir mit Hilfe eines Supermikroskops 'unzăhlige Wunder' erblicken werden:

III, 315f. Пособствуя ему, собо10 направляют

И видеть чудеса несчетны сподоблярт?

Diese Erwartung hat auch Fénelon ausgesprochen: "Que ne verrions nous pas si nous pouvions subtiliser toujours de plus en plus les instruments qui viennent au secours de notre vue, trop faible et trop grossiêre?" (Démonstr. ,S.24) Diese Sătze bestătigen, daB unsere Autoren das 'mikrobiologische Interesse' des 18.Jahrhunderts teilen, das man "le siecle des petitesses" genannt hat. 21 
AuBer den Augen und dem Mikroskop, so sehr man es auch verbessern mag, besitzt der Mensch zur Wahrnehmung der Dinge noch ein inneres Sehvermögen: die Vorstellungskraft. Sie vermag mit ihrem Licht auch da einzudringen, wo das Sehen nicht mehr möglich ist. Man kann deshalb von den unsichtbaren Dingen, von denen wir aber untrüglich wissen, nicht behaupten, sie existierten nur im Traum. Vielmehr muB man zugeben, daB sie, obwohl unseren Augen verborgen, in Wirklichkeit da sind. Dies will Tred. wohl in dem folgenden labyrinthischen Satz zum Ausdruck bringen:

III,317ff. Hо в случае таком образований мощь Возможет просветить видения в нас нащь: От видимых не всех, но ведомых нелокно, Незримых ум отнодь мечтать нам тьмы возможно, А оны тьмы в вещах так должно полагать, Что сокровенны в тех от нас их признавать.

In dieser Passage beruht nur das erste Verspaar auf dem franzorsischen Text: "Mais suppléons par l'imagination à ce qui nous manque du côté des yeux." (S.24) Fènelon bezeichnet die 'Einbildungskraft' als 'eine Art Mikroskop', "qui nous représente en chaque atome mille mondes nouveaux et invisibles." (ebd.) Er will aber nicht weiter in diese Mikrowelt eindringen. Die 'imagination' músse 'anhalten und unterliegen' und 'sich tausend unbekannte Wunder entgehen lassen': "... il faudra qu'elle s'arrête, qu'elle succombe, et qu'elle laisse enfin dans le plus petit organe d'un ciron mille merveilles inconnues." (Demonstr.,S.24)

Der unfăngliche Abschnitt III, 323-958 handelt in Auseinandersetzung mit der Automatentheorie Descartes' von der Tierseele und dem Organismus der Tiere.

Zu Beginn wird hervorgehoben, daB alle Tiere, so verschieden sie auch sein moggen, in dreifacher Hinsicht ubereinstimmen: sie haben organe, mit denen sie sich verteidigen, sich ernăhren und sich fortpflanzen können. Daß trotz der unübersehbaren Vielfalt der Arten bei jedem Tier dieselben lebenswichtigen Funktionen da sind, erscheint unseren Autoren staunenswert. In der Feoptija wird die 'dxeifache Ausrüstung' so beschrieben:

III,325ff. И узрим мы во всех троякое сие,
Что крайнейше дивит познание мое.
Зрим первое в скоте, чем может борониться -
III,329
Второе, пищу чем он может потреблять -
А третие в нем есть, чем может умножаться -


Fénelon verwendet die Formel Descartes', "la machine de l'animal", die Tred. hier vermieden hat. Als wesentliche Bestandteile der "machine de l'animal" werden genannt: "...elle a trois choses qui ne peuvent etre trop admirées: $1^{\circ}$ elle a en elle-même de quoi se défendre...; $2^{\circ}$ elle a de quoi se renouveler par la nourriture; $3^{\circ}$ elle a de quoi se perpétuer son espèce par la génération. Examinons un peu ces trois choses." (Démonstr., S.24)

Unter $1^{\circ}$ stellt Fénelon verschiedene Instinkthandlungen der Tiexe dar, und zwar nicht nur solche, die der Verteldigung dienen. So führt er bei diesem Punkt auch den Instinkt des Hundes an, der die Făhrte eines Hirsches verfolgt. Diese Inkonsequenz wollte Tred. Offensichtlich vermeiden. Er hat deshalb den Instinkt zum vierten gemeinsamen Wesensmerkmal aller Tiere exklart: III,333f. Четвертое внутрь есть, что Аивнейше еще, Которое зовем побудком мы вобще; -

In III,333-440 folgt eine Erorterung über den Instinkt der Tiere. Zunăchst stellt Tred. fest, was der Instinkt bewirkt: durch ihn 'weiB' das Tier, was es notig hat und was ihm schadet. Instinktiv flieht es vor der Gefahr (335f.). Dieses Verhalten des Tieres als 'Verstand' einzuschătzen, wăre aber falsch und ubertrieben, meint der Autor:

III,337f. Умом сей не хочу, то ложно, величать; Довольно мне его здесь действо примечать.

Er beschrănkt sich darauf, die wixkungsweise des Instinktes zu kennzeichnen. Tred. hat es abgelehnt, den Instinkt der Tiere zu uberschatzen, ihn der Vernunft des Menschen gleichzustellen oder ihr gar uberzuordnen (vgl. auch III, 354f. und III, 379f.)

Der 'Instinkt' hat im Laufe des 18.Jahrhunderts ein imer gröBeres Ansehen exlangt. Fontenelle erklät z.B.: "Man versteht unter dem Ausoruck Instinkt etwas, was zu unserer Vernunft hinzukomet und von vorteilhafter wirkung auf die Bewahrung meines Daseins ist, etwas, was ich tue, ohne zu wissen warum, und das trotzdem sehr nutzlich für mich ist, und darin liegt das Wunderbare des Instinktes." 22 Rousseau spricht sogar vom 'göttlichen Instinkt': "Alle Lebewesen, die wir kennen, haben ihren Instinkt, der sie nicht tăuscht." Er nennt den Instinkt "die Stimme des Gewissens, durch die Gott sich uns zu exkennen gibt und zu uns spricht." 23

Tred. beschrănkt sich, der Démonstration folgend, auf das Faktum, von dem Fénelon ausführt: "Les animaux ont ce qu'on nome un instinct, pour s'appro- 
cher des objets utiles et pour fuir ceux qui peuvent leux nuire. Ne cherchons point en quoi consiste cet instinct; contenons-nous du simple fait, sans raisonner." (Démonstr., s.24f.)

Das instinkthafte Verhalten der Tiere wird an folgenden Bildern deutlich gemacht: Das Lamm láuft, so schnell es kann, zu seiner Schafmutter, sobald es sie von weitem erkennt. Das 'sanfte Schaf' wittert den sich năhernden Wolf. Die ganze Herde gerăt in Verwirrung und Furcht, fügt Tred. hinzu. Dem Hund genügt der Geruch, um das wild in seinen Verstecken aufzustöbern (III,339ff.) Die Beispiele hat Tred., abgesehen von der Bemerkung über die aufgeregte Herde (343f.), aus der Demonstration (S.25). Sie schildern vor allem, wie der Instinkt die Tiere in heftige Bewegung setzt. Anschaulich wird beschrieben, wie die Adern schwellen (wie von einem 'inneren Blasebalg aufgeblasen'), wie die Krăfte des Tieres wachsen, seine Bewegungen 'flink und feurig' und alle Glieder geschmeidig werden. Wie diese Verănderung zustande kommt, kann sich der Autor nicht erkláren:

III,347ff. Не вем какой в скоте мех мадувает жилы И умножает в нем невероятно силы, Проворным быть дает и резвым сей устав, И каждый в нем творит толь гибким он состав.

Fénelon bleibt bei der Mechanismus-Metapher und vergleicht deshalb den Instinkt mit einer 'ungestümem Triebfeder': "Il y a dans chaque animal un ressort impétueux qui rassemble tout a coup les esprits, qui tend les nerfs,... qui augmente d'une manière incroyable...la force, l'agilité, la vitesse..." (Démonstr., S.25)

Auf den Streit der Meinungen zwischen jenen, die den Tieren wegen ihres Instinktes auch Verstand zuerkennen und anderen, die ihnen sogar die Vorstellungskraft absprechen möchten, will sich Tred. nicht einlassen:

III,354ff. Tо много на сие хотя теряіт слов,

Которыи скотам иль смысл дать поспешарт,

Иль и мечтаний уж конечно их лишают;

Однак я не сужау за блато здесь вступать

В те тонкости и глубь бездоннуо копать.

Er hat den Standpunkt Fénelons eingenommen, der so formuliert: "Il n'est pas question ici de savoir si les betes ont de la connaissance: je ne pretends entrer en aucune question de philosophie." (Demonstr.,S.25) Fénelon begründet seine Auffassung, indem er zunăchst darauf hinweist, daß das Instinktver- 
halten der Tiere ohne Uberlegung ablauft und erinnert daran, daB solche 'unüberlegten Bewegungen' auch im 'menschlichen Mechanismus' vor sich gehen: "Les mouvements dont je parle sont entiêrement indélibêrés, même dans la machine de l'home." (Démonstr.,S.25) zur Illustration bringt Fénelon an dieser Stelle den Selltănzervergleich. Diese Gedanken verraten den EinfluB der 'Automatentheorie' Descartes'. Danach ist der Mensch das 'Compositum' eines organischen Automaten und einer substantiell mit ihm vereinigten Seele. Die anthropologische Theorie Descartes' wird von R.Specht so gekennzeichnet: "...zwischen menschlichem und tierischem Automaten / besteht $\underline{T}$ allein der unterschied, dab der eine mit einer seele substantiell vereinigt wird und der andere nicht." 24 In diesem Zusammenhang hat R.Specht auf Descartes' Entwurf einer magnetischen Seiltănzermaschine hingewiesen (Descartes, Cogitationes privatae $x, 231) .25$

Tred. stimmt mit Fénelon in der Auffassung überein, daB die Instinkthandlungen nicht aus Uberlegungen des Verstandes hervorgehen. Wo haben sie aber dann ihren Ursprung? In diesem Punkte weicht Tred. etwas von seiner Vorlage ab. Wăhrend die Antwort Fénelons von der Automatentheorie beeinflußt zu sein scheint, weist Tred. die Behauptung $a b$, die (instinktiven) Bewegungen seien rein korperlicher Art:

III,359f. Довольствуось сказать, что те́ла их обраты Не можно утвердить впрямь чести без утраты.

Er hat den Seiltanzervergleich zwar aus der Demonstration ubernomen, ihn aber in seinem sinne verwendet. Tred. erzăhlt: jemand tanzt auf einem Seil, die Stange in den Hănden. Da făngt ex an zu erklăren, was inn auf dem schwankenden Seil halt, auch wenn er sich dreht und wendet. Sein Reden reikt inn jedoch sofort ins unglück. Er verliert das Gleichgewicht und sturrzt kopfüber vom Seil:

III,361ff. На верви пляшет кто из нас в руках с шестом,

А станет говорить, толкуя сам о том,

Что держит там его на той веревке тряской,

Коль ни вертится он на ней различно пляской,

То вринет разговор тотчас его в напасть

И приведет на низ стремглав с нее упасть.

Für Tred. liegt der springende Punkt in folgendem: Wăren die Bewegungen des Seiltănzers nur kórperlicher Art, so kónnte inn das Sprechen nicht aus dem Gleichgewicht bringen. Die Bewegungen sind ja eingeubt und laufen mechanisch 
ab. Der Unfall beweist, daß die Schritte des Tănzers in jedem Augenblick von seiner Aufmerksamkeit begleitet werden müssen. Wird er abgelenkt, so fallt er vom Seil. - Abgesehen vom Inhalt,ist die Erzăhlweise reizvoll. Die volkstümliche Art ist dem Gleichnischarakter der Passage angepaBt. Fénelon hat das Gleichnis argumentierend entwickelt: "Si un homme qui danse sur la corde raisonnait sur les rêgles de l'equilibre qu'll garde merveilleusement sans raisonner, et sa raison ne lui servirait qu'a tomber par terre. Il en est de même des bêtes." (Démonstr., S.25)

In der năchsten Passage wendet sich Tred. gegen die Auffassung, die instinktiven Reaktionen der Tiere gingen aus verstandesmaBigen Uberlegungen hervor. In drei Konzessivsătzen nimmt er tatsăchlich vertretene oder fiktive Meinungen auf, labt sie scheinbar einen Augenblick gelten, um sie danach um so schărfer abzulehnen. Die Verse 367ff. zeigen diese Art des Argumentierens: "Mögen sie sagen, daß die Tiere wirklichen Verstand haben":

III,367 Пусть говорят, что скот смысл подлинншй имеет, "Mögen sie hartnăckig behaupten, die Tiere kennten die Regeln der Mechanik": III,371ff. Твераят пусть о скоте, что правила он знает Mеха́нически все и точно поступает По них во всем своем, по них его весь двиг, По них Бежит, пливет, по них вертится вмиг, Der Autor übertreibt absichtlich, um die These und ihre Vertreter unmöglich zu machen. Wieviele mechanische Regeln müBten dann von den Tieren beachtet werden! Alle Bewegungen eines Tieres, ob es läuft, schwimmt, sich versteckt oder sich wehrt, alles geht nach mechanischen Gesetzen vor sich. Sie alle sollte das Tier kennen und jeden Augenblick anwenden? "Wenn ich das hore, kann ich nur lachen", spottet der Autor:

III,377 Я, слшша всё сие, вот только что смехсь, -

Ironisch unterstellt er seinen Kontrahenten die Behauptung, die Tiere seien bessere Mathematiker als die Menschen:

III,379f. Хоть математик толь скот есть, пусть такме бают, Что столько сих наук ни лоди сами знарт, -

Schlieblich hălt Tred. denen, die behaupten, der Instinkt der Tiere sei vom Verstand gelenkt, entgegen, daß auch der Mensch hăufig spontan handelt, ohne vorher zu überlegen. Elner weiteren widerlegung bedarf es darum nicht:

III,387f. Кто момет смысл придать обратов тех началу, Korда ни в наших тень смисла видим малу? 
Die besprochene Versfolge unterscheidet sich von der Vorlage vor allem durch ihre rhetorisch-polemische Form. Fénelon hat gegen die These vom Verstand der Tiere so argumentiert: "Dites, si vous voulez, qu'elles raisonnent comme les hommes... Leur raisonnement ne peut jamais servir a expliquer les mouvements que nous admirons le plus en elles. Dira-t-on qu'elles savent les plus fines règies de la mécanique..? Dira-t-on qu'elles savent naturellement les mathematiques, que les hommes ignorent? Osera-t-on dire qu'elles font avec deliberation...tous ces mouvements si impetueux et si justes, que les hommes mêmes font sans étude et sans y penser?" (Démonstr.,s.25)

Wie steht es aber mit der Ansicht, die Tiere handelten ausschlieblich nach ihrem Instinkt? Die Anhănger dieser These sagen, bei den Tieren geschehe aus Instinkt das, wozu wir Menschen den Verstand notig haben:

\section{III,395f. На что ж рассудок нам, в скоте что без рассудка Так делается всё от одного побудка?}

Der Scharfsinn im Verhalten der Tiere sel ihm unbegreiflich, bestatigt der Autor, aber er verherrliche deswegen nicht die Tiere, die kein Denkvermogen haben. Alle Weisheit, die wir an den Tieren sehen, hat vielmehr ihre Ursache im Schopfer. So münden die Uberlegungen, ob das Verhalten der Tiere aus dem Verstand oder aus dem Instinkt hervorgehe, in dem Bekenntnis zum Schopfer, der alles weiB, voraussieht und lenkt:

\section{III,401ff. Конечно, тварей всех премудрость та в творие, Который знает всё, в преде что и в коние, И как бшвает что, и бшть чему есть можно, Всё зрит и правит всем всесильно и неложно.}

Darum ist der 'Instinkt', so schliebt Tred., ein blobes Wort ohne klaren Sinn. Er versteht den 'Instinkt' als die 'Kunst des Höchsten', die in den Tieren wirkt: III,409f. Ясняй, искусство ми всевшннего в скотах Побуаком можем звать, чем двимутся те в мах; Unsere menschliche Erfindungsgabe ist nur ein 'Schatten', gemessen an dem, was die Intelligenz des Schopfers in den Tieren hervorbringt:

III,411f. Наш вымысл есть тому ни тенио подобен; Тот разум крайний есть, ум мало наш удобен.

Tred. denkt vor allem an die große Zahl unwillkürlicher Bewegungen des Tieres, die wir mit dem Verstand aberhaupt nicht beqreifen konnen:

III,413 Невоьных мног есть ряд Авижений у скота; III,415 Притом мы двигов тех отнодь не постигаем; 
Tred. stützt sich auf die Ausführungen Fénelons über den Instinkt, die hier gekürzt zitiert werden: "C'est l'instinct, dira-t-on, qui conduit les betes... mais cet instinct est une sagacite et une dextérité admirables, non dans la bête,... mais dans la sagesse superieure qui la conduit...Qu'on ne parle donc plus d'instinct $n i$ de nature: ces noms ne sont que de beaux noms dans la bouche de ceux qui les prononcent. Il y a, dans ce qu'ils appellent nature et instinct, un art et une industrie superieure, dont l'invention humaine n'est que l'ombre. Ce qui est indubitable, c'est qu'il y a, dans les betes, une nombre prodigieux de mouvements entierement indeliberes, qui sont executés selon les plus fines règles de la mécanique. C'est la machine seule quí suit ces règles..." (Démonstr.,s.25f.) Fénelon unterstreicht, daB er diese Tatsache 'unabhăngig von aller Philosophie' verstehe. Vermutlich spielt ex dabei auf die Lehre Descartes' an, nach der die Tiere Automaten sind, deren Funktionen rein aus den Gesetzen der Mechanik und Dynamik exklart werden müssen. Descartes hat diese mechanistische Deutung, die von inm Jedoch nicht durchgăngig und undifferenziert vertreten worden ist, in dem 'Uhrengleichnis' veranschaulicht. 26 Es besagt: wie die Bewegung einer Uhr aus der Kraft, der Lage und Gestalt ihrer Gewichte und Räder hervorgeht, ebenso notwendig vollzieht sich die Bewegung der Organismen aus dex bloBen Anordnung der Organe. 27

Auch Fénelon hat zwar das Tier mit einer Uhr verglichen. Bei ihm 'sprengt' jedoch die von inm beschriebene Wirklichkeit des lebendigen Organismus diese Metapher. Was würde man von einer Uhr halten, so fragt er, "die zur rechten Zeit flieht, sich krümmt, sich verteidigt...Könnte man glauben, die Federn dieser Uhr hatten sich durch reinen zufall gebildet, angeordnet und vereinigt?" Sein Uhrengleichnis zielt ab auf die Bewunderung des Schopfers: "N'admirerait-on pas l'art de l'ouvier?" (Demonstr.,S.26)

In derselben Absicht hat Tred. das Stichwort 'mexанисм' (III,418) aufgegriffen, um sofort festzustellen, daB es das Rătsel des lebendigen Organismus nicht erklăren kann. Sicherlich sehen wir in den Tieren einen 'vollkommenen Mechanismus', sagt Tred., aber wer hat ihn denn zuerst in Bewegung gesetzt? Tred. benutzt die Metapher 'mex'(418), 'Blasebalg', der wie bei einer orgel in den Mechanismus 'hineinblast':

III,417ff. Однак зрим механисм мы совершенный в тех, Но в механисм какой сначала дует мех, То первейшей вины, кроме твориа, не знар, - 
Aus dem Bekenntnis zum Schōpfer erwăchst die Doxologie, in der die alleinige wirksamkeit Gottes gepriesen wird:

III,421ff. Бог вещи сотворил, бог Авиги впечатлел, Eог, положив устав, вранаться повелел,

В двимении хранит и вещи управляет.

Dem philosophischen Gottesbegriff der 'prima causa' (419) werden die konkreten Züge des Schópferglaubens beigelegt. Gott wird gepriesen, indem seine Taten genannt werden. Das Pathos liegt hier im Inhalt, nicht in der Form.

Durch die Alleinwirksamkeit Gottes werden aber die sogenannten 'Zweitursachen' nicht ausgeschlossen. Der Begriff hat in der Philosophie der Occasionalisten, deren wichtigste Vertreter Malebranche und Geulincx waren, zentrale Bedeutung. Als 'Zweitursachen' verstanden sie die Naturgesetze und die occasionellen ursachen, die zum Weltplan der Vorsehung gehoren, "der den Ablauf aller Ereignisse von Ewigkeit her geordnet hat. " ${ }^{28}$ Tred. verdeutlicht das Verhăltnis zwischen der 'Erstursache'(Gott) und den 'Zweitursachen' mit einem für seine russischen zeitgenossen einleuchtenden Vergleich: Gott ist der 'Selbstherrscher', sie sind seine 'Untertanen':

III,424ff. ОАнак сие вторых причин не отдаляет:

Самодержавный Он, второе всё есть раб;

Источник всех он сил, им подданный не слаб;

In der durch die Lehre Descartes' ausgelosten Diskussion über die Tierseele wendet sich Tred. gegen zwei Seiten. Die eine versteht die Tiere als reine Automaten, die andere schreibt ihnen einen Verstand $z u$, der dem menschlichen mindestens ebenbürtig ist:

III,429f. Простых махин я действ хоть не даю скотам, Но сходственна ума им с нашим не придам; -

Das Tier kennt nur einzelne Dinge, sagt Tred. Es besitzt auch Vorstellungskraft. Aber es ist nicht imstande, aus dem einzelnen Allgemeinbegriffe zu bilden, weil es nicht abstrakt denken kann. Es fehlt dem Tier 'reine Vernunft III,431ff. Единственное скот хотя и познавает,

K повсемству $*$ от того отнодь не отвлекает;

Понятий сила есть от вображений в нем,

Разумности той нет, что чистою зовем.

Die Auffassung Tred.s wird aberraschenderweise durch eine AuBerung I.Kants bestatigt, der den Unterschied zwischen dem reflektierenden Bewubtsein des Menschen und dem vorreflexiven BewuBtsein des Tieres einmal an einem plasti- 
schen Beispiel so erklărt hat: "Demnach wenn ein Wesen urteilen kann, so hat es die obere Erkenntniskraft. Findet man Ursache, ihm diese letztere abzusprechen, so vermag es auch nicht zu urteilen. Die Verabsăumung solcher Betrachtungen hat einen berühmten Gelehrten veranlaßt, den Tieren deutliche Begriffe zuzugestehen. Ein Ochs, heiBt es, hat in seiner Vorstellung vom stalle doch auch eine klare Vorstellung von seinem Merkmale, der Türe, also einen deutlichen Begriff vom Stalle. Es ist leicht, hier eine Verwirrung zu verhüten. Nicht darin besteht die Deutlichkeit eines Begriffs, daß dasjenige, was ein Merkmal vom Dinge ist, klar vorgestellt werde, sondern daB es als ein Merkmal des Dinges erkannt werde. Die Tủre ist zwar etwas zum Stalle Gehöriges und kann zum Merkmal desselben dienen, aber nur derjenige, der das Urteil abfaBt: diese Tur gehört zu diesem Stalle, hat einen deutlichen Begriff von dem Gebăude, und dieses ist sicher über dem Vermögen des viehes." 29

An der Automatentheorie Descartes' kritisiert Tred. vor allem, daB behauptet wird, die Tiere seien 'reine' Automaten, nichts als Automaten. DaB es zwischen Mensch und Tier, was den organismus betrifft, auch viel Gemeinsames gibt, steht außer Frage. So benutzt Tred. das Bild 'махина' (435), ăhnlich wie Fénelon das 'Uhrengleichnis' als eine Art 'Sprengmetapher': Die mannigfachen Verhaltensweisen eines Tieres lassen erkennen, da $B$ es unangemessen ist, von einem 'einfachen Automaten' zu sprechen:

\section{III,435ff. Hе знаю как, скоты не просто, но махина, \\ С какоо наших дел несходна ни едина, - \\ Сама собол та стоит, идет, бежит, \\ Таится, глас дает, боронится, лежит; \\ Та нравится собой и делает исправно, \\ Собо10 та себя живит и кормом равно. -}

Die Ahnlichkeit dieser Versreihe mit dem 'Uhrengleichnis' Fénelons ist augenfällig. Unsere Autoren unterscheiden deutlich zwischen dem 'Automatismus' im Bereich des Organischen und dem artefaktischen 'Mechanismus', einen Unterschied, den Descartes, gehindert durch seinen fundamentalontologischen Dualismus, mit dem die Wirklichkeit in res cogitantes und res extensae aufgeteilt wurde, nicht wahrgenommen hat. 30

III, 441-520 handeln von der Fāhigkeit des tierischen organismus, sich durch Nahrung und Schlaf zu erneuern.

Der neue Abschnitt ist mit dem vorhergehenden durch Assoziation verknüpft. 
Das Stichwort gibt die Bemerkung, daB das Tier (im Unterschied zur Maschine) sich selbst durch das Futter kraftigen kann (440). Nun wird beschrieben, wie der tierische Organismus diese erstaunliche Erneuerung tăglich vollbringt. Der Autor schildert die einzelnen Momente des Vorganges: Von der schweren Arbeit des Tages ist das Tier schwach und trăge geworden. Nun darf es sich satt fressen. Das Futter gibt inm die verlorene kraft zurück:

III,445ff. Отягощенну толь работоо всяк день,

Что прмдет от того в расслабшуо он лень,

Потеряннуо корм вси силу возвращает

И всо утробу в нем довольно насьщает, -

Ahnlich hat Tred. dies in der Démonstration gelesen: "L'animal, borné dans ses forces, s'épuise bientot par le travail; mais plus 11 travaille, plus il se sent pressé de se dédommager de son travail par une abondante nourriture. Les aliments lui rendent chaque jour la force qu'il a perdue." (S.26)

Darauf wird der VerdauungsprozeB geschildert, wie man sich inn im 18.Jahrhundert dachte: Der Saft von der verdauten Nahrung wird vom Groben getrennt, dringt in die Adern ein, wo er sich in Blut verwandelt. Dieses fliebt durch unzăhlige GefaBe und belebt alle organe:

III,451f. В них претворяясь в кровь, а в разныи сосуды,

В бесчисленныи ж те, вхояя, живит все уаш.

Von dort lauft es durch den ganzen korper, wird dick und nimmt das Aussehen von Fleisch an:

$$
\begin{aligned}
& \text { III,453E. Оттуау исхояя, по телу уж течет, } \\
& \text { Сгустевши, там себе вия плоти привлечет. }
\end{aligned}
$$

Die Assimilierung der Nahrung wird in der Demonstration so dargestellt: "... (elle) se change en une espèce de liqueur; puis elle se purifie, come si on la passait par un tamis pour en séparer tout ce qui est trop grossier; ...elle se subtilise et devient du sang: enfin elle coule et s'insinue par des rameaux innombrables, pour arroser tous les membres;...elle devient chair elle-merme..." (S.26f.)

In Verbindung damit kommen unsere Autoren auf das Phănomen der Metamorphose zu sprechen, das ihnen wunderbar erscheint. Das 'leblose Futter', das dem Tiere Tag für Tag frische kraft gibt, verwandelt sich in ein lebendiges Wesen:

III,457ff. Бездушный оный корм, кой разно прегорит, Хивотное что Аень СОбой животворит; Потом бывает он и сам уж сим животным,- 
Fénelon schreibt: "L'aliment, qui était un corps inanimé, entretient la vie de l'animal, et devient l'animal même." (Demonstr.,S.27) Er nennt diesen Vorgang "une espéce de métamorphose". (S.26)

Was unsere Autoren meinen, machen sie an einem Beispiel deutlich: Tred. sagt, "was vor vier Jahren ein Pferd war, hat sich in Dampf und Rauch verwandelt, und was einst Heu, Hafer oder Gerste war, ist heute ein gutes Pferd, das sich den Sporen des Reiters nicht widersetzt." Der 'неnрестанный круг' (II,211) wiederholt sich hier auf einer anderen Ebene:

III,463ff. Что пред чети́рьмя был конь некий где годами,

То стало пар и чад нечувственно менами,

Но сено было что, овес или ячмень,

То оный добрый конь, по сей который день, -

Fenelon hat das Beispiel so beschrieben: "Ce qui était, il y a quatre ans, un tel cheval, n'est plus que de l'air ou du fumier. Ce qui était alors du foin et de l'avoine est devenu ce meme cheval..." (Démonstr.,s.27)

Die andere Quelle der Erneuerung des Organismus ist der Schlaf:

III,469f. От пищи повсегда есть неотлучен сон:

Привременный покой в животном каждом он.

In der Démonstration beginnt das neue Thema mit dem Satz: "À la nourriture se joint le sommeil." (S.27)

wăhrend des Schlafes hören die außeren Bewegungen auf, heiBt es in der Feoptija weiter, und die 'krăfte innen', d.h. die Organfunktionen, sind gemindert. Allein die Atmung bleibt, alles andere 'sinkt gleichsam zu Boden'. Die Metapher drückt aus, daß die Ruhelage des Organismus der Lage des Schlafenden entspricht:

III,473f. Hо остается в мем дыхание одно, Аругое жизни всё как падает на Ано.

Fenelon hebt hervor, daB außer der Atmung auch die Verdauung wăhrend des Schlafes weitergeht, weil sie der Erneuerung der Krăte dient. Nur die Funktionen sind unterbrochen, die Kraft kosten: "Il ne lui reste que la respiration et la digestion: c'est a dire que tout mouvement qui userait ses forces est suspendu, et que tout mouvement propre a les renouveler s'exerce seul et librement." (Démonstr.,S.27)

Eigens wird erwăhnt, daß das Schlafbedürfnis der Tiere in die zeit der năchtlichen Dunkelheit făllt. Dann können sie sowieso nicht arbeiten und 'auf dem Felde umhertraben': 
III,478ff. Хивотному затем и нужно есть уснуть,

Как в темноте номной нельзя уже работать,

Ни рыца взад и епред копнтом в поле ботать.

Tred. hat hier den Text der Demonstration anschaulich erweitert. In der Vorlage heiBt es: "Ce repos, qui est une espece d'enchantement, revient toutes les nuits, pendant que les ténèbres empechent le travail." (S.27) Unsere Autoren halten es nicht für selbstverstăndlich, daB Schlaf und Dunkelheit zusammenfallen, sondern sehen auch darin eine sinnvolle ordnung. Der Schöpfer hat das Bedürfnis der Geschópfe und die außeren Naturexscheinungen einander zugeordnet. Diese Auffassung spricht aus der 'wer'-Frage: III,481f. Промежки сии кто ж уставил в точный час, Не Аля одних скотов, но купно и Аля нас, -? Von der Wohltat der Nacht für Mensch und Tier war schon in II,646ff. die Rede. Der Wechsel von Tag und Nacht ist die 'munderbare Ordnung' (Чин Аивный, II,632), die an den Schöpfungssegen cottes nach der Sintflut erinnert:

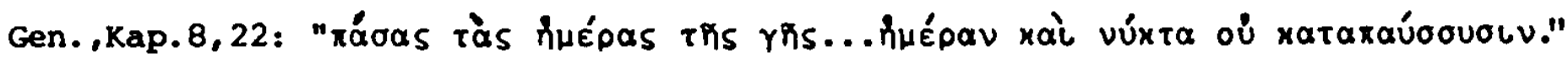

Das zitierte Verspaar 481f. mit der rhetorischen Frage 'wer hat diese Pausen angeordnet' geht auf die Démonstration zurück: "Qui est-ce qui a inventé cette suspension?" (S.27) Dort folgen zwel weitere mit 'qui est-ce qui' eingeleitete rhetorische Fragen, die Tred. ausgelassen hat.

Die in beiden Texten hăufig vorkommenden 'wex'-Fxagen scheinen auf biblisches Vorbild hinzuweisen. Im Buche Hiob, Kap. 38 gibt es eine Reihe solcher Fragen:

(2) "Tús oưtos 8 xpúxtwv he Boùńv,

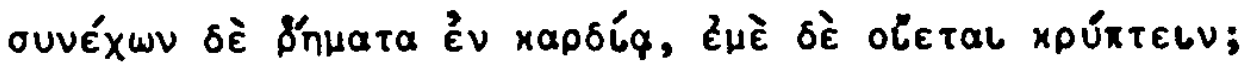

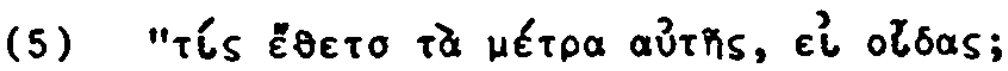

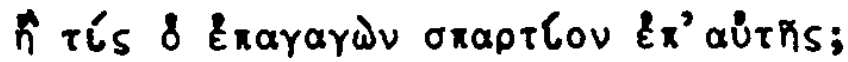

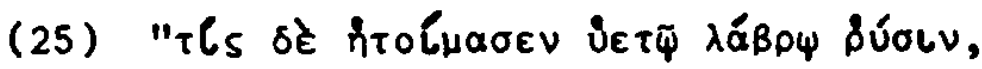

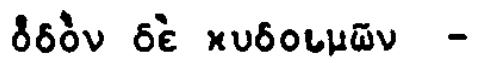

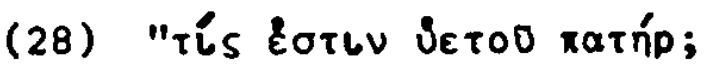

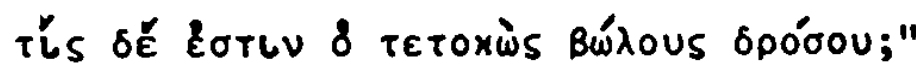

In III, 485-492 schildert Tred. anschaulich das Erwachen von Mensch und Tier, 'wenn die Morgenrote Ihren Glanz ausgieBt':

III,485f. Потом, как пролиет заря свой яркий блеск,

Встает и человек, и камдий скот, и меск.

Dieses Verspaar hat in der Démonstration keine Parallele. 
'Vergessen sind alle Mühen', Die Kraft hat sich erneuert. Dann arbeiten die Tiere wieder so, als sei es zum ersten Mal:

III,489f. Работают опять мивотные тогда,

И толь, что как работ не знали никогда, -

Ihr Arbeitseifer wird sichtbar an den 'gespannten Sehnen' und der 'gestrafften Haut', die sich, wie es scheint, noch 'an keiner Last aufgerieben hat':

III,491f. Все жилы напряглись, еся кожа распростерлась

И буято никаким та бременем не терлась.

Mit diesen Versen hat Tred. den folgenden Text der Vorlage wiedergegeben:

"Le lendemain, toutes les fatigues passées sont comme anéanties. L'animal travaille comme s'il n'avait jamais travaille...Par ce renouvellement, les nerfs sont toujours pleins d'esprits, les chairs sont souples, la peau demeure entière, quoiqu'elle dot, ce semble, s'user." (Démonstr.,s.27)

Der lebendige Organismus hat -das unterscheidet inn von der toten Materiedie Fähigkeit, sich immer wieder zu erneuern. Das wird an zwei Beispielen deutlich: Ein Reiter nutzt viele sattel ab, ohne das Fell des Pferdes zu beschădigen. Ein knabe trăgt manchen Anzug auf, bis er erwachsen ist:

III,497ff. Кзъездит много сеял на конской коже в век

И всадник И в пути кой часто человек.

И отрок не ояно всяк платьиче износит,

Пока еще себя до меры роста взносит.

Die Beispiele sind, wenig verăndert, aus der Demonstration übernommen worden: "La peau d'un cheval use plusieurs selles. La chair d'un enfant, quoique si tendre et si délicate, use beaucoup d'habits, pendant qu'elle se fortifie tous les jours." (S.27f.)

Tred. ist von der tăglich sich wiederholenden Erneuerung der Krăfte eines Tieres durch Nahrung und Schlaf so begeistert, daB er sich zu der Behauptung verstiegen hat, gabe es 'vollkommenes Futter', so würde das Tier dadurch die Unsterblickeit und ewige Jugend bekommen:

III,501ff. Korяа 6 свершеннй корм нашел себе в жизнь скот, Tо mor бы получить бессмертие чрез тот

$И$ получил бы тем и вечную он младость, -

Dies ist naturlich poetischer Uberschwang, der z.T. durch die Vorlage veranlabt worden ist. Dort ist zwar nicht an 'volkomenes Futter', aber an eine ebenso irreale 'vollkommene Erneuerung' gedacht: "Si ce renouvellement était parfait, ce serait l'immortalite et le don d'une jeunesse éternelle." 
Fênelon făhrt fort: "Mais come ce renouvellement $n$ 'est qu'imparfait, l'animal perd insensiblement ses forces et vieillit...." (Demonstr.,s.28)

DaB ein Tier allmahlich seine Krafte verliert und alt wird, liegt nach Tred.s Meinung daran, daB es auf Exden nur 'unvollkommene Nahrung' gibt:

III,505ff. Но пища вся его несовершенна здесь,

Затем помалу он и гибнет, тлея весь;

Лишается не вдруг своих сил и ветшает; -

Nach allgemeinem Gesetz muB alles Geschaffene das Zeichen der Unvollkommenheit an sich haben und darum zu Ende gehen, erklärt Tred. Er fügt einschrănkend hinzu, dies gelte fưr das einzelne Lebewesen, Jedoch nicht für die Art:

III,509ff. Всё, что созданно есть в своей природе как,

Несовершенств иметь то долюенствует знак,

А истлевая, с тем скончать свор и бытность,

Особой приходить, не родом всем, в забытность.

Dies allgemeine Gesetz hat Fénelon so formuliert: "...tout ce qui est créé doit porter la marque du néant d'ou il est sorti, et avoir une fin." (S.28)

In III,513-520 folgt in der Feoptija eine Digression uber die alleinige Vollkommenheit des Schöpfers.

Das Attribut der Vollkommenheit eignet ausschlieBlich dem Schopfer und schließt eben dadurch die Geschopfe davon aus:

III,513f. Един всесовершен создатель есть всему: Не можно совершенств иметь всех ничему.

Die Geschöpfe haben aber in verschiedenem Grade an der Vollkommenheit Anteil: III,515 Мы в совершенствах зрим степени различны, -

Hier wird die Vorstellung von einer stufenleiter der Geschopfe angedeutet, wie sie von A.Pope in 'Essay on Man', Ep.I,207ff. beschrieben wird:

"Far as Creation's ample range extends,

The scale of sensual, mental pow'rs ascend:

Mark how it mounts, to Man's imperial race,

From the green myriads in the peopled grass."

DaB der Schöpfer keinem Geschöpf die höchste Vollkomenheit beilegen konnte, leuchtet unmittelbar ein, meint Tred. Ein 'vollkommenes Geschópf' wăre ein widerspruch in sich selbst. Dieses Argument ist aus der Theodizee Leibnizens bekannt, in der aus dem Begriff des Geschópfes, zu dem die Endlichkeit gehort, mit $\log i s c h e r$ Notwendigkeit auch dessen Unvollkommenheit abgeleitet wird: ${ }^{31}$ 
III,517ff. Но крайнейших не мог зимяитель им подать,

Легко возможно мам умом то понимать,

Чтоб камдой вдруг иметь все совершенства, пречно;

Быть должно одному такому всеконечно.

Der Abschnitt III,521-760 erortert das Thema: die Fortpflanzung der Tiere. Im vorhergehenden wurde festgestellt, daB zwar das einzelne Tier stirbt, die Art jedoch bleibt (512). Die Betrachtungen des neuen Abschnitts knūpfen daran an. Es veranlaBt unsere Autoren zum Staunen, daB die Tiere ihre Art nicht nur erhalten, sondern sie sogar vermehren:

III,521f. Коль Аивно как скоты свой умножают род!

И умножаясь, так мир полнят те чрез плоя!

Fénelon: "Qu'y a-t-il plus admirable que la multiplication des animaux?" (S.28) Noch einmal wird festgehalten, daß jedes Tier stirbt. Tred. drückt es volkstủmlich aus: 'sein ganzer Mechanismus wird aufgelöst'. Das Verb 'peшиться uero' bedeutet nach Pawlowskij 'etw. einbüBen, einer Sache verlustig gehen' (S.1432) und wird als volkstümlicher Ausdruck gekennzeichnet. Die Vermengung von 'hohem' und 'niederem' stil ist für Tred. im Unterschied zu Lomonosov kein Tabu. Er sagt:

III,523f. Бессмертна, знаем, нет ни одного животна, Решится вся его махи́на, коль ни плотна.

Fénelon stellt die Endlichkeit des Einzelwesens und die Dauer der Art in deutlichen Gegensatz zueinander: "Regardez les indivus; nul animal est immortel... tout est anéanti. Regardez les espèces; tout subsiste, tout est permanent..." (Démonstr.,S.28) Tred. weist erlăuternd darauf hin, daß doppelt soviele Tiere, oder noch mehr, geboren werden als sterben:

III,527f. Ромдается уже на паяших место двое,

Иль большее иисло родится, неж мрет кое:

Er deutet dies als ein Zeichen der Füsorge des Schopfers für die ganze Natur:

III,529f. Строения нам знак не ясно ль подан сей?

Печется некто варуг тем О природе всей.

Im folgenden wendet sich Tred. in Ubereinstimmung mit der Démonstration gegen die Theorie, die verschiedenen Arten der Tiere seien durch Zufall entstanden. Wenn es so wăre, hăte irgendwann die Entstehung einer Art vom Menschen beobachtet werden müssen. Un die Zufallsthese zu entkrăften erwidert Tred.: Ist denn seit den altesten Zeiten, 'nочти с начала света', seit es uberhaupt menschliche WiBbegierde gibt, ist wohl jemals beobachtet worden, daB 
ein Tiger, Lowe, Hund, Pferd oder Esel durch Zufall auf die Welt gekommen ist? Vielmehr ist Jedes Tier, auch der Mensch, von seinen Eltern geboren worden. Tred. fabt zusamen:

\section{III,535ff. H, словом, никаких скотов, ни человека Не видано нитде и никотда от века, Чтоб произшел какой припадком в свет из них, А не ромден бш тот от сродних был своих; -}

Die Stelle entspricht den Ausführungen Fenelons: "Depuis qu'il y a sur la terre des hommes soigneux de conserver la mémoire des faits, on n'a va ni 1ion, ni tigre, ni sanglier, ni ours se former par hasard...Chacun de ces animaux doit sa naissance a un certain male et une certaine femelle de son espèce." (Démonstr., S.28)

In III,539-608 folgen Betrachtungen, die nicht von Fénelon abhångig sind. Zu Anfang reflektiert der Autor über die Tatsache, daB alle Lebewesen, Tiere wie Menschen, durch Zeugung und Geburt zur Welt kommen. Von diesem Naturgesetz sind nur die ersten Geschopfe, die Primaten einer jeden Art, ausgenommen. Sie sind von der 'ersten Ursache' geschaffen worden:

III,539f. Из коих, первых всех мивотншх, выклочао

От первой тех винш созданншх заклочар.

Die Nachkommen jener 'ersten', ebenso die 'mittleren', d.h. die jetzt Lebenden,und auch die 'letzten' unterstehen dem Gesetz von Zeugung und Geburt:

III,543f. Tак и послеяни все от парш породятся;

Так средни на земле, не и́нако, плодятся.

Die Frage, woher die ersten Geschopfe jeder Art kommen, hat Tred. mit der Lehre der Bibel beantwortet: Gott hat sie geschaffen. Ist in der Folgezeit das Naturgesetz an die Stelle des Schópfers getreten? Davon kann keine Rede sein, denn das Naturgesetz ist nur ein Mittel in der Hand der Vorsehung:

III,545f. 0 cnoco6e я сем когда здесь roвopw,

То промшсл я такой в нем самом ясно зри, -

Der Schopfungsglaube wird durch das Gesetz der Geburten nicht aufgehoben, sondern modifiziert und im sinne der 'creatio continua' rational interpretiert. Mit unduldsamer Schărfe verurteilt Trod. die Andersdenkenden: sie müssen 'verblendet und für immer un den Verstand gebracht sein':

III,547f. Что оного не зреть - бить должно ослепленну И всеконечно уж вовек обезумленну. 
III,549-608 enthălt einen Hymnus auf die Liebe.

Schon bei den Tieren lassen sich Zeugung und Geburt nicht allein biologisch erklaren. Tred. hebt hervor, daB z.B. Lowin und Lowe sich aus zuneigung paaren und ein Junges zur Welt bringen:

III,549ff. Чтоб скимну выйти в свет, без львицы и без льва

Не можно, АОлг, чтОб те соединились Ава

Взаимно в сильной той внутрь склонности аруг к аругу, Weiter fragt der Autor: was bewegt die Tiere, für ihr Junges solche Mine auf sich zu nehmen?

III,553ff. Что ж преклоняет львов, для оного плода,

В спряжении своем K поднятио труда,

Который обоим как тягостен не мнится,

Так зельно та к тому чета еще стремится?

Die Frage leitet einen Hymnus ein, in dem die Liebe der Geschlechter, d.h. der Eros (557-64), die Agape (565-74), die Liebe als Weltharmonie (575-80) und die Elternliebe (591-608) in teilweise enthusiastischen versen und beziehungsreichen Metaphern gepriesen wird. Der Hymnus wird durch eine Passage unterbrochen (581-90), in der die pervertierte und die vollkommene Liebe einander gegenübergestellt werden.

Was für eine 'reiche Gabe' ist das, die in den beiden Geschlechtern 'das Feuer füreinander entzündet'?

III,557f. Какой тот полам деум толь пребогатый дар, Кой вспламеняет так К собщению в них жар?

Die Antwort, 'es ist die Liebe', ist so inhaltreich, daB der Autor sie mit vielen Metaphern ausschmückt. Die Liebe ist 'ein himmlischer Magnet', der die Herzen zueinander hin zieht, sagt Tred. mit einer dem physikalischen Bereich entlehnten Metapher. Sie ist ein 'aufrichtiger Bund', nicht allein für uns Menschen, sondern für alle Geschöpfe. Obwohl bisher nur von den Tieren die Rede war, hat der Autor in seinem Hymnus zugleich an den Menschen gedacht. Andererseits beleuchtet es seine Einstellung zu den Tieren, daB er sie unbedenklich dem Menschen an die Seite stellt und sie der 'Zuneigung und Liebe zueinander' für făhig hält:

III,559f. Взаимна то гобовь, магнит сердец небесний, Не нас ояних, всего что тварь, союз нелестный.

Mit einer Metapher, die den für das Denken Descartes' zentralen Begriff der Bewegung überbietet, nennt Tred. die Liebe 'Mutter und ziel der Bewegung'. 
Sie ist 'der Saft der ganzen Natur', das 'Leben', die 'Schönheit' und 'die Blüte der Schónheit' :

III,561f. Авижений мать и чель, всея природы сок, И жизнь, и красота, И красоты цветок.

Alle Geschobfe empfinden die 'unvergăngliche SuBe' der Liebe. Für den Menschen bedeutet sie 'unaussprechliche Freude':

III,563f. Всегдашняя жившх и их нетленна сладость;

Разумншх здесь чинов неизреченна радость.

In einer weiteren 'Strophe' wird die Liebe als ethische Macht gepriesen. Sie lberredet uns zum 'Ehrbaren und Guten'. Sie gibt uns innere Ruhe und will, daB wir Frieden halten:

III,565f. Вина клоняща нас и к чести и к Аобру, Дахиа нам покой, веляща быть в миру, -

Sie heilt das 'Gift der Feindschaft' und stiftet Eintracht. Sie ist voller Sanftmut und hat nichts Boses vor:

III.567f. Целяща яА вражды, К согласио ведуиа, Вся тихости полна, зла лота не имуща, -

Die Liebe macht die Schwachen mutig. Sie trostet in der Trauer. Sie laßt uns Mitleid empfinden mit allen, die in Not sind:

III,569f. Бодряща слабых та, а тешаща в печали, По беяствуощих всех нас приводяща в жали.

Sie macht, daß unser irdisches Leben nicht langweilig, sondern vollkommen glücklich wird:

III,571f. Та делает всо жизнь здесь Аольнуо не скучну

И совершенно всо ее благополучну; -

Die Liebe ist der 'Năhrboden der Freihelt und aller Weishe1t'. Ohne sie ist die Güte ein 'Nichts, ein Schatten':

III,573f. Грунт вольности она, грунт мудрости всея, Не сущее, но тень добро́та без нея.

Die ganze Passage scheint in Inhalt und Stil vom 13.Kapitel des I.Korintherbriefes des Apostels Paulus inspiriert worden zu sein. Wie in I.Kor.Kap.13 wird die Agape mit einfachen Worten in kurzen Satzen gepriesen. Sie wird nicht definiert, sondern personifiziert und handelnd vorgestellt. Die Verbalformen beherrschen die Passage: die Liebe 'gibt, befiehlt, heilt, führt, ermutigt und tröstet'.

In der Feoptija wie im I.Kor.13 ist die 'Agape' gemeint, d.h. die Liebe, die 
im Unterschied zum vorher geschilderten 'Eros', nichts für sich selber will.

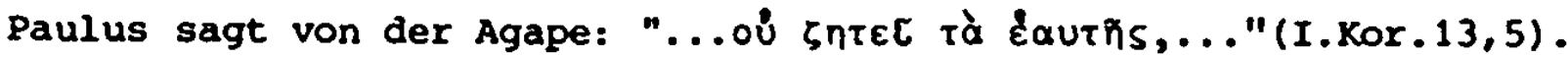

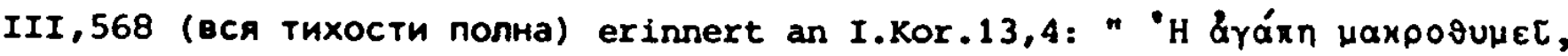

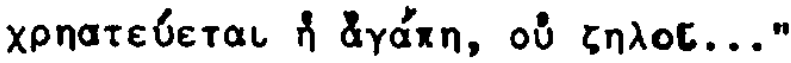

In III,574 (не сущее, но тень доброта 6ез нея) scheint I.Kor.13,3 anzuklin-

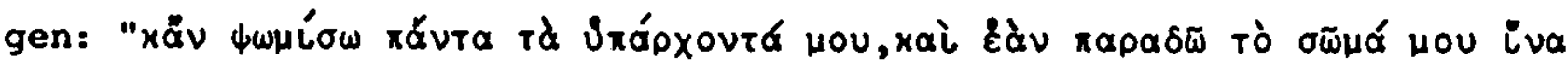

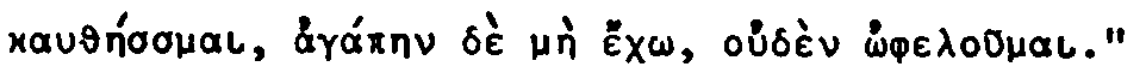

Der Apostel Paulus beschreibt in I.Kor.13 die Liebe, mit der sich Jesus Christus den Mühseligen und Beladenen zugewandt hat. Das 'Ermutigen der Schwachen', das 'Trósten der Betrübten' und das 'Erbarmen wit denen, die in Not sind', gehort zum Kern des Evangeliums.

Die Verse III,575ff. handeln von der universalen Kraft, 'die die Welt im Innersten zusammenhălt'. Sie ist von den Großen der Geistesgeschichte mit verschiedenen Namen benannt worden: Plato nannte sie 'Weltseele', Newton 'Gravitation', Descartes 'Bewegung', In derselben Reihe wird auch die 'Kette' als Symbol der Weltkraft angegeben. Es ist $z$ vermuten, daB Tred. damit 'the chain of being' gemeint hat, die ex aus A.Popes 'Essay on Man' kannte. Wie zu III,239ff. ausgefürt wurde, hat das Bild der 'Kette' im 'Essay' eine doppelte Bedeutung: als 'Chiffre für das Kontinuum der Existenzformen' (B.Fabian) und "als dichterisches Symbol für die physikalische Kraft,... als Chiffre für die Gravitation". 32 wie der Kontext zeigt, hat Tred. in III,576 die 'uenь вещей' als Symbol der das Weltall zusammenhaltenden Kraft verstanden. Mag diese Kraft von den Autoritaten verschiedener Zeiten unterschiedliche Namen erhalten haben, ich meine, sagt Tred., die Liebe hălt die Welt zusammen. Sie ist die Kraft, die von den großen Denkern letzten Endes gemeint war. Sie bringt die Harmonie und den Zusammenhang aller Wesen zustande:

III,575ff. Конечно, мнится мне, лобовь то назнвают, Которуо вещей цепь тверау признавают, Подвижностьо - Декарт, влечением - Невтон,

А естества душой превелией - Платон.

In einer FuBnote erwăhnt Tred. noch die Anschauung der 'Chaldăer' von der 'Sympathie zwischen himmlischen und irdischen Körpern', die seine Auffassung zu bestatigen scheint: "Халдеи содержали, что есть симпатия мехау небесними и земными вещами. " 33

Tred. unterstreicht noch einmal, daB er die 'vollkommene' Liebe im sinn hat, 
die allen Lebewesen zum gemeinsamen Glück 'eingepflanzt' ist:

III,587f. 0 той я говорю, есть коя совершенство,

Всажяенное в живых на ошиее блаженство.

Im Gegensatz zu dieser Schöpfungsgabe steht die 'zuchtlose Liebe', die als 'Frucht dex Sünde' gekennzeichnet wird:

III,589 Бесчинная лобовь есть беззаконий плоя, -

Sie ist, losgelöst von der schöpfungsmäBigen Bestimmung, nichts als 'Feuex und verzehrende Leidenschaft':

III,590 Та огнь есть, страсть палить, не семя множить роА. An der Pervertierung der Liebe ist der 'schlechte Charakter' schuld. Gibt es überhaupt etwas Gutes, das ein schlechter Charakter nicht verdirbt und vergiftet, fragt der Autor:

III,583f. Нрав коего Аобра во зло не превращает?

Отравн нрав своей чему злый не собщает?

In diesem Zusammenhang kritisiert Tred. eine gewisse Dichtung, in der die von ihm gerühmte 'Himmelstochter' als 'fleischliche Liebe', voller Unreinheit und Begierden dargestellt wird:

III,585f. И в басне есть моя небесна дщерь побовь

Плотска́я, нечистот и похотений, кровь.

Eine asketische Tendenz liegt wohl nicht in dex Absicht des Autors. Dagegen spricht seine positive Bewertung der Gattenliebe in III,557f. Er verurteilt vielmehr den sexuellen Libertinismus, dem die personale Beziehung fehlt. Die 'reine Liebe' hingegen umschließt das gemeinsame Liebesglūck, die Zeugung neuen Lebens und die liebevolle Sorge für das Neugeborene. Das Glück der Individuen und die im Schöpfungsplan vorgesehene Fortdauer des Lebens gehen gleichermaßen aus der Liebe hervor. Wie soll man diese wunderbare Ubereinstimmung erklăren? Dem Autor ist sie ein sicherer Hinweis, daB die Liebe vom Schöpfer den Geschöpfen 'eingeflöBt' worden ist:

III,593ff. Не ясно ль вияим мы в сем промысл от твориа, Что воАрузил пюбовь животных Он в серАца? Не токмо ж аля того, взаимно 6 им любиться, Еаинственно или чтоб тьмами расплодиться, Но купно, чтОб и плод рОжденный тот побить, Родившей кой еще млеко́м долг воздоить.

Einen ahnlichen Gedanken hat A.Pope im 'Essay on Man', Ep.III,119ff. ausgeführt. Die Stelle könnte Tred. angeregt haben: 
Ep.III,119ff. "Not Man alone, but all that roam the wood, or wing the sky, or roll along the flood, Each loves itself, but not itself alone, Each sex desires alike, 'till two are one. Nor ends the pleasure with the fierce embrace; They love themselves, a third time, in their race.

Thus beast and bird their common charge attend, The mothers nurse it, and the sires defend.

Der letzte Absatz des Hymnus, Feoptija III,599-608, handelt von der elterlichen Liebe.

In einem zehn Zeilen umfassenden Ausrufungssatz rühmt der Autor die eifrige, herzliche und barmherzige Liebe der Eltern zur Frucht 'der Lenden und des Leibes':

\section{III,599ff. А что $* 6$ бы описать родительску усераность \\ И всю горячесть их, и всю их милосераность \\ К рожвенному от чресл и От утроб плоду, \\ Кой получат они в свою себе чреду, -}

Die Wendung 'от upecת $n$ от yтро6' ist offenbar biblischer Herkunft. In der Septuaginta hat '\&opús' die Bedeutung von russ. 'upecra'. 'Oopús in der Bedeutung "Lende als Ausgangsort der Zeugung" ist ein "nur in LXX und in Abhăngigkeit von ihr im NT nachweisbarer sprachgebrauch." 34 Als Belegstellen seien genannt:

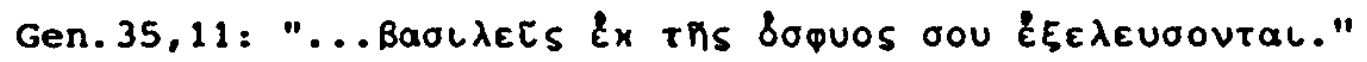

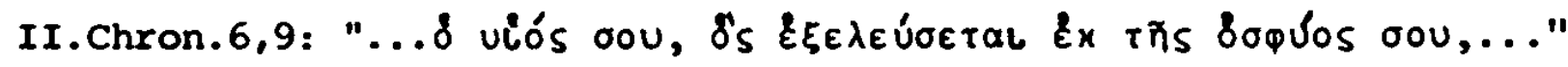

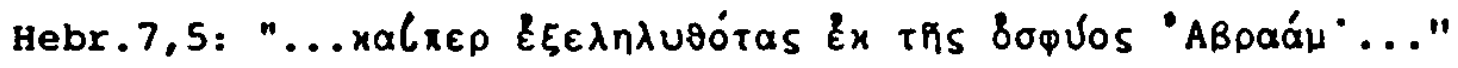

Die Wendung 'Frucht des Leibes' kommt 2.B. in Deuteronomium28,4 vor:

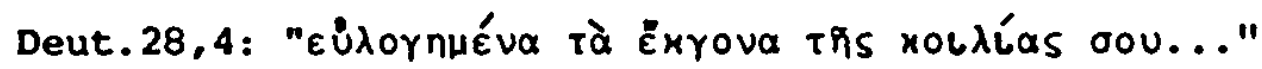

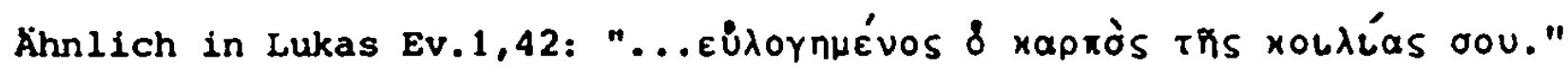

Der Autor konstatiert voller Staunen, daB aus der Liebe der Eltern schlieBlich eine 'Herde' hervorgeht (из родивших быть конечно должно стада,603). Aus den Kindern werden wieder văter und Mütter, die dasselbe Gefühl der Treue In sich spüren, das denen, die keine Kinder haben, unwahrscheinlich vorkommt (III,603-607). Der Hymnus schliebt mit dem Ausruf: 'Elterliche Liebe hat keine Grenze':

$$
\text { III,608 В родительской побви колика есть безмерность! }
$$


In III,609-760 geht es um die Dauer der Arten.

Zu Anfang wird behauptet: Jede Tierart, die auf die Welt gekommen ist, besteht unzăhlige Jahre:

III,609f. Животных каждый род, исшедший так во свет,

В нем пребшвает уш чрез многие тьмы лет:

Mit diesen Versen kehrt Tred. zum Text der Demonstration zurück: "Toutes ces différentes espèces se conservent ¿ peu près de même dans tous les siècles'(28).

Unsere Autoren sind der Auffassung, daB seit tausenden von Jahren keine Tierart ausgestorben oder von einer anderen verdrăngt worden sei. So versicher 1 Tred. :

III,611ff. Чрез тшсящи веков чтоб кой искоренился

Конечно и совсем из жизни истребился,

Не видно и ниже́ не слишно есть того.

Hătten die Raubtiere wie Băren, Löwen, wolfe u.a. übermăbig zugenommen, führt Tred. weiter aus, so wăren lăngst die Schafe, Kălber, Ochsen, die 'bărtigen Ziegen', die 'trăgen Esel' und die 'großmütigen Pferde' ausgerottet worden:

III,622ff. Брадатше притом и козы и козлы,

Ленивейшии мски и веледушны кони,

Легчащие наш труд и рыщущи в погони,

Уж были 6 все давн вконец истреблены

И родом бы своим так всем погублены: -

In dieser Passage fallen die 'homerischen' Epitheta auf.

Tred. fahrt fort: Der Grimm der Raubtiere hatte auch vor dem Menschen nicht haltgemacht, und so wăre die ganze Erde leer geworden:

III,627f. Их ярость и до нас достигнуть бы имела,

И так бы вся земля конечно опустела, -

Dem Gedankengang liegt dieser Text der Demonstration zugrunde: "Si les especes des ours, des lions et des tigres se multipliaient a un certain point, ils détruiraient les espèces des cerfs, des daims, des moutons, des chevres et des boeufs; ils prévaudraient même sur le genre humaín, et dépeupleraient la terre."(S.28) Fénelon wird durch diese Uberlegung zu der Frage veranlaBt: 'wer ist es, der so genau das Maß einhălt', daß jene Arten zwar niemals aussterben, aber auch niemals überhandnehmen? "Qui est-ce qui tient la mesure si juste pour n'éteindre jamais ces especes, et pour ne les laisser jamais trop multiplier?" (Démonstr., s.28)

Tred. gibt auBerdem zu bedenken: wenn sich die wilden Tiere im UbermaB vermehrten, so kămen die 'gnädigen Absichten' des Schopfers nicht zum Ziel.Dies 
ist aber mit der Gottesvorstellung unvereinbar. Darum kann man sich darauf verlassen, daB die Zahl der Raubtiere nicht unbegrenzt zunimmt:

III,629ff. А всех бы преблагих намерений конец

Не исполнялся тем, кой поломил творец.

Но лютых тех зверей число есть не чрезмерно;

Сочтенное предел себе имеет верно.

Diese Tatsache flöBt dem Autor höchste Bewunderung ein. Aus ihr 'leuchten' ihm 'Weisheit, Macht, Rat und Fürsorge' des Schopfers entgegen:

III,633ff. Как в прочем ясно зрим премудрость, так и в сем

Mогунество, совет, раяение о всем;

Всех свойства сии здесь повсіду толь сияют,

Что примечающ ум безмерно уяивляют.

Er preist 'die rechte Hand Gottes', von der um unsertwillen die Zahl der wilden Tiere in Schranken gehalten wird:

III,639f. Неложно, от его число зверей десницы,

Нам, лодам, өреаных тех, есть вклочено в границы!

Die 'rechte Band' Gottes ist biblischer Sprachgebrauch. Als Beispiel sei Ps.

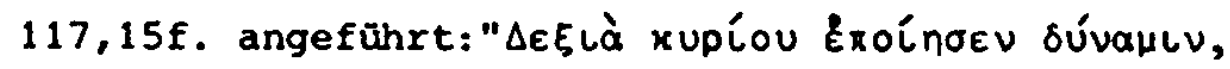

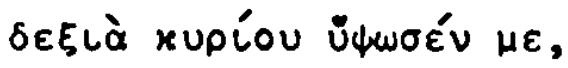

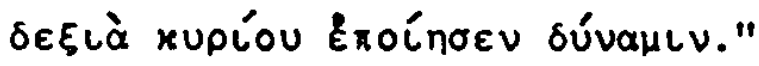

Der doxologische Satz 639f. wird im folgenden parănetisch gewendet: die 'Weisheit, Güte und Macht' des Schopfers, die in der gesamten schopfung zutage liegen, sollen uns in Begeisterung versetzen und unseren verstand erleuchten:

III,641ff. Bсё долженствует нас сие всех приводить,

Дивящихся, в восторг и ум наш просветить

Строением во всем премуарости толики,

И благости творца, и силы превелики;

Die Trias von Weisheit, Macht und Güte als Ausdruck für die Wesensfulle Gottes findet sich in der Feoptija an vielen Stellen. Bier wird hervorgehoben, daß die Herrlichkeit des Schöpfers in der Welt so offenbar ist, daB sie der Mensch nicht übersehen kann, es sei denn aus 'eigensinniger Blindheit':

$$
\begin{aligned}
& \text { III,645ff. Смотрение его толь ясно зримо есть, } \\
& \text { Что не возможет скршть от нас никая лесть } \\
& \text { И что без слепотш извольныя не момн } \\
& \text { Не видеть нам везде того, что есть неломно. }
\end{aligned}
$$

In Form einer hypothetischen Uberlegung erinnert der Autor nochmals an die 
Gefahr, die dem Menschen von einer ubergroßen Zahl wilder Tiere drohen wirde. Er will unterstreichen, daB Gott um des Menschen willen die Gefahr begrenzt hat: III,649f. Премногому числу когда 6 тех быть зверей, То было без числа терзаемых лодей.

Wozu gibt es aber uberhaupt solche gefahrlichen Tiere? Die Frage hat Tred. des ofteren beschaftigt. In III,168ff. hat er darauf geantwortet, daB die wilden Tiere dazu da sind, um dem Menschen durch ihre Raubgier und Grausamkeit als abschreckendes Beispiel zu dienen. AuBerdem kann der Mensch seinen Mut und seine Tapferkeit bei der Jagd uben und braucht die Gelegenheit dazu nicht im Kriege zu suchen (III,185f.).

In III,651-672 bringt Tred. im Rahmen einer theologischen Digression weitere Argumente vor, die das Vorhandensein der Raubtiere in der 'besten der möglichen Welten' rechtfertigen sollen. Er sagt: cott hat eine genügend groBe 2 ahl von wilden Tieren vorgesehen, um die Menschen wegen ihrer Sünden $2 u$ bestrafen:

III,651f. Предвидел вьшний бог довольны к нашей казни

И зависти и злоб толь неисчетны разни.

Als Werkzeuge der strafenden Gerechtigkeit Gottes erfullen also die Tiere in einer moralischen Weltordnung einen hoheren 2weck. Sie sind zwar nach Gottes Willen eine Plage fūr den Menschen, aber cott läBt nicht zu, daB sie uns in ihrer Grausamkeit vollig verschlingen. Nachdenklich fügt der Autor hinzu: "wenn unser hinfalliger Leib nicht wegen unserer Bosheit in die Grube müBte": III,656ff. А мучимым нам быть зверьми не попустила, Чтоб лотость их всех нас вконец не поглотила, Когда 6 от завистей и свойственных нам злоб Наш страждущий живот не сходит в смертный гроб.

Der Tod wird hier nicht als Naturvorgang interpretiert, sondern als Folge und Strafe der Sünde verstanden. Diese Auffassung geht auf die Bibel zurück. Der Apostel Paulus hat sie im Romerbrief, Kap.6,23 prăgnant formuliert: "rd ràp sqúvla tr̃s ápaptías vávaros,..."

'Смертмый rpo5' (658) hat hier wohl ksl. Bedeutung wie in II,226 (vgl.s.100). Es heibt im obiqen Zitat 'Grab,Gruft'. (Pawl..273).

"In die Grube hinabsteigen" ist eine alttestamentliche Metapher für 'sterben'.

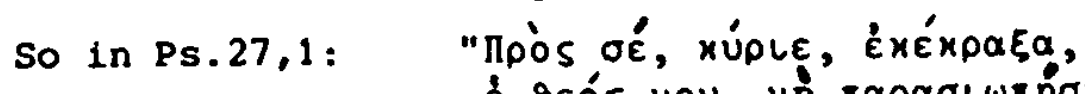

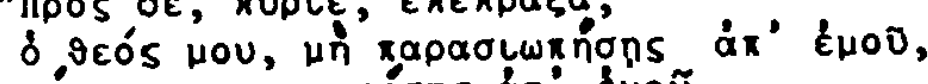

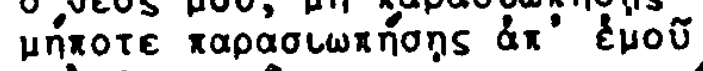

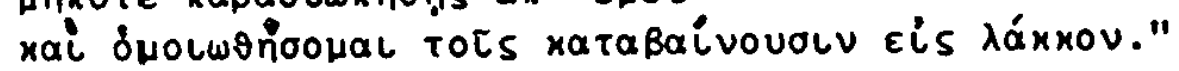


Die Einsicht, daB aus der Sande der Tod folgt, soll den Menschen zur Besinnung veranlassen, daB er den Weg der Gerechtigkeit geht und sich bemunt, die Ursache seines Elends zu erkennen, um es künftig vorsichtiger zu vermeiden:

III,659ff. Сие * Aа человек опомнится со6010,

Да, правды на стезе став, шествует уж тор,

И да вину беды потщится познавать,

От коей впредь ему 6 опасней убегать.

Auf diese Weise haben unsere Bosheit und der Neid, so schãdlich und beklagenswert sie auch sind, manchmal ihren Nutzen:

III,663f. Hо злость и зависть в нас, за вред коль нам ни слезны, Однако иногда бывают те полезны.

Von ihnen gepeinigt und gequălt, erkennt der Mensch seine Laster und versucht die Leidenschaften $z u$ băndigen:

$$
\begin{aligned}
& \text { III,667f. Томясь и мучась он так в бедстве и напасти, } \\
& \text { Пороки зрит свои, Обуздавает страсти. }
\end{aligned}
$$

Die Selbsterkenntnis bewirkt, daß der Mensch zurjckgezogener lebt:

$$
\text { III,669 С собой тогАа тесняй живя и весь в себе, - }
$$

Als denke er an einen stoischen Weisen, sagt Tred. von dem zur Selbsterkenntnis gekommenen Menschen, "er laufe nicht ungestüm in jener Hetzjagd der anderen" :

III,670 И буйно не хоАя В той От Аругих гонь6е, -

Vielmehr überlegt er alles vernünftiger und bessert sich dadurch mehr und mehr, wie es ihm geziemt:

III,671f. А всё, что он и как, уж здравей размышляет,

А тем себя всяк час, как Аолжно, исправляет.

Bemerkenswert ist in dieser Passage, daB Tred. dem Bosen eine, wenn auch eingeschrănkte, positive Bedeutung beilegt (иногда бывают те полезны, (664). Sonst denkt er undialektisch über das Böse und stimmt der biblischen Auffassung $z u$, daB der Tod die Folge und Strafe der Sünde ist (657f.). Im Unterschied dazu werden im 'Essay on Man' die 'Passions and Imperfections' des Menschen durchaus positiv verstanden. So entspringt z.B. aus der 'Selbstliebe' die physische und psychische Vitalităt des Individuums:

$$
\text { Ep.II,59 "Self-love, the spring of motion, acts the soul." }
$$

Nach A.Pope sind Măngel, Schwăchen und Leidenschaften des einzelnen nicht schădlich für die Gemeinschaft, sondern bilden ihre feste Grundlage: sie machen die Menschen voneinander abhăngig und bewirken, daß sie sich zu gegenseitiger Ergănzung zusammenschließen: 
Ep.II,253f. "Wants, frailties, passions, closer still ally

The common int'rest, or endear the tie."

In einer vom Harmoniegedanken geprägten Weltanschauung, in der jede 'Dissonanz als nicht exkannte Harmonie' (Essay,Ep.I,291) erscheint, gibt es keine scharfe Grenze zwischen gut und bose. Selbst die 'niedrige Selbstliebe', d.h. der Egoismus, ist insofern gut, als die eigensūchtigen Bedūrfnisse der MaBstab sind, an dem wir die der anderen prüfen können:

Ep.II,292f. "Ev'n mean Self-love becomes, by force divine, The scale to measure others wants by thine."

Tred. ist in der angeführten Passage dem harmonisierenden Verstăndnis des Bösen, wie es im 'Essay on Man' vorliegt, vorsichtig gefolgt. Er hat jedoch im Unterschied zum 'Essay' gefordert, daB der Mensch, durch die eigene Bosheit zur Selbsterkenntnis geführt, stāndig an seiner Besserung arbeiten solle.

In III,673ff. kehrt Tred. zum Gedankengang der Démonstration zurück. Er beklagt es, daB wir wegen der abstumpfenden Wirkung der Gewohnheit das Wunder der Fortpflanzung nicht mehr als wunderbar erkennen. Die Gewöhnung hält uns vom Nachdenken ab und macht, daß wir 'die helle stimme der Natur' nicht mehr horen:

III,675ff. Привычка, может быть, мысль нашу превращая,

А дивное в себе не дивным толь собщая,

От размышлений вдаль всегда уводит нас

И слышать не дает природы светлый глас.

Der Gedanke (ohne die Metapher 'nрироды светлый глас') hat in der Démonstration diese Form: "Mais enfin, cette propagation continuelle de chaque espece est une merveille a laquelle nous sommes trop accoutumés." (S.28)

Die nachfolgenden Beispiele III,679-686, die aus der Vorlage stammen, sollen das Nachdenken veranlassen.

Was würde man von einem 'Künstler' denken, fragt der Autor, der Unren herstellte, die sich selbst fortpflanzen konnen? Einem solchen 'Künstler' würde man alle Vollkommenheit zuschreiben:

III,679ff. Что бУдУт О таком ХУдомнике все мыслить

И совершенстөа в нем имеот сколько числить,

Который бы часи такии здесь сложил,

4 тоб от самих был плод и в роди 6 оный жил?

Nicht weniger ware ein Architekt zu bewundern, der ein Haus baute, das aus 
sich ein anderes hervorbringen, und in dem sogar jedes zimmer sich selbst renovieren kőnnte, wenn es baufallig geworden ist:

\section{III,683ff. 0 зодчем как домов таком 6ш рассуждалось, Чтоб от его палат жилище созидалось Apyroe o ce6e, и сам бы всяк покой Возобновлялся В рОА, при ветхости, сОбой?}

Die grotesken Fragen, mit denen die Aufmerksamkeit geweckt werden soll, werden pointiert beantwortet:

III,687 Мн всё то зрим в зверях, зрим в каждом то животном. Durch die Wiederholungsfigur 'то зрим - зрим то' wird die Antwort rhetorisch hervorgehoben: was kein Unrmacher oder Architekt in seinem Fach kann, eben das sehen wir bei jedem Tier.

Die Passage stimnt genau mit der Vorlage Uberein: "Que penserait-on d'un horloger, s'il savait faire des montres qui d'elles-mêmes en produissent d'autres à l'infini...Que dirait-on d'un architecte, s'il avait l'art de faire des maisons qui en fissent d'autres, pour renouveler l'habitation des hommes, avant qu'elles fussent prêtes a tomber en ruine?" (Démonstr.,s.28f.) Die uberraschende Antwort lautet: "Voild ce qu'on voit parmi les animaux"(29)

In den Versen 688-694 wird diese Antwort erweitert. Tred. greift die bekannte Uhrenmetapher Descartes' auf, stellt sie aber als unzulanglich hin. Er sagt: die Tiere sind zwar physische Mechanismen, die sich in gewisser Weise mit Uhren vergleichen lassen. Sie unterscheiden sich aber davon wesentlich. Anstelle des Uhrwerks haben sie in sich einen 'gewissen seelischen Hauch'. Das dafür gebrauchte Wort 'nap' ubersetzt Pawlowskij (992) mit 'Lebenshauch, Hauch der Tiere'. Die Tiere 'fühlen alles', sie 'verstehen sehr vieles', vor allem unterscheiden sie sich von allen Mechanismen durch ihre Făhigkeit, sich zu vermehren. Diese Făhigkeit hat der Schöpfer 'von Anbeginn in sie hineingelegt, damit sie dadurch sein beabsichtigtes ziel erfüllen' :

$$
\begin{aligned}
& \text { III,693f. С начала ту вложил способность в них твореи, } \\
& \text { Его } 6 \text { им исполнять намеренный конец. }
\end{aligned}
$$

Fénelon sagt von den Tieren: "Ils ne sont, si vous le voulez, que de pures machines comme les montres; mais enfin l'auteur de ces machines a mis en elles de quoi se reproduire a l'infini par l'assemblage des deux sexes." (Dém. ,S.29)

Der Abschnitt III,695-760 handelt von den Zeugungstheorien.

Das Thema war seit der im Jahre 1678 veroffentlichten Entdeckung der Sperma- 
tozoen durch Leeuwenhoeck aktuell geworden. Der hollandische Naturforscher' (1632-1723) hatte als erstex unter dem Mikroskop die Eigenbewegung der 'Samentierchen' entdeckt und war zu der Ansicht gekommen, "daB eine individuelle Praformation im mănnlichen Samen vorliege." 35 Im Gegensatz zu den 'Prăformisten', deren Theorie auch Leibniz zuneigte, vertraten die 'Ovisten' -zu ihren bekanntesten vertretern gehorten Haller und Swammerdam- die Theorie einer Zeugung aus dem Ei. Die wohl konsequenteste Richtung der Ovisten lehrte, wie es in den Primecanija zu Feoptija III,703ff heiBt, "что в яичниках Еөы в сжатом вияе уже суиествовал весь человеческий род." - Andere Forscher wandten sich gegen jede Art von Präformismus und nahmen statt dessen an, daB jedes Individuum von Fall zu Fall geprăgt würde. Hier unterschieden sich die Anhănger einer 'absichtlichen Prăgung' von denen einer 'allmăhlichen Bildung', wăhrend Physiologen wie Needham, Bonnet und Musschenbroeck die 'zufállige Prăgung' des Individuums annahmen.

Die Meinungsverschiedenheiten der Forscher waren in erster Linie auf die Zeugung des Menschen bezogen und erregten wegen ihrer theologischen Konsequenzen erhebliche Unruhe. Das Thema war so brisant, daB z.B.J.J.Scheuchzer von der Zensurbehơrde in zürich gezwungen wurde, "die Lehre von den Samentierchen als unzüchtig aus seinen Schriften zu streichen", wie Chr.Siegrist mitteilt. 36

Fénelon wie auch Tred. haben die Zeugungstheorien ausschlieblich im zoologischen kontext erörtert und sich damit aus theologischen Verwicklungen geschickt herausgehalten.

Tred. trăgt in der Form der aus der Rhetorik stammenden 'Appellfigur', der sogenannten 'concessio', drei zeitgenössische Forschermeinungen vor, ohne sich auf die eine oder andere festzulegen. Zunăchst skizziert er die oben erwăhnte praformistische Samentheorie. Ihr zufolge wird das Einzelwesen aus den in der Art angelegten und von Generation $z u$ Generation weitervererbten Spermatozoen gezeugt, so daB die Art niemals aussterben kann:

$$
\begin{aligned}
& \text { III,695ff. Пусть множатся они аля собственного плоду } \\
& \text { 0т семени, что в них есть вложено по роду } \\
& \text { И пребывает то в них в непредельный круг. } \\
& \text { И так, что не́льзя им перевестись как варуг. }
\end{aligned}
$$

Die zweite Theorie bezeichnet Tred. mit den Worten 'нарочна заrotoвka', 'absichtliche Anschaffung'. Sie unterscheidet sich von der ersten dadurch, daB die Individuen nicht im Samen 'prăformiert' sind, sondern bei der zeugung je- 
weils aktuell gepragt werden. Auch nach dieser Theorie ist jedoch die Art schon 'vorbestimmt' und mit Fruchtbarkeit ausgestattet:

III,699ff. Пусть производит их нарочна заготовка,

0т коей их родам всегдашня обновка.

Но значит өсё сие, что өесь зараней род

Их предусмотрен есть и всем снабден на плод.

Fenelon unterscheidet eine "génération d'animaux...par des moules" von einer Zeugung "par une configuration expresse de chaque individu." (Demonstr.,S.29) Sie entsprechen deutlich den von Tred. umrissenen Lehrmeinungen. Nimmt man an, so führt Fénelon aus, daß das Einzelwesen ohne Präformation bei der zeugung seine spezielle Prăgung empfăngt ("...qu'd chaque génération l'indivu reçoit, sans aucun moule, une configuration faite expres..."), so stellt sich die Frage: "qui est-ce qui conduit la configuration d'une machine si composée..." Setzt man dagegen voraus, făhrt Fénelon fort, daß alles durch die 'Formen' ('moules') determiniert wird, so bleibt zu fragen: "Qui est-ce qui les a préparé? Ils sont encore biens plus étonnants que les machines qu'on veut faire éclore." (Démonstr.,S.29)

Tred. benutzt in dieser Passage die Begriffe 'семя', 'марочна заготовка' und 'зародыши' ('Keime'). Was er dazu sagt, deckt sich weitgehend mit den Darlegungen Fénelons über 'les moules'. Es läbt sich daher nicht entscheiden, ob Tred. mit dem Begriff 'зародыun' auf eine weitere, von den genannten unterschiedene Zeugungstheorie hinweisen wollte -dafür spricht der neue Begriff und der Neuansatz der Argumentation: "nycrb уверяют нас..."(703)- oder ob die 'Samentheorie' in den Versen 703-728 exlăutert und ergånzt werden soll. Darauf deutet die Parallele in der Demonstration.

Die 'зародиши', von denen jedes einzelne Tier einen bestimmten Vorrat erhalten hat, existieren vor inm seit 'unvordenklichen Zeiten':

III,703ff. Пусть уверяют нас, что в камдом порознь звере

Припасено по их числу, по их и мере,

Зародиши пред сим ум за седмь тысяч лет, -

Die 'зародиии' sichern den Fortbestand der Art:

III,707f. И никогда 6 отнодь здесь не переводился,

Один бы от того и далей так родился.

Die Parallelstelle in der Démonstration lautet: "... on s'imagine des moules dans les animaux qui vivaient il y a quatre mille ans, et on assurera qu'ils étaient tellement renfermés les uns dans les autres a l'infini, qu'il y en a 
eu pour toutes les générations de ces quatre mille années, et qu'il y en $a^{\prime}$ encore de préparés pour la formation de tous les animaux qui continueront l'espece dans la suite de tous les siecles?" (S.29)

Auffallig sind die Zahlenangaben 'седмь тысяч лет' bzw. 'quatre mille ans', mit denen die Dauer der 'зародиии' und der 'moules' bezeichnet wird. Dazu ist anzumerken, daB die Zahlen 'sieben' und 'vier' in der religionsgeschichtlichen Uberlieferung eine besondere Rolle spielen. Die Verwendung der Siebenzahl in Mythus und Kultus, zuerst bei Sumerern und Babyloniern, dürfte nach Meinung von K.H.Rengstorf ihren Ausgangspunkt in der Feststellung der kosmischen Bedeutung dieser Zahl (vier Mondphasen zu je etwa sieben Tagen) haben. Von der Beobachtung, "daB die Zeit in Perioden ablăuft, die sieben Tage umfassen, kommt es zu der gedanklichen Verknüpfung von Sieben und voller Periode, und von da aus ist es dann nur noch ein Schritt bis zur Gleichsetzung des abstrakten Zahlbegriffs Sieben mit dem Begriff des Ganzen und vollen und dahin, daB sich mit der Sieben jeweils die Vorstellung eines geschlossenen und vollkommenen Ganzen verknüpft..." 37 Rengstorf weist auf die beherrschende stellung der siebenzahl im Ritual des alten Israel hin, bei Entsühnungen und Reinigungen, im Opferzeremoniell und bei den Gebeten. Auch die 'sieben Bitten' im christlichen Vater Unser stehen in diesem Zusammenhang. Auf dem Boden der israelitischen Uberlieferung gehơrt vor allem hierher der 'Sabbat' als der cott gewiomete siebente Tag, "daneben das gesamte, auf hebdomadischen Fristen aufgebaute Festjahr Israels...mit dem ziele, das Verhătnis des Volkes zu Gott in seiner Totalităt zu ordnen..." 38 zusammenfassend stellt Rengstorf fest: "Die Siebenzahl trăgt somit den Charakter der Totalitat, und zwar den der von Gott gewollten und geordneten Totalitat." 39

DaB die 'Sieben' auch bei den Griechen und Germanen in der mythischen Tradition -man denke an Mărchen und Volkslieder- eine Rolle spielt, braucht nicht weiter belegt zu werden.

Ahnlich wie die 'Sieben' ist auch die 'Vier' als Inbegriff der Totalitat und Universalitat verstanden worden. Den Ursprung der allgemeinen religionsgeschichtlichen Bedeutung der 'Vier' sieht Balz "in der Orientierung nach vier Seiten...Die vier Himmelsrichtungen oder Weltgegenden erfassen den ganzen Horizont." 40 Im griechischen Sprachbereich wird auf die dem Empedokles zugeschriebene Lehre von den vier Elementen hingewiesen, die bei inm mit vier Gottern gleichgesetzt werden. "Nur der Demiurg selbst könnte ihre gegenseitige Umarmung wieder auflosen." 41 Balz nennt ferner die Zahlenmystik der Pythago- 


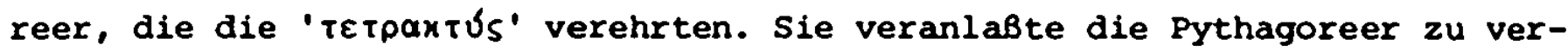
schiedenen spekulativen Uberlegungen. So fanden sie heraus, daB "die Summe der ersten vier Zahlen zusammen 10 ergibt, also zugleich die Basis des dekadischen

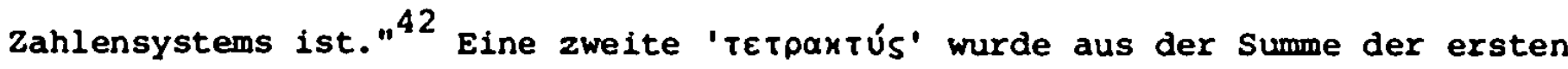
vier geraden und ungeraden Zahlen $=36$ gebildet. Darauf führten die Pythagoreer alle Harmonien, besonders der musikalischen Grundverhăltnisse zurück. 43 Was das Alte Testament betrifft, erinnert Balz u.a. an die vier Paradiesesströme, "die das Weltganze unschreiben"(Gen.2,10ff.), und an "die Verteilung des Reiches durch Gott $\varepsilon l_{S}$ toùs téooapas \&uḱpous toõ oủpavoõ, Da 11,4." Balz erwăhnt weiter die Vierzahl in der Theophanie des Ezechiel, Kap.1 und bemerkt dazu: "Ohne ausgesprochenen Bezug zu den vier Himelsrichtungen geht es hier um die Universalität der Macht Jahwes." Im Blick auf das gesamte Alte Testament fügt Balz hinzu: "...auch sonst dominiert die Vierzahl als zahl der Totalität." 44

Diese Feststellung wird im Neuen Testament bestătigt. Balz führt u.a. folgende Belegstellen an: "Die téooapas hifépas, die Lazarus bereits im Grabe liegt ( $\mathrm{J}$ 11,17, vgl 39), drücken die Endgültigkeit und Unaufhebbarkeit des

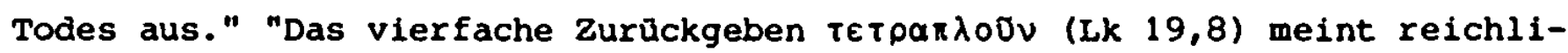
ches zurückgeben." 45 In der Johannesapokalypse erscheint die zahl vier ebenfalls als Ausdruck der Totalitä. In Apk.7,1 ist davon die Rede, daB an den

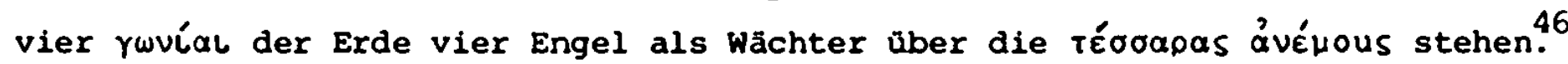

Unsere Autoren Tred. und Fénelon haben die beschriebene Tradition wenigstens in großen zügen gekannt. Sie haben deshalb mit ihren Angaben 'за ceamb тысяч лет' bzw. 'quatre mille ans' die totale Dauer der 'зародыши' bzw. 'moules' ausdrücken wollen. Im Unterschied zur vorlage hat Tred. der 'Siebenzahl' den Vorzug gegeben.

Nicht weniger erstaunlich als die unbeschränkte Fortdauer der 'зародыши' erscheint Tred. ihre innere Beschaffenheit. Sie enthalten in sich den genauen 'GrundriB', nach dem die Gestalt des Einzelwesens im Mutterleib wăchst und reift, bis sie bei der Geburt fertig herauskommt:

\section{III,709ff. Но что сим надлежит зародышам иметь \\ Cвоих весь образ тел и так в утробе спеть, \\ Имеющим уже вск точную основу, \\ Bозрастшуо ж до мер, к исшествию готову; -}

Das Phănomen ist derart verwickelt, fügt der Autor ein, daB der Verstand sich eher verwirrt, als daß er die wunderbare Weisheit, die darin liegt, verstehen 
kơnnte :

III,714f. Ум понимаяй то смятется сам скоряй,

А нежель может в том постигнуть муарость чуАнУ, -

Fénelon schreibt über die Beschaffenheit der 'moules': "Ces moules, gui ont toute la forme de l'animal, ont dejja...autant de difficulté a etre expliqués que les animaux mêmes: mais ils ont d'allleurs des merveilles bien plus inexplicables." (Demonstr.,S.29) Die Vorstellung, daB jedes Tier bel der Zeugung einzeln geprăgt wird, hălt Fénelon für einleuchtender als die Theorie der zeugung durch 'moules': "Au moins la configuration de chaque animal, en particulier, ne demande-t-elle qu'autant d'art et de puissance qu'il en faut pour executer tous les ressorts qui composent cette machine." (S.29) Darauf schildert er die Schwierigkeiten, die in der Annahme einer Zeugung durch 'moules' liegen: "Mais qu'on suppose les moules: $1^{\circ}$ Il faut dire que chaque moule contient en petit, avec une delicatesse inconcevable, tous les ressorts de la machine même..."(S.29) Fénelon ist der Ansicht, es erfordere mehr Kunst, ein so kompliziertes Werk in winzigem Format herzustellen, als ein groberes zu machen

" $2^{\circ}$ Il faut dire, que chaque moule...renferme distinctement, au dedans de soi, d'autres moules contenus les uns dans les autres à l'infini pour toutes les générations possibles dans la suite de tous les siècles." (Démonstr.,S.29f.) Was könnte kunstvoller und erstaunlicher sein, fragt Fénelon, als diese Vorbereitung einer unbegrenzten Zahl von Individuen, die alle in einem einzigen Wesen prăformiert sind, aus dem sie ans Licht kommen sollen? Die Annahme der 'moules' erklăt nicht die unendilche Reihe der Zeugungen der Tiere. Im Gegenteil, setzt Fenelon hinzu, und deutet seine physikotheologische Uberzeugung an: "...au contraire, les moules montreraient un plus grand artifice et une plus étonnante composition." (Démonstr.,s.30)

Tred. schildert die höchst komplizierte Beschaffenheit des 'зародыш', die daran deutlich wird, daB in seinem GrundriB im kleinsten Maßstab das Ganze vorhanden ist: alle inneren Teile und "die Telle dieser Telle wie in einer Salbe verteilt sind":

III,717ff. Во-первых, Аолмно в той всему основе быть,

В малейшем и всему ж размере в той не ныть,

И так, чтоб били в ней все внутренние части,

И части сих частей разобраны, как в масти.

Die Ubereinstimmung diesex Passage mit dem ersten Punkt Fénelons ist offensichtlich. Im Unterschied zu Fénelon fehlt bei Tred. die Gegenüberstellung 
der Zeugung durch Einzelprăgung bzw. durch Praformation in den 'зародwu'. Fénelon hat dabei deutlich der Einzelprägung ("configuration de chaque animal, en particulier") den Vorzug gegeben.

Uber die komplizierte Beschaffenheit der 'sapoдuwn' sagt Tred. weiter: Jeder 'Keim' muB in sich soviele 'Keime' enthalten, daß daraus ad infinitum Individuen geboren werden:

III,721ff. Потом зародыш всяк чтоб столько содержал

Зародьшей в себе, из сих бы насажал

8 себя $m$ еще всяк их и столько $\%$, и нарочно

Долг скольким быть нИ всем, чтОб в век родиться точно.

Diese Verse entsprechen dem zweiten Punkt der Darlegung Fénelons.

In zwei rhetorischen Fragen auBert sich das staunen: Können wir soviele 'Vorbereitungen' in einem einzigen 'Keim' überhaupt fassen?

III,725f. Уготовлений столь обнять возможно ль нам

8 зародыше одном по всем его рядам?

Können wir denn diese Zahl in unseren Verstand aufnehmen, ohne daß er sich verwirrt?

III,727f. В понятии у нас сему числу вмещаться

Возможно ль без того, ему чтоб не смущаться?

Tred. răumt ein, er wisse nicht, welcher Theorie er recht geben solle:

III,731 Из них не знаю я, которо право Аелом, -

Aber, welche von diesen 'Meinungen der Gelehrten' man auch annehmen mag, überall ist 'die höchste Kunst zu riechen', bemerkt der Autor bildhaft:

III,729f. Но кое мнений сих от мудрых ни принять,

Везде искусство долг всевине обонять: -

Die dargestellten zeugungstheorien widersprechen nach Meinung Tred.s dem Schöpfungsglauben nicht, sondern setzen ihn voraus; denn, wenn man ihnen auf den Grund geht, wird die Weisheit des schöpfers sichtbar:

III,732 Премуарость зрю во всех я при рассуаке зрелом.

Eine Theorie lehnen unsere Autoren jedoch entschieden ab: daB die Tiere durch 'zufälliges Zusammentreffen von Atomen ohne Zeugung entstanden seien'. Fénelon sagt: "Ce qu'il y a de manifeste et d'incontestable,...c'est que le concours fortuit des atomes ne produit jamais sans génération,...ni lions, ni tigres, ni ours, ni éléphants etc.: ils ne sont jamais produits que par l'accouplement de leurs semblables." (Démonstr.,s.30)

Tred. tritt der Zufallstheorie in den folgenden Versen entgegen: 
III,733ff. ОАнак, сомнений в сем, от вернейших примет,

Нимало никаких и никому уж нет,

Что не родится скот припадком во вселенной,

Ни в мшсли мнить того нельзя в неизумленной; -

In die nachfolgende Aufzahlung von Tieren hat Tred. auch die Menschen als

'Herren über sie' aufgenommen. Mit dieser Wendung wird wohl auf die biblische Schopfungsgeschichte, Gen, 1,26 angespielt. Dort heiBt es:

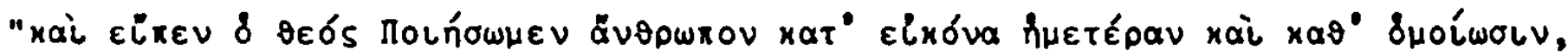

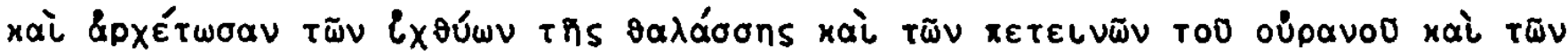

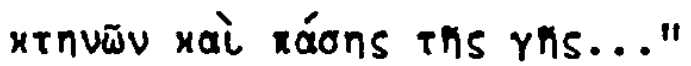

Tiere und Menschen entstehen nicht durch zufallige Kombination von Atomen. Jedes Einzelwesen ist von seinem Elternpaar gezeugt worden, betont Tred.:

III,737ff. Медведей, ни овец, ни львов, ни лошадей

Oт случая не зрим, ни сим господ, людей,

Hо все от пары те подобнше родятся

И после көк жена и муж совокупятся.

Dies bedeutet aber nicht, daB die Eltern die eigentlichen 'Urheber' der Zeugung sind:

III,742f. Совокупившись уж с лобовио чета,

В рождении своем искусству не причина, -

Die Paarung der Tiere wird anthropomorph gedeutet: 'c mo6osmo'.

DaB die Eltern nicht die 'Urheber' der Zeugung sind, wird so begründet: Ein

'Urheber' weiB, wie er sein Werk geschaffen hat. Das Elternpaar durchschaut jedoch die Vorgånge nicht, die zur Geburt des eigenen Kindes füren:

III,746ff. Но не дается ей отнодь ниже́ вестей

Познать бы точно, Как, что оныя в утробе

Составилось и есть по сродной ей особе.

Vater und Mutter sind Werkzeuge, formuliert Tred. prăgnant:

III,749f. Орудие - оте4, оруаие и мaтb,

Чтоб то производить, а кек - того не знать.

Die zweitrangige Bedeutung der Eltern im Schopfungsvorgang der Zeugung wird in der Démonstration, auf die die Verse Tred.s zurũckgehen, so geschildert: "Les deux animaux qui en produisent un troisième ne sont point les véritables auteurs de l'art qui éclate dans la composition de l'animal engendré par eux. Loin d'avoir l'industrie de l'exécuter, lls ne savent pas meme comment est composé l'ouvrage qui résulte de leur génération...1ls n'ont été que des in- 
struments aveugles et involontaires, appliques d l'execution d'un art merveilleux qui leur est absolument etranger et inconnu." (S.30) Hinter der Auffassung Fenelons steht die Kausalvorstllung der Cartesianer Geulincx und Malebranche, die neben der Alleinwirksamkeit Gottes nur eine Quasi-Kausalitat von Zweitursachen gelten lieBen. So lehrten sie im Hinblick auf die zeugung: "der vater ist füx das Erzeugte nur ãuBere und occasionell hervorbringende Ursache, weil seiner Handlung als wirkung die Zeugung nur per accidens folgt." 47

Das physikotheologische Bekenntnis ăußert sich wieder in einer Reihe von ehrfürchtigen Fragen: woher kommt dann aber die wunderbare Kunst? Welche Kraft ist es? Welcher 'Allweise' hat dem El ternpaar geboten, Nachkomen zu zeugen? (Wer hat es so geordnet), daß das Paar selbst nicht weiB, wie 'die Frucht' sich bildet, sondern daB es ein 'fertiges' Geschöpf zur Welt bringt? III,753ff. Какая сила? Кто премудрый, и весьма,

Той паре повелел родить? А чтоб сама

8 плоде своем отнодь составов та не знала?

Да только чтоб совсем готовое рождала?

Unabhångig davon, ob man dem Tier Verstand beilegt, vieleicht sogar einen Verstand, der dem menschlichen uberlegen ist, oder ob man jeden Gedanken beim Tier verneint: an seiner zeugung ist es nicht beteiligt, noch vermag es zu erkennen, wie es erzeugt worden ist:

\section{III,757ff. Хоть смысл Аай весь скоту, хоть отыми и мысль, \\ Хоть нашего ума в нем выше разум иисль, \\ Творенио однак себя ОН не причастен, \\ Ни, как есть сотворен, познать сие не властен.}

Die Passage ist in der Démonstration vorgegeben: "D'ou vient-il, cet art si merveilleux qui n'est point le leur? Quelle puissance...sait employer, pour des ouvrages d'un dessin si ingenieux, des instruments si incapables de savoir ce qu'ils font...? Il est inutile de supposer que les betes ont de la connaissance. Donnez-leur-en tant qu'il vous plaira dans les autres choses, du moins il faut avouer qu'elles n'ont, dans la generation, aucune part d l'industrie qui éclate dans la composition des animaux qu'elles produisent." (S.30)

In III,761-816 wird in einer Reihe von Exempeln das erstaunliche Verhalten der Tiere geschildert.

Das neue Thema ist durch Assoziation mit dem vorigen verknūpft. Als Anknüp- 
fungspunkt dient das Stichwort 'смысл'. Das Verhalten der Tiere, in einer Folge von Bildern aufgezeigt, scheint darauf hinzuweisen, daB es aus uberraschenden geistigen Fahigkeiten entspringt. Das Thema ist in der Feoptija schon einige Male, z.B. in III,339ff., beruhrt worden.

Im vorliegenden Abschnitt hat sich Tred. nur teilweise an die Demonstration gehalten. Die einleitende Bemerkung hat ex aus thr ubernommen:

III,761f. Нас некоих мивых дивят вельми дела, Как наша есть о тех примета вся зрела́.

vgl. Démonstr.,s.30: "...supposons tout ce qu'on raconte de plus étonnant de $l$ 'industrie des animaux."

Aus der Démonstration stammt auch das Bsp. des Hundes, der zweimal die Făhrte des Wildes verfehlt hat und trotzdem auf einem 'dritten Wege' weitersucht:

III,763f. Посмотрим мы на пса; сей мукою томится

И третьим уж путем за зверем вслед стремится, -

Das tut der Hund nicht 'auf gut Glück' (Кak нaо6ум, 766), sondern, wie der Zusammenhang zeigt, zielstrebig.

Fénelon schreibt: "Admirons...la certitude avec laquelle un chien s'élance dans le troisième chemin, dès qu'il a senti que la bête qu'il poursuit n'a laisse aucune odeur dans les deux premiers." (Demonstr.,s.30f.)

Die beiden folgenden Tierbeispiele Fenelons (die kalbende Hirschkuh sorgt für die Sicherheit des Jungtieres; die Spinne spannt thr Netz aus, um Mucken zu fangen) hat Tred. ausgelassen. Das Exempel der vorsichtigen Birschkuh konnte Tred. entbehren, denn auch der stolzierende Pfau, den er schildert, zieht seine Jungen da auf, wo ein Bund sie nicht aufspüren kann:

III,767ff. Аивлюсь, как мшшло я, из птиц на исполине
И толь хвостом своим гордящемся павлине,
Как воспитать детей старается своих
Там, где $6 \mathrm{nec}$ находить не мог по духу их.

Eine Tierlegende, deren Herkunft nicht geklärt werden konnte, erzăhlt von dem wunderbaren Verhalten der agyptischen storche, die sich wie eine streitmacht den aus der libyschen wüste den Grenzen Agyptens sich năhernden geflügelten Schlangen entgegenwerfen, so daß sie keinen großen Schaden anrichten können: III,771f. Не ибисы ль летят к пределам вдруг Ливийским, Влететь бы помешать в Египет стаям змийским!

Die Storche wissen genau, wann die geflügelten Schlangen bei südwind ins Land eindringen wollen und vernichten sie rechtzeitig: 
III,776ff. Так не впускают власть араконов тех упрямо

Внутрь самшя страны, их истребляя там

И не дая от них великим бшть вредам.

Die Herkunft der Anekdote von der Schildkrote und dem Adler (779-82) kann ebenfalls nicht năher belegt werden. Der Autor fragt, wie kann eine Schildkröte sich vor dem Adler retten? Sie scheint wegen ihres Panzers unangreifbar zu sein. wird der Adler von dieser Beute ablassen? Er bringt sie auf ungewöhnliche Weise zur Strecke:

III,779ff. Желвь в черепе своем как от орла спасется?

Схвативши сей того, с добшчей вверьх несется

И смотрит на низу, гАе 6 камня, с высоты

0 кой бы череп тот разбить без мешкоты.

Tred. hat die Szene mit sparsamen sprachlichen Mitteln anschaulich skizziert. Das Motiv ist seit der Antike bekannt, wie die Uberlieferung vom Tode des Aischylos in sizilien zeigt.

Das Exempel vom 'listigen' Reiher hat Tred. in der Demonstration vorgefunden. Es stellt uns den 'langbeinigen' Vogel vor, der seinen langen Schnabel unter dem Flügel versteckt hălt und daher wehrlos erscheint. Greift ihn aber ein anderer vogel an, so erschreckt er ihn, verjagt oder tötet ihn mit der Spitze seines langen Schnabels:

\section{III,783ff. Представим мы себе в ум иапло долгоногу, Аивятся и ее видавшие подлогу; \\ Она хорОнит ноС Свой АОЛгий поА крыло, Чтоб испужать $и$ вдруг нападшу птицу зло \\ Самой ей умертвить там носа остротоо,}

Иль варуг we 6 ту прогнать его $*$ прочь долгото0.

Beachtenswert ist die Erzāhlweise: nach episch-beschreibendem Eingang (783785) wird die dramatische Wendung, die in der Mitte der Versreihe einsetzt, durch das dopelte 'Bapyr' und die wiederholte Partikel 'we' im letzten Vers lebhaft hervorgehoben.

Der Text unterscheidet sich in Einzelheiten von der französichen Vorlage: "Admirons encore, $s$ 'il le faut, le héron, qui met, dit-on, sa tête sous son aile pour cacher dans ses plumes son bec, dont il veut percer l'estomac de l'oiseau de proie qui fond sur lui." (S.31) Mit dem Ausdruck 'on dit' weist Fénelon auf eine ungenannte Quelle dieser Tieranekdote hin.

Das 'alltagliche' Verhalten vieler Tiere ist jedoch nicht weniger erstaun- 
lich. Mit der wiederholten Frage 'не дивно ль' macht Tred. darauf aufmerksam, wie die Beutelmeise ihr Nest flicht, wie die Maus mit ihren 'zăhnchen' feste Gegenstānde zernagt. Ist es nicht wunderbar, fragt der Autor, daB das schwache Würmlein Holz zerfriBt und der blinde Maulwurf unter der Erde seinen Weg befestigt?

III,791f. Не дивно ль, что Арева червочик хилый точит?

Слепษй крот иаучи в земле путь свой толочит?

Wunderbar auch, wie die kluge Schwalbe inx Nest an die Felswand klebt, und dabei noch schnell!

III,793f. Не дивно ль, как гнездо и ласточка хитра

К утесу прилепить и в том еще быстра?

Ein spektakulăres Beispiel für Tierklugheit bietet der Kampf des Ichneumon gegen das Krokodil. Tred. schildert, wie das Ichneumon aus dem Schlammoden hervorkriecht, einem schlafenden krokodil in den offenen Rachen springt und in dessen Eingeweiden Unheil anrichtet. Es fxiBt mit Vorliebe die Leber des Krokodils, und nachdem es auch den Magen verzehrt hat, macht es sich wieder davon. Nicht genug damit, das Ichneumon weiB auch die Eier des Krokodils zu finden und, "damit das grausame Reptil sich nicht vermehre, zerstōrt es diese sofort." Diese Legende hat in der Demonstration keine Parallele:

III,795ff. Размыслим хитрость ту, в ихневмоне котора, Сей вшвалявшись весь в грязи тин от задора, Когда спит крокодил, в его отверсту пасть Bapyr вскакивает так, что строит там напасть; Oн печень в нем, себе любимую съедает, А черево проев, вон после выбегает, И яица его он смыслен находить, Не расплодился 6 тот змий лют, спешит те бить.

Die von Tred. erzăhlte Tierlegende hat überraschende Ähnlichkeit mit dem "im 'Physiologus' geschilderten Kampf zwischen Ichneumon (Hydrus) und Krokodil", von dem Chr.Gerhardt in seinem Aufsatz 'Die Kriegslist des Pelikans' berichtet. 48 Die Stelle hat im 'Physiologus' diesen Wortlaut: "De Yaro...cum uiderit corcodrillum in litore fluminis dormientem ore aperto. uadit et volutat se in lutro quo possit facilius inlabi in fauces. ueniensque insiliet in os corcodrilli. qui subito uiuum transgluciet..." ${ }^{4}$ Die in der 'Physiologus'Stelle folgende allegorische Deutung des Vorgangs auf Menschwerdung, Tod und Höllenfahrt Christi fehlt in der Feoptija. Der Frage, ob Tred. das Ichnemon- 
Exempel unmittelbar aus dem 'Physiologus' oder aus einer anderen Quelle bezogen hat, kann hier nicht nachgegangen werden.

Vom fremdartigen Ichneumon kehrt Tred. zu bekannten Erscheinungen in der Tierwelt zurūck. Ihn entzückt der Gesang der vögel, 'der geschwătzigen und süßen Sănger' :

III,803f. Приятно слышать нам премногих в разни птичек, Толь щебетливых тех и сладостных певичек.

Ein singender Vogel erfreut uns. Ein 'sprechender Vogel' setzt uns dagegen in Erstaunen, weil ex etwas kann, was man von einem Vogel nicht erwartet. Es ist ja die Sprache, die, wie Descartes betont, den Menschen vom Tier unterscheidet. 50

III,805f. Чуаимся, Как сквореИ, иль сойка говорит,

Иль и сорока тож, иль попугай творит.

Die Reihe der Beispiele abschlieBend, erklăt der Autor, es sei unmoglich, das staunenswerte Verhalten der Tiere hier und in fernen Lăndern vollstăndig aufzuzăhlen. Das kơnnte kein Naturforscher:

III,807f. Но сиислить может кой естественник иль в птицах, В зверях, или в скотах, иль в гадах, червях, мшицах, -

III,810 Ведущихся у нас и в дальнейших краях, -

Die Tiere tun viele wunderbare Dinge, die dem Menschen alle Ehre machen können: III,811f. Предивные дела и вымысли чудесны,

Из коих многи нам быть могут не бесчестны?

Nachtrăglich erwăhnt der Autor noch das intelligenteste Tier (oder nennt er es mit besonderer Betonung zuletzt?): der Affe ist schon zur Halfte ein Mensch: III,813f. Не обезьяне ль так во всем дано быть в век, Что, праведно сказать, та впол есть человек?

In III,817-922 wird das Thema 'Tierseele' noch einmal in den Mittelpunkt gestellt.

Ergibt sich etwa aus den vorgefuhrten Exempeln, daB das Tier mehr Vernunft besitzt als der Mensch?

III,817f. Но заключим ли мы из тех животных дел, Чтоб разума в себе скот больше нас имел?

- Fénelon, dem sich Tred. nun wieder enger anschließt, mahnt zur Vorsicht: "... la nature entiere est pleine de ces prodiges. Mais qu'en faut-il conclure sérieusement? $\mathrm{Si}$ on $\mathrm{n}^{\prime} \mathrm{y}$ prend bien garde, ils prouveront trop. Dironsnous que les betes ont plus de raison que nous?" (Démonstr.,s.31) 
Für die Uberlegenheit der Tiere scheint zu sprechen, daB sie 'ohne Kunst und Wissenschaft' tun, was ihnen gemå $B$ und nützlich ist:

III,821f. Без всех искуссто они и без наук творят, Что есть пристойно им и что полезно зрят; -

Wix Menschen dagegen irren uns trotz allen intellektuellen Aufwands hăufig: III,823ff. C рассудком мы своим, с науками, с советом Не зрим, что должно нам, толь часто, оним светом, И часто ж разум наш приводит нас в обман, An dieser Stelle hat Tred. den Text der Démonstration gekürzt. Dort werden die Wissenschaften, die den Tieren verschlossen sind, einzeln aufgefuhrt: "Elles n'ont étudié ni dialectique, ni geometrie, ni mécanique; elles n'ont aucune méthode, aucune science, ni aucune culture..." (S.31) Der Instinkt der Tiere ist aber weniger anfallig für Irrtumer als die menschliche Vernunft: "Nous nous trompons a toute heure, apres avoir bien raisonne ensemble: pour elles, sans raisonner, elles executent, a toute heure, ce qui paraIt demander le plus de choix et de justesse; leur instinct est infaillible en beaucoup de choses." (S.31)

Das Versagen der Vernunft demütigt uns zwar, răumt Tred. ein, aber es bestătigt nicht, daB die Tiere einen besseren Verstand haben:

III.827f. Tо правяа, но сие, хотя нас и смиряет,

0 лучшем в тех уме не удостоверяет.

In einem von der Vorlage unabhăngigen Einschiebsel (829-838) versucht Tred. das hăufige Fehlverhalten der menschlichen vernunft zu erklaren. Er fuhrt es darauf zurück, daß dem Menschen neben der Vernunft der freie wille gegeben ist, der unsere Entscheidungen und Handlungen vor allem bestimnt:

III.829f. При разуме еще нам воля подана, Избраний госпома и наших действ она: -

Der wille besiegt oft die Vernunft und verleitet sie zum Borsen. Tred. beschreibt den inneren Zwiespalt im Menschen:

III,833f. Так истину побло и, что добро, я 3рю,

Но, ненавияя ложь и зло, сие творю.

Die Verse erinnern an einige Züge der Anthropologie des Apostels Paulus. Im

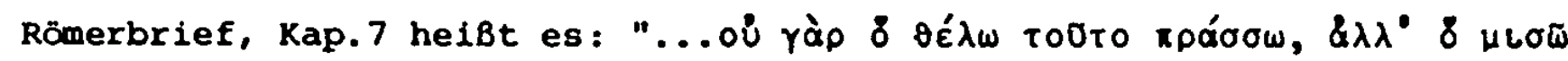

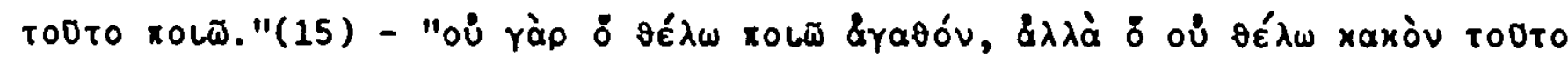
xрá́ow." (19)

Das Tier kennt nach Meinung Tred.s diesen inneren Widerstreit nicht. Das 'na- 
türliche Gesetz' zieht das Tier ungewollt zu dem hin, was ihm nützt:

III,835f. Естественншй устав влечет скота невольно

К тому, что аля него полезно и довольно.

Warum wir Menschen mit freiem Willen 'beehrt' worden sind, dafur alle Gründe anzuführen, fehle ihm der Raum, erklart der Autor:

III,837f. Но волей мы почто свободной почтены,

Тому здесь объявлять не место все вины.

Das wunderbare Verhalten der Tiere erklăt Tred. mit der Einwirkung des Schopfers :

III,839f. Что ж однолично скот всяк действует и дивно,

То положить твориу так не было противно - (vgl.III,401)

Die Tiere sind das Werk der Weisheit des Schopfers. Ihnen ist wenigstens

'eine gewisse Art Geist' zuteil geworden:

III,841f. Премуарости его в них дело признаю,

Хоть аух махинам сим я некий придар.

Tred. hat die Mechanismus-Metapher Descartes' im eigenen Sinne umgedeutet. Dies macht der anschlieBende Unren-Vergleich deutlich. Descartes hat das Bild so interpretiert, daB die Bewegungen der Organismen (auch des menschlichen) "ebenso notwendig aus der bloßen Anordnung der Organe folgt,...wie die Bewegung einer Uhr aus der Kraft, der Lage und der Gestalt ihrer Gewichte und Räder folgt." 51 Descartes hat demnach im Uhrengleichnis seiner 'Automatentheorie' eine anschauliche Form gegeben.

Dagegen haben unsere Autoren den Vergleich physikotheologisch verstanden: Aus dem genauen Gang einer Uhr, die auBer dem Uhrwerk nichts Besonderes enthalt (geschweige denn 'Verstand'), folgern sie, daß ein Meister sie erdacht und in Gang gesetzt hat:

III,845ff. Кроме м пружин, ума не зрю в часах я тех,

То заклюиить могу при слушамиих всех,

Что мастер тех часов зараней всё исправил

h, рассуанв умом, потом обрат составил. (vgl.III,688ff.)

Ebenso weist alle Klugheit der Tiere auf den Schöpfer hin. Er wollte in seiner Weisheit, daB sie klug sein sollten. Als er sie schuf, hat er in seiner Gute fur alles gesorgt:

III,849ff. Так точно хитрость всо животных я скотов

Tвориу напредь даD, не то что дать Готов.

Премуарость им его толь хитрым бшть велела,

Koгда творя о всем, по благости, радела. (vgl.III,401;840) 
Diese Auffassung entspricht der Kausalvorstellung der Occasionalisten, nach der cott nicht in singulären Akten tätig wird, sondern den Ablauf der Ereiǵnisse von Ewigkeit her geordnet hat. 52 Dieselbe Tendenz hat das Uhrengleichnis auch in der Demonstration: "Par exemple, quand je vois, dans une montre, une justesse sur les heures qui surpasse toutes mes connaissances, je conclus que si la montre ne raisonne pas, 11 faut qu'elle ait été formée par un ouvrier qui raisonnait en ce genxe plus juste que moi. Tout de même, quand Je vois des betes qui font, a toute heure, des choses ou 11 parait une industrie plus sare que la mienne, j'en conclus aussitot que cette industrie si merveilleuse doft etre nécessairement ou dans la machine, ou dans l'inventeur. qui l'a fabriquée. Est-elle dans l'animal męme?... si cette industrie n'est pas en lui, 11 faut qu'elle soit dans l'ouvrier qui a fait cet ouvrage, comme tout l'art de la montre est dans la tête de l'horloger." (S.31f.)

Jemand kōnnte einwenden: wie kommt es aber, daß die Tiere trotz ihres Instinktes Fehler machen?

III,853ff. Не возражай, что скот с своим побудком тем Нарочно будто 6 он бшл осужденный кем Погрешности творит, во многом заблумдая.

Tred. erwidert, es sei nicht verwunderlich, daB die Tiere nicht unfehlbar sind. Wir können uns aber nicht genug darüber wundern, daB sie sich manchmal außerst 'vorsichtig' verhalten:

III,859f. Но надивиться нам довольно невозможно, Что некогда весьма их действо осторожно.

Die Verse sind der Démonstration nachgebildet: "Ne me répondez-point que l'instinct des betes est fautif en certaines choses. Il n'est pas etonnant que les betes ne soient pas infaillibles en tout, mais il est étonnant qu'elles le soient en beaucoup de choses." (S.32)

Der Einwand wird mit der für unsere Autoren typischen 'umgekehrten Argumentation' widerlegt: Wenn die Tiere in allem unfehlbar sein sollten, müBten wir ihnen vollkommene Vernunft und vollkommenen willen zuschreiben:

\section{III,861ff. Korда 6 всегяа во всем исправных зреть нам их,}

То 6 разум совершен признать был долг самих

И надобно 6 придать, на их особно доло,

Премногих совершенств исполненнуо воло.

Mit Ausnahme eines Wesens können die anderen nicht vollkommen sein. Sie würden sich gegenseltig begrenzen. Die Pluxalităt vollkommener Wesen wird daher 
als 'in sich widersprūchlich' bezeichnet:

III,867f. Hе можно бшть другим, сия в себе есть пречно,

Еаиного кроме́, сөершенным бесконечно.

Dieses Argument ist schon in III,517ff. vorgebracht worden. Die zugrunde liegende Uberlegung Fénelons sieht so aus: "Si elles l'etaient en tout, elles auraient une raison infiniment parfaite; elles seraient des divinites. (Diesen Ausdruck hat Tred. fortgelassen). Il ne peut $y$ avoir, dans les ouvrages d'une puissance infinie, qu'une perfection finie; autrement Dieu ferait des créatures semblables a lui, ce qui est impossible." (Démonstr.,S.32) Nicht ganz eindeutig ist das folgende Verspaar, in dem es heibt, daB kein Ding, wenn es auch nur begrenzte vollkommenheit hat, ohne 'Glückseligkeit' sei:

III,869f. Однак Границы свойств и меры совершенств Не показуит вещь, что та есть без блаженств. Dahinter könnte die Auffassung stehen, daß der Schöpfer jeder Kreatur, auf welcher 'Stufe' sie auch stehen mag, den ihr gemäBen Anteil an 'Glückseligkeit' gegeben hat. Wahrscheinlich ist der Satz aber im Sinne der Vorlage zu verstehen: "La borne n'est donc pas une preuve que l'ouvrage soit sans ordre et sans raison." (Démonstr.,S.32)

Im folgenden soll wohl die allgemeine Aussage der Verse 869f. an einem Beispiel verdeutlicht werden. Tred. sagt: wenn ich einem Irrtum erliege, so folgt daraus nicht, daB ich ohne Verstand bin, sondern nur, daB mein Verstand unvollkommen ist:

III,871f. Koгда в чем обманусь, не следует так точно, Чтоб я без смысла был, то следствие порочно, -

III,875f. Но только, что мой смысл в себе несовершенный

И всяким родом свойств он есть неукрашенный.

So folgt aus der Tatsache, daß das Tier in vielem unverständig, in manchen Dingen aber sehr verständig ist, daB es 'eine gewisse Art Denken' besitzt: III,879f. По правде заклочит по сей уж всяк причине, Что некотора мысль в животной есть скотине.

Die Verse geben diese Uberlegung Fénelons wieder: "De ce que je me trompe quelquefois, il ne s'ensuit pas que je ne sois point raisonnable, et que tout se fasse en moi par un pur hasard; il s'ensuit seulement que ma raison est bornée et imparfaite. Tout de même, de ce qu'une bête n'est pas infaillible en tout par son instinct, quoiqu'elle le soit en beaucoup de choses,...il 
s'ensuit seulement que cette machine n'a point une raison sans bornes." (S.32)

In III,881-922 versucht Tred. darzulegen, welcher Art die Tierseele ist. Fénelon hat die Frage gestellt: "Si vous dites que les betes ont des ames differentes de leurs machines, je vous demanderai aussitôt: De quelle nature sont ces ames entièrement différentes des corps, et attachées d eux?" (S.32)

Unabhängig von Fénelon hat Tred. seine eigenen Gedanken darüber entwickelt. Schon bisher hat er der Theorie Descartes', die Tiere seien reine Mechanismen, widersprochen und ihnen 'eine gewisse Art Geist' (некий AyX, 842) und 'ein gewisses Denken' (некотора мысль, 880) zugestanden. Jetzt ergănzt er diese Aussagen: Tiere haben das Wissen, das ihnen gemảs ist:

III,885f. Что знание в скотах, пристойное им, есть, То за обман принять не можно, ни за лесть; -

Die Kraft ihrer vorstellungen und Empfindungen ist deutlich sichtbar:

III,887 Мечтания и чувсте в них сила ясно зрится, -

Welcher Art aber die Seele ist, die das alles in ihnen bewirkt, lät sich schwer bestimmen. Der Autor gibt offen $z u, d a B$ er es nicht weiB:

III,888f. Но от какой ауши сие всё в них творится, Незнание мое охотно признаю, -

In frommer Bescheidenheit bekennt er, dab der schöper mehr zu tun vermag, als der Mensch mit seinem Verstand begreifen kann:

III,890ff. Приемля правау в мысль конечнуп сию,

Что больше сотворить могущий есть создатель,

Нем человек понять возможет рассуждатель.

Einfacher ist es, die Tierseele von der menschlichen Seele abzugrenzen: Tiere haben keine 'reine Vernunft', die ihrem Wesen nach unsterblich ist, und durch die wir Menschen uns von den Tieren unterscheiden:

III,893ff. Едино говори, что чистого в них нет

Ума, который всех в нас умствований свет,

Кой естеством своим бессмертен есть вовеки

И коим от скотов мы разны человеки: -

Die menschliche Vernunft hat die Făhigkeit zur Abstraktion, die den Tieren ebenso fehlt wie das wissen von ewigen Wahrheiten:

III,897f. От вещества сему дано мысль отвлекать,

А при единствах всех и бесконечность знать. 
III,899f. Нет знания у них такого непреречно:

Не знают те никак, что истиным есть вечно.

Tred. lābt die Mechanismus-Formel für die Tiere nur eingeschrănkt gelten:

III,901 Махины суть скоты, не без души однак; -

Die Alltagserfahrung zeigt uns, daB die Tiere nicht unbewuBt leben wie etwa die Pflanzen, sondern feines Gefuhl und Verstehen, Vorstellungskraft und Gedăchtnis besitzen:

III,902ff. Бездушными назвать по општу не так

Растения, И жизнь, И чувственность толь нежну,

Понятие, мечту, мечте и память смежну

Ежеминутно мы зрим ясно толь в скотах,

Что не́льзя впрямь сказать: ауии нет в их телах; -

An dieser Stelle protestiert Tred. heftig gegen die 'Autcotentheorie' Descartes'. Er nennt den Gegner, mit dessen Lehre er sich schon des ofteren auseinandergesetzt hat, mit Namen:

III,909f. ОАин Картезий был, Кой смело рассуаил

И ма́хинами скот простыми утвераил; -

Besonders anstర̋Big ist für den Autor das Attribut: die Tiere seien 'einfache Mechanismen', d.h. nichts als Mechanismen. Descartes hatte die Existenz einer Tierseele u.a. mit dem Argument abgelehnt, daB diese auch unsterblich sein mũsse. Diese Ansicht weist Tred. zurück:

III,911f. Дать Ауши, по его, скотам, то Аать и вечность Бессмертную $*$ Аушам, в сем у него преречность.

SelbstbewuBt vertritt er seinen Standpunkt gegen den des berühmten Philosophen: Mag Cartesius behaupten, die Tiere hătten keine Seele; ich habe zu ihr 'einen anderen Weg':

III,913f. Картезий пусть тверАит, что те бездушны суть;

Я к бытио ауш в них аругой имео путь; -

Im folgenden Vers unterstreicht Tred. seinen Standpunkt durch die Anapher:

$$
\text { III,915 Я знаю, что Ауша их есть иного рода, - }
$$

Er kennt oder berücksichtigt allerdings nicht die differenzierten Äußerungen Descartes' über das Problem der Tierseele, aus denen eine Entwicklung seiner Einstellung zu erkennen ist. AuBer der prinzipiellen Verneinung, die im Dualismus von res cogitans und res extensa begründet ist, gibt es Aussagen Descartes', in denen er mit der Einschränkung 'non sicut nos' gewisse seelische Funktionen bei den Tieren zuzugeben scheint. In einer Arbeit von Wilh.A.J. 
Meyer, "Descartes" Entwicklung in der Erklärung der tierischen Lebenserscheinungen", GieBen 1907, aus der E.Heintel in seinem Aufsatz 'Tierseele und Organismusproblem' zitiert hat, heiBt es z.B.: "Weshalb sagt D. immer wieder bis zum Exmüden 'bruta non sentiunt $s i c u t n \circ s$, non imaginantur s 1 c u $t$ no s, non cogitant $s$ i $u t n \circ s^{\prime}$ " $^{53}$ Gegen Ende seines Lebens kommt Descartes, so berichtet Heintel, zu der freilich negativen Einsicht, "daB es nicht bewiesen werden konne, daB uberhaupt kein BewuBtsein in den Tieren vorhanden sei." 54 Das tierische BewuBtsein sei im Unterschied zum reflexiven BewuBtse in des Menschen "Ionte a ces organes", wie Descartes gesagt hat. ${ }^{55}$ Heintel fügt hinzu: so macht Descartes "manche aufschluBreiche Bemerkung über tierisches Empfinden (besonders über den Schmerz) und Begehren, tierisches Gedăchtnis und tierische Phantasie, Instinkt und Reflexhandlung. " 56 Den 'dogmatischen' Mechanismus (Physikalismus) mancher Cartesianer hat Descartes nicht geteilt, stellt Heintel fest.

Die Schwankungen in der Haltung Descartes' sind u.a. darin begründet, daB "die den Tieren etwa zugebilligte Seele der Lehre der Kirche entsprechend als sterblich zu betrachten, die Annnahme einer sterblichen tierischen Seele aber den Glauben an die unsterbliche menschliche Seele zu erschütern imstande gewesen wăre." 57

Tred. macht den Unterschied zwischen der Seele des Tieres und der des Menschen an zwei Punkten deutlich: Die tierische Seele kennt keine 'ewigen Wahrheiten': III,916 0 вечных правдах нет в ней мшсли, ни довода;-(vgl.III,900) Ferner: Die Seele des Tieres stirbt zusammen mit dem Körper, wăhrend die menschliche Seele unsterblich ist:

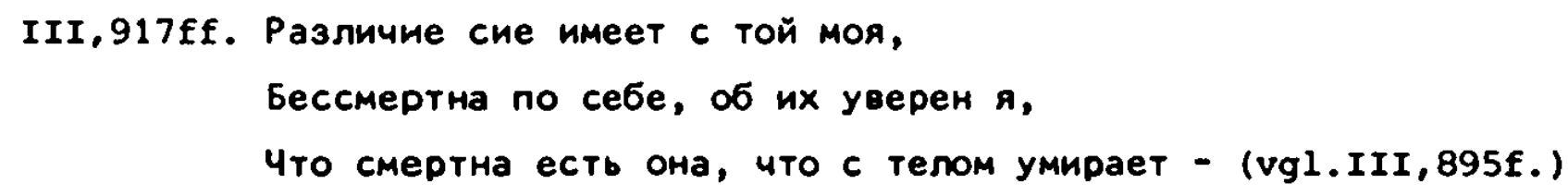
Wenn auch die Tierseele 'von anderer Art' ist, so kann sie doch keineswegs geleugnet werden. Tred. weist deshalb mit rhetorischer Emphase die Meinung zurück, die Tiere hăten keine Vorstellungen und Gefühle:

III,921f. Против Декарта весь наш општ вопиет, Что мысли Он и чувств животным не дает.

Wie aus dem Aufsatz von E.Reintel hervorgeht, ist diese konsequent mechanistische Auffassung weniger von Descartes, als von manchem Cartesianer vertreten worden. Als Beispiel erwăhnt Heintel das Verhalten von Malebranche, von dem Leibniz berichtet, er habe "eine ihm freundlich wedelnd entgegenkommende 
trăchtige tündin duxch einen rohen FuBtritt zum klăglichen Aufheulen gebracht und auf den Vorwurf seines Begleiters mit philosophischer Geckenhaftigkeit erwidert: 'wissen Sie denn nicht, que cela ne sent pas'."58

Das Verhaltnis der Physikotheologen zu den Tieren wird von W.Philipp so gekenneeichnet: "Im Hinblick auf die Tierwelt, ihre Achtung und ihren Schutz, uberwindet die physikotheologische Aufklarung Scholastik, Descartes und Wolff. Weder Abdruck supranaturaler Verhaltnisse nach der analogia entis noch mechanische Konstruktion ist das Tier, sondern Reflektor der neuen Transzendenz. " 59

III,923-958: Polemik gegen die Materialisten.

Der Abschnitt beginnt mit einer affektbetonten Apostrophe der Gegner, die behaupten, das 'Fleisch' denke von sich aus, ohne daB es der Annahme einer Seele bedurfe. Tred. nennt die Anhänger dieser These 'gottlos' und 'verachtungswirdig' :

III,923f. Ho вас, у коих плоть собо0 только мислит,

В презренных разум мой и в нечестивых числит.

Wie sich die Materialisten die Entstehung des Denkens in der Materie vorstellten, hat Tred. in den folgenden Versen beschrieben: Aus der ursprünglichen Unbewegtheit, in der sie nicht denkt, gexat die Materie in Bewegung und kommt zunåchst zum Bewußtsein ihrex selbst. Auf einer bestimmten 'stufe' des Bewegungsvorgangs bringt die Materie schließlich das Denken hervor:

III,925ff. Движений быть должна, по-вашему, степень,

В которой плоть еще в свою не мислит лень;

Потом долг наступать аругим степеням разным, -

III,929f. И станет вдруг себя извнутрь в тех познавать, Познав, о прочем всём доводно рассуждать.

Die Passage stammt, abgesehen von der polemischen Apostrophe, aus der Démonstration: "Il faut, selon vous, qu'il y ait un certain degré de mouvement ou la matiexe ne raisonne pas encore, et puis un autre à peu près semblable ou elle commence tout-a-coup a raisonner et a se connaltre." (S.33) Seit Demokrit (460-360) und Epikur (341-270) gibt es die Lehre, die aus der Bewegung der Atome im leeren Raum, aus ihrer Gestalt und ordnung nicht nur alle Erscheinungen der Korperwelt, sondern auch alle geistigen Tătigkeiten erklărt. Diese materialistische Erklărung der Lebensvorgănge hat im 17./18. Jahrhundert weit um sich gegriffen. Wăhrend Descartes (1596-1650) die immaterielle Substanz der menschlichen seele als res cogitans grundlegend vom kor- 
per als einer res extensa unterschied, neigte der von inm zum studium dex Reflexbewegungen angeregte Arzt und Naturforscher Boerhave in Leyden auf Grund seiner physiologischen Experimente stark zu materialistischen Vorstellungen. Zu denken ist auch an die Untersuchungen John Lockes (1632-1704), aus denen er den SchluB zog, daB es keine 'eingeborenen Ideen' gäbe. Alle unsere vorstellungen, so lehrte er, stammen aus den Wahrnehmungen der sinne (sensation), die durch die Tatigkeit der Seele (reflexion) bewubt gemacht, verknupft und miteinander in Bezlehung gesetzt werden. Da Locke das Verhaltnis der intellektuellen Tatigkeiten zu ihren ursprünglich sinnlichen Inhalten nicht eindeutig bestimnt hat -unbestimnt blieb vor allem, in welchem Grade die Seele bei der Verbindung der Vorstellungen selbsttatig gedacht wurde- haben sich aus der Lockesschen Lehre verschiedene Anschauungen entwickeln können. 60 So hat Voltaire (1694-1778), der die Lehre Lockes in Frankreich durch seine 'Lettres sur les Anglais' (1734) bekanntmachte, sie im sensualistischen sinne umgedeutet "und zeigte sich sogar... nicht abgeneigt, dem Schopfer die Macht zuzutrauen, daB er das Ich, welches Korper ist, auch mit der Făhigkeit ausstatte, zu denken." 61 Durch einseitige Konsequenzen aus cartesianischen Theorien kam der Arzt Pancratius Wolff zu der Auffassung, die er in seinen 'Cogitationes medico-legales' (1697) vertreten hat, "daB die Gedanken mechanische Tătigkeiten des menschlichen Leibes, insbesondere des Gehirns seien." 62 Im Jahre 1713 erschien der anonyme 'Briefwechsel vom Wesen der Seele', in dem "die Lehren von Bacon, Descartes und Hobbes zu einem anthropologischen Materialismus fortgeführt werden: zwischen dem Seelenleben des Tieres und dem des Menschen wird nur ein gradueller Unterschied anerkannt, Vorstellungen und Willenstatigkeiten werden ausnahmslos als Funktionen der erregten Gehirnfasern betrachtet." 63 In dieser Reihe ist schlieblich Julien offral de Lamettrie (1709-1751) zu nennen, der den anthropologischen Materialiamus auf die Spitze getrieben hat. Den Anregungen Boerhaves folgend, hat er den Mechanismus des Lebens bel Tieren und Menschen studiert und ist von der völligen Abhăngigkeit der Seele vom Korper uberzeugt. Er hat die 'Automatentheorie' Descartes' von den Tieren auf den Menschen ausgedehnt. "Der nur graduelle Unterschied zwischen beiden exlaubt auch für die menschliche Seelentatigkeit keine andere Erklărung als die, daß sie mechanische Funktionen des Gehirns sind." 64 In seinen Schriften (z.B. 'Histoire naturelle de l'ame',1745 und 'L'homme machine',1748) zieht de Lamettrie aus der Mechanik Descartes' die 'unabweisbare Konsequenz' des Materialismus. Nach der Auffassung Imettries 
ist es "ein Ubergriff der Metaphysik", so kammentieren Windelband-Heimsoeth, "dem 'Geiste' eine eigene Substantialităt neben der Materie zuzuschreiben. Der Begriff der Materie als des an sich toten Kōrpers, welcher des Geistes als bewegenden Prinzips bedūxfe, ist eine willkürliche und falsche Abstraktion: die Erfahrung zeigt, daß die Materie sich bewegt und lebt." 65

Vor diesem Hintergrund ist die Emotion zu verstehen, mit der Tred. die Befürworter der materialistischen These: 'das Fleisch' bzw. 'die Materie denkt', angreift. Zum Schema der Auseinandersetzung mit ihnen gehort, daB der Autor in einem Konzessivsatz, der nicht durch die Vorlage veranlaBt ist, 'einen Augenbl1ck' die Richtigkeit der materialistischen These unterstellt, um sie danach um so schärfer zurūckzuweisen:

$$
\begin{aligned}
& \text { III,931f. Положим мы телерь на время за неложно, } \\
& \text { Что мшслить веществу, как Ауху, есть возможно. }
\end{aligned}
$$

Fénelon folgend, hat Tred. in einer Reihe von rhetorischen Fragen aufgezeigt, daB die These der Materialisten auf bestimmten Voraussetzungen beruht, die von ihnen nicht begründet worden sind. Die mit 'KTO' (sechsmal) bzw. mit 'qui est-ce qui' (fünfmal) eingeleiteten Fragen zielen auf einen persönlichen Urheber ab:

\section{III,933f. Но двигов тех степень кто точную из6рал?} - Лине́і кто нашел, по той и Авиги склал? Vgl. "Qui est-ce qui a su choisir ce degré précis de mouvement? Qui est-ce qui a découvert la ligne selon laquelle les parties doivent se mouvoir?"

III,935f. Величину, размер, фигуру кто и точность Во всякой части в нем? кто всю другу побочность, -?

Vgl. "Qui est-ce qui a pris les mesures pour trouver au juste la grandeur et la figure que chaque partie a besoin d'avoir...?" (S.33)

\section{III,939f. Снаружи учреяил кто стройное толь тело, Что всяк по мере член свое имеет дело?}

Vgl. "Qui est-ce qui a réglé la figure extérieure par laquelle tous ces corps doivent être bornés?" (S.33)

AbschlieBend fragt der Autor, wer 'jede Eigenschaft ersonnen' habe, die aus der trăgen Materie eine denkende gemacht hat. Es brauchte ja nux 'ein Teilchen' weggenommen $z u$ werden, so würde sie aufhoren $z u$ denken:

III,941ff. И словом, свойство всё кто оно изобрел, Чтоб мшсльми вещество ленивое согрел? От коего нельзя отнять ни малой части, Тому чтоб не престать уж мыслить в той напасти? 
In Vers 942 steht die eigentümliche Metapher: die trăge Materie wird 'durch die Gedanken erwămt'.

In der Démonstration lautet die Stelle so: "En un mot, qui est-ce qui a trouvé toutes les combinaisons dans lesquelles la matiere pense, et dont la moindre ne pourrait etre retranchée sans que la matiere cessat aussitot de penser?" (S.33) So setzt die These: 'die Materie denkt', wenn sie einen sinn haben soll, auf Schritt und Tritt den Schopfungsglauben voraus. Dies bringen die 'wer'-Fragen zum Ausdruck. Nur der Schöpfer ist imstande, die Verhăltnisse zu schaffen, unter denen sich unsere Autoren eine 'denkende Materie' vorstellen konnen. Damit wirde freilich die materialistische These im Kern verandert. Sie würde aufhoren, materialistisch $z u$ sein. Kurz und bundig formuliert Tred.:

III,949f. Итак, хоть положить, что мыслит вещество, Сказать долг, что ему мшсль дало божество.

Nach Meinung der Materialisten sorgt der zufall für die Art der Bewegung, die Gestalt und Konstellation der Atome, die in der Materie das Denken zur Folge haben. Dem widerspricht Tred.: der 'unverstăndige Zufall' konnte nicht einmal die geordnete Materie, geschweige denn ein vernüntiges Wesen 'machen':

\section{III,945ff. Безумншй не возмог ни чинна вещества \\ Припадок сделать вам, не то что сунества \\ Разумного того и мшслаща природно,}

Fénelon entgegnet den Zufallsanhăngern ironisch: "Si vous dites que c'est le hasard, je reponds que vous faites le hasard raisonnable Jusqu'au point d'otre la source de la raison meme." (Démonstr.,s.33)

In den folgenden Versen setzt Tred. die Auseinandersetzung mit den materialistischen Zufallsglaubigen selbståndig fort. Er fordert sie schroff auf, 'vom dummen zufall abzulassen':

\section{III,951 0тстать уже пора от глупого припаяка: -}

Der ganze Abschnitt enthălt Elemente eines Glaubenstreites, der mit einer Schmahung der 'Gottlosen' beginnt (923f.), den Inhalt ihrer falschen Lehre kennzeichnet (925-930), deren Voraussetzungen aufdeckt (931-948) und die Materialisten auffordert, ihren Irrglauben aufzugeben (951). Schlieblich wird die wahre Lehre verkündgt: 'das Fleisch denkt nicht'. Ohne 'Zugabe' kann es von sich aus nicht denken. Diese 'Zugabe' ist die Seele. Der 'hochste cott' hat die Seele mit dem materiellen korper uberaus weise vereinigt zu zwecken, die er in seiner groben Macht kennt: 
III,952ff. Не мыслит плоть, ниже́ и мыслить без придатка

Возможет та собой; a тот Аушой всегаa

Без всякого уму зовется в нас вреда,

Спряженной с веществом премудро вьиним богом,

Аля ведомых концов ему в могутстве многом.

Nach der Anthropologie Descartes' besteht das 'menschliche Compositum' aus einem 'organischen Automaten', der mit einer Seele 'substantiell vereinigt' ist. 66

Tred. kommt auf das Hauptthema zurück und erklărt polemisch: wer die Tierseele leugnet, der muß selber zum 'unverstăndigen Vieh' gehơren:

III,957f. О скотских не Аушой доказывать делах -

В безумных самому быть долг тому скотах.

In III,959-1028 beruft sich Tred. auf Platonismus und stoa für seine Auffassung von der Tierseele, verurteilt abex die pantheistischen Tendenzen dieser philosophischen systeme.

Im SchluBteil der III.Epistel hat Tred., der Demonstration folgend, die 'alten Weisen', d.h. Philosophen und Dichter der Antike zur Bestatigung der eigenen Anschauungen aufgeboten. Die Berufung auf 'die Alten' war ein gangiger Topos in der Dichtung des 18. Jahrhunderts. ${ }^{67}$ Unsere Autoren haben in der stoischen Logosphilosophie eine frühe, wenn auch begrenzte Erkenntnis der Wahrheit gesehen, daB der Schōpfer der ganzen Natur das Zeichen seiner Weisheit und Macht aufgeprägt hat. Tred. beginnt den Abschnitt mit einer 'zuwendung zu dem fiktiven Adressaten Evsevij. Die bloBe Nennung des Namens stellt das Minimum einer 'Apostrophe' dar. DaB Tred. diese für die Epistelform spezifische Figur auch im funktionalen sinne handhaben kann, zeigen andere Beispiele, etwa Feoptija Ep.I,469-483. Jetzt, am Ende der III.Epistel, setzt der Autor seinem fiktiven Partner auseinander, daB die Philosophie der 'alten Weisen', gemessen an der eigenen 'aufgeklarten Weisheit' zwar unvollkommen gewesen sei; sie hätten jedoch die intellektuelle und moralische Verderbnis der Menschheit vorausgesehen und gelehrt, daB der Geist der hochsten cottheit in ganzen Universum 'ausgegossen' sei, und daB seine Weisheit in der ganzen Natux, besonders deutlich aber in den Tieren, wirke. Das Wirken des göttlichen 'Logos' in der Welt sei mit dex Tätigkeit der seele in unserem Körper zu vergleichen: 
III,959ff. Хоть в Аревних муарецах, Еөсевий, не свершена

Вся мудрость толь бшла, коль наша просвещена,

Однак, предеидя те разврат людских умов

И заблуждений всех и өсех обманов ков,

Старались утверяить, что челуо өселенну

Ум вышня божества есть разлит нам явленну,

И что его всетда сама премудрость в ней,

И дейстөует везде она в матуре всей,

А особливо есть то Аействие ө мивотных,

Как Ауши в наших суть телах непраздны плотных; -

Abgesehen von der Anredeform, dem Vergleich der antiken mit der 'aufgeklărten Weisheit' und der erweiterten Kennzeichnung der Verderbnis entspricht diese Versreihe dem vorgegebenen Passus der Demonstration: "La philosophie des anciens, quoique très imparfaite, avait néanmoins entrevu cet inconvênient; aussi voulait-elle que l'esprit divin, répandu dans tout l'univers, fat une sagesse supérieure qui aglt sans cesse dans toute la nature, et surtout dans les animaux, comme les ames agissent dans les corps..." (S.33)

Nach stoischer Lehre, so fahren unsere Autoren fort, waren 'Funken' der gottlichen Vernunft der Ursprung der 'geborenen Wesen'. Jedes Tier empfängt sie von der cottheit und bewahrt sie in sich bis an sein Ende. Beim Tode trennt sich diese von ihrem Ursprung her unsterbliche Kraft vom Staube, steigt auf zu den himmlischen 'Nestern' und bleibt dort inmitten leuchtender Sterne:

$$
\begin{aligned}
& \text { III,971ff. Твердили те тогда, что искры вьшня бога, } \\
& \text { От разума его нашедшие премнога, } \\
& \text { Рождаемого суть началом естества, } \\
& \text { И что их кажяый скот, прияв от бомества, } \\
& \text { Содермит внутрь себя до самыя кончины, } \\
& \text { При коей сила та, бессмертия с причины, } \\
& \text { От персти отстая, до вишних всходит гнезд } \\
& \text { И пребывает там между зарями звезд. }
\end{aligned}
$$

Die Verse geben den entsprechenden Text der Démonstration wieder: "Ils ajoutaient que ces étincelles de l'esprit divin etaient le principe de toutes les générations; que les animaux les recevaient dans leur conception et a leur naissance, et qu'au moment de leur mort, ces particules divines se detachaient de toute la matière terrestre, pour s'envoler au ciel, ou elles roulaient au nombre des astres." (S.34) 
Tred. erklart zwar diese philosphischen Ansichten für falsch, erkennt aber zugleich an, 'daB sie voller Vernunft und wohlüberlegt' seien:

\section{III,979f. Сих муарствований есть хоть мнение и ложно, \\ Но разума исполнь, притом и осторожно.}

F'enelon urteilt: diese Philosophie, die GroBartiges und Mthisches vereinigt, hat 'Vergil in seinen Versen über die Bienen mit soviel Anmut zum Ausdxuck gebracht.' : "C'est cette philosophie, tout ensemble si magnifique et si fabuleuse, que Virgile exprime avec tant de gráce par ces vers sur les abeilles, oll il dit..." (Démonstr.,S.34)

Tred. erweitert aus eigener Kenntnis die Angaben uber Vergil. Er nennt inn 'Gipfel und Haupt der rōmischen Dichter' und sagt, Vergil habe diese philosophische Ansicht in den Georgica in dichterischer Form vorgebracht:

\section{III,981ff. Вергилий, римских верьх пиитов и глава, \\ Гео́ргических книг оставил нам слова, \\ Стихов и мерой стоп межау собой сплетенны, \\ 0 мнении таком там всно приведены.}

Damit hat Tred. den Titel eines 'Lehrgedichts' der Antike zitiert, das in der Geschichte der Gattung eine beispielhafte Rolle gespielt hat. DaB er zuerst die metrische Form der Georgica ins Auge faBt, ist bezeichnend für sein besonderes Interesse an diesen Fragen. Im Blick auf den Inhalt der Georgica heiBt es, Vergil habe darin die Themen des Landbaus besungen. Den Abschnitt über die Bienen bezeichnet Tred. mit einer Metapher aus der griechischen Mythologie als Vergils 'Schwanengesang':

III,985f. Он земледелий в них поя о всех делах, А лебединый глас свой взнесши о пчелах, -

Er rühmt die für Vergil charakteristische dichterische schönheit und den hohen Stil des Abschnitts:

III,987f. С обынною себе воспел там красотоп

И предлагал сие так слога высотоо, -

Vergil habe, erklărt Tred, auf Fénelon zurückgreifend, die klugheit der Bienen solchermaßen vorgeführt, daß der Betrachter ihnen wegen ihres sinnvollen Verhaltens gottlichen Verstand zuschreiben möchte:

III,989ff. Что хитрость оных пчел к тому уж привела

Взираяинх на их толь мудрые дела,

Чтоб в них им признавать ум божий достоверно.

Fénelon faBt die Schilderung, die Vergil von der Lebensweise der Bienen gibt, 
zusamen: "...il dit que toutes les merveilles qu'on $y$ admire ont fait dire a plusieurs qu'elles étaient animées par un souffle divin et par une portion de la Divinité..." (Démonstr.,s.34)

Nach der Lehre der Stoiker erfült das göttliche 'Pneuma' den 'unermeBlichen Himel', die Luft, die Erde und alle 'weiten Meere'. Es erfüllt ebenso die 'lebendige Kreatur' und bleibt in ihr, solange sie lebt. Dann steigt es, da es seinem Wesen nach unsterblich und 'einfach' ist, zu den Sternen in der höchsten Höhe hinauf:

III,992ff. Hаполнив оним бог всё не6о пребезмерно, Весь возаух, земло вср, пространны все моря

Им полнит, равно тварь животнуо творя,

И в оной тем умом пота он пребшвает,

Пока жимотных тех состав не истлевает;

Потом, ито суиность в нем бессмертна и проста,

В число восходит звезд в превыспренных местах. (vgl.976f.)

Die Stoiker verstanden das 'Pneuma' als 'gestaltenden Feuergeist' der Gottheit (vgl. die wendung 'искры вышня 6ога',971 bzw. 'étincelles de l'esprit divin', Démonstr.,S.34), "welcher alle Dinge durcharingt und in ihnen als das tatige Prinzip waltet: er ist das Weltall als in sich selbst bewegtes, zweckvoll und gesetzmäßig entfaltetes Lebewesen. "68

Fénelon hat die Pneuma-Lehre dargestellt, ohne den Begriff 'Pneuma' zu verwenden: "...dans la persuasion ou ils étaient que Dieu remplit la terre, la mer et le ciel; que c'est de là que les bestes, les troupeaux et les hommes regoivent la vie en naissant; et que c'est la que toutes choses rentrent et retournent lorsqu'elles viennent à se detruire, parce que les ames, qui sont le principe de la vie, loin d'être anéanties par la mort, s'envolent au nombre des astres, et vont etablir leur demeure dans le ciel:" Hier folgt in der Démonstration ein zitat aus den Georgica (lib.IV), das Tred. ausgelassen hat:

"Esse apibus partem divinae mentis, et haustus

Aetherios, dixere: deum namque ire per omnes

Terrasque, tractusque maris, coelumque profundum:

Hinc pecudes, armenta, viros, genus omne ferarum,

Quemque sibi tenues nascentem arcessere vitas:

Scilicet huc reddi deinde ac resoluta referri

Omnia; nec morti esse locum, sed viva volare

Sideris in numerum, atque alto succedere coelo." (S.34) 
Unsere Autoren behaupten, diese Lehre sei schon vor den Stoikern von Plato vertreten worden:

III,999f. Ко мненио сему всяк стоик пригеождался, А прежде еше их Платон в нем уеверждался; -

Auffallend ist die drastische Verb-Metapher: jeder Stoiker wax auf diese Lehre 'festgenagelt' .

Fénelon spricht von dem 'Eindruck', den die gottliche Weisheit auf die Stoiker und vor Ihnen auf Plato gemacht habe: "Cette sagesse divine,...avait tellement frappé les stoiciens, et avant eux Platon, qu'ils croyaient que le monde entier était un animal; mais un animal raisonnable, philosophe, sage..." (Démonstr.,S.34) - Fénelon folgend, schreibt auch Tred. den Stoikern die Auffassung $z u$, die ganze Welt sei ein vernūnftiges Wesen, welches das mănnliche und weibliche Prinzip in sich trage:

\section{III, $1001 f$. И толь, что челый свет животным звали уж, \\ Который был по их с умом жена и муж.}

$\mathrm{Zu}$ 'целшй свет' merkt Tred. an, daß 'von den Neuen der Italiener Giordano Bruno derselben Ansicht' gewesen sei: "Из новых сего мнения был Иордан Брун, италиане4." (Anm.1 zu III,1001,S.260)

Aus der Demonstration ubernimmt Tred. schlieblich noch das Thema des stoischen Pantheismus. Er sagt von den Stoikern, sie haben die vielen Götter zu einer Gottheit 'zusammengeschmolzen', die sie 'Natur' nannten. Der 'Natur' haben sie alle gotttlichen Prădikate beigelegt: sie ist ewig, unendlich, vollkommen, göttlich, allmāchtig, allweise und allgegenwărtig:

\section{III,1003ff. Сих множество божеств в единое сливали; \\ Оанако тем они натуру признавали, \\ Которая была как вечная у них \\ И беспредельна так в свершенствах всех своих, \\ Божественна притом и купно всемогуща, \\ Премудрая во всем, она и всоду суца.}

Den Versen liegt der folgende, von Tred. erweiterte, Satz Fénelons zugrunde: "Cette philosophie réduisait la multitude des dieux à seul; et ce seul dieu a la nature, qui était éternelle, infaillible, intelligente, toute-puissante et divine." (Démonstr., S.34)

Fénelon beurteilt die stoische Lehre maBvoll: wohl kritisiert er die Philosophen, die poetischen Phantasien erlegen sind. Sie haben wie Fabeldichter auch den unbelebten Teilen des Universums Leben, Intelligenz, Kunst und planvolles 
Verhalten angedichtet. Aber Fénelon kxitisiert ohne Leidenschaft. Sein ausgewogenes Urtell mündet in gedămpftes Lob und sanften Tadel: "Sans doute 1ls avalent bien senti l'art qui est dans la nature, et lls ne se trompaient qu'en attribuant a l'ouvrage l'industrie de l'ouvrier." (Démonstr.,s.34f.)

Ein anderer Ton schlágt uns im Finale der III.Epistel der Feoptija entgegen: wăhrend sich Fénelon kritisch vom Pantheismus der stoiker distanziert und über sie in der dxitten Person spricht, klagt Tred. sie wie ein Inquisitor direkt an. Nur gegen die Atheisten ist er ausfallender geworden (vgl. I,55ff.) als hier bei seinem Angriff auf die pantheistischen Stoiker. Er apostrophiert sie als 'Weise', die in inrem Ruhm glanzen wollten und doch in ihrer Weisheit 'blind' waren:

III, 1009f. Hо, о! сиявши вы толь в славе муарец4, Вы были по своей той муарости слепцы.

Solche 'Weisheit', die in Wirklichkeit 'blind' ist, kann nur mit Ironie genannt werden. Der 'Blindhe1t' hat Tred. schon die 'Gottlosen' in Ep.I,1 bezichtigt: "Прокляни, Евсевий, нечестивых слепоту..." Die 'Blindheit' bzw. das 'Nichtsehenwollen' (не хотат усмотревать...,I,3) gehören ebenso wie die Bezelchnungen für das 'Dunkel': мрак,I,5; Tbma,I,61 und mrna,III,1025 zum Negativkatalog in der Feoptija. Auf der anderen Selte wird das Gute durch die Metaphorik des Lichtes bezeichnet. Dies steht nach Meinung von W.Philipp im zusammenhang mit der 'Bevorzugung des Gesichtssinnes' in physikotheologischen Schrifttum.

Tred. wiederholt die Schmăhung der Weisen: eure Weisheit war 'blinder Unverstand'. Er wirft den Anhăngern lhrer Lehre 'lasterhafte Blindheit' vor:

III,1023f. पто мудрость в еас бuла безумие слепое, Порочной слепоти, ту признававших, вдвое.

Die beiden zitierten Verspaare 1009f. und 1023f. erinnern an Worte des Paulus in Röm.Kap.1,22: "páoxovtes elval oopol Éuwpávonoav,..." und I.Kor.3,19:

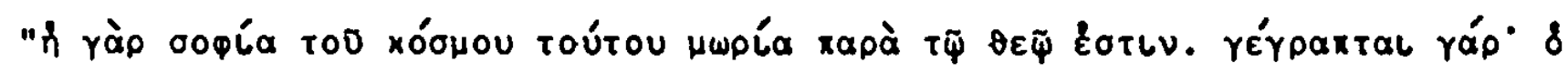

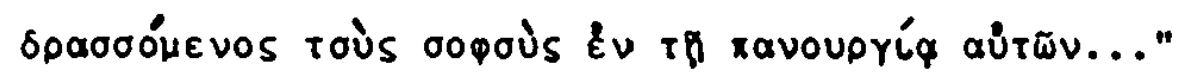

Die Kritik Fénelons an den alten Phllosophen, sle seien in die 'Phantasien der Dichter zurückgefallen' ("...les philosophes, force de s'eloigner des poetes, retombalent dans toutes les imaginations poétiques."S.34) hat Trod. als Vorwurf gegen die stoiker gerichtet:

III, $1011 \mathrm{f}$. От стихотворншх снов себя далеких мнили И дорого себя пред ними толь ченили; - 
III,1013f. ОАнак, и не хотя, на их вступали след

И упадали так вы в тот же самый бред.

Den Kern des pantheistischen Irrglaubens sieht Tred. nicht anders als Fénelon darin, daB auch den Teilen der Welt, die weder etwas verstehen noch sich vorstellen können, Vernunft zugeschrieben wird:

III,1015ff. Приписывали ум таким частям во свете,

Которы о себе быть не могли в примете;

Да и не токмо те могли ито разуметь,

Но не могли ниже́ понятия иметь.

Von Fénelon unabhăngig droht Tred. den Pantheisten mit der ewigen Verdammis, die er in Vers 1019f. mit einer griechischen, in Vers 1021ff. mit einer christlichen Vorstellung unschreibt:

III,1019f. Tenерь, но поздо уж, Олимпу вы дивитесь, Как красотой его, лишены сей, язвитесь; -

Als pantheistische Stoiker haben sie den Glauben an die Götter Griechenlands aufgegeben. Jetzt sehnen sie sich vergeblich nach der Schönheit des olymp. Sie haben ihn für immer verloren.

Auf der anderen Seite droht den Pantheisten das Jüngste Gericht. Weil sie eine Irrlehre verbreitet haben, werden sie 'zum Tage des himmlischen Weckrufes' nicht zugelassen. Möglicherweise spielt Tred. mit dieser dem militärischen Bereich zugehorigen Metapher auf die neutestamentliche Vorstellung der 'Posaune' des Jüngsten Tages an, die gleichsam das Signal für die Auferweckung der Toten gibt:

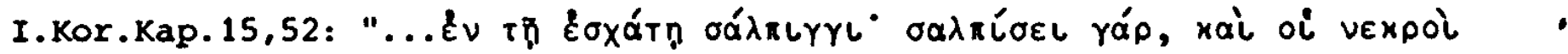

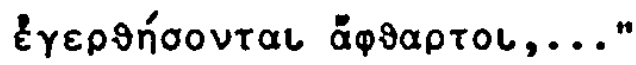

Vermutlich meint Tred. in den Versen 1021f. das Schicksal, das den Stoikern im Jüngsten Gericht zuteil wird:

III,1021f. На обличений стщА, дано вам знать, как мно, Недопущенным всем небесных зорь ко ано, -

Trotz des 'dichten Nebels', der in den stoischen Philosphen herrscht, findet Tred. an ihrer Lehre aber auch etwas 'Lobenswertes'. Nach dem vorangehenden Verdikt wãe diese positive Wendung kaum zu verstehen, wenn sie nicht aus der Vorlage kăme, in der die forensische Passage der Feoptija ohne parallele ist.

Der stoische Lehrsatz, nichts in der Welt sei von selbst geworden, sondern von dem Allweisen erschaffen, hat Tred.s volle Zustimmung. In diesem Punkt identifiziert er unbedenklich die stoische Logoslehre mit dem 'Pneuma' des 
III,1025ff. Однак, при густоте в вас бывшия здесь мглы, Нам должно вас почесть достойных похвалы, Что ничего собой не мнили в свете ставша, Но от премудра всё, вещали вн, создавша.

IV. Epistel: Das Wunder des menschlichen Organismus weist auf den Schöfer hin

In IV, 1-20 wird das Thema angegeben: der Mensch soll sich selbst als Werk Gottes erkennen und ihn dafür preisen.

Die Epistel wird mit einer feierlichen Apostrophe eroffnet, in der das anthropologische Thema angekündigt wird. Der Mensch, durch seinen Verstand vor den Tieren ausgezeichnet, erkennt sich selbst als Werk der höchsten Weisheit, Gute und Macht des Schópfers. Darum fordert der Autor den Evsevif zu gemeinsamer Bewunderung und Lobpreisung auf. Zur Aufforderung, die gottliche Trias, "премудрость Bышнего" (3), "6лагость его" (4) und "сила всемогушего твориа" (5) zu 'bewundern', zu 'erheben' und zu 'preisen', tritt eine weitere Form der Gottesbeziehung: die Liebe zu dem 'Vater, der seine Kinder liebhat':

\section{IV,5f. Возвеличим силу всемогущето твориа}

И возлобим сердцем чаропюбното отца; -

Die Verbindung des 'Vaters' (vgl. II,312: 'оте4 премилосердый' und II,663: 'хранитель и отец') mit dem 'Schópfer' im Gottesbegriff der Feoptija beruht

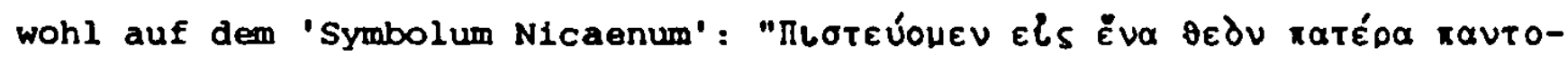

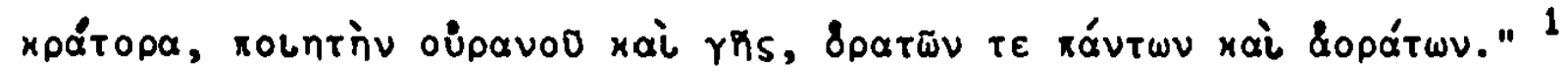
Tred. steht mit seiner Aussage in Ubereinstimmung mit der cotteslehre der griechisch-orthodoxen Kirche.

Uber das Verháltnis des Menschen zu Gott sagt Tred. zu Evsevij:

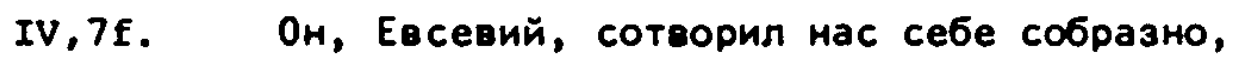
По подобию создав своему, не разно.

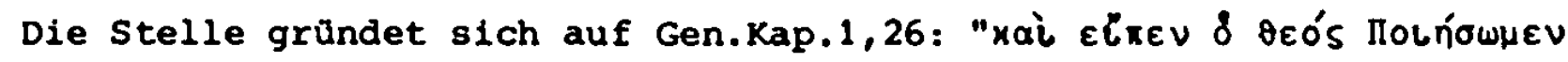

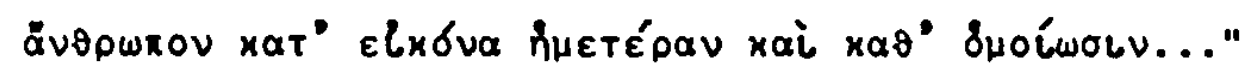

Die lange und vielgestaltige Auslegungsgeschichte dieses Textes kann hier nicht nachgezeichnet werden. Strittig ist schon, ob die beiden Begriffe 'Elxw' und 'Suoíwols' dogmatisch zu unterscheiden sind oder im wesentlichen synonym verstanden werden müssen. P.Althaus, der sich in exegetischer Hịnsicht auf die 'Theologie des A.T.' von W.Eichrodt beruft, meint, daB der

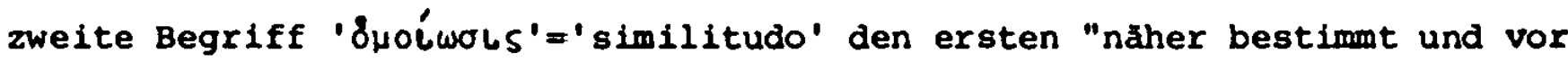


MiBverståndis schütz"... "Der Begriff 'Bild' IEZxẃv=imagol soll nicht grob sinnlich gefaBt, sondern im Sinne gleichnishafter Ahnlichkeit verstanden werden." 'wichtig ist vor allem, was 'Ebenbildlichkeit' bzw. 'Annlichkeit' des Menschen mit Gott bedeutet. Die katholische Theologie versteht unter 'imago' -so P.Althaus- die Vernünftigkeit und Freiheit des Menschen, die zu seinex unverlierbaren, schöpfungsmäigen Ausstattung gehören. Die 'similitudo' hingegen hat der Mensch durch die Sunde verloren. Sie kann ihm nach katholischer Lehre jedoch als übernatürliches 'donum superadditum' durch die Gnadenmittel der Kirche zurückgegeben werden. Auf evangelischer Seite bestreitet vor allem K.Barth die natürliche Ebenbildlichkeit (imago) des gefallenen Menschen mit Gott. Sie ist "nicht als eine uns ruhend und gesichert eignende" Eigenschaft, "nicht als datum, sondern als dandum" zu verstehen, das dem Menschen jeweilig als freie Gnadengabe des $\mathrm{Hl}$. Geistes im Glauben an Jesus Christus zuteil wird. ${ }^{3}$

Im Unterschied zu K.Barth faBt P.Althaus die 'imago' als in bestimmter Begrenzung unverlierbare Ebenbildlichkeit des Menschen mit Gott. Ex sagt: "Man wird an die Personhaftigkeit des Menschen denken müssen. Darin ist er vom Tier unterschieden und Gott ahnlich, daB er seiner selbst bewuBt und zur freien sittlichen Selbstbestimmung gerufen ist." "Althaus legt den Ton darauf, daB der Mensch 'gerufen' ist, seine Ebenbildlichkeit zu verwirklichen. Dies kann nach Althaus positiv nur in der Gemeinschaft mit Gott geschehen, für die der Mensch durch seine schöpfungsmäßige Personalităt bestimmt ist. Durch den Bruch der Gemeinschaft mit Gott wird dagegen die 'personale Verfassung' des Menschen, d.h. seine Vernünftigkeit und Freiheit, "in ihrem sinne verkehrt und (zum) Mittel der sünde." 5 An der katholischen Lehre beanstandet Althaus, daB die 'imago' von ihr als 'neutral' gegenüber dem Gottesverhaltnis angesehen wird, also auch auBerhalb des Gottesverhăltnisses unbeschädigt bleibt. Die Gemeinschaft mit Gott erscheint als ein zusatzliches übernaturliches Geschenk, "dessen Verlust das Menschenwesen nicht bis in die Wurzel schädigt und verdirbt; (so) daB dem Menschen nach dem Fall mehr oder weniger offen noch der freie wille zugeschrieben wird." 6

Von der 'imago' im Sinne der schöpfungsmäßigen Verfassung des Menschen unterscheidet Althaus die christologisch bestimmte Ebenbildlichkeit mit Gott. Zusammenfassend erklart Althaus: "Man kann beides zugleich sagen: daB der Mensch in seinem Personsein schopfungsmäBig und unverlierbar das Bild Gottes darstelle; und: $d a B$ ihm 'die Gerechtigkeit und Heiligkeit' (Eph.4,24), das Abbild des heiligen Wesens Gottes, erst durch Christus zuteil werde." 7 
Fénelon und Tred. erwăhnen den biblischen Begriff des 'Ebenbildes', ohne uber ihn theologisch zu reflektieren. Bemerkenswert ist, daB Tred. in diesem Zusammenhang zum Lobpreis und zur Liebe cottes, also zur Gemeinschaft mit cott auffordert, die, wie ausgeführt worden ist, zur wesensmäigen Bestimmung des Menschen gehort. Die personale Beziehung zu seinem Schopfer und 'Vatex', dazu die Gabe der Vernunft zeichnen den Menschen vor den Tiexen aus. Darum exoffnet gerade die Betrachtung des Menschen einen neuen und tieferen Einblick in die Weisheit, Güte und Macht des Schopfers:

IV,1ff. Пре́йдем от жиеотных до сеятейшего из них Cmuслом неловека, $h$, no нас уже самих Вишнего премуарость зря, оной почуаимся; Zu diesem Eingang hat Fénelon nur das Stichwort gegeben, das Tred. eigenstăndig entfaltet hat. Ohne ein neues Kapitel in seinem 'Traite' zu beginnen, schliebt Fénelon das neue Thema an das vorige an: "Ne nous arretons pas da-

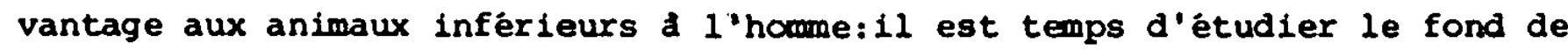
l'home meme, pour découvrir en lui celui dont on dit qu'il est l'image."(35)

Mit einem Lobpreis Gottes, in dem deutlich der 8.Psalm anklingt, meditiext Tred. Uber die Stellung, die dem Menschen innerhalb der Geschopfwelt zugowiesen worden ist. Der Hymnus beginnt mit der Anrede:

\section{IV, 9 Коль твое пречуано, боже, имя по земле!}

Sie entspricht den versen 2 und 10, die gleichlautend, wie eine Klammer den 8.Psalm umschließen:

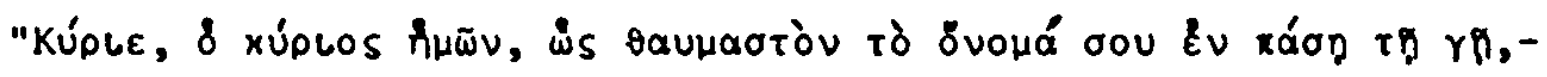
Spezield veranlaBt wird der staunende Lobpreis durch die Betrachtung des menschlichen Doppelwesens: er steht zwischen den Tieren und den Engeln. Einerseits ist der Mensch 'erdăhnlich' wie die Tiere. Andexerseits hat Gott inn nicht der Verwesung uberlassen wollen:

IV,10 Быть земной подобним не благоволил нам тле.

Gott hat den Menschen nur wenig geringer gemacht als die himmlischen Geistex, indem er uns als vernūnftige und zugleich kơperliche Wesen geschaffen hat:

IV,11f. Малим не́чем от чинов уменьшил небесных,

Зиждя и разумншх нас, купно и телесных.

Vers 12 geht auf einen Satz der Démonstration zurūck, in dem sich die anthropologische Auffassung Descartes' abzeichnet: "L'home rassemble en lui ces deux manières d'être: il a un corps comme les etres corporels les plus inanimés; il a un esprit, c'est d dire une pensée par laquelle il se connait, et 
aperģoit ce qui est autour de lui." (S.35)

Von Gott nur ein wenig kleiner gemacht.als die Engel, ist der Mensch den Tieren gegenüber mit 'Ruhm gekrōnt und ihnen allen ūbergeordnet worden':

IV,13f. Славою в отмене восхотел нас увенчать

И ная всем поставить первими, всему в печать.

Die Verse 11 und 13f. stammen aus dem 8.Psalm, Vers 6 und 7:

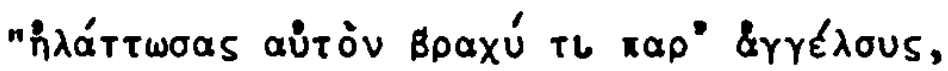

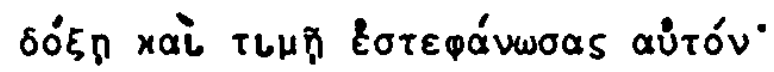

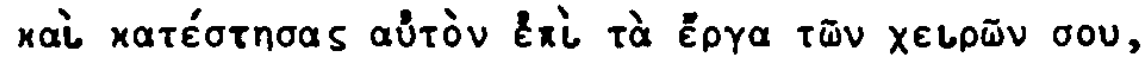

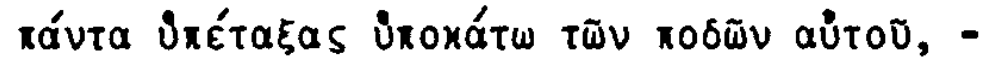

Dem Menschen wird aufgetragen, über die Tiere zu herrschen $(I V, 14)$. Dieses Motiv erinnert an Gen.Kap.1,26. Dort heiBt im Zusammenhang mit der Gottebenbildlichkeit des Menschen:

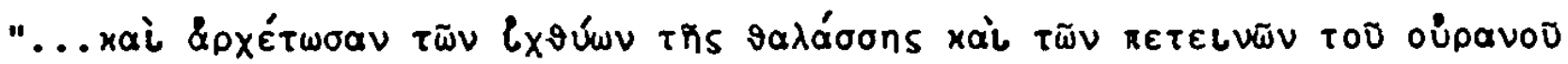

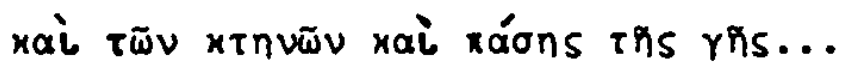

Tred. sagt ferner, daB 'jedes Geschöpf uns die gebührende Ehre erweist' und setzt die eigentümliche Wendung hinzu: 'sie preisen dich (Gott), wenn sie uns über dich (reden) hören':

IV,15f. Се нам каждая тварь честь должную приносит,

Слушая нас о тебе, тя и превозносит.

Nach der Legende hat Franz von Assisi den Vögeln gepredigt. Ob Tred. an ăhnliche Uberlieferungen gedacht hat, läBt sich nicht feststellen.

In hymnischen Ausrufen preist der Autor die göttliche Herrlichkeit, deren Glanz die 'Sterne des $\mathrm{H}$ immels' ubertrifft und die Vielzahl seiner unbegreiflichen wunder:

IV,17f. Велелепность выше светлых есть твоя небес!

Множес тво повсоду непостижных толь чудес!

Ännlich wie im 8.Psalm schlieBt der Hymnus mit der Verherrlichung des gōttlichen 'Namens', mit der er auch begonnen hat. Das Verspaar bringt zum Ausdruck, es sei nicht schwer, Gott zu erkennen, nachdem er sich am Menschen selbst erwiesen hat. Der Mensch kann an seinem eigenen Organismus Gottes Wunder wahrnehmen:

IV,19f. Господи! о! боже наш! Имя твое чуано!

Человеку по себе тя познать нетруано. 
IV, 21-32: Unser Körper ist nicht von den Eltern hervorgebracht, sondern letztlich von Gott geschaffen worden. Das anthropologische Thema wird zunăchst im Blick auf den menschlichen Korper erortert. Dort zeigt sich, bemerkt Tred., 'die Wahrheit des Schopfers', die imstande ist, 'die Lüge der Gottlosen auszulöschen':

$$
\begin{aligned}
& \text { IV,21f. Начнем, в-пероых, тело человече разбирать, } \\
& \text { Истиной сотворша, нечестиош ложь стирать. }
\end{aligned}
$$

Vers 21 gibt den Satz der Vorlage wieder: "Commençons l'étude de l'home par la consideration de son corps." (Démonstr.,S.35)

Unsere Autoren wenden sich gegen die scheinbar plausible Ansicht, der Körper des Menschen sei durch die Zeugung von seinen Eltern hervorgebracht worden. Dieser Auffassung haben sie schon hinsichtlich der Fortpflanzung der Tiere widersprochen (2.B. III,545 und III,739-750). Sie haben dort die von den Cartesianern vertretene These vorgebracht, daB die Eltern nur occasio, nicht aber causa der Zeugung sind. Fénelon nennt die Eltern 'instruments aveugles' der Zeugung. Tred. hat die Rolle des Elternpaares bei den Tieren so gekennzeichnet:

$$
\text { III,749f. Оруяие - оте4, орудие и мать, - }
$$

Im anthropologischen Kontext heiBt es jetzt:

$$
\begin{aligned}
& \text { IV,25f. Тело нам, конечно, не родители творят: } \\
& \text { Ромршееся токмо из утробы оно зрят. }
\end{aligned}
$$

Die Eltern haben keine Macht daruber, wie sich der Körper des Kindes im Mutterleib bildet:

IV,27f. В устроении того нет их малы части,

Не имеот никакой то составить власти.

Fénelon hat diese Tatsache ebenfalls unterstrichen: "En effet, ce $n$ 'est point la sagesse des parents qui forme un ouvrage 81 compose et régulier; ils $n$ 'ont aucune part à cette industrie." (Démonstr.,s.35)

Das embryonale Stadium des Lebens liegt im Dunkel. Auch eine Mutter weiB nicht, wie das Kind in ihrem Leibe 'angefangen' hat. Das wird jede Mutter ihren Kindern bestătigen, meint der Autor:

$$
\begin{aligned}
& \text { IV,23f. Чадам скажет всяка мать: я не понимаю, } \\
& \text { Как вы в чреве зачались, и совсем не знак. }
\end{aligned}
$$

Was 'jede Mutter ihren Kindern sagen wird', wie Tred. es ausdrückt, das sind in der Demonstration die Worte einer bestimmten Mutter: im II.Makkabäerbuch ermutigt eine Mutter ihre sieben Söhne zum Martyrium, indem sie ihnen vor- 
halt, dab sie sie zwar geboren, ihnen aber nicht das Leben gegeben hat. Gott, der ihnen das Leben gegeben hat, wird es ihnen gnădig wiedergeben, wenn sie es um seines Gesetzes willen fahren lassen. Fénelon verweist auf diese stelle der Hl.Schrift: "Je ne sais, disait une mère a ses enfants, dans l'Écriture sainte, coment vous vous êtes formes dans mon sein." Er nennt II.Makk. 7,22:

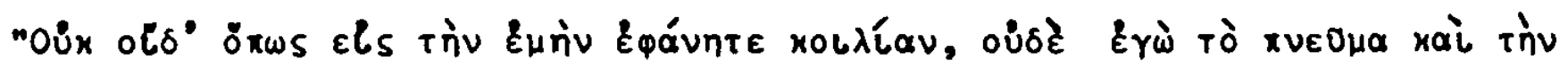

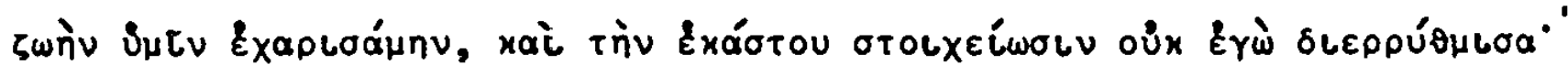
Von den verneinenden Wendungen 'я не понимар' (23), 'совсем не знар' (24), 'не родители творят' (25), 'не имеот никакой то составить власть' (28), in denen die menschliche Ohnmacht bezeugt wird, hebt sich das Bekenntnis zum wahren Schópfer des Menschenleibes ab. Die 'Kunst' des Höchsten zeigt sich gerade darin, daß er den Menschen 'von Erde genomen' hat, erklart Tred., auf Gen.2,7 anspielend:

\section{IV,29f. От земли всё взято, но всевшиний наш творец,} Мнится, в том искусство показал свое вконец.

Die Bibelstelle (Gen. 2,7) lautet:

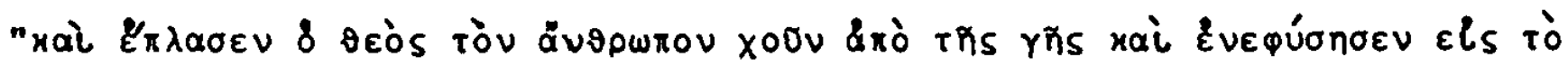

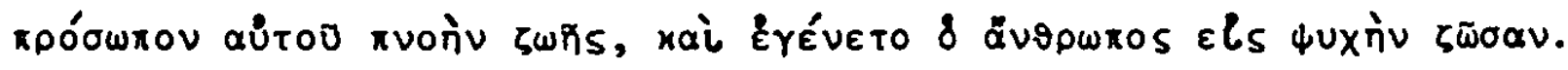

Mit Staunen weist Tred. auf den Kontrast hin zwischen der 'schmutzigen Materie' und dem aus ihr gebildeten keineswegs groben, sondern zarten Körper des Menschen:

IV,31f. Гнусно вещество, но коль вычищено делом!

Не вчерне всё вияно уж зритса нежным телом.

Fénelon nennt den aus 'Schlamm' geformten Korper des Menschen ein 'Meisterwerk' des Schópfers: "Ce corps est petri de boue; mais admirons la main qui l'a fagconné. Le sceau de l'ouvrier est empreint sur son ouvrage; 11 semble avoir pris plaisir à faire un chef-d'oeuvre avec une matiere si vile." (S.35)

IV, 33-48: Das skelett des Menschen wird beschrieben und gibt AnlaB zur Betrachtung und Bewunderung.

Ein anatomischer Atlas wird vor uns aufgeschlagen. Der erste Blick fáltt auf das Skelett des Menschen, das die Muskulatur trăgt. Obwohl die Knochen schwach und poross sind, lassen sie sich nicht leicht spalten:

IV, 33f. Видим мы, что кости держат на себе всю плоть; Утлы, но не скоро можно вдоль их расколоть.

Vers 33 entspricht der Vorlage: "Jetons les yeux sur ce corps, ou les os soutiennent les chairs qui les enveloppent." (Démonstr.,S.35) 
Die Sehnen (жилш,35) sind gleichsam 'stricke', sagt Tred. (буато верои,35). Sie können sich ausdehnen und zusamenziehen und ermoglichen dadurch die notwendigen Bewegungen und die erforderliche Geschmeidigkeit der Glieder:

$$
\begin{aligned}
& \text { IV,37f. Раздаясь в составах и спрягаясь в них, Аают } \\
& \text { Способ нужным Аоигам и потребну масть всем льот. }
\end{aligned}
$$

Fenelon hat es ahnlich dargestellt: "...les nerfs qui $y$ sont tendus en font toute la force; et les muscles, ou les nerfs s'entrelacent, en s'enflant ou en s'allongeant, font les mouvements les plus justes et les plus reguliers."(35)

Neben ihrer Festigkeit wird die Beweglichkeit der Knochen hervorgehoben:

$$
\begin{aligned}
& \text { IV,39f. В должном расстояни кость всяка разгибаясь } \\
& \text { И спосо6но - вертлугах та сеом стибаясь, - }
\end{aligned}
$$

Fénelon schreibt, daB die knochen in bestimmten Abstanden unterbrochen und in Gelenken 'eingepaBt' sind: " Les os sont brisés de distance en distance; $11 s$ ont des jointures ou $12 \mathrm{~s}$ s'emboltent les uns dans les autres." (S.35) Schon Cicero habe diese kunstvolle Verbindung der Knochen durch Gelenke bewundert, bemerkt Fénelon. Als Belegstelle nennt er 'De Nat. Deor.' lib.II, $n^{\circ} 53$. Die Notiz zeigt, daB die bewundernde Betrachtung des menschlichen Korpers nicht erst bei den Physikotheologen des 18.Jahrhunderts verbreitet war, sondern in die Antike zurückreicht.

Tred. hat noch eigens darauf hingewiesen, daB die Gelenke den Menschen vor dem Hinfallen schützen sollen. Wenn dies trotzdem ab und zu geschieht, liegt es nicht an der Art des Knochenbaus:

IV,43f. Oт Aругих причин сие иногда бывает,

Не костей от слога в нем, что он упадает.

Mit einem Ausruf der Bewunderung unterbricht Tred. die anatomische Beschreibung: so schwach die menschlichen GliedmaBen auch sind, sie konnen ausdauernd und kraftig arbeiten:

IV,45f. Коль все слабш членш, аиво есть сие из аив, Но - трудах коль теераш и коль сильны напротив!

Fénelons Berufung auf Cicero ("Cicéron admire avec raison le bel artifice qui lie ces os.",S.35) fehlt bei Tred. Das zitierte Verspaar 45f. beruht auf den Fragen Fenelons: "Qu'y a-t-il de plus souple pour tous les divers mouvements? mais qu'y a-t-il de plus ferme et de plus durable?" (Démonstr.,s.36)

Schlieblich weisen unsere Autoren darauf hin, dab das skelett langer als alle anderen Telle des Korpers der Verwesung widersteht: 
IV,47f. Как истлеет тело в прах наше уж no смерти, Неких и тогаа костей не́льзя вдруг тле стерти.

So auch Fénelon: "Après même qu'un corps est mort, et que ses parties sont séparées par la corruption, on voit encore ces jointures et ces liaisons qui ne peuvent qu'à peine se détruire." (Démonstr.,s.36)

In der Darstellung der anatomischen Verhaltnisse lassen sich das beschreibende, das betrachtende und bewundernde mowent deutlich voneinander unterscheiden. In ihrer Verbindung kennzeichnen sie die physikotheologische sicht der Natur.

IV, 49-60: Das menschliche Nervensystem.

In Ubereinstimmung mit Fénelon führt Tred. aus: Durch die von Gehirn ausgehenden Nerven flieBen die 'Lebensgeister'. Tred. stellt sich die Nerven als 'Röhren' vor, durch deren Höhlung die 'Lebensgeister' alle Teile des Körpers erreichen kŏnnen, ohne von Widerstănden aufgehalten $z u$ werden:

IV,49f. Становые жилы от мозгу все врозь идут, По своим те трубкам Аухи жизненны ведут; -

Abgesehen von der Röhren-Metapher stimmen die Verse mit der Vorlage uberein: "Du cerveau, qui est la source de tous les nerfs, partent les esprits." (S.36) Diese 'Geister' sind so schnell (скоробежны,51) und von so feiner Substanz (тонкостио существа, 52), dаß man ihren Lauf weder sehen noch betasten kann (ни взором, ни касанием обнять,54). Von Natur aus sind sie in stāndiger Bewegung. Sie laufen durch den ganzen korper und setzen, ohne daB wir uns dessen bewußt werden, die Bewegungen in Gang, verăndern sie mannigfach, und wenn sie das eine getan haben, eilen sie schon zum anderen:

IV,57ff. Te во всем так теле бегают от края в край, Приключают двиги нечувствительно как втай

И в различны те собой видЧ претворяют,

САелав ТО, Потом Аругой САелать ускоряют.

Damit hat Tred. in eigenen Worten gesagt, was Fénelon über die 'esprits' und ihre Tatigkeit geschrieben hat: "Ils sont si subtils, qu'on ne peut les voir, et néanmoins $\mathrm{si}$ réels et d'une action si forte, qu'ils font tous les mouvements de la machine... Ces esprits sont en un instant envoyés jusqu'aux extrémités des membres: tantôt ils coulent doucement...; tantöt ils ont... une impétuosité irrégulière; et ils varient à l'infini les postures, les gestes et les autres actions du corps." (Démonstr.,S.36)

Die Frage der Verbindung von Seele und Körper, eine der Fragen, "die die Zeit 
bewegten" 8 , wird im vorliegenden Abschnitt mit einem Denkmodell Descartes' beantwortet. Dieser hatte in dem Bemühen, das 'commercium mentis et corporis' zu erklăren, den Begriff 'spiritus animales' eingefuhrt. Da nach seinem dualistischen System eine direkte Einwirkung der immateriellen seele auf den materiellen Körper ausgeschlossen 1st, wird diese Kausalităt durch Substanzen vermittelt, deren feine Stofflichkeit zugleich materiell und imateriell ist: die 'spiritus animales'. Es fallt auf, daB Tred. die beiden Bestandteile des Begriffs mit 'Аухи жизненны' (50) ubersetzt hat, wăhxend Fenelon nux das substantiv 'esprits' wiedergibt. Aus diesem Sprachgebrauch labt sich wohl schlieBen, daB Tred. den originalen Terminus Descartes' gekannt hat.

Den Namen des Philosophen erwăhnen unsere Autoren in diesem Zusammenhang nicht. Sie ubergehen auch die anderen Theorien, wit denen Descartes das 'comercium mentis et corporis' erklăren wollte, z.B, die Bedeutung der zirbeldrüse als einer Art Schaltstelle zwischen Körper und Seele sowie die Vorstellung von den 'dispositions'.

IV,61-105: Die Haut.

'Der menschliche Korper, von den Inneren Organen, Adern, Săften und knochen zerfurcht, ist ganz von einer glatten Haut umgeben'. Mit dieser die Vorlage erweiternden Schildexung einer anatomischen Landschaft beginnt der neue Abschnitt:

IV,61ff. Тело человече разними внутри частьми, Жилами, и елагой, и парами, и костьми, Как от аебрей в густоте, буаучи изрыто, Кожею есё есть вокруг гладко0 покрыто.

Dem labyrinthischen Inneren wird das glatte Außere des Korpers gegenübergestellt.

Der Autor weist darauf hin, daB die Haut an Wangen, Stirn und Lippen dün ist, wegen 'der Schonheit und des lieblichen Anblicks':

IV,67f. A сие Аля красотш и аля нежна взора, Нашим лучшим 6ш частям бшть не без убора; -

Den asthetischen Gesichtspunkt hat schon Fênelon herausgestellt: "Regardons cette chair; elle est couverte, en certains endroits, d'une peau tendre et delicate, pour l'ornement du corps." (Démonstr.,S.36)

DaB die Haut das Gesicht schönmacht, heben unsere Autoren durch die Gegenvorstellung eines enthăuteten Gesichtes hervor: 
IV,69ff. С краснейшего если кожу снять когда лича,

Мерзкою явиться красота вся до конца,

И смотрящим уж гадка будет о́на рома.

In diesen Versen wird die Schilderung der Démonstration nachgeahmt: "Si cette peau, qui rend l'objet si agréable et d'un si doux coloris, était enleveo, le même objet serait hideux, ferait horreur." (S.36)

Nicht weniger sinnvoll und zweckmäBig als die zarte Haut des Gesichts erscheint unseren Autoren, daB diejenigen korperteile, die stark beansprucht werden, von einer dicken Haut geschützt sind, damit sie sich nicht 'verbrauchen', 2.B. die Fußsohlen (на nogowsax, 75) und der Nacken (на затылке,77).

IV,72ff. Но в Аругих местах лежит толще та ж вот кожа,

Чтоб частям, покрштым ећ, труА пристойный несть,

А себя 6 всегдашним трением вдруг не известь.

Auch in der Vorlage sind das beschreibende und das teleologische Moment unmittelbar miteinander verbunden: "En d'autres endroits cette même peau est plus dure et plus épaisse, pour résister aux fatigues de ces parties." Als Beispiele werden ebenfalls 'la peau de la plante des pieds' und 'celle du derriere de la tête' angeführt. (Démonstr.,s.36)

In der năchsten Passage geht es um die Poren. Von ihnen heiBt es, daB sie uber die ganze Haut verteilt sind, daß man sie aber nicht fühlen und sehen kann. Durch sie schwitzt der Mensch:

IV,78f. Кожа еся сия кругом скважинки имеет,

Ими точно человек изнутри потеет; -

Bemerkenswert findet es Tred., daB zwar der SchweiB, aber niemals Blut aus den Poren dringt:

$$
\begin{aligned}
& \text { IV,82ff. Нечувствительны они, видеть их не можно; } \\
& \text { Только ж все отверсты толь в коже осторожно, } \\
& \text { Что кровь не выходит оными вон никогда: }
\end{aligned}
$$

Fénelon vergleicht die von Poren durchsetzte Haut mit einem Sieb (crible,S.36) und făhrt fort: "Quoique la sueur et la transpiration s'exhalent par ces pores, le sang ne s'échappe jamais par la." (Démonstr.,s.36)

Für dieses von Fénelon bezeichnete Phănomen hat Tred. die Erklărung: die 'Kraft' des Blutes ist gerade so groB, daB es durchscheint, aber kein Tropfen durch die Haut sickert:

IV,85f. Такову имеет силу наша кровь всегда, Чтоб сквозь тело ону зреть только можно било, - 


$$
\text { IV,87 А сверьх кожи } 6 \text { из нее капельки не всплило. }
$$

wăre die Haut dagegen dünner und durchlăssiger, so würde das Gesicht ganz von Blut übergossen:

IV,88f. Ежели 6 всей коме тоне да и реже быть,

То 6 всему, конечно, кровьр долг лицу заплыть -

Diese hypothetische Erwăgung hat Tred. von Fénelon übernommen: "Si la peau était moins serrée et moins unie, le visage paraitrait sanglant, et come écorché." (Démonstr.,S.36)

Solche hypothetischen Erwăgungen, wie wir sie ahnlich schon bel den Erwăgungen zu den Elementen (Erde:II,85ff; Wasser:II,321ff; Luft:II,494ff.) antrafen, stellen unser Autoren an, um die tatsăchliche Beschaffenheit der Dinge eindrucksvoll zu rechtfertigen. Das 'rechte Mas', der ausgewogene Zustand des Gegebenen gilt weder als zufallig noch als naturnotwendig, vielmehr offenbart sich darin das wirken des Schopfers. Die 'wer-Fragen', die sich hier anschließen, sind Ausdruck der physikotheologischen tberzeugung: "Qui est-ce qui a su tempérer et mélanger ces couleurs pour faire une si belle carnation, que les peintres admirent, et n'imitent jamais qu'imparfaitement?" (Dém.,S.36) Daraus hat Tred. eine Reihung von doxologisch gemeinten Fragen entwickelt:

IV,92f. Кто $\%$ бы так поставил в должных мерах өсе сие?

Коме кто и крови подал хорошство свое?

Die Schonheit der Baut wird in den Versen 94f. naher beschrieben: inre durchscheinende, rosige Farbe wird ebenso bewundert wie ihre lilienhafte Blăsse:

IV,94f. Кто сквозь кожу оидеть дал роз румяность алу?

Кто лилией по коже бель ра́злил толь присталу?

Kein irdischer Maler, versichert der Autor, hat solche Farben auf seiner Palette. Die vollkommene Kunst des 'höchsten Malers' erweist sich darin, daB sie uns zugleich nūtzt und schmückt:

IV,98f. Hо верьховнейший зограф так все совершает,

Что чем пользу нам творит, тем и украшает.

Die Verbindung von Nutzen und schönheit in der Schopfung wird in der Feoptija hăufig hervorgehoben (2.B.:Schönheit und Nutzen der Gebirge,II,146; Vegetation und Bodenschatze der Erde, II,101ff.).

Als weiteres Kennzeichen des gottlichen Schaffens wird seine 'Vielfalt' betont. Tred. weist auf die vielen Unterschiede der blassen und rosigen Bautfarbe sowie der mehr oder weniger rundlichen Gesichtsformen hin: 
IV,100f. В белизне различий сколько нами зрится сей?

Сколько и в румянце? сколько в круглости черт всей?

Von Petersburg bis Peking sehen die Menschen so verschieden aus, daB man meinen könnte, der Mensch sei dort ein anderes Geschopf:

IV, 102f. От Петрополя в лице разность до Пекина

Толь велика, что как тварь человек там ина.

Dies ist eine der nicht gerade häufigen stellen in der Feoptija, die russisches Lokalkolorit haben. Der Autor denkt an den weiten euro-asiatischen Raum mit seinen zahlreichen Völkerschaften. Unter den Millionen von Menschen ist es schwer, sagt er, einen $2 u$ finden, der einem anderen zum Verwechseln ăhnlich ist:

IV, 104f. Трудно в миллионах точно схожего найти

По всему Аругому, чтоб тому с сим в смесь пойти.

Die Verse IV, 106-121 enthalten eine volkstümliche Typenlehre und Charakterkunde.

Das Stichwort 'Verschiedenheit' (разность, 102 und 106) verbindet diese Passage mit der vorigen. Tred. setzt hier die phanotypische Verschiedenheit der Menschen -vermutlich von folkloristischen vorstellungen beeinfluBt- in Beziehung $2 \mathrm{u}$ bestimmten Charaktereigenschaften. So erscheint eine Person entweder hager oder würdevoll und achtunggebietend. Diese hat ein angenehmes Außere, Jene sieht schrecklich, mürrisch, stolz oder aufgeblasen aus:

IV, 107ff. Та особа есть остра, иль важна, почетна;

Та приятна с вияа, а иная вся страшна,

Иль вся и угрома, иль спесива, иль пьшна; -

Tred. meint, der Charakter eines Menschen lasse sich vor allem aus seiner Physiognomie ablesen. Mancher Mensch hat die Gesichtszüge eines Herrschers, ein anderer sieht 'viehisch' aus:

IV,110f. Человек с лица иной есть весьма господствен, А иной с того ж лица совершенно скотствен; -

Der Autor nennt ferner das Gesicht des Bösewichts, der sich den Anschein eines Freundes gibt, das Gesicht des verschlagenen Menschen oder das des Dummkopfes:

IV, 112f. Есть личе злодея, друга ль кажуце, плута ль;

Есть лукавца кое иль глупца по всем чертам.

Zum volkstümlichen Aberglauben gehört das Mißtrauen gegen die 'Kahlkópfigen, Stotterer und Rothaarigen', die von Geburt her 'gezeichnet' seien und als böse gelten: 
IV,114f. उол, кого внак естество сроду запятнало:

Как плешившх, и заик, рижих так немало.

Tred. stimmt dieser primitiven Physiognomik nicht unbedingt zu und rămt ein, das das Aussehen trügen kann:

IV,116 Хоть чело, и очи, и личе почасту лгут, -

Er teilt aber den Argwohn gegenuber den 'Blinzelnden', denen die Leuto aus Exfahrung aus dem Wege gehen:

IV,117 Hо от moprocnenux лоди - опwте бегут. -

Wer kann alle Verschiedenheiten der menschlichen Charaktere aufzahlen und deuten, heibt es abschliebend. Schon an einem einzigen zeigt sich der 'Woifter'. Erst recht macht die Vielfalt Gottes grenzenlose Weisheit sichtbar:

IV,120f. По одной основе деловца зрим одного, Но безмерно муара по различиям того.

Die Meisterschaft des Schopfers erweist sich daran, daB es unzahlige Typen und Charaktere gibt. Der Lobpreis der Vielfalt wird auch nicht dadurch gedämpt, daB auBer guten und ansehnlichen auch böse und häBliche Menschen auf der Welt sind. Das Theodizeeproblem wird hier auber acht gelassen. Der Autor zielt ausschlieblich darauf ab, daB die Verschiedenheit der Menschen -'unter Millionen gleicht nicht einer dem anderen'(104f.)- die Existenz eines erfindungsreichen schöfers beweist.

IV, 122-161: Adern und Blutkreislauf des menschlichen Körpers.

Die Adern werden mit 'kleinen Röhren' vergllchen, Das GefaBsystem wird durch das aus der Demonstration Jbernomene Bild eines Baumes, dessen zweige herabhăngen, veranschaulicht. Txed. unterscheidet zwischen den Adern, durch die das Blut zu den GliedmaBen flieBt, und denen, durch die es zum 'Zentrum' zurückdrăngt. Die russischen Aquivalente fü frz. 'artères' und 'veines' fehlen in der Feoptija:

IV,122ff. В человечем теле суть трубочки премноги, Схожи с ветвями аревес, также и отлоги.

В них иними иленое до конец кровь в нас течет,

A - созерат Аругими к чентру ток свой та өлечет; In der Démonstration heibt es: "On trouve dans le corps humain des rameaux innombrables: les uns portent le sang du centre aux extrénttés, et se nomment arteres; les autres le rapportent des extrénites au centre, et se nomment veines." (S.36) 
Von den Bestandteilen des Blutes erwăhnt Tred. besonders das 'Blutwasser', das den raschen Lauf des Blutes in den Adern ermóglicht. 'Wie die Erde von Flūssen wird der menschliche körper vam Blut getrănkt', sagt Tred. mit einem Vergleich aus der Démonstration:

IV,126ff. С нео неразлучен есть водный сок и пресный, Он ее живит, чтоб путь в жилах не был тесный. Кровио поится тело, кое человек Собственно имеет, ра́вно как земля от рек; -

Fenelon nennt das Blut einen 'süBen und 81 igen Saft', der geeignet ist, 'die feinsten und beweglichsten (Lebens-) Geister zurückzuhalten': "Par ces divers rameaux coule le sang, liqueur douce, onctueuse, et propre, par cette onction, a retenir les esprits les plus déliés... Ce sang arrose la chair, come les rivieres arrosent la terre." (Démonstr.,s.36f.)

Der Blutkreislauf wird von Fénelon nur knapp behandelt: "Après s'être filtré dans les chairs, il revient a sa source, plus lent et moins plein d'esprits; mais se renouvelle et se subtilise encore de nouveau dans cette source, pour circuler sans fin." (Demonstr.,s.37)

Dagegen hat Tred. den Blutkreislauf und seine physiologische Bedeutung eingehend dargestellt (IV,130-161).

Demnach gibt es einen 'direkten, kuxzen Weg' (прямый путь, 131; тот в себе кратчайший, 132) und einen 'Seitenweg, der sehr lang ist' (побочнмй...Аолжайший путь, 131f.).

Ohne medizinische Fachausdrücke zu verwenden beschreibt Tred. den Weg des Blutes von der linken Herzkammer durch die Hauptschlagader in die 'GefaBzweige' bis zu den auBersten Enden der feinsten Adern:

IV,134ff. Слева шед от сердча, та прямо в милу входит, Ей 'большоо' имя есть, а по сей доходит, По ее и веткам, до краев тончайших жил;

Dann fließt das Blut durch die Venen zurück, die von den Ärzten, so bemerkt Tred.. 'Ауплястая или пустая жила'(139) genannt werden. Der 'kleine Kreislauf' nimot folgenden Weg:

IV,138ff. K правой сераца стороне жилог Аругсо, Что 'Ауплясто1' врачи иль зовут 'пусто0',

Притекает ходом $\mathrm{k}$ легкому уже потом, Oт сего вот паки $к$ сердиу слева; так кругом. Wie der Hinweis auf die 'врачи' zeigt, bietet der Autor keine eigenen Erkennt- 
nisse dar. Es handelt sich auch nicht un neue Forschungsergebnisse. Der 'kleine Blutkreislauf' durch die lunge war schon in der ersten Hăfte des 16. Jahrhunderts von dem spanischen Mediziner Miguel Servet entdeckt worden. Tred. vermittelt seinen russischen Losern das medizinische wissen vor allem in physikotheologischer Absicht, ad maiorem gloriam Dei. In zweiter Linie steht der poetologische zielgedanke des 'docere et delectare', der für das Lehrgedicht des 18.Jahrhunderts maBgebend war, und den Tred. in der Feoptifa befolgt hat.

In IV,142-161 wird die physiologische Funktion des Blutkreislaufs dargelegt.

Zuerst wird die Ausscheidungsfunktion des Blutes genannt (142-49). Es sondert verschiedene safte $a b$ und scheldet alles 'Dicke und Untaugliche' aus thnen aus:

IV, 142ff. Аолжность крови: отделять разнше мокротш,

Bce w и то прочь отлучать оншх от Аоброты,

Что в них есть густое иль негодное совсем,

Чтоб вреда не сделать и не в тягость бшть бш тем.

Bemerkenswert ist, daB die Funktion sogleich teleologisch gedeutet wird: das Blut schwemt die Schlacken aus, damit diese keinen Schaden anrichten und den Organismus belasten.

Die Absonderung von Galle in der Leber und die Nierenfunktion werden als vergleichbare Vorgãnge bezeichnet:

IV, 146f. Отделяется так желчь в печени известно;

В почках наших так моча, бшть ей в них невместно; -

Die Entstehung der 'Lebensgeister' (vgl. IV,50) in den windungen des Gehirns stellt sich Tred. ahnlich vor wie die Absonderung von Speichel im Munde:

IV, 148f. Tак животнш ау́хи в сложншх мозговшх местах,

Равно так и слина отделяется в устах.

Das Blut dient des weiteren als Nahrflüssigkelt des Organismus. Zu diesem Zweck 'verăndert' es sich und nimmt die Beschaffenhelt des Fleisches und der Knochen an. Die physikotheologische sicht komt im Hinweis auf die teleologische Bestimmung und durch das Staunen uber die 'Verănderung' des Blutes zum Vorschein:

$$
\begin{aligned}
& \text { Кровь чтоб в теле части все такме и питала, } \\
& \text { К плоти и кога К Костям та уме пристала, - } \\
& \text { IV, } 153 \text { Чудно пременившись состоянием свомм. }
\end{aligned}
$$

SchlieBlich hat das Blut die Aufgabe, die Korperwăme zu erhalten: 
IV,154f. Крови теплотой своей сохранять долг тело, Oное и возаращать есть ее $\boldsymbol{x}$ в нем дело, -

Bier erscheint dem Betrachter bemerkenswert, daB 'die wunderbare Harmonie des Kōrpers', d.h.đie gleichbleibende wărme erhalten bleibt, und der körper nicht vor innerer Hitze verbrennt:

IV,158f. Дивный нашего өсего тела строй хранится,

Получает теплоту, жаром не палится.

In diesem Zusammenhang werden noch einmal die Poren der Haut erwähnt (vgl.IV, 78ff.), durch die unmerklich Feuchtigkeit verdunstet:

IV,160f. Прочии истоки и нечувственны пары

В маленьки по коже выдыхаются диры.

IV, 162-197: die Gliedmaßen des menschlichen Körpers: Beine und FüBe.

Mit einer tberleitungsformel wendet sich Tred. der Betrachtung der GliedmaBen zu, wobei er sich wieder der Darstellung der Démonstration anschließt:

IV,162f. Но рассмотрим уж теперь членов ряд чиновный,

Уаивлению всегда в смыслящих өиновный.

Der Nachsatz, mit dem Tred. die vorlage erweitert, macht deutlich, daB die Beschreibung der anatomischen und physiologischen Einzelheiten die 'Denkfähigen' zur 'Bewunderung' veranlassen soll.

Fénelon beginnt mit der Aufforderung: "Voyez-vous cet arrangement et cette proportion des membres?" (Démonstr.,S.37)

Zuerst hebt Tred. die erstaunliche Tragfahigkeit der Beine hervor, die als 'Hauptstützen' das Gewicht des Körpers lebenslang zu tragen haben:

IV, 164 Се́гн, ни́же ноги, главные подпоры нам, -
Человече тело всё, чрез всю жизнь работно,
IV, 166f. Держат в тягости его на себе и плотно.

Fénelon nennt die Beine 'säulenartig' und veranschaulicht mit dieser Metapher ihre Festigkeit, auf der 'das ganze Gebäude' ruht: "Les jambes et les cuisses sont de grands os emboités les uns sur les autres.... ce sont deux espèces de colonnes égales et régulières qui s'élèvent pour soutenir tout l'édifice."(37)

Neben inrer Festigkeit wird die 'Biegsamkeit' der Beine aufgezeigt, die von den Kniegelenken abhăngt:

IV, 168ff. 0бе те подпоры изгибаются, Аолг rae:

Чашка, что в колене, аля того в своей иреде,

Чтоб сбираться без труда слогам можно было

И итоб каждое легко и способно плыло. 
In der Démonstration wird dies so beschrieben: "Mais ces colonnes se plient, et la rotule du genou est un os d'une figure a peu près ronde qui est mis tout exprès dans la jointure pour la remplir et pour la defendre, guand les os se replient pour la flechissement du genou." (S.37)

In den Versen 172-181 ist von den FüBen die Rede. Tred. benutzt die atatische Metapher 'nonctas' fur 'FuB' im auffalligen Kontrast zu dem beweglichen und feingliedrigen Bau der FüBe, der so gemacht ist, daB sie sich beim Gohen krümmen und strecken konnen:

$$
\begin{aligned}
& \text { IV,172 Камдая подпора получила сеой подстав, - } \\
& \text { IV,174f. Но толь стройно сопряжен, что ему сгибаться, } \\
& \text { Аа и разгибаясь впред можно подаваться. }
\end{aligned}
$$

Die Verse geben diesen Satz der Demonstration wieder: "Chaque colonne a son piédestal, qui est composé de pièces rapportées, et 81 bien jointes ensemble qu'elles peuvent se plier ou se tenir roldes selon le besoln." (S.37)

Die anatomische Besonderheit der FuBe sehen unsere Autoren darin, dab sie aus vielen kleinen Knochen und vielen Sehnen bestehen, so daB sie in der Lage sind, sich nach allen Selten 'scharf' zu drehen und sich schnell zu bewegen:

IV,177ff. Маленьких в них много ладом собрано костей;

Много в них и жил весьма, деигам бн острейшим

Обращаться долг куяа и бшеать бшстрейшим: -

Fénelon vermerkt, daB die Fủe zugleich geschmeidig und fest sind: "Dans ce pied on ne volt que nerfs, que tendons, que petits os etroitement lies, afin que cette partie soit tout ensemble plus souple et plus ferme, selon les divers besoins." (Démonstr.,S.37) Wichtig ist, daB der anatomische Bau ded Zweck des Korpertells in hohem MaB entspricht.

Von den zehen wird gesagt, daß sie gelenkig sind und sich so flink bewegen, daB man ihre Bewegungen kaum beobachten kann:

IV,180f. На ногах и пальцш гибко двищутся в складах,

И приметить труано скорость гибкости в следах.

Nach Fénelon haben die Zehen die Aufgabe, beim Gehen den Korper im Gleichgewicht zu halten: "...les doigts mêmes des pleds, avec leurs articles et leurs ongles, servent a tater le terrain sur lequel on marche, a s'appuyer avec plus d'adresse et d'agilité, a garder mieux l'equilibre du corps..." (Démonstr.,s.37

Tred. weist darauf hin, daB die Beine den korper halten, wenn er zu fallen droht. 
IV, 184f. Buбerawt обе то́тчас нórn варуг напред,

Сдерживают тело, не пуская пасть во вред, -

Die Verse geben einen Satz der Vorlage wieder: "Les deux pieds s'étendent en avant, pour empeccher que le corps ne tombe de ce côté-là quand il se penche ou qu'il se plie." (S.37)

Die Beine beginnen in der 'Häfte' des Körpers, sagt Tred., und sind ihrerseits in Halften unterteilt:

IV, 188f. Te подпоры те́ла с половины начались

И на половины ж по себе там разнялись; -

Das Wort 'половина' hat Tred. wohl absichtlich akzentuiert, weil es ăhnlich wie 'равномерность' die Harmonie und das EbenmaB andeutet, in dem er einen Grundzug des göttlichen Schöpfungsplans sieht, der auch im menschlichen organismus erkennbar ist.

Fénelons Beschreibung der Beine endet beim Hütgelenk, das dem Menschen 'die Bequemlichkeit sich auszuruhen' gibt, 'indem er sich auf die beiden gröBten Muskeln des ganzen körpers setzt': "Les deux colonnes se réunissent par le haut pour porter le reste du corps; et elles sont brisées dans cette extrémité, afin que cette jointure donne a l'homme la commodité de se reposer, en s'asseyant sur les deux plus gros muscles de tout le corps." (Démonstr. ,s.37)

Tred. fügt in den Versen 192-197 in einem einzigen Finalsatz eine Aufzählung aller Funktionen an, zu denen wir die Beine gebrauchen: nichts an ihnen ist starr und steif, konstatiert der Autor:

IV,192ff. Всё ж сие, чтоб можно без боязни нам ходить, Совокупно но́ти, также разно разводить, Как угодно - так сгибать, разгибать ли прямо, Нет отнодь в тех ничего, было 6 что упрямо; -

zuletzt vermerkt Tred., daB wir uns auch setzen können. Scherzhaft setzt er hinzu, daß wir dazu an beiden Seiten 'weiche Kissen' haben:

IV, 196f. Наконе4, способно 6 и садиться было нам,

А сидеть - подушки мягки суть по сторонам.

IV, 198-233: Die inneren Teile des Körpers: die Rippen und das Rückgrat.

Mit dem Hinweis, daB der Leib und seine 'Stützen' miteinander im EbenmaB sind, schlieBt Tred. das neue Thema, der Démonstration folgend, an das vorige an: IV,198 Всё с подпорами у нас тело равномерно, -

Fénelon benutzt die Metapher eines wohlproportionierten, von Săulen getragenen 
Gebăudes .

Bedeutungsvoll erscheint unseren Autoren, daB die lebenswichtigen Teile im Inneren des Korpers an geschutzter stelle liegen. Tred. weist darauf hin, daB sie auBerdem von Bindehăuten bedeckt sind:

IV, 199ff. Внутрь содержатся все в нем нужны части верно,

В самой им средине наялежало пребывать

И себя надежней в перепонках укрывать.

Die Verse entsprechen der Vorlage: "Il contient toutes les parties qui sont nécessaires à la vie, et qui par conséquent doivent être placées au centre, et renfermees dans le lieu le plus sar." (5.37)

Die vom Rückgrat bogenformig ausgehenden Rippen schirmen diese Teile wie 'Helmgitter' $a b$, fahrt Tred. fort:

IV, 202f. Ребра от спины аугой по числу взрастают, Как за́бралами те все части ограждают.

Die Metapher 'за6pano' (ksl.) wird von Pawlowskif (375) mit 1.Helmgitter, Visier; 2.Wand, Mauer, Schutz wiedergegeben. Die erste Bedeutung paBt gut zu der anatomischen Form der Rippenbogen. Tred. will die besondere Sorgfalt herausstellen, wit der der Schopfer die inneren organe geschützt hat. Die von Fenelon benutzte Metapher 'cercle' ist weniger augenfállig: " $C$ 'est pouquoi deux rangs de côtes assez serrées, qui sortent de l'épine du dos,... forment une espece de cercle pour cacher et tenir a l'abri ces parties si nobles et si délicates." (Démonstr.,s.37f.)

Nicht alle inneren Organe werden Jedoch von den Rippen geschützt. Uber dem Leib schließen sich diese nicht, sagt Tred., damit sie die Ausdehnung des Magens bei der Aufnahme von Speisen nicht behindern:

IV, 206f. Принимая так живот пищу внутрь особно, Расширяться может в сей пустоте способно.

Fénelon hat den anatomischen Sachverhalt ahnlich beschrieben: "(les cotes)... n'achevent de former le cercle que jusqu'd un certain endroit,...afin que le dedans puisse s'élargir avec facilité pour la respiration et pour la nourriture." (Démonstr., S. 38)

In den Versen 208-217 ist das Rückgrat Gegenstand bewundernder Betrachtung. Die hypothetische Erwăgung: was wăre, wenn die wirbelsăule aus einem geraden, festen Knochen bestūnde, soll die Erkenntnis wecken, daB der schöpfer eine Meisterleistung vollbracht hat. Mit einem starren Rückgrat kơnnten wir uns nicht 'krümmen': 
IV,210f. Если 6 вся была пряма и тверда собо0,

То 6 сотнуться не́льзя нам нашеј спиноп.

Darum hat der Schōpfer das Rückgrat aus Bestandteilen zusammengesetzt, die miteinander verbunden sind und sich ausdehnen und geschmeidig biegen können:

IV,212ff. Се на то создатель мудро толь предусмотрил,

Что ту из составов сломных купно сотворил,

Кои все, один в аругом укрепившись ладно,

Могут раздаваться тем и стибаться складно; -

Die wirbel sind innen offen, so daß sie den Lauf der 'Lebensgeister' nicht aufhalten:

IV,216f. Посреднне скважни сделаны у позвонков,

Не остановить бы хода жизненных Аухо́в.

Die bewundernde Betrachtung Tred.s geht auf die folgende Passage der Demonstration zurück: "...l'épine du dos...serait trop roide et trop fragile, si elle n'était faite qued'un seul os; en ce cas, les hommes ne pourraient jamais se plier. L'auteur de cette machine a remedié a cet inconvenient en formant des vertebres, qui, s'embortant les uns dans les autres, font un tout de pièces rapportées... Ce composé est tantôt souple et tantôt roide: il se redresse et se replie en un moment, comme on le veut. Toutes ces vertèbres ont dans le milieu une ouverture qui sert...pour y envoyer promptement des esprits par ce canal." (S.38)

In den Versen 218-233 schildert Tred. noch einmal die bewunderswürdige Beschaffenheit der Knochen, indem er fxüher Gesagtes (IV,33-48) teilweise wiederholt. Der Abschnitt beruht auf dem Text Fénelons. Am Anfang steht die rhetorische Frage:

IV, 218 Но как и костям самим много не дивиться?

vgl. "Mais qui n'admirera la nature des os?" (Démonstr.,s.38)

Drei Eigenschaften rufen die Bewunderung des Betrachters hervor: die Festigkeit, das geringe Gewicht und die Beweglichkeit der Knochen in den Gelenken. Zum ersten Punkt weist Tred. darauf hin, daB die Knochen auch nach dem Tode 'unverletzbar' (невредимы, 221) sind. Fénelon sagt: "...la corruption même de tout le reste du corps ne les altère en rien." (Démonstr.,s.38)

Das geringe Gewicht der knochen wird mit inrer porósen Substanz erklät:

IV,222f. А однак несчетны в них дирочки, как соты,

Отчего те и легки и Аля их же льготы, -

Die Zellen des Knochengewebes vergleicht Tred. mit 'Honigwaben' (соты, 222). 
Die Hohlung der Knochen ist vom Knochenmark ausgefüllt, das sie auch von innen ernāhrt:

IV,224f. Мозжечку в средине преисполнены оне,

Кой им есть как пица изнутри, а не извне.

Fénelon hat dies so beschreiben: "...(les os) sont pleins de trous innombrables qui les rendent plus légers; et lls sont même, dans le milieu, pleins de la moelle qui doit les nourrir." (Demonstr., s.38)

Die Ernăhrung der Knochen stellt Tred. sich so vor: jeder Knochen ist an einer bestimmten Stelle durchbohrt, so daB der 'Saft' von den anderen knochen 'eindringen' kann:

IV, 226f. Кажда пронзена есть кость, и в том месте точно,

Где в нее втекает сок из других нарочно.

Nach der Démonstration laufen durch diese రffnungen 'Bănder', die die Knochen miteinander verbinden: "Ils sont perces precisement dans les endroits ou doivent passer les ligaments qui attachent les uns aux autres." (S.38)

SchlieBlich machen unsere Autoren darauf aufmerksam, daB die knochen an den Enden dicker sind als in der Mitte. Daraus ergibt sich ihre Beweglichkeit in den Gelenken:

IV,228ff. 8ce коним суть толще обшчайно у костей, Нежели у средних толстота их есть частей:

От Аругой дабы одна возмогла скоряе

Повернуться, и чтоб быть Авигам их споряе, -

Auch Fenelon hebt hervor, daB die anatomische Form der Knochen ihrer Bowoglichkeit zustatten kommt: "...leurs extrémites sont plus grosses que le milieu, et font comme deux tetes à demi-rondes pour faire tourner plus facilement un os avec un autre..." (Démonstr.,s.38)

IV, 234-297: Die inneren Organe: Lunge und Magen. Die Funktionen der Atmung und der Verdauung.

Aus der Gesamtheit der inneren Organe werden im vorliegenden Abschnitt die Atmungs- und Verdauungsorgane zur Betrachtung ausgewahlt. Das Prinzip der Auswahl gehort zu den Gattungsmerkmalen des Lehrgedichts. Chr.siegrist weist auf die Verwandtschaft zwischen dem eklektischen Verfahren des Lehrdichters und der essayistischen Methode hin und skizziert die Einstellung der zeitgenơssichen Theorie zum 'Auswahlprinzip: "Dem Dichter stehen alle Freiheiten der Wahl zu Diensten: er kann beifügen und auslassen, amplifizieren und eliminieren, beschleunigen oder retardieren, uberspringen oder wiederholen..." 9 
Neben dem Prinzip der 'Auswahl' gehört "die Freiheit des Dichters in bezug auf sein poetisches Arrangement", auch darin dem essayistischen Verfahren ahnlich, zu den typischen Merkmalen des Lehrgedichts. 10

Diese allgemeinen zuge lassen sich auch in dem zu analysierenden Abschnitt beobachten. Nach einem Hinweis auf die Anordnung der lebenswichtigen Organe 'bei den Rippen' (все при peбрах...вплочены орга́ны,...и на жизнь созда́ны, 234f.) und der Aussage, daB sich die Nahrung durch den verdauungsprozeB in 'Blut und Fleisch verwandelt' (...от коих пища тлеет и бывает кровь, 236), wird die elementare Bedeutung der Atmung für den Organismus hervorgehoben. Sie dient nach zeitbedingter Anschauung vor allem zux 'Kühlung' der inneren Hitze, die durch den unaufhörlichen Kreislauf des Blutes und der 'Lebensgeister' entsteht:

IV,238ff. Нужно людям нам дышать: то в нас прохлаждает

Внутренний жар, кой всегаа кровь в нас возбуждает

В круг неоянократным волнованием своим

И аухов животных разбегание за ним.

Tred. führt weiter aus, daß die Atemluft uns im Innern 'ernahrt' und die lebenswichtigen Teile ständig 'erneuert' :

IV,242f. Bоздух внутрь питает нас, он и непрестанно Обновляет всё, что есть в нас на жизнь созда́нно.

Die Versreihe beruht auf dem Text der Demonstration: "Dans l'enceinte des côtes sont placés...tous les grands organes, tels que ceux qui servent a faire respirer l'homme, ceux qui digèrent les aliments, et ceux qui font un sang nouveau. La respiration est nécessaire pour tempérer la chaleur interne, causée par le bouillonnement du sang, et par le cours impétueux des esprits. L'air est comme un aliment dont $\mathrm{l}^{\prime}$ animal se nourrit, et par le moyen duquel il se renouvelle dans tous les moments de sa vie." (S.38f.)

Ebenso wie die Atmung wird auch die Verdauung als 'notwendig' bezeichnet, weil sich durch sie die speise 'zur rechten Zeit' in 'Blut und Fleisch verwandelt' :

IV,244f. Тление внутрь нужно, ибо пища ирез сие

В кровь и плоть во время пременяется свое; -

In den Versen IV,263ff. werden die Phasen des Verdauungsvorgangs dargestellt. Zuvor weist Tred. summarisch darauf hin, daB das Blut bei seinem Kreislauf alle Teile des Körpers erreicht (vgl.IV,150ff.) und als 'nützlicher Saft' jedem Organ die Kraft, die ihm mangelt, zuführt: 
IV,248ff. Кровь есть сок полезний: недостатки каждый член

Bсе им натраждает и бшвает укреплен

В силу, ТОЙ КоГАа из них всяК в себе лишится - (-8.III,447) Die Darstellung deckt sich mit der Fénelons: "La digestion n'est pas moins nécessaire pour préparer les aliments d etre changés en sang. Le sang est une liqueur propre à s'insinuer partout, et a s'epaissir en chair...,pour reparer dans tous les membres ce qu'ils perdent sans cesse par la transpiration et par la dissipation des esprits." (Démonstr.,s.39)

Eine systematische Anordnung des stoffes kann weder von der essayistischen Methode Fénelons noch von dem Lehrgedicht Tred.s erwartet werden. Die Poetik der Zeit erlaubte dem Lehrdichter logische Sprünge in der Anordnung des stoffes und bezeichnete sie mit dem Begriff 'beau desordre', der für die -scheinbare- Phantasieordnung der Ode geprăgt worden war. 11

So kann man sich erklăren, daß auf die Skizze des Verdauungsprozesses in den Versen 244-251 nicht etwa die Beschreibung des Magens und des stoffwechsels folgt, sondern die der Lunge (252-259). In der Aufeinanderfolge: Atmung (238243), Verdauung (244-251), Lunge (252-259), Magen und stoffwechsel (260-275) sind die korrespondierenden Themen überkreuzgestellt.

Die Aufgabe der Lunge unschreibt Tred. mit der doppelten Bewegung des Einund Ausatmens, das, wie er unabhăngig von der Vorlage hinzufügt, 'den Lauf des Blutes begleitet und beschleunigt' und ein blühendes Aussehen bewirkt:

IV, 252ff. Легкое, втягая воздух внутрь на камдый миг

И чрез сопротивный испуская оный Авиг,

Провождает кровный хоА, тот творит поспешным,

А мивотному дает цвесть и видом внешным; -

Fenelon vergleicht die Lungen mit 'schwamnigen Hüllen', die sich leicht ausdehnen und zusammenziehen können: "Les poumons sont comme de grandes enveloppes, qui, etant spongieuses, se dilatent et se compriment facilement."(39)

Als sinnfälige Metapher für die Lunge hat Tred. aus der Vorlage den 'Blasebalg' ubernommen, der ununterbrochen in Bewegung ist:

IV,257 Лeгкое есть точно Aуош непрестанно мех, -

Vgl. "(les poumons)...forment une espece de soufflet en mouvement continuel."

Es folgen in der Feoptija Ausfuhrungen uber den Magen, die Verdauung und den stoffwechsel (260-275).

Der Magen, 'стомах' (260), auch 'желудок' (270), wird mit einem 'Kesselchen' verglichen: 'котлик' (260). Die Bezeichnung 'cтомаx' ist wohl aus lat.'sto- 
machus' entlehnt worden, welches 'Speiserohre', 'Schlund' und synecd. 'Magen' bedeutet (Stowasser,466). Wenn das 'Kesselchen' leer wird -die Metapher stammt von Tred. - verursacht es sofort Hunger und will wieder mit Speise gefüllt werden:

IV, 260ff. Ho как опустеeт котлик наш, кой есть стома́x, То он приключает голод человеку в мах:

Хочет он наполнен быть ядию вот паки.

Die Vorstellung ist originell und anschaulich. In ihrer volkstümlichen Unkompliziertheit unterscheidet sie sich von der fast modern wissenschaftlich anmutenden Erklărung Fénelons, wonach das Hungergefühl durch ein 'Auflösungsmittel' im Magen -heute würde man von Enzymen sprechen- verursacht wird: "L'estomac a un dissolvant qui cause la faim, et qui avertit l'home du besoin de manger." (Démonstr.,S.39)

Wāhrend Tred. nur das Begehren des Magens, 'wieder gefüllt zu werden' angibt, klingt bei Fénelon das Verständnis für die Freuden der Tafel hindurch: "Ce dissolvant, qui picote l'estomac, lui prépare par ce mésaise un plaisir très-vif lorsqu'il est apaisé par les aliments. Alors l'homme ce remplit délicieusement d'une matière étrangère.... qui lui déplaît même quand il la voit étant déjà rassasié." (Démonstr.,s.39)

Tred. hat diesen Passus ausgelassen, vielleicht, weil ihm in seinen oft gedrückten Verhältnissen beides fernlag: 'köstlich zu speisen' und übersattigt zu sein. Den physiologischen Vorgang der Verdauung, wie er in der Démonstration geschildert worden ist, hat Tred. genau nachgezeichnet. Danach wird die Speise nach dem 'Kauen' im Magen verdaut und in einen milchigen Brei verwandelt, der auf einem 'weiten Umweg' zum Herzen gelangt:

$$
\begin{aligned}
& \text { IV,263ff. Всяка пища, как в него I scil.'в стомах'T придет после } \\
& \text { жваки, } \\
& \text { В нем варится то́тчас и меняается в млеко', } \\
& \text { Кое к сердиу Идет, обходя путь далеко. }
\end{aligned}
$$

Dort nimmt diese 'Milch' die Form, Farbe und Kraft des Blutes an und fließt in die 'große Ader', sagt Tred., den schon in IV,135 benutzten Begriff wiederholend:

IV, 266f. Там прмемля вия и чвет, всіо и кровну силу,

$$
\text { Входит в ту 'большуо' так, как сказал я, жилу. }
$$

Während der milchartige Saft in den Adern fließt, wird alles, was nicht dauernd im korper bleiben soll, 'hinausgeworfen':

IV,268f. Hо пока тот в милках идет сок еще млеко́м, Всё, что есть непрочно, отвергается броском; - 
Fénelon hat den Weg, den die Nahrung im menschlichen Körper nimmt, so beschrie ben: "...les aliments...se confondent tous en une liqueur douce, qui devient ensuite une espèce de lait nommé chyle, et qui, parvenant enfin au coeur, $y$ reçoit, par l'abondance des esprits, la forme, la vivacité et la couleur du sang. Mais pendant que le suc le plus pur des aliments passe de l'estomac dans les canaux destinés a faire le chyle et le sang, les parties grossières de ces mêmes aliments sont séparées...et elles sont rejetées en bas..." (S. 39)

Tred. führt aus: die Abbauprodukte verlassen den Magen und werden durch den Darm ausgeschieden. Diesen vergleicht er mit 'Röhren besonderer Art', die in vielen Windungen von den Organen, mit denen wir atmen, entfernt liegen:

IV,270ff. Из желудка ж исходя собными трубами

\section{(Сии все уаллены многими кругами}

От органов оных, коими Аышим внутри), -

Der Autor scheut sich nicht, auch den stuhlgang zu erwăhnen, der, wie er sagt den Körper nicht nur nicht schwăcht, sondern ihn 'sogar von einer stinkenden Last befreit':

IV,274f. Оное не токмо нас тем не истощает, Но от бремени еще смрадна облегчает.

Die drastische Bezeichnung des Vorgangs (Идет вон из тела чрез отверстия без при, IV,273) wird durch die diskrete Formel ' $6 е 3$ npu' kaum abgeschwăcht.

Mit französischer 'délicatesse' formuliert Fénelon: "...les parties grossières...sont rejetées en bas, pour en délivrer le corps par les issues les plus cachees, et les plus reculeees des organes des sens, de peur qu'ils n'en solent incommodés." (Démonstr.,s.39)

Aus der bisherigen Betrachtung des menschlichen Körpers zieht Tred. den physikotheologischen SchluB:

IV,276f. Словом, в человечем столько теле есть чудес, Что конечно должно здатель быть от небес.

In den 'Wundern' des menschlichen Körpers offenbart sich also die Existenz des Schöpfers. Damit hat Tred. den zentralen Glaubenssatz der Physikotheologen prägnant ausgesprochen, der nach seiner Auffassung durch die Anatomie und Physiologie des Menschen 'bewiesen' wird. In der entsprechenden Stelle der Démonstration fehlt diese schlußfolgerung. Dort heiBt es, die Wunder des menschlichen Organismus seien sogar in jenen Funktionen zu finden, die uns 'beschămend' vorkommen: "Ainsi les merveilles de cette machine sont si grandes,...meme jusque dans les fonctions les plus humiliantes..." (S.39) 
Die menschliche Anatomie hat unbestreitbar auch eine häbliche und abstoBende Seite. Wie stimmen das Aăbliche und AbstoBende mit dem Bekenntnis zum himmlischen Schöper zusammen? Dieser Einwand scheint hinter den Erwăgungen zu stehen, die in den Versen 278-289 angestellt werden und in eine Doxologie einmünden $(290-297)$.

Zunăchst räumt Tred. ein, daß die inneren Teile des körpers nicht so schön sind wie die auBeren:

IV,278f. Правда, в внутренних частях красна нет убору

И не столь приятны те, сколь наружны, взору.

In der Vorlage steht: "Il est vraj que les parties internes de l'home ne sont pas agréables à voir comme les extérieures." (S.39f.)

Die Verschiedenheit wird aber gerechtfertigt und als weise Absicht des Schopfers interpretiert. Schlieblich versichern unsere Autoren, daB die Allmacht, Weisheit und Gute des Schöpfers gegen den Augenschein gerade an dem scheuBlich anzusehenden Innern des Korpers transparent werden. Man solle zuerst bedenken, daB die inneren Teile ja nicht zum Anschauen geschaffen sind, sondern 'damit wir leben kōnnen', fügt Tred. eigens hinzu:

IV, 280f. Но сие знать должно, что они сотворены, Не чтоб всяк их видел, но, чтоб жили мы, даны: -

Er betont, der Schópfer habe absichtlich diese Teile vor unseren Augen verborgen: IV, 282 Зрим намерение мы нас всех сотворивша, -

Fénelon weist ebenfalls darauf hin, daB die inneren Organe nicht zum Anschauen gemacht sind: "...remarquez qu'elles ne sont pas faites pour etre vies." (S.40)

Hinzu kommt: der Schopfer hat gewollt, daB wir elnen 'geoffneten Leib' nicht ohne Entsetzen sehen könnten, so daB wir ihn nur im auBersten Notfall offnen sollten:

IV,284ff. Что без крайня видеть ужаса не должно нам,

Как утроба вскрыта представляется глазам;

И что ону раскрывать, может быть, мы чужды,

Без пристойныя $\mathrm{K}$ тому крайнейшия нужан.

Bei Fénelon lautet die Stelle so: "Il fallait même, selon le but de l'art, qu'elles ne pussent être découvertes sans horreur, et qu'ainsi un home ne pot le découvrix,...qu'avec une violente répugnance." (Démonstr.,S.40)

Am Beispiel des Verwundeten, dessen Anblick unser Mitleid erregt, wird weiter deutlich, daB der abstoBende Anblick der 'inneren Teile' nach dem plan des Schöpfers eine positive Wirkung hervorruft. Er soll unser Mitgefühl wekken: 
Tred. hat das Beispiel aus der Démonstration entlehnt: "C'est cette horreur qui prépare la compassion et l'humanité dans les coeurs, quand un homme en voit un autre qui est blessé." (S.40)

Weshalb sind die 'inneren Teile' des menschlichen Körpers nicht so schön und angenehm anzusehen wie die ăuBeren? In den Versen 290-297 gibt Tred. die Antwort, auf die es inm letzten Endes ankommt: Sie sehen nur 'widerlich' aus, sind aber in Wirklichkeit wunderbarer als die äuBeren. An ihnen können wir den kunstreichen Schöpfer um so deutlicher erkennen und ihn dafür preisen:

IV,290ff. Внутренние те однак части больше дивны, Хоть видению они по себе противны;

Любопытству болей можно в оных примечать

И твориа искусна, по всему в них, величать.

Tred. schlieBt den Abschnitt mit dem feierlichen Bekenntnis, daB der 'allmächtige, allweise und unendlich gütige Schōpfer' sich in der wunderbaren Tătigkeit der 'inneren Teile' offenbart:

IV, 294ff. Подлинно, что части те, в хитрости обильны,

Чудным действием своим зрятся все толь сильны,

Что явить вдруг могут всемогущего творца,

И того премуара и блажайша $6 е 3$ конца.

Fénelon führt an dieser stelle ein zitat aus 'De Civ. Dei', lib.XXII, cap. XXIV, $n^{\circ} 4$ des Kirchenvaters Augustin an, von dem Tred. einige Motive benutzt hat: "Ajoutez, avec saint Augustin, qu'il y a dans ces parties internes une proportion, un ordre et une industrie qui charment encore plus l'esprit attentif que la beauté extérieure ne saurait plaire aux yeux du corps. Ce dedans de l'homme...est précisément comme il doit etre pour montrer une boue travaillée de main divine..." (Démonstr.,S.40)

Die doxologischen Verse IV,294-297 sind in der Vorlage ohne Parallele.

Das Vorhandensein des Haßlichen und Abstoßenden in der Welt, wie es von unseren Autoren an den 'inneren Teilen' des Körpers exemplifiziert worden ist, offenbart nach ihrer (berzeugung besonders eindrucksvoll die Macht, Weisheit und Güte des Schöpfers. Darin sehen sie zugleich die Erlaubnis, es poetisch darzustellen.

Die Darstellung des 'Widrigen' ist in der Poetik seit der Antike als Problem gesehen und verschieden gelōst worden. Einige Lösungsversuche hat H.P. 
Herrmann in seinem Aufsatz 'Naturnachahmung und Einbildungskraft' vorgestellt. Danach hat Aristoteles das Problem so gelost, daB das 'Nachahmen' der Natur sowohl das Schöne als auch das HaBliche umfassen sol1. ${ }^{3}$ Das Nachahmen der Natur macht dem Dichter in jedem Falle Freude, "weil ex damit eine Tátigkeit ausubt, die dem Menschen von Kind an eigen ist und den Quell all seines Lernens darstellt; und dem Aufnehmenden macht es Freude, weil er entweder das original wiedererkennt..., oder weil er die artistische Făhigkeit bewundert, mit der der Dichter bei der Darstellung vorgegangen ist." 14 Das aristotelische Prinzip der 'Naturnachahmung' hatte, wie H.P.Hermann hervorhebt, bis ins 18.Jahrhundert Geltung. Es ist von N.Bolleau in seiner für die 2eitgonössische Dichtung maßgebenden Schrift L'art poetique (1674) nacharücklich vertreten worden. "Que la Nature donc soit vostre etude unique", empfiehlt Boileau den Dichtern. ${ }^{15}$ Er schrejbt der Dichtung die Aufgabe $2 u$, den 'ordre naturel' abzubilden, "da in der Natur, die als der gesamte Bereich des Menschlichen verstanden wird, die wahrheit selbst enthalten sei und augenscheinlich werde."16 Im Gegensatz dazu wollte E.Batteux in seiner Schrift 'Les beaux arts réduits à un même principe' (1746) das Prinzip der 'Nachahmung' auf die 'belle nature' einschranken. 17

Für Fénelon und Tred. gilt das Prinzip der Naturnachahmung in der Weise,daB sie die Gegenstănde auswăhlen, die nach ihxer Meinung am deutlichsten die Existenz und Herrlichkeit des Schopfers bezeugen, unabhăngig davon, ob diese zur schönen oder widrigen Natur gehören. Dieses Kriterium steht auch hinter der Passage von den abstoßenden 'inneren Teilen' des menschlichen Kórpers und ist von Tred. in den oben zitierten Versen IV,295ff. ausgesprochen worden.

IV, 298-327: Die Arme, von den Schultern bis zu den Fingerspitzen.

Die Bemerkung, daB die beiden Arme an den Schultern beginnen und von gleicher Lănge sind, wird von dem emphatischen Ausruf unterbrochen: was kơnnen wir mit ihnen bloB alles machenl

IV, 298ff. От раме́н произросли по странам доe ру́ки, Сими каковм теорим и колики штуки!

Aолготоо равны обе меж собой оне.

Fénelon beginnt den Abschnitt deskriptiv: "Du haut de cet ouvrage... pendent les deux bras...qui ont une parfaite symétrie entre eux." (Démonstr.,s.40)

Mit bildhaften, von inm selber gefundenen Metaphern schildert Tred., wie vielseitig, geschickt und ausdrucksvoll die Arme des Menschen sind: Bald gleichen sie den 'Querbalken' an der Wand, bald den 'Rudern an den Schiffen'. 
bald den 'Flügeln der Vögel', bald den 'Zweigen der Băume'. So sind die Arme von der 'höchsten Macht' geschaffen worden. Die rhetorische Figur der Anapher soll die wirkung der Bilder in den folgenden Versen unterstreichen:

IV, $301 \mathrm{ff.} \mathrm{Tо} \mathrm{как} \mathrm{переклады} \mathrm{распростерты} \mathrm{при} \mathrm{стене,}$

То как весла у судов, то у птиц как крила,

То как ветви Арев их власть вышня сотворила; -

Das nächste Bild zeigt ein nebeneinanderher gehendes Paar. Ihre Hănde bilden eine Art 'Girlande':

IV, 304

Иль моя С чужою как Фестон межау столпов;

Diese Metapher scheint Tred. besonders gefallen zu haben. Er hat sie bereits in seiner Tragödie 'Deidamija' (1750) benutzt. Darin wird auf dem Hohepunkt der Handlung die der Göttin Diana geweihte Zarentochter vom eigenen Vater zum Opfertode geführt. Die Szene hat Tred. In einem Brief an die Kanzlei der Akademie vom 28.Nov.1750 so skizziert: "...Вторая царевна. Ея аттитода горестная; на голове у нея венок из цветов; руки связаны Фестом на такое подобие, как они вешаются между двух столбов. Правую руку передала она отиу своему, а левую, также и лице, подняла к небу." 18

Ob dem Menschen die Arme mehr 'an Stelle von Dienern' oder 'zur Zierde' gegoben sind, weiB der Autor nicht ohne weiteres $z u$ sagen. Ihm scheint aber, daB beides zusammengehört. Die Formel 'prodesse et delectare' klingt an:

IV, 305ff. Словом, человеку вместо ль поданы рабов, Больше ль на красу ему, впрямь сказать не можно:

06ое то зрится в них вдруг от нас неложно.

Nach dieser Digression schaltet sich Tred. wieder in seine Vorlage ein. Er übernimmt die Anmerkungen der Démonstration zur Anatomie der Arme, Hände und Finger. Die Einzelheiten werden wie in der Démonstration teleologisch gedeutet. So heiBt es: die Arme sind in den Schultern 'befestigt', und mit allem versehen, damit sie sich mühelos bewegen kónnen:

IV, 308f. B nле́чах утвержде́нны, нужным им снабдены всем;

Авиги есть без нужаы можно делать им затем.

Fénelon schreibt: "Les bras tiennent aux épaules, de sorte qu'ils ont un mouvement libre dans cette jointure." (Démonstr.,S.40)

Auch in bezug auf die Lănge der Arme meint Tred. die Absicht des Schöpfers zu erkennen: IV,310f. Мера в них обеих есть такова нарочно, Что все части доставать те́ла могут точно.

So steht es auch in der Démonstration: " Les bras sont de la juste longueur 
qu'il faut pour atteindre à toutes les parties du corps." (S.40)

Die Arme haben viele und starke Sehnen, weil sie mehr als alle anderen Glieder des kơrpers arbeiten müssen:

IV,312f. Часто о них и сильны жилы, Аля то что несть

Труя частей всех в теле больший должно оным есть.

Fénelon hat daneben noch die 'Lenden' genannt: "Ils sont nerveux et pleins de muscles, afin qu'ils puissent, avec les reins, etre souvent en action, et soutenir les plus grandes fatigues de tout le corps." (Démonstr.,S.40)

Die 'Bestandteile' der Arme (wie der Zusammenhang zeigt, sind zuerst die Hănde gemeint) eignen sich für die verschiedensten Tătigkeiten. Zunăchst wird ihre Beweglichkeit und Geschicklichkeit aufgezeigt. Sie kōnnen etwas 'wegwerfen' (отринуть, 316) und 'ergreifen' (схватить, 316), etwas 'heranziehen' (nривлещь, 317) und 'zurückgeben' (о6ратить,317 ist hier wohl im Sinne von 803вращать gemeint). Sie kőnnen 'zubinden' (связать,318) und 'losbinden' (развязать, 318) auch 'festhalten' (Aержать, 318). In Freiheit so oder anders zu handeln, ist den Hănden eigen, sagt Tred. zusammenfassend:

IV, 319 Действовать в свободе им так и инак сродно.

Die Kraft und Geschmeidigkeit der Hănde werden in der Démonstration ăhnlich geschildert: "Les mains... ont toute la force et toute la souplesse convenables pour tater les corps voisins, pour les saisir, pour s'y accrocher, pour les lancer, pour les attirer, pour les repousser, pour les démêler, et pour les détacher les uns des autres." (S.40)

Jede Hand ist mit fünf Fingern ausgestattet, um damit leicht und ohne Mühe arbeiten zu kơnnen:

IV, 320f. Пятерицу перстов у обеих вияим рук

Делать бу им каждо легие дело и без мук.

Auch die Fingernăgel sind nicht vergessen worden. Sie sind den Fingern als 'Endstücke beigegeben worden', sagt Tred.:

\section{IV, 322 За наконешники им при́даны и ногти, -}

Die Form des part. pt. pass. 'nриданы' ist ein Ausdruck des Glaubens an den Schöpfer, der den Menschen bis ins kleinste ausgestattet hat.

Damit die Finger sich in der Mitte biegen können, sind sie mit Knöcheln versehen:

$$
\text { IV, } 323 \text { А стибаться пополам есть у них и локти. }
$$

Fénelon hat die Knochel als Teile der Hand bezeichnet: "Les mains sont un tissu de nerfs et d'osselets... (Demonstr.,S.40). Er hat sie deshalb bei den Fingern nicht eigens erwăhnt, deren kunstfertigkeit aber besonders betont: 
"Les doigts, dont les bouts sont armés d'ongles, sont faits pour exercer, par la variété et la délicatesse de leurs mouvements, les arts les plus merveilleux." (Démonstr.,S.40)

Tred. ergănzt die Beschreibung der Finger durch ein Detail, das selbst dem aufmerksamen Fénelon entgangen ist: er bewundert 'die kleinen Buckel' innen an den Fingerspitzen. Gäbe es sie nicht, wie sollte man Harchen oder Strohhalme aufheben?

IV, 324f. Аивны и горбочки перстов на концах внутри;

Волоски, соломки, ими сжавши, всяк бери.

In Vers 325 fält die volkstümliche Redewendung auf. Dem Autor kommt es darauf an zu zeigen, daB jede anatomische Einzelheit ihren Sinn und Zweck hat, die Fingerkuppe nicht weniger als der ganze Arm.

Schlieblich braucht der Mensch seine Arme, um damit im Notfalle den ganzen Körper halten 2 u können, erklärt Tred.:

IV, 326f. Руки человеку так напоследок нужны,

Что пои случае сдержать тело всё услужны.

Diese Verse geben einen Passus der Démonstration, in dem des näheren vom Gleichgewicht die Red ist, gekürzt wieder. Die von Tred. benutzte Stelle lautet: "Les bras et les mains servent encore,...a mettre le corps en état de se pencher, sans s'exposer à aucune chute." (S.40)

IV, 328-337: Der Hals.

Tred. führt aus: Zwischen den Schultern erhebt sich der Hals. Ihm hat der Schöpfer zwei Eigenschaften gegeben, die einander sonst ausschließen: Festigkeit und Biegsamkeit. Die 'Macht des Höchsten' hat sie aber miteinander verbunden:

IV, 328f. На плечах в средине шея вверьх произросла;

Твердость ей и гибкость вышнего власть подала.

Der Hinweis auf die 'Macht des Höchsten' fehlt in der vorlage, die einfach den anatomischen Sachverhalt nennt: "Au-dessus du corps s'éléve le cou, ferme ou flexible, selon qu'on le veut." (S.41)

MuB man etwas Schweres auf dem Kopf tragen, wird der Hals so steif, als wăre er aus einem einzigen Knochen gemacht:

IV, 330ff. Нужно ль несть на голове что-нибудь тяжело? Шея станет вся тогда твердое толь дело, Что Как та Из КОстИ только САелана ОАной.

Die direkte Frage Vers 330 belebt die Darstellung durch ein Element volkstüm- 
Wenn man abex den Kopf neigen oder in eine bestimmte Richtung drehen muB, so wendet sich der Hals augenblicklich biegsam dorthin. Die Verwunderung des Autors uber den schnellen Wechsel von der starren zur biegsamen Haltung kamt in den kurzen Wendungen der folgenden Verse adăquat zum Ausdruck:

IV,336f. В ней сие предивно: хочешь ли? тотча́с прытка

И тверда бшвает, почитай И DАруг гибка.

Die lebendige Redeweise $T r e d . s$ in diesen Versen unterscheidet sich von der literarischen Diktion seiner Vorlage: "Est-il question de porter un pesant fardeau sur la tête, le cou devient roide come s'il n'était que d'un seul os. Faut-il pencher ou tourner la tete, le cou se plie en tous sens, comme si on en démontait tous les os." (Démonstr.,S.41)

Tred. verwendet sowohl russ. 'weg' (331) als auch ksl. '8ug' (334) zur Wiedergabe von frz.'le cou'. (vgl. Pawl.220)

IV, 338-381: Der Kopf (Schădel, Gehirn, Offnungen der Sinnesorgane, Nacken und Gesicht).

Wăhend innerhalb der einzelnen Abschnitte der stoff nicht selten regellos disponiert zu sein scheint (beau désordre), folgt die Betrachtung der menschlichen Anatomie im ganzen einem einleuchtenden Plan: Von den Beinen angefangen, werden die Korperteile in aufsteigender Richtung erörtert.

Am ausführlichsten beschaftigen sich unsere Autoren mit dem Kopf. An diesem Teil des Körpers erscheint innen alles sinn- und bedeutungsvoll. Hier sind nach ihrer Meinung die Absichten des Schopfers mit Hănden zu greifen. DaB sich der Kopf 'oben' (сверьху шея, 338) befindet, gilt bereits als zeichen für seine Bedeutung. Zum Herrschen bestimmt, thront er gewissermaben über dew Köper: IV, 340 Телом человечим обладает всем глава: -

Das ksl. 'rnasa' (Pawl.241) enthălt eine feierliche Nuance wie das deutsche Wort 'Haupt'.

Die Stelle ist von der Vorlage abhăngig: "Ce cou, médiocrement élevé au-dessus des épaules, porte sans peine la tete, qui regne sur tout le corps." (S.41) Tred. fugt hinzu, daß der Kopf als Sitz der Vernunft und der Sprache fahig ist, über den Korper zu herrschen:

$$
\text { IV, } 341 \text { В ней наш смшсл и знаки из нее уму, слова́. }
$$

Die Sprache ist nach Descartes eines der wichtigsten Kriterien zur Unterscheidung des Menschen vom Tier. 19

Hieran schließt sich die aus der Vorlage ubernomene hypothetische Exwagung: was ware, wenn der Kopf kleiner bzw. grober wăe. Sie fuhrt zu dem Ergebnis, 
daB der Schöpfer es recht gemacht hat. Ein zu klein geratener Kopf stănde nicht im richtigen Verhältnis zum körper:

IV,342f. Буде 6 меньше та была, то 6 в ней меры с телом, Как пристойно, не нашлось размерений делом.

Ein übergroBer Kopf hingegen störte nicht nur die gute proportion, sondern auch das Gleichgewicht des Körpers:

$$
\begin{aligned}
& \text { IV, 344ff. Буде ж бы та больше, не считая что одна, } \\
& \text { Из всего та те́ла, не была отнодь складна́, } \\
& \text { Тягость бы ее в одну сторону склонила: - }
\end{aligned}
$$

Seine Vorlage ergänzend, verdeutlicht Tred. die Gesichtspunkte der Schönheit und des Nutzens durch das hypothetische Gegenbild:

$$
\text { IV, } 347 \text { Тем бы отняла красу́, вред бы причинила. }
$$

Fénelon argumentiert so: "Si elle était moins grosse, elle n'aurait aucune proportion avec le reste de la machine. Si elle était plus grosse, outre qu'elle serait disproportionnée...sa pesanteur accablerait le cou, et courrait risque de faire tomber l'honme du côté ol elle pencherait un peu trop."(S.41)

Starke Schädelknochen beschũtzen 'den Schatz in Innern':

IV, 348ff. Окружают кости крепкие со всех сторон

Голову ту нашу нужных ей аля оборон;

То $ж$, дабы ей содержать без вреда в средине

Bсё сокровище, -

Die Verse greifen auf den Satz Fénelons zuxück: "Cette tête, fortifiée de tous côtés par des os très-épais et très durs, pour mieux conserver le précieux trésor qu'elle enferme..." (Démonstr., s.41)

Tred. hat die Stelle im folgenden durch zwei zusătze erweitert. Einmal fügt er hinzu, daB das Gehirn aus zwei Hăften (Hemisphăren) besteht. Zweitens weist er ausdrücklich, im Unterschied zu der mehr verhaltenen Ausdrucksweise der Démonstration, auf das Wirken des Schopfers hin: der Schöpfer wollte diesen 'Schatz' (das Gehirn) 'dort' (im Schãdel) verbergen, 'wie man einen kostbaren Schatz in der Erde vergräbt'. Mit diesem Vergleich spielt Tred. vermutlich auf das Gleichnis Jesu vom 'Schatz im Acker' an (Matth. 13,44):

IV,351ff. Bсё сокровище, из двух в камдой половине,

Кое там зиждитель щеяро восхотел укрыть,

Равно как бесценный в земло клая, в нее зарыть.

Die betont theistische Formulierung ist für die Feoptija charakteristisch, ebenso wie der emphatische rhetorische stil, der die Affekte erregen soll. 
Tred. gerât im Blick auf die 'weiche, feuchte und zarte' Gehirnsubstanz in höchste Bewunderung (мозг мягок, Сшр, хлипко уготован, 354). Ausgerechnet in dieser unansehnlichen Masse ist alle 'Klugheit' der 'unergrüdlichen Vernunft' eingeschlossen. Man kann darüber nicht genug staunen, ruft er aus:

IV,356f. Здесь вся хитрость тонно непостижного ума:

Мозгу наяиеиться невозможно есть весьма!

Die entsprechende Stelle der Démonstration, in der das Gehirn (le cerveau) als "substance humide, molle et spongieuse" bezeichnet wird, lautet: " $C$ 'est la le centre des merveilles dont nous parlerons dans la suite." (S.41) In der Feoptija hören wir den begeisterten Redner, hier den zurückhaltenden Essayisten.

Die für die Sinnesorgane (Augen, Ohren, Nase) und für den Mund bestimmten Uffnungen im Schádel beschreibt Tred. nach dem Vorbild Fênelons. Auch hier setzt or hin und wieder eigene Akzente. So leitet er die Passage mit einem personifizierenden Satz ein, der das Bemulhen des Autors um die Poetisiexung des Stoffes zeigt: der Schădel 'sorgt' gleichsam für die Sinnesorgane, indem er Ihnen Platz lảst:

IV, 358f. Yepen, как нарочно, сам о6 очах радеет, 06 ушах, о носе, рте: скважинш имеет, -

Fénelon schreibt: "Le crâne se trouve percé réguliêrement...pour les deux yeux, pour les deux orellles, pour la bouche et pour le nez." (Demonstr., S.41)

Von den Sinnesorganen selber will er 'an ihrer stelle' berichten, fugt Tred. hinzu:

IV, 360f. Ho таких отеерстий, уяш требуют каких, Изочте́ннш мнок, в поломениях своих -

Voller Bewunderung macht der Autor auf das hochst komplizierte Geflecht von Nerven aufmerksam, das 'von künstlerhäden geknüpft' worden ist:

IV,362f. Суть в сплетениях везде жилы там пресложншх, Ha потребу есе от рук сеязаны художншх.

Wieder benutzt Tred. die Gelegenheit, auf das Wirken des Schópfers ausdrücklich hinzuweisen (от рук связанш худомншх). In lehrhaftem Ton bemerkt Fenelon: "Il y a des nerfs destinés aux sensations qui s'exercent dans la plupart de ces conduits." (Démonstr., S.41)

Das in der Mitte der Schádelbasis gelegene 'Siebbein' wird von Tred. 'xprul', 'Knorpel', speziell 'Nasenknorpel',genannt. Auch hierbel hebt er vor allem den teleologischen Gedanken hervor: der 'Knorpel' ist dazu da, daß die 'Geruche' direkt in das Gehirn kommen: 
IV, 364f. В кость хряи полотен, а положен аля того,

ЧтОб МАти в мозГ прямо вонности всей чрез него.

Dex Satz stammt aus der Demonstration: "Le nez... a un os cribleux pour faire passer les odeurs jusqu'au cerveau." (5.41)

Ein Zeichen der fürsorglichen Weisheit des Schöpfers sieht Tred. auch darin, daß die Sinnesorgane doppelt mit 'Nerven' ausgestattet sind ('жила' bedeutet: Ader, Sehne, Nerv; Pawl.367). Wird eine Seite beschădigt, so kann ihre Funktion von der anderen übernommen werden:

IV, 366ff. Хил устроено число оннх всех двойное, Чтоб, когаа с одной странш Аействие какое

Повредиться может, было равное с Аругой,

Не от сей гАе службы жилы, ни Аабы от той.

Fénelon legt dar, daß 'die wichtigsten Sinnesorgane doppelt vorhanden sind': "Parmi les organes de ces sensations, les principaux sont doubles, pour conserver dans un cote ce qui pourrait manquer dans l'autre par quelque accident." (Démonstr.,S.41)

Die Sinnesorgane sind so zweckmăBig koordiniert, daß der Mensch sie entweder 'hübsch' zur Seite oder geradeaus richten kann:

IV,370f. Bce органы сии так слог имеют срядно,

Что их может человек обращать как взглядно; -

Mit Hilfe der Halswirbel können sie sich schnell in die erforderliche Richtung arehen:

IV, 374f. Шейнши составы өсе помощь им собщают

И собо0 все те варуг должно обращают.

Fénelon hat dies so beschxieben: "Ces deux organes d'une même sensation sont mis en symetrie,...afin que l'homme en puisse faire un plus facile usage, ou a droite, ou a gauche, ou vis-d-vis de lui... D'ailleurs la flexibilité du cou fait que tous ces organes se tournent en un instant de quelque côté qu'il veut." (Démonstr.,S.41f.)

Den Text der Vorlage kürzend, erwăhnt Tred. den Nacken und die Haare in zwei Versen. Am Hinterkopf befinden sich die 'hărtesten Teile', die überdies noch von einer 'Decke aus Haaren' umgeben sind:

IV,376f. На затылке части тве́рдейши положены́

И $x$ тому 2 покровом волосов обложени́.

Fénelon meint, der Hinterkopf sei deshalb so hart, weil er 'am wenigsten imstande ist, sich zu verteidigen'. Ferner erklărt er, daB die Haare nicht nur zum Schutz, sondern auch zum Schmuck da sind: "Tout le derrière de la tate, 
qui est le moins en état de se défendre, est le plus épais: il est orne de cheveux, qui servent en mème temps fortifier la tête contre les injures de l'air. Mais les cheveux viennent sur le devant pour accompagner le visage et lui donner plus de grâce." (Démonstr., S.42)

Das 'Gesicht' hat Tred. mit schmuckenden Beiwortern, die auf seine Schónheit und wurde hinweisen, beschrieben:

$$
\begin{array}{ll}
\text { IV, } 378 & \text { Предня часть всея главн есть личе толь слично, - } \\
\text { IV, 380f. Человеку о́но достолепна красота } \\
\text { И его достоинсто слетоварна высота. }
\end{array}
$$

Das Kompositum 'světozarnyj' trifft man, wie Tschižewskij anmerkt, bei simeon Polockij (Večerja duchovnaja,381) und im Oktoechos (II 534).

Das Doppelepitheton 'dostolepnyj' ist auf dieselbe Weise gebildetwie das von Tschizewskij aufgefunrte 'blagolěpnyj', das in worterbuch von Lavrentyj zyzanij und bei simeon Polockij (Večerja duchovnaja, 381) belegt ist. 20 Fênelon erklărt kurz und bundig: "Le visage est le côté de la tête qu'on nomme le devant..." (Démonstr.,S.42)

IV, 382-483: Die fünf Sinne.

Der Abschnitt wird mit einem Ausrufungssatz, der zwei Verspaare unfaBt, eroffnet. Voller Bewunderung weist Tred. darauf hin, daB die Sinnesorgane (чувственныи члены, 382) im Gesicht auf schöne Weise beieinander sind. Wieviel Ursache haben wir, ruft ex aus, selbst die stellen, an denen sie sich in solcher ordnung und Harmonie befinden, zu bewundern!

\section{IV, 384f. Иx такой порядок и такой престройншй чин,}

Что местам Аивиться, не самим, коль есть причин!

Diese Verse unterscheiden sich durch ihre ponalităt von dem deskriptiven stil, in dem Fénelon den neuen Abschnitt beginnt: "Le visage est le coté de la tete...oul les principales sensations sont rassemblees avec un ordre et une proportion qui le rendent très-beau..." (S.42)

IV, 386-443: Die Augen.

Schon die stelle, an der sie sich befinden, wird als bedeutsam angesohen: IV, 386f. Очи под челом среди, в месте самом главном, Dort sind sie, 'damit sie die ganze Schöpfung, so fern oder nahe, so weit oder hoch sie sein mag, sehen können':

IV,388f. Чтоб им всо тварь иидеть, коль бшла 6 ни далека́, Коль ни приближенна, коль өдали ни өшсока! 
Dieser pathetischen Perspektive gegenuber, die den Mikro- und den Makrokosmos elnbezieht, nimmt sich das Gesichtsfeld der Augen, wie es von Fénelon angedeutet wird, klein und alltäglich aus: "Les deux yeux sont égaux, places vers le milieu et aux deux côtés de la tête, afin qu'ils puissent découvrir sans peine de loin, a droite et a gauche, tous les objets etrangers..." (S.42)

AuBer zum Sehen sind die Augen dazu bestimmt, 'zum Wohle des Menschen achtzugeben'. Tred. fügt hinzu: 'bis ans Ende seines irdischen Lebens':

IV,390f. И чтоб, вияя, стереглись $к$ пользе человека

До назначенны ему здесь кончины века.

Fénelon sagt, die Augen befinden sich deshalb an ihrer Stelle, "...afin... qu'ils puissent veiller commodement pour la sarete de toutes parties du corps. Nach mythischer tberlieferung, auf die Fénelon zurückgreift, sind die Augen dadurch sehend geworden, daB 'ein himmlisches Feuer', dem nichts sonst in der Natur gleicht, in ihnen entzūndet wurde. Die Wendung ist von Fénelon, wie es scheint, metaphorisch aufgefaBt worden: "Celui qui les a faits y a allume je ne sais quelle flamme céleste, a laquelle rien ne rassemble dans tout le reste de la nature." (Démonstr.,s.42) Vor allem 'je ne sais quelle...' deutet auf metaphorisches Verstandnis hin.

Tred. hat den Passus aus der Démonstration aufgenommen und ihn hymnisch akzentuiert:

IV, 392ff. Сотворивший очи на өидение мам дня

Искры в них небесны и небесного огня,

По щедроте положил, да и красотою

Возвеличил, ничему 6 не равняться с тор.

In beiden Texten wird die 'Spiegel'-Metapher auf die Augen angewandt:

IV, 396f. Сии суть зерцала: Фбраз всяк в них естества

Начертан бшвает мудростию божества; -

Die Formel 'durch Gottes Weisheit' hat Tred. dem vorgegebenen Text Fénelons hinzugefügt. Dieser schreibt: "Ces yeux sont des especes de miroirs, ou se peignent... dans le fond de la rétine, tous les objets du monde entier..." (42)

Das Verspaar 398f. ist von Tred. eingeschoben und laßkt sein Bemühen erkennen, die Darstellung zu poetisieren: unser Geist sieht die ganze Natur mit Hilfe der 'lichten Augen'; sie schenken inm das 'Licht der Welt durch die Strahlen der Morgenröte':

IV, 398f. Всі природу вияит ум светлыми очами,

Света подают ему свет зарей лучами. 
Als 'wunderbar und nicht leicht zu verstehen' bezeichnet Tred. das optische Phănomen, daB wir die Dinge nicht doppelt sehen, obwohl wir zwei Augen haben: IV,400f. Чудно! И постигнуть точно есть не малый труа, Что зрим не Авойнше вещи, а Авойный зреть УА; Diese Erscheinung ist von Fenelon in ansprechender Weise erklart worden. Er vergleicht die beiden Sehnerven mit zweigen, die 'sich zu demselben Stamm vereinigen': "...les deux nexfs qui servent a la vue dans nos yeux ne sont que deux branches qui se réunissent dans une même tige..." (Démonstr.,s.42) zur Veranschaulichung benutzt Fénelon ferner den Vergleich mit einer Brille, in der zwei Glasser verbunden sind: "...comme les deux branches des lunettes se réunissent dans la partie superieure qui les joint." (S.42) Tred. hat jedoch von diesen Erklarungsversuchen Fénelons keinen Gebrauch gemacht. Er hat ausschlieblich das 'Wunderbare' der Erscheinung herausgestellt, um dadurch auf die Affekte einzuwirken. Ihm ist es an dieser stelle wichtiger, das Gefül der Ehrfurcht vor der Weisheit des Schópfers auszulósen, als zu rationaler Erkenntnis beizutragen. Die Stelle ist rhetorisch geprăgt, entsprechend dem von Cicero vertretenen Gedanken der 'affektiven Wirkungskraft' der Rede, der auch in der Poetik des 18.Jahrhunderts Geltung hatte. Durch ihn, so legt H.P.Herrmann dar, "erhebt sich die Rhetorik nach ihrem Selbstverstännis uber die bloB theoretische Philosophie und Wissenschaft: durch ihre... Affekthaltigkeit ist sie imstande, nicht nur auf die vernunft, sondern vor allem auf den willen des Menschen zu wirken." 21 Es liegt nahe, daB Tred. als Professor der Rhetorik ("как латинския так и россииския зловениии") 22 von deren klassischen Mitteln auch in der Feoptija vielfaltigen Gebrauch gemacht hat.

In IV, 404 beginnt ein lăngerer Alleingang Tred.s bis IV,483. Dieser Teil, in dem verschiedene Themen zur Sprache kommen, enthălt nur gelegentliche Anklange an die Démonstration. Tred. hat die Vorlage kurz vor dem SchluB des Abschnitts über die Augen ( es fehlte nur noch die Bemerkung Uber die Augenbrauen und Augenlider) beiseite gelegt.

Erregt von der wunderbaren Tatsache, daB wir die Dinge zwar mit zwei Augen, aber nicht doppelt sehen, verfallt der Autor in eine Axt 'Schelte' der Unglaubigen, die darin nicht die 'Weisheit des Brohsten' sehen wollen:

IV,404f. Мудрости в сем вшшни, в мудрованиях нелеп, Точно кто не вияит, и с очами тот есть cлеп; -

Der Unglăubige ist trotz seiner Augen 'blind'. Diese paradoxe Wendung erinnert an biblische Parallelen, 2.B. an Jesaja, Kap.6,9f.: 


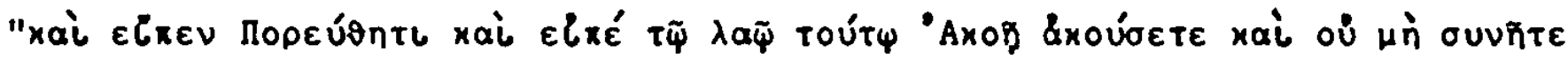

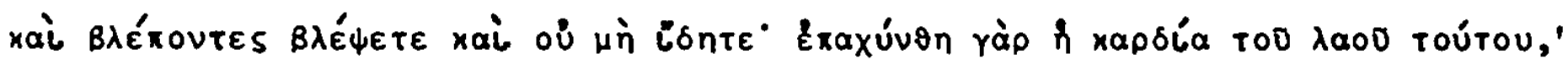
Die Jesajastelle von der 'Verstockung' wird im Matth. Ev.,Kap.13,14f. zitiext.

Dem Unglāubigen werden intellektuelle und moralische Defekte unterstellt: er ist nicht nur 'schwachsinnig', sondern 'ganz von Sinnen'. Er 'tobt in Leidenschaften':

IV,406f. Tот не токмо мазван бить момет малоумным, Но бессмысленным совсем и страстами шумным.

Solche Schmähungen des weltanschaulichen Gegners sind in dex Feoptija nicht selten (vgl. 2.B. I,335f.). Sie sind keine individuelle Eigentumlichkeit des Schriftstellers Tred., sondern stellen, wie zu der genannten stelle bemerkt wurde, ein Stilmittel der Physikotheologen in der Auseinandersetzung mit den Atheisten dar. ${ }^{23}$ Der 'prophetische Affektsturm' (W.Philipp) gegen die Unglăubigen bildet bei vielen Physikotheologen den wirkungsvollen Kontrast zu der Bewunderung, mit der sie die Werke des schöfers preisen.

Die vorliegende stelle ist ein Beispiel für den schnellen Wechsel des Tons in der Feoptija. In den Versen 404-407: Schelte der Unglăubigen. Gleich danach preist der Autor ein weiteres 'Wunder' der Optik, namlich die Tatsache, daB wir die Dinge nicht umgekehxt, sondern 'aufrecht' sehen:

IV,408f. Коль не меньше яивно, что мы зрением своим Не в ббрат все веци, да верьх ве́рьхом прямо зрим!

Auch hiexbei verzichtet Tred. auf physikalische Erklarungen. Er deklariert das 'aufrechte' Sehen als ein wunder, das aufs neue die Weisheit des Schöpfer: offenbar macht und uns geradezu 'notigt', an ihn zu glauben:

IV,410f. Bсё сие премуарость нам в здавшем изъявляет

И его толика бить верить заставляет.

Es folgen zwei rhetorische Fragen, die suggestiv ausdrūcken, daß der 'gesunde Menschenverstand' verbiete, so viele Wunder als 'zufálig' hinzustellen:

IV, $412 f$. Как припадку многи чудеса толь сотворить? Момет ли, кто с здравым разумом, так говорить?

Von der rhetorischen Digression wechselt der Ton wieder zur nüchternen Beschreibung. Dex hăufige Wechsel der Tơne ist gerade im philosophischen Lehrgedicht erwinscht, um Monotonie auszuschließen, stellt Chr.siegrist generell fest. 24

In IV,414-423 wird die Anatomie des Auges dargestellt. Danach besteht der Augapfel aus folgenden Teilen: der Hornhaut, der Regenbogenhaut mit der Pupil- 
le, dem Glaskorper und der Netzhaut. Zur Bornhaut sagt Tred.: IV, 414 В оке оболочка есть, в-первых, роговая, Die Regenbogenhaut und Pupille werden so beschrieben:

IV,416f. Следует за сео, виноградной что зовут, С дирочкой в том месте, в коем зеницу кладут; -

Vom Glaskorper heiBt es:

IV,419 Bлага следует потом именем кристальна, -

Hinter dem Glaskorper, so fuhrt Tred. weiter aus, dehnt sich die Netzhaut, bestehend 'aus Sehnerven' mit vielen 'kleinen Knoten' und 'kaum sichtbaren LOchern':

IV,421ff. У сея простерта, а Аальности, на самом Ане Сеточка тонка́ вельми, зрительства из жилок, Mного тут как узелков, так чуть зримых Аирок.

In IV,424-439 werden verschiedene Theorien des Sehens erortert.

Einige der 'Alten' waren der Meinung, berichtet Tred., das Sehen kome durch die Lichtstrahlen, die unsere Augen aussenden, zustande:

IV,424f. В Аревних неки мнили, испуцением лучей

Зрение что наше делается от очей.

Als Vertreter dieser Ansicht werden in den 'Primecanija' zu Feopt.IV, $425 f$. (S.518) Pythagoras (582-500 v.Chr.) und Euklid (3.Jh. v.Chr.) genannt.

Diese Theorie werde dadurch widerlegt, meint Tred., daB wir die Fixsterne sehen kónnen, die für unsere 'strahlen' unerreichbar sind. Darum halten 'die heutigen Gelehrten' diese Meinung 'der Alten' für sinnlos:

IV, 428f. To догмат сей древних опровержен самым тем,

А новейшим муарым и неугоден стал всем.

Sie lehren vielmehr, daB unsere Augen Lichtstrahlen empfangen. Die 'goldenen Strahlen', die von den Dingen ausgehen, werden in der Hornhaut unserer Augen und in dem gallertartigen Glaskorper gebrochen und vereinigen sich auf der Netzhaut, um dort ein genaues Bild der Dinge darzustellen. So hat es die gottliche 'Vorherbestimung' festgesetzt: IV, $431 \mathrm{ff}$. ...те лучи златыи

0т вещей идущи, в оболочках наших глаз,

Также в их и елагах преломляртся всяк раз, Чтоб на сеточке сойтись и вещей вия точншй Сшедшимся изобразить чрез предел нарочншй.

Die Versreihe macht deutlich, wie sich Tred. bemüt, eine Synthese zwischen 
der neuen naturwissenschaftlichen Erkenntnis und dem Glauben an die Alleinwirksamkeit des Schopfers herzustellen. Darauf zielt die gesamte physikotheologische Bewegung ab. Man bediente sich $z u$ diesem $2 w e c k$ der von den Occasiona. listen mit ihrer Lehre von den 'Zweitursachen' bereitgestellten begrifflichen Mittel: Gott, als 'prima causa', habe es von Anfang an so eingerichtet, daB die 'causae secundae' die von ihm vorherbestimmten ziele herbeifüren. So wirc auch der optische Vorgang als eine Kette von 'Zweitursachen' gedeutet, die kraft 'gewollter Vorherbestimmung' funktionieren.

Tred. erwăhnt noch eine dritte Theorie des Sehens, die die Lehre der 'Alten' mit der neuen Auffassung zu verbinden suchte. Er geht aber darauf nicht naher ein:

IV,436f. Некоторы мужи древних пе́рвейший догмат Вкупе съединили со вторым и новым в лад.

Nach dem Einschub uber die Theorien des Sehens kommt der Autor noch einmal auf die Anatomie des Auges zurück (440-443). Er nennt die Augenlider, Wimpern und Brauen, die den Zweck haben, das Auge vor dem Eindringen von Fremdkörpern zu schützen, die Lichtstrahlen zu brechen und die Hitze zu vermindern:

IV,440ff. У очей суть веки, влажа 6 окружали их, чрез ресничн, брови защищали 6 от других

Нечистот и порошков и чтоб преломляли

Ход лучей и некак зной их бы умаляли.

In diesen scheinbar kleinen Dingen zeigt sich dem Autor wieder die Fürsorge des Schöpfers.

Die Verse uber die Augenlider haben eine gewisse Ahnlichkeit mit diesem Passus Fénelons: "Les yeux sont ornés de deux sourcils égaux; et afin qu'ils puissent s'ouvrir et se fermer, ils sont enveloppés de paupières bordées d'un poil qui défend une partie si délicate." (Démonstr.,s.42)

IV, 444-453: Die Ohren.

Tred. setzt seinen 'Alleingang' fort mit der Betrachtung des Ohres und des Hörens. Zunăchst beschreibt er das ohr, das nach seinen Worten aus dem Gehorgang, dem Trommelfell, sowie aus AmboB, Hammer und steigbügel besteht:

IV, 444ff. С лишим мы ушами. Изгибна́я пустота Уха достигает до тех самых мест, где та

Тоненька препонка есть, что тимпан зовется. Наковальня, молоток, стремя тут бподется.

Wie geht nun das Horen mit diesem organ vor sich? Tred. schildert den Weg 
eines Lautes durch den Gehorgang zum Trommelfell:

IV,448f. Чуть лишь звон внутрь уха войдет в ону пустоту,

Как и не однажда поразит препонку ту.

Die Verse veranschaulichen die Funktion der Schallwellen. Diese setzen die 'Drillings'-Werkzeuge in Bewegung, die wiederum die Luft im Innern des Ohres 'aufrühren' :

IV,450f. Вот тройня ОрУАий тех в Авиг же свой прихояит,

В возмущение КОЙ внУтрь ВозАУХ тем Приводит.

Wenn das Gerăusch durch die Nerven zum Gehirn gelangt, dann 'hort der von dieser Erpfindung getroffene Verstand' :
IV, $452 f$.
Хилками до мозга до́йдет весь когда сей шум,
Так тогда и сльшит пораженный чувством ум.

Die detaillierte Beschreibung der anatomischen Verhaltnisse, die lebhafte Schilderung des Horvorgangs, die Verwendung einer Reihe von Metaphern: all das sind nach den MaBstaben der Zeit wesentliche Elemente der Poetisierung. IV, 454-459: Der Geruchssinn.

Beim Riechen, so stellt es Tred. dar, werden Partikel der duftenden Korper mit der Luft in die Nase eingesogen. Sie treffen auf den Teil des organs, der aus zahlreichen kleinen Nerven besteht. Wenn diese ein wenig berührt werden, kann der Verstand nicht untatig bleiben: 'er muB riechen':

IV, 456ff. Как в Ашшани машем благовонншх частки тел

Возаухом влекутся В нозАрИ, Всюау КОй поспел,

То тех жилочек крайки тем разятся разно:

Вот уму не обонять не бшвает праздно.

IV, 460-467: Der Geschmackssinn.

Das dem Geschmackssinn zugeordnete Organ, die Zunge, hat 'der allgütige Schopfer' mit vielen pyramidenformigen 'kleinen Beulen' versehen, die die verschiedenen Geschmacksempfindungen unterscheiden können:

IV,460ff. Bкусов ми язиком можем разнь распознавать:

Пирамидншх много шишечек в смесь разметать

Благоизволил по нем преблагий зищяитель, -

Im Nachsatz wird unterstrichen, daß der Schopfer 'alles' in Weisheit 'hervorgebracht' hat:

IV,463 Как в премуарости есему сам произвояитель.

Im Kontext bezieht sich die Aussage auch auf die anderen Sinnesorgane und ist darüber hinaus das generelle Merkmal des gottlichen wirkens in der Welt. 
Das Schmecken wird durch 'Geschmacksteilchen' ausgelost, die die pyramidenformigen Knotchen auf der zunge berühren. Die Berührung wird dem Gehirn übermittelt, und die Vernunft stellt den Geschmack fest:

IV, 464f. Лишь от часток вкусных сделается всем им трус,

И сей в мозг прешлется, разум тот и знает вкус.

Das Wort 'Tpyc' wird im 'Cловарь' zum Text der Feoptija (S.557) mit 'cotpaceние, землетрясение, волнение стихий' wiedergegeben. Das wăren in diesem $\mathrm{Zu}-$ sammenhang sehx starke Ausdrücke, ahnlich wie 'возмунение' (IV,451) füx die Luftschwingungen im Ohr. Möglicherweise hat Tred. solche grotesken tbertreibungen gewollt, um auf den Affekt zu wirken. Einfacher ist aber, 'Tpyc' hier mit 'Zittern' zu übersetzen. Abschließend vermerkt der Autor, daB Speichel nötig ist, damit die Geschmacksteilchen sich auflösen und zergehen:

IV,466f. Что м разводятся сих тел частки, то причина

Распусканио тому есть готова слина.

'Слина' steht für das heute gebrăuchliche 'croна'.

IV, 468-483: Der Tastsinn.

Diese der Haut zugeordnete Sinneswahrnehmung behandelt Tred. an letzter Stelle unter den herkómmlichen 'fünf Sinnen'. Der 'weise Schöpfer' hat dio Haut für ihre Aufgabe als Sinnesorgan in ahnlicher Weise wie die zunge mit einer großen Zahl von 'pyramidenformigen Knotchen' ausgestattet:

IV,468ff. Kожа, способ чувства прикасательного в нас,

Пирамидных также шишечек на ней припас

Мудрый множество творец: -

Kaum wird dieser Körperteil von etwas berüht, so 'bringt der Verstand ein Urteil uber die fremde Sache hervor':

IV,472f. Вещь едва наружна тронет тела оный уд,

0 чумой той вещи и произведет ум суА.

Eine leichte Berührung der 'Knötchen' wird meist als angenehm empfunden:

IV,474f. K шишечкам тихонько тем до́тык как бывает,

То приятность из того в разум прибегает: -

Wenn die Berührung sehr stark ist, 'fühlt die seele sie als eine Krankheit':

IV,476f. Eсли ж та дотычка будет как не хороwа,

Иль сильна чрез меру, чувствует болезнь Ауша.

Den stărksten Schmerz fühlen wir, wenn etwas (in unserem körper) 'auseinander. zureiBen' droht: 
IV,480f. И чем 6лиже прй́ет $\mathrm{K}$ разорванио чего,

Тем чувстөительнейший буяет боль нам от того.

Zwischen den beiden Extremen der angenehmen und der schmerzhaften Berührungen liegen die neutralen Tastempfindungen:

IV, 482f. Прочии прикосн все так бывают өнятны,
Что ни бо́льны их себе ставим, ни приятны.

Die eigentliche Sinneswahrnehwung geschieht im Gehirn, so hat Tred. es bei allen 'fünf Sinnen' herausgestellt. Er bezeichnet diese Zentrale mit verschiedenen Worten: 'ym', 'pasym', 'Aywa', ohne wesentlichen Bedeutungsunterschied. Nach einer Bemerkung von H.P.Herrmann werden "im frühen 18. Th. Seele und Geist noch oft gleichgesetzt". Der Geist ist nach dieser Auffassung noch nicht sache des einzelnen, "sondern...die allgemeine Făhigkeit zu fühlen und zu denken, wie sie jeder Mensch zu Jeder zeit besitzt." 25

Die Substantive 'ROTHK' (474) und 'מotw4ka' (476) stamen dem 'Crosapb' zufolge (546) vom polnischen 'dotyk', das mit russ. 'ocязаниe' ubersetzt wird.

IV, 484-499: Die würde und Schönheit des Gesichts.

In Vers 484ff. nimmt Tred. wieder die Verbindung mit der Demonstration auf. Fénelon hat zunăchst die Bedeutung der Stirn für den Gesichtsausdruck herausgehoben: "Le front donne de la majesté et de la grâce à tout le visage: il sert a relever les traits." (Demonstr.,s.42)

Tred. wiederholt das und setzt hinzu, das 'elne gewolbte, runde stirn' dem Gesicht gut ansteht:

IV,484f. Придает величий и красш лицу чело, Кое, как пристойно, витибом так и кругло́.

Von 'Schönhe1t und würde' des menschlichen Gesichts war schon in IV, $378 f$. die Rede.

Weiter heibt es: das Gesicht wăe ohne die Nase 'flach und entstellt':

IV, 486f. Буде 6 посредине нос не 6 uл, то 6 явилось กлоско наше всё лице, тем бы осрамилось; -

In der Vorlage wird das noch weiter ausgefürt. Der Satz, auf den Tred. zurückgegriffen hat, lautet: "Sans le nez, posé dans le milleu, tout le visage serait plat et difforme." (S.42)

Die Nase befindet sich 'zwischen Augen und Mund', damit sie nach dem Geruch beurteilen kann, was 'gut und bekommlich zur speise' ist:

IV, 488ff. Oн стонт меж взором и устами, чтоб понять Всё, ему как Ао́лжно, аухом точно обонять, . 
IV, 490f. Что на пищу может быть здраво и пригодно,

И по ауху что тому, кушать нам есть сродно.

Die Anatomie wird also teleologisch interpretiert, wie es in der Démonstration vorgegeben ist: "Il est placé immédiatement au-dessus de la bouche, poux discerner plus commodément par les odeurs tout ce qui est propre a nourrir 1 'home." (S.42f.)

Viel tragen die Lippen zum Ausdruck des Gesichts bei (IV,492-499). Tred. rühmt mit kurzen Ausrufen ihre 'herrliche Rote' und ihren lebhaften Glanz, der das 'ganze Gesicht schōn macht':

IV,492ff. Рассмотри румянец благолепнейший устек,

Коль их цвет сияет! Коль красно́ тот оживлен!

Всё лице красят устна! -

Tred. verwendet den ksl.pl.'ustně' für 'ycta' (vgl. Pawl.,1671).

Das Kompositum 'blagolêpnyj' ist, wie D.Tschizewskij anmerkt, bei Sreznevskij (7) belegt. 26

Die Passage ist durch ihren enthusiastischen Ton gekennzeichnet, der von der wiederholungsfigur (коль -! коль-!) noch verstarkt wird.

In der Vorlage werden die Leser aufgefordert: "Voyez les lèvxes: leur couleur vive, leur fralcheur, leur figure, leur arrangement et leur proportion avec les autres traits, embellissent tout le visage." (S.43)

In lyrischem Ton fügt Tred. hinzu: zusamen mit den Augen 'erleuchten die Lippen unser Antlitz mit reinen Strahlen':

$$
\text { IV, 494f. - Купно те с очами }
$$

Освещают зрак наш весь чистыми лучами: -

Es folgt eine Aufzăhlung von Gemütsbewegungen, die das Mienenspiel von Lippen und Augen auf dem Gesicht 'abbilden' :

\section{IV,496ff. Веселят, печалят, показујт тишину, \\ Изъявляют ауха низкость, также вышину, \\ Чувствуемым страхом внутрь равно поражают: \\ Словом, кажау на лице страсть изображакт.}

Die Reihe deckt sich nicht ganz mit der Fénelons. Dessen Aufzählung hat Tred. ergånzt durch: 'тишина' (Stille, Friede), 'Ауха низкость, также вшиина' (Niedrigkeit und Hohelt des Geistes) und 'ctpax' (Furcht). Fénelon schreibt: "La bouche, par correspondance de ses mouvements avec ceux des yeux, l'anime, l'égaie, l'attriste, l'adoucit, le trouble, et exprime chaque passion par des marques sensibles." (Démonstr.,S.43) 
IV, 500-513: Die Teile des Mundes (Lippen, Zăhne und Zunge).

Nicht nur für die Physiognomie sind die Lippen von Bedeutung. Im folgenden geht es un ihre Funktion beim Essen und Sprechen:

IV,500f. И устна не токмо восприемит ядь в уста,

Речь всь прерыварт, не бшла 6 речь коль часта.

Vers 500 gibt genau die vorlage wieder: "Outre que les lèvres s'ouvrent pour recevoir 1'aliment,..." (S.43). In Vers 501 hat Tred. selbstândig die Tătigkeit der Lippen beim Sprechen zusammengefaBt: 'die Lipper. unterbrechen die Rede, so schnell (oder: dicht) sie auch sein mag'. Gedacht ist wohl an das abwechselnde Sichoffnen und SchlieBen der Lippen wăhrend des Sprechens. Fénelon hat das so beschrieben: "...elles servent encore, par leur souplesse et par la variété de leurs mouvements, a varier les sons qui font la parole." (Démonstr., S.43)

$\mathrm{DaB}$ ein und dasselbe Organ zu verschiedenen Zwecken voll geeignet ist, wird als weiterer Beweis für die hohe Kunst des Schopfers angesehen. Diese wird auch daran deutlich, daß die Lippen zugleich schón und zweckmäig bzw. notwendig sind.

Wenn die Lippen sich offnen, werden zwel Reihen von zăhnen sichtbar, die durch das zahnfleisch verbunden sind:

IV,502f. Ho korAa отверстU суть, то вApyr показуют

Ава порядка внутрь зубов: десна их связуют.

Damit will der Autor nicht nur eine anatomische Anmerkung machen, sondern auf die Ordnung und Harmonie (Ава nоряка... зубов), die auch in den Details zu finden ist, aufmerksam machen.

Darauf hat schon Fénelon hingewiesen: "Quand elles s'ouvrent, elles découvrent un double rang de dents dont la bouche est ornee: ces dents sont de petits os encâssés avec orare dans les deux måchoires..." (Démonstx.,S.43)

Nun exst gehen unsere Autoren auf den alltaglichen Gebrauch der zahne ein: sie sind dazu da, die Nahrung 'im Nu' zu zerkleinern, sagt Tred.:

IV, 504 Ими прежде пина истончится всяка в мах, -

Fénelon vergleicht die zăne mit einer munle: "...les dents brisent cumme un moulin les aliments..." (Démonstr., s.43)

Dann gelangt die Nahrung in den Magen. Ausdrücklich wird vermerkt, daB sie dorthin nicht 'durch Jenes Rohr geht, das uns der Schópfer zum Atmen gegeben hat', obwohl dieses dicht bei der Speiserohre liegt: 
IV,506ff. СХодит впрочем та в него трубкон не то0,

На дьшание творец даровал нам ком;

Меж со600 хоть сии очень близко расстоят, -

Die Stelle geht auf Fënelon zurück, der aber hier 'den Schopfer' nicht nennt: "...ces aliments...passent dans l'estamac par un conduit different de celui de la respiration; et ces deux canaux, quoique si voisins, n'ont rien de commun." (Démonstr., S.43)

In den Versen 510-513 wird geschildert, wie sich die Zunge beim Sprechen verhalt. Von ihr als Organ des Geschmackssinns war bereits in IV,460-467 die Rede.

Tred. vergleicht, der Vorlage folgend, die flinken Bewegungen der zunge bei der Lautbildung mit den 'klimpernden Fingern', die eine Melodie spielen:

IV,510f. Действует язык в устах толь всегда поспешно, Коль брячаючих нам зреть пе́рсты в песнь успешно.

Bei der Axtikulation verăndert die zunge stăndig ihre Lage im Mund:

IV,512f. Уааряет в нёбо, зубы он бьет иногаа, Неки то внутрь лижет, гибок всё то повсегда.

In der Démonstration werden die Bewegungen der zunge mit denen der Finger beim Spielen eines Instruments und des Bogens (2.B. eines Geigenspielers) verglichen: "La langue... fait dans la bouche ce que font les doigts, ou ce que fait l'archet d'un maItre sur un instrument de musique; elle va frapper tantôt les dents, tantôt le palais." (S.43)

IV, 514-543: Die Luftrohre.

Sie wird von Tred. in Ubereinstimung mit der Vorlage als ein 'kleiner Kanal' beschrieben, der 'durch den Rachen bis in den Brustraum fuhrt':

$$
\text { IV,514 От него каналец есть сквозь гортань до Груди, - }
$$

Fenelon schreibt: "Il y a un conduit qui va au dedans du cou, depuis le palais jusqu'à la poitrine." (Démonstr.,s.43)

Auf die Formulierung 'au dedans du cou' scheint sich der Nachsatz Tred.s zu beziehen, daß wir den 'kleinen Kanal' nicht von außen sehen können:

$$
\text { IV, } 515 \text { Сами зреть его извне мы не можем, лояи; }
$$

Die Luftröhre besteht aus kleinen Ringen und ist ganz hohl, damit der Atem ungehindert hindurchgehen kann und eine helle stimme hervorbringt:

IV, 516 Сей весь из колечек очень малых состоит -

IV,518f. Ho по всей той пустоте чист, ничем не занят,

Буато 6 как нарочно был ма сие он нанят, 
IV,520f. Чтоб отндяь идуна Ауха внутрь не пресекать

И всегда 6 конечно светлий голос издавать.

Die Darlegung ist wie in der Vorlage teleologisch ausgerichtet. Tred. hat lediglich das Detail fortgelassen, daß die Luftrohre innen mit einer dünen Haut überzogen sei. Die Passage lautet in der Demonstration: "...ce sont des anneaux de cartillages enchassés tres-juste les uns dans les autres, et garnis au dedans d'une tunique ou membrane tress-polie, pour faire mieux résonner l'air poussé par les poumons." (S.43)

Zum Gaumen hin hat die Luftrohre eine kleine offnung 'wie die einer Flote'. Diese Spalte bringt, indem sie sich zusammenzieht oder offnet, eine hơhere oder tiefere stimme hervor:

IV,522ff. В нёбе и у сторонш, да не чем сипеет,

Малую каналец сей скважинку имеет,

Коя есть похожа на свирельнуг собой,

А сжимаясь, также разжимаясь, голос свой

Произносит толще тем иль гласит им тоне, -

DaB dieses Organ den Zweck hat, die Stime hervorzubringen, hat Tred. mit dem eingeschobenen Finalsatz hervorgehoben: 'Aа не чем сипеeт', (damit sie keine heiseren Laute von sich gibt, 522).

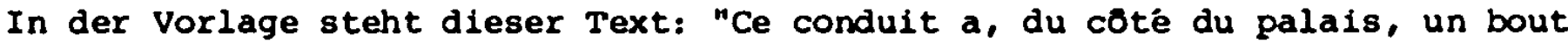
qui n'est ouvert que comme une flate, par une fente qui s'élargit ou qui se reserre a propos, pour grossir la voix ou pour la rendre plus claire." (S.43)

Als Schutz gegen das 'Verschlucken' fungiert der Kehldeckel. Tred. bezeichnet ihn als 'kleines Dach', uber das hin die vom Speichel durchtránkte Speise von der Zunge in die Speiserohre fließt. Das 'kleine Dach' verschlieBt die Luftröhre, damit keine Speise 'hineinspringen' kann:

IV,528ff. Но дабш внезапу положенна пища в рот

В духовнй каналец не өскочила прямо тот,

0т гласо́в канала есть кровелька такая,

По которой всяка ядь, слинами смокая,

Катится С язи́ка надлемот КУАа вниз ей -

Die detaillierte Beschreibung ist von der Démonstration abhăngig. Fénelon vergleicht die 'Klappe' uber der 'stimmröhre' mit einer 'Zugbrücke': "...il y a une espece de soupape qui fait sur l'orifice du conduit de la voix comme un pont-levis pour faire passer les aliments, sans qu'il en tombe aucune par- 
celle subtile ni aucune goutte par la fente dont je viens de parler."(S.43f.)

Der Kehldeckel ist so weich und zart, daß er, in der Kehle schwingend, der Stime die Schōnheit einer klingenden Orgel gibt:

IV,534f. Tа мягка́ толь и тонка́, что, дрожа в гортане,

Голосу красу дает в зеонком как органе.

Die Orgelmetapher hat Tred. eingefügt. In der Demonstration heiBt es: "Cette espèce de soupape est très-mobile, et se replie très-subtilement; de maniere qu'en tremblant sur cet orifice entr'ouvert, elle fait toutes les plus douces modulations de la voix." (S.44)

Tred. hált einen Augenblick inne und meint reflektierend: 'mich dükt, wenn man, wie flüchtig auch immer, nur eine Reihe unserer inneren Organe, ihre Ordnung und ihre gesetzmaßigen Funktionen beschreibt, so reicht das aus, um die höchste Weisheit zu zeigen und den verstăndigen Menschen uber die Maßen in Erstaunen zu versetzen':

IV,536ff. Мнится, что довоЛЬно мУАрОсть вышно Изъявить,

Смыслящего ж можно пребезмерно удивить,

Ежели, коль ни слегка, внутренних составов

Наших токмо ряд сказать, чин и их уставов;

Tred. hat hierbei nicht nur an die menschliche stimme, sondern an den gesamten Organismus gedacht: in der Anatomie und in den Lebensvorgăngen des mensch lichen Körpers offenbart sich die 'höchste Weisheit'. Im Unterschied zur Démonstration, in der 'die wunderbare Kunst der inneren Teile' hervorgehoben wird, hat Tred. die physikotheologische Formulierung gewăhlt. Fénelon schreibt: "Ce petit exemple suffit pour montrer en passant, et sans entrer d'ailleurs dans aucun détail de l'anatomie, combien est merveilleux l'art des parties internes." (Démonstr., S.44)

Uber die menschliche stimme, 'dieses überaus angenehme Organ', merkt Tred. noch an, sie sei uns 'für die Verschiedenheit der klänge und zur Schönheit' gegeben:

IV,540f. Человеча гласа всеприятный сей орган,

Кой на разность звонов и на красоту нам дан, Das 'Schōne' und das 'Nützliche' ist auch in dieser 'Gabe' des Schöpfers vereinigt. Die stimme ubertrifft an Vielfalt und Schönheit der Töne alle Musikinstrumente. Als Beispiele nennt Tred. die 'Leiern und Trompeten'. Jedes Instrument ahmt die menschliche stimme als unübertreffliches Vorbild nach : 


$$
\begin{aligned}
& \text { IV,540 } \\
& \text { IV,542f. Мусикийских лир и труб роды превшает, } \\
& \text { Следует ему из сих всяк, да возглашает. }
\end{aligned}
$$

In der Démonstration steht an dieser Stelle: "Cet organe,...est le plus parfait de tous les instruments de musique; et tous les autres ne sont parfaits qu'autant qu'ils l'imitent." (S.44)

IV, 544-555: Die erstaunlichen Leistungen der Sprech- und Hororgane.

Die zarte Beschaffenheit der Organe, die wir zum Sprechen gebrauchen, steht im auffallenden Gegensatz zu ihrer starken Inanspruchnahme. Darauf lenkt Tred. mit einer Reihe von rhetorischen Fragen die Aufmerksamkeit:

IV,544f. Onисать кто может нежность всех орга́нов в нас, Коими собщаем прочим многозычный глас?

Das Adj.comp. 'многозичный' kann zwar sonst nicht belegt werden, es gehort aber zu den "vielen Komposita mit blago-, dobro-, mnogo-, samo-, die wir bei Tred. treffen." 27 Die meisten dieser Komposita sind nach Tschižewskij keine Neuschópfungen. 'Многозычншй' ist seinen Bestandteilen gemå etwa mit 'vieloder lauttónend' zu übersetzen.

Tred. fahrt fort: beim Sprechen 'tellen' wir die stime, ohne befüchten zu mũssen, daß dabei dem zarten Organ etwas zustöBt, oder daB es inm wehtut: IV,546ff. И которыми дели́м сей мы глас на части,

А на члены части те, не боясь мапасти, Чтоб ту непрершеность пресещи́, где так деля, Aа $и$ от сечений многих оных не боля?

Zu dieser Darstellung des Sprechvorgangs gibt es in der Démonstration keine Parallele. Fénelon ist von der Stimme gleich zum Geschmacks- und Geruchssinn ubergeganen: "Qui pourrait expliquer la dëlicatesse des organes par lesquels l'homme discerne les saveurs et les odeurs..." (Démonstr.,s.44) Man kann vermuten, daB dem Sprachforscher Tred. besonders daran lag, den Sprechvorgang darzustellen.

Erwăhnenswert ist, $\mathrm{daB}$ auch B.H.Brockes in seinem Gedicht 'Die Luft' auf diesen Vorgang anspielt:

\section{Wer kann dieses Wunder fassen, \\ DaB sich einer Stimme Klang \\ So gar oft muB teilen lassen... 28}

Was das Cehor leistet, findet der Autor, hier wieder mit der Vorlage ubereinstimmend, nicht weniger staunenswert. Zwel Dinge hebt er hervor: die Vielzahl 
der verschiedenen Stimmen und Töne, die das Gehor treffen und von ihm aufgenommen werden, und der 'Nachklang' des Gehorten. Von diesem sagt der Autor: ich kann es mir nachtrăglich vergegenwărtigen, 'so daß ich der Reihe nach jeden Teil zergliedere', ohne den Wohlklang zu vermindern:

IV,550ff. Что за множество гласов и толико разных

Поражает слух мой так, в звонах же не праздних?

Что за чудо! Гласы ль странны толь чрез свой закон,

Что, и как умолкнут, оставляют в слухе звон?

Так что рядом и тогда всяк член разделяо

И ни сладости в себе, ни их умаляр?

Im letzten Verspaar spricht besonders vernehmlich der engagierte Philologe. Die vorangehenden Verse stimmen mit der Démonstration uberein: "Mais comment se peut-il faire que tant de voix frappent ensemble mon oreille sans se confondre, et que ces sons me laissent, après qu'ils ne sont plus, des ressem. blances si vives et si distinctes de ce qu'ils ont été?" (S.44)

IV,556-565: Die 'weise Absicht' des Schopfers wird am Beispiel der Augen und Ohren aufgezeigt.

In diesem Abschnitt werden einige Betrachtungen nachgeholt, die inhaltlich zu den bereits behandelten Themen 'Augen' (386-443) und 'Ohren' (444-453) gehoren. Tred. hat sie aus der vorlage ubernommen.

Der gütige Schöpfer hat uns in weiser Absicht einen 'feuchten Vorhang' für die Augen gegeben, um sie damit zu schlieBen, wenn die Nacht kommt. Ex hat dafür gesorgt, daß unsere Ohren dann geoffnet bleiben, damit sie uns bei 'schrecklichen Gerăuschen' in der Nacht sofort wecken. Tred. hat die Betrachtung in die Form der ehrfürchtigen Frage gekleidet: 'ist es nicht die weise Absicht des gutigen Schopfers, der alles vermag und so voller Fürsorge ist', dab er...?

IV,556ff. Hе намерение ль мудрое в 6лагом творие, Смогшем всё, толико и попекшемся дельце́, Что нам завес даровал влажный он на очи, Тем бы нам их закрывать, найдет как тьма ночи?

А чтоб бшть отверстым нашим и тогда ушам,

Да разбудят вскоре в страшны шумы по ночам?

Die Fragen werben um die andăchtige zustimung des Lesers. Mit dem Wort 'Aелец' ('Gesetzeskenner', 'Sachkundiger', Pawl.347) verwendet 
Tred. einen ganz unkonventiellen Namen fur den Schopfer.

Fenelon hat diesen Text: "Avec quel soin l'ouvrier qui a fait nos corps a-t-il donné a nos yeux une enveloppe humide et coulante pour les fermerl et pourquoi a-t-il laissé nos oreilles ouvertes?" (Démonstr.,S.44) Von Fenelon erfahren wir, daB diese Betrachtung auf Cicero zurückgeht ('De Nat. Deor. lib.II, $\left.\mathrm{n}^{\circ} 36\right)$ : "C'est, dit Cicéron, que les yeux ont besoin de se fermer a la lumière pour le sommeil, et que les oreilles doivent demeurer ouvertes pendant que les yeux se ferment, pour nous avertir et pour nous éveiller par le bruit, quand nous courons risque d'atre surpris." (Démonstr.,S.44)

Des weiteren weisen unsere Autoren uns staunend darauf hin, daB wir mit unseren Augen auf einmal die ganze Welt ubersehen könnnen, und daß diese kleinen Organe vom Anblick der ungeheuren GroBen nicht beschădigt werden:

IV,562ff. В очи наши кто всаяил небо, море, земло,

Так что камду тварей сих видя вдруг объемло?

Как толь в малом уде момет уменаться оия

Величии огромнах малостам всем 6ез обия?

Die beiden Fragen sind bei Fénelon vorgegeben: "Qui est-ce qui grave dans mon oeil, en un instant, le ciel, la mer, la terre, situés dans une distance presque infinie? Comment peuvent se ranger et se démeller dans un si petit organe les images fideles de tous les objets de l'univers, depuis le soleil jusqu'a des atomes?" (Démonstr., S.44)

Das Motiv scheint verbreitet gewesen zu sein. Auch Brockes erwahnt es in seinom Gedicht 'Die himmlische Schrift':

"Und dennoch kơnnen wir so ungemess' ne Hohen

Mit unsern kleinen Augen sehen..." 29

IV,566-593: Das Gedảchtnis.

Fénelon definiert das Gedăchtnis als 'die Substanz des Gehirns, welche Vorstellungen von so vielen Dingen, die sich uns im Laufe des Lebens eingeprăgt haben, geordnet aufbewahrt'. Staunend ruft er aus: "n'est-elle pas le prodige le plus étonnant?" (Démonstr.,s.44)

In verkürzter Form fragt Tred., was für eine Kraft im Gehirn das sei, die alle Vorstellungen aufbewahrt:

IV,566f. Что за сила в мозге та, коя сохраняет

Bображенное a ceбе и не погубляет?

Im folgenden vergleicht ex das Gedăchtnis mit einem Buch. Wir bewundern die 
Bucher, führt Tred. aus, weil sie vergangenes Geschehen genau aufbewahren. Das Gedăchtnis ist aber den Büchern weit überlegen. Es ist unvergleichlich und nicht hoch genug einzuschătzen. Jeder findet in ihm das 'eingeprăgte Bild' vergangener Jahre, wie weit sie auch zurückliegen moggen. Der Autor will sagen, daB kein Buch imstande ist, den Inhalt des Gedăchtnisses zu fassen und im richtigen Augenblick bereitzustellen:

$$
\begin{aligned}
& \text { IV,568ff. По премногу книгам удивляемся затем, } \\
& \text { Что хранят исправно прошлы бытия совсем. } \\
& \text { Коль же мозг и память есть наша несравненна -! } \\
& \text { IV,572f. Всяк находит точно при потребности своей, } \\
& \text { Сколь ни есть лет проилих, впечатленный образ в ней. }
\end{aligned}
$$

Fénelon, auf den Tred. zurückgreift, hat diese gualităt speziell dem Gehirn des 'Gelehrten' zugeschrieben. Daher nennt er neben den 'Fakten' auch die 'Sammlung von Gedanken' als Inhalt des Gedăchtnisses: "On admire avec raison l'invention des livres, ou l'on conserve la mémoire de tant de faits et le recuell de tant de pensées; mais quelle comparaison peut-on faire entre le plus beau livre et le cerveau d'un home savant? ....'c'est dans ce petit réservoir qu'on trnuve a point nommé toutes les images dont on a besoin." (S.44f.)

Tred. stellt die Tătigkeit des Gedăchtnisses als eine Folge von Impulsen dar, die prompt befolgt werden. Was auch immer man herbeiruft, kcrmt schnell. Was immer man fortschickt, geht im Nu weg und verbirgt sich an einem unbekannten Ort, 'so als wollte es anderem nicht den Platz wegnehmen':

$$
\text { IV,574ff. Всяк что в той ни призовет, так то скоро прияет, }
$$

Как что ни ото́шлет он, өдруг всё и отндет:

В неизвестном месте кроется всё уходя,

Равно как, другого не могло 6 стеснить, радя.

Die Verse stimmen mit der Vorlage uberein: " (C'est dans ce petit réservoir qu'on trouve toutes les images dont on a besoin):on les appelle, elles viennent; on les renvoie, elles se renfoncent je ne sais ou, et disparaissent, pour laisser la place a d'autres." (Démonstr.,S.45)

Die Buchmetapher erweist sich als geeignet, noch andere Tátigkeiten des Gedăchtnisses zu illustrieren. Jeder kann nach Belieben 'das Buch der Vorstellungen' aufschlagen und schließen; er kann in inm blattern und es vom 'vorderen bis zum hinteren Buchdeckel' durchsehen:

IV,578f. Книгу вображений всяк вольно раскрывает И, когда захочет, ту скоро закрывает 
IV,580f. Иль прекияшвает в оной все листы скоря,

Oт доски заглаеной АО Аоски - мей задней зря.

So ist die Buchmetapher schon in der Demonstration ausgewertet worden. Anstolle der konkreten Bezeichnung 'vom Titelblatt bis zum Rückblatt' heiBt es dort: "... on passe soudainement d'un bout d l'autre." (S.45) AuBerdem hat Fenelon noch das Register eines Buches zur Veranschaulichung der Gedăchtnisfunktion herangezogen: "... on a méme des especes de tables dans la mémoire, pour indiquer les lieux ou se trouvent certalnes images reculées." (Démonstr.,s.45)

Tred. fügt ein, daB dieses Buch 'zum Lohn für fleibiges Suchen' jedem zuverlăssige Aufzeichnungen lăngst vergangener Ereignisse vorlegt:

IV,582f. Представляет та ему, за прилежны иски,

Нумиых самых проилых действ вернше записки.

Unsere Autoren haben ihre Betrachtung uber das Gedăchtnis so gegliedert: a) sein Wesen (566-573), b) seine Funktion (574-583), c) das Gedăchtnisorgan, das Gehirn (584-587).

Auch das Gehirn ist einem Buche vergleichbar, einem Speicher von Worten, 'die der Verstand 11est'. Anders als bel elnem Buche ninterlassen abor dit Worte weder 'Spuren noch Striche'. Die Materie, aus der dieses Buch besteht, ist 'fein und zart', zugleich aber 'dauerhaft und fest':

IV,584ff. Но слов склая есех оных, кои в памяти ум чтет,

Ни следов, ни че́рток в мозге нашем не кладет;

В книге оной вещество тонко есть и нежно,

Только ж долго пребшвать прочно и наяежно, -

Tred. hat den Text der Vorlage nur geringfügig verăndert. Dort wird noch die Autopsie des Gehirns erwahnt und dessen zusammensetzung naher beschrieben: "Ces caracteres innombrables, que l'esprit de l'homme lit intérieurement... ne laissent aucune trace distincte dans un cerveau qu'on ouvre. Cet admirable livre n'est qu'une substance molle, ou une espece de peloton composé de fils tendres et entrelacés." (S.45)

Der Abschnitt uber das Gedăchtnis schlieBt bei Fénelon mit einem verhaltenen Lobpreis jener 'Hand', die es verstanden hat, in einem so ungeformten Klumpen so kostbare und mit so schöner Kunst geordnete Bilder zu verbergen: "Quelle main a su cacher dans cette espece de boue, qui paraft si informe, des images si précieuses, et rangées avec un $s i$ bel art?" (Démonstr.,s.45)

Tred. hat diese Passage amplifiziert und seiner Bewunderung der Allmacht, Weisheit und Güte des Schöpfers doxologischen Ausdruck gegeben. Die Stelle 
besteht aus drei rhetorisch kunstvoll aneinandergereihten Ausrufungssátzen. Die beiden ersten rühmen die Macht und Weisheit jener 'Hand', die eine solche Ordnung und so 'zarte Teile' aus einem Material geschaffen hat, das ihnen nicht wesensgemăß ist, nămlich aus Exde:

\section{IV,588ff. Как не удивиться вседержавной силе той И руке премуарой, сотворившей чин такой Из земли несродны толь! нежные толь части Сотворившей, говори, из земли по власти!}

Die Verse sind durch die zeilenüberspringende Periode gekennzeichnet, der Trod. durch das eingeschobene 'roBopw' persönlichen Nacharuck gegeben hat. Der Akzent der Versreihe liegt auf dem doppelten Chiasmus der beiden Satzglieder 'сотворившей' (589 und 591) und 'из землм' (590 und 591). Die Verse enthalten Anklange an die biblische Schöpfungsgeschichte. In Gen.Kap.2,7 heiBt es:

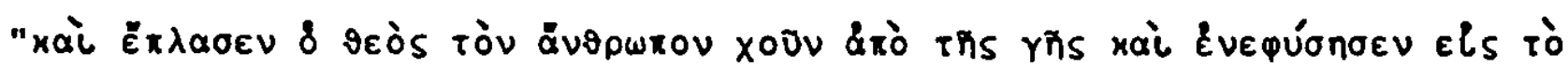

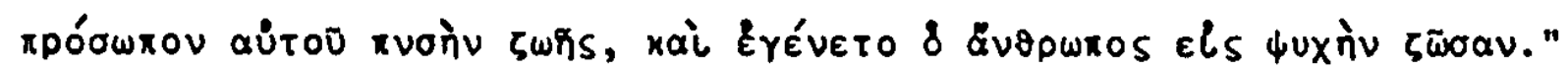

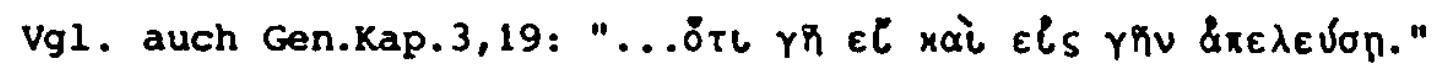

Der dritte Ausrufungssatz hat in aer vorlage keine Parallele. Er ruft dazu auf, die Güte des Schopfers anzuerkennen, die in seinem Werk zu sehen ist:

IV,592f. Как и не призна́ем 6лагости чрез зриму моць,

Если не объемлет грубшх нас страстей здесь нощь!

Nach Auffassung Tred.s kann sich der Mensch dem Eindruck der Macht, Weisheit und Güte des Schöpfers mit gutem Grund nicht entziehen. Sein angemessenes Verhalten gegenüber dem Schöpfer ist Bewunderung und 'Anerkennung' - Verweigert er diese, so handelt er aus bosem willen. Er ist von der 'Nacht der groben Leidenschaften unfangen'. Der Unglaube wird somit als moralischer Makel gekennzeichnet.

Mit der Betrachtung des Gehirns ist die Beschreibung des menschlichen Körpers 'im großen und ganzen' abgeschlossen. Zurückblickend bemerkt Fenelon: "Tel est le corps de l'homme en gros." (Démonstr.,5.45) Er verzichtet darauf, Einzelheiten der Anatomie in wissenschaftlicher Form 2 u erortern. Seine Absicht war, die Kunst aufzuzeigen, die in der Natur am Werke ist, und die der 'einfache Blick' ohne wissenschaftliche Schulung exkennen kann: "Je n'entre point dans le détail de l'anatomie; car mon dessein n'est que de découvrir l'art qui est dans la nature, par le simple coup d'oell, sans aucune science." (S.45) damit bekraftigt Fénelon im besonderen, was er am Anfang seines 'Traité' allgemein erklăt hat: "Je ne puis ouvrir les yeux sans admirer l'art 
qui eclate dans toute la nature: le moindre coup d'oell suffit pour apercevoir la main qui fait tout." (Démonstr.,S.1) Das entspricht der physikotheologischen Grundichre, nach der eich die Macht und weisheit des Schopfera für jedermann sichtbar in seinen Werken offenbart: "La sagesse et la puissance qu'il a marquees dans tout ce qu'il a fait le font voir, come dans un miroir, a ceux qui ne peuvent le contempler dans sa propre 1dee." (Demonstr.,S.2)

In IV,594-599 formuliert Tred. nochmals die physikotheologische Absicht der Epistel.

In Ubereinstimung mit der Démonstration erklăt er rückblickend, er habe sich bemüht, in aller Kürze, ohne auf anatomische Details einzugehen, den menschlichen Korper darzustellen, so dab jeder die Kunst des Schópfers daraus erkennen könne. Der menschliche korper stellt, bemerkt Tred., die Welt im kleinen dar:
IV,594ff. В анато́мическу глубь бшл я не намерен
Описанием өступать: тнался быть здесь верен
Кратким, да и вкратце, изъяснением всего,

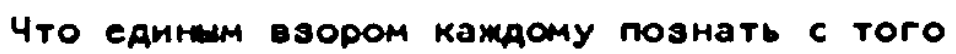
Всё искусство во творце, весь мир сотворившем
И B едином теле тот нашем сократившем.

IV,600-619: Die Wohlproportioniertheit des menschlichen Korpers.

Der menschliche Kơrper könnte durchaus gröBer oder kleiner sein, als er ist, erklart Tred. zu Anfang:

IV,600 पеловек по телу больше мог и меньше быть. So steht es auch in der Démonstration: "Le corps de l'home pourrait sans doute être beaucoup plus grand et beaucoup plus petit." (S.45) Bedenkt man Jedoch die Auswirkungen, so kann man nur staunen, wie weise der Schopfer das rechte MaB gewahlt hat. Waren wir kleiner, so konnten wir manchem Unheil nicht entrinnen: viele wilde Tiere würden uns ohne Furcht angreifen und zertreten:

\section{IV,601ff. Если 6 были меньше, бедстоий бы в нас не избшть: Многи зоернши скотн за́все нападали И, конечно 6, не боясь, нас они топтали.}

In der Démonstration wird als Beispiel die zwergenhafte Grobe von 'einem FuB' genannt: "S'il n'avait, par exemple, qu'un pied de hauteur, 11 serait insulté par la plupart des animaux, qui l'ecraseraient sous leurs pieds." (S.45)

Ausfürlich werden die Schwierigkeiten ausgemalt, die sich ergaben, wenn 
die Menschen Riesen wăren. Solche riesenhaft groBen Menschen waren 'VielfraBe' und warden, auch wenn ihre zahl klein ware, viel Nahrung verschlingen:

$$
\begin{aligned}
& \text { IV,604ff. Буде ж бس великим чрезешиайно всем 6шть нам, } \\
& \text { То } 6 \text { обжирин бшл человеки по устам; } \\
& \text { Много } 6 \text { пищи ми в иисле малом поглотили; - }
\end{aligned}
$$

Fenelon spricht mit einer tbertreibungsmetapher von Menschen, die so groB wie die 'höchsten Kirchtürme' sind: "S'il était haut comme les plus grands clochers, un petit nombre d'hommes consumeraient en peu de jours tous les aliments d'un pays." (Demonstr.,S.45)

Wenn wir Riesen wăren, so malen unsere Autoren weiter aus, fănden wir keine Pferde odere anderen Reittiere, die uns tragen, oder wie Fénelon ergănzt, in einem Wagen ziehen kơnnten:

IV,607f. Коней и Аругих скотов 6 не находили, Комм бы возможно на себе нас здесь носить; -

Vgl.: "...ils ne pourraient trouver ni chevaux, ni autres betes de charge qui pussent les porter ni les trainer dans aucune machine roulante..." (S.45)

Txed. gibt zu bedenken, daß oin Chaos die Folge sein müßte:

$$
\text { IV,609 Весь бы тем Порядок Аолжно было нам смесить; - }
$$

Wir fănden nicht genug Material, um in der stadt oder auf dem Lande für uns Hăuser bauen zu kơnnen:

IV,610f. Не могли найти венеств мы себе довальных

Как К строению градских, так домов напольных; -

Vgl.: "...ils ne pourraient trouver assez de matériaux pour batir des maisons proportionnées a leur grandeur..." (Demonstr.,s.45) Fénelon welst ferner darauf hin, daß nux eine geringe zahl solcher Menschen auf der Erde leben könnten, denen die meisten Annehmlichkeiten fehlen würden.

Das Gedankenexperiment abschliebend, erklăt Tred.: wir wăren uns und den anderen Lebewesen, die für uns geschaffen sind, zur Last:

$$
\begin{aligned}
& \text { IV,612f. В тягость мы } 6 \text { уи били в жизни и себе самим } \\
& \text { И мивотным равю, саеланнмм Аля нас, Аругим. }
\end{aligned}
$$

Vor diesem Hintergrund rüht Tred. die 'aberaus weise Erfindung', die in dex 'măBigen GröBe' des Menschen zum Ausdruck kommt:

IV,614f. Но умеренность сия человеча тела,

Bымысла премуара толь и премуара дела, -

Fenelon faBt seine Bewunderung in die eindringliche Frage nach dem Urheber, der dem Menschen das genaue MaB und allen anderen Lebewesen das rechte MaB 
im Verhåltnis zum Menschen festgesetzt hat: "Qui est-ce qui a régle la taille de l'homme a une mésure précise? qui est-ce qui a réglé celle de tous leg autres animaux avce proportion a celle de l'homme?" (Demonstr.,S.45)

Die wirdige und hoheitsvolle Erscheinung des Menschen komt in seiner aufrechten Haltung zur Geltung. Sie zeichnet inn vor allen Geschópfen aus, die dazu geschaffen sind, seinen Bedürfnissen zu dienen:

IV,616ff. Что един сановий в ееличавности наш вия,

Кой из всех жиеотних - емспренняя токмо зрит,

0тменяет нас от всех төарей тех созданших,

Ha потребности притом наши здесь нам данних.

Die anthropozentrische Formel 'на nотребности...наши' (619), wie auch 'mивотным..., сделанным аля нас" (613) ist eigener Zusatz Tred.s. Im ubrigen hat ex den Text der Vorlage wiedergegeben: "L'home est le seul de tous les animaux qui est droit sur ses pieds. Par la il a une noblesse et une majesté qui le distinguent, même au dehors, de tout ce qui vit sur la terre." (S.45f.)

IV,620-629: Der Mensch ist den Tieren überlegen.

Zwar hat der Mensch keine naturlichen Waffen wie die Tiere, stellt Tred. fest, aber wir haben die Geschicklichkeit, die wilden Tiere zu zahmen und sie uns $2 u$ unterwerfen:

IV,620ff. Нет у нас орудий, каковы суть у зверей, Но у нас Аосужество, Ведостаток мнимый сей, И дейстоительне толь, что мы усмиряем

Лотости во всех зверях, их и покоряем.

Den Hinweis, der Mensch sei im Verhăltnis zu seiner GröBe und zu seinem Gewicht stäkker als die Tiere, mit dem Fénelon den Abschnitt einleitet, hat Tred. ausgelassen. Vielleicht hat inn diese Behauptung nicht Uberzeugt: "... un home vigoureux a plus de force de corps que la plupart des bates farouches." (Demonstr.,S.46) Er hat also seine vorlage nicht unkritisch kopiert.

Nach Fénelon manifestiert sich die 'Geschicklichkeit' des Menschen in der Herstellung von waffen fur die Jagd sowie in der Kunst, die wilden Tiere zu zăhmen und zu dressieren: "Mais l'homme, qui n'a point dans ses membres de si fortes armes naturelles, a des mains dont la dextérité surpasse, pour se faire des armes, tout ce que la nature a donné aux bates. (S.46)

DaB der Mensch den Tieren durch seine Waffen Uberlegen ist, hat Tred. uner- 
wăhnt gelasser. Dagegen hat er die Kunst, Tiere zu băndigen und zu dressieren, anschaulich beschrieben. So zwingt der Mensch z.B. den Lowen, 'ihm freundlich zu sein'. Dieser kommt. 'ohne Gebrull, und ohne daB man ihn bitten muB, zu ihm': IV,624f. Человек заставляет ласковым $\alpha$ ce6е быть льва, Сей $к$ нему приходит без пронения и зва.

Mancher wilden Tiere bedient sich der Mensch zum zeitvertreib. Ex bandigt die wilde Veranlagung bei den Elefanten und reitet auf ihnen:

IV,626ff. Oн употребляет в них неких на забавм,

Укроная в слонах аичь и аики нравы;

И на сих он ездит, и на титрах бистрых тех,

Преодолевает, словом, человек их всех.

Tred. hat in diesen Versen die Vorlage frei verwendet. So hat er das 'Reiten auf schnellen Tigern' hinzugefügt, ein Glanzstück der Raubtierdressur, an dem die tberlegenheit des Menschen besonders deutlich wird. Mit Vers 629: 'der Mensch bezwingt sie alle', hat Tred. die Passage abgerundet.

Die Parallelstelle hat diesen Wortlaut: "...il salt même les apprivoiser dans leur captivité, et s'en jouer comme 11 lui plalts 11 se falt flatter par les lions et par les tigres; 11 monte sur les éléphants." (Démonstr.,S.46)

Damit schlieBt Fenelon die Ausfuhrungen zur Anatomie und Physiologie des Menschen, die, wie wir sahen, zum grobten Teil als Vorlage der IV.Epistel der Feoptija benutzt worden sind.

In den Versen IV,630-647 beschaftigt den Autor das Thema des Todes.

Die Betrachtingen über die KorpergröBe des Menschen zusamenfassend, bekennt Tred.: der 'allweise Schopfer' hat es gut mit dem Menschen gemeint, daB or uns nicht zu klein und nicht zu groB geschaffen hat:

IV,630f. Благ премуарый $к$ нам творец сотворив толиких, Как ни малwх телом нас, так и не великих.

Die gute Absicht des Schópfers mit dem Menschen wird selbst durch die Tatsache des Todes nicht widerlegt. Auch das Sterben des Menschen wird als sinnvolles, von der Güte des Schópfers vorherbestimntes Ereignis gedeutet, denn, so argumentiert Tred., eine unbegrenzte zahl von Menschen könnte auf der Erde keinen Platz finden.Wegen der Ubervolkerung lägen eie in unaufhorlichem streit miteinander:

IV,632ff. Благ, что умираем: неиссиетно нас иисло,

Хить определенно уместиться 6 не могло

На земном уж для иисла непространном шаре; 


$$
\text { IV,635 Были } 6 \text { непрестанно ми и } 8 \text { бессмертном сваре. }
$$

Der Gedanke, daß ohne den Tod die Erde an Ubervolkerung zugrunde gehen müBte, wird auch im zeitgenössischen deutschen Lehrgedicht vertreten, z.B. in den 'Philosophische(n) Gedanken uber die gottliche Weisheit bey dem sterben des Menschen' von Chr.Friedr. Zernitz (1748). "in dem Gedicht", so bemerkt Chr. Siegrist, "wird der Tod als sinnvoller, lāngst eingeplanter Prozeß qedeutet":

"So bleibet cottes Zweck, der in dem Sterben ruht,

Der oft beweinet wird, im großen Weltbau gut." 30

Die rationalen Erwăgungen genügen Tred. jedoch nicht. Ohne den Tod, so reflektiert er weiter, 'wurden wir noch eher der Bybris erliegen, wenn uns nicht ein besonderer Segen zurückhielte' :

IV,636f. Как знать? M山 6 и в гордость ближе были упадать, Разве 6 особлива удержала благодать.

An dieser Stelle ist der EinfluB von A.Popes 'Essay on Man' zu erkennen, in dem die Hybris als die Wurzel alles tbels hingestellt wird:

Ep.I,123ff. "In Pride, in reas'ning Pride, our error 1ies;

All quit their sphere, and rush into the skies.

Pride still is aiming at the blest abodes,

Men would be Angels, Angels would be Gods.

Aspiring to be Gods, if Angels fell,

Aspiring to be Angels, Men rebel;

And who but wishes to invert the laws

of order, sins against th'Eternal Cause."

Wăhrend Pope die Bybris (pride) daxin sieht, daß der Mensch mit dem ihm bestimmen Platz in der 'Kette des Seins' unzufrieden, hoher hinauswill, versteht Tred. 'ropaoctb' im Sinne der biblischen Erzăhlung vom Sündenfall. Der Kern dieser Exzahlung Gen.Kap. 3 ist darin zu sehen, daß der Mensch, durch die Pseudo-Verheikung: 'Ihr werdet sein wie Gott' (Gen.3,5) geblendet, dem Gebot des Schopfers zuwiderhandelt. Ex gibt die Gemeinschaft mit cott auf, um unabhăngig und autonom zu sein. Darin besteht die Hybris, die den Menschen zu Fall bringt und der. Tod nach sich zieht. Der zusamenhang von sundenfall und Todesschicksal wird in dem Fluchwort uber Adam ausgesprochen (Gen.3,19):

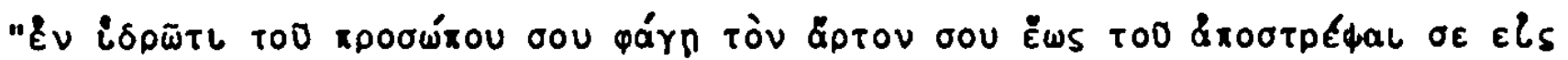

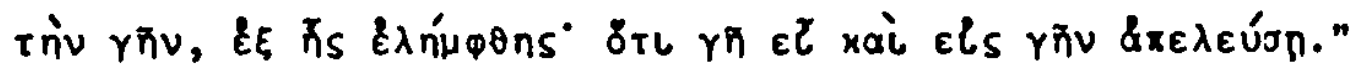

Zu beachten ist, daB der Tat Adams und Evas nichts von einem titanenhaften Aufbegehren anhaftet. Sie lassen sich einen scheinbar geworhnlichen Ungehorsam 
zuschulden kowmen. Das unterstreicht die Allgemeingultigkeit des dargestellten Phánomens. LaBt man alle mythologischen zuge der Geschichte beiseite, so wird in ihx der satz ausgefuhrt, "daß Menschsuin notwendig bedeutet sandersein." 31 Gerade auf dem Boden der positiv bowerteten Schopfungsgaben der Denk- und willensfreiheit des Menschen kommt es zur sünde. G.Quell formuliert: "Weil (dem Menschen) Vernunft und Fahigkeit eigenen urteils ober Welt und cott eingeboren 1st, 1st inm das Motiv zur sünde gegeben." 32 Infolge seiner schopfungsmaBigen 'Struktur' ist es "... dem Menschen moglich und lockend..., die inm zukowmende Haltung der Kreatur aufugeben, seinen Schopfer mit Kritik zu betrachten und selbst 'wie cott' ungehemet und nur sich selbst verantwortlich, 24 denken und zu handeln. " 33 Darum sind die vom Erzahler geschilderten ersten Menschen 'Typen der Menschheit uberhaupt'. Der Erzahler will zeigen, "daB auch die Art, wie beide an Gott handeln, mutatis mutandis keine andere ist als wie jeder Mensch in Denken und Tun gegen Gott schuldig wird. "34

In den Versen 638f. bekennt sich Tred. 2u dem "Schicksalszusammenhang... innerhalb der Menschheit in Sunde und Tod durch die Tat des Adam". 35 IV,638f. Ha падение moе в праотце взираю:

Винный и преступник ули так умирах.

Auf eine weitere Bibelstelle anspielend, bekraftigt Tred. seine Auffassung, daB unsere 'sterblichkeit' die strafe für die sünde sel:

IV,640 Beqan, что смертность наша есть греха оброк, -

Tred. meint den Satz des Apostels Paulus in Röm.Kap.6.23:

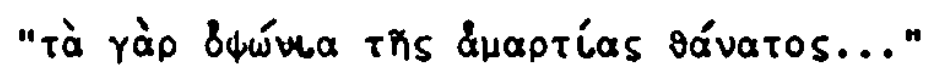

Die Vorstellung, die aus dem Wort des Apostels spricht, wird von w.Grundmann so umschrieben: "...die Herrin sunde zahlt an ihre soldlinge den Tod als sold aus. Damit ist die die Welt beherrschende Todesmacht auf die sunde zuruckgefunrt." 36

Tred. hat den zusammenhang von sünde und Tod mit dem durch die zinspflicht des russischen Bauern gepragten Begriff 'o6pok' bezeichnet, der aber auch allgemein mit 'Gehalt, Besoldung, Dienstlohn' (ksl.,Pawl.860) ubersetzt werden kann.

Der Autor fahrt fort, Gott vollstreckt sein gerechtes Urteil uber den sundigen Menschen, indem er inn sterben last und seinen Leib dem Tode 'zur gebührenden Stunde' zum Opfer übergibt:

IV,644 Се хотя по правде умирать нас осуаил, - 
IV,646f. Тем, как правшй судия, отяал смерти в жертву

Тело в должный час, сему 6 быть тогда уж мертву!

Gott als dex Richter, dex rod als strafe dex sünde - das sind in einem Lehrgedicht der Aufklårung ungewohnte Gedanken. Im Blick auf die deutsche Lehrdichtung der Zeit erklărt Chr.Siegrist: "...vom Lutherschen Gedanken vom Zusammenhang von Tod, sünde und Gericht hat sich im Bewritsein des 18.Jahrhunderts nicht viel erhalten." 37

Es ist deshalb bemerkenswert, daB Tred. an dieser Stelle Elememte der orthodoxen Kirchenlehre von der sünde vorbringt, die in der Theologie des Apostels Paulus (Rőm.Kap.5-7) ihren Ursprung haben, aber schon im Alten Testament (Gen.Kap.3) angelegt sind. Tred. entschărft diese Gedanken aber sogleich, indem ex sie den Barmonievorstellungen der Aufklărung unterordnet. Wohl stimmt er dem Satz zu: 'der Tod ist der süde Sold' (Rom.6,23), aber -fahrt er fortGott ist in Wahrheit nicht der Richter, sondern der 'Wohltăter'. Als solcher überlåbt er uns nicht dem 'Verhăngnis'. Er hat uns sogar durch unsere sterblichkeit eine 'Wohltat' erwiesen. Sterblich ist ja nur der Korper. Sein Tod 1st der unvermeldbare Durchgang zur ewigen Gluckseligkeit. So hat cott den 'Schaden' durch die Gnade in 'unseren Nutzen' verwandelt:

IV,641ff. Hо благотворитель не оставит нас и в рок;

Мертвенность он нашу здесь дал нам в благодейство

И преводит так по ней в вечное блаженство.

Се хотя по правде умирать нас осудил,

Но вред в нашу 2 пользу благостио обратил.

Trotz einiger Anklănge an den christlichen Sprachgebrauch sind diese Gedanken mit der neutestamentlichen Auffassung vom Hell, wie sie vor allem Paulus dargelegt hat, unvereinbar. Für Paulus gibt es kein Heilshandeln Gottes, losgelosst von Jesus Christus. Rettung von Sünde, Tod und Gericht wird dem Menschen allein durch die Exlosungstat Christi zuteil. Diese enge Verbindung von Soteriologie und Christologie wird z.B. in Róm.6,23 sichtbar. Tred. hat nur den ersten Teil dieser Stelle erwăhnt: 'смертность наша есть rрexa о6рок' (640). Bei Paulus heiBt sie: "Tà yàp stwívla tñs \&uaptías távatos, tò oe xáplona too

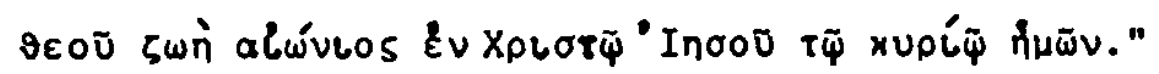

IV, 648-661: Finale.

Die Rastlosigkeit und Vergånglichkeit des menschlichen Lebens bilden das durch eindrucksvolle Vergleiche poetisierte Thema des letzten Abschnitts der Epistel. 
Zuerst wird das Leben mit einem Gebirgsbach verglichen. Ahnlich wie in Ep. II,346ff. schildert Tred., wie das herabstürzende Wasser tosend wieder emporschlagt, aber wegen seines Gewichtes umblegt und zurückfliebt. 'Sein ganzes Ungestüm strebt geradeaus - und plottzlich (făllt es) im Bogen (zurück)'. Das Wasser 'schlagt sich selbst', wie es seine Art 1st. Es hat in seiner schnellen Strómung keine Stunde Ruhe:

IV,648ff. Как вода с мест горних пу́шена в верьх с шумом биет, А прегнувшись весом, вопреки струо лиет;

Bсё стремительство ее прямо - варуг аугор;

И сама себя сечет срОАною водоо;

б̈строте покоя оной всей нет ни на час,-

Так жизнь наша буйна сильно подстрекает нас;

Das Bild des herabstūrzenden Wassers $1 \mathrm{aBt}$ sich in verschiedener Beziehung mit dem menschlichen Leben vergleichen. Tred. sieht die Analogie vor allem in der ungestümen Art, mit der uns das Leben antreibt.

Ein weiteres Bild kommt dem Autor in den Sinn: das Leben gleicht einem Fluge. Jeder meint voller Hoffnung, er fllege bis 'zur letzten Grenze'. Selbst 'auf der Rückreise', 'unaufhorlich in neuen Nichtigkeiten', meint er zu den höchsten sternen aufgestiegen $2 u$ sein:

IV,654ff. Всяк надежан полн, летя ж с ней $K$ послеяней грани, Сам в обратах, в суетах нових беспрестани, Мнит, что уи АО самих височайших звезА взлетел. Der Autor will deutlich machen, daB der Mensch in seinem fluchtigen Leben vielen Illusionen nachjagt, ohne es zu bemerken.

Die Metapher 'fliegen' zeigt im hebraischen Urtext des 90.Psalms (Vers 10) die Flüchtigkeit des menschlichen Lebens an. Luther übersetzt: "...es fahret schnell dahin, als flogen wir davon." Wortlich heiBt es: "...es geht eilends voruber, und wir fliegen." In der Septuaginta fehlt die Metapher.

Das năchste Bild stellt das plotzliche Ende des Lebens vor Augen. Die gottliche Vorsehung setzt dem Menschen die Schranke. 'In einem Augenblick zügelt sle auch alle seine Gedanken und schleudert inn von dem vermeintlichen Gipfel ins Tal des Todes':

$$
\begin{aligned}
& \text { IV,657ff. Се w его в едино преткновение предел, } \\
& \text { Купно все и мисли в нем вмиг обуздавает, } \\
& \text { С мнимия гори как в дол смерти низвергает. }
\end{aligned}
$$

Das Substantiv 'nредел' wird vom 'Cловарь' zur Feoptija (S.552) mit 'npeдо- 
пределение, предначертание, судьба' wiedergegeben. Die Verbform 'обуздавает' (658) erweckt die Vorstellung von einem Reiter, der sein pferd aus vollem Lauf plotzlich zum stehen bringt. So gebletet die 'Vorsehung' dem Menschen unvarmittelt Halt.

In den beiden letzten Versen der Epistel wird das Leben mit einer Quelle verglichen. Wie eine quelle 'verrinnt' unser kurzes Leben. 'Allmăhlich', aber sicher 'zieht es der Tod an sich':

IV,660f. Так, как сей источник, краткий век наш весь течет: Исподоволь, токмо ж верно смерть к себе влечет.

Der SchluB der IV.Epistel ist von Tred. deutlich poetisch gestaltet worden. Neben den schon genannten Bildern und Metaphern fallen die Personifikationen auf. 'Das Leben' treibt uns an, gibt uns die Sporen (nодстрекает нас, 653). 'Die Vorsehung' setzt uns ein Hindernis (nреткновениe, 657), zügelt uns (06yзAaвaet, 658), wirft uns ins Tal des Todes (в дол смерти низвергает, 659). Auch der Tod wird wie in der folkloristischen Dichtung personifiziert. Da 'cmeptb' weiblich ist, konnte das Verb 'влечь' den Nebensinn eines verlockenden Ziehens enthalten.

Poetisch wirksam ist auch der Gegensatz zwischen dem Bild des zur 'letzten Grenze' aufstrebenden Menschen und seinem Ende im 'Tal des Todes'. 'Aon' entspricht nach dem 'Cловарь' (S.545) dem gebrăchlichen 'АОлина' und 'низина'.

Uber der Darstellung des Menschenlebens liegt ein Schatten von 'vanitas'Stimmung, wie sie klassisch im Prediger Salomo zu Wort komt (Eccl.Kap.1,2):

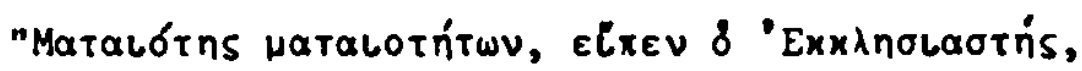

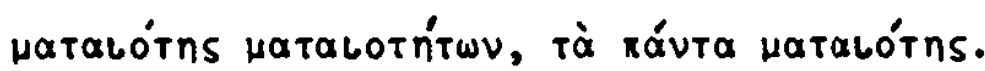

Die Passage macht deutlich, daB dem Autor, gemessen an den poetischen Regeln seiner zeit, differenzierte Ausdrucksmittel zu Gebote standen.

V.Epistel: Das Zusammenwirken von Geist und Korper offenbart Gottes Weisheit und Gute

v,1-10: Die Herrlichkeit cottes wird am deutlichsten im geistigen Wesen des Menschen.

Der schón, zweckmabig und kunstvoll gestaltete koxper des Menschen mit seinen vielfaltigen Funktionen laBt in allen Einzelheiten die Weisheit des Schopfers erkennen, hat Tred. in der vorangehenden Epistel verkündigt. Er bekraf- 
tigt dies zu Anfang der V.Epistel:

V,1 Создатель есть премудр по телу человечу.

Aber auber seinem korper hat der Mensch 'seele, Geist, Vernunft, Wille, Gefühl, Vorstellungskraft, Phantasie, Gedachtnis'. Es wird sich zeigen, was Tred. im einzelnen darunter versteht. Ex sieht den Menschen als 'geistiges Wesen', das mit dem korrper lebenslang vereinigt, in standiger Wechselwirkung mit inm lobt. In der V.Epistel soll der Mensch aus dieser Sicht betrachtet werden. zum Thema dieser Epistel bemerkt der Autor in der Prosaeinleitung: "... acя ncuxorornя преялагается екратие, но ясно." 1

Nach Meinung von G.Huttl-Worth hat Tred. das gemeineuropajische Fremdwort 'nchxолorия' in das Russische eingefuhrt. ${ }^{2}$

Verglichen mit dem Geist ist der körper ein 'Nichts und kann sich niemals mit inm messen', erklart Tred., rhetorisch ubertreibend:

$$
\begin{array}{ll}
\text { v,2f. Hо смысл и разум наш когда, как долг, примечу, } \\
\text { То тело пред умом покажется мичто, - } \\
\text { V,6 }
\end{array}
$$

Ist Gott schon als Schopfer 'der materie des Fleisches' grob, so muß er nach der Regel a minore ad maius als 'uberaus groB' gepriesen werden, weil er uns mit dem Verstand 'erleuchtet' hat:

$$
\begin{aligned}
& \text { v,7f. Велик есть бог, что так вещь плоти сотворил, } \\
& \text { Но бог превелий, нас что смыслом озарил, - }
\end{aligned}
$$

In der Démonstration beginnen die Ausfürungen zur Psychologie mit dem Satz: "Mais le corps de l'homme, qui paraft le chef-d'oeuvre de la nature, n'est point comparable d sa pensée." (s.46)

Tred. hat diese These zu einem feierlichen Eingang erweitert, an dem die theistischen Wendungen ins Auge fallen.

V,11-30: Geist und Korper sind ganz und gar voneinander verschieden.

Die 'Psychologie' der V.Epistel beruht auf dem ontologischen Dualismus von Körpern (res extensae) und geistigen Wesen (res cogitantes) in der Lehre Descartes' :

$$
\text { V,11f. Различен есть ум наш от тела сунестом: }
$$

Тот одарен преА сим различншх свойств рОАством.

Im folgenden bestimmt Tred. die Verschledenhelt von Korper und Geist durch eine Reihe von antithetischen Attributen, die sich aus den Aussagen Descartes' uber die beiden substanzen herleiten.

So wird zuerst der aktive Geist dem passiven, trăgen körper gegenuberge- 
stellt:

$$
\text { V.13f. Страдательно, с себе дейсто тело не имеет, }
$$

Дейстөителен ум наш и вещи разумеет.

Die Materie des menschlichen Körpers, von Tred. 'nлoтb' genannt, hat weder Empfindungen noch Gedanken. Der Geist dagegen ist durch Empfindung und Denken ausgezeichnet:

V,15f. Всех чувственностей плоть и мислей лишена, Но чуественностьо мшсль и умством взвышена.

Den einpaarig geformten Antithesen folgen mehrpaarige.

Die Korper sind von fester Substanz. Jeder xorper fullt einen bestimmten Teil des Raumes aus. Der Geist aber durchdringt die korperlichen Substanzen und bringt in ihnen vernünftige Handlungen hervor:

V,17ff. Тел всяких тверд есть роя чрез собственно убранство,

Оано не пустит всех в свое аругих пространство,

Но проницает аух все рядом сам тела

И производит них разумнше дела.

Ferner ist die Materie teilbar, nach Ansicht vieler sogar unendlich teilbax. Der Geist ist jedoch seinew Wesen nach 'einfach' und nicht aus Teilen zusammengesetzt. Darum hat er das BewuBtsein seiner selbst und kennt ebenso die Dinge der AuBenwelt, zu denen er sein Denken 'durch flinke Werkzeuge' (gemeint sind wohl die sinnesorgane) 'hinfuhrt':

v,21ff. Толь вещество притом в себе самом раздельно,

Что многии кладут делимим беспредельно,

Но ум прост естеством, В нем нет отнодь частей,

Чего аля много в нем внутрь о само́м вестей

Он знает как себя, так всяки вещи внешны,

Чрез способш свор мшсль изводя поспешны.

Im 'Cловарь' zur Feoptija (S.547) wird für 'извести' 'nривести' vorgeschlagen.

Tred. war anscheinend über die Theorien, die Teilbarkeit der Materie betreffend, gut unterrichtet. Nach Descartes sind die 'Korpuskeln' als Elemente der Korperwelt zwar physikalisch nicht weiter teilbar, "als mathematische Gebilde aber sind auch sie bis ins unendliche teilbar, a.h. es gibt keine Atome." 3

Tred. kommt zu dem Ergebnis, daB körper und Geist grundverschieden sind, so daß sich weder die geistigen Eigenschaften von denen der Korper, noch diese von jenen ableiten lassen:

V,27f. $\quad$, словом, умных свойств не можно произвесть

Из свойственностей тел, ни сии с теми свесть. 
Mit einem Wortspiel polemisiert der Autor gegen diejenigen, die dem 'Geist' das 'geistige Wesen' absprechen. Es sind 'wahrlich Leute, die im Licht das Licht nicht wahrnehmen':

$$
\begin{aligned}
& \text { V.29f. Во свете света те впрямь всё не созерцахт, } \\
& \text { Ауховность бшть в уме которы отрицают. }
\end{aligned}
$$

Die Wesensverschiedenheit von Körper und Geist wird im vorliegenden Abschnitt, der in der Démonstration keine Parallele hat, in Form einer 'antithetischon Differentialbestimmung' (Chr.Siegrist), die als besondere Definitionsform auch im deutschen Lehrgedicht vorkommt, aufgewiesen. 4

Zur Terminologie ist anzumerken, daß die Begriffe, die das geistige Wesen des Menschen bezeichnen, noch nicht eindeutig festliegen. So lassen sich z.B. 'ym' und 'AYX' semantisch kaum unterscheiden. Das Substantiv 'mucro' steht nicht nur in der Bedeutung von 'Gedanke' (өсех чуөственностей плоть и мыслей лишена, 15). Es bedeutet auch 'Denkvermogen' (но чувственностьо мысль и умством взвышена, 16). 'Умство' entspricht dem heutigen 'умствование', 'убранство' dem heutigen 'украшение'. 'Aуховность' verwendet Tred. im sinne von 'Geistigkeit'. Spater hat das wort die Bedeutung 'aer geistliche stand', 'die geistliche Behörde' bekommen (Pawl.342).

V, 31-50: Das Denken geht nicht aus der materiellen Substanz hervor.

In diesem Abschnitt, der grobtenteils mit der Vorlage übereinstimmt, widerspricht Tred. der Theorie des anthropologischen Materialismus, die in ihrer schroffsten Form, wie sie von dem Franzosen Lamettrie (1709-1751) vertreten wurde, die menschlichen Seelentatigkeiten als mechanische Funktionen des Gehirns erklărte. ${ }^{5} \mathrm{zu}$ denken ist auch an die Auffassung von Thomas Hobbes (1588-1679). Er sucht zu zeigen, "daß Sinnesempfindungen die einzigen Elemente des BewuBtseins abgeben und daB durch inre verknüpfung und unbjldung auch das Gedächtnis und das Denken zustande komen." 6

Dagegen behauptet Tred., daß die Materie keinesfalls denken könne. Das gilt unbestreitbar hinsichtlich der toten Materie:

$$
\text { v.31f. Не видим мыслей здесь в несчетности мы тел: }
$$

Tred. zieht daraus den sentenzartigen SchluB:

$$
\begin{aligned}
& \text { v,33f. Мы закльчаем так доводно и не ложно, } \\
& \text { Что мшслить веществу отнодь есть невозможно. }
\end{aligned}
$$

Weniger pointiert stellt Fénelon fest: "Il est certain qu'il y a des corps qui ne pensent pas; on n'attribue aucune connaissance a la pierre, au bois, aux métaux, qui sont néanmoins des corps." (Démonstr., S.46) 
Auch in der organischen Materie, z.B. bei den Tieren, lassen sich die seelischen oder geistigen Tatigkeiten, die jeder unvoreingenommene Betrachter feststellt, nicht als mechanische Prozesse im Organismus erklăren. Unsere Autoren ziehen die Meinung, das Tier sei eine 'bloße Maschine', Ins Lăcherliche:

$$
\text { v,35f. Неразвращемный кто услишит, что всяк скот }
$$

Махима просто есть, варуг засмеется тот; -

Bereits in III,429-434 hat Tred. die 'Maschinen-Theorie' zurückgewiesen und in III,921f. Descartes' Leugnung der Tierseele emphatisch verurteilt. Die Verse V,35f. stammen aus der Vorlage: "Il est meme si naturel de croire que la matiere ne peut penser, que tous les homes sans prévention ne peuvent s'empecher de rire quand on leur soutient que les betes re sont que de pures machines; parce qu'ils ne sauraient concevoir que de pures machines puissent avoir les connaissances qu'ils prétendent apercevoir dans les betes." (S.46)

Den Kausalsatz 'parce qu'ils ne sauraient concevoir...' hat Tred. In seinem Hang zur Rhetorik zu einer ironischen Frage ungeformt. Ist es nicht widersinnig anzunehmen, fragt er, eine 'einfache Maschine' könne sich vernünftig verhalten, ohne Vernunft zu haben?

$$
\begin{aligned}
& \text { V,37ff. Увериться о том не можно всеконечно, } \\
& \text { И произнесшу то не вмговорить пречно, } \\
& \text { Что как махина та простая, по его, } \\
& \text { Имеет разум весь без разума всего? }
\end{aligned}
$$

Mit dem Wortspiel in Vers 40 unterstreicht Tred. die Unhaltbarkeit der Mechanismus-Teorie in bezug auf die Tiere.

'Die Materie kann nicht denken' (33) - mit diesem Motto zielt Tred. vor allem auf die Position der anthropologischen Materialisten, die die Psychologie vollstăndig durch Nervenphysiologie ersetzen wollten. So hatte bereits der Arzt Pancratius Wolff in seinen 'Cogitationes medico-legales' (1697) gelehrt, "daß die Gedanken mechanische Tatigkeiten des menschlichen Leibes, insbesondere des Gehirns seien." 7 Gegen solche Behauptungen berufen sich unsere Autoren auf die Autorităt bestimmter Philosophen der Antike, die, obwohl Anhănger der materialistischen Weltanschauung, die geistigen Phănomene auf elne Materie eigener Art zurückführten, die sie als 'fünftes Element' bezeichneten. Dieses 'Element' sei gottlichen und himmlischen Ursprungs, denn von den irdischen Elementen kơnne keines die Gedanken hervorbringen und sich selbst kennen. Die Anschauungen dieser 'Weisen des Altertums' werden von Tred. so dargelegt : 
V,41ff. Встарь неки мудрецш, бесплотности не зная,

И все по веществу, что есть, предрассуждая,

Именовали ум стихех маш ум,

Но пятор стихий аля оного всех Аум,

Незримим не́чем, иль божественным, небесным, -

V,47ff. Отноды те не могли в себе так утвераить,

Чтоб коя из земншх стихий произвояить

Все мшсли возмогла и знать себя внутрь верно,-

То прекословно бить казалось им безмерно.

Tred. stutzt sich auf die vorlage, in der es heiBt: "De la vient que les anciens mêmes, qui ne connaissaient rien de réel qui ne fat un corps, voulaient néanmoins que l'âme de l'homme fot d'un cinquiéme élément, ou une espèce de quintessence sans nom,...toute céleste et toute divine, parce qu'ils ne pouvaient concevoir que la matiere terrestre des quatre ellements pot penser et se connaftre elle-même." (Démonstr., s.46f.) Fénelon zitiert hierzu Cicero, Tuscul. Quaest.,1ib.1, $\mathrm{n}^{\circ}$ 10: "Axistoteles quintam quamdam naturam censet esse, e qua sit mens..." (zit. Demonstr.,5.47,Anm.)

An diesem Punkte trennt sich Tred. vorubergehend von seiner Vorlage. Der Abschnitt V,51-272 enthalt eine Kette von Definitionen der wichtigsten psychologischen Begriffe. AuBerdem wird das Thema der Vereinigung und der Wechselbeziehung von Leib und seele behandelt.

Definitionen abstrakter Begriffe, wie sie in der v. und vi. Epistel der Feoptija hăufig vorkommen, sollen zur Veranschaulichung beitragen. Diesem zweck kann schon die 'enumeratio partium' dienlich sein, aus der sich die 'definitio realis" ergibt, die "eine Sache in inrem sosein benennt." 8

In Analogie zu dieser Definitionsform wird in v,51-60 der menschliche Verstand durch die Aufzahlung seiner Tatigkeiten bestimnt.

Der Verstand hat die Făhigkeit, alle Dinge zu 'begreifen', ihre Eigenschaften 'zusammenzusetzen' und zu 'zerlegen' sowie ihre Ursachen zu 'erforschen': V.51ff. Смысл что сверьх вещества наш может всё понять И качества вещей слагать и разделять, Понятнх качеств тех, чрез многии начины, Разыскивает он со6010 все причины; -

Hinzu kommt die auf Quantitaten gerichtete messende und vergleichende Tatigkeit des Verstandes: 
V,55f. Количеств есех размер и сходстөа их взае́м

Oн познавает впрямь все в умстве том своем; -

Die Verse 51-54 scheinen sich auf das phllosophische, die verse 55f. auf das mathematische Denken zu beziehen.

Der Verstand hat ferner die Fahigkeit zur Abstraktion:

$$
\begin{aligned}
& \text { V.57f. OH мислм от еяинств и еидов отвлекает } \\
& h \text {, отөлекая так, повсемство постигает; - }
\end{aligned}
$$

Das Abstraktum 'noscemctвo' 1st vom ksl. Adjektiv "pov'semstv'n-" abgeleitet, das Miklosich (586) mit lat. 'catholicus' wiedergegeben hat.

AuBerdem hebt Tred. die Freiheit des menschlichen Verstandes, sein Denken auf jedes inn verlockende $z$ lel zu richten, hervor:

$$
\text { v,595. OH, словом, правит мысль, с избранием к кониу, }
$$

Себе кой предломил изряастеа по личу.

In v,61-66 wird der menschliche Verstand durch eine 'definitio a contrario' umschrieben.

Im Unterschied zum Menschen ist das Tier unfahig, abstrakt zu denken. Darauf hat Tred. schon in III,431f. hingewiesen. Das Tier kent nur das $\because 1 n z \in 1-$ ne: die einzelne Handlung, das einzelne Begehren:

$$
\begin{aligned}
& \text { 0,61ff. От скотского ума наш точно сим различен: } \\
& \text { Внутрь токмо есть себя познанмем тот сличен } \\
& \text { И знать еще притом имеет только власть, } \\
& \text { Какое действо в мем иль есть какая страсть. }
\end{aligned}
$$

Der Verstand des Menschen wird durch seine große Uberlegenheit gegenüber dem des Tieres gekennzeichnet:

$$
\text { v,65f. Hо наш пред скотским смисл есть нечто превелико }
$$

И расстояний нет, что 6 бшло чем толико; -

V,67-70: Der Verstand des Menschen im Vergleich zu dem der Tiere und zu der vollkommenen Intelligenz Gottes (definitio a comparatione).

Mit einer gewissen Einschrankung definiert Tred. den menschlichen Verstand als ein Mittelding, das ebenso weit von den Tieren wie von der gottlichen Intelligenz entfernt ist:

$$
\begin{aligned}
& \text { V,67ff. Почти могу сказать, что столько человек } \\
& \text { От скотского своим өнутрь разумом далек, } \\
& \text { Коль расстоит а себе от нашего ум бомий } \\
& \text { И сколько маш с умом всех совершенсте не схомий. }
\end{aligned}
$$

Eine Mittelstellung hat auch A.Pope dem Menschen im 'Essay' zugewiesen: 
Ep.II,3f. "Plac'd on this isthmus of a middle state,

A being darkly wise, and rudely great."

Ep.II,7f. "He hangs betwocn; in doubt to act, or rest,

In doubt to deem himself a God, or Beast."

Der menschliche Geist enthalt zwei Komponenten: Vernunft und willen; abex beide bilden eine Einheit:

V,71ff. Ум смшсленншй с себе сугубое сие

Содержит, но одно то суие обое;

Bо-первых разум в нем, а что второе - воля:

V,77-92: Wesensbestimmung der Vernunft (definitio essentialis).

Zunăchst wird die Vernunft als die Fahigkeit $z u$ 'verstehen' und $z u$ 'urteilen' definiert. Die Tautologie in dieser Bestimmung wird im Russischen deutlich:

IV,77f. Tо разумом зовем, что внутрь нас разумеет

И о вещах собой что рассуждать умеет.

Zum Wesen der Vernunft gehort, daß sie durch 'reines Denken', d.h. a priori, Allgemeinbegriffe wie 'Geist', 'Gesetz', 'Universum' bilden und 'gut und bose' beurteilen kann:

IV,79f. Чрез чисту разум мисль поемлет, что есть аух, Закон, добро иль зло, и что вобще весь круг; -

In diesem Verspaar ist wohl die Unterscheidung von theoretischer und praktischer Vernunft angedeutet.

'Поемлет" (79) kommt vom ksl. "poemati=poimati", das Mikl. (607) mit lat.

'sumere', griech. 'Lambanein' wiedergegeben hat.

Des weiteren wird die Vernunft dadurch bestimmt, daB sie die Prinzipien der Logik, Mathematik und Metaphysik 'durch reines Denken' exkennt. In diesem Zusammenhang führt Tred. z.B. den Satz des Widerspruchs an:

V,81f. $\mathrm{OH}_{\text {ev }} \approx$ знает опрямь, что невозможно пречным

5WTb Bkyne no ce6e.

ăhnlich: $\quad \mathrm{v}, 85$

Так невозможно бить и варуг не бшть конечно,

Erwăhnt wird auch das mathematische Axiom, daB das Ganze großer ist als ein Teil des Ganzen:

V,84 Tак больше своея бшть части долг всему; -

Die Vernunft hat auch die metaphysische Idee der 'ewigen Wahrheiten':

$$
\text { V.82E. - a присвояет вечным }
$$

То истинам, инак не можно быть чему; -

Als Urteilskraft vergleicht die Vernunft die Gedanken miteinander, verknüpft 
Ahnliches und sondert aus, was nicht zueinander pabt:

v,87ff. Сличает мисли в нас рассудок меж собой, Зря сходства есть иль нет меж ними иин какой;

По сходству мшслей тех он их совокупляет,

Но вопреки от той аругу⿰ отделяет.

So ist die Vernunft eine richterliche Instanz fur die Gedanken:

v,91f. Сие есть, утверждать иль отрицать суяя,

K согласиь одним, впреки аругим ведя.

Die Definition der Vernunft kann sicher nicht als sonderlich poetisch gelten. Eine gewisse Veranschaulichung wird aber durch die Personifikation des abstrakten Begriffs und durch die Aufzahlung der verschiedenen Tatigkeiten der Vernunft erreicht. Die bildhafte Bedeutung verschiedener verben trăgt zur Konkretisierung bei: 'совокуплять', 'отяелять', 'суаить'.

V,93-112: Wesensbestimmung des Willens.

Als bewegende kraft ăuBert sich der Wille, wenn wir uns gern und ungezwungen den Dingen zuwenden, die unsere vernunft als gut erkennt und jene meiden, die sie für bơse befindet:

$$
\begin{aligned}
& \text { V.93ff. В чем воля: ум когда собой доброугодно } \\
& \text { К тем двимется вещам и явимется свободно, } \\
& \text { Которы разум наш бшть судит все добром, } \\
& \text { А отбегает он от тех, что судит злом. }
\end{aligned}
$$

Daxaus folgt die definitio essentialis:

$$
\text { V,97 Есть воля, чтоб хотеть и чтоб ей отвращаться: - }
$$

Der Wille ist 'frei', insofern er sich für oder gegen etwas entscheiden kann. Als 'vernünftiger wille' entscheidet er sich aber grundsatzlich fur das Gute und will mit dem Bösen nichts gemein haben:

$$
\text { V,98 Та хочет, что А०бро, не хочет с злом собщаться. }
$$

Der Mensch erkennt jedoch nicht 'mit einem Blick', was ihm nutzlich oder schadich ist. Darum will er oft das Falsche:

V,99ff. Противных сих в ней действ грунт состоит весь в том, Что всяко существо во взоре не простом,

Не в возносимом свне к природе человека,

Полезна есть ему иль вредно то от века; -

Der 'gesunde Wille' in uns kann nicht anders, als das $z$ u wollen, was uns nützt und 'wegzuschicken', was uns schadet: 
V,103f. Тем воля здрава в нас не может не желать

Полезного өсего, өреда ж не отсшлать.

Der wille trachtet nach dem, was entweder far uns selber oder fur einen anderen gut ist. Un aber diesen Zweck zu erreichen, wuB man sich bemühen, die Mittel auszuwahlen:

V.105f. Хелаем мы добра то аля него само́го -

Сие ж и есть конец, - ТО Аля Аобра Аруго́́⿱一; -

V,109f. Hо получить конеи, то сим уж наслаждаться,

На тот посреясто искать, в избрании труждаться; -

Wenn bel der Wahl der Mittel etliche wegen gewisser Kennzelchen ausgeschieden werden, so nennen wir diesen inneren Vorgang 'отмет', 'Ablehnung':

V,111f. Отставятся 2 когда аля некоих примет,

Отставка та уме зовется в нас отмет.

'0тмет' ist von "otmetati" abgeleitet, das im 'Concise Dictionary of old Russian' (Mch.1970) von H.G.Lunt mit 'oтвepratb, отклонять' wiedergegeben wird (S.45).

Im folgenden stellt Tred. zwel weitere Begriffe seiner 'Psychologie' vor:

' навuk' und 'Cвободность'.

V,114-140: Die Freiheit.

Sie wird umschrieben als 'Tauglichkelt' zur Beurteilung der Erscheinungen ohne ăuBeren und inneren Zwang:

$$
\mathrm{V}, 113 \mathrm{ff} \text {. }
$$

-навык и свободность.

Послеяня - действ и та ж суждения угодность,

без принуждений всех извнутрь и то жизвне,

Но точно вольно так, как өижу либо мне.

Tred. unterscheidet zwei Arten von 'Freiheit'. Die elne rennt er 'неразнственна'. In den 'Primečanija' zur Feoptija (S.519) wird dafür 'безразличная', 'gleichgultig' vorgeschlagen. Die 'gleichgultige Freiheit treibt ebenso nach dieser wie nach jener Seite':

$$
\text { V,117f. Неразнственна одна свобода в нас зовется, }
$$

Котора к сей и К той равно стране несется.

Sie hat ihre Wurzel in 'dunklen', d.h. verworrenen Vorstellungen:

$$
\begin{aligned}
& \text { V.119ff. Сия свобода в нас тогда бывает так, } \\
& \text { Когда есть не разгнан познания весь мрак: } \\
& \text { Из темншх мнений мы пюбое выбираем - }
\end{aligned}
$$


Nach Moinung Tred.s steht diese Freiheit auf der 'niedrigsten Stufe', weil wir sie 'zum Guten wie zum Bösen führen können', Je nachdem, ob wir der Vernunft gehorchen oder 'ungestum hinter Trăumen hersegeln' :

$$
\begin{aligned}
& \text { V,125ff. Нижайша есть степень в том нашея свободы: } \\
& \text { Мы можем ту в добро и в зло повесть с природм, } \\
& \text { Кога послушны мы иль разуму живем, } \\
& \text { Иль за мечтами вслед стремительно плывем. }
\end{aligned}
$$

Teile dieses Gedankengangs finden sich in anderem Zusamenhang auch in der Demonstration: "Je sens que j'ai un voulolr, pour ainsi dire, deux tranchants, qui peut se tourner a son cholx vers le oul et vers le non, vers un objet ou vers un autre." (S.73f.) Fénelon spricht ebenfalls von elnem niederen und einem hoheren Grad des freien willens: "...nous avons va qu'elle est un bien inférieur au bon vouloir, parce qu'il est mellleur de bien vouloir que d'avoir simplement une volonté susceptible du bien et du mal." (s.71)

Die 'andere Freiheit', die Tred. nun ins Auge faBt, schwankt nicht hin und her. Sie wahlt auch nicht auf Grund von 'dunklen Vorstellungen etwas Beliebiges' $(v, 121)$. Vielmehr: wenn eine sache klar erkannt und die Unklarheit bosoitigt ist, entscheiden wir uns fur sie. Die deutlichen Vorstellungen bewegen dann den willen zur Wahrheit und zum Guten. Die vollkommene Freiheit besteht also darin, daB unser Wille das Wahre und Gute erwahlt:

$$
\begin{aligned}
& \text { И,129 Сругая вольность в нас нарока произвольна, } \\
& \text { V,133ff. Сея свободш вся степень есть совершенна; } \\
& \text { Познанная уш вещь в ней темноты лишенна, } \\
& \text { Ту избираем мы как правду и Аобро: } \\
& \text { В том вольности сея и грунт весь и ядро. }
\end{aligned}
$$

Die Definition der Freiheit in den Versen 117-136 geschieht in Form einer 'antithetischen Differentialbestimmung' (Siegrist). Die Aussagen uber die beiden verschiedenen Arten von Freiheit verdeutlichen sich wechselseitig.

Die abstrakten Gedanken werden durch eine Folge von metaphorischen Wendungen illustriert:

$$
\begin{array}{ll}
v, 118 & \text { '...к сей и к той равмо стране несется' } \\
v, 120 & \text { 'когда есть не разгнан познания весь мрак' } \\
v, 121 & \text { 'из темных мнений мы побое вшбираем' } \\
v, 125 & \text { 'нимайша...степень... нашея свободы' } \\
v, 128 & \text { '..за мечтами вслея стремительно плывем' } \\
\text { v,136 } & \text { '...вольности сея и грунт весь и ядро' }
\end{array}
$$


Nach inrem Inhalt bexuht die Versreihe auf der Freiheitslehre Descartes', in der Elemente des thomistischen Determinismus und des scotistischen Indeterminismus verschmolzen sind. Descartes lehrt, "daB nur ale klaren und deutlichen Vorstellungen eine so zwingende... Macht auf den Geist ausuben, daB er sich ihrer Anerkennung nicht entziehen kann, wăhrend er unklaren und verworrenen Vorstellungen gegenüber die schrankenlose und grundlose Betătigung des liberum arbitrium indifferentiae behalt." ${ }^{9}$ offensichtlich hat Tred. den Begriff 'неразнственна свобода' (117) der von Descartes aufgenommenen scholastischen Formel 'liberum arbitrium indifferentiae' nachgebildet.

In V,137-140 führt Tred. aus, daB nicht nur dem willen, sondern auch dem Geist Freiheit zuzuschreiben 1st. Deshalb werden ihm auch seine Irrtumer 'angerechnet'. Die Vorausetzung aller 'Anxechnungen' ist die Freiheit:

V,137ff. Свободу не одной приписшвать долг воле, быть также и уму есть должно в произволе;

Так заблуждений ложь вменяется ему;

Причтений всяких грунт есть вольность по всему. Als Aquivalent für ksl. "prič'tenie" gibt Mikl. lat. 'computatio' an (688). Fénelon hat den Zusammenhang von Freiheit und Verantwortlichkeit des Menschen an anderer Stelle der Demonstration mit Nachdruck cargelegt: "C'est... cet empire sur mes propres actes, qui fait que je suis inexcusabje quand je veux mal, et que je suis louable quand je veux bien...c'est la le fondement de toute police, de toute instruction, et de toute régle des moeurs." (S.75)

Die Verantwortung des Menschen auf Grund seiner Freiheit bezieht sich aber nicht allein auf die Taten. Weil der menschliche Geist frei ist, folgert Tred, werden inm auch seine Irrtümer angerechnet. Diese Auffassung erinnert deutlich an die Ethik Descartes', deren Grundgedanken von Windelband-Heimsoeth so skizziert werden: "Aus der klaren und deutlichen Erkenntnis der Vernunft folgt notwendig das rechte Wollen und Handeln; aus den dunklen und verworrenen Trieben der Sinnlichkeit ergibt sich praktisch die sünde wie theoretisch der Irrtum durch MiBbrauch der Freiheit... Der Irrtum erscheint danach als Akt der willensfreiheit in Parallele zur sande und damit als Schuld: er ist die Schuld der Selbsttăuschung. "10 Diesen Gedanken hat namentlich Malebranche (EntrIIIf.) ausgefürt, setzen Windelband-Heimsoeth hinzu.

V,141-148: Definition von 'Habuk'

'Навык', in Vers 113 neben 'свободность' als 'Beigabe' des menschlichen Geistes genannt (npибавок в yme), ist vom kls. Verb "navyknovati" abgeleitet, das 
Mikl. (399) mit 'discere' übersetzt. Demnach handelt es sich bei dem Substantiv un eine durch Lernen erworbene 'Fertigkeit' des menschlichen Geistes.

Tred. bestimmt 'навык' als eine 'Kraft', ale durch 'sehr haufige Uberlegung und Willensimpulse' zustande kommt (definitio causalis):

$$
\begin{aligned}
& \text { V,141ff. Та сила навык есть, что ча́стейшим рассуаком } \\
& \text { И частейшим притом хотения побудком } \\
& \text { Мы получаем так, - }
\end{aligned}
$$

Alle 'навыки' tragen dazu bel, fahrt Tred. fort, Vernunft und willen $2 u$ vervollkommnen (definitio finalis):

V, 145f. Bсе навыки K тому co6ox cпосnеwaxt,

Что разум весь они и воло совершают.

Als die wichtigsten 'Fertigkeiten' werden 'муарость', 'Аобрый смысл' und 'А०брота' erörtert.

In den Versen 149-153 wendet der Autor drei Definitionsarten an, um 'myapoctb' zu bestimen.

Mit einer definitio essentialis wird festgestellt, daB die 'myapoctb' erkennt, 'was wahr und falsch und moglich' sowle 'was gut und böse' ist. Sle hat also theoretische und praktisch-ethische Einsicht:

v,149f. Познавши муярость то, что правеяно и ложно,

1 Что есть добро и зло и что в себе возмомно,

Die definitio finalis sagt aus, daB die 'myapocto' den Geiste dazu dient, 'passonder zu urteilen und sich ziele zu setzen':

v,151f. Способней может уж судить и предложить Делам своим конец, а тем уму слумить; -

Schlieblich wird 'MyApoctь' ex negativo definiert, indem sie in Gegensatz zu ' besten mit 'Weisheit' $2 u$ ubersetzen:

V,153 Мы буйством то зовем, что муарости противно.

In V,154-158 wird 'Аобрый смысл' definiert.

Von ihm heibt es zunăchst, er sei aus vielen Erfahrungen hervorgegangen (definitio causalis):

V,154 По многим АОбрый смысл шеА опнтам предивно, -

Darum kann ex um so schneller die Mittel, die zum ziele fuhren, finden, auswăhlen, vorschlagen und Unvernünftiges verhindern (definitio finalis):

$$
\begin{aligned}
& \text { V,155 Скоряе средства так, ведуиие K кониу, - } \\
& \text { V,157 Сам может находить, - }
\end{aligned}
$$




$$
\text { v, 157f. }
$$

- nх избирать в неглумность

И прилагать К тому, но претит неразумность.

'Herлумность' ist vom ksl. Adjektiv "negloum'n-" abgeleitet, das von Mikl.belegt und mit 'nugis abstinens' übersetzt wird (424).

Aus den Definitionen ergibt sich für 'АОбрый смисл' als wohl zutreffendste Ubersetzung 'gesunder Menschenverstand'.

Sowohl die 'мудрость' als auch der 'АОбршй смшсл' erscheinen in der Versreihe personifiziert als Diener, die dem 'ym' untergeordnet sind und für ihn ganz bestimte Funktionen ausüben.

V,159-162: Definition der Tugend ('Аобродетель').

'Добродетель', synonym für 'доброта' (148), wird mit Hilfe der definitio a simili, a contrario bestimmt. Positiv bezeichnet Tred. sie als 'vernünftige Liebe zu dem, was man tun muB':

V,159f. То Аобродетель есть, кто по лобви когда, НО умной, Полнит всё, что АОлжно есть всегда; -

Die negative Definition folgt aus dem Gegensatz der Tugend zum Laster:

v, 161f. Противное что ей, зовется то пороком,

Но большим как добро не гюбится нароком.

V,163-166: Die körperlichen 'Fertigkeiten'.

Darunter versteht Tred. die Bewegung der Glieder, die auf den Impuls des Geistes von den 'Lebensgeistern' bewirkt werden:

0,163ff. От навыков ума телесны различать
Конечно должно есть: скоряе сим качать
От разума дано телеснши все членш,
Что чаще аухи К ним бшварт устремленнш.

Der Gedanke verrăt den EinfluB der Lehre Descartes' von den 'spiritus animales'. Mit dieser zum Dualismus von Geist und korper nicht recht passenden Vorstellung hat Descartes 24 erkläen versucht, wie der Geist gleichwohl die willkürlichen Bewegungen im Korper verursacht. Die Annahme der 'Vital- und Animalgeister' gehört nach Meinung von R.Specht 2 u jenen Modellen in der cartesischen Anthropologie, die "Spuren der Schulwissenschaft tragen". 11 Tred. hat die Funktion der 'Аухи жизненны' bereits in Ep.IV,49-60 beschrieben.

V,167-170: Die 'Fertigkeiten' der Vernunft.

Sie treten nach außen als Wissenschaft in Erscheinung: 
V,167f. Разумный навык как бывает зрим отвне,

Hаукох тогда зовется он во мне, -

Sofern unser wille auf das Gute gerichtet ist, haben die 'Fertigkeiten' der Vernunft den Namen 'Sittlichkeit' :

$$
\text { V,169f. Hо навыки так зрим, когда воли правы, }
$$

То называем те уме ми до́бры нравы.

Das ksl. Adjektiv "prav-" wird von Mikl. mit lat. 'rectus', gr. 'euthys, orthos' ubersetzt.

V,171-202: Die Vereinigung von Geist und Korper und das 'commercium mentis et corporis'.

Tred. leitet den Abschnitt mit einem physikotheologischen Lehrsatz ein: 'der allweise, allgutige und allmăchtige schöpfex' hat unseren Geist barmherzig mit dem Körper verbunden. Beide Wesen hat er so fest 'vereinigt', daB sie im 'Tun und Leiden' wechselseitig aufeinander wirken:

V,171ff. Премудрый, всеблагий, всемоцный он творец,

Создавший умну тварь блаженства наконец,

Сопряг духовный ум в нас с телом милосердо,

Но оба суиества соединил толь твердо,

Что действий и страстей взаимность в оных есть.

An einem Beispiel wird der Begriff 'sзanmнoctb' verdeutlicht: einerseits wird eine Bewegung, die im Körper vor sich geht, sofort vom Geist 'aufgenommen'; andererseits 'erweckt' eine 'Neigung' im Geist Bewegungen im Korper:

V,176ff. Какой бы в теле двиг ни мог себя известь,

Tогда ж тот от ума поемлем весь бывает:

Взаимно склонность в сем, в том двиги возбуждает.

Die Voraussetzungen dieser Anschauung, die wir auch bei Fénelon finden, liegen in der Anthropologie Descartes'. Danach ist der Mensch ein 'Compositum'. Der eine Bestandteil ist ein organischer Automat, der andere die mit inm substantiell vereinigte seele. "Streng genommen", so erlautert R.Specht, "bedeutet die Vereinigung der nicht teilbaren seele mit dem teilbaren korper ihre unmittelbare Vereinigung mit nur einem Teil des Teilbaren, nămlich der zirbeldruse. Diese Annahme ist die Grundlage der Commercium-Lehre Descartes'."12 Die Seele (bzw. der Geist) wirkt auf den Korper. Eine unmittelbare Verursachung der körperlichen Bewegungen durch die Seele ist jedoch wegen des cartesischen Substanzen-Dualismus nicht moglich. Die Einschaltung der 'spiritus animales' verstöbt streng genommen gegen das Prinzip des Systems. Fur Des- 
cartes kann es daher nur eine indirakte Kausalitat geben, die ex mit scholastischen Termini wie 'dispositio', 'occasio', 'causa per accidens' umschrieben hat. "Dispositionen dieser Art, die haufig als occasiones bezeichnet werden, verursachen zwar indirekt, Jedoch infolge einer von Gott gesetzten hypothetischen Notwendigkeit, mit naturgesetzlicher Prazision. Ähnliches gilt für die geistigen Akte", so interpretiert R.Specht diese Auffassung. 13

Auch die andere Seite des 'commercium' bleibt im Grunde dunkel, urteilt R. Specht, "namlich die Art, in dex der koxper in der Seele auf dem Wege uber die Drüse die...sentiments und passions hervorzurufen vermag". "Aus den verschiedenartigen Außerungen Descartes' zum 'commercium' folgert R.Specht: "Für Descartes ist die Wechselwirkung dem Intellekt so wenig zugănglich wie inxe Ursache, die Vexeinigung. "15

Tred. Scheint das Abstraktum 'cклонность' (178) im Sinne Descartes' als 'dispositio' verstanden zu haben. Mikl. ubersetzt das ksl. Verb "s-kloniti" mit lat. 'deflectere' (927).

In V,179-190 trăgt Tred. verschiedene Theorien uber die psycho-physische Kausalităt vor.

Dex zuerst angeführten Anschauung zufolge ubt der Geist 'auf natürliche Weise' Einfluß auf den Köxper aus. Belde stehen miteinandex in Wechselbeziehung:

$$
\text { V,179f. Пусть натекает сей естественно на то, }
$$

Не натекает пусть взаем из них никто, -

Damit lst anscheinend die Theorle des 'influxus physicus' zwischen Geist und Korper gemeint, die in dem cartesischen Modell dex 'spiritus animales' zum Ausdruck kommt.

Im Unterschied zur 'naturlichen' Kausalităt wird die These vertreten, daB allein Gott die Bewegungen sowohl des Korpers als auch des Geistes hervorbringt: v, 181f. Пусть случаем они быварт, токмо богу

В деиг тело привояить, а разум в мысль премногу; -

'Случай', lat. 'occasio', ist das Schlüsselwort für die Kausalvorstellung der spăteren Schüler Descartes', der sogenannten Occasionalisten. Dex eigentliche occasionalismus beginnt mit der These, daB Gott nicht nur die Bewegungen des Korpers, sondern auch die Gedanken effektiv verursache. Dex menschliche Willensakt sei nur eine Quasi-Ursache, eine occasio für cott, die Bewegung zu bewirken. Der menschliche Geist diene lediglich als auslosende occasio bei der Entstehung der Ideen. Nach R.Specht ist "dieser Punkt...erst bei cordemoy exreicht." 16 wie die angefürten Verse 181f. zeigen, hat Tred. den 'eigentli- 
Nach der dritten Theorie laufen die Bewegungen des Korpers und die Gedanken scheinbar unabhăngig voneinander in eigenen Bahnen. Sie wirken aber trotzdem harmonisch und gleichzeitig zusammen:

V.183ff. Пусть тело от себя в Авимении бежит,
Себя и разум наш мыслями блажит,
Аа ходит в мих одмо, Как по кольцу, следами
Своими и Аругой Аа мисли шлет рядами,
Все Аействия ведя согласно толь и варуг,
Что будто меж собой текут на Аруга Аруг; -

In diesen Versen dürfte die von Leibniz vertretene 'prăstabilierte Harmonie' von Seele und Leib gemeint sein. Die Beschreibung ist besonders ausgeschmückt: V,184: 'unser Geist verherrlicht sich durch seine Gedanken'. 'Snawnto' ist von "blažiti" abgeleitet und wird im 'Cловарь' zur Feoptija mit 'ублажать, өеличать, прославлять' wiedergegeben (543).

In V,185 werden die Bewegungen des Korpers mit der Metapher 'wie im Kreis' gekennzeichnet.

V,186: die Aktivităt und der Zusammenhang der Gedanken wird durch die wendung 'der Geist sendet die Gedanken reihenweise aus' veranschaulicht. Die Verbmetaphern enthalten zugleich einen personifizierenden Effekt.

Tred. referiert die verschiedenen Lehmeinungen in Form von Konzessivsãtzen. Ex läbt es dahingestellt sein, welche von ihnen die Frage der psycho-physischen Kausalităt zutreffend beantwortet:

\section{V,189f. Поднесь еще сего определить не можно}

И знать, которо есть из трех тех мнений ложно.

v,191-202: Die Vereinigung von Geist und korper hat ihren ursprung nicht im Zufall, sondern im Plan des Schöpfers.

Mit dem Satz: Geist und Korper komen miteinander zur Helt, faBt Tred. eine ausgedehnte Diskussion uber den zeitpunkt der Vereinigung knapp zusammen:

$$
\begin{aligned}
& \text { V.191f. Но что сопряженш, сомнения в том нет, } \\
& \text { И что одно С Аругим исхояит прямо в свет. }
\end{aligned}
$$

Die 'weise Vereinigung' erscheint 'uberaus wunderbar', gerade weil sie aus zwei heterogenen Substanzen besteht. Der rümende Ton der Ausrufungssatze V,193f. hebt sich von der distanzierten Erwagung in den Konzessivsatzen 179ff. rhetorisch wirksam ab:

$$
\begin{aligned}
& \text { v, 193f. Премуаршй есть союз! и больше толь преяивншй, } \\
& \text { Что в разности существ бшть мнится сопротивншй! }
\end{aligned}
$$


Der 'c0103' exhalt die begeisterten Attribute 'премудрый' und 'предивншй', die auf den 'nремудрый творец' (171ff.) als Urheber hinweisen.

Der Zustimmung des Lesers gewiB, Iragt Tred., ob die 'Vereinigung' nicht das Werk der Weisheit des Schöpfers sei und stellt ironisch die Gegenfrage, wie sie denn aus dem 'dummen zufall' entstehen konne:

v,195f. He муарого ль сие творение дельца?

Как от припадка то возможет стать глупца?

Die Ironie wird durch Personifizierung des 'Dumbopfs Zufall' gesteigert.

Der Autor will aber nicht nur emotional überreden. Ex appelliert daruber hinaus an die Einsicht: wir können nicht einmal mit unserer Vexnunft begreifen, wie Geist und Körper so 'harmonisch, wundervoll und schön' zusammenwirken -wie sollte der völlig sinnlose zufall die 'Vereinigung', die doch die Voraussetzung des Zusammenwirkens ist, herbeifuhren können:

v,199ff. И разумом понять не можем мы сего, Єезумнейшийли тот припадок, без всего,

Возможет произвесть союз сей толь согласный,

По действам же ето толь чудный и прекрасный.

Fénelon argumentiert auf der Grundlage der Lehre vom Dualismus der Substanzen gegen die Zufallstheorie. Er fragt: "Le hasard a-t-il accroche, par un concours d'atomes, les parties du corps avec l'esprit?" (Démonstr.,S.49) Wenn der Geist sich an Teile des Korpers 'anhăngen' kann, făhrt Fénelon fort, dann mübte er selker aus Teilen bestehen und folglich ein richtiger korper sein. Diese Voraussetzung widerspricht aber dem Prinzip des 'unteilbaren' Geistes. Daraus folgt: "Si au contraire l'esprit n'a point de parties, rien ne peut $l^{\prime}$ accrocher avec celles du corps, et le hasard n'a pas de quoi les attacher ensemble." (Démonstr.,S.49)

Tred. hat in den Versen 171-202 die Themen der 'Vereinigung' und des 'commercium mentis et corporis' im wesentlichen selbstăndig behandelt. Insbesondere hat sein Bericht uber die verschiedenen Kausalvorstellungen $(179-190)$ in der Démonstration keine Parallele. Er wird aber in dieser Epistel noch einmal auf die commercium-Lehre im AnschluB an die Demonstration zurückkommen.

V,203-226: Psychische Funktionen, die mit korperlichen Erscheinungen zusammenhăngen.

Aus der Vereinigung von Geist und Korper 'nach Gottes RatschluB' folgt, daß bestimmte Funktionen des Geistes bzw. der Seele nicht im 'reinen Geiste', sondern im körperlichen Medium in Erscheinung treten. Als Beispiele nennt 
Tred.: Fủlen, sich etwas vorstellen können, Phantasie, Gedăchtnis und Erinnerung. Nur die 'reinen Ideen' sind vom Kơrper unabhăngig:

V,207ff. Чистейших сверьх идей уму приосщено

И чувствовать притом, образовать дано,

Мечтать еще тела́ и памятовать равно,

Что понято, по сем и вспоминать исправно.

Im folgenden bestimt Tred. diese Begriffe mit den schon bekannten Definitionsarten, die oft nur zur Tautologie führen.

Das 'Fülen' wird dadurch ausgelost, daB wir korperliche mpfindungen von den Dingen haben, durch die unser Geist ihre Anwesenheit, Menge und Beschaffenhe1t aufnimmt:

V,211ff. $Y_{M}$ чувствует rorá, когда upez чувства он (def. caus.)

Телесны те вещей присутство и притон

В количествах и в их всех качествах поемлет, -

(def. fin.)

Die 'Vorstellung' wird tautologisch dadurch bestimmt, daB man sich abwesende körper, die man kannte, nach ihrer Grobe und Beschaffenheit wieder 'vorstellt' (definitio finalis, amplifiziert):

$$
\begin{aligned}
& \text { V.215ff. Ум оразует как поня́тше тела, } \\
& \text { В отсутствии уже, и такме их дела. } \\
& \text { Себе колики те и каковш являет, } \\
& \text { Чем паки пред себя их точно преставляет. }
\end{aligned}
$$

Die Phantasie, so heiBt es weiter 'ruft alle möglichen Korper ins Leben' (im Unterschied zur 'Vorstellung', die sich mit wirklich existierenden, wenn auch abwesenden Korpern befaBt):

V,219f. Мечтает ум, как он возможности все тел

Слагать и разлучать живет поемля смел. (defin. realis)

Das Gedáchtnis kennzeichnet der Autor mit einer definitio realis:'es bewahrt viele Eindrücke von den Dingen im Gehirn':

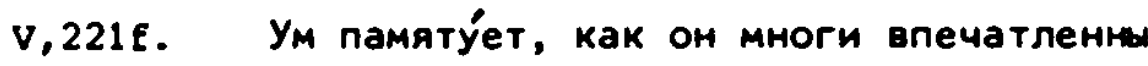

Вещей идеи в мозг хранит блодя нетленны,

Etwas weniger formal mutet die Definition der 'Erinnerung' an: Sie vermag etwas scheinbar Vergessenes wieder bewuBt zu machen, wenn nur ein Unstand der Sache, 2.B. ihre Umgebung, haftengeblieben ist:

\footnotetext{
V,223ff. A вспоминает он, когда уж почитай

Забыл какую вещь, но ежели не тай

Окрестность в нем ояна от вещи той пребудет,
} 
V,226 То, вспоминая всо, всея так не забудет.

Diese Bestimmung exscheint wie ein Vorlaufer der modernen Auffassung von den verschledenen 'Elngangskanalen' des Gedachtnisinhalts.

V,227-260: Die Krafte des Willens: 'Lust', 'Bewegung' und 'Leidenschaft'.

Tred. zăhlt ơrei 'Krăfte' auf, die er im folgenden erlăutert:

$$
\text { V,227 В уме хотящем суть: охота, подвиг, страсть. }
$$

'Oxота' wird als 'lustvolle Neigung zum Guten' definiert. Wie der zusammenhang deutlich macht, ist das 'Gute' hier nicht ethisch, sondern im sinne des 'Nützlichen' zu verstehen:

$$
\text { V,228 Охота - склонность есть K AO6ру, его за сласть; - }
$$

Tred. unterscheidet zwei Arten von Lustgefuhl: das eine wird von auBen, das andere von innen verursacht.

So wird 2.B. Essen und Trinken als Lust empfunden. Hunger und Durst werden personifizlert: 'der Hunger will essen und den Magen besanftigen', 'der Durst will trinken und den Mund befeuchten':

\section{V,231f. Глад хочет ядь вложить, Аа укротить стомах,}

A жажда хочет пить и всё смочить в устах; -

Die geschlechtliche Lust kommt dagegen von innen. Tred. definiert sie mit biologischer Nüchternheit als Mittel zum Zweck der Fortpflanzung:

v.233f. Hо похоть, да чрез то размножить наше племя,

Из тела своего кладет в чужие семя.

Grob und vulgar wirkt der zusatz, die geschlechtliche Lust sei 'ein Bedürfnis des Korpers, sich von zeit zu zeit zu erleichtern und zu entieeren':

V,235f. Потребность та, нтоб всем слегииться телом нам,

Есть спосо6 испражнать то всё по временам.

'Подвиг', synonym mit 'подвижность' (237) wird als kraft bestimmt, die den Korper gemảB der Aktivităt der 'Lebensgeister' in Bewegung setzt:

v.237f. Подвижность, сила есть в деижении 6 бшть телу,

Мивотных тех аухов по бегу в нем и делу; -

Der Begriff 'Lebensgeister' (vgl. zu V,166) stammt aus der Anthropologie Descartes', der damit die Wirkungsweise der Seele auf den Korper zu erkláren versucht hat. $\mathrm{Zu}$ seinen Bemühungen, die Art der Kausalităt beim 'commercium' zu erfassen, macht R.Specht die Anmerkung: "Descartes hatte die wirkungsweise der Seele auf den Leib und des Leibes auf die Seele nicht erklart, sondern auf verschiedene Weise umschrieben. Die eine lieb alles offen und erklarte,... 
daB aus dew bloBen Willen zu einer bestimmten Bewegung diese folgt." 17 Diese Auffassung komt in der Feoptija so zum Ausdruck:

$$
\begin{aligned}
& \text { v,239f. Нам ясно есть весьма, что, лишь sахочет ум, } \\
& \text { В движении уже всяк тела член не в глум. }
\end{aligned}
$$

Das Verhaltnis von Geist und Korper hat Tred. mit dem Gleichnis vom Ritter und seinem Schwert $2 u$ verdeutlichen versucht. Ex schildert, wie der Ritter sein Schwert im Kampf zu führen weib. Es ist in seiner Hand eine wirkungsvolle, vielseitige Waffe. Ohne inn ist es bloBer Stahl. Ungekehrt ist der Kampfer ohne das Schwert macht- und wehrlos. Das Gleichnis soll nach dem Verstandnis des Autors die wechselseitige Abhangigkeit von Geist und korper und zugleich die fürende Rolle des Geistes veranschaulichen. Die Passage ist von der Démonstration unabhăngig:

v,241ff. Подобен ум бойцу, мечу подобно тело:

Сим машет ум мечом, сим целится он смело,

Сим колет и сечет, сей отторгает вспять

И вкладывает сей меч он 8 номны́ опять.

'CTpactb' wird als eine 'Kraft des Geistes' definiert, die inm das Gute und das Bose zeigt, aber so, daß ex sich 'in exster Linie' dem Guten zuwendet oder dem, was ihm gut zu sein scheint, das tbel dagegen, oder was ihm so vorkommt, meidet:

v.245ff. Страсть - сила есть ума;себе он кажет сео

Добро и зло, но так, что чрезвычайно ею

Он Клонится К АОбру, иль К виду уж добра,

Да $и$ or зла бемит, или от видов зла.

Als 'Wurzel' der Leidenschaften sieht Tred. die 'Selbstliebe' an. Im Vergleich zu ihr sind alle übrigen Leidenschaften 'partiell':

V,249f. Tо самолюбность есть, что корень меш страстами:

Все прочие уж В ней как будто суть настями.

Der 'Anblick des Erstaunlichen' 1st die 'Gelegenheit', bei der die Leidenschaften, mit denen stets Ehrsucht und Hochmut verbunden sind, erregt werden:

$$
\begin{aligned}
& \text { V.251f. Однако случай К ним есть уяивлений взор; } \\
& \text { С сим Аружны завсетяа Как почесть, так презор. }
\end{aligned}
$$

Tred. führt einen Katalog von Affekten an. Obenan stehen Liebe und HaB, darauf folgen 'wüschen' und 'nicht wollen', 'Hoffnung und Furcht', 'Freude und Traurigkeit', 'Zorn und Wohlwollen': 


$$
\begin{aligned}
& \text { V,253ff. Лобить или иметь что в ненависти - главно } \\
& \text { Межау страстями есть, хоть видом то неравно. } \\
& \text { За сими НАет варуг - мелать иль не хотеть; } \\
& \text { Надежда уи по сим и страх, чтоб нам робеть; } \\
& \text { По сих и радость вся, по сих печаль заботна; } \\
& \text { По сих и пщлкий гнев и склонность доброхотна. }
\end{aligned}
$$

Der Katalog enthalt die Grundformen der Affekte, die Descartes in 'Les passions de l'ame' aufführt. Er nennt: Verwunderung (admiratio), Liebe und HaB, Verlangen (désir), Lust und Unlust (laetitia - tristitia). Daraus leitet er "das ganze Heer der 'partikularen' Leidenschaften als Arten und Unterarten ab." 18

Ahnlich sind die Affekte von A.Pope klassifiziert worden. Im 'Essay on Man' ist fast die ganze Ir.Epistel den 'passions' gewidmet. Als wichtigste werden genannt:

Ep.II,117f. "Love, Hope, and Joy, fair pleasure's smiling train, Hate, Fear, and Grief, the family of pain."

In der Démonstration findet sich kein Katalog der Affekte.

Im Verstăndnis der Affekte stimmt Tred. mit dem 'Essay on Man' in folgendem uberein: Er leitet die Leidenschaften aus der Selbstliebe ab (V,249). Vgl. 'Essay', II,93 "Modes of Self-love the Passions we may call" Motiviert werden sie von dem, was für das Individuum gut ist oder gut zu sein scheint $(V, 245-247)$.

Vgl. 'Essay', II,94 "'Tis real good, or seeming, moves them all."

Der wichtigste Unterschied besteht darin, daß im 'Essay' die Leidenschaften positiv, in der Feoptija dagegen im allgemeinen negativ beurteilt werden. Nach dem 'Essay' gehoren die Affekte mit der Vernunft zusammen zu einem system psychologischer Krăfte:

Ep.II,53f. "Two Principles in human nature reign; Self-love, to urge, and Reason, to restrain;"

Das ziel wird freilich nur dann erreicht, wenn die Vernunft die Führung innehat. Sie kann jedoch nicht ohne den vitalen Antrieb durch die 'passions' auskommen. Pope veranschaulicht das rechte Verhaltnis von vernunft und Leidenschaft mit einem Gleichnis:

Ep.II, 107f. "On life's vast ocean diversely we sail, Reason the card, but Passion is the gale."

Die ethische Aufgabe des Menschen besteht somit in einer stăndigen Harmonisie- 
rung des widersprüchlichen in sich selber nach dem Vorbild der Natur, in der Gott Harmonie durch die Băndigung der Elemente immer wieder herbeifuhrt:

$$
\begin{aligned}
& \text { Ep.II,111f. "Passions, like Elements, tho' born to fight, } \\
& \text { Yet, mix'd and soften'd, in his /God's } \bar{T} \text { work unite." }
\end{aligned}
$$

Nach meinung Popes beruht die Weltordnung auf der Harmonie der Gegensatze:

"All Discord, Harmony, not understood." (Ep.I, 291)

Im Unterschied hierzu ist für Tred. die dualistische Metaphysik Descartes' auch fur die Ethik maßgebend geworden. So werden in der Feoptija die Leidenschaften vorwiegend negativ bewertet. Die 'cтpacto' ist Gegenspielerin der Vernunft. Sie widersetzt sich der Gotteserkenntnis und wirkt als treibende Kraft bei den Atheisten. 'Страсть' wird oft in polemischem Zusammenhang genannt:

$$
\begin{aligned}
& \text { I,61f. Тьма ль вас прегустая, безаконийли всех сласть, } \\
& \text { Горяость ли безумна, затверяела ль коя страсть - }
\end{aligned}
$$

Sie gilt als Wurzel der Feindschaft gegen Gott, 'die durchaus nicht will, dab cott sei'. Sie ist der Trieb zur sunde:

v,847ff. Поистине здесь всяк божественну зрит власть,

Но отричает кой ту чрез извольну страсть,

Котора бога бшть отнодь бш не желала,

Чтоб, мести не боясь, бесчинием пылала.

v, 261-272: Die geistigen Funktionen haben ihren Ursprung in der Seele, nicht im 'Fleisch'.

Mit der enumeratio der im vorhergehenden besprochenen geistigen Tatigkeiten und Krafte (Denken, Fuhlen, Vorstellen, Erinnern, Affekte und willensakte) faßt Tred. die wesentlichen Begriffe des Einschubs V,51-260 zusammen. Er versichert seinem Adressaten, den er hier zum ersten Mal in der V.Epistel anredet, daß alle diese Phănomene eine gemeinsame Wurzel haben:

$$
\begin{aligned}
& \text { v,265f. } 0 \text { том, Евсевий, нет сомнения нимало: } \\
& \text { Всему тому есть мисль по корено начало. }
\end{aligned}
$$

Der Autor nennt jeden 'gottlos', der das 'schone' geistige Vermögen (267) dem Körper zuschreiben will. Der 'rechtschaffene verstand' hălt dafur, daB das 'Denken' ein Akt der Seele ist. Die 'enumeratio' der geistigen Tátigkeiten (261-264) zeigt, daß 'Denken' hier das geistige Leben insgesamt und nicht nur die intellektuelle Komponente bezeichnet:

V,269f. Всяк нечестившй мысль ту присвояет телу, Но правый смысл в ауше такому мнит быть аелу, - 
Wăhrend Tred. den Andersdenkenden religios diffamiert, argumentiert Fénelon zwar entschieden, aber ohne Polemik: "Mais supposons tout ce qu'on voudra, et ne contestons contre aucune secte de phllosophes. Voici une alternative que nul philosophe ne peut eviter. Ou la matiere peut devenir pensante,... ou bien la matiere ne saurait penser; et ce qui pense en nous est un etre distingus d'elle, qui lui est uni." (Demonstr.,s.47)

Im Aufbau der V.Epistel bildet die rhetorisch geprăgte Passage 261-272 mit der Aufzăhlung der geistigen Funktionen und der Apostrophe an Evsevij einen Uhergang. Nach dem Einschub V,51-260 kehrt Tred. In Vers 273ff. zum Gedankengang der Démonstration zurück.

V,273-322: Hypothetische Erwăgungen uber die 'denkende Materie'. Die zwei verschiedenen Naturen im Menschen.

Nach dem schon bekannten Denkmuster greift Tred. die materialistische These noch eimmal in einem Konzessivsatz auf, untersucht inre voraussetzungen und widerlegt sie gründich. Selbst wenn man annimmt, 'der Korper kơnne denken', muB man doch hinzufügen, daß ex nicht immer gedacht hat:

v.273ff. Хотя и положить, что телу мислить можно,

Однак при том сказать так надлежит неложно,

Что мислит не всегда конечно вещество -

Derselbe Mensch, der heute 'denkt', konnte vor 'fünfzig Jahren' noch nicht denken. Ebenso wenig hat die 'koxperliche Materie' eines Knaben, 'zwolf Jahre bevor er zur Welt kam, denken, BewuBtsein haben, noch gar für sich sorgen kơnnen' :

V,279ff. Вот 8 отроке каком плоть за двенаяцать лет,

Как оншй не исшел рождением на свет,

Не мислила отнодь и знаний не имела,

Ни о себе самой, конечно, не радела.

Daraus folgt, daB die (organische) Materie das 'Denken' erst 'empfangen' hat. Zu den Voraussetzungen der materialistischen These gehort, daß das Denken 'aus der besonderen Anordnung gewisser Teile, die harmonsich zusammengefügt werden', entsteht:

V,283ff. Затем долг Говорить, что вещество сио

Всо получает мисль, в потребность ту своw,

От некоих частей, изряано учрежяенних

И волг и в стройний чин разлогом приведенных.

Bel der (toten) Materie eines Steins oder Sandhaufens werden wir jedoch 'kei- 
nen Schatten' des Denkens finden, solange wir auch danach suchen mogen:

$$
\begin{aligned}
& \text { v.287ff. Воззрим на камень ми иль на бугор песку, } \\
& \text { Хотя пребудем коль ни далго ми в иску́, } \\
& \text { Однак ми а камне том ниме́ а песке обрямем } \\
& \text { Ту нашим мисль трудом, ее ни тени сряцем. }
\end{aligned}
$$

Tred. hat den Gedanken aus der Demonstration wbernomen und den Wortlaut der Vorlage nur wenig geăndert. Fenelon fuhrt aus: Wenn man einrăumt, die Materie könne zu denken anfangen (...peut devenir pensante), muB man auch zugoben, daß sie nicht von jeher denkend war. Hier fünt Fénelon das Beispiel des knaben an, der 'zehn Jahre vor seiner Geburt' ganz sicher noch nicht dachte: "...par exemple, la matiere du corps d'un jeune home ne pensait point dix ans avant sa naissance..." (Demonstr.,S.47) Die 'denkende Substanz' vorausgesetzt, muB hinzugefügt werden: "...il faudra donc dire, que la matiere peut acquérir la pensée par un certain arrangement, et par un certain mouvement de ses parties." (5.47) Diese Uberlegung bezieht sich aber allenfalls auf die organische Matexie. Von der 'toten' Materie sagt Fenelon: "Prenons, par exemple, la matiere d'une pierre ou d'un amas de sable: cette portion de la matidre ne pense nullement." (S.47)

Unsere Autoren nehmen also die Materialisten beim Wort. Wie verhalt es sich mit ihrer These, das Denken komme durch die Form, Anordnung und Bewegung der materiellen Teilchen zustande? Die Materie muB also erst in die richtige Verfassung gebracht werden, damit in ihr Gedanken entstehen können:

v,291f. Итак, чтоб в венестве те мысли произвесть,

То особливо всь исправность должно снесть; -

Es geht darum, ihre 'Natur zu ordnen', in ihr die 'entsprechende Gestalt zu schaffen', Ihren Teilen 'die gebührende Bewegung' zu geben und alles 'nach $M a B, Z a h l$ und Gewicht' gleichmaBig einzuteilen:

V,293ff. Его расположить, во-первшх, долг матуру
И о оном учреяить пристойнуо фигуру;
Потом его частям приличний даиг подать,
Всё мерой, өсё числом, всё весом разверстать.

Die Begriffe 'motus' und 'figura' sind in der Physik Descartes' die obersten Modi, die das Wesen der Körper (res extensae) bestimen. Bei den Organismen fuhrt "das Paar der obersten Modi, motus und figura,...zur dispositio partium", durch die der menschliche Leib fur die Vereinigung mit der Seele "disponiert' wird. 19 
Die Aussage 'всё мерой, всё иислом, всё весом разверстать' (296) geht auf die Bibel zurück. Im Buche 'Sapientia', Kap.11,20 (LXX) wird Gottes Schopferweisheit gepriesen:

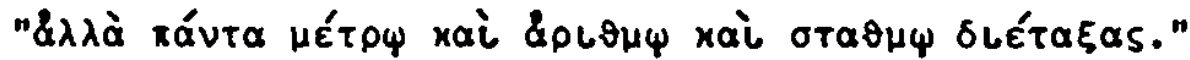

Tred. hat die Formel bereits in Ep.I,227f. in doxologischem zusammenhang verwendet (vgl. die Anmerkungen $z u$ der Stelle).

In der vorliegenden Passage will Tred. deutlich machen, daB die materialistische Theorie der Entstehung des Denkens Bedingungen voraussetzt, die nur der Schópfer selber herbeifuhren kann. So steuert die Argumentation wieder auf das physikotheologische Bekenntnis hin, das in den folgenden rhetorischen Fragen zum Ausdruck kommt: Wer hat diese groBe 'GleichnaBigkeit' gefunden? 'Равномерность' (297) bezieht sich auf 'всё мерой... разверстать' (296). Wex konnte in diese 'Unendlichkeit der Einzelheiten eintreten'? V,297f. Но кто ж cио нашел толику равномерность? Вступить в сщо кто смог подробностей безмерность?

Wer hat die Bewegung genau so, wie sie sein muB, in eben diesem Grad und keinem andern, angefangen?

$$
\begin{aligned}
& \text { v,299f. Начать кто двиг сперва так точно, долюно как? } \\
& \text { В степени точно той, а ме в другой не так? }
\end{aligned}
$$

In der folgenden als climax geformten Reihe wird auf die Erschaffung des Menschen 'aus Staub von der Erde' angespielt. (vgl. Gen.Kap.2,7; s.0.S.291) Der Mensch besteht aus 'schmutziger Materie', sagt Tred. im Blick auf die Schoppungsgeschichte. Scheinbar können sich auch die Materialisten in diesem Punkt auf die Bibel berufen. Sie ubersehen aber, daB gerade an der nichtigen Materie der Schópfer seine Macht demonstriert hat. Voller Ehrfurcht fragt Tred.: Wer hat die schmutzige Materie zur Grundlage bestimmt und sie neugestaltet, um einen menschlichen Korper zu schaffen? zugleich weist der Autor darauf hin, daB dieser Korper bei seiner Geburt 'ohne Gedanken' ist, aber im Laufe der zeit zum Begreifen und zu Verstand kommt:

V,301ff. Кто внусном веществе, то превращая снову, Чтоб тело сотоорить, расположил основу, Родившись кое так и точно как без аум С часа приходит в час в понятие и 8 ум?

Die Analyse der These vom materiellen Ursprung des Denkens fuhrt zum Ergebnis, daB der Glaube an den Schópfer letzten Endes bestătigt wird.

In der Demonstration hat die den Versen Tred.\& zugrunde liegende Passage 
diesen Wortlaut: "Qui est-ce qui a su trouver...cette proportion (pasmomepHOCT(), cette configuration, cet arrangement, ce mouvement en un tel sens et point dans un autre (Aвиr... Tak точH), ce mouvement a un tel degre, au-dessus et au-dessous duquel la matiere ne penserait jamais? (в степени точно той, a не apyroй не так?) qui est-ce qui a donné toutes ces modifications si justes et 81 précises a une matiere vile et informe (a rнусном веmеств), poux en former le corps d'un enfant (чтоб тело сотеорить), et pour le rendre peu a

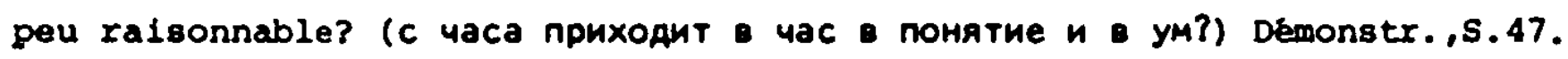
Trod. hat in diesen Text eingefügt: 'alles nach MaB, Zahl und Gewicht' (296) und die Frage: 'wer konnte sich in diese Unendlichkeit der Einzelheiten einlassen'? (298)

Als Alternative zu der hypothetischen Exwăgung uber die 'denkende Materie' unreiBt der Autor anschliebend die cartesische Lehre vom Dualistous der Substanzen. Danach sind die im Menschen vereinigten zwei Substanzen vollig verschieden. Die eine kennen wir nux nach ihrer Gestalt und inren Bewegungen. In der anderen finden wir Verstand und Denken. Die eine 'Natur' gibt uns von der anderen nicht die geringste Vorstellung; im Gegenteil, was wir in der einen sehen, ist der anderen entgegengesetzt:

v,315ff. Te оба естества не сходнм меж собой:

Оано возможем знать фигурой мы какой

И знаем по ето сие ми двигам ра́вно, -

v,319ff. Рассудок мы - Аругом и мысль находим 8 нем,

$И$ то нам о Aругом не подает при сем

Идеи никакой, Аа, напроти́в, есть Аивно,

Что зримо всё в оАном - Аругому сопротивно.

Die Verschiedenheit der beiden 'Naturen' im Menschen ist von Fénelon ahnlich dargestellt worden: "Volld deux natures dissemblables. Nous ne connaissons l'une que par des figures et des mouvements locaux; nous ne connaissons l'autre que par des perceptions et paŕ des raisonnements. L'une ne donne point l'idée de l'autre, et leurs idées n'ont rien de commun." (Démonstr.,s.47f.)

V, 323-422: Der Schopfer hat Korper und Geist des Menschen so miteinander vereinigt, dab sie lebenslang voneinander abhangig sind.

Zu Anfang wird das Problem formuliert: woher komt es, dab zwel vollig verschiedene Wesen in einem Menschen vereinigt sind, so dab sie das ganze Leben hindurch voneinander abhangen? 
V,323ff. Итак, осталось знать, чем оба суиестөа,

Различного совсем межяу собой родства,

Соединились толь претвердо в человеке,

Что от себя взаем в его зависит веке?

Fenelon fragt: "D'ou vient que des atres $s 1$ dissemblables sont si intimement unis ensemble dans l'homme?" (Demonstr., S.48)

Nun werden die beiden Bestandteile des 'commercium' einzeln gepruft:

$$
\begin{aligned}
& \text { V,327 Телесны двиги чем рамдарт скоро мшсль, - } \\
& \text { v,329f. Чем мшсли в бшстроте и той неизреченной } \\
& \text { В обратности велят быть телу уреченной? }
\end{aligned}
$$

Die verse sind der vorlage nachgebildet: "...d'ou vient que les mouvements du corps donnent si promptement et si infailliblement certaines pensées a l'ame? d'ou vient que les pensées de l'ame donnent...certains mouvements au corps?" (Demonstr., S.48)

Die Vereinigung von Korper und Geist dauert das ganze Menschenleben hindurch,'achtzig Jahre und mehr'. Bei Fénelon heibt es: 'slebzig oder achtzig Jahre'. Woher kommt diese lebenslange und ununterbrochene verbindung?

$$
\begin{aligned}
& \text { v,331ff. Собщении сии чем с восемьдесят лет } \\
& \text { И более к тому ж в исшедшем теле ө свет } \\
& \text { Претвердо может толь взаимно содержаться } \\
& \text { И беспрершвно весь лодский век продолжаться? }
\end{aligned}
$$

Vgl.:"d'ou vient que cette societé si réguliere dure soixante-dix ou quatrevingts ans sans aucune interruption?" (Demonstr.,s.48)

In beiden Texten steht wohl das Psalmwort vom 'biblischen Alter' im Hintergrund (Ps.89,10 LXX):

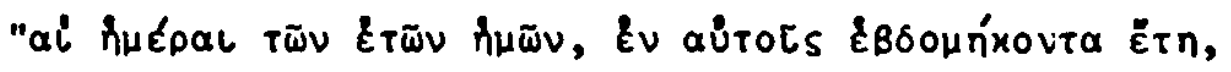

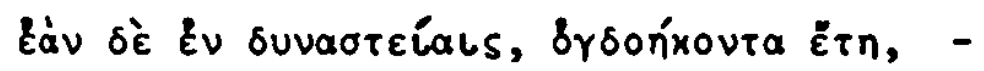

Tred. bekennt, daß wir nicht begreifen können, woher es kommt, daB zwei verschiedene Naturen so genau in allen Dingen zusammenwirken:

$$
\begin{aligned}
& \text { v.335ff. Чем двух суиеств сољз и розно действо их } \\
& \text { Бнварт точны так во всех делах своих, } \\
& \text { Что и понять нам то и разобрать довольно } \\
& \text { Не можно есть отнов, коль ни трудимся больно? }
\end{aligned}
$$

Fénelon hat hier einen etwas anderen Text. Er erklăt, daB das Zusamenwirken von Korper und Geist zu der Meinung gefuhrt habe, beide seien ein 'einfaches und untelibares Ganzes': "...que tant de gens sont tentés de croire que 
c'est un tout simple et indivisible..." (Demonstr.,s.48)

Die wiederholte Frage nach der Ursache der Vereinigung und des 'commercium' von Korper und Geist im Menschen bleibt ohne Antwort. Die anschliebende Frage nach dem Urheber zeigt aber an, wo unsere Autoren die Antwort gefunden haben:

$$
\text { V, 339f. Кто сии сунества взаем соединил, }
$$

А разность обойх толь ясно разгранил?

Vgl.: "Quelle main a pu lier ces deux extrémités?" (Démonstr.,S.48)

An spaterer stelle wird Tred. die Frage zur Doxologie des Schopfers ausweiten.

zunăchst werden in retardierender Weise andere Losungsversuche ausgebreitet. Den Gedanken, die beiden 'Naturen' hatten sich von selbst vereinigt, lehnen Fénelon und Tred. ab. Dieser erklart:

v,341f. Tе сами меж собой вточь не соединились

И, Аруг на аруга зря, взаимно не склонились.

Vgl.: "Elles ne se sont point liées d'elles-mêmes." (Démonstr.,s.48)

Eine Vereinigung hatte in diesem Falle entweder von der k3rperlichen Materie oder vom Geist ausgehen müssen. Das 'Fleisch konnte aber den Geist nicht zu sich rufen', stellt Tred. fest. Es konnte nicht einmal an inn denken, 'so träge, grob und leer von Gedanken' ist es:

$$
\begin{array}{ll}
\text { v,343 Плоть ме могла } k \text { себе призеать того ума, } \\
\text { v,345f. Ни мшслить так } 06 \text { нем могла когда со5о0, } \\
\text { Толь праздна, толь груба и мислей с пустото0. }
\end{array}
$$

Fénelon stellt die 'Vereinigung' als einen 'Pakt' dar und spricht der Materie die Făhigkeit und denwillen ab, die 'Bedingungen' aufzustellen: "La matiexe n'a pu faire un pacte avec l'esprit; car elle n'a par elle-même ni pensée ni volonté pour faire des conditions." (Démonstr.,S.48)

Hatte andererseits der Geist sich 'bewuBt und freiwillig dem Gesetz des Korpers unterworfen', so mübte er sich dessen exinnern. Er kann die 'Unterwerfung' nicht vergessen haben, fügt Tred. hinzu, weil das Gedăchtnis 'sein vornehmster Schmuck' ist. AuBerdem wirde der freie wille gegen die Unterwerfung revoltieren:

$$
\text { V,347Ef. He помнит ра́вно ум, чтоб телу под закон }
$$

Нарочно подаллся и добровольно Он:

Cего забшть ему не можно есть поданаства, Что переого в числе в нем память есть убранства,

А sольность, сунества его почти как грунт, Так наглость с стороны произвела 6 в нем бунт. 
Durch die Metaphern 'убранство' und 'бунт' hat Tred. die aus der Dsmonstration entlehnte Begründung auf eigene Art akzentuiert und verbildlicht.

Fénelon stellt fest, daß der Geist sich nicht im geringsten erinnere, 'elnen Pakt mit der Materie gemacht zu haben'. Er făhrt fort: "S'1l avait résolu librement et par lui-meme de s'assujetir a la matiere, il ne s'y assujetirait que quand 11 s'en souviendrait, et quand il lui plairait." (Démonstr.,s.48)

Es gibt jedoch keinen Zweifel, konstatieren beide Autoren ubereinstimmend, daB der Geist vom Korper 'abhăngig' ist und sich nicht selbst von inm trennen kann, bis der körperliche Tod ihn vom korper scheidet:

$$
\begin{aligned}
& \text { О,353 Инак, бесспорно, он зависит впрямь от тела, - } \\
& \text { V,355f. И отлучиться сам не может от того, } \\
& \text { Пока не разлучит телесна смерть его. }
\end{aligned}
$$

In der Vorlage steht, 'daß der Geist sich nicht vom korper befreien kann, es sei denn, daß er die Organe des Körpers gewaltsam zerstorte': "Cependant 11 est certain qu'il dépend malgré lui du corps, et qu'il ne peut s'en délivrer, a moins qu'1l ne détruise les organes du corps par une mort violente." (S.48) Trod. hat dlese Ausdrucksweise abgeschwacht.

Beide Autoren geben ferner zu bedenken: Selbst wenn der Geist sich freiwillig mit den Körper vereinigt hăte, so folgt daraus nicht, daß die Materie dem Geist unterworfen wăre und sich nicht vielmehr nach ihren eigenen Gesetzen bewegte (V,357-360, vgl. Demonstr.,S.48). Hinter dieser tberlegung steht die Lehre Descartes' vom Dualismus der substanzen. Danach ist eine direkte Kausalitst des Gelstes auf die Bewegungen des Korpers ausgeschlossen. Diese gehorchen vielmehr den Gesetzen der Mechanik.

Trotz des Dualismus von Korper und Geist vertreten unsere Autoren nachdrücklich das 'commercium mentis et corporis'. Tred. kleidet es in prägnante, rhetorisch stilisierte Verse:

\section{V, $361 \mathrm{ff.} \mathrm{Взаимно} \mathrm{аругу} \mathrm{Аруг} \mathrm{находятся} \mathrm{поделастны,}$ \\ Взаимно те во всех своих делах согласны. \\ Лишь ум замшслит, еАруг приходит тело в Авиг; \\ Лишь в Аеиги плоть пришла, ум начал мыслить вмиг.}

Bemerkenswert ist, daB in diesen Versen die Wechselwirkung von Geist und korper ohne die Annahme eines 'influxus physicus' und ohne vorstellungen aus dem Bereich der occasionellen Kausalităt interpretiert wird. (vgl. $v, 239 f$. Wenn der Geist es will, setzen sich alle Glieder des Korpers in Bewegung, 'als zoge sie femand mit einer Maschine' oder 'steche sie mit sporen'. Der 
zweite Vergleich -er findet sich nicht in der Vorlage- labt an einen Reiter denken, der sein pferd dem eigenen willen gefügig macht:

v,365ff. Ym eоcхотел, тотиас вce uлem n coctasm

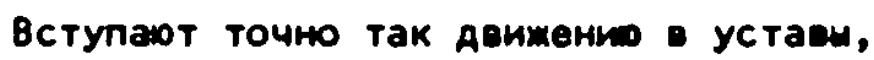

Не инак как 6 к кто их сильно натянул

Махинор К тому, боднами иль кольнул,

Fénelon hat die Wirkung des Geistes auf den Korper so beschrieben: "L'esprit veut, et tous les membres du corps se remuent d $l^{\prime}$ instant, comme $s^{\prime} 118$ etaient entraines par les plus puissantes machines." (Demonstr.,S.48)

Das 'commercium' kann auch von der anderen Seite in Gang gesetzt werden: V.371f. C другой стран,, еАва в двиг при́дет вещество, Как еАруг и мшслит уи разумно сумество Die Bewegung der korperlichen Materie 18st in Geist u.a.die Gefahle, z.B. 'Trubsal und Freude' aus:

$$
\text { V,373 И оцуиает скорбь или какуо радость, - }
$$

In der Vorlage heiBt es: "Le corps se meut, et a l'instant l'esprit est forcé de penser avec plaisir ou avec douleur a certains objets." (5.48f.)

Descartes zufolge "betrifft das commercium mentis et corporis: die Enweckung undeutlicher Vorstellungen im Geist durch den korper auf der einen und die Verursachung villkurlicher Bewegungen im korper durch den Geist auf der anderen seite." 20

Auf die Schilderung des 'commercium' folgt, bezeichnend für die Einstellung unserer Autoren, die physikotheologische Frage: wessen Hand 18t so allmachtig, daB auf inr GeheiB Fleisch und Geist in Harmonie zusammenarbeiten und sich 'ohne Vermischung der beiden Naturen' freundschaftlich alle Dienste erweisen?

V.375ff Всё премогуиа толь сия есть чья рука,

Котора так могла велеть, что не анка

Ни плоть, ните стал ум, взаем итоб им труаиться,

В согласии чтоб бшть и Аружно толь водиться,

Без смеса Авух суместе услуги есе казать, -?

Der Ausdruck 'ohne Vermischung der zwei Naturen' erinnert an eine christologische Formel, die Tred. sehr wahrscheinlich aus seinen theologischen studien kannte. Die 'communio natuxarum', "i.e. mutua divinae et humanae Christi naturae participatio", wird von den Dogmatikern u.a. mit den Attributen "\&our-

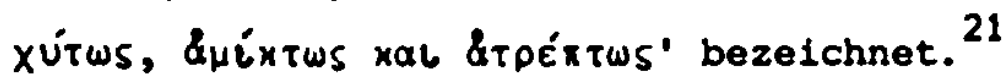


Fenelon hat die Frage anders ausgedrückt. Bel ihm fehlt die Formel 'ohne Vermischung der zwei Naturen': "Quelle main également puissante sur ces deux natures si diverses a pu leur imposer le joug, et les tenir captives dans unu société si exacte et si inviolable?" (Démonstr.,s.49)

Ainnlich wie in V,339f. wird auch diesmal die physikotheologische Frage nicht weiter entfaltet. Tred. bereitet das feierliche Bekenntnis zum Schópfer vor, Indem er erst einmal die Auffassung zurückweist, die 'Vereinigung' von Körper und Geist sel auf den 'Zufall' zuruckzufuhren. Der Zufall hat nach seinen Worten weder Sinn noch Kraft; er 1st weder 'bitter noch süB':

$$
\text { V,381f. Кто скажет, что их так соединил припадок, }
$$

В ком смысла нет, ни сил, не горек кой, не сладок?

Ironisch fragt Tred., ob der, welcher die 'Vereinigung' dem zufall zuschreibt, selber verstehe, was er sagt oder kompetent sei, es anderen vernúnftig zu exkläen:

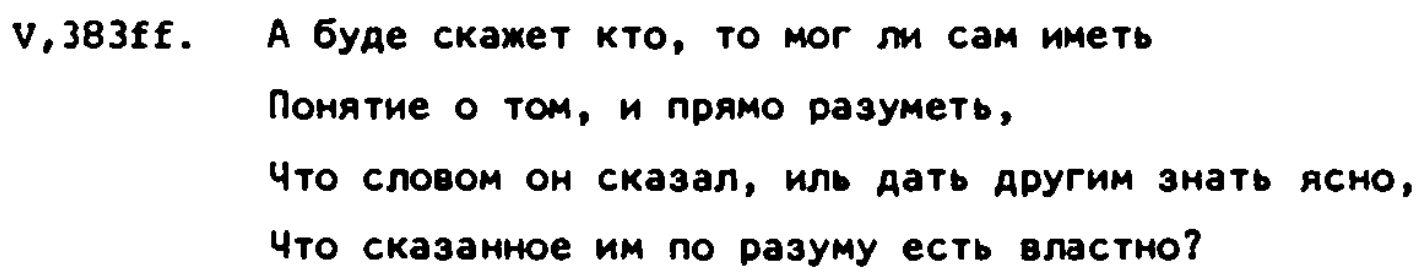

Fenelon greift die Zufallstheorie ohne unschweife an: "Dira-t-on que c'est le hasard? Si on le dit, entendra-t-on ce qu'on dira, et le pourra-t-on faire entendre aux autres?" (Démonstr.,s.49)

Die 'zufallige' Vereinigung mit dem korper widerspricht auch der Wesensart des Geistes. Dieser düfte sich nicht als geistig schătzen, meint Tred.. wenn der zufall inn mit dem Korper zu vereinigen vermochte:

$$
\begin{aligned}
& \text { v.387f. Kогда припадок мог их так соединить, } \\
& \text { То долг уму себя Ауховным не ченить. }
\end{aligned}
$$

Der Geist lehrt uns aber selber, dab er von anderer Art 1st als die 'trage Materie'. So führen alle Uberlegungen darauf hinaus, daß der 'vergeblich gepriesene' Zufall absolut nichts habe, wodurch er den Geist mit dem kórper so fest vereinigen konnte:

$$
\begin{aligned}
& \text { v, } 391 \mathrm{ff.} \text { Вот следует затем, что нету ничего } \\
& \text { В гласимом тиетно толь припадке из того, } \\
& \text { Чем момно сорзи́ть толь твердо разум с телом, - }
\end{aligned}
$$

Fénelon macht geltend, daB die nicht aus Teilen zusammengesetzte Seele nicht durch den zufall an die tellbare Materie des Körpers 'angehăngt' werden kơnne: "S1 au contraire l'esprit n'a point de parties, rien ne peut l'accrocher avec 
celles du corps, et le hasard n'a pas de quoi les attacher ensemble." (S.49)

Die Polemik gegen die Zufallslehre und ihre Verfechter bricht in unseren Texten immer wieder auf. In der Fooptija z.B. bei der Kosmologie (I,231f; I,353-56), bei der Frage nach dem Ursprung des Denkens (III,945ff.) und bei der Physiologie des Menschen (IV,4loff.). Fénelon hat, in Ton zurückhaltend, in der Sache entschieden gegen den 'hasard' als Prinzip der 'epicuriens' Stellung genommen. Er setzt sich damit vor allem in ch.III.. Premiere Partie der Démonstration, S.77ff, auseinander (Réponse aux objections des epicuriens). Dieses Kap. ist in der Feoptija nicht ausgewertet worden. Beide Autoren machen deutlich, daB zwischen der zufallstheorie und dem Glauben an den Schöpfer ein unüberbrückbarer Gegensatz besteht.

In wirksamem Kontrast zu der Abweisung der zufallstheorie steht im folgenden das preisende Bekenntnis zur Weisheit, Gute und Allmacht des Schopfers, der die zwei Naturen im Menschen fest miteinander vereinigt hat. Mit einem katechismusartigen Satz bekennt Tred.: 'die Alweisheit' hat diese Vereinigung 'erdacht', 'die Gute' hat sie 'erwăhlt', 'die Allmacht' hat sie 'ins Werk gesetzt': $v, 395 f$. Премуарости дол быть, чтоб тот с00з познать; Долг благости бшть тут, чтоб оный предызбрать,

А напоследок долг быть всемогущей власти

И бесконечно той державной, не отчасти, Чтоб Аейством сочетать, чтоб Аейство произвесть

И чтоб взаимность деух существ претвердо сплесть.

Damit ist die Frage nach dem Urheber der 'Vereinigung' und des 'commercium', die in V,339 und V,375 gestellt wurde, endgülig beantwortet.

Die folgende Passage stellt eine Art Gegenprobe dar, durch die das Bekenntnis bestatigt wird. Tred. stellt, Motive des Vorhergehenden wiederholend, zwei Moglichkeiten heraus. Entweder bilden Fleisch und Geist einen homogenen korper (состав несочетанный, 401), so ist zu fragen, wie es komme, daß diese 'Sache' (seщь, 403) zu denken begonnen hat. Nach Tred.s bberzeugung hat sie das Denken von einem anderen empfangen:

$$
\begin{aligned}
& \text { v,405f. Итак, кто дал ей мисль иметь сам должен ону, } \\
& \text { По разуму сия и по его закону, - }
\end{aligned}
$$

Angencmmen, das Denken entstehe aus der 'Bewegung der Materie' (vgl.V,295), so setzt auch dies einen 'weisen' Urheber voraus, der den 'Mechanismus' so gemacht hat, 'daß ex inm die Gedanken zur Bewegung' gegeben hat: 


$$
\text { V,411f. То из составов сих кто ж мудрый сотворил }
$$

Махину так, что в двиг ей мысли подарил? (vgl.v.299f.)

Wenn abex ungekehxt fleisch und Geist zwei vexschiedene Wesen sind (vgl.v, 315ff.), deren Vereinigung für uns unbegreiflich ist (vgl.v,335ff.), so drăngen sich erst recht die Fragen nach der 'überaus weisen' und starken Macht auf, die die beiden Naturen zu wechselseitigem Dienst vereinigt hat (vgl.v, $375-380)$ :

$$
\begin{array}{ll}
\text { V,415 Премудра коя власть совокупила их - } \\
\text { v,417ff. Но так, что разум весь отнодь того не знает, } \\
\text { Кто с телом, да и как, его сочетавает? } \\
\text { Чья сильная толь власть ум с телом хоть Аелит, } \\
\text { Однак в еяинстве быть союзном им велит - ? }
\end{array}
$$

Fénelon entfaltet an dieser Stelle die 'Alternative', wobei er schon Gesagtes z.T. wiederholt: "Enfin mon alternative revient toujours, et elle est decisive. Si l'esprit et le corps ne sont qu'un tout compose de matiere, d'ou vient que cette matière, qui ne pensait pas hier, a commence a penser aujourahui?qui est-cequi lui a donné ce qu'elle n'avait pas...? ...quel ouvrier a su trouver toutes ces combinaisons $s i$ justes et si précises pour faire une machine pensante? $\mathrm{Si}$ au contraire l'esprit et le corps sont deux natures differentes, quelle puissance supérieure a ces deux natures a pu les attacher ensemble...?" (Démonstr.,S.49)

V,423-534: Von der absoluten und gleichzeitig unbewuBten Macht des Geistes uber den körper

V,423-452: Unser Geist verdankt seine Herrschaft uber den eigenen Korper der Weisheit des Schopfers.

Zu Anfang des neuen Abschnitts wird das Thema genannt:

$$
\begin{aligned}
& \text { V,423f. Уму ная телом есть господственная власть, } \\
& \text { Хоть и в границах та его ная оным часть; }
\end{aligned}
$$

Unser bloBer Wille setzt mühelos die Glieder des Korpers in Bewegung. Tred. schildert den vorgang anschaulich. Auf GeheiB des Willens făngt jedes Glied zu arbeiten an, alle Sehnen spannen sich, der ganze Mechanismus führt gehorsam den Befehl aus:

$$
\begin{aligned}
& \text { V,425f. Простая воля в нас, в хотени не готовом, } \\
& \text { Привояит членш в Авиг велящим буато словом; - } \\
& \text { V,429ff. Лишь внутренно скажу: "Ступай мое всё тело" - } \\
& \text { Тотчас уже оно и Авигнулось в то дело, }
\end{aligned}
$$


V,431ff. Ho скоро так, что есяк илен начал работа́ть, Bсе wил напряглись, всё стало помогать, Вся ма́хина уже послуина полнить sолм, -

Die Beschreibung deckt sich im wesentlichen mit der Vorlage: "Remarquez que l'empire de mon esprit sur mon corps est souverain, ... Il est souverain dans son étendue bornée, puisque ma simple volonté,...fait mouvoir tout a coup immédiatement tous les membres de mon corps, selon les régles de cette machine. ...Je dis en moi-même cette parole 81 intérieure...:Que mon corps se meuve; et il se meut. A cette simple et intime volonté, toutes les parties de mon corps travaillent déjă, tous les nerfs sont tendus,...et toute la machine obeit,..." (s.49f.)

Fénelon geht sogar so weit, in dem Verhaltnis von Geist und korper ein Abbild der Herrschaft cottes über die welt zu sehen: "C'est précisément celle /puissance $\bar{T}$ que les hommes persuadés de la Divinité lui attribuent dans tout l'univers." (Démonstr.,S.50) In diesem Zusammenhang vergleicht Fenelon den menschlichen willensakt mit dem biblischen Schöpfungsbefehl: "Comme l'Ecriture nous represente Dieu, qui dit, apres la creation de l'univers: que la lumiero soit, et elle fut." (S.50)

Tred. ist seinem literarischen Vorbild darin nicht gefolgt. Ihm geht es darum, daß der 'Vernüntige' in der Herrschaft des Geistes uber den Korper die weise ordnung cottes erkennt und ihn dafür preist:

$$
\begin{aligned}
& \text { V,437ff. Разумншй человек, тем божество познаоший, } \\
& \text { Всесильности жего себя вовек предавший, } \\
& \text { Единому сио всо хитрость прияает, } \\
& \text { Премуарость же его с величием поет. }
\end{aligned}
$$

Damit hat Tred. den Gedanken Fénelons verăndert und seinen versen hymnische Tonalitat beigelegt.

Der Autor ist davon uberzeugt, daB der Geist und Wille des Menschen die Macht aber den korper nicht aus sich selber haben, da sie schwach und unvollkomen sind:

$$
\begin{array}{ll}
\text { V.441 Возможно ль то причесть уму, кой слабим знар, - } \\
\text { V,443 Могу ль посерить я, что воля власть сио, - } \\
\text { V,445f. Конечно от себя и по себе имеет, } \\
\text { Уверен, что сеершетсто не верьх в ней, и слабеет? }
\end{array}
$$

Die rhetorischen Fragen entsprechen denen der Vorlage: "L'attribuerai-je d mon faible esprit...? /scil. la puissance ${ }^{\top}$...croirai-je que ma volonté a cet 
empire suprêne par son propre fonds, elle qui est si faible et si imparfaite?" (S.50) - Ferner geben unsere Autoren 24 bedenken, daß nur der eigene Körper und kein anderer der Macht unseres willens unterworfen ist. Das veranlaBt Tred. zu der Frage:

v,447ff. Почто ж из многих теп впасть над единым ей, Которо тольКо есть В Подяанности своей? Aругое no еe велению недвижно,

Fénelon fragt: "Mais d'ou vient que, parmi tant de corps, elle n'a ce pouvoir que sur un seul? Nul autre corps ne se remue selon ses désirs." (S.50)

So führen die Erwăgungen unserer Autoren von allen Seiten zur Bewunderung des Schópfers, die sie nach biblischem vorbild sehr oft in die Form der 'WerFrage' kleiden:

V,451f. Кто ж силм над одним ей телом столько дал? И кто подвластным бшть одно ей предмз6рал?

Diese besondere Art, Gott $2 u$ loben, findet sich auffallend oft im Buche Hiob. In der Demonstration wird mit der theistischen 'Wer-Frage' die zufallsthese der Materialisten abgewiesen: "Qui lui a donné sur un seul corps ce qu'elle n'a sur aucun autre? osera-t-on encore revenir a nous alléguer le hasard?" (50) V,453-534: Auch die unbewuBten Handlungen des Geistes im Köper weisen auf den Schöpfer hin.

Die Macht des Geistes über den Körper ist nicht nur 'souverăn', sondern zugleich 'blind', erklart Tred. im AnschluB an seine Vorlage:

\section{V,453 Господственная власть ее слепа есть равно:}

Vgl.: "Cette puissance, qui est 81 souveraine, est en neme temps aveugle" (50) rred. verdeutlicht diese Aussage mit drei Beispielen, die er aus der Demonstration ubernommen hat.

Zunăchst weist er darauf hin, daB sich ein einfacher Bauer auf seinem Acker ebenso tuchtig bewegt wie ein gelehrter Physiologe bei seiner Arbeit. Der Geist des 'elnfaltigen Mannes' herrscht uber seine kxafte, Glieder und Sehnen, die er selbst nicht alle kennt. Er wendet sie richtig an, ohne sie miteinander zu verwechseln:

V,454ff. Простшй поселянин умеет столько ж справно

всё тело обращать по воле в свой залот,

Искусншй - Аеле том коль сам физиолог.

Es kommt in dem Beispiel nicht darauf an, daB der Bauer und der 'Physiologe' unterschiedilch qualifizierte Berufe haben, sondern dab die körperlichen Be- 
wegungen der beiden unabhăngig von ihrem wissen uber anatomische und mechanische Zusammenhănge, das bei beiden sehr verschieden ist, vor sich gehen:

У,457ff. Ум простака того повелевает силам,
И членам тела всем, и совокупно жилам,
А сам не знает их, ниже́ слыхал о тех,
Ни их разделов он не ведает же өсех;
Однак, потребш как, порядком обретает
И за другуо ту микак не принимает.

Das Beispiel ist in der Demonstration vorgegeben: "Le paysan le plus ignorant sait aussi bien mouvoir son corps que le philosophe le mieux instruit de l'anatomie. L'esprit du paysan commande à ses nerfs, a ses muscles,...qui ne connaIt pas... Sans pouvoir les distinguer, et sans savoir ou ils sont, il les trouve; il s'adresse précisément à ceux dont il a besoin, et il ne prend point les uns pour les autres." (S.5O)

Ferner wird die unbewuBte Herrschaft des Geistes uber den Korper am Beispiel eines Seiltănzers veranschaulicht. Mit etwas anderem Akzent ist der Vergleich schon bei den Instinkthandlungen der Tiere (III,361ff.) herangezogen worden. Tred. schildert den Auftritt des Artisten. Kaum schickt dieser sich an, sein Kunststūck vorzufüren, als auch schon alle Sehnen, Gelenke und jeder Teil des Korpers vom Geist in Bewegung gebracht werden. Der Seiltănzer weiB selber nicht, wie es zugeht, und wie sich sein korper bei der vorfürung streckt und biegt:

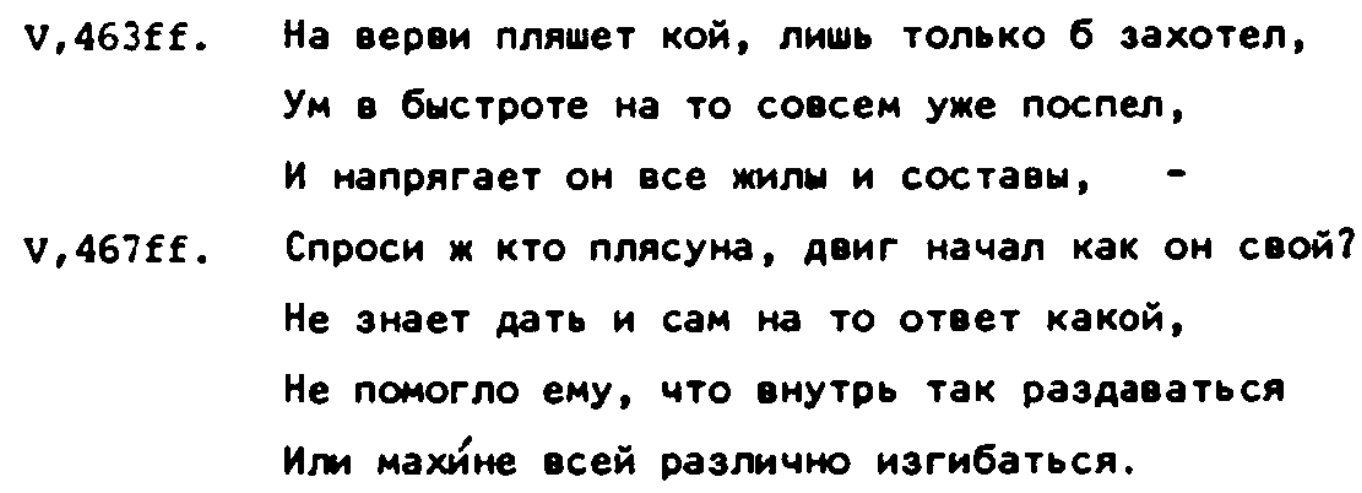

Die Schilderung rred.s stimmt inhaltlich mit der Vorlage uberein: "Un danseur de corde ne falt que vouloix, et a l'instant les esprits coulent avec impátuosité,...tous les nerfs se tendent ou se relachent a propos...Demandez-lui quels sont ceux qu'il a mis en mouvement, et par ou 11 a comencé a les ébranler; 11 ne comprena pas même ce que vous voulez lui dire; 11 ignore profondément ce qu'il a fait dans tous les ressorts intérieurs de sa machine."(S.50f.)

In der Diskussion uber das Wesen der Reflex- und Instinkthandlungen vertre- 
ten unsere Autoren, wie das Selltanzer-Glelchnis zelgt, die Auffassung, daB die Bewegungsmechanismen beim Menschen zwar unbewuBt, aber vom Geist und willen verursacht verlaufen. Dadurch untorscheiden sie sich von dem AutomatenBegriff Descartes', "der dadurch ausgezeichnet 1st, daß seine sămtlichen Funktionen durch die klaren Gesetze der Dynamik erklărbar sind." 22 Unsere Autoren verdeutlichen ihre abweichende Ansicht wohl nicht zufallig mit dem Bild des Selltanzers. Vermutlich bezieht es sich auf den von Descartes in seinen 'Cogitationes privatae' vorgelegten Entwurf elner automatischen Seiltănermaschine. 23

Das folgende Beispiel soll wohl zeigen, das die 'unbewubte Herrschaft' des Geistes machmal dem bewußten Tun des Menschen überlegen ist. Tred. erzăhlt von einem Lyraspieler: er kennt jede Saite seines Instruments und sieht beim Spielen hin. Trotzdem greift er manchmal einen falschen Ton. Dagegen regiert unser Geist den Körper, ohne sich zu irren. Er kennt weder die Natur der Bewegungen, noch weiB er wie sie entstehen; aber er gebietet daruber, und ohne ihn kommen sie nicht zustande:

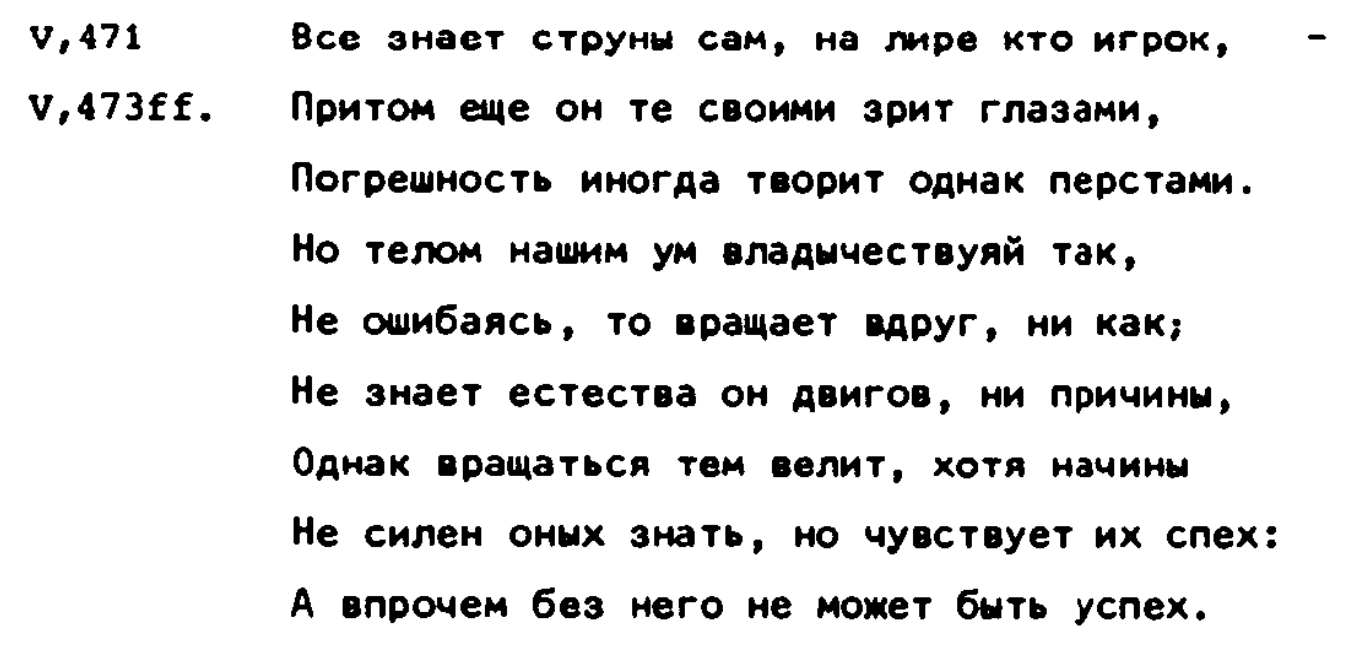

Das Bild entspricht der Vorlage. Dort heibt es: "Le joueur de luth, qui connalt parfaitement toutes les cordes de son instrument, qui les volt de ses yeux,...s'y méprend: mais l'ame, qui gouverne la machine du corps humain, en meut tous les ressorts à propos, sans les voir...; et elle ne s'y mécompte point." (S.51)

Die 'unbewabte, blinde' Herrschaft des Geistes veranlaBt Tred. Ebenso zu der physikotheologischen Frage wie die vorher gezeigte 'souverăne' Macht des Geistes uber den Körper:

V,481f. По чьей же власти то, я вопросить желаю?

Кому ту приписать, кроме творца, не знар?

Tred. erweltert die Fragen $z u$ dem persónlichen Bekenntnis, daß der Schópfer 
'alles sieht, was der Mensch nicht sieht und alles schafft, was der Mensch nicht kennt'. 'Ihm allein sind alle diese Handlungen klar, die ich nicht verstehe':

V.483ff. Он вияит всё, чего сам человек не зрит
И сам чего не весть, создатель то творит;
Мне действа все сии бшварт непонятны,
Единому тому быть долюенствуот внятны.

Die Verse stimmen inhaltlich mit der Démonstration aberein, sind aber durch ihre persónliche Ausdrucksweise charakterisiert. In der Vorlage hat die Passage diesen Wortlaut: "Que d'aveuglement! que de puissance! I'aveuglement est de l'homme; mais la puissance, de qui est-elle, a qui l'attribuerons-nous, si ce n'est a celui qui volt ce que l'homme ne voit pas, et fait en lui ce qui le surpasse?" (S.51)

In v,487-498 wird die schon vorher (, $447 f f$.$) erwāhnte Tatsache, daB der$ Gelst und wille eines Menschen nur uber den eigenen Korper Herr 1st, naher ausgeführt. So gern unser Geist alle anderen korper, die uns ungeben, und die wir genau kennen, 'bewegen' mochte: nux der eigene korper gehorcht ihm. Von den anderen korpern gilt:

v,491f. Но ни оАно из них, по воле той его, Не ходит никогда в деиг с места сөоего; -

Tred. verdeutlicht die Begrenztheit unseres willens auf den eigenen korper mit einem im russischen Text ins Auge fallenden Wortspiel: kein Staubkornchen erhebt sich, kein Grashalm zittert auf Befehl unseres willens:

v.493f. Не может повелеть пояняться еверьх пилинке,

Ни, чтоб тряхнулась хоть одинажды, былинке; -

Fénelon schreibt: "Mon ame...n'a aucun pouvoir pour ébranler le moindre atome par sa volonté..." (Démonstr.,s.51)

Hieran schlieBt sich ein Augustin-zitat, als dessen Quelle Fénelon 'De Anima et ejus orig., lib.IV, cap.V.VI, $n^{\circ} 6,7$; t.x. angibt. Das zitat wird mit den Worten eingeleitet: "Saint Augustin, qui a fait ces réflexions, les a parfaitement exprimées." (Démonstr.,S.51)

In der Feoptija fehlt die quellenangabe des zitates. Es wird so gekennzeichnet:

v, 499f. Сие приметив всё, в учителях не мал

0 действиях души словами так сказал:

Warum Tred. Augustin nicht nennt, lät sich wohl kaum aus Rücksicht auf die zensur erklaren. Auch Lomonosov hat Augustin, z.B. In dem 'nnçmo o noльзe стекла' zitiert. Im 'Сеодний каталог русс. книг гражданской печати XVIII в.' 
Nr.5909 (Bd.III,1966,S.24) findet sich ein 'Реectp материям содержанимся в сочинениях Блаженнаго Августина, напечатанных на российском языке!, Spbg.0.J., gedruckt in der synodaltypographie, nach 'Сеодншй kaтanor', s.25inicht vor 1795.

Als Zitat eines 'nicht unbedeutenden Lehrers' hat Tred. nux die Verse 501-516 kenntlich gemacht. In den Versen 517ff. wird abex das zitat mit geringfugigen Ainderungen fortgegetzt.

Der Kirchenvater meditiert an der genannten Stelle darüber, das unsere Seele zwar alle Teile des Korpers belebt, aber nichts uber sie weiB. Tred. zitiert: v,501ff. "He могут цели бшть и мивн без напасти, Как токмо от Ауши, все внутренние части, Но легче может аух наш оны оживлять, Неж знании об них себя сам сподоблять."

In der Démonstration beginnt das Zitat folgendermaßen: "Les parties internes de nos corps... ne peuvent etre vivantes que par nos ames; mais nos ames les animent bien plus facilement qu'elles ne peuvent les connattre..." (S.51) In einer Reihe von satzen auBert sich Auguotin ubcx das ihm ratselhaft erscheinende Nichtwissen der Seele von den willkürlichen und unwillkurlichen Bewegungen des mit ihr vereinigten Körpers. Tred. zitiert:

V,505 "Не знает членов всех внутри се6е подвластных Ни аля чего, не весть, всяк движется состав,

ЕГО Приняе указ И нУАячий устав; -"

In der Reflexion Augustins heiBt es weiter: der Gelit weiB nicht wie es komt, daB die Adern die Kraft haben, unaufhorlich ihre Arbeit zu tun:

v,509f. 'Ниже́ причины той, что непрестанно жилы

На действие свое имејт точны сила -11

Fénelon hat die Uberlegungen Augustins uber die willkürlichen und die unwillkūrlichen Bewegungen so wiedergegeben: "L'ame... ne sait point pourquoi elle ne met les nerfs en mouvement que quand 11 lui plart, et pourquol au contraire la pulsation des veines est sans interruption, quand nême elle ne le voudrait pas." (Démonstx. .s.51)

Tred. setzt das zitat fort: der Geist weiB nicht, warum er 'unwillkülich' empfindet, wahrend ex die Körperteile willkülich bewegt:

$$
\text { v,513f. "Hе знает, отиего в нем чувство не по воле, }
$$

А члены двимет все, когда есть в произволе, -"1

In der Démonstration steht: "L'ame... ne sait point pourquoi elle sent malgré 
elle, et ne meut les membres que quand il lui plait." (S.51f.) Fenelon fahrt, den Kirchenvater zitierend, fort: "C'est elle qui fait ces choses dans le corps. D'ou vient qu'elle ne sait ni ce qu'elle fait, ni comment elle le fait?" (Démonstr.,S.52)

Dementsprechend übersetzt Tred.:

$$
\begin{aligned}
& \text { V,515f. "Зависит от Ауши, но та не весть сама, } \\
& \text { Что действует и как и Аля чего весьма". }
\end{aligned}
$$

In der Feoptija ist hier das Ende des zitats der Worte des ungenannten, aber 'bedeutenden Lehrers' angezeigt. Aus der Vorlage ergibt sich, daß auch der Passage V,517-528 die Meditation Augustins zugrunde liegt.

Hier laBt Tred. einen 'durch seine Kunst berühmten', in der Wissenschaft führenden 'Anatom' darüber reflektieren, wie es $2 u$ erklären sei, daß er 'den ganzen Himmel, die Sonne und den schónen Schmuck der Sterne' mit einem Blick erfassen kơnne, 'ohne dazu einen Lehrer notig zu haben'. Warum muB ich studieren, fragt ex sich, um $2 u$ erkennen, wie eine Bewegung in mir entsteht? Ich

\begin{tabular}{|c|c|}
\hline$v, 517 f$ & Анатомист, Своим Искусством всюду Славнжй, \\
\hline \multirow{8}{*}{$v$, s21ff. } & Аругими научен и стал в науке главный \\
\hline & Твердит: нет нужА, тому 4 то 6 у коГО учиться, \\
\hline & Что расстояньми вдаль могло толь отлучиться- \\
\hline & Весь неба, солнца, зеезд толь красный в виА убор,- \\
\hline & Единым езглядом се мой постигает взор. \\
\hline & Почто ж мне нумно есть учиться, Аа позма́о, \\
\hline & Откуду Авиг во мне, того не постигаю? \\
\hline & $\begin{array}{l}\text { Коснулся К персту я, однак не знаю как, } \\
\text { А делается всё в угодность мне и так; - }\end{array}$ \\
\hline
\end{tabular}
beruhre meinen Finger, aber ich weiB nicht, wie das geschieht:

Die Herkunft dieser Meditation ist durch die Vorlage erwiesen: "Ceux qui s'instruisent de l'anatomie, dit encore ce Pere, apprennent d'autrui ce qui se passe en eux, et qui se fait par eux-mêmes. Pourquoi, dit-il, n'ai je aucun besoin de legon pour savoir qu'il y a dans le ciel, a une prodigieuse distance de moi, un soleil et des étoiles? et pourquoi ai-je besoin d'un maltre pour apprendre par ou commence le mouvement, quand je remue le doigt? Je ne sait comment se fait ce que je fais moi-meme au dedans de moi." (S.52) Das zitat endet mit einem Satz Augustins, den Tred. nicht ubernommen hat: "Nous somes trop allévés a l'égard de nous mêmes, et nous ne saurions nous comprendxe." (52)

Von Augustin inspiriert erscheint die zusamenfassung des Abschnitts, in der 
unsere Autoren ihre Bewunderung für die Macht des Geistes über den Körper ausdrücken. Weil diese Macht auch die unbewuBten Handlungen bestimnt, weist sie uber sich hinaus auf den schöpfer:

V.531ff. Душевной власти сей ная телом всем моим, Над членами его, что совокупны с ним, Как не Аивиться мне весьма и непрестанно?

Та Аействует всем им, не зная как, то странно!

Vgl.: "En effet, nous ne saurions trop admirer cet empire absolu de l'ame sur des organes corporels qu'elle ne connait pas, et l'usage continuel qu'elle en fait sans les discerner." (Démonstr.,S.52)

V,535-710: Die Macht des Geistes uber den Körper wird am Phănomen der Vorstellungskraft (Gedăchtnis und Erinnerung) beispielhaft verdeutlicht.

Am Anfang wird das Thema hervorgehoben: jene Macht des Geistes ist vor allem in der im Gehirn lokalisierten Vorstellungskraft sichtbar:

$$
\text { V.535f. В образовани та сперва явна́ есть власть; }
$$

Образований мозг в союзе главна часть.

Die Verse geben den einleitenden Satz der Vorlage wieder: "Cet empire se montre principalement par rapport aux images tracees dans notre cerveau." (S.52)

In den Versen V,537-556 spricht Tred. vom Gedăchtnisinhalt.

Er besteht, so wird ausgeführt, aus den 'Bildern der Dinge', die man wahrgenommen hat, und die sich im Grunde des Gehirns festgesetzt haben. 'Ich sehe sie alle in meinem Geiste so deutlich, als waren sie selber in mir unversehrt gegenwartig' :

V,539ff. Я образы вещей, поятых уж давно

И всельшихся, не вем как, в мозговое Ано,

Зро в мысли все моей и зро еще раздельно,

Как сами 6 те внутри присутствовали цельно.

Bei Fénelon lautet die Stelle: "Je connais tous les corps de l'univers qui ont frappe mes sens...: j'en ai les images distinctes qui me les represent, en sorte que je crois les voir lors même qu'ils ne sont plus." (S.52) So gleicht das Gedächtnis einem 'mit FleiB geschmückten Schatzkasten' :

v,543f. Так память есть во мне, как $6 \mathrm{ы} \mathrm{ковчег} \mathrm{какой,}$ Нарочно распещрен, да будет Он Арагой, Die Metapher 'ковчеr' stammt nicht aus der Vorlage. Fénelon vergleicht das Gehirn mit einer 'Gemăldesammlung': "Mon cerveau est comme un cabinet de peintures..." (Démonstr.,s.52) 
Diese Metapher nimmt Tred. in den folgenden Versen auf:

$$
\begin{aligned}
& \text { V,545f. Где все картина те в порядок становятся, } \\
& \text { Как господину есть угодно, Аа вместятся; - }
\end{aligned}
$$

Die Bilder des Gedăchtnisses ubertreffen die der besten Maler, stellt Tred. in Ubereinstimmung mit der Demonstration fest. Sie zeichren sich durch 'lebensechte Farben' aus und entsprechen genau der wirklichkeit:

$$
\begin{aligned}
& \text { V,547ff. Зографи ясно толь не могут нмкогаа } \\
& \text { Изобразить, ниме в безмерности труда, } \\
& \text { Коль Образш в моей главе бмваот точны } \\
& \text { И живностьф чветов и сходством узорочны. }
\end{aligned}
$$

Bei ihrer Betrachtung kann man etwaige Fehler finden und korrigieren:

V,551ff. Koraа смотріо на них и взор к ним возвожу,

То, буде в коей есть, погрешность нахому,

А разбирая ту, как должно иеправляю, -

Tred. faßt zusammen: die Gedăchtnisbilder sind an Vollkommenheit allen Künsten uberlegen:

v.555f. Все действа по себе образований сих

Свершенством вшше суть искусств хоть бы каких; -

In der Demonstration hat der Vergleich zwischen den Bildern der Maler und denen, die im Gedăchtnis aufbewahxt werden, diese Form: "Les peintres, par leur art, $n$ 'atteignent jamais qu'a ressemblance imparfaite pour les portraits que j'al dans la tête; ils sont si fidéles, que c'est en les consultant que j'aperçois les défauts de ceux des peintres, et que je les corrige en moimame. Ces images, plus ressemblantes que les chefs-d'oeuvre de l'art des pointres, se gravent-elles dans ma tate sans aucun art?" (S.52)

V,557-568: Das Gedăchtnis ist ohne unser Zutun entstanden.

Die rhetorische Frage der Vorlage: "ces images...se gravent-elles dans ma tête...?", hat Tred. in eine Aussage umgeformt:

$$
\begin{aligned}
& \text { v,557f. К нам в головы они вливаются собор, } \\
& \text { Не бывши влеченм в ту силою какою. }
\end{aligned}
$$

Im folgenden wird von neuem die Buchmetapher herangezogen, die bereits in IV,566-587 für das Gedăchtnis ausgewertet worden ist und dafür nochmals in V,667-696 in Anspruch genommen wird.

In der vorliegenden Passage unterstreicht Tred., daß die unzahlbaren Buchstaben in dem 'großen Buch' des Gedăchtnisses ohne unser Zutun zusammengekommen sind: 
V,561f. А ито Аивняй, собой в ту собрались все книгу,

Без нашего $\mathrm{K}$ тому чувствительного Авигу.

Dies ist die Antwort auf die rhetorische Frage Fenelons: "...est-ce un livre dont tous les caractéres se solent rangés d'eux-mêmes?" (Démonstr.,s.52)

Unsere Autoren bestreiten die Annahme, der Mensch habe sein Gedachtnis bewuBt aufgebaut. Die Metaphern 'Buch' und 'Bilderkabinett' enthalten zwar, auf das Gedăchtnis bezogen, die Vorstellung, es sel durch das planmäige Sammeln von Gedanken und Eindrüken vom Menschen selber geschaffen worden. Dies wird aber ausdrücklich verneint. Fénelon schreibt: "S'll y a de l'art, 11 ne vient pas de mol; car je trouve au dedans de mol ce recueil d'images sans avoir jamals pensé ni a les graver, ni a les mettre en ordre." (Demonstr.,s.52)

Tred. hat die Verneinung der eigenen bewuBten Beteiligung am Entstehen des Godăchtnisses nachdrücklich erweitert:

v,563f. Сие искусство всё не от меня взялось:

Не чувствуо отніэдb, чтоб то во мне велось.

Er fügt hinzu: ich sehe in mir eine sehr große Ansammlung von Bildern, aber keine kunstfertigen Hande, die sie gemacht haben:

v,565f. Собрание енутри зрш вияов я премногих,

Не зря рук никаких, те сделавших, худогих; -

AuBerdem wiederholt er das Argument Fénelons:

v,567f. He ayman никогда я онш собирать,

Ни вкоренить в себя, ни в чин их учреждать; -

V,569-666: Das Erinnerungsvermogen ist dem Willen unterworfen.

wahrend die Gedăchtnisbilder sich ansameln, ob wir wollen oder nicht, brauchen wir unseren willen, um sie uns zu vergegenwartigen:

V,569f. A представлан все себе когда угодно

И то еще во өсем, как прежде были, сходно.

Das Willensmoment der Erinnerung ist auch von Fenelon hervorgehoben worden:

"Mais encore toutes ces images se presentent et se retirent comme 11 me plaft, ..." (Démonstr., S.52)

Wie die Bilder auf GeheiB des Willens kommen und gehen, haben unsere Autoren schon bel dex menschlichen Physiologie beschrieben (IV,574ff., bzw. Démonstr.. S.45). Hier wird es z.T. wiederholt:

v,577ff. \& токмо что всегда их нахому готових, При старих образа́х премномество и новнх.

По воле все моей встая приходат варуг, 


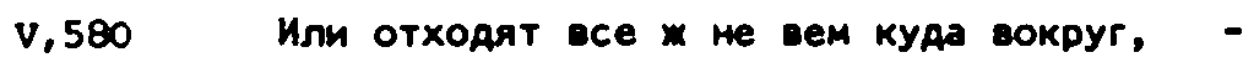

Trotz ihrer groben zahl storen sich die Erinnerungsbilder nicht gegenseitig, da sie, wie Tred, eigens vermerkt, goradozu in militarischer Formation goordnet sind:

V,581f. Ho He mewant GwTb Apyr Apyry a tom nopagke,

В котором долг стоять, Как В некоем десятке.

Den Vergleich 'как в некоем десятке' hat Tred. dem Text der Vorlage hinzugefugt. Hiex heibt es: "L'agitation de tant d'images anciennes et nouvelles qui se réveillent, qui se joignent, qui se séparent, ne trouble point un certain ordre qu'elles ont." (S.53)

Anschaulich wird geschildert, wie sich manche Erinnerung erst nach mehrmaligem Bemulhen einstellt:

v.583ff. По первой воле как предстать $и$ не спешат,

Оанак уеерен $я$, что не вдалм лежат:

Искать их долг еще и призыеать вторично,

А буде нумно есть, то Аолг зеать и третично.

Durch die Betonung des mehrmaligen Suchens hat Tred. den Text der Vorlage erweitert: "Si quelques-unes ne se présentent pas au premier ordre, du moins Je suis assuré qu'elles ne sont pas loin." (S.53)

Die Dinge, nach denen ich in meiner Erinnerung suche,sind mir nicht ganz und gar unbekannt, als hăte ich sie nie zuvor gesehen, reflektiert Tred.:

v,587f. Hе так не знах их, как коих не знавал

И никогда отноды глазами не өидал; -

Ex fahrt fort: 1ch kenne sie aber nicht deutlich (He rouнo,589) oder nur tellweise (отчасти,590). Das restliche wissen, das ich noch von ihnen habe, genügt jedoch, um sie wiederzuerkennen, oder un das abzuweisen, wonach ich jetzt nicht gesucht habe. Der innere vorgang kamt in lebhafter und volkstimlicher Redeweise zum Ausdruck:

V,591ff. पего искал, но как не то яеится мне,

To rosops я внутрь и вем, что не во сне:

"Прочь-прочь, я не тебя искал теперь заботно".

Fénelon hat diese Reflexion so ausgedruckt: "...je sais confusément ce que je cherche. Si quelque autre image se présente en la place de celle que $f$ 'ai appelée, je la renvole sans hésiter, en lui disant: Ce n'est pas vous dont f'ai besoin." (Demonstr.,s.53) 
In V,594-618 geht es um das Problem des 'Vergessens'.

Im AnschluB an die Vorlage fragt Tred., wo denn die Dinge seien, die wir vergessen haben:

V.594 Ho rде $*$ те вещи суть sабытые толь плотно?

Das Adverb 'плотно' (fest, sicher, dicht, Pawl.1065) kennzeichnet hier die subjektive Meinung; denn der Kontext sagt aus, daß man sich der scheinbar 'fest vergessenen' Dinge doch schlieblich erinnert:

V.595f. Bо мне конечно все, затем что нахому

И сысканных енутри пред взор я привожу.

Fénelon versichert, daB die 'halb vergessenen' Dinge nur in mir selber gablieben sein können: "Mais où sont donc ces objets a demi-oubliés? Ils sont présents au dedans de moi, puisque je les $y$ cherche, et que je les y retrouve." (Démonstr.,s.53)

Warum muBte ich aber so lange nach ihnen suchen, fragt Tred. weiter:

V,597 Почто ж искал я толь? и где те пребывали?

Vg1.: "Enfin, comment y sont-ils, puisque je les cherche longtemps en vain?" (S.53) - Hier fügt Fénelon wieder ein zitat aus Augustins 'De Anima et ejus orig.' ein (lib.IV,cap.vII, $n^{\circ} 10$ ), das Tred. im wesentlichen ubernommen hat. Auch diesmal gibt er die quelle nicht an.

Dem zitat zufolge meditiert Augustin daruber, daß er mit allem, was er vergesse, ein Stück seiner selbst verliere: "Je ne suis plus, dit saint Augustin, ce que j'étais, lorsque je pensais ce que je n'ai pu retrouver", so leitet Fénelon die Passage ein.

Tred. verăndert den Satz, indem er hinzufügt, daß der 'Substanzverlust' der Person durch das Finden wieder wettgemacht wird:

v,599f. Иным я был совсем, когда я тех искал,

А как их изобрел, не тот тогда ум стал.

Die Verse sind in der Feoptija nicht als zitat ausgewiesen.

Die Meditation des Kirchenvaters umkreist die Fragen des 'Vergessens und Wiederfindens': "Je ne sais, continue ce Père, comment 11 arrive que je sois ainsi soustrait a mol-meme et privé de moi, ni comment est-ce que je suis ensuite comme rapporté et rendu a moi-même." (Démonstr.,S.53)

Tred. hat kurz und bünig ubersetzt:

v,601f. He зна!o, отчего себя я был лишенный

И как потом опять К себе стал возеращенный.

Hierauf folgt ein Zusatz, der in der Vorlage keine Parallele hat: 
V,603f. Кна забиту вень, себя не момем знать, Ни состояний в нас тогдашних постигать: -

In dem zitat heibt es weiter: solange wir etwas suchen, was wir vergessen haben, sind wir uns selbst entfremdet; wir komen erst wieder zu uns, wenn wir das Gesuchte gefunden haben: "... nous sommes come si nous etions des btrangers élolgnés de nous: nous $n^{\prime} y$ arrivons que quand nous trouvons ce que nous cherchons." (Démonstr.,5.53)

Tred. hat diesen Passus amplifiziert:

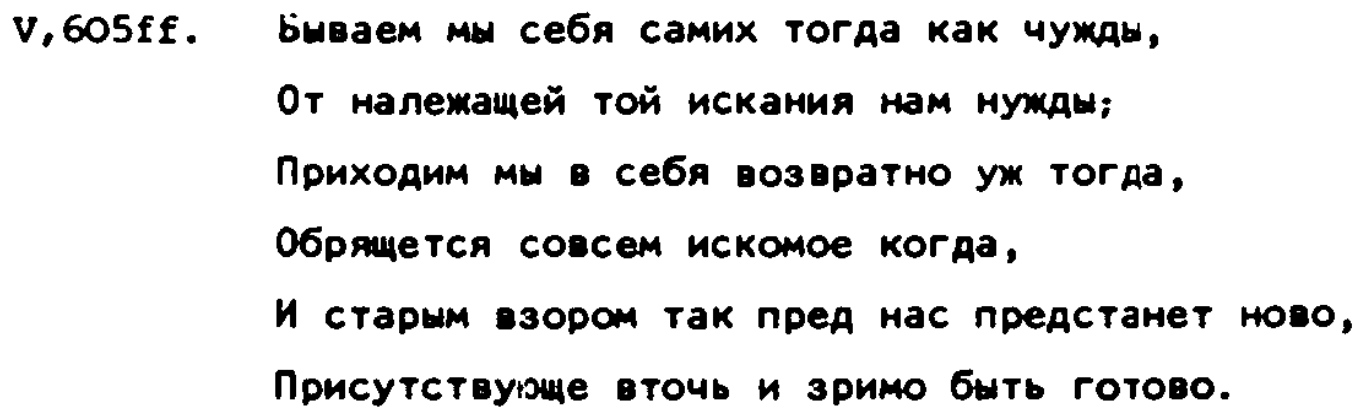

Die umstandilche Erklarung trifft jedoch nicht den meditativen sinn und stil der Augustin-stelle.

Deutlich verandert hat Tred. auch den folgenden Gedanken: "Mals ou est-ce que nous cherchons, 81 ce $n$ 'est au dedans de nous? et qu'est-ce que nous cherchons, si ce n'est nous-mêmes?" (Demonstr.,s.53)

Zwar ist die erste Frage wortlich wbersetzt worden:

$$
\text { V,611 Ho rqe i искали мн, как не в себе самих? }
$$

Dagegen hat die zweite Frage ihren kontemplativen Sinn verloren:

$$
\text { v,612 पего, как не вещей, мы инем внутрь своих? }
$$

Das zitat endet mit dem Ausdruck des Staunens: "Une telle profondeur nous etonne." (Démonstr.,S.53) - Tred. hat dafur noch starkere Worte:

\section{V.613 0 глубине такой мне помнилять ужасно!}

Unsere Autoren halten es fur bemerkenswert, daB wir uns selbst des Vergessens bewrit sind. Das bildet den Anreiz, in der Erinnerung zu suchen und uns scheinbar vergessene Dinge zu vergegenwartigen:

$$
\begin{aligned}
& \text { V.617f. B sабитность помно } 9 \text {, что вспомнить то мне момно, } \\
& \text { и вспомн } 4 \text { то я так, предстанет то неломно. }
\end{aligned}
$$

V,619-666: Der Inhalt des Erinnerungsvermogens: Personen, Sinneseindrucke und Gemutsbewegungen.

An einzelnen Beispielen wird gezeigt, wie die Erinnerung das menschliche Leben gewissermaBen im Zeitraffer zusammenfaBt. Sie stelit uns z.B. einen Menschen in den verschiedenen Lebensaltern vor Augen: jung, erwachsen und mit 
grauen Haaren. Manchmal exinnert man sich sogar an die Kleidung, die er getragen hat: $v, 619 f$. उнакомого личе прея мой я ставло свет,

\section{Bо времена его различншх в мизни лет, -}

V,622ff. И каковш носил он из одемд уборы.

3ро человеком вот спереа я молодым,

Вот старым зро его $w$, потом ум и седым; -

Die Verse sind der vorlage nachgebildet: "... Je me rappelle les portraits de chaque personne en chaque age de la vie ou je l'al ve autrefois...:d'abord je la vois enfant, puis jeune, et enfin agée." (S.53f.)

Ebenso wie das Vergangene vermogen wil uns auch Zukünftiges zu vergegenwărtigen. Dasselbe Gesicht, 'dessen rosige Schónheit ich küsse', sagt Trod., kann ich mir mit Runzeln bedeckt vorstellen:

$$
\begin{aligned}
& \text { v,625f. На том ме я пице мориины образуо, } \\
& \text { На коем красоту румянуо целую. }
\end{aligned}
$$

In der Vorlage steht: "Je place des rides sur le méme visage ou je vois d'un autre côté les graces tendres de l'enfance." (S.54)

Mit Verwunderung vermerkt der Autor, dab unsere vorstellung die verschiedenen zeiten verbindet, unterscheidet, aber nicht verwechselt:

\section{V.629f. Я ळа те края взаимно различам}

И купно их кладу, однак же не мешам.

In V,635-640 werden die Sinneseindracke genannt, die wie ein 'Schatz' in der Exinnerung aufbewahrt werden. Uber die vorlage hinaus zahlt Tred. auch die 'Worte und stimmen' dazu:

$$
\begin{aligned}
& \text { v,635f. Износит из себя сокровище сие } \\
& \text { Все речи, гласш все, вразнь варуг ли обое; - }
\end{aligned}
$$

Ferner bringt die Exinnerung die verschiedenen sinnesempfindungen hervor, die sich dem Gedăchtnis eingeprăgt haben:

$$
\begin{aligned}
& \text { V,637 Износит өсякий вкус, и всякий чвет, и краску, } \\
& \text { v,639f. Всё, были чувства чем когяа порахены, } \\
& \text { И вещи все, в мою что память влохени́. }
\end{aligned}
$$

In der Vorlage lautet die stelle: "De ce trésor inconnu sortent tous les parfums, toutes les harmonies, tous les golts, tous les degrés de lumiere, toutes les couleurs et toutes leurs nuances; enfin toutes les figures qui ont passé par mes sens, et qu'ils ont confiées a mon cerveau." (S.54)

Zu den Erinnerungen gehoren auch die Gemutsbewegungen, von denen in V,640666 die Rede ist. 'Zorn und Liebkosung' (rнes $и$ nacka) sind schon vorab in 
Vers 638 erwăhnt worden. Unsere Autoren legen dar, daß die Gemutsbewegungen in der Erinnerung gewissermaBen die Rollen tauschen. Tred. macht dies am Beisplel der Freude deutlich, die für inn 'vor füf Jahren eine grobe wonne' war. Jetzt aber ist inm die Erinnerung daran 'irgendwie eine Last':

$$
\begin{aligned}
& \text { V,641f Воспоминар ту, когяа хочу я, раяость, } \\
& \text { Лет за пять коя мне била велика сладость: - } \\
& \text { V,645f. Я помно, что весьма бшл весел в оно время, } \\
& \text { Не так теперь и та мне память некак бремя. }
\end{aligned}
$$

Von der zeitangabe abgesehen, unterscheiden sich die Verse nicht vom franzósischen Text: "Je renouvelle quand il me plaft la joie que $j$ 'al ressentie il $y$ a trente ans:...je me souviens d'avoir ets bien aise, et je ne suis point actuellement dans ce souvenir." (S.54)

Auf der anderen Seite verlieren auch Schmerzen und Verluste in der Erinnerung ihre frühere Schăfe: 'sie können mich nicht mehr aufwihlen, ich fühle keine Spur mehr von ihrer Grausamkeit:

$$
\begin{aligned}
& \text { V,647f. } 8 \text { ставло пред себя и скорби и печаль } \\
& \text { И всё, что потерял или чего мне жаль: - } \\
& \text { v,653f. He moryt возмуцать уж moero те ayха, } \\
& \text { Свирепости их всей не чувствуо ни слуха. }
\end{aligned}
$$

Auch damit gibt Tred. im wesentliche den Text der Vorlage wieder: " $D$ 'un autre côté je renouvelle d'anciennes douleurs: elles sont présentes,...mais elles ne sont plus elles-mémes, elles ne me troublent plus, elles sont émoussées." (Demonstr., S.54)

Tred. bezeichnet die ausgestandenen Leiden, in denen vielleicht personliche Erfahrungen nachklingen, sehr expressiv. Er spricht von der 'Grausamkeit' des Leidens (свирепость,654), von der 'rüstigen Qual' (мучительность бодра, 655) und, wit einer an Hiob erinnernden Wendung, von dem 'alle Eingeweide verzehrenden Kummer' (внутренности все снедающая горесть,658).

Im Buche Hiob, Kap. 30,27 steht:

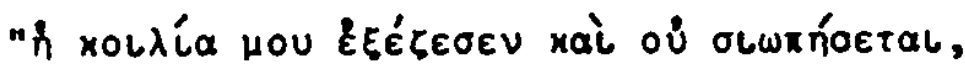

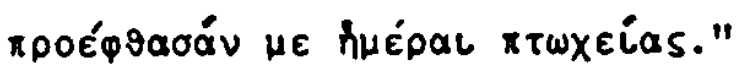

Die Unerbittlichkeit psychischer Leiden wird durch zwei Verbmetaphern hervorgehoben: sie 'stoßen' den Menschen wie 'mit den Bornern' und 'zerstoren' ihn (бодут... тлят,660). 'Бодать' bedeutet 'mit den Hornern stoßen' (Pawl., S.68).

In der Exinnerung sieht man aber die uberstandenen korperlichen und seeli- 
schen Leiden (6onectb,657; горесть,658) in einem anderen Licht:

V,659f. Tеперь уже меня собою веселят, Нимало не бодут, ниме́ нимало тлят, -

Die bemerkenswerte Umkehrung der Empfindungen durch die Erinnerung ist von Fênelon ahnlich beschrieben worden: "Je vois toute leur rigueur sans la ressentir, ou, si je la ressens, ce $n^{\prime}$ est que par représentation,...l'image des douleurs passées me réjouit. Il en est de même des plaisirs." (Démonstr.,S.54) V,667-710: Das Gedăchtnis als Beispiel für das vom Schöpfer bewirkte 'commercium mentis et corporis'.

Das 'Wunder' des Gedăchtnisses wird mit zwei Metaphern umschrieben, von denen die erste seine organische Grundlage, die andere die psychische Funktion bezeichnet:

V,667f. Два чуда я в себе непостижимы зрю.

ОАно, Что Памать есть Как книга, Говоро:

Das Gedăchtnis ist von unseren Autoren mehrfach (zuletzt V,559ff. bzw. Demonstr.,s.52) mit einem Buche verglichen worden, das sehr viele Bilder und Buchstaben enthaalt. Staunend vermerkt Tred., dab ihre sorgfaltige ordnung weder vom Menschen gemacht, noch durch zufall entstanden ist:

V,669 Премного видов в ней вкоренено есть разных,
v,671ff. Внутрь толь все предстоят порядочно пред мной,
Что крайнейше меня Аивят за чин собой;
Однак не От меня учреждены толь срядно,
НИ так мог учреаить припадок их изрядно.

Diese Verse unterscheiden sich durch ihren emotionalen Ton vom Text der Vorlage. Fénelon schreibt: "Volla donc deux merveilles également incompréhensibles; l'une, que mon cerveau soit une espèce de livre, ou il y ait un nombre presque infini d'images et des caracteres rangés avec un ordre que je n'ai point fait, et que le hasard n'a pu faire." (Démonstr.,s.54)

Die Formeln 'nicht von mir gemacht' und 'nicht durch Zufall' werden von unseren Autoren noch besonders unterstrichen:

$$
\begin{array}{ll}
\text { v,675f. Hе тщался никогда я в память вкоренить, } \\
\text { Ни буквы в кните сей в тот чин соеяинить; - (s.v,567f.) } \\
\text { V,679f. Конечно учредить ниме припадок мог: }
\end{array}
$$

Не мудрости Одной в нем нет, Он всем убог,

Fénelon versichert: "Je ne l'ai point fait; car je n'al jamais eu la moindre pensée ni d'écrire rien dans mon cerveau,... Le hasard n'a pu non plus faire 
un si merveilleux livre..." (Démonstr.,S.54)

Die fur die atheistische Weltanschauung typische Zufallstheorie wird in unseren Texten bei feder sich bietenden Gelegenheit zurückgewiesen, ausfünlich z.B. bei der Kosmologie $(I, 211-222)$.

Die Wendung: 'nicht von mir gemacht', scheint auf die Lehre des Raimund von Sabunde hinzuweisen, auf die sich nach Meinung von W.Philipp die Physikotheologen des 17./18. Jahrhunderts hăufig berufen haben. ${ }^{24}$ w.Philipp füht aus, daB R.von Sabunde sich in seinem Hauptwerk, dem 'liber creaturarum' (1436), mit der Moglichkeit auseinandersetze, "daß der Mensch eine sinnlose Zufallsklumpung von Atomen" sei. 25 zur Uberwindung dieser situation habe Sabunde aus der Betrachtung der "Wunderwelt der Geschopfe und Herrlichkeitsvollkommenheit des Schopfers" 26 zwei Aussagen entwickelt: die existentielle Aussage 'Ich-vonGott-gemacht' und die entgegengesetzte 'Nicht-von-mir-gemacht'. Beide sind dialektisch aufeinander bezogen: "Je stärker ich das 'Nicht-von-mir-gamacht' der anderen Geschopfe erkenne und bekenne,... un so vollmăchtiger wird...meine existentielle Aussage 'Ich-von-Gott-gemacht. Indem mir der Schopfer in den Kraturen begegnet, anerkenne ich im Erkennen." 27

Annlich argumentieren unsere Autoren in bezug auf das Gedăchtnis: da es 'nicht von mir gemacht' und nicht 'durch Zufall' geworden ist, erweist es sich als ein 'Wunder' der weisen und măchtigen 'Hand' des Schöpfers:

$$
\begin{aligned}
& \text { v,683f. Чья ж муарая рука в чреждении была, } \\
& \text { Что всё составить то способно возмогла? }
\end{aligned}
$$

Vg1.: "Quelle main donc a pu le composer?" (Demonstr.,S.55)

Die Verbmetapher 'lesen' bezeichnet das 'andere Munder': das Gedăchtnis als geistige Funktion:

V,685f. Aругое чудо есть, как память, рассуждар, Что в книге оной всё способно я читар, -

Unsere Autoren erklären das Zusammenwirken von geistiger Kraft und organischem Substrat in der Gedăchtnisfunktion analog zur willkürlichen korperlichen Bewegung, bei der "aus dem bloBen Willen zu einer bestimmten Bewegung diese folgt" ${ }^{28}: v, 687 f$. Лnub ronbko 6 ro unrarb korpa $g$ saxoren $И$ должнуо $к$ тому прилежность внутрь имел.

Tred. halt sich an seine Vorlage, in der es heiBt: "La seconde merveille que je trouve dans mon cerveau, c'est de voir que mon esprit lise avec tant de facilite tout ce qu'il lui plast dans ce livre interieur." (S.55)

Beide Autoren heben die eigentümliche Diskrepanz hervor, daß auf der einen 
Seite die Substanz unseres Gedachtnisses uns unbekannt ist, wăhrend wir andererseits eine 'beinahe hơhere Gewalt' daruber haben:

$$
\text { V,691 Ни память мне сама известна прямо есть, - }
$$

Fénelon: "...la substance de mon cerveau elle-même,...m'est entièrement inconnue." (Démonstr., S.55)

\section{V,697ff. Почти верьховну власть над тварию имео,}

Да и повелевать ей предержавно смео,

А воль исполнять та и спешит мою,

Что должность так творит немедленно своо.

Fenelon erklart: "...j'ai une puissance come divine sur un ouvrage que je ne connais point....: ce qui n'entend rien entend ma pensée, et l'exécute dans le moment." (Démonstr.,s.55)

Die 'hohere Gewalt' ist aber auf den eigenen korper begrenzt:

$$
\text { v,701 Без власти есть мой ум над прочими телами: - }
$$

Vgl.: "La pensée de l'home n'a aucun empire sur les corps;...Il n'y a qu'un seul corps que ma simple volonté remue, come si elle était une divinité..." (vëmonstr.,S.55)

Das 'commercium mentis et corporis', auf das die Meditation Augustins gerichtet wax, und das von Descartes, wie R.Specht meint, "nicht erklart, sondern auf verschiedene Weise umschrieben" 29 worden ist, wird von unseren Autoren als ein wunder im physikotheologischen sinne verstanden. Ihre Betrachtungen über das Zustandekommen der Bewegungen des Körpers wie uber die Funktion des Gedachtnisses münden in die Doxologie:

$$
\begin{aligned}
& \text { V,707ff. Кто ж с телом мысль мою навек соединил } \\
& \text { И властию ее над оным толь почтил? } \\
& \text { Кто межау ними ту сопряг так и взаимность, } \\
& \text { Что чувствуочих нас всегда приводит в Аивность? }
\end{aligned}
$$

Diese Verse sind eine hymische Erweiterung der Frage, die Fénelon am SchluB des Abschnitts gestellt hat: "Qui est-ce qui l'a unie a ce corps, et lui a donné tant d'empire sur lui?" (Démonstr.,s.55)

V,711-832: Die Vernunft bezeugt sowohl durch inre 'Hoheit' als auch durch ihre Schwachheit die Existenz des Schöpfers.

Mit der Demonstration übereinstimmend, nennt Tred. die menschliche Vernunft 'erhaben' und 'schwach' zugleich:

$$
\text { V,711 По грунту разум наш величествен и слаб: }
$$

Vgl.: "...le fond de notre esprit. J'y trouve un mélange...de grandeur et de 
faiblesse." (Demonstr.,S.55)

In v,711-794 geht es zuerst un die 'Erhabenheit des Geistes' (велмине ума). Unser Geist hat die Făhigkeit, das Vergangene mit dem Gegenwartigen zu verbinden und sich auf Grund seiner Exfahrungen die zukunft auszudenken:

\section{v,713ff. Прошедшее уже не смятно ограняет \\ И с настояним то в себе соеяиняет; \\ Oн проницает так до будущего сам, \\ По настоящим всем и прошлым всем делам; -}

Mit diesen Versen greift Tred. auf die Vorlage zurück: "Sa grandeur est réelle:" il rassemble sans confusion le passé avec le présent, et il perce par ses raisonnements jusque dans l'avenir." (S.55)

Die Hoheit des Geistes erweist sich ferner im Begriffsvermogen. Darauf hat Tred. bereits in $v, 79 f$. hingewiesen. Hier wird die Idee des Unendlichen hervorgehoben:

V,717f. Имеет о себе ияек, и о теле,

И Бесконечном что нахояится отяеле.

vgl.: "...il a l'idee des corps et celle des esprits; il a l'idbe de l'infini mềme...." (Démonstr. .S.55)

Kraft der inm innewohnenden Idee des Unendlichen urteilt der menschliche Geist, daß endliche Dinge wie z.B. gecmetrische Figuxen oder Zahlenreihen nicht geeignet sind, die Unendlichkeit darzustellen. Tred. ahmt die dialogische Argumentation der Vorlage an dieser stelle nach:

v,721ff. Скажи: триангул есть собо0 бесконечность,

Тотчас ответом Он находит тут преречность

И скажет, что границ - ней нету, ни конца,

Тем ни фигурш нет, ни заяа, ни лица.

Fénelon stelltden Dialog mit der eigenen Vernunft so dar: "Dites-lui que l'infini est triangulaire; il vous répondra sans hésiter, que ce qui n'a aucune borne ne peut avoir aucune figure." (Demonstr.,S.55)

Das Unendliche lät sich weder geometrisch noch arithmetisch bestimen. Es ist woder eine unendilche sume von Teilen noch von zahlen. Gegen die Annahme, das Unendliche setze sich aus Teilen zusammen, wendet sich Tred. mit einem Verspaar, das nicht auf der Vorlage beruht:

v, 725f. Cпроси: та состоит коликими частями?

Oн скамет, ито не долг сиислить ее костями:

Auch eine noch so groBe Zahl ist nicht imstande, das Unendliche auszudracken: 
V,729ff. Кто часть одну найти возможет в бесконечном,

Tот найдет и Аругу́ в успехе скоротечном;

ТОТ К оАному числу аругое приложить

И может уж еще на счетах положить.

Fenelon hat ahnlich argumentiert: "...parce que si on pouvait y marquer une premiere ou une derniere unité, on pourrait ajouter quelque autre unité auprès de celle la, et par conséquent augmenter le nombre..." (Démonstr.,S.55) Kurz, das Unendiliche ist durch Endliches nicht definierbar; dagegen erkennen wir das Endliche mit Hilfe des Unendlichen:

V.737 Чрез бесконечность мш конечность познаваем, -

Die Formulierung geht auf Fénelon zurück: "C'est même dans l'infini que mon esprit connait le fini." (Demonstr.,S.56)

Mit einer Reihe von Beispielen, die nach dem Prinzip der Negation gebildet sind, wird diese These verdeutlicht. So wird die Krankheit als Verlust der Gesundheit, die Schwachheit als Mangel an Kraft, die Dunkelheit als Fehlen des Lichts bestimmt:

$$
\begin{aligned}
& \text { V,751ff. Без света тьмы познать не можно есть никак; } \\
& \text { Без здравия того, что есть болезнь; итак, } \\
& \text { Мы знаем, что в себе конечно и предельно, } \\
& \text { Тем - что есть без конца, что вдруг и нераздельно. }
\end{aligned}
$$

Die Passage ist nach dem Muster der Démonstration gebildet: "Ce $n$ 'est donc que la privation de l'infini; et on ne pourrait jamais se representer la privation de l'infini, si on ne concevalt l'infini meme; comme on ne pourrait concevoir la maladie, si on ne concevait la santé, dont elle n'est que la privation. D'oul vient cette idee de l'infini en nous?" (S.56)

Der menschliche Geist transzendiert sich selbst zu seinem Erstaunen durch die Ideen, die er in sich hat. Sie werden als 'allgemein', 'ewig' und 'unwandelbar' charakterisiert:

$$
\begin{aligned}
& \text { V.755ff. В уме есть то само́м, дивился } 6 \text { он чему } \\
& \text { И мог превосходить себя сим по всему. } \\
& \text { Повсемственны его ияеи, купно вечны, } \\
& \text { Пременоо ниже́ не могут быть пресечны. }
\end{aligned}
$$

Die Hoheit des menschlichen Geistes exweist sich vornehmlich darin, daB ihm solche Ideen innewohnen. Damit wird, ohne ausdrückliche Erwăhnung die Auffassung abgewiesen, der menschliche Geist habe die 'Ideen' aus der AuBenwelt empfangen. Fenelon hat sie als Ausweis der 'Hoheit' des Menschengeistes ge- 
priesen: "Oh! que l'esprit de l'homme est grand! il porte en lui de quoi s'étonner et se surpasser infiniment lui-même: ses idées sont universelles, eternelles et immuables." (Démonstr.,S.56)

Das Attribut der 'Universalitat' wird an Satzen der Logik und der Gocmetrie aufgezeigt. Die Satze, daß etwas nicht zugleich sein und nicht sein kann (Satz des Widerspruchs), oder daB das Ganze grober ist als ein Teil des Ganzen, gelten immer und überall:

$$
\begin{aligned}
& \text { v,759f. Kогда скажу: нельзя быть купно и не быть; } \\
& \text { Аолг более өсему единой части слыть; - } \\
& \text { Всем истинам таким быть инако не можно, } \\
& \text { И всё сие везде и повсегда неломно. }
\end{aligned}
$$

Dasselbe gilt von den Satzen der Geometrie:

V,761ff. Без прямизны тот круг, кой круг есть совершенный;

Меж пунктов деух прямый путь больше сокращенный;

Oкруг равно везде от центра отстопт, -

Fénelon konstatiert im Blick auf die logischen und geometrischen wahrheiten: "Elles sont universelles...toutes ces vérités ne peuvent souffrir aucune exception... Ces regles sont de tous les temps, ou, pour mieux dire, elles sont avant tous les temps, et seront toujours au dela de toute durée compráhensible." (Démonstr.,S.56)

Mit Pathos versichern unsere Autoren, daß diese sătze wahr bleiben, 'mag die Welt zerbrechen' und niemand mehr uber diese Wahrheiten nachdenken. Sie sind keinem wandel unterworfen:

$$
\begin{aligned}
& \text { v,767ff. Пусть сокрушится мир и буАет он ничто, } \\
& \text { Пусть рассумдать о сем не станет ум никто; } \\
& \text { Оанак те праван есе останутся собо0, } \\
& \text { Не вредны никогда пременою какою, - }
\end{aligned}
$$

Die Verse stehen im Einklang mit der Vorlage: "Que l'univers se bouleverse et s'anéantisse; qu'il $n^{\prime} y$ ait plus même aucun esprit pour raisonner sur les etres...mais enfin ces verités n'en seraient pas moins constantes en ellesmêmes, quoique nul esprit ne les connat..." (S.56f.)

Die Unabhăngigkeit der logischen und mathematischen Axione vom erkennenden Subjekt wird durch den Vergleich mit den Sonnenstrahlen veranschaulicht: sie scheinen, 'selbst wenn alle Menschen keine Augen hătten, um sie zu sehen': v,775ff. Подобно как лучи от солнца есть светлы И noscerá - себе без өсякие те мглы, 
v,777f. Хотя 6 у всех лодей очей зреть не имелось,

Сияние однак лучей всегда 6 белелось.

Der vergleich stammt aus der pemonstration: "...comme les rayons du soleil n'en seraient pas moins veritables, quand même tous les hommes seraient aveugles, et que personne n'aurait des yeux pour en etre éclairé." (S.57)

Der Vergleich erinnert daran, dab aie von Descartes aufgestellten Kriterien der Wahrheit, 'clarté' und 'évidence' zur Lichtmetapher gehoren.

Die 'ewige' Geltung der unmittelbar einleuchtenden wahrheiten hat Fénelon an der einfachen arithmetischen Gleichung 'zwei und zwei sind vier' aufgezeigt. Er beruft sich auf ein Wort Augustins in 'De Lib.Arb.,lib.II, cap.VIII, $n^{\circ} 24$ et seq.; t.I: "En assurant que deux et deux font quatre, dit saint Augustin, non-geulement on est assuré de dire vrai, mais on ne peut douter que cette proposition $n$ 'ait été toujours également vraie, et qu'elle ne doive l'être éternellement. Ces idées que nous portons au fond de nous-mêmes, n'ont point de bornes et n'en peuvent souffrir..." (Démonstr.,S.57)

Tred. gibt den Inhalt der stelle wieder, ohne sie als zitat auszuweisen:

v,779ff. Что дважаш Ава числом четшре токмо суть,

От вечности сему числу такой был путь.

Не токмо знаем то и твердо мы и прямо,

Но и сомниться всяк не может в нас упрямо,

Что истиною есть от вечности всея,

То не лишится ввек уж правды своея.

Die 'ewigen' Wahrheiten verandern, 'sel es auch nur ein wenig', fügt Tred. hinzu, hieße die Vernunft 'zerstoren':

V,791f. Идей сих правоту хоть чуть-чуть пременять,

То разум наш и смысл с рассуаком истреблять.

"Changer nos idèes, ce serait anéantir la raison même", erklărt Fénelon. (S.57

Kein anderes Geschöpf besitzt solche Hoheit des Geistes wie der Mensch, ruft Tred. am Ende dieses Abschnitts emphatisch aus:

v,793f. Величие ума толико превосходно,

Что чувстауемым всем созданиям несродно!

Fénelon fordert abschließend auf: "Jugeons de notre grandeur par l'infini immuable qui est empreint au dedans de nous, et qui ne peut jamais y être effacé." (Démonstr., S.57)

Die Verse $V, 795-832$ handeln von der 'Schwachheit' des menschlichen Geistes.

Die Betrachtung wird von Tred, so eingeleitet: 
V,795f. Оанак великость та не беспредельна есть:

Далеко от него всесовершенства честь.

Fenelon beginnt den Abschnitt mit der Mahnung, uns angesichts der schwachnelt unseres Geistes vor Uberheblichkeit zu hüten: "Mais de peur qu'une grandeur si réelle ne nous éblouisse et ne nous flatte dangereusement, hatons-nous de jeter les yeux sux notre faiblesse." (Demonstr.,s.57)

Bei der Darlegung der menschlichen 'Schwachheit' geht Tred. im großen und ganzen eigene Wege. Er beklagt zuerst das Versagen der Vernunft gegenüber den Leidenschaften. Sie irrt oft und ist 24 schwach, das Gute 24 wollen:

v,797ff. Протиоится страстям коль сла6о он кипящим,

Коль мало против них бывает бодро баящим!

И заблуждений коль в рассуаностях его!

Без сил хотеть добра - он есть как без всего.

wăhrend Tred. besonders die Schwăche der praktischen Vernunft herausstellt, erscheint in der Démonstration das Nichtwissen und der Mangel an Erkenntnis, der Auffassung Descartes' entsprechend, als Wurzel nicht nur des Irrtums, sondern auch der 'Unordnung' des willens: "Ce meme esprit, qui voit sans cesse l'infini,...s'ignore profondement lui-meme; il marche comme a tatons dans un abIme de ténebres: il ne sait ni ce qu'il est, ni comment il est attaché a un corps...Il ignore ses propres pensées et ses propres volontés...Il se trompe; ...Il joint a l'erreur des pensées le déréglement de la volonté; il est réduit a gémir dans l'expérience de sa corruption." (S.57f.) Uber den ursăchlichen Zusammenhang zwischen der 'Schwachhelt' der Vernunft und dem bosen willen und Handeln des Menschen vgl. das zu V,117ff. Gesagte.

Fux Tred. steht fest, daB die Vernunft wegen ihrer Unvollkommenheit ' $n$ icht aus sich selber' entstanden sein könne. Sie häte sich sonst die höchste vollkommenheit, die sie bei sich vermiBt, beigelegt:

$$
\begin{array}{ll}
\mathrm{V}, 801 & \text { Не ясно ль, что наш ум не от себя стал суиим? } \\
\mathrm{V}, 803 \mathrm{f} \text { К Конечно } 6 \text { он себе верьховнейи те Аал, } \\
\text { Лишенного себя которых внутрь познал. }
\end{array}
$$

Mit dieser Begründung hat Tred. schon in I,93ff. die Meinung verworfen, die menschliche Vernunft sei aus sich selbst hervorgegangen.

Die Kalamitat der Vernunft liegt darin zu wissen, daß es unvergleichlich besser warke, alles zu können und zu wissen, als Kơnnen und wissen mur in begrenztem Maße zu besitzen: 
V,809ff. Он знает, что моия всё - лучше несравненно,

И знать, что 6 было өсё м ему всегда явленно,

А нежели иметь с пределом моць сио

И нечто токмо знать чрез участь ту свою.

Andererseits kann die Vernunft nicht durch zufall entstanden sein:

V,813 C аругой страны, не мог создать ума припадок: -

Der in der Feoptija an vielen stellen geschmahte Zufallsglaube wird in den folgenden versen effektvoll zurückgewiesen:

V,814ff. В безумном не могло премудрых быть догадок.

В бессильном, и кой есть толико слаб и хил,

Не можно обрестись к созданию толь сил.

Избранию в благом был долг, а то пустое,

Не то, чтоб нечто бшл, иль нечто 6 был благое.

Nach dem für die Feoptija typischen Argumentationsschema folgt auf das 'nicht von selbst' - 'nicht durch Zufall' das Bekenntnis zun Schöpfer. Er allein kann ein 'denkendes Wesen schaffen', es mit 'freiem willen' ausstatten und es mit 'einem korper vereinigen', der inm 'gehorcht': die wichtigsten Themen der V.Epistel werden in diesen Stichworten noch einmal aufgegriffen:

V,819ff. Тварь мыслящу создать, тУ вольну сотворить,

И с телом сопрящи, и то ей покорить -

Б̈ть должно есть в творие как силе пребезмерной,

Так благости ж такой и мудрости всеверной.

Die in der Feoptija oft genannte Dreihelt von Allmacht, Allweishelt und Gute entspricht dem Cottesbild Augustins, der darin einen Hinweis auf die Trinitat gesehen hat. 30

Die von Gott geschaffene Vernunft ist in der Lage, aus dem Begriff des Schópfers seine wesentlichen Attribute abzuleiten. zuerst werden genannt:Voll kommenheit und Unendlichkeit:

V,823ff. Созданмый разум сам вещает, что творец

Не ни быть должен есть, как совершен вконец,

Несовершенств в себе, ниже́ отншдь предела

Имеяй, -

Die Vernunft 'lehrt' ferner, daB der Schopfer keine materielle Korperlichkeit hat, sonderr. 'aus sich selbst' als Geist existiert:

V,826f. -

Тем самобштншй Аух, по естеству простый, - 
Die Vernunft weiB aus sich selbst, daB Gott 'von Ewigkeit zu Ewigkeit', 'heilig', 'Anfang und Ende', 'immer wirkende und alleinige Ursache' ist. Er Ist 'über alle wesen, auch über die der unzuganglichen ordnung erhabun': v,828ff. Or века и вовек предсутствуя святый, Начало и конец, өседетельна причина, Превыше всех суиеств и необходна чина.

In Vers 830 sind wahrscheinlich die 'himmlischen Wesen' gemeint.

Tred. identifiziert die Gottesvorstellung der Vernunft mit dem 'lebendigen Gott' : V,831 Но судество сие и есть живуиий боr, -

So wird cott in der Bibel hăufig genannt: z.B. Ps.42,3; Jes.37,4; Jer.5,2; Matth.16,16. Der theologischen Problematik dieser Identifizierung ist sich Tred. offensichtlich nicht bewuBt. Er ist davon uberzeugt, den 'lebendigen Gott' mit der Argumentation aller Episteln seines Poems 'bewiesen' zu haben: $\mathrm{v}, 831 \mathrm{f}$.

- живуций бог,

Доказанншй чрез весь эпистол сих предлог.

'Mpeanor' ist von Mikl. (724) belegt und mit gr.'prothesis', lat.'propositio' übersetzt worden.

tber das 'Beweisen' der Physikotheologen urteilt W.Philipp, es "ist in Wirklichkeit ein irrationaler Bekenntnisakt". "31 sie bewegen sich, so Philipp, in einem 'theologischen Zirkel': der Glaube an den Schöpfer wird bei der glăubigen Betrachtung der Welt immer schon vorausgesetzt. Nach Meinung von Philipp ist aber zwischen Physikotheologie und Thoologia naturalis deutlich zu unterscheiden: "Schliebt jene a posteriori aus der Fulle der Welt auf Gott, so will diese auf dem Wege apriorischer Vernunftschlüsse Existenz und Eigenschaften Gottes exweisen." 32

In der Feoptija ist die apriorische Richtung hauptsăchlich in der I. und VI. Epistel vertreten. Wie die Passage V,823-832 zeigt, trifft man sie aber hin und wieder auch in den ubrigen Episteln an.

V,833-850: In einer an Evsevif gerichteten Apostrophe preist der Autor den schópfer angesichto seiner herrlichen Werke und klagt die Gottlosen an, weil sle aus bösem willen davor die Augen verschlieBen.

DaB Tred. von Zeit zu zeit den Namen des fiktiven Adressaten nennt, ist zunăchst in der Epistelform der Feoptija, mit der sie literarischen Vorbildern folgt, begründet. Zugleich bietet der Name des Partners dem Autor Gelegenheit zu einer intimen Sprache, die sich hier im persönlichen Bekenntnis und in dex 
Anklage der Gottesleugner aubert.

Evsevif solle nicht meinen, sagt der Autor, es sei bloBe 'Neugier', d.h. rein theoretisches Interesse, das urss veranlabt, cott in der Natur zu sehen:

v,833f. Не мни, Евсевий, быть простым то любопытством,

Что бога можем зреть естественным всем бытством; -

Vielmehr reiBt uns die 'Erhabenheit aller Geschopfe' zur Bewunderung hin, bekennt Tred. :

V,835ff. Великость тварей есех, пред нас что предстает,

Такуо о творие идер подает,

Что невозможно есть тому не УАивляться -

Die Verse wiederholen das physikotheologische Credo: alle Kreaturen stellen uns Gottes Dasein und Wesen vor Augen, so daB wir nicht anders können, als ihn zu bewundern. Es gibt eine 'analogia entis' zwischen der schöpfung und ihrem Schopfer. So ist z.B. der unendliche Raum ein Gleichnis der Unendlichkeit Gottes. Seine Weisheit erkennen wir in allem 'Vernünftigen', seine Güte in allem Guten:

V,839ff. Пространством аля вещей безмерность мы его,

Премудрость познаем от дельного всего;

Избранием доброт благуо зрим в нем воло -

Der Autor erklart, es sei inm unbegreiflich, wie man angesichts der Schönheit der Schopfungswelt in 'solcher Blindheit der cottlosigkeit' beharren kann:

v,843f. Не вем, как можно бшть толикой слепоте

Безбожия, при сей созданий лепоте? (S.I,67ff.)

Der Unglaube kann sich nicht darauf berufen, daß es an einer deutlichen offenbarung cottes fehle. Er ist im bossen willen verwurzelt, der mutwillig die Augen vor der sichtbaren Herrlichkeit des schopfers verschliebt:

V,847f. Поистине здесь всяк божественну зрит власть,

Но отрицает кой ту чрез извольну страсть, -

Tred. wirft den cottesleugnern vor, sie wollten einfach nicht, daß Gott existiere, damit sie ungestraft 'zuchtlos' leben kơnnen:

$$
\begin{aligned}
& \text { v.849f. Котора бога быть отнодь бы не желала, } \\
& \text { Чтоб, мести не боясь, бесчинием пилала. }
\end{aligned}
$$

'Бесчиние' wird von Mikl. (20) mit gr. 'ataxia', lat. 'incontinentia' wiedergegeben. Die Wendung 'мести не боясь' deutet die biblische Vorstellung des Jünsten Gerichts an.

V,851-870: Der trügerischen Sicherheit der Gottlosen wird das Bekenntnis zur Existenz Gottes und zur Unsterblichkeit der seele entgegengesetzt. 
Der Abschnitt beginnt im Stile einer prophetischen Unheilsankundigung:

V,851 Но Аа трепещет внутрь вся беззаконий лесть!

Ein biblisches Beispiel für diese Redeform 1st etwa Jesaja, Kap.32,11:

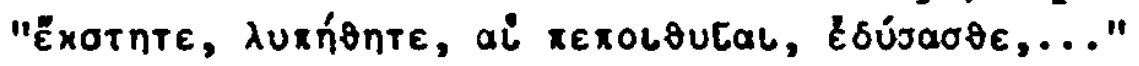

Dem 'gottlosen Betrug' und denen, die sich ihm ergeben haben,wird zweierlei entgegengehalten: der 'heilige und gerechte' cott existiert, und die uns von ihr qeschenkte Seele ist unsterblich:

v,852f. Не токмо всесвятнй и прадедншй бог есть, Бессмертна и душа, от бога нам пода́нна; -

Darum gibt es kein Entrinnen vor dem Gericht Gottes.

Die Unsterblichkeit der Seele wird philosophisch aus der Prámisse abgeleitet: die seele ist eine unteilbare substanz:

V,859f. Простое, как Ауша, есть без частей рояство, Бессмертно есть затем аушевно сунество.

Der materielle Korper hingegen zerfallt durch den Tod in viele Telle:

v,857f. Телесна смерть тела́ решит на многи части,

Так умирахт те от таковой мапасти; -

Das philosophische Argument wird durch einen AnalogieschluB a minore ad maius erhartet: selbst der Körper wird nach dem Tode nicht einfach ein Nichts, sondern löst sich in die Grundstoffe auf, aus denen er besteht. Wie sollte die Seele, die doch von hoherer Art ist als der korper, in der 'Gelst und verstand blühten', im Nichts vergehen? rred. schlieBt sentenzartig:

V,867ff. Умерше тело есть по смерти не Ничто:

Тем момно ль не сказать о аухе больше то?

Не умирает аух по той телесной смерти:

Безместно, чтоб раздел частей того мог стерти.

V,871-900: Die Unsterblichkeit der Seele 1st im Wesen Gottes begründet.

Der Glaube an die unsterblichkeit der seele beruft sich theologisch zuerst auf die Allmacht cottes:

V,871ff. Итак, на мал конец, дотоль Аух будет мив, Аоколь всесильншй бог, господь благолюбив, В ничто не превратит, родством души не мертвой, -

Das entspricht biblischer Auffassung, wie sie etwa Hiob, Kap.12,10 ausgesprochen wird:

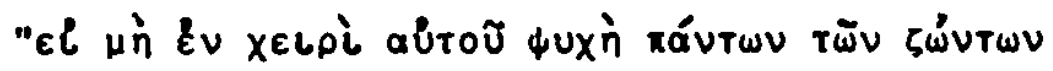

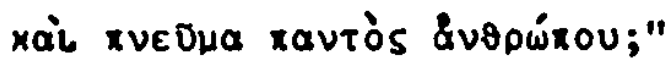


MuB es demnach der Glaube dem allmăchtigen Gott anheimstellen, ob und wie lange der die Seele 'lebendig' erhalt, so gibt es doch ein zweites 'Unterpfand' der Unsterblichkelt: die Gäle Guttes:

V,875f. ОАнак душ всеблагий не уничтожит бог;

Из свойств его тому суть некия в залог.

Das ksl. Substantiv 'зanor' hat Mikl. (212) mit lat. 'pignus' übersetzt.

Nach seiner Gute hat Gott das 'geistige Wesen' des Menschen $(y m, 878)$ für die Seligkeit und Vollkommenheit geschaffen (Аля бламенства,877). Ohne diese Hoffnung wăre das irdische Leben unertrăglich, voller Qualen und 'Unbehagen': V,881f. Да созидал бы их на сущие здесь муки,

Терпящих повсегда несносны в теле скуки.

Zu meinen, cott habe die Seele nur für das qualvolle Leben im Körper geschaffen, um sie danach zu vernichten, hieße Gott für grausam halten. Das wăre jedoch Gotteslasterung:

V.883f. Tоль літа бога мнить не токмо не хвала, Но истинныя есть безбожия хула.

Als triftiges theologisches Argument far die unsterblichkeit der seele wird ferner die gottliche Gerechtigkeit angegeben. Sie fordert, daß der Mensch für alles, was er mit freiem willen an Gutem oder Bösem getan hat, von Gott Ehre oder Strafe empfangt:

V,889f. Чтоб получил иль казнь, иль почесть равномерну, За произвольность дел иль Аобру, иль неверну.

D1e Gerechtigkelt Gottes kann sich abor nur dann voll verwirklichon, wenn Lohn oder Strafe uber das irdische Leben hinausreichen:

\section{V,885ff. Всеправеден есть бог. Он правдор своер \\ Не может сотворить, чтоб зол иль благ Аушех \\ Препровождал всю жизнь который человек, \\ Бессмертен бы уж тот не пребшвай вовек, -}

Vom 'Gericht nach den Werken' (889f.) schreibt Paulus in Róm.Kap.2,5f.:

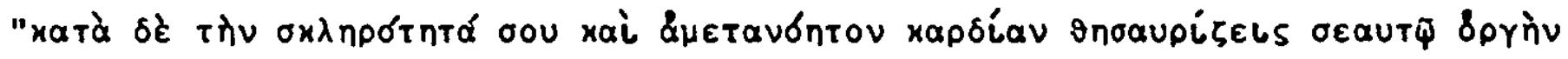

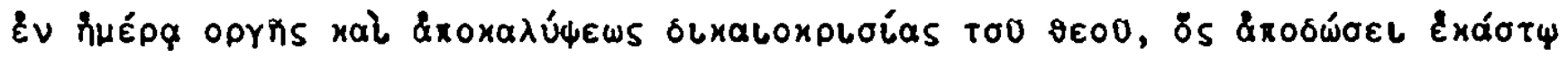

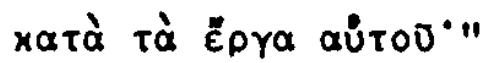

Der Glaube an die Unsterblichkeit stützt sich uberdies auf die Wahrhaftigkeit Gottes. Er selber hat die Idee der Unsterblichkeit in unsere Seele 'gepflanzt' und ein starkes Verlangen danach geschaffen: 
v,891ff. Бог купно всеправдив. Правдивость mе его,

Бессмертие дает аушам всем аля сего,

Что яснуо Он 8 ниХ О том идех өсеял

И сильное к тому телание содеял.

Aus der Beiligkeit Cottes folgt schlieblich, daB die Seele in jener Welt für alles, was sie getan hat, zur Verantwortung gezogen wird. Des setzt aber inre Unsterblichkeit voraus. Der hellige Gott kann nicht betrügen. Sollto er das zuletzt unbeachtet lassen?

v,895ff. И как бог пресвятый не может обмануть,

То момет лм сие конечно преминуть,

Чтоб не бшла ауша бессмертнор в том свете,

0 scex делах cвоих по данном там ответе?

V,901-912: Lobpreis der uberweltlichen Herrlichkeit Gottes, die sich uns in den Wundern der Schopfung offenbart.

Die Epistel schliebt mit einer Lobpreisung Gottes: er wird als unverănder11ch, wunderbar und treu gepriesen. Ex 1st wahrhaftig und richtet ohne Ansehen der Person:

V,901f. Бог неизменншй есть как чуден, так и верен!

Бог истинен, и суд его неличемерен!

Die rhetorische Form des Verspaares korrespondiert, betont durch das feierliche Metrum des trochăischen Hexameters, seiner hymnischen Aussage. Der Satz, daB Gott 'Ohne Ansehen der Person' richtet, hat eine Parallele in I.Petr.1,17:

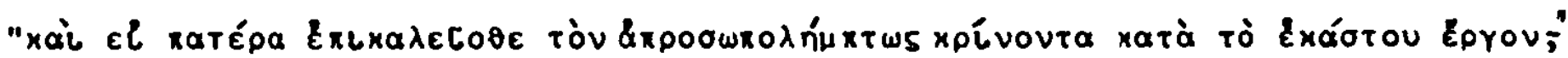

Tred. wiederholt den physikotheologischen Kernsatz, dessen Enfaltung inm vor allem am Herzen liegt: Gott offenbart sich uns Menschen in einer Vielzahl von Wundern:

V,903 Бог в мноместве земншм является чудес,

Zugleich mit der offenbarung Gottes in der Welt hebt Tred., auf biblische Vorstellungen zurackgreifend, die Transzendenz cottes hervor:

v,904ff. Имеяй свой престол превние всех небес,

ГАе Грозншх молний огнь Бесь оншй освещает

И приступить К зарям собой не допущает.

Das Bild vom 'Thron Gottes' findet sich z.B. in der Berufungsvision des Propheten Jesaja (Kap.6,1):

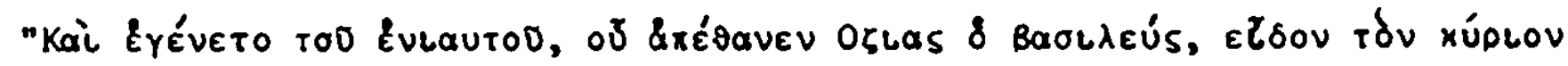

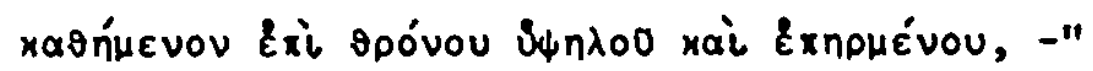


Bei dem 'Feuer drohender Blitze' um den Thron Gottes denkt man etwa an Apoc.Joh., Kap.4,5:

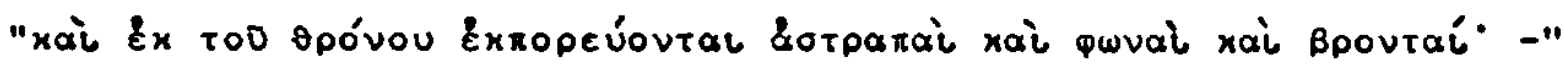

Fủr die 'Unzugănglichkeit' Gottes kann auf I.Tim.,Kap.6,16 verwiesen werden:

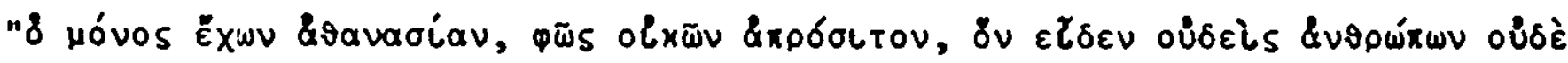

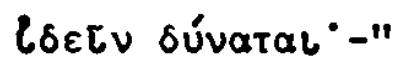

Der uberweltliche Gott steht auch uber aller zeit, bekennt Tred.:

$$
v, 907 f \text {. Бог прежде тварей всех и прежде всех веков: }
$$

Как есть его предел, пребудет ввек таков.

Auch diese stelle stimet mit dem biblischen Gottesgedanken wberein. In Gen. Kap. 1, 1 heiBt es:

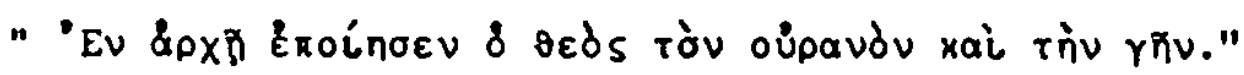

Zu denken ist auch an Ps.89,2 (LXX):

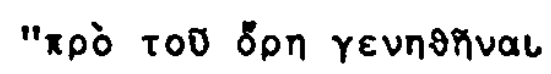

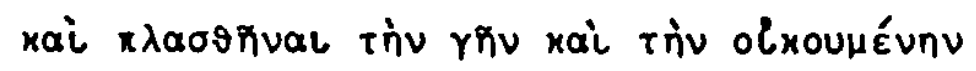

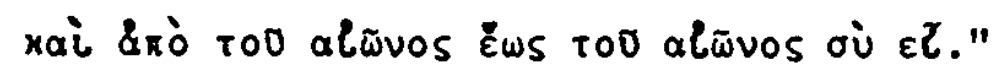

Eine weitere Bibelstelle klingt in den folgenden versen an:

V,909f. Пред ним сил многи тьмы сияниями блещут, Величества его в люблении трепеиут.

Die Ahnlichkeit mit Jes.,Kap.6,2f. ist offensichtlich:

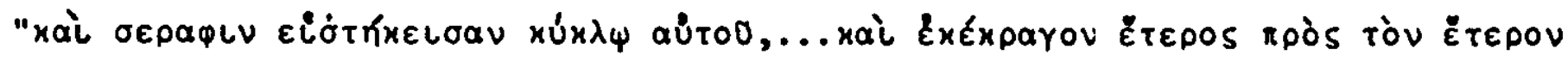

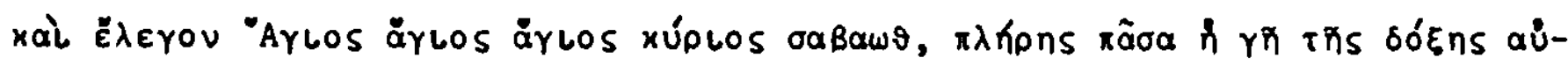
тоO."

Zu nennen ist auch die bekannte Stelle aus der Weihnachtsgeschichte, Luk. Evgl. .Kap. 2,13:

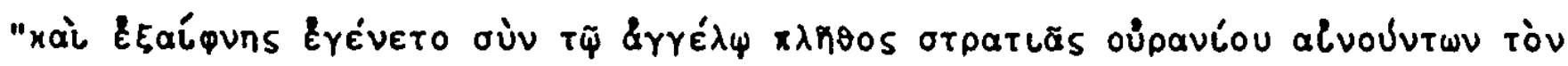

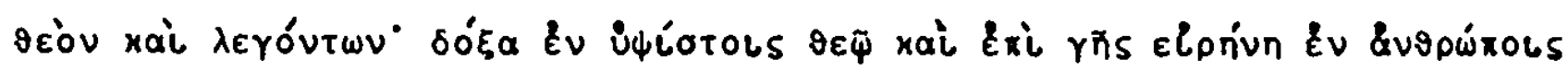
ยủsoxías."

Den 'cил многи тьмы' (909) entsprechen in der Jesajastelle die 'oеpaplv'. Dabei ist anzumerken, daß der Gottesname, hebr. 'Jahve Zebaoth', 'Jahve dex Heerscharen' bedeutet. Der Evangelist Lukas hat dafür das gr. Aquivalent - if orparıá oúpávios' eingesetzt.

Am SchluB der Epistel bekraftigt der Autor nochmals sein Bekenntnis zur Unsterblichkeit der Seele, wobei er sich zuletzt nicht auf philosophische Argumente, sondern darauf beruft, daB 'Gott den Geist nicht zu Staub vernichten wollte'. Offenbar denkt Tred. an das Jüngste Gericht, in dem cott eine 
endgultige Entscheidung uber die Manschen fallt: den Guten erweist sich cott als die Liebe, den Bósen als Schrecken:

v,911f. No6oвb благим всем 6ог, a sлим душам есть страх:

Sor ayxa he cyann penutb - cmeptesbmin npax.

Der neutestamentliche Gedanke vom Universalismus des Heils, der neben dem vom doppelten Ausgang des Gerichts festgehalten wexden muB, ist in diesen Versen nicht berücksichtigt worden. Vom Universalismus des Heils spricht z.B. Paulus im Rơmerbrief Kap.11,32:

"ouvéx In dieselbe Richtung zeigt I.Tim.,Kap. 2,4:

"Is /ర vetu."

Das Verhaltnis der beiden eschatologischen vorstellungen zueinander ist schwierig zu bestimmen. Nach P.Althaus muB "man die beiden Gedanken in ihrem widereinander stehen lassen." 33 Er vertritt die Auffassung: "Wir mussen uns hüten, Gottes Vergeltung an seinen Feinden judaistisch zu denken statt evangelisch... Die durcharingende Schăfe seines Gerichtes bleibt Mittel selner Liebe, den Menschen zu sich zu ziehen... "34

VI.Epistel: Die Eigenschaften Gottes - die Notwendigkeit des 'Fürsprechers'die Notwendigkeit der offenbarung durch Christus.

Die einleitenden Verse weisen auf den Inhalt der Epistel hin: in ihr sollen die Elgenschaften Gottes behandelt werden, nachdem im vorhergehenden das 'an den Geschópfen sichtbare Dasein Gottes unbestreitbar bewiesen worden ist': VI,1ff. По доказанном уже непреоборимо Преверьховном бштии, что по теарям зримо, Полнейше возможем некак бога мы познать, Как о сөойствах бога прямо будем рассумдать. Das neue Thema erfordert eine andere Methode des Denkens. Der 'Beweis' für das Dasein Gottes ist uberwiegend induktiv gefürt worder: 'no Taapam'. Die 'Eigenschaften' Cottes sollen rational deduziert werden: 'npamo будем paccymдать'.

Im AnschluB an die "unter dem Namen des...Dionysius Areopagita (De div.now. VII,3) beruhmt gewordene Lehre von der via triplex: der via negationis (Epal-

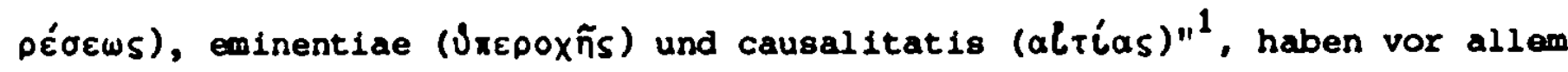
die Scholastiker die Lehre von den Eigenschaften cottes entfaltet und einen 
Katalog von Attributen Gottes aufgestellt. W.Elert nennt als Beispiele: Albert d.Gr., S.theol.I,4 qu.20 (simplicitas); I,5 qu.23 (aeternitas). Alexander v.Hales, Suma I qu.9...et qu.10 (omnipotentia, immensitas) ${ }^{2}$ Ferner: Rupert v.Deutz, De omnipotentia Del , MSL 170, 453ff. - Bugo v. St.Victor, De potestate et voluntate Del, MSL $176,839 \mathrm{ff} .^{3}$ Man meinte, auf den 'drel Wegen' "diese Attribute in systematischer vollstănigkeit finden zu kónnen." 4

Die 'via triplex' wird von w.Elert so skizziert: "Die via causalitatis /will] aus dem Tatbestande der Welt direkte schlüsse auf bestimmte Eigenschaften Gottes ziehen..." - "Die via eminentiae will andere Eigenschaften Gottes ermitteln, indem sie alle an den Kreaturen wahrnehmbaren vollkommenheiten in vollkomenstem MaBe von Gott aussagt..." - Bei der via negationis "soll an Gott alles hinweggedacht werden, was wir an uns selbst an Unvollkommenheit wahrnehmen." Aus heutiger theologischer Sicht urteilt Elert: "Die drei 'Wege' ...sind selbstverstădlich für uns ungangbar." Die 'via causalitatis' endigt, so Elert, "vor dem 'verborgenen Gott'." Gegen die 'via eminentiae' ist zu sagen, daB wir infolge der begrenzten menschlichen Vorstellungsmoglichkeiten "gar keinen MaBstab für mögliche Superlative, die uber unsre eigene vermeintliche Vollkommenheit hinausgehen", besitzen. - Die 'via negationis' schlieBlich "fuhrt...zu keinen gottlichen Attributen, sondern...schafft in unseren Gedanken ein Vakuum. 5

Unter den folgenden Voraussetzungen ist es nach Auffassung von w.Elert theologisch legitim, von Attributen cottes zu reden: diese müssen im 'Selbstzeugn1s' Gottes, d.h. In der Hl.schrift, begründet seln. Ferner muß jedes ein zelne Attribut die untrennbare Einheit des Wesens und Wirkens cottes bezeugen. Schlieblich muB beachtet werden, daB die Attribute cottes weder voneinander isoliert gedacht, noch in ein rationales system gebracht werden können. 6

Die von Tred. In der VI.Epistel der Feoptija aufgefuhrten Eigenschaften Gottes bilden ein russisches Aquivalent zu den scholastischen Katalogen der gottlichen Attribute. Nach scholastischem Vorbild teilt Tred. die Eigenschaften cottes in absolute und respektive, bzw. relative ein (camoctostenbme и возносительные, Feopt.,s.304). Bei den zuletzt genannten unterscheidet ex solche, die auf die 'natūrliche' und andere, die auf die 'sittliche' Welt bezogen sind (естественные, bzw. нравственнше, Feopt.,S.304). Die scholastische Terminologie und Denkweise, die Tred. vermutlich bei seinem theologischen studium an der Sorbonne kennengelernt hat, kommt, wie in den traditionellen 
Gottesbeweisen der I.Epistel, so vor allem bei den Erwăgungen uber die gottlichen Attribute in der VI.Epistel zum Ausdruck.

Die 'Demonstration', Tred.8 wichtigste Quelle im physikotheologischen Te1l der Feoptija, spielt in der VI.Epistel nur eine untergeordnete Rolle. Zwar behandelt auch Fénelon in der 'Seconde Partie' der Dewonstration die Attribute Gottes. Dort werden im 5.Kap., Art.I die 'Unite de Dieu', Art.II, die 'Simplicite de Dieu', Art.III, die 'Immutabilite de Dieu', Art.IV, die 'Immencite de Dieu und Art.V, die 'Science de Dieu' erortert.Tred. hat Jedoch nicht nur einen umfangreicheren Katalog von Attributen, sondern hat diesen daruber hinaus, der scholastischen Lehrtradition folgend, in 'attributa absoluta' und 'respectiva s. relativa' eingeteilt.

VI,7-235: Die 'attributa absoluta' Gottes (самостоятельные свойства боra).

Die Verse VI,7-17 handeln von der 'Ayxoвноctb' Gottes:

$$
\text { VI, } 7 \text { B-первих, познаваем, что боr есть и жизнь и Аух; - }
$$

Weil Gott 'Leben und Geist' ist, hat ex ein vollkomenes BewuBtsein seiner selbst:

$$
\text { VI, } 8 \text { себе он сведом; Внутренний имеет слух; }
$$

Die Aussage steht in bewritem Kontrast zu der eindrücklichen Bekundung des 'Nichtwissens' des Menschen über sich selber im AnschluB an das AugustinZitat in V,501ff. Nach den Vorgăngen in seinem Inneren gefragt, konne der Mensch nur antworten: 'He sнav':

$$
\begin{aligned}
& \text { V,515f. Зависит от души, но та не весть сама, } \\
& \text { Что действует и как и для чего весьма. }
\end{aligned}
$$

Das Nichtwissen uber sich selber zeigt die geschopfliche Ohnmacht des Menschen. Gott dagegen ist 'sich selber bekannt'. Er ist seinem Wesen nach 'unaufhorliche Tatigkeit:

/ñosнasaem/

$$
\text { VI, } 10 \text { по сущности своей непрестанну дельность. }
$$

Das erinnert an die Formel des Thomas v. Aquin, cott sei 'actus purus et perfectus' (Suma theol., qu.3.a.1.2; qu.87.a.1.,zit. w.Elert,a.a.0.,s.229). Diese Deutung wird durch VI,46 gestützt:

бесконечен, посему, Аействе беспредельном, -

Die Aussagen, Gott sei seinem Wesen nach 'Leben und Geist' (VI,7), or sei darum 'unaufhơrlich tătig' (semper ubique actuosus), kơnnten aus der Bibel vielfach belegt werden. Die biblische Bezelchnung 'lebendiger cott' ist nur è $1 \mathrm{n}$ Ausdruck dafür. Die Zusammengehörigkeit von 'Leben und Geist' in der

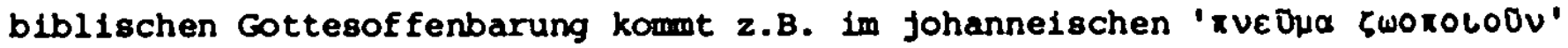


(Joh.6,63) zum Ausdruck. Erinnert sei auch an das 'Einblasen' des gottlichen 'Lebensgeistes' bel der Erschaffung Adams in der bereits zitierten Stelle

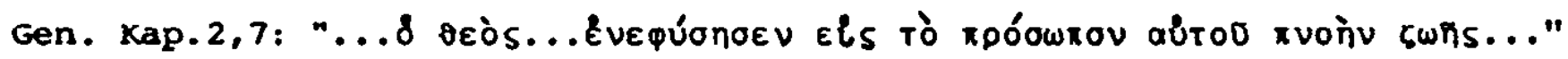
Zu denken wăre auch an Hiob,Kap. 33,4:

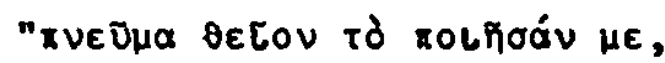

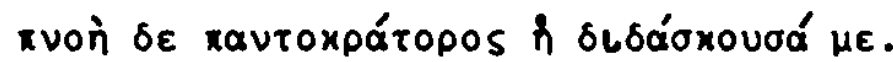

Vom unaufhorlichen 'Schaffen Gottes bis auf den heutigen Tag' sagt Jesus

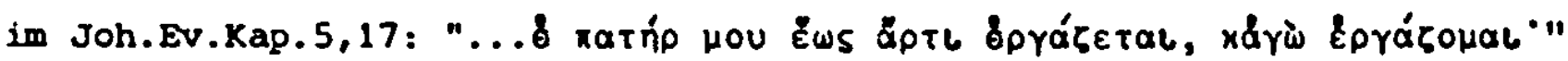

Bei dem groBen Angebot von biblischen Belegstellen uberrascht es, daB Tred. sich bei den Aussagen uber Gott nicht auf die Bibel beruft, sondern statt dessen apriorisch vom 'geistigen Wesen der Seele' auf die 'Geistigkeit' cottes schliebt:

VI,11f. Мы сио Ауховность присвояем боместөу

По ауше Ауховной, по ее и существу.

Nach dem Grundsatz der 'via causalitatis': "effectus testatur de causa eiusque perfectione ${ }^{7}$, zieht Tred. die SchluBfolgerung:

VI.13f. Что в произведе́нном есть, есть же то известно.

A не прежяе быть в вине, понимать безместно; -

Dem Grundsatz der 'via eminentiae' gemäB: "quidquid exstat in effectu praeexistit in causa" ${ }^{8}$, schlieBt Tred. nach scholastischem vorbild, daB Gott in vollkommener Weise 'lebendig und geistig' ist:

$$
\begin{aligned}
& \text { VI,15f. Тем иль превосходно, прежде то иль суие в ней: } \\
& \text { Бог жив и Ауховен по причине точно сей. }
\end{aligned}
$$

Von dem ksl. Adjektiv "douchovn-", das Mikl. (182) mit 'spiritualis' ubersetzt, hat Tred. mit dem Suffix -ost' das Abstraktum "duchovnost' "gebildet, das die 'spiritualitas' Gottes ausdrückt.

In VI, 18-29 geht es un die 'самодовольность' Gottes.

Diese Eigenschaft bedeutet vor allem, daB cott 'aus sich selbst' ist und sich selbst regiert:

$$
\begin{aligned}
& \text { VI,18f. Понимаем бога мы и самодовольна, } \\
& \text { быть возмогша от себя и собой престольна. }
\end{aligned}
$$

Wenn man daran denkt, wie beharrlich Tred. vom Menschen, von der menschlichen Vernunft und Seele erklart hat, das sie ihr Dasein 'nicht aus sich selber' haben (vgl. 2.B. V,801f.), so sticht der Satz, Gott existiere 'or ce6я', besonders hervor. Веi dem Ausdruck ' собой престольный' wird man daran erinnert, daß die griechischen Kirchenvater Gott als 'autoxpatwo' bezeichnet haben. Zu 
den zahlreichen mit 'auTos' zusammengesetzten Attributen cottes bei den griechischen Kirchenvatern vgl. K.Barth, Kirchl.Dogmatik, II,1 S.340.

Die Formel 'Or ce6g' entspricht dem 'a se', bzw. 'per se' oder 'ex se' bei Anselm v. Canterbury: "summa natura...per se ipsam et ex se ipsa est, quidquid est" (Monol.6). Annlich: "Ille igitur solus a se habet, quidquid habet" (De casu diab.1). 9 Damit ist die scholastische Lehre von der 'aseitas' Gottes angedeutet. Der 'aseitas' korrespondiert die hochste Vollkommenheit. Darin ist cottes 'Selbstgenugen' begrundet: er bedarf keines anderen:

VI,28f. B Gore w npesocходн совершенства все в себе;

Тем он и доволен, по своей чтоб бить судьбе; -

Die Verse erinnern an den Cottesbegriff Anselms, in dem 'absolutes Sein' (aseitas) und 'absolute Vollkommenheit' verschmolzen sind. Nach Anselm ist Gott 'ens perfectissimum'; seinem Sein eignet eine Vollkowmenheit, "wie sie hoher und grober nicht gedacht werden kann". ${ }^{10}$ Dahinter steht die vorstellung des mittelalterlichen Realismus von den Gradabstufungen des Seins, die vom 'absoluten Sein' bis zum 'Nichtsein' reichen. Cott ist als 'ens perfectissimum' nach Anselm zugleich 'ens realissimum'. Auf der anderen seite bedeutet schon die geringste Unvollkommenheit eine Minderung des Seins, so daB das 'Nichtsein' als Inbegriff aller Unvollkommenheit gedacht wird. Tred. hat diesen Gedanken so ausgedrückt:

VI, 20f. Cунество, вотором хоть 6u мне́йшее нашлось Внутрь несовершенство, не собой то извелось

Wie kônnte das 'Nichts' als auBerste Unvollkommenhelt das 'Allervollkommenste' enthalten, das aus sich selbst existiert? fragt Tred. Die rhetorische Frage soll den Widersinn einer solchen Meinung unterstreichen:

VI, 25ff. Hо Ничто ль возможет большее есех по сему

Несвершенство исклочить рещи пустотоп,

А вклиоинть вещь большу всех, бить тому 6 собою?

Die 'самодовольност' Gottes entspricht seinem vollkommenen Sein.

Das Abstraktum ist von dem ksl. Adjektiv "samodovol 'n-" abgeleitet, das Mikl. (819) mit 'sibi sufficiens' wiedergibt.

VI, 30-43: Aus der Vollkommenheit Gottes folgt 'unumgănglich' seine Existenz. VI,30f. Без малейшей пустоты все в нем пребезмерно, Тем необходимшй есть битием он верно.

Das ist der Grundgedanke des sogenannten 'ontologischen Gottesbeweises' 
Anselms, in den von der 'Essenz' Gottes auf seine Existenz geschlossen wird. Nach den Voraussetzungen des mittelalterlichen Realismus "kann das Vollkommenste nur als selend gedacht werden und existiert somit kraft der Notwendigkeit seiner eigenen Natur". 11 Tred. wiederholt diesen Grundgedanken Anselms in Form eines Lehrsatzes:

$$
\text { VI,36 В суцности вседолжной бштность равно такова, }
$$

Der 'ontologische Gottesbeweis' ist bereits in Feopt.I,47ff. dargelegt worden.

Ein belebendes Element kommt in die abstrakten Daxlegungen durch die unvermittelte Zuwendung an den Adressaten: halte diese SchluBfolgerung nicht für mangelhaft:

$$
\text { VI,34 Круг дово́яный сей не мни быть отнодь порочным, }
$$

Die Einheit von 'ens perfectissimum' und 'ens realissimum' wird von Tred. auch so umschrieben, daB cott die Ursache seiner eigenen Existenz ist:

$$
\text { VI,38 Тем самодоволен бог быть се6е в причину. }
$$

Der Ausdxuck 'ce6e в причину' weist deutlich auf die scholastische Formel hin, Gott sei 'causa sui', mit der die 'aseitas' interpretiert worden ist. Die beiden Formeln haben Jedoch, wie K.Barth anmerkt, unterschiedlichen Inhalt: "Sagen wir also, daB Gott 'a se' ist, so sagen wir nicht, daB cott sich selbst schaffe, hervorbringe, verursache, wohl aber: das er...der ist, der in sich selber Alles schon hat und ist....dessen Sein also keines Entstehens und Bestehens bedarf..."12

Weil Gott das Sein aus sich selber hat, fahrt Tred. in der scholastischen Argumentation fort, konnte er auch die Menge der Kreaturen hervorbringen nach dem Grundsatz, daB jemand anderen nur das geben kann, was er selber besitzt:

VI,39ff. Инак не возмог бы он произвесть по инну

Толь существ премногих: не имехщий чего,

Аать аругим не может мерой никакой того.

An diesem Punkt wird die philosophische Redeweise durch einen hymnischen Ausruf unterbrochen:

$$
\begin{aligned}
& \text { VI,42f. Так то он есть, иже есть! толь всесовершенный, } \\
& \text { Что всевечна бытия долюно не лишенный! }
\end{aligned}
$$

Die Verse preisen das einzigartige Sein Gottes, das im vorhergehenden Gegenstand rationaler Uberlegungen war. Der erste Halbvers erscheint wie ein Bekenntnis, in dem der alttestamentliche Gottesname 'Jahve' anklingt. Dieser wird in der Septuaginta so gedeutet (Exod. Kap. 3,14):

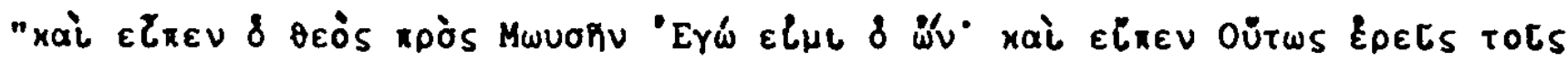




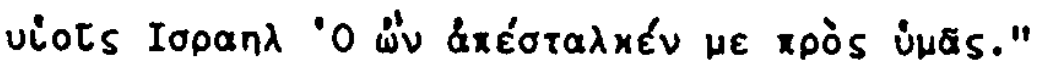

Die rhetorische Form und die Wortwahl (ksl. 'ume' = 'kоторий') sowie elative superlative (всесовершениий, всевечншй) geben dem verspaar hymnische Tonalitat. - Das Stichwort des Abschnitts 'необхояиммй' (31), ksl. "neobchodim-", wird von Mikl. (432) durch 'quem circumire non possumus' wiedergegeben.

Die Verse VI, 44-61 handeln von der '6есконечность' Gottes.

Damit greift Tred. das scholastische Attribut der 'Infinitas Del' auf. Der Begriff des 'Unendlichen', der in der griechischen Philosophie urspranglich etwas Unfertiges und Unvollkommenes bezeichnete, hat in der stoa und im Neuplatonismus eine vollige unwertung zum Positiven erfahren. Er wurde zum Pradikat der gottlichen Urkxaft, die nach der Lehre der stoisch-neupythagoreischen Naturphilosophie die Welt durchwaltet. Im Neuplatonismus ist das 'Eine', aus dem die Fulle der Weltgestalten durch Emanation hervorgehen, "unendich,

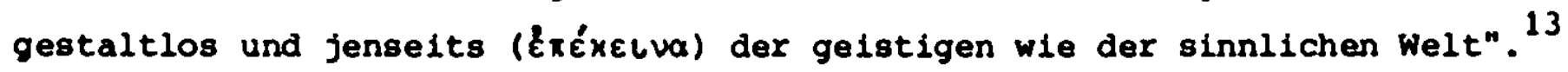
Windelband stellt fest: "So ist der Begriff der Unendlichkeit durch diese SchluBentwicklung der alten Philosophie ein integrierendes Merkmal der höchsten wetaphysischen Realitat geworden: er gebürt nicht nur dem Weltall in seiner răumlichen und zeitlichen Ausdehnung, sondern auch...vor allem der cottheit." 14

Diesen Sinn hat die 'infinitas Dei' auch im scholastischen Sprachgebrauch, auf den Tred. zurückgreift:

\section{VI,44f. Бог сый, бесконечен естестеом и бытием:}

Нет отнодь пределое никаких в том обоем.

Das Folgende ist nach den Begriffen 'ectectвo' (48-51) und '6wtиe' (52-55) gegliedert.

Gottes Wesen umfaBt alle Vollkomenheiten, unbegrenzt der zahl und dem Grade nach:

$$
\begin{aligned}
& \text { VI,48f. Бесконечность в первом /естеством]: совершенстеа все } \\
& \text { По числу без края, да и по степе́rm всей: - при сей }
\end{aligned}
$$

Der Autor hat dabel wieder das 'ens perfectissimum' aus dem 'ontologischen' Gottesbeweis Anselms v. Canterbury im Blick.

Auch das Dasein Gottes ist 'unendich': es ist ohne Anfang und ohne Ende. Tred. macht das unvorstellbare unendliche Sein Gottes durch das sinnbild des Kranzes anschaulich:

VI,52f. Ta $m$ to no второму: im начала, in конца Бor he и́matb a Guтстве, равно как нет у венца; - 
In der Antike wurde der Kranz in Verbindung mit dem Kultus in erster Linie als Heils- und Schutzzeichen verstanden. "In inm kommt der Segen der cottheit zu seinem Träger." 15 Im Unterschied dazu benutzt Tred. hier die Kranzmetapher als rationales Symbol des Unendlichen.

Als weitere Merkmale des göttlichen Seins nennt Tred.: 'menpenommo' (unwandelbax), 'mепрестанно' (unaufhorlich), 'настояне nовсегяa' (immerwăhrend) und 'несозданно' (ungeschaffen), VI,54f. Sie kennzeichnen Gott als den 'Ewigen': $\quad$ VI, 56

Потому и вечншй нарицаемий есть бог: -

Das Wort 'ewig' charakterisiert das unendliche Sein Gottes im Verhaltnis zur zeit. Als 'unendlich' erfült Gott zugleich jeden Raum:

VI,58ff. Наполнением сеоим бесконечный равно:

Сунностио всею он полнит толь исправно

Всякое пространство, что границ отнодь в ней нет,

'Hanолнение' (58 und 47) ist von dem bel Mikl. (409) belegten ksl. Verb "napl-nievati" (implere) abgeleitet. Das Adjektiv 'бесконечный' (58) bzw. 'бесконечен" $(44 ; 46)$ entspricht dem ksl. "beskonc'n-", das Mikl. (18) mit 'infinitus' ubersetzt.

Die Aussagen sind nach scholastischem Muster teils 'via negationis', teils 'via eminentiae' gebildet worden. $2 u$ jenen gehóren: '6есконечность' (48), 'без края' (49), 'беспредельно' (46) sowie die mit Verneinungspartikeln zusammengesetzten Begriffe und Wendungen wie: 'ни начала, ни конца' (52), 'непрестанно' (54), 'несозданно' (55), 'границ в ней нет' (60).

Auf die 'via eminentiae' bezlehen sich z.в.: 'всесовершенный боr' (50), 'крайншй всеконечно' (50), 'настояще повсегяа' (55) und 'он полнит...всякое пространство' (59f.).

In V1,62-75 erörtert Tred. die 'безмерность' Gottes.

Das neue Attribut wird ohne tbergang an das vorige angehangt:

VI,62f. Всяк и точно по сему утверждает верный, Что как бесконечный бог, так он и безмерный.

Zur Idee der 'безмерность' Gottes beruft alch Trod. auf nicht năhor bezolchnete 'Weise':

VI,64f. Что 2 бы нам идео о безмерности иметь,

Tо о боге должно с мудрими так разуметь:

Sie lehren, Gott sei in allem und auBerhalb aller Dinge, er sei höher als alles und zugleich niedriger als alles: 


$$
\begin{aligned}
& \text { vI,66f. Пребшеает внутрь всего, вне всего живучий, } \\
& \text { И всего ж он вьше сам, сам и ниме суший, - }
\end{aligned}
$$

Die Verse sind durch Gegensatzpaare und wiederholungsfiguren mit Bedacht gestaltet. Die 'Gезмерность' Gottes labt sich nur in paradoxen Wendungen andeuten: 'So innerlich etwas sein mag - Gott ist es noch mehr', lehren fene 'Weisen': ferner: 'kein Teil der Welt erstreckt sich uber Gott hinaus':

VI,68f. Частио какоо не внутри найпаче он,

Ни Aруго0 такое распростерт есть болей вон,

Die Formulierungen, in denen sich das Interesse des Frommen an der Immanenz Gottes ăußert, komen denen der Mystiker nahe. Dank seiner 'GesmepHoctb' ist cott allen Kreaturen gleich nahe:

vI,74f. По безмерности своей бог есть сый повсюау

$И$ не больше там иль здесь, весь внутрь И внеуду.

Die stelle erinnert an einen Passus in der Predigt des Apostels Paulus auf

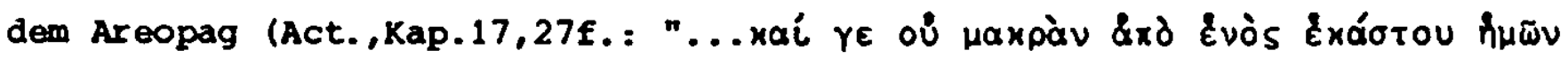

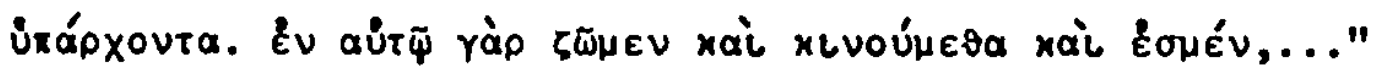

Der Ausdruck 'весь внутрь $n$ Bнеуду' (75) betont in gleichem MaBe die Imanenz wie die Tranzendenz Gottes; er ist augenscheinlich der scholastischen Formel 'totus intra et totus extra' nachgebildet.

Als der 'Jenseitige' geht cott nicht in der Welt auf, sondern 'steht ihr vor', 'erhallt und beschutzt' sie:

VI,70f. Но един $и$ чел везде предсеяит хранячий,

Всё содержит и хранит всоду председящий, -

Die Verse heben den uberweltlichen Rang Gottes hervor.

zugleich 'durchdringt' Gott die Welt, wird ihr immanent und setzt seinen

Geist zu ihrem wăchter ein:

VI,72f. Coqepжa, coбow проницает всё кругом,

Проницая $\%$, Аухом делает весь мир стрего́m.

Das dem menschlichen Verstande unzugăngliche Verhaltnis von Immanenz und Transzendenz cottes wird durch die verschrănkte Syntax sinnbildilich dargestellt.

Im Unterschied zur Feoptija dominiert in Popes 'Essay on Man' die Immanenzanschauung:

$$
\begin{aligned}
& \text { Ep.I,267ff. "All are but parts of one stupendous whole, } \\
& \text { Whose body Nature is, and cod the soul; } \\
& \text { That, chang'd thro" all, and yet in all the same, }
\end{aligned}
$$


Ep.I,270ff. "Great in the earth, as in th'aethereal frame, Warms in the sun, refreshes in the breeze, Glows in the stars, and blossoms in the trees, Lives thro' all life, extends thro' all extent, Spreads undivided, operates unspent,...

Ep.I,279f. To him no high, no low, no great, no small; He fills, he bounds, connects, and equals all."

Das Abstraktum 'Gезмерность' (64) ist von dem bei Mikl. (15) belegten ksl. "bezmer'n-" (immensus) abgeleitet.

In VI,76-114 geht es un die 'Allwissenheit' Gottes (всеведение).

Das Attribut wird aus der Prämisse deduziert, daß Gott die 'höchste Vernunft' ist:

$$
\text { vI,76 Бог есть и всевеяуи, ибо крайний разум в нем: - }
$$

Durch unsere eigene Vernunft, die sich ihrer Grenzen bewubt ist, erkennen wir a priori, daB Gott die 'höchste Vernunft' ist (via eminentiae). Diese Erkenntnis wird in plastischer Anschaulichkeit durch die 'schóne ordnung der Welt' bestatigt:

$$
\begin{aligned}
& \text { VI,77ff. Частио мы прямо дознаваемся о сем, } \\
& \text { Что всем человекам он даровал ум власный, } \\
& \text { Частио ж нам мира чин возвещает красный. }
\end{aligned}
$$

Bei diesem Stichwort greift Tred. den leibnizischen Gedanken auf, daB Gott aus vielen möglichen Welten diese Weltordnung ausgewăhlt hat. Sie hat weder in unserem Verstande noch in der Materie thren ursprung:

VI,80ff. Из возможншх многих происшел что сей един

Всех вещей порядок, ни в уме $⿻$ тому нет вин,

И ни такме в веществе, но в едином боге

Та содержится вина в твердом вся предлоге; -

Daraus folgt, făhrt Tred. fort, daß der 'Höchste' diese Beschaffenheit der Welt vorhexwubte, durch welche er uns seine unermebliche vernunft gezeigt hat

$$
\text { vI,84f. Следует, что прежде вшшний сей состав познал, }
$$

Крайний свой которим разум нам и показал.

Die göttliche Vernunft enthălt die Vorstellung aller 'möglichen' und 'wirklichen' Dinge. Sie ist darum 'im hochsten Grade intuitiv und vollkommen':

vI,86ff. Разум бомий есть показ всех себе возможных

И действительно вещей суиих и неложных,

Самозрительнейший и всесовершенний тот, - 
Das Adj.comp. 'самозрительный' und das Subst. 'Самозрение' sind nach Meinung von G.Huttl-Worth von Tred. dem vulgarlat. 'intuitio' (Betrachtung) nachgebildet worden. 16

Um die Allwissenheit cottes zu bestimmen, haben die scholastischen Theologen verschiedene Distinktionen eingefuhrt, von denen einige auch in unserem Text anklingen. Sie unterscheiden z.B. die 'scientia simplicis intelligentiae' cottes von der 'scientia visionis'. Mit der ersten "ist das wissen Gottes um das nach seinem willen nur Mogliche, aber nie Wirkliche" gemeint. 17 Die 'sc. visionis' dagegen unfast das in Vergangenheit, Gegenwart und zukunft wirklich Existierende. Das Mögliche steht von Ewigkeit her als nur möglich vor dem Geiste Gottes:

VI,92f. Первое у бога, от превечности всея,

В разуме возможним било токмо престоя.

Gott kennt das Vergangene, fahxt Tred. fort, weil er es selber geschaffen hat. Ex kennt auch das Gegenwartige. Sollte der 'Allgegenwartige' es nicht sehen?

$$
\text { VI,96f. Знает боr прошедше: и6о всё сам сотворил. }
$$

Знает настояне: всоду ль сый того 6 не зрил?

Bei den zuküntigen Dingen, die Gott in seiner Allwissenheit voraussieht, werden die 'notwendigen' von den 'zufalligen' unterschieden:

$$
\begin{aligned}
& \text { VI,98f. Буауиих два чина суть, иль необходимы, } \\
& \text { Иль случайно от ума во́льна изводимы. }
\end{aligned}
$$

DaB Gott alles weiB, was mit 'Notwendigkeit' geschehen wird, versteht sich von selbst, erklart Tred.:

$$
\text { VI,100 Bcë в необходимом ведает конечно бог: - }
$$

Es 1st dem Gesetz von Ursache und wirkung unterworfen, das cott allen Dingen auferlegt hat, so daß im Vergangenen Jeweils die Ursache für die Gegenwart liegt. Im Geiste Gottes fallen daher Ursache und wirkung zusammen:

vI,102ff. В мире вещи купно все так располоме́нни, Что межау́ собой они твердо сопряженнш, И всегда есть а прошлом настоящему вина;

Тем в уме у бога действом купншм есть она, -

Das Kausalgesetz ist demnach für Tred. keine autonome Grobe, sondern wird theonom begründet: es liegt nach dem willen cottes allem Geschehen in der materiellen Welt zugrunde. Das wissenschaftliche Interesse an der kausalgesetzlichen Erklarung der Erscheinungen wird so auf der Linie von Descartes und Leibniz mit dem religiosen Anliegen des Schöpferglaubens in Einklang gebracht. 
wie steht es aber mit der Allwissenheit Gottes in bezug auf die Dinge, die nicht aus der 'notwendigen' Verknüpfung von Ursache und wirkung in der materiellen Welt hervorgehen, sondern die der Mensch wit 'freiem Willen' hervorbringt. Tred. nennt sie im Unterschied $2 u$ den erstgenannten 'zufallig'. Er versichert, das Gott auch die Handlungen des freien willens vorausweiB:

\section{VI.110 Действа вольные людей ведает как вольны; -}

Ahnlich hat schon Augustin gelehrt: "... ipsae nostrae voluntates in causarum ordine sunt, qui certus est Deo eiusque praescientia continetur." 18

Daraus folgt die uneingeschrănkte Bewunderung der vollkommenen gottlichen Intelligenz, die nicht nur die ganze Wirklichkeit, sondern auch das nur mögliche unfaBt:

VI,112ff. Разума не можно совершеннейша понять,

Как которий токмо может купно өсё обнять, Что возможно по себе, -

VI,114b-151: Die Weisheit Gottes.

Sie offenbart sich darin, daB Gott sowohl in der geistigen als auch in der materiellen Welt alles nach dem von ihm gegebenen Gesetz auf vollkommene ziele hin geordnet hat:

$$
\text { VI,114ff. } \quad \text { - TeM } и \text { Aолжно Gory }
$$

Муарость крайно причитать и безмерно многу

Тог в умном мире, тол в венном свете он

Всё к концам свершенным разряаил и дал закон.

Tred. hebt besonders hervor, daB cott das universale z1el wit den zielen der einzelnen so verbunden hat, daB diese das Mittel sind, durch das Jenes auf kurzestem Wege erreicht wird:

$$
\begin{aligned}
& \text { VI,122ff. Следует, что - боге есть знание такое, } \\
& \text { обществе́ннейший конец сопрягает кое } \\
& \text { С собными концами, чтоб их средствиями слыть } \\
& \text { По́лнейшими теми, но прекратким бы всем быть, } \\
& \text { К полученио конца оного последня; }
\end{aligned}
$$

Im folgenden ist der EinfluB von Gedanken der Theodizee, wie sie von Leibniz vertreten wurde, nicht zu ubersehen. Tred. legt dar, die Weisheit habe cott 'bewogen', nux diese eine Welt aus der Vielzahl moglicher Welten zu verwirklichen:

VI,128f. Мудрость преклонила бога токмо к одному

Из возможных чину, в веществах чтоб быть ему; 
Er fugt hinzu, daß der Willensakt Gottes, durch den er diese Weltordnung 'ausgewahlt' hat, von den Theologen 'Vorsehung' genannt wird:

VI,132ff. Аейство оно вогм, коим чин сей бог избрал, Прочи ж все оставив, в веществе сему быть дал, Назнвается от всех мудрейших судьбор; -

Tred. betont, daB die Vorsehung Gottes keineswegs nur die eine Wahl treffen konnte, vielmehr hat Gott aus der Fulle der Moglichkeiten die von inm als beste beurteilte Weltordnung ins Werk gesetzt:

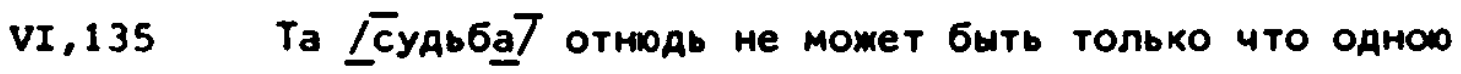

$$
\begin{aligned}
& \text { VI,138f. Так одним определить действом воли точним } \\
& \text { Рассумденншй лучшим чин в веществе быть прочним; }
\end{aligned}
$$

Dazu hat Gott nicht nur seine Weisheit, sondern auch die 'Gute' bewogen. Diese 'Güte', die aus allem das Beste fūr uns auswăhlt, die auf das vollkommenste abzielt, ist die einzige ursache für die 'Bevorzugung' die unserer Welt von cott zuteil geworden ist:

$$
\mathrm{VI}, 145 \mathrm{ff} \text {. }
$$

\section{- благость бory aлA cero}

Присвоять конечный долг; хощет та и верно,

Из всего, что лучше есть, клонится всемерно

К большим и множайшим совершенствам вся она;

Тем ала сих едина предпочтению вина.

Die Tatsache, daß Gott diese unsere Welt ausgewahlt hat, veranlaBt uns ferner, ihm das Pradikat der 'camoизвольность' beizulegen. Im 'Cловарь' zum Text der Feoptija (554) wird 'самоизвольный' mit 'яействуюиий по собственной воле' umschrieben. Tred. gebraucht in der Prosaeinleitung zur VI.Ep. (S.304) das wohl synonym gemeinte Subst. 'Gnaronpoиздольность', das von G.Huttl-Worth mit 'willenskxaft' ubersetzt wird. ${ }^{19}$ Im folgenden Verspaar will Tred. sagen, daB cott uber alle Mittel verfügt, un seine 'uberaus weisen ziele' zu verwirklichen:

VI,150f. Долюно присвоять еще и самоизвольность:

К действу мУарейших причин имать бог довольность.

vI,152-171: Die gottliche Allmacht.

Die Welt verdankt ihre Existenz nicht nux der 'Auswahl', sondern auch der Allmacht cottes. Schopferischer wille und schopfermacht sind bei cott eines. wollen und Vollbringen, bei uns Menschen zwei verschiedene Dinge, gehen bei cott Hand in tand:

VI,154ff. Бог соретельну в cебе воло всп имеет, Что восхонет, купно и монио и деет; 
VI, I56f. 8cё едино в боге и хотеть и содевать,

Но весьма различно в человеках, должно знать.

Die verse erinnexn an Psalm 32,9 (LXX):

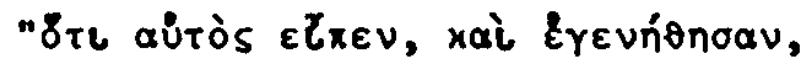

aútòs Éveteíidato, xaì Extíoonoav.

Die 'Allmacht' Gottes wird aus dem Begriff seines 'ewigen Wesens und Seins' deduziert und a posteriori durch das Dasein und die Ordnung der Welt bestatigt:

VI,158ff. Сила божия сия есть пребесконечна,

Ибо мшслим ми когда, ботия что вечна

Суиность, купно бШтность, чтО по сим Он есть собой,

И что в бшт все вещи произвел и в чинный строй,

То ми признаваем мощь вск в нем беспредельну, -

Kraft seiner 'Allmacht' kann Gott zwar 'alles' schaffen, aber er schafft

nichts 'Widersprüchliches', nichts, was unsere Vernunft als unmoglich ansieht:

VI,164 Бесконечна сила может точно всё творить, -

А однако речь та, 'всё', пречншх не объемлет,

Коим невозможно бать ум наш сам поемлет, -

Mit anderen Worten: Gott bindet sich an die Gesetze dex Logik.

Das 'allervollkommenste' Wesen schafft nur Vollkommenes. Ware es anders, so ware Gott nicht allmáchtig:

$$
\begin{aligned}
& \text { VI,168ff. Hо 'всё', что бшть может совершенством естества, } \\
& \text { От всесовершенна сделается суиества. } \\
& \text { Напротив ме, бог бш бшл моци не инуиим, } \\
& \text { А ме то, чтоб бшть ему крайно всемогуиим. }
\end{aligned}
$$

Das abstrakte Substantiv 'всемоryщество' (8. Prosaeinleitung zur VI.Ep.,S.304

ist bei Mikl. (118) belegt.

Der Abschnitt VI,172-197 handelt von der 'Einheit' Gottes.

Er beginnt mit dem monotheistischen Credo:

$$
\text { VI,172 Бо един есть токмо. - }
$$

Eine biblische Parallele steht in Deut. Kap.6,4:

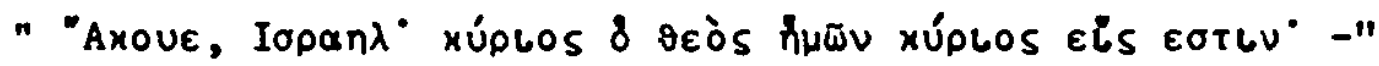

Tred. beruft sich aber zunăchst nicht auf die Bibel. Das Bekenntnis zu dem 'einen' Gott wird vielmehr aus dem Begriff seiner Vollkommenheit abgeleitet: weil Gott das allervollkommenste Wesen ist, hat er die allerhochste Realitat. Deshalb kann es keine gleichrangigen Wesen neben ihm geben: 
VI,178ff. Но что өсякородно бог есть всесовершенный,

То всевещностио он крайно украшенный.

กосемy нe mowet pastux ecex he nсклимать

И себя едина токмо суиим не сличать.

G.Huttl-Worth ubersetzt 'Bce日euноcтb' mit 'allesumfassende Realitat' und merkt an: "In einer 1760 erschienenen Ubersetzung verwendet Tred. das abgeleitete simplex 'вещность' für franz. 'réalité'... 20

Wie aus der Vollkommenheit Gottes seine 'Einheit' deduziert wird, so folgt aus der Unvollkommenheit des Menschen, daß es viele seinesgleichen gibt:

VI,176f. Тем не исклочает многих и подобных он, [иеловек]

Также всех подпавих под предельности закон.

Ahnliches hat Tred. schon in III,513ff; 519f. und 865-868 ausgefuhrt.

Einen indirekten Beweis für den Monotheismus gibt Tred., indem er sich bemüht, den Polytheismus logisch zu widerlegen. Er argumentiert so: gabe es viele Gotter, so hatten sie entweder die Macht, ihre Gedanken voreinander zu verbergen, oder sie wăren nicht imstande, diese geheimzuhalten:

VI, 1821f. Если $\sigma$ многим бшть богам, то $\sigma$ иль моцны были,

Мысли собственны свои от Аругих чтоб крыли,

Иль таить тех мшслей не могли 6 взаимно все; -

Tred. macht auf das Dilemma aufmerksam, dab im ersten Fall die Götter zwar allmăchtig aber nicht allwissend, im zweiten Fall wohl allwissend, jedoch nicht allmăchtig wären. Daraus ergiebt sich für den Autor:
VI, 189 .
в обоем ме слоге ми богами равмо слыть.

Wie verhalt sich der monotheistische Gottesgedanke der Vernunft zum chxistlichen Trinitătsdogma? Hier wird die kirchlich-orthodoxe Bindung Tred.s deutlich. Er wechselt von der Argumentation a priori zur ehrerbietigen Anerkennung der Autorităt der Heiligen Schrift:

VI,190ff. Ho когаa святое нам слово предлагает,

Что бог вшиний в пресвятой тройце пребывает,

То мы, упадая пред величием сим ниц,

Суиества в единстве признаваем тройцу лиц, -

Die Trinitatslehre steht als solche nicht in der Bibel. Das gilt insbesondere von den für sie konstitutiven Begriffen 'Wesen' und 'Person', mit denen "die Einheit Gottes in den Seinsweisen des Vaters, des Sohnes und des Heiligen Geistes" 21 unschrieben wird. Johannes v. Damaskus (geb. vor 700, gest. vor 754), "der letzte und zugleich einfluBreichste der Kirchenvater der grie- 
chischen Kirche", 22 hat dem Trinitatsdogma folgende Form gegeben:"Vater, Sohn

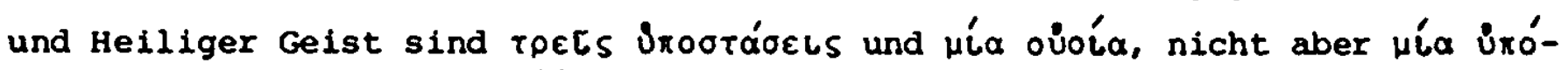
otaols oder Ěv xpóawrov."23 Mit der Formel ' $\mu$ lí ov̉oía' wird die Einheit Gottes

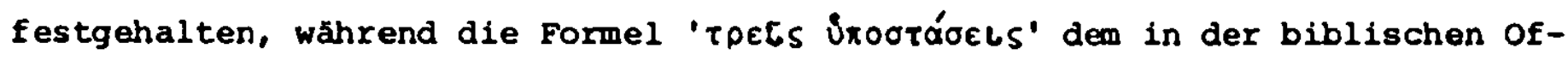
fenbarung bezeugten "dreimaligen Anderssein des einen Gottes in den Seinsweisen des Vaters, des Sohnes und des Heiligen Geistes" ${ }^{24}$ entsprechen soll. Dex Vers VI,193 gibt demnach die orthodoxe Trinitătslehre korrekt wieder.

Mit der Wendung 'упадая пред величием сим ниц' hat Tred. einen charakteristischen Zug dex orthodoxen Liturgie bezeichnet, die Proskynese als sinnfallige Form dex Anbetung. So bekennen die Glasubigen im 3.Artikel des 'Symbolum

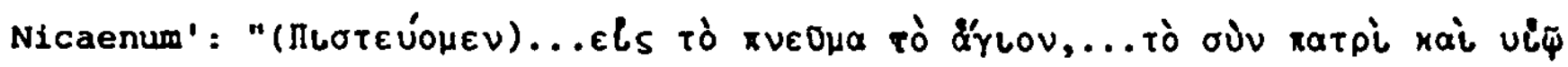

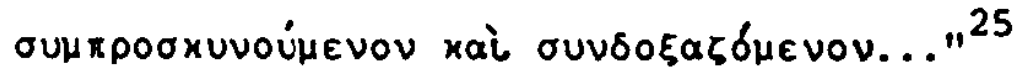

Tred. versichert, daB er, was die 'Geheimnisse des Glaubens' angeht, nicht die Vernunft, sondern die 'Worte der Schrift' als Autorităt anerkenne:

\section{VI,194f. A до таинства притом разумом такова}

Не касаемся отнодь без писаний слова; -

In Anlehnung an ein Wort des Apostels Paulus fügt ex hinzu, daß wir 'die Vernunft im Gehorsam des Glaubens gefangennehmen'; der Glaube, nicht aber die schwache Vexnunft, sei in dieser Beziehung 'das ganze Licht':

$$
\begin{aligned}
& \text { VI.196f. Веры мы пленяем в послушание ум здесь, } \\
& \text { Вера в сем едина, а не слабый ум, свет весь. }
\end{aligned}
$$

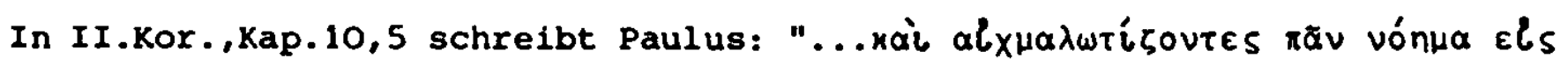
th̀v úxaxot̀v roo Xplotõ, ..."

Der Begriff "iedin'stvo" findet sich bei Mikl.(1154) und wird mit 'unitas' wiedergegeben.

In VI, 198-235 exlăutext Tred. die 'Unverăndexlichkeit' Gottes.

Die 'непременность' wixd als das 'gemeinsame Band allex göttlichen Eigenschaften' bezeichnet:

$$
\text { VI.198 Божиих свойств обща связь есть в нем непременность; - }
$$

Sie bedeutet, daB Gott nichts 'durch Verganglichkeit' verliert und nichts neu empfăngt: $v I, 199 f$. Hе теряет ничего cex он upes тленность

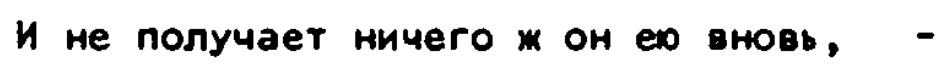

Die 'Unverănderlichkeit' Gottes wird a priori aus dem Begriff des aus sich selbst ewig existiexenden, vollkommenen Wesens abgeleitet: 
VI,204f. Бог есть сам со6о0, суиий еечно 6ез причин;

Всех сөершенсте прекрайних не возмог не бить в нем чин.

Der unverănderliche Bestand der Eigenschaften cottes wird dadurch bewahrt, das er keine von ihnen jemals 'fxeiwillig' aufglbt und niemand sie inm entreiken konnte:

VI,208f. Тем сам добровольно не лишится их всегра,

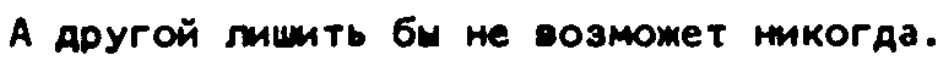

DaB Gott seinem Wesen nach 'unveranderlich' 1st, leuchtet jedem unmittelbar ein, meint Tred.:

VI,212f. पто $*$ Gor непременен сунество по естеству, То так и прилично, каждий оидит, божестоу.

Hier ist anzumerken, daß sich Tred. mit der rationalen Evidenz der 'Unverănderlichkeit' Gottes begnügt. Ex hatte sie leicht mit Bibelstellen belegen können, z.B. mit Jac.,Kap.1,17:

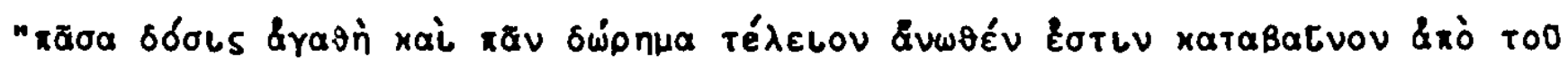

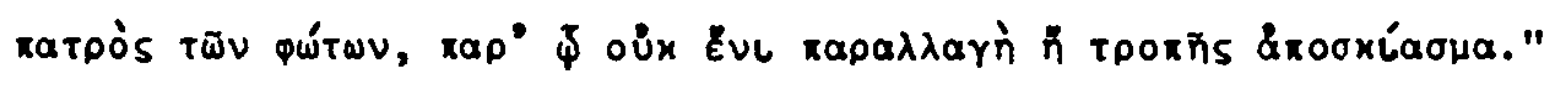

Zu den klassischen Belegstellen in der Bibel für die 'Unverănderlichkeit' Gottes gehort auch Hebr.,Kap.1,12:

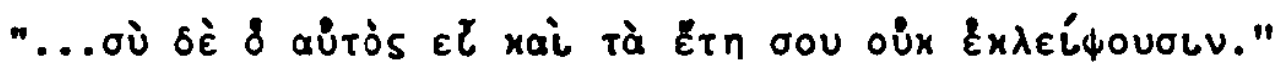

Schwerer $z u$ verstehen ist es, răunt Tred. ein, weshalb cott nicht dann und wann seine Ratschlüsse ándert, wie das bel Feldherren, Seefahrern, Ratgebern, Baumeistern und Kaufleuten immer wieder vorkommt:

VI,214ff. Но труаняй есть понимать, как не пременяет

Бо по случаям судеб, что узаконяет

Как то : полководцах и случается в пловцах,

Как в мужах советни, в здателях, и как в купцах.

Der Grund ist dieser: Menschen mussen ihre Entscheidungen andern, weil sie die Ereignisse nicht voraussehen konnen. Bei Gott gibt es solche 'Dunkelheit des Nichtwissens' nicht. Er weiB, was die ganze Welt harmonisch zusammenhălt:

VI.220f. Но незнаний мрака : бore такового нет,

Знает, что В причинах Аружно весь содержит спет.

Das heibt jedoch nicht, daß cott an seinen einmal gefaBten RatschluB gebunden ware. Es ist inm ein leichtes, ein a u B e r e s schicksal abzuandern. Als Beispiel nennt Tred. die Vexschonung der stadt Ninive. Daruber heiBt es im Buche Jona, daß cott inr zur Strafe fur die sünden ihxer Bewohner den Un- 
tergang ankundigen laBt. Als diese aber BuBe taten, "reute ihn des Ubels, das er geredet hatte ihnen zu tun, und tat's nicht" (Jona,Kap.3,10):

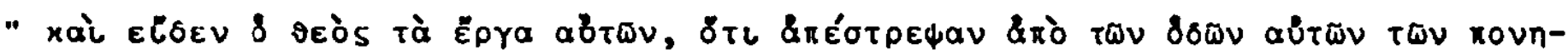

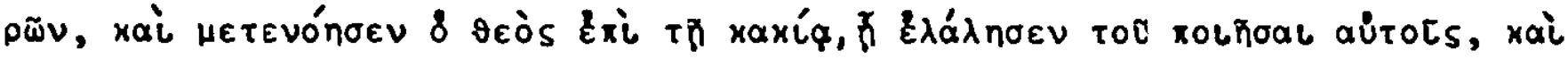
oủx E̊roínoev."

Ein Sinneswandel Gottes erscheint Tred. unvereinbar mit seinem Verstandnis der 'непременность'. Darum deutet er die Verschonung Ninives, dem Sinn der Geschichte zuwider, als einen Akt der gottlichen Macht. Gott habe die Androhung des Untergangs der Stadt zum 'Vorwand' genommen, um seine Macht, den a $u$ B $\mathrm{C}$ e $\mathrm{n}$ Verlauf des Schicksals zu andern, zu beweisen:

VI,222ff. А однак не можем мы не признать охотно, Что суаьбу меняет бог в внешней вещи льготно,

Коей под прелогом токмо быть определил,

Так как Нинивии града он н погубил.

И От мони своея бог преходит в дело,

Tred. unterstreicht jedoch, daB es sich nur um eine Anderung der 'außeren Uinge' handele:

VI,227 Но премена в вещи ж та, говорю я смело.

Der 'Höchste' selber ist 'unverănderlich'. Viermal wird dieses Attribut in den Versen 228-235 wiederholt: Gottes Sein, Vernunft, wille und Macht sind 'unverănderlich':

$\begin{array}{ll}\text { VI,228 } & \text { Непременен вышний всеконечно бытием: - } \\ \text { VI,230 } & \text { Непременен также он разумом конечно: - } \\ \text { VI,232 } & \text { Непременен купно волею своею он: - } \\ \text { VI,235 } & \text { Непременен весь и в моць преходить до дела! }\end{array}$

Das ksl. Adjektiv "nepremen' $n$-" ist bei Mikl. (438) belegt und mit 'immutabilis' übersetzt. Tred. hat das Subst. 'неnременностb' für das von den Scholastikern verwendete Attribut 'imnutabilitas' gebraucht.

In VI,236-642 werden die 'attributa relativa' Gottes dargelegt (свойства возносительные).

Innerhalb dieser Gruppe unterscheidet Tred. nach scholastischem Beispiel die auf die 'natürliche Welt' bezogenen von den auf die 'sittliche Welt' bezogenen Eigenschaften Gottes.

VI, 236-445: Die 'естественные свойства' Cottes.

In den Versen 236ff. wird das neue Thema eingeleitet und sein Verhăltnis zu dem vorhergehenden bezeichnet: 
VI, 236ff. K свойстеам 6оra sзносним приступаем rosopя:

Or наружи сии прояеляют всех царя,

Токмо ж внутренние те в мисль преanonaraxt.

Tred. legt dar, daB nach Auffassung der Theologen nur zwel Elgenschaften cottes auf die 'naturliche Welt' bezogen sind: sein 'Schopfertum' und die 'Vorsehung' :

VI,239f. Деа их токмо по вещам мудрыи считахт:

Перьое в тех зданность, промшсл следует потом, -

In VI, 241-325 handelt Tred. vom Schopfer und seinem Werk.

Nach einer im 18.Jahrhundert verbreiteten Metapher ist Gott der 'Baumeister', der die Welt als unser 'gemeinsames Haus' erbaut hat. Tred. hat sich diese Metaphern zu eigen gemacht und eine Art Wortspiel daraus gebildet:

\section{VI, 241 Здатель зиждет строя, строит зикдя Обиий дом.}

Die Metaphern heben die planvolle ordnung und sinnxeiche Einrichtung der Welt hervor, die zu bewundern die Physikotheologen nicht müde wurden. In dem Bild des 'gemeinsamen Hauses' kundigt sich vielleicht auch das entstehende kosmopolitische BewuBtsein des Zeitalters an: der gottliche Baumeister hat das 'gemeinsame Haus' für alle Menschen erbaut, damit sle eintrăchtig zusammenleben.

Der Autor scheint auf die neuplatonische Lehre von der Präexistenz aller Dinge im Geiste Gottes anzuspielen: Gott habe die Idee der Welt, die von Ewigkelt her in inm war, dann in sinnlich wahrnehmbarer Gestalt 'hervorgebracht:

vi,242ff. Всех вещей, которш суть бога вме уж делом,

Не било кроме идей в разуме всечелом.

божия то воля вечншм суцностям дала

Чуестеуему битность $и$ - нее произвела.

Diese Spekulation identifiziert Tred. Ohne weiteres mit dem Schopfungsglauben und setzt hinzu, daB wir Gott als den Schópfer der Welt und alles dessen, was sichtbar und unsichtbar 1st, verehren:

VI,246ff. Воли божия сие дейстео именуем

Сотворением; теориом бога и честеуем

Вияимого мира и есего, что суме в нем

Есть и пребшеает, зримо и не зримо анем.

Die Wendung 'зримо и не зримо' erinnert an den ersten Artikel des Nicaenum:

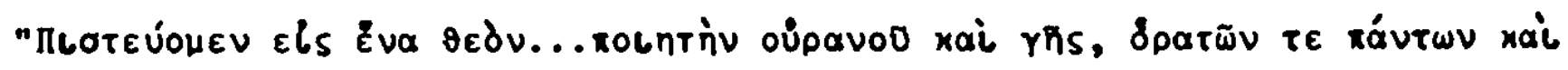
\&opátwV." 26 
Den Begriff 'Welt' definiert Tred. In persönlicher Rede: 'ich bezeichne die Gesamtheit aller Dinge, inre feste, unaufhörliche Verbindung, als Welt':

VI,250f. Миром называіо я всех вещей счетанность,

Иль союз претвердый их, в том и непрестанность.

Bei dem Stichwort 'Welt' greift Tred., sich z.T. wiederholend (vgl.vI,80ff., VI, 142ff.), die Idee der Vielzahl möglicher Welten von neuem auf:

VI,252 Множество возможных миров было без конца: -

Der Schöpfer muB also einen Grund gehabt haben, folgert Tred., daB er diese unsere Welt anderen möglichen Welten vorgezogen hat:

vI,253f. Тем быть долг причине у премудрого творца,

По которой он избрал сей мир пред аругими -

Es kann inn dabei nur die Wahl des Besten geleitet haben. In seiner Güte hat Gott diese Welt wegen inrer denkbax gröBten vollkommenheit bevorzugt:

VI,259 Благостио сей для тех предпочтен в уставе; -

Die Uberlegung führt zu dem SchluB, daB 'diese Welt die beste aller Welten', und daB sie auch in bezug auf ihre Ausdehnung die gröbte ist:

VI,260f. Следует, что самый лучший есть из всех мир сей

И что величайший по пространности он всей.

Damit hat Tred. die bekannte Formel der Leibnizischen Theodizee von der besten aller möglichen Welten aufgegriffen und den Superlativ der gualität durch den der Quantităt ergănzt. Ohne auf das Problem des tbels einzugehen, versteht Tred. den Satz rein optimistisch. Im Unterschied dazu hat Leibniz zeigen wollen, daB diese Welt trotz inrer unbestreitbaren zahlreichen Ubel aus der Hand des allmăchtigen und gütigen Schöpfers hervorgegangen ist. Er tut dar, daB die physischen tbel in einer sittlichen Weltordnung notwendig auf die moralischen Ubel folgen müssen: sie sind strafe für die Sünden. Das moralische Ubel ist aber in der Endlichkeit und Begrenztheit der Geschöpfe begründet. Nach Leibniz hat die Monade als endliches Wesen dunkle und verworrene Vorstellungen, aus denen notwendig die verworrenen Sinnentriebe als Motive der sünde hervorgehen. Endlichkeit und Begrenztheit (das metaphysische Ubel) gehören zum Begriff des Geschöpfes. Eine Welt von vollkommenen Geschöpfen wăre nach Auffassung von Leibziz eine contradictio in adiecto. Nur der Schöpfer ist vollkomen. Leibniz will also in seiner Theodizee das tbel in der Welt nicht etwa leugnen, sondern beweisen, "daB diese Welt so wenig Ubel enthät, als es nach dem metaphysischen Gesetz irgend möglich war". 27 sie ist die Welt der 'kleinsten Ubel'. Diese Einschrankung ist manchmal nicht be- 
achtet worden. Zu der 'optimistischen' Deutung der Leibnizischen Theodizee bemerkt Windelband: "Das 18.Jahrhundert faste die Sache so auf, als habe Leibniz wesentlich beweisen wollen, dab die Welt die denkbar vollkomenste sel." 28 Ein prăgnantes Beispiel für diese Auffassung sind die Verse A.Popes am Ende der I.Ep. des 'Essay on Man':

I,291ff. "All Discord, Harmony, not understood;

All partial Evil, universal Good:

And, spite of Pride, in erring Reason's spite,

One truth is clear, "Whatever IS, IS RIGIT."

Die Verse VI,261ff. exinnern an die Kirchenlehre von dex 'creatio ex nihilo: Tred. füht aus, die ganze Welt sel aus dem Nichts 'aufgetaucht'. Das'Nichts' sel aber weder als 'Materie' noch als 'Ursache' zu verstehen. Es bezeichnet die 'leere Nacht' vor dem Dasein der Dinge:

VI,262ff. Но из ничего сие битие всё всплмло.

То ж ничто не веществом, не причиной бшло;

Означало только состояние вещей

Бшвше прежде вещи, то есть их пустых нощей.

Das Verbum 'всплшеть, есплшть' ('hervorschwimmen, auftauchen', Pawl.170) ist hiex bildlich und nicht als Ausdruck der Emanationslehre zu verstehen. Die alten Dogmatiker betonten die Partikel 'ex' (nihilo) und lehrten: " $e x$ ' non designat sed excludit materiam". 29

Aus der Endlichkeit und Unvollkommenheit aller Kreaturen, der geistigen wie der materiellen. folgt, das sie von 'einem anderen' geschaffen worden sind:

VI,270f. Сиречь вечность, никаким обрашом не можно;

Следственно, сотворени те аругим неложно, -

Ausdrücklich grenzt Tred. die 'creatio ex nih1lo' von dem neuplatonischen Emanationsbegriff ab:

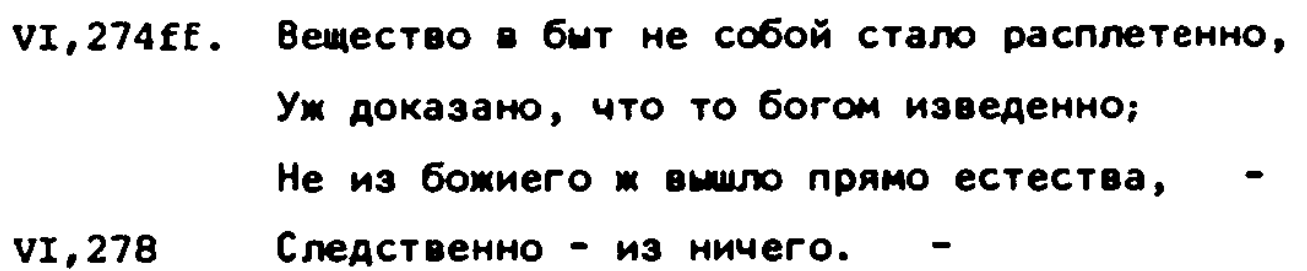

Als zweites wesentliches Element der kirchlichen Schopfungslehre neben dem 'ex nihilo' betont Tred. die freie Entscheidung des Schopfers:

VI,284 Bпрочем вся созданность вольнейний есть произвол: Die alten Dogmatiker lehrten, der Akt der Schopfung sei "non ex necessitate naturae sed ex libertate voluntatis". 30 
Mit einem AnalogieschluB a minore ad maius bekraftigt Tred. seine Auffassung: wenn schon der Mensch gewisse schöpferische Făhigkeiten hat: er kann neue Gedanken denken und neue sittliche Eigenschaften bekommen und in die Tat umsetzen - wieviel gröBer muB die Schopferkraft Gottes sein. Sollte cott, der alle Vollkommenheit hat und in allem überreich ist, zu schwach sein, um die Kreaturen zu schaffen?

$$
\text { VI,278ff. }
$$

Могут мысли изводить новше Аушами,

Нравственные и́мства такме новы получать, Разуму и телу действом оны вновь собщать;

А всесовершенный бог, кой всем преобилен, К издеденио суиеств мог ли быть бессилен?

In der nachsten Passage stellt Tred. die Frage nach der Ursache und dem Zweck der Schōpfung und beantwortet sie mit Begriffen der Schultheologen, die von der 'causa impulsiva', der 'causa creationis efficiens' und dem 'finis ultimus' der Weltschöpfung sprachen.

Das Motiv (causa impulsiva) zur Erschaffung der Welt ist die Güte des Schöpfers, sein wille, alle kreaturen glücklich zu machen:

VI,285ff. Побуждающему, цело к зданио, не впол,

Есть причиной божестеу благосераность точно,

Чтоб с собой ублажить и Аругих всех прочно.

Ganz ăhnlich haben die alten Dogmatiker formuliert: "Causa impulsiva est bonitas del sola, qua Deus sese ut summum bonum communicare voluit." 31

Nach G.Hüttl-Worth ist '6rarocepaHoctb' "eine von Tred. neu gebildete Variante zu ksl. "blagoserdie" = Güte." 32

Die 'өина творяща' Tred.s (288) entspricht der 'causa creationis efficiens' der Dogmatiker, womit sie den 'Deus triunus' meinten. Tred. sieht vor allem die Weisheit und macht Gottes beim Schopfungswerk beteiligt: seine Weisheit hat den Geschöpfen nichts vorenthalten, was ihnen angemessen ist. Seine Macht hat ihnen zum Wesen die Existenz hinzugegeben und sie miteinander verbunden:

$$
\text { VI,288ff. Но вина теоряща, мудрость частио его, }
$$

Суиностей пристойншх не лишивша ничего;

Частио ж и сила а нем бытие придавша

К сущности той всех рещей их и сочетавша.

Eine weitere Bestimmung der Schöpfungslehre übernimmt Tred. mit dem Begriff 'вина конечна' (292), der dem 'finis ultimus' der Dogmatiker entspricht. Die- 
se lehren: "Finis ultimus est Dei gloxia." 33 Tred. erklart: die schopfung zeigt 'wie in einem Spiegel' die Vollkommenheit des Schopfers, damit alle Menschen seine Herrlichkeit preisen:

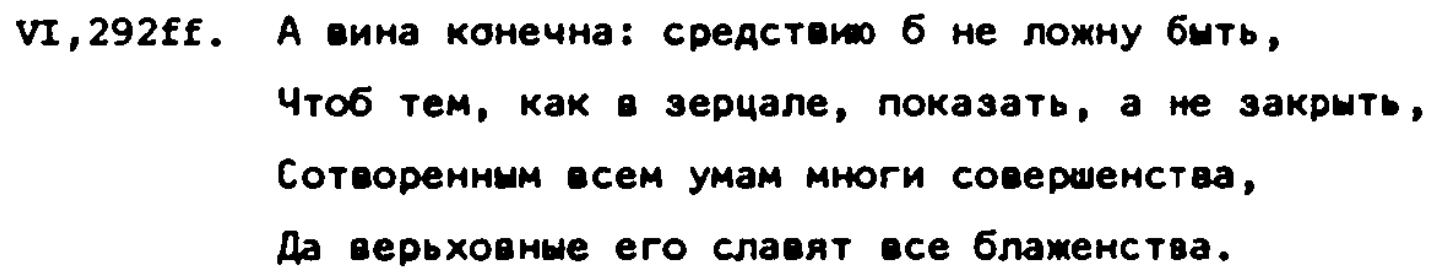

Die fü das Weltverstăndnis der Physikotheologen bezeichnende Spiegel-Motapher hat rred. In der Demonstration vorgefunden: "La sagesse et la puissance qu'il a marqueses dans tout ce qu'il a fait le font voir, come dans un miroir, a ceux qui ne peuvent le contempler dans sa propre idee." (S.2)

Der Apostel Paulus verwendet die Spiegel-Metapher in I.Kor.,Kap.13,12:

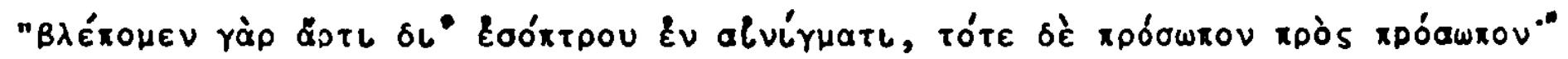

Nach Auffassung von G.Kittel steht der paulinische Satz in deutlichem Zusammenhang mit Num. Kap.12,8. Dort ist nach rabbinischer Exegese des hebx. Textes davon die Rede, daB Gott sich dem Mose 'mittels eines hellen Spiegels' offenbart habe und nicht nur durch 'Traum und Vision' wie den Propheten. Den Ansatz zu dieser Deutung bildet deas hebr. Nomen "mar-eh" (Num.12,8), das im Alten Testament (Exod.38,8) "und auch im Rabbinischen (Beispiele strack-Billerbeck III,452) Spiegel heiBt". ${ }^{34}$ G.Kittel fürt aus: "Damit ist deutlich, daß 'Schauen im Splegel' eine Redeform für das Teilhaben an der Gottesoffenbarung, und zwar, wie das Beispiel des Mose zeigt, in einem sehr hohen sinn, sein kann." Die Anwendung des Bildes der 'Splegelschau' auf die cottesoffenbarung hăgt - so meint G.Kittel, der sich auf eine einschlagige arbeit von J.Behm beruft - "In ihren Ursprüngen zweifellos mit der im Hellenismus vorhandenen Katoptromantie zusammen". Auf die Herkunft des Bildes der Spiegelschau aus dem 'hellenistischen zauberbrauch' weist schon die Tatsache hin, "dab in allen hierhergehorigen stellen der rabbinischen Literatur von den verschiedenen für den Splegel gebrăuchlichen worten nur das Fremdwort 'ispeklarja' verwendet wird". Das rabbinische Wort 'ispeklarja' = gr. 'oxєxAáplov' bedeutet sowohl 'Glas' als auch 'Spiegel'.

G.Kittel hebt hervor, daß in dem Bild dex 'Spiegelschau und -offenbarung' keinesfalls ein abwertender sinn liegt. Es ist nicht daran gedacht, daB der Spiegel nur ein 'unscharfes Bild' gebe. "Ebenso liegt...der Gedanke völlig fern, daß man durch den Spiegel nicht die Sache selber, sondern nur ein Abbild sieht." Als Bestatigung funrt G.Kittel an: "Mose wird Ja gerade als der 
gepriesen, der die höchste, unmittelbarste offenbarung empfăngt, wenn er Gott in einem klaren Spiegel sieht." Daraus ergibt sich: Schauen " $\delta \iota "$ toórtpou" 1st vollwertige offenbarung. In dem wort des paulus 1. kor.13,12 kommt

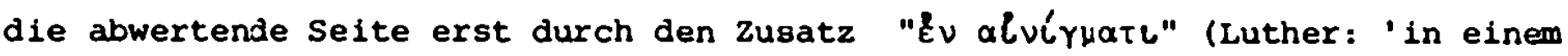
dunkeln Wort) heraus. Kittel interpretiert: "...dem jetzigen (\&"ptน) unvoll-

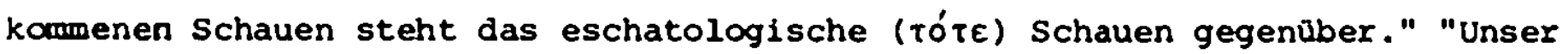
pneumatisches Schauen ist 'nux' Ev alvíruarl (nicht: ist 'nur' ol" Eoórtpou)", will der Apostel nach Meinung G.Kittels sagen. 35

Tred. unterstreicht, daß die Welt aus vielen Gründen 'spiegel der Vollkommenheiten Gottes' genannt werden kann:

VI,296f. Tвердо по премногу может тварь, что создана́, Божих зерцалом совершенств быть названа́.

Die Metapher bringt auch hier zum Ausdruck, daB Gott sich in allem Geschaffenen vollgültig offenbart hat. Der Mensch kann Gott aus der Schöpfung erkennen. Seine höchste Bestimmung ist, 'Gott bestăndig zu preisen':

VI,307ff. Да творца знать и честить тщится та безмерно; /тварьТ Посему последний умных тварей есть конец

Славить нелрестанно бога, он нам есть отец.

Nach Röm. ,Kap.1,21 sollte der Anblick der Schöpfungswerke den Menschen dazu

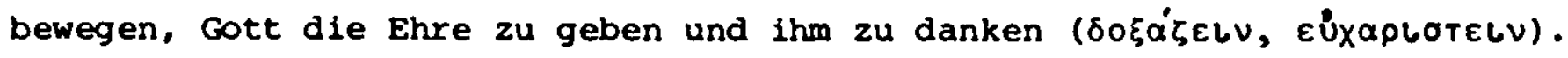
Als besonderen Grund, Gott zu preisen, fuhrt Tred. an: 'er ist unser Vater'. Hier zeigt sich, daß ex an die biblische offenbarung denkt. Aus dem philosophischen Gottesbegriff laBt sich die Aussage 'Or mam есть отеu' nicht ableiten.

Die Tatsache, daB alle Geschöpfe ohne Ausnahme 'Spiegel' der vollkommenheit Gottes sind, begründet inre solidarităt. Cott hat alle kreaturen, von der unbeseelten Materie bis zum vernunftbegabten Menschen, dazu geschaffen, daB sie einander 'Helfer und Diener' zum Glück werden:

VI,302f. Да один Аругому в них будет споспешитель

И да счастию взаем аругу Аруг служитель.

Dieser schöne sozialethische Gedanke ist in der Feoptija schon früher dargelegt worden. In Ep.II,197ff. wird ausgeführt, daB die Menschen in Freundschaft miteinander leben sollen. Deshalb habe Gott die Rohstoffe aber die ganze Erde verteilt und damit die Menschen im Geben und Nehmen voneinander abhăngig gemacht: 
II,197f. Всё есть, но не во всех землах, что лодям нужно! Не явно ль хомет бог нам меж собой жить Аружно?

Die vom Schöpfer gewollte Zusammengehörigkeit der Geschópfe kommt auch in der neuen Einstellung zu den Tieren zum Ausdruck, wie die III.Epistel gezeigt hat. Tred. versteht die Tiere im Gegensatz zu Descartes nicht als Mechanismen, sondern als Geschöpfe eigenen Wertes, die auf ihre Weise die Weisheit, Macht und Güte des Schopfers widerspiegeln. Die Verbundenheit mit den Mitgeschopfen steht in enger Beziehung zu dem theozentrischen Weltbild der Physikotheologen. W.Philipp spricht von der "sozialethischen Valenz der doxologischen Haltung". 36

Die Idee der wechselseitigen Dienstbarkeit der Geschopfe ist von A.Pope in Verbindung mit der Vorstellung von der 'chain of Love' so beschrieben worden: Ep.III,22ff."One all-extending, all preserving Soul

Connects each being, greatest with the least; Made Beast in aid of Man, and Man of Beast;

All serv'd, all serving! nothing stands alone;

The chain holds on, and where it ends, unknown."

Da diese Welt der Güte (286), Weisheit (288) und Macht (290) des Schópfers entstammt und dem zweck dient, ihn zu verherrlichen (292ff.), kann sie durch keine andere Welt uberboten werden. Die Frage, ob es eine bessere Welt geben könne, wird darum entschieden zurückgewiesen:

\section{VI,310f. Oпрове́ржен сей вопрос: мог ли всемогущий}

Лучший сотворить иный, нежели мир сущий?

In Ubereinstimmung mit Leibniz bekrăfigt Tred., daß Gott sich bei der Erschaffung der welt von seiner Weisheit und Gute hat leiten lassen:

VI,312ff. В здании бог мира самым лучшим осем вина́м
Следовал конечно, зная совершенно сам,
Кои мудрости его более достойны,
Более жи обрелись благости пристойны; -

Wollte man annehmen, daB cott eine bessere Welt als die unsere hătte schaffen können, so wăre er unserer Welt gegenuber nicht gütig und weise gewesen. Diese Annahme wird als tơricht abgewiesen:

VI,316f. Верить, что мир лучший сотворить сего он мог,

То суаить безумно, что не благ, не мудр наш боr.

Am SchluB des Abschnitts polemisiert Tred. gegen bestimmte spekulationen, die über das Schöpfungsthema gemacht worden sind. Z.B.: hătte Gott die Welt 
nicht von Ewigkeit hex schaffen können, oder den Menschen als ein unendiches Wesen? Ferner: was hat der Höchste gemacht, bevor er die Welt exschuf? Tred. nennt diese Spekulationen 'wahnwitzig':

VI, 318ff. Hо вопросом: мог ли он мир творить от века?

Mог ли бесконечну тварь здать иль человека?

И что делал вышний прежде, нежель мир создал?

Не могу, чтоб прямо сумасбродными не клал:

Die beiden zleest angeführten Fragen sind 'widersinnig', 'absurd', 'unmöglich' und deshalb 'teuflisch' :

VI,322f. Первыи конечно Ава пречны и безмесны, Невозможны по всему, отчего и бесны; -

Die dritte Spekulation verspottet Tred. mit einem Wort, das er Augustin zuschreibt: Gott habe vor der Erschaffung der Welt für die Neugierigen die Hölle hergerichtet:

VI,324f. A в ответ на третий с Августином вскликну в лад:

Бог тогаа пытливым приуготовлял сим аА.

Das hiex Augustin zugeschriebene Wort stammt in Wirklichkeit nicht von diesem. Augustin erwähnt es als scherzhaft gemeinte Antwort eines anderen, die er selber aber nicht für angemessen hält. In den 'Confessiones' XI.12sqq. heiBt es: "ecce respondeo dicenti: quid faciebat Deus antequam faceret coelum et terram: respondeo non illud, quod quidam respondisse perhibetur joculariter eludens quaestionis violentiam: Alta inquit scrutantibus gehennas parabat. - Libenter enim responderim, nescio quod nescio. - Audenter dico. antequam faceret Deus coelum et terram, non faciebat aliquid; si enim faciebat, quid nisi creaturam faciebat?" 37

In VI, 326-405 handelt Tred. von der gottlichen 'Vorsehung' .

Er bezeichnet sie in VI,330f. mit drei Begriffen: 'провидение', 'промысл' und 'cтроение'.

'Провидение' ist von dem bei Mikl.(692) belegten ksl. "provideti" abgeleitet, das dort mit 'praevidere' übersetzt wird. Es bezeichnet die 'Vorsehung' in Sinne des 'voraussehens'.

'Промысл' erscheint bei Mikl.(699) als 'providentia'. Von Sreznevskif (II, 1545f.) wird 'nромысл' u.a. mit 'забота, попечение, предначертание, промисл Божий' wiedergegeben. Das Wort ist daher speziell als göttliche 'Fürsorge' zu verstehen.

'Строение' wixd von Mikl.(891) als ksl. "stroienile" aufgeführt, fur das ex 
'administratio', 'curatio' einsetzt. Damit ist die göttliche 'Lenkung' und 'Verwaltung' der Welt gemeint.

Der Abschnitt beginut mit einer Definition der 'providentia Dei', wie sie ahnlich in scholastischen Texten und in der lutherischen orthodoxie des 17. Jahrhunderts zu finden ist. Tred. bestimmt die 'Vorsehung' als diejenige Aktion Gottes, durch die er unaufhorlich die von inm geschaffene Welt gemäB der ordnung und den Gesetzen, die er gegeben hat, regiert und erhalt:

VI, 326ff. Аействие, которым бог в мире непрестанно
Управляет и хранит всё, что есть созданно
По известну чину и по положе́нным всем
От себя законам, непреложно твердым тем,
Провидением его, промислом, третично
И строением к тому $\%$, именуем слично.

Zum Vergleich sei die von Chr.E.Luthardt zitierte Definition der 'providentia' des orthodoxen Lutheraners Joh.Andreas Quenstedt (1617-1688) angefunrt, die in wesentlichen Stucken mit Feopt.VI, 326ff. ubereinstimmt:

"actio externa totius Irinitatis, qua res a se conditas universas ac singulas tam quoad speciem quoad individua potentissime conservat inque eorum actiones et effectus coinfluit et libere ac sapienter omnia gubernat ad sui gloriam et universi huius atque imprimis piorum utilitatem ac salutem."38

Die Ahnlichkeit ist wohl auf gemeinsame scholastische quellen zuruckzuführen. Das Verhaltnis der altprotestantischen orthodoxie zux Scholastik wird 80 beschrleben: "Diese Systeme dex orthodoxen Dogmatik sind nicht zu verstehen ohne Kenntnis der Philosophie, die un die Wende des 17.Jh.s die Universităten eroberte...Diese Schulphilosophie, die das wissenschaftliche Fundament der Dogmatik im Geiste jener zeit bildete, war aristotelische Scholastik, ihrer Axt nach also der Scholastik des Mittelalters und der Neuscholastik des nachreformatorischen Katholizismus verwandt. "39 Gemeinsames Kennzeichen von Scholastik und altprotestantischer Dogmatik ist vor allem "die von der allgemeinen Begriffsbestimmung (Definition) ausgehende, diese formell zergliedernde und durch ungezălte Thesen und Antithesen, 'Distinktionen' und 'Quästionen' zu weiteren Begriffsbestimmungen gelangende 'definitive Methode' . "40

Tred. fuhrt weiter aus, daß sich die 'Vorsehung' auf die beiden vollig verschiedenen Reiche erstreckt, in die nach der Lehre Descartes' die Welt geteilt ist: alle Dinge sind entweder körper oder Geister. So unterscheidet auch Tred. zwei Arten von Geschopfen: 
VI.332f. Два конечно вида тварей числится вобще:

Есть өид весь телесный и разумный өид еще.

In der Korperwelt bewirkt die vorsehung die Erhaltung der Materie in konstanter Menge und die Bewegung der koxpex nach bestăndigen Gesetzen:

VI,334ff. На телесный зрим когда, еидим, что хранится

Всё в количестве одном вещество и алится.

Постоянним чином в свете цельные тела

Движутся как спе́рва оным всем стезя легла.

Analog zur Erhaltung der Arten in dex Tierwelt (vgl.III,609f.) kennt Tred. die Exhaltung dex verschiedenen Arten der Materie:

vi,338f. Вещи в роде өсе своем цело пребывакт

И не гибнут роди их и не убывают.

Die spezielle Füxsorge Gottes gilt aber dem Menschen, stellt Tred. bewundernd fest:

VI,340f. И на человеков смотрим также мы когда, Зрим, что бог печется дивно и о нас есегяа.

So hat Gott für den Fortbestand dex Menschheit durch die Erschaffung dex beiden Geschlechter gesorgt:

VI,342f. Мужеский и женский пол состоит в нас равно,

Столько женцин, сколько есть и мужчин исправно.

In seiner Fưrsorge hat Gott die Erde, die er uns zur wohnstatte bestimmt hat, mit allem, was wir brauchen, ausgestattet:

VI,344f. Gог нас всех поставил пребывать на сей земле, Дал ей всё, что нужно, не пропасть в ее 6 нам тле, -

Gott hat der Erde 'Nahrung für uns alle', dazu auch, was zur 'Befreiung vom Schaden' und zu unserem 'Ergótzen' dienen kann, gegeben:

VI,346f. K пропитанию всех нас, от вредов $k$ избаве, Дал и может что служить к нашей всей забаве.

Bei der 'Befreiung vom Schaden' ist wohl an die Heilkrăfte der Natur, etwa an die 'зелия врачебны' (II,194) zu denken. Tred. will sagen, daß Gott großzügig für den Menschen gesorgt hat und auf dessen leibliches und seelisches Wohl bedacht ist.

Der Glauben an die besondere rursorge Gottes scheint entgegenzustehen, da $B$ die Menschen oft vergeblich gegen die übermächtigen wilden Tiere kămpfen müssen, die ihnen viel Unheil zufügen: 


\section{VI,348ff. Mногажды бшварт устремления подей, \\ В силе многомощншх, злейших же самих зверей, \\ Тщетны, коль ни хитро их вимшленны средства, \\ Aa manáctи наведут и печальны следства, -}

Die Existenz der wilden Tiere, ein schwer erklărbares Rătsel für die optimistische Weltanschauung, hat Tred. in Ep.III,168ff. auf verschiedene Weise zu rechtfertigen versucht. Im folgenden entschăft er das Problem durch die Behauptung, daB das 'Tun der Gerechten in schwierigen Lagen ein glückliches Ende nimmt, und daB sie oft den Siegeskranz erhalten' :

VI,352f. А живущих правдой действа сча́стлившй конец, По препонам, часто 2 получаот и венец.

Die stelle erinnert an die scholastische Auffassung, nach der zwar alle Menschen unter der Vorsehung cottes stehen, jedoch: "Speciailssime divinae providentiae objectum sunt homines pii ac fideles, utpote qui sunt velut nucleus humani generis, quos propter mundus adhuc a Deo sustentatur et conservatur." 41

In einer Apostrophe an Evsevij macht Tred. die besondere Fursorge cottes für den Menschen an einzelnen schon früher behandelten Naturerscheinungen deutlich. Die Passage erhalt durch die zuwendung an den fiktiven Adressaten einen persōnlichen Ton. Tred. apostrophiert ihn als gleichgesinnten, ebenbürtigen Partner, der selber uber die 'zarte Fürsorge' Gottes für uns nachgedacht hat:

VI,354f. Но, Евсевий, мно, что ты мыслил сам прилежно,

Попечение 06 нас божие коль нежно; -

Evsevij möge z.B. bedenken, daß das Licht der sonne ein unentbehrliches, kostbares Geschenk des Schōpfers ist, ohne das wir wie Blinde lebten. Ohne das Licht der Sonne wăre die ganze Natur tot:

VI,356ff. Вияишь, сколько нужен солнечншй мам в свете свет,

И сему коль дару никакой цены здесь нет!

иили 6 без него слепым в мире мы подобно,

И всё $б$ было естество мертво, неудобно.

Ferner, daß uns der Wechsel von Tag und Nacht gegeben ist, weil wir die Ruhe notig haben:

VI,360f. И как мы имеем нужау также отянхать,

То и ночь, в премену, подана́, чтоб почивать.

Den 'wunderbaren Wechsel von Tag und Nacht' hat Tred. bereits in II,632f. beschrieben und als weise ordnung des Bochsten bezeichnet. Bier fügt er hinzu: Es war cottes Wille, daß die Sonne 'den Tag regiere': 
VI,362 Восхотел 6ог, чтоб ная днем солнце власть имело, -

Die biblische Wendung klingt an (Gen., Kap.1,16):

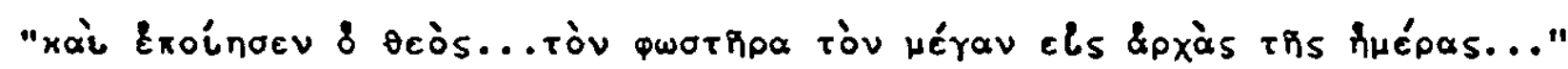

Dem willen des Schöpfers gemåß soll die Sonne dem Menschen dienen: sie läBt uns die Wunder der Natur sehen; sie spendet Leben und wărme; sie soll mit 'mildem Feuer' die Welt erwărmen:

$$
\begin{aligned}
& \text { VI,364ff. И не токмо } 6 \text { средством было нам оно } к \text { тому, } \\
& \text { Чудеса чтоб видеть в естестве, да и } к \text { сему, } \\
& \text { Чтоб и мизнь, и теплоту купно подавало, } \\
& \text { И умеренным огнем вещи } 6 \text { согревало. }
\end{aligned}
$$

Der Autor erinnert Evsevif weiter daran, daß der Schōpfer dem Mond und den Sternen 'befohlen' habe, die Nacht $z u$ erleuchten und sie ein wenig 'von der ihr eigenen Finsternis zu reinigen':

VI,368f. Но луне с звездами повелел ночь освещать

И от сродна мрака некак ону очищать.

Tred. faBt zusammen: Der Schöpfer hat zu unserem Wohl für den wechsel von Licht und Finsternis, Arbeit und Ruhe gesorgt:

VI,372f. Tо свет, то тьма ра́вно; иногаа труа, там покой;

Всё ж, чтоб нашей пользе не был вред здесь никакой.

In der Passage treten als Hauptmerkmale der Naturbetrachtung in der Feoptija die theozentrische, die teleologische und die anthropozentrische Betrachtungsweise hervor, wie wir sie auch bei Fénelon, Brockes und anderen Physikotheologen antreffen.

Diese Naturbetrachtung ist theozentrisch: alle Erscheinungen sind im Willen Gottes begründet. Er 'gebietet' der Sonne, dem Mond und den Sternen (362; 368). Der Wechsel von Tag und Nacht ist von ihm festgesetzt (361). Sie ist ferner teleologisch: alles in der Natur hat seinen gottgewollten Zweck. Diese Sicht kommt in einer Reihe von Finalsãtzen zum Ausdruck ( $365 f$. 373).

Schlieblich: die Natur wird unter anthropozentrischem Blickwinkel gesehen. Ver Mensch ist von der Fürsorge cottes umgeben ('nonечение об нас божие', 355). Gott hat die Welt so eingerichtet, daB sie dem Menschen zum Besten dient (373).

Wie die Tageszeiten versteht Tred. auch die Jahreszeiten als Ausdruck göttlicher Fürsorge für den Menschen. Mit einer Reihe von Fragen an Evsevij werden die wohltaten genannt, die der Mensch den verschiedenen Jahreszeiten 
verdankt.

Die Einleitungsformel 'как тебе не мнится зря' (374) beherrscht die Fragenkette. Es folgen: 'как сие, что...?'(378); 'то не Аивно ль чудо, 4то...7'(384)

Dex Autor führt Evsevif vor Augen, daß nach dem winter die Sonne zu uns zurückkommt 'zu den warmen zeichen' des Tierkreises. Er schildert in lyrischem Ton, wie sie 'die verdorrten Băume zu neuer Frucht lebendig macht' und durch ihre Anwesenheit 'das schone Jahr' beginnt. 'Wie kommt Dir das vor?' fragt er, im voraus gewiB, dab Evsevif darin die 'zarte Fursorge' des Schopfers sieht:

VI,374ff. Как те6е то мнится зря, что к нам солнце паки Вспять приходит по зиме, в теплы оны знаки?

A древа́ увядши оживляет в новый плод

И своим присутством красншй начинает год?

Zu 'теплы оны знаки' (375) wird in den 'Примечания' zur Feoptifa (S.520) angemerkt: "знаки Зояиака, соответствуощие летним месяцам...' Die veraltete (ptolemåische) Vorstellung von der 'Rückkehr' der Sonne kennzeichnet Tred. durch altertümliche Worte: 'nakи' für 'опять' (374) und 'вcnatb' anstelle von '

Darauf beschreibt Tred., wie wir uns aufs neue 'zum kalten Kreis' entfernen, nachdem uns die Sonne ihren Dienst erwiesen hat. Die Sonnenwende wird anthropomorph dargestellt: die Sonne 'befürchtet, uns mit ihrer stăndigen Glut lästig zu werden und zu schwăchen'. Wieder wird der Partner gefragt: 'wie denkst Du darüber?'

VI,378ff. Kaк сие, что, показав всем нам в том услугу,

Отлучаемся опять $\mathrm{k}$ хлаянейшему кругу,

Харом нам яокучить опасаясь так своим,

Да не ослабеем от того бессменным им?

Der Autor weist darauf hin, daB wir den plotzlichen Wechsel von starkem Frost zur Hitze nicht ertragen konnten (vgl.II,673f.). 'Ist es nicht ein wunder', fragt er, 'daß dieses Gestirn sich uns schrittweise nahert und von uns entfernt?

VI, 384f. Tо не Анвно ль чУАО, что сие сөетило $\mathrm{k}$ нам

Близко приступает и ухояит по стопам -?

In den 'schrittweisen' Gang der Natur (vgl.II,671: 'стеnенами') sieht Tred. geradezu ein Prinzip der vom Schopfer dem Menschen angepaBten Welt. Wie der Mensch sich buchstăblich 'schrittweise' fortbewegt (II,666: 'степенями иауи, бывает человек'), so geht aus Rūcksicht auf den Menschen, so deutet es Tred., 
eine Jahreszeit in die andere über. Wer wollte angesichts dieser menschenfreundlichen Ordnung leugnen, fragt er, daß Gott als Freund der Menschen darauf bedacht ist, daB sie sich stets wohl befinden und seine wohltaten genieBen, zu denen auch die winterliche Abkühlung gehört:

VI,388ff. Всяк 6Ы рек, что вышний упражняется ль в аругом, Как чтоб токмо были в состоянии благом За́все человеки здесь? И чтоб наслаждались Бллагодетельством его, Аа и прохлаждались?

Auch die Tiere werden unter anthropozentrischem Blickwinkel betrachtet. Sie genießen zwar ebenso wie der Mensch die Wohltaten des Schöpfers; aber ihnen sind sie gegeben, damit sie uns dienen:

VI,392f. И хотя животны ра́вно ж пользуится тем, Но аля нашей службы дарова́но то им всем.

Tred. erláutert dies und führt an, daß wir uns vom Fleisch bestimmtex Tiere exnăhren, uns mit ihrem Fell bekleiden und sie zu unserer Hilfe bei den verschiedensten Arbeiten heranziehen. Uberspitzt behauptet er, die Tiere 'atmen nur um unser:willen':

VI, 397 Так ито те и дышут токмо раяи нас самих.

Die Physikotheologen hielten die Auffassung, daß alles in dex Natux zum Nutzen des Menschen da sei, die von den Stoikern im Ubermaß vertreten wurde, für biblisch begründet. Sie konnten sich z.B. auf die schópfungsgeschichte berufen, die in der Erschaffung des Menschen ihren töhepunkt hat. Ferner auf Bibelstellen wie Psalm 103,14 (LXX):

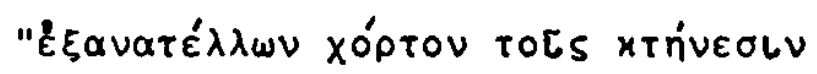

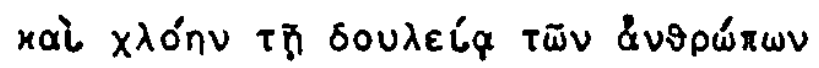

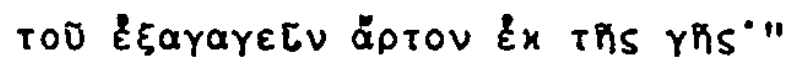

W.Philipp bemerkt: "Die biblische Position fand die Physikotheologie...bei Raimund von Sabunde wieder, der die Einzigartigkeit des Menschen und das Aufihn-hin der Natur vertrat." 42

Im Gegensatz dazu hat A.Pope im 'Essay on Man' die anthropozentrische Auffassung als menschliche Uberheblichkeit angeprangert und verspottet:

Ep.I,131f. "Ask for what end the heav'ly bodies shine, Earth for what use? Pride answers, 'Tis for mine'."

Ep.III,27f. "Has God, thou fool! work'd solely for thy good, Thy joy, thy pastime, thy attire, thy food?" 
Ep.III,45f. "While Man exclaims, "See all things for my usel" "See man for minel" replies a pamper'd goose."

Tred. hat sich durch die Polemik Popes in seinem Anthroposorphismus nicht beirren lassen.

Nach theologischem Urteil ist eine rein anthropozentrische Sinnbestimmung der Welt angesichts der Unendlichkeit, Fulle und Ratselhaftigkeit des Kosmos nicht moglich. Wohl gehort zum christlichen Glauben die Gewisheit, daB cott in der Welt für alles gesorgt hat, was der Mensch zum Leben braucht. "Die Welt ist wirklich fü den Menschen da", urteilt P.Althaus. "Aber diese Beziehung und zuordnung des ganzen Kosmos auf den Menschen, auf sein auBeres und sein inneres Leben, das Leben vor cott und mit cott besagt noch lange nicht, daß alles, die Pflanzen, die Tiere, die Welt der Gestirne a 1 e $1 \mathrm{n}$ um des Menschen willen geschaffen sei und nur in der Bezlehung auf ihn seinen Sinn habe." 43

Am Schlub der Passage welst Tred. auf das Uberzeugendste Beispiel hin, das Gottes Fursorge deutlich macht: er erinnert an die reiche physische und poychische Ausstattung des Menschen selber. Sie nochmals im einzelnen zu betrachten sei Jedoch nicht notig, meint der Autor:

VI, 398ff. Нет уж нумд, чтоб ми здесь паки рассмотрелм

Человека самого: мм уразумели

Как состав - нем внешний, так и внутренний убор:

YM, речь, разность иуествий и даров всех Аивншй сбор.

wie in einem Katechismustext folgt auf die Frage: 'wer hat das dem Menschen gegeben?' die Antwort: 'Gott ist es, der dem Menschen Jeden Nutzen verschafft:

VI,402f. Kто w ему то Ааровал, Аа употребляет?

Бог, кой человеку все пользы промынляет.

Ein vernünftiger Mensch kann sich den zahlreichen Exempeln der Fursorge Gottes nicht verschließen, meint Tred. Darum nennt ex den, der trotzdem daran zweifelt, 'dumm oder gottesfeindlich' :

VI,404f. Глупым иль злобожним такового должно звать,

Коему сомненно промисл бомий признавать!

In VI, 406-445 geht es un die 'Vorsehung' als 'xpaнение', 'содейство' und 'ynрасление'.

Diese Einteilung beruht offenbar auf einem scholastischen Schema, das sich auch bei Theologen der lutherischen orthodoxie findet: "Forma providentiae tribus absolvitur actibus, sc. conservatione, cooperatione s. concursu, et 
gubernatione." 44

Den Terminis 'xранение' bestimmt Tred. mit einer definitio finalis:

$$
\text { VI,410 Чрез хранение весь мир бытность продолжает; }
$$

Der orthodoxe Lutheraner Joh.Andreas Quenstedt (1617-1688) definiert: "Conservatio est actus divinae providentiae, quo Deus res omnes a se creatas in suo esse...conservat quousque vult." ${ }^{44 a}$ Der Lehrsatz von der 'conservatio' ist gegen die mechanistische und naturalistische Anschauung gerichtet, derzufolge die Welt ohne die gottliche 'Erhaltung' fortbesteht.

Die Termini 'содейство' (407) bzw. 'содействие' (411), das bei Polikarpov in der Bedeutung 'cooperatio' belegt ist, ${ }^{45}$ entsprechen dem scholastischen Begiff 'cooperatio s. concursus'. Tred. umschreibt 'содействие' als die Einwirkung Gottes, mit der er seinen Geschópfen in allen Dingen hilft. Wir sind 'im Sein und Handeln' vom Schöpfer abhăngig. 'Durch ihn schlăgt unser Herz':

VI,411ff. Боо содейстөием в делах тварям споспешает;

Мы зависим в бытстве, да и в действе от творца;

Им есмы, им точно наши движутся сердца;

'Eсмы' ist ksl. Form der 1.pl.praes. von 'быть'. Inhaltlich erinnern die Verse an Act.,Kap.17,28, die biblische Belegstelle der 'concursus'-Lehre:

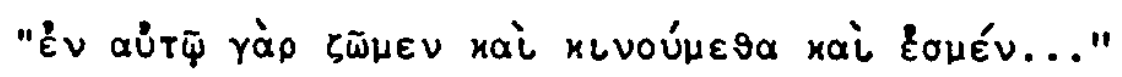

Annlich wie Tred. hat Joh.A.Quenstedt die völlige Abhăngigkeit des Menschen vom gottlichen 'concursus' beschrieben: ohne die gottliche Mitwirkung, sagt er, könnten wir 'keinen Finger ausstrecken': "in ipso sumus tanquam conservante, in 1 pso quoque movemur 1.e. omnes nostras actiones et motus ipsius concursu perficimus, adeo ut sine eius concursu ne digitum quidem extendere, nec minimum motun quidem perficere possimus." 46

Tred. legt jedoch Wert auf die Feststellung, daß wir durch die gottliche 'Einwirkung' nicht unsere willensfreiheit verlieren:

VI,414 Hе лишаемся $\$$ мы тем нашея свободы.

Auf die Schwierigkeiten des Problems wolle er sich aber hier nicht einlassen, fügt er hinzu:

VI,416f. C нас содействий праваы прсдовольно есть сея,

Труаностей в разборы не вступах здесь те я.

Zum göttlichen 'ynрадление' wird ausgeführt, daß Gott die materielle Welt durch die Naturgesetze regiere, nach denen alles ungehindert zum ziele kommt:

VI,418f. 8ещным правя миром, бог положил законы,

По которым всё к концу йдет без препоны. 
Den'vernünftigen Wesen' hat Gott 'die Regel inres freien Handelns selbst vorgeschrieben', er selber lenkt sie:

$$
\begin{aligned}
& \text { VI,420f. А разумным теарям правило действ вольных их } \\
& \text { Сам преднаписуя, направляет и самих; - }
\end{aligned}
$$

Im folgenden schildert Tred. das wirken des gottlichen 'yправление', das uns manchmal einleuchtend, oft aber ratselhaft vorkommt. Es erscheint uns 2.B. einleuchtend, wenn cott die gute Tat belohnt und die bose bestraft:

VI,422f. Cоплетает Он АОбрО с Аобрим Аейством сродно;

Он за злые их дела злом казнит природно; -

Da sehen wir Gott als den Huter einer gerechten Weltordnung. In vielen Fallen können wir Jedoch nicht einsehen, warum Gott die Geschicke der Menschen so verschieden lenkt. Bald befreit or sie von Krankheiten und MiBgeschick:

$$
\text { VI,424 Tо } \mathrm{x} \text { от болезней свобомдает } и \text { от бедств, - }
$$

Bald 'erhebt er ein gefallenes Haus', bald stüzt er jemanden, weil er sich zu Unrecht erhöht hat, oder Gott weiB warum:

VI,426f. То возносит падший АОм, то и низлагает

По неправде взнесся кой, иль за что сам знает.

Der Hochste selber verteilt die Geschicke: 'Bitteres und SuBe', 'Betrübnis, Krankheiten und Kummer und die ersehnte Freude':

$$
\begin{aligned}
& \text { VI,430f. Вишний разделяет сам горесть нам и сладость, } \\
& \text { Скорбь, болезни, и печаль, и желанну радость; - }
\end{aligned}
$$

Nach seinen 'freigebigen Fugungen' beglückt er die einen und labt andere hier ungluaklich bleiben:

VI,432f. По судьбам пренедрым ублажает, зришь, он сих,

А коснеть бессчастно оставляет здесь других: -

Das eingeschobene 'зришь' erneuert die Anrede an Evsevif und erinnert damit an den Epistelcharakter.

Tred. fahrt fort: bei 'Jenen' fließt das ganze Leben schön im Uberfluß dahin, wăhrend andere ihr Leben lang in Armut sein müssen. 'Nicht ohne Grund', fügt er hinzu: vi,434f. Вся в обилии течет жизнь у тех прекрасно;

Всо ж в уботестве инш Аолг быть не напрасно; -

Am SchluB dieser Aufzahlung menschlicher Schicksale heiBt es: dieser leidet; Jener kann seine Lebenszeit 'blühend' verbringen und 'dem Glück noch Vergnügungen hinzufügen' :

VI,436f. Страждет сей, тот может процветая век свой жить

и еще утехи к благоденству приложить. 
Die Versreihe uber die menschlichen Geschicke (430-437) ist durch verschieden gebildete Antithesen gekennzeichnet:

a) ein negativer Begriff steht in demselben Vers einem positiven gegenuber (горесть - cлaAoctb, 430).

b) in ein und demselben Vers werden mehrere negative Bezeichnungen einer positiven entgegengesetzt (скорбь, болезни, и печаль - радость, 431).

c) die Antithese kommt durch ein Verspaar zum Ausdruck: 431f. und $434 \mathrm{f}$.

d) im ersten Vers eines Verspaars folgt einer negativen Aussage eine positive, die im zweiten Vers weiter ausgeführt wird: $436 \mathrm{f}$.

Auf die Frage, warum die Schicksale so verschieden sind, antwortet der Autor ehrfürchtig: 'das weiB allein der allgütige cott':

VI,438f. Ho неравенству почто должно быть такому?

Весно токмо самому богу преблагому.

Er bringt alles hervor, deutlich oder auf verborgene Weise und lenkt das menschliche Schicksal so, daB wir uns wundern müssen. Tred. verwendet in VI,441-443 verschiedene Bezeichnungen für 'Schicksal': 'npeper', 'pok', 'участь'. Eine wird durch ihre stellung am Ende besonders hervorgehoben:

' судьба правдива'. Tred. will sagen, daB auch die ungleichen Geschicke Gottes 'gerechte Fügung' sind.

Vor den 'Abgründen' des göttlichen 'ynравлениe' erschreckend, preist ex die 'unausfcrschliche Tiefe' der Weisheit Gottes:

VI,444f. Тем и восклицаю, ужасаясь бездн сих дна:

0 ! премуарость, в коей неиспытна глубина.

Die Verse lassen das Wort des Apostels Paulus, Rö.11,33 anklingen:

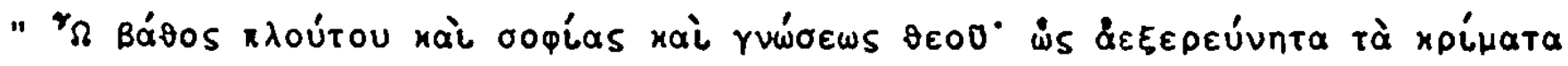

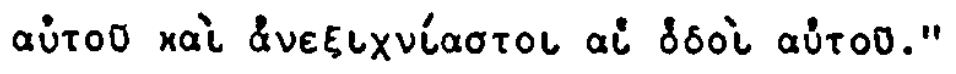

VI, 446-642: Die 'нравственные свойства' Gottes.

In den Versen 446-455 skizziert Tred. den Fortgang der Epistel, in der nun die 'ethischen Attribute' Gottes dargelegt werden sollen:

VI,446f. 0 последних бога я свойствах начинаю

Предлагать, которы в нем нравственныя знаю, -

Er will sie in dieser Reihenfolge behandeln:

VI,453ff. Bлагосераность, в-первых, и потом его ж внимать

Совершеннейшуо к нам, обще всем, правяивость,

А притом же, наконец, в нем и справедливость.

Tred. schickt voraus, daß die göttlichen Eigenschaften wegen der 'Unendlich- 
keit' seines Wesens von unseren ethischen Eigenschaften 'unendlich verschieden' sind:

vI, 448f. Но от наших нравншх всеразличнейшие те,

То ж no бесконечной естества в нем простоте.

So kann von der 'Güte' Gottes, wenn man sie mit der menschlichen vergleicht, nur in der hơchsten steigerung gesprochen werden (via eminentiae):

VI,456ff. Перөим оншм свойстеом, кое назнваем мы

Нравственним по сходстеу, с нашими сводя уми,

Познавается бог наш крайно благосерящи,

Инак буде изъяеить, то премилосердм.

In seiner Gnade hat der Hochste den vernünftigen Geschopfen 'ein gewisses Ebenbild seiner eigenen Vollkommenheiten mitgeteilt' :

VI,460f. Милостио сео, вишний совериенств своих

Теарям образ некий сообщил, побя все их, -

Er hat die Menschen 'dem MaB ihrer Vollkommenheit entsprechend' gluckselig geschaffen und sie 'auf dieser stufe', d.h. auf der eines Geschopfes, sich selber auch ahnlich gemacht:

VI,462f. Да с собой, по мере тех, сотворил блаженнш,

В сей степени и к себе также приближенны.

Der Ausdruck 'ळраз некий' erinnert an Gen. ,Kap.1,26f.:

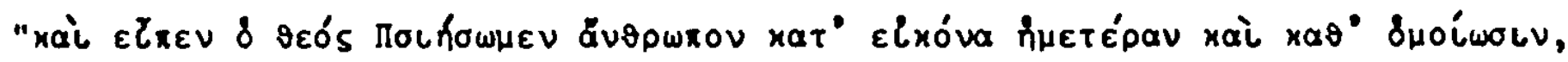

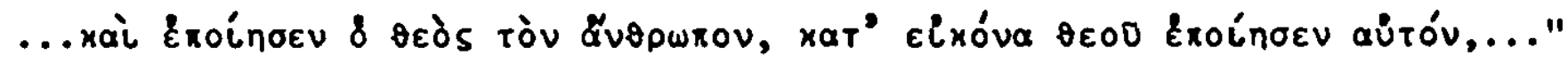
Der Mensch kann mit der Vollkowmenheit, die Gott ihm gegeben hat, völlig zufrieden sein, meint Tred., 'so daB wir uns eine bessere nicht winschen kónnen'. Es ist ein ungebührliches Verlangen, daB cott uns mehr Gnade erweisen soll, als uns notig ist:

VI,467ff. Так что большего себе, кое нам являет, Мы желать не можем; больше милости открыть,

Нежель нам потребно, непристойности долг бшть.

Der Mensch kann aber durch eigene schuld die Vollkommenheit, mit der ihn Gott 'geschmuckt' hat, verlieren. Ex verliert sie durch offene oder heimliche Bosheit, aber auch, wenn er in seiner MaBlosigkeit mit der Vollkommenheit, die Gott inm aus Gnade gegeben hat, nicht zufrieden ist:

VI,470ff. Посему разумна тварь, как себя лишает

Совершенства, коим бог ону украшает,

А лишает явним и сердечним самим злом, - 
vI,474f. Также и когда она ITварь], будучи толь вольна,

В милость совершенством, ей данным, не довольна.

Hier greift Tred. einen Grundgedanken des 'Essay on Man' auf, nămlich Popes Polemik gegen den mit seinem 'Stand' innerhalb der Schöpfung unzufriedenen Menschen. Ihm wird entgegengehalten:

Ep.I.,69ff. "Then say not Man's imperfect, Heav'n in fault;

Say rather, Man's as perfect as he ought;

His knowledge measur'd to his state and place,

His time a moment, and a point his space."

Pope verurteilt die Hybris als sünde gegen die göttliche Oranung, als Aufstand gegen Gott:

Ep.I,123f. "In Pride, in reas'ning Pride, our error lies;

All quit their sphere, and rush into the skies."

In VI,476-515 wird exneut die Theodizee-Frage behandelt: wie stimmt der Glaube an Gottes Barmherzigkeit und die Behauptung, der Mensch sei in gewissem Sinne das Ebenbild Gottes mit der Tatsache des Ubels in der Welt zusammen?

Nach Meinung Tred.s steht das 'natürliche Ubel' wie Durst, Hunger , Krankheit und ähnliches nicht im widerspruch zux Barmherzigkeit Gottes. Es dient erstaunlicherweise hăufig gerade der Erhaltung des Lebens. Tred. erlăutert seine Auffassung am Beispiel des Hungers, der den Menschen treibt, etwas zu essen:

VI,476ff. 3ло естественное, жажда, скорбь и также глад,

И что есть иное и приводится а приклая,

Милосераио сему всяко не противно,

Но найпаче то еще тем бывает дивно,

Что собой способно $\mathrm{K}$ сохраненио всех нас;

Гладные ль мы? Вот ищем что-нибуаь поесть тотчас.

Uber das 'moralische Ubel', die Sünde, sagt Tred., daß Gott, wenn er es auch zulasse, uns doch gerade davon abbringen wolle:

VI,482f. Нравственное зло, что грех, бог хоть попуцает,

Но от зла сего всех нас прямо отвращает.

Diese 'Zulassung' widerspricht nicht der 'besten Weltordnung', betont Tred. Er sieht die wurzel der Sünde im freien willen der Menschen, die die 'Geradheit der Seele' verloren haben und 'mehr dem Bosen zuneigen. Darum nennt er die Sünde ein 'schiefes Sein': 
VI, 484ff. Лушиу чину мира попудение сие

Не могло бшть пречно: криво грех есть бштие;

А лишенио прямизнш наших ауш по воле,

Кои склонн бить хотят К злу такому боле.

Der Begriff 'nопуиение' entspricht dem der 'permissio', mit dem die alten Dogmatiker die Existenz der Sünde in der von Gott regierten Welt zu erkláren versuchten. Chr.E.Luthardt faBt diese Meinung so zusamen: "Deus quidem permittit sed non vult 'tò' permissum." 47 Erlăuternd fügt er hinzu, der Begriff 'permiss10' als besonderer Aspekt der gottlichen 'gubernatio' sei dogmatisch notwendig, "weil sonst cott die Ursache der sünde würde". 48

Die Formulierung Tred.s, dab wir 'mit freiem Willen die Geradheit unserer See$10^{\prime}$ verloren haben, und daß die sünde ein 'schiefes', verkehrtes Sein sei, exinnert an eine ahnliche Stelle im 'Essay on Man':

Ep.IV,111f. "What makes all physical or moral 111?

There deviates Nature, and here wanders will."

Hier ist anzumerken, daB sowohl das hebr. 'ḥta' als Wurzel des Begriffs 'Sünde' wie das gr. Verbum 'ápaptávelv' im Grundsinn bedeuten: 'den richtigen Punkt verfehlen'. 49

Das Ubel in beiden Gestalten als 'natürliches' und 'moralisches' bildet nach Tred. gleichsam die Folie, vor der sich das Gute um so sichtbarer abnebt:

VI,488f. Говоро: не пречнш лучшу миру скорбь и грех, Но еще и больше момно знать аобро от тех, -

Er exlautert dies durch den Vergleich, daB weis und schwarz besonders deutlich voneinander abstechen, wenn man die Farben nebeneinanderhalt:

$$
\begin{aligned}
& \text { VI,492ff. Так, сему подобно, с белшм купна чернота } \\
& \text { Кажет нам ясняе, скалько с тем в ней разнота, } \\
& \text { А тогда ж и белизна толь себя являет, } \\
& \text { Что своим ту блеском всо болей очерняет. }
\end{aligned}
$$

Ferner exklăt Tred. das Bose als notwendige Folge der willensfreiheit. Gott 'wahrt unsere Integritát', indem ex uns nicht zwingt, sondern frei entscheiden laBt. Er weiB genügend Mittel, un zu verhindern, dab unsere Seele ins Verderben sturzt:

VI,496ff. Hо и бor премуаршй целость нашу всо хранит, Нас не принумдая, да не бить нам возбранит В наших вольнмии делах; Аал довольни средства, Чрез которы не прийти момем в Аушевредства. 
Die scholastischen Theologen sprachen von der 'impeditio' als "actus providentiae gubernatricis, quo Deus actionem creaturarum pro arbitrio suo constringit, ne effectum dent, quod vel naturali vel libera agendi vi alias efficerent." 50

Schlieblich hat Gott 'die beiden Ubel' zugelassen, damit der Mensch sich in ihnen bewăhren könne. Im Kampf gegen das Ubel kommen die besten Eigenschaften des Menschen zur Vollkommenheit. Sonst würden sie verkommen, und der Mensch wärde die Seligkeit verlieren:

VI,500ff. Bпрочем, зла те оба аля того попуиены, Да не в лучшем мире лучшие развращены И выго́днейшие все будут совершенства, Ни да тварь лишится так лучшего блаженства.

Gott hat das 'Unvollkommene' zwar zugelassen, aber er hat es auch durch das von ihm ausgehende Ubel gekennzeichnet, so daß wir es meiden können:

VI,508f. Должного в которой вещи совершенства нет, убегать зря можем из нее ияуиих бед.

wăre das Böse 'verborgen', d.h. für uns unerkennbar, dann ginge die göttliche ordnung zugrunde:

VI,510 Развратился 6 чин, когда 6 злу быть утаенну;

Man hielte dann alle Dinge für sehr gut. Damit tauschten wir uns aber über die Natur der Dinge und kămen, ohne Lüge und Bosheit zu kennen, durch sie um:

VI,514f. Мы 6 обманывались все вещностей в природе И, не зная лжи и зла, гибли 6 ими в сброде.

Dann häte Gott das Ubel nicht nur 'zugelassen', sondexn 'bewrut gewollt':

$$
\text { VI,513 A cиe уж было } 6 \text { от твориа нарочным злом; - }
$$

Das wäre jedoch eine MiBdeutung dessen, was das fromme Denken mit dem Begriff 'Zulassung', 'permissio', 'nопуuенne' zum Ausdruck bringen wollte.

In VI,516-549 behandelt Tred. die 'Wahrhaftigkeit' cottes.

Er verwendet dafür das Subst. 'истинность' (516), abgeleitet vom ksl. Adj.

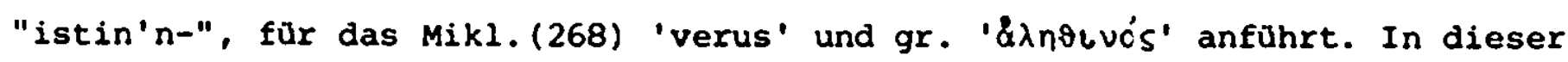
Bedeutung steht auch 'npaвanвость' (530). Das ksl.Adj. "prav'div-" ist bei Mikl. (656) belegt und wird durch 'iustus', gr. 'oixalos' wiedergegeben.

Der Abschnitt beginnt mit einer Definition der göttlichen 'истинность', die besagt, daß Gott uns nicht betrügen kann, sondern so handelt, daB wir uns darauf verlassen können:

VI,516ff. Истинность в прещедром таково свершенство есть, Что свою тем воло объявляя, всяку лесть 
VI,518f. Он не момет приобиить, но творит всемерно

8 искренности то своей прямо купно верно.

Die Trias von Macht, Weisheit und Güte, die das wesen cottes ausmacht, gibt uns die Gewahr, daB der 'allzeit wahrhaftige' uns nicht betrigen kann:

VI,520f. Мощь, премуарость, милость выннему препоной суть,

Что всегяа правдивый не возмомет обмануть; -

Ein Wesen, das andere betrŭgt, könne diese dreifache vollkommenheit nicht haben, behauptet der Autor. Entweder fehle es inm an Macht, das auszuführen, was er versprochen hat, oder an Weisheit, nur das zu versprechen, was es auch halten kann, oder an Güte und dem willen, mit der Tat für sein wort einzustehen:

VI,522E. Кто обманывать Аругих лестио умеет,

Тот в себе трех совершенств оных не имеет.

VI,525f То иль нет том силы дело оное издать, -

Нет иль мудрости в таком, обещать ито можно

VI,528f. Иль нет напоследок благости и воли в нем,

Чтоб стоять как в слове, и стоять так в деле всем.

Da demnach das Attribut der 'Wahrhaftigkeit' mit rationaler Evidenz aus dem Gottesbegriff folgt, schlieBt Tred., daB wir uns 'hinsichtlich der Wahrhaftigkeit des schöpfers nicht irren kơnnen' (530f.). Das ergibt sich aus der prämisse Descartes', daß alles, was klar und deutlich ist, auch wahr sein müsse. Sonst hatte uns ja der 'Allergerechteste' durch dieses Wissen getăuscht, fahrt Tred. fort:

VI,532f. Если 6 было и́нак, өсеправеднейший сам нас

Тем обманыеал бы знанием на всякий час.

Durch das Attribut 'ecenpaведнейший' wird Jeder Gedanke, Gott sei einer Tåuschung făhig, als blasphemisch abgewiesen. Tred. konstatiert, wenn wir etwas 'fest verstehen', können wir nicht umhin, es auch zu glauben:

VI,534f. Ибо мw ym что когАа твердо разумеем,

То не верить впрямь все так всяко не умеем.

Das ist die rationalistische Unkehrung der theologischen Formel 'fides quaerons intellectum' bzw. des 'credo, ut inteligam'.

Die 'Wahrhaftigkeit' Gottes ist auch das Unterpfand dafür, daB die Idee der Unsterblichkeit und das Glücksverlangen in allen Menschen einmal erfullt werden. Der 'wahrhaftige' Gott kann diese Idee und dieses Verlangen 'nicht zum SpaB' in unsere Seele 'eingepflanzt' haben: 
VI,538ff. Бог, понеже ясно в нас все́ял сам идег

0 бессмертии таком в вложил 8 нас ею

Heзarnaaиmoc nomenaниe во всех

Быть бы нам блаженным, обманул бы вот на смех

Нас понятием таким, если 6 заблумдали

Разумением и в ложь счастия желали.

Tred. spielt in diesen Versen auf die Lehre Descartes' von den 'ideae innatae' an. 51

Auf Erden finden wir aber das Glück weder in Ehre und Ruhm noch in Reichtum, Luxus und Genüssen. Unser ruheloses Suchen ist also auf eine gröBere, jenseitige Exfüllung gexichtet:

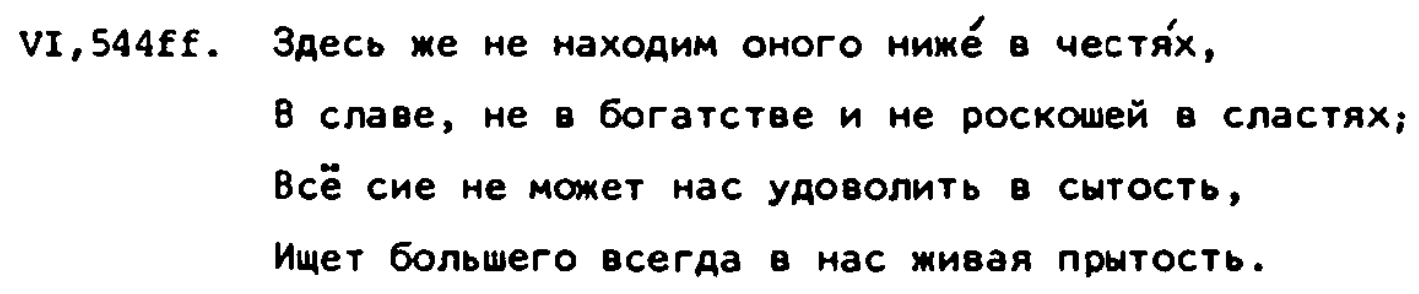

Wir können mit der Erfüllung unseres Glücksverlangens rechnen, weil Gott wahrhaftig ist. Seine 'Wahrhaftigkeit' ist bestädig. Dies kommt im letzten Verspaax des Abschnitts, in dem die Adjektive 'nравдивый' und 'всеистинный' kunstvoll verschränt (chiastisch) wiederholt werden, zum Ausdruck:

VI,548f. Потому правдивый и всеистинный наш бог

Не всеистиннымбы, не правдивым сам быть мог.

Die Passage über das Glück enthălt einige Anklănge an Verse $A$. Popes in Ep.IV des 'Essay on Man'. Darin preist der Dichter das Glück als Ziel und Zweck des menschlichen Lebens:

Ep.IV,1 "OH HAPPINESS! our being's end and aim!"

Er nennt es eine 'Pflanze aus himmlischer Saat':

Ep.IV,7 "Plant of celestial seed! -

Die irdischen Glücksgüter werden jedoch von beiden Autoren verschieden beurteilt. Wăhrend Tred. ohne zogern erklărt, daß sie den Menschennicht befriedigen kōnnen, ăuBert sich Pope differenzierter. Er sagt: zwar hănge das Glück nicht von der. 'Glacksgatern' $a b$, aber der 'honest Man' wisse Reichtum, Ehre und Ruhm recht zu gebrauchen. In Verbindung mit der 'Tugend' (virtue) bekommen die Güter des Lebens eine positive Bedeutung:

Ep.IV,185f. "To whom can Riches give Repute, or Trust, Content, or Pleasure, but the Good and Just?" 
Ep.IV,217f. "Look next on Greatness; say where Greatness lies? Where, but among the Heroes and the Wise?"

Als Beispiel wahrer Grobe nennt pope Sokrates:

Ep.IV,236 "Like Socrates, that Man is great indeed."

Nach Meinung Popes liegt das Glück auf Erden allein in der 'Tugend':

Ep.IV, 309f. "Know then this truth (enough for Man to know)

"Virtue alone is Bappiness below."

In dem Abschnitt VI,550-615 geht es um die 'Gerechtigkeit' Gottes.

Zu Anfang steht eine Definition des 'npaseaHoe':

VI,550ff. Праведное всё есть то, что какой прилично

Вещи иль по естеству, иль что такще слично

И согласно прамо по праеительстеу с ней есть; -

In den Formeln 'no естеству' und 'no nраеительстеy' greift Tred. auf die Un-

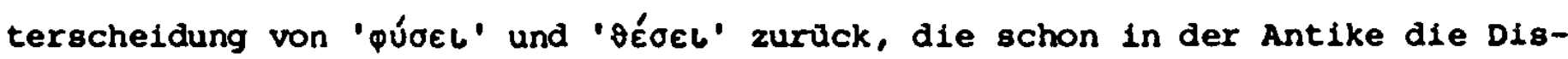
kussion um den Ursprung von Recht und Sittlichkeit bestimmt hat. Was 'qúoel' gilt, wird als gleichbleibende Norm für alle Menschen und Zeiten angesehen,

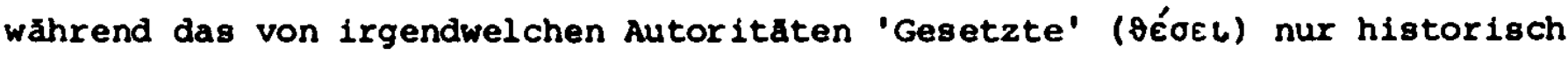
bedingten Wert hat. Im 17.Jahrhundert beherrscht der Gegensatz von ' und ' $\theta \varepsilon ́ \sigma \iota 5$ ' die Auseinandersetzung zwischen Hobbes und der neuplatonischen Schule von Cambridge. "Für Hobbes entsprangen Recht und Sittlichkeit gesellschaftlicher Satzung..." Die 'lex naturalis', auf die die englischen Neuplatoniker die Ethik gründeten, war dagegen für sie "nach stoisch-ciceronianischem Prinzip eine unmittelbare, dem menschlichen Geiste eingeborene GewiBhe1t". 52

Tred. labt in seiner Definition beide standpunkte gelten: 'иль nо естестеу, иль... по правительству' (551f.). Als Autorităten, von denen 'Satzungen' ausgehen, nennt er:

VI,553 Власть ли то, иль сила, внсота или то честь.

Auf cott bezogen, bezeichnet das Attribut 'gerecht', was der gottlichen Natur gemă 1st. Tred. weist darauf $h i n$, daß auch die anderen Attribute: 'weise', 'barmherzig', 'wahrhaftig', 'Schopfer', 'Erhalter' und 'Vater' Ihren Inhalt von Wesen Gottes erhalten:

VI,554ff. Что * есть праведен наш 6ог, то есть что пристоймо Самому D нем естестеу (как то Он достойно Муар, и благосерден, и прасяие, и есех теорец,

И хранитель равно и пекуиийся отец), - 
Unser Denken bezeugt, daß Gott gerecht ist. Wollte man die Gerechtigkeit von cott abtrennen, so fehlte etwas an seiner vollkommenheit. Jeder sieht ein, dab das nicht wahx ist:

VI,558ff. Праведншм чтоб бшть ему; то нам изъявляет

Твердо мшсль, как от него правду отделяет:

Был бы недостаток совершенства в оном сей.

Aus diesen Uberlegungen zieht Tred. den SchluB: Gott ist unendlich gerecht. Seine Fügungen sind gerecht. Seine Gerechtigkeit ist ewig:

VI,566f. Праведен бог посему есть и всеконечно;

Праведен судьбы его, в нем и правда вечно!

Das Verspaar ist durch die wiederholungsfigur rhetorisch pointiert.

Der Abschnitt VI, 568-615 ist durch das stichwort 'npaвAa' bestimmt.

Er stellt eine Art Hymnus auf die göttliche 'npaspa' dar, bestehend aus Strophen zu sechs Versen (568-591) und solchen zu acht versen (592-615) und bildet ein Gegenstūck $z u$ dem Hymnus auf die Liebe in Ep.III,557ff.

'Правда', ksl. "prav'da", ist bei Mikl. (656) belegt und wird mit 'veritas',

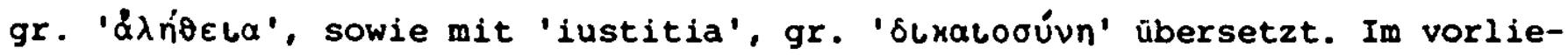
genden Abschnitt überwiegt die Bedeutung 'Gerechtigkeit' .

In seiner Gerechtigkeit kann Gott nicht zulassen, daß das 'vernunftige Geschöpf' sich 'schmeichle', alles Wohl von sich aus 2 u haben, anstatt es von dem 'Geber' zu erbitten:

VI,568ff. Правдо своео не́льзя богу попустить, Чтоб могла тварь уंмна прямо так себя польстить, Что она благое всё от себя имеет, Да о дателе себе блага не радеет;

Luther hat diesen Gedanken bei der Auslegung des ersten Gebotes in seinem Großen Katechismus positiv ausgedrückt: "Ein Gott heißet das, dazu man sich versehen soll alles Guten und zuflucht haben in allen Nöten." 53

Ließe nämlich Gott die menschliche Autarkie zu, so würde er damit deutlich zeigen, daß er nicht die 'Quelle des Heils' ist:

VI,572f. Инак бог бw ясно попуиением казал, Что он не источник блага и не то создал.

Die Metapher 'Quelle' wird in der Bibel hăufig auf Gott angewandt. In Psalm 35,10 bekennt der Fromme:

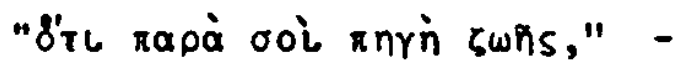


In diesem $2 i$ tat hat 'xmyn'' fast die Bedeutung 'Ursprung', 54 labt aber auch das unerschopfliche Fließen und Hervorbringen anschaulich werden. In Jer., Kap. 2,13 wird die 'Quelle', die 'lebenaiges', d.h. fliebendes Wasser gibt, der 'zisterne' gegenübergestellt. Der Prophet gibt die Klage Gottes uber das Verhalten seines Volkes wieder:

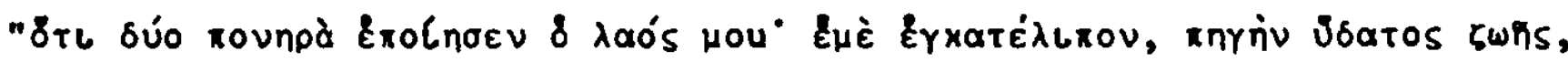

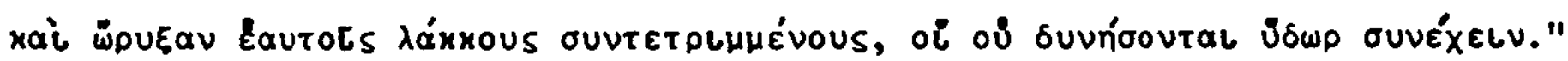
In der năchsten Strophe legt Tred. dar, daß die Gerechtigkeit cottes nicht zulasse, dab einer dem anderen Schaden zufugt und inm sein Eigentum nehmen will:

VI,574ff. Правдой богу попустить есячески не можно, Чтоб теарь у́мна умну тварь, в совести безбожно,

Всяко повреждала, то есть чтоб она всея,

Без греха, доброты собственнейшия ея

Bосхотела ту лишать:

Wenn Gott das ungestraft zuließe, wåre er nicht barmherzig und nicht gnădig: VI,578f. $\quad$ - бor Heбnarocepaum

Показал себя 6 чрез то и немилосердым.

In seiner Gerechtigkeit will Gott von den 'vernunftigen' Wesen, also von Jedem Menschen, daß ex sich als einzelner un das Glück aller bemühe:

VI,580ff. Правдор своер хощет от разумншх бor, Чтоб всяк о взаимном счастии стараться мог, И взаимно чтоб о том каждшй и старался; Die Anapher 'взаимно' unterstreicht den sozialethischen Imperativ, der theonom begründet wird. Er ergibt sich aus der 'uberreichen Gnade' Gottes, die allen gilt:

VI,583f. Инак не согласно 6 он действовать казался Оной пребогатой милости ко всем своей, -

Dex sozialethische Gesichtspunkt ist bereits in Ep.II,197ff. hervorgehoben worden.

Parallele Gedanken hat Pope im 'Essay on Man', z.B. In IV,35ff. entfaltet:

Ep.IV, 35ff. "Remember, Man, 'the Universal Cause

Acts not by partial, but by gen'ral laws;'

And makes what Happiness we Justly call

Subsist not in the good of one, but all.

There's not a blessing Individuals find,

But some way leans and hearkens to the kind." 
In der folgenden Strophe führt Tred. aus, daß 'Gott nicht anders könne', als die sünden durch Lohn und Strafe und durch seine Gebote zu verhindern und zugleich die Tugend in uns zu vermehren:

\section{VI,586ff. Правдон своею не творит препоны \\ Чрез возмездие и казнь, такое чрез законы \\ Всем грехам не может и не вдруг производить \\ Добродетель сильно, чтоб ее в нас расплодить; -}

In āhnlicher Weise haben die alten Dogmatiker das von ihnen so genannte 'Attributum divinum energetikón' umschrieben: "vi cuius Deus omnia quae aeternae suae legi sunt conformia vult et agit, craturis convenientes leges praescribit, bonos remuneratur et impios punit." 55

Die Passage VI,592-615 besteht aus drei 'strophen' zu je acht zeilen, die ebenfalls von der 'npaвда' Gottes handeln.

Auf Grund der Gexechtigkeit, so fährt Tred. fort, steht Gott in unversöhnlichem Gegensatz zur Sünde. Von Anfang an hat ex den Sünder zu seinem Feind und die sünde als das ihm auf ewig verhaßte Böse erklărt:

$$
\begin{aligned}
& \text { VI,592ff. Напоследок, правдой примирить себе отнод } \\
& \text { Грешников не может, буде прежде грешный лод } \\
& \text { Бог врагом ум объявил, грех же ненавистным } \\
& \text { и по естеству его злом конечно присным. }
\end{aligned}
$$

Gott sah sich genötigt, 'allen Sünden den Krieg zu erklăren', sonst hătte es den Anschein, daß er 'die Grenzen' der Herrschaft des Bösen 'ausdehnte':

$$
\text { VI,598f. Tем не mor не объявить всем грехам он брани, }
$$

Не явиться 6,ито он злу расширяет грани.

In seiner Gerechtigkeit hat Gott den Menschen aber auch seinen willen kundgetan, damit jeder dem Guten nacheifere:

$$
\begin{aligned}
& \text { vi,596f. Но праваивостию человеком повелел, } \\
& \text { Чтоб в них каждый добрым быть всегАа раяел; - }
\end{aligned}
$$

Hatte Gott beschlossen, nach seiner Gerechtigkeit die Sünde an den Menschen zu bestrafen, so wăren wir längst umgekommen und mit seele und Leib auf ewig verloren:

$$
\begin{aligned}
& \text { VI,600f. Посему бог если } 6 \text { правдой так определил, } \\
& \text { Чтоб в самих он лодях ненавистный грех казнил, } \\
& \text { Уж давно } 6 \text { погибли мы самым точно делом, } \\
& \text { Как душою в век веков, так и нашим телом. }
\end{aligned}
$$

Damit stimmt Tred. der orthodoxen Kirchenlehre $z u$, derzufolge die 'iustitia 
vindicatrix Dei' die hăteste Bestrafung des Sunders fordert. Als biblische Belegstelle kann z.B. Röm.1,32 angeführt werden:

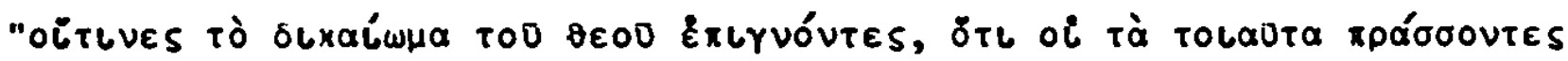

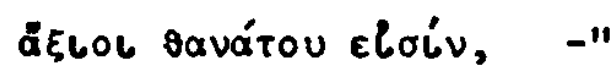

Die Verschonung des Sünders wird von Tred. mit Hilfe der aus neutestamentlichen Stellen entwickelten Kirchenlehre vom Versơhnungswerk Christi begründet. DaB wir nicht 'umkommen', verdanken wir dem 'Fürsprecher', der die 'Rache der gottlichen Gerechtigkeit durch instandiges Bitten abwendet': VI,604f. Но что мы не гибнем, то ходатай некий есть, Кой упрашивает божиея правды месть.

Das bittende Eintreten des erhohten Christus fur die Menschen (intercessio) ist von den alten Dogmatikern so beschrieben worden: " intercessio Chr. est alter actus officil sacerd., quo $\mathrm{Chr}$. ' $\theta \varepsilon \alpha ́ v t p \omega r o s ' ~ v i$ universi meriti sui pro omnibus hominibus imprimis vero electis suis.... interpellat ad impetrandum ilsdem quaecunque corpori, atque animae praecipue, salutaria esse novit. "50

Die biblische Begründung dieser Lehre wurde z.B. In I.Joh.2,1f. gesehen:

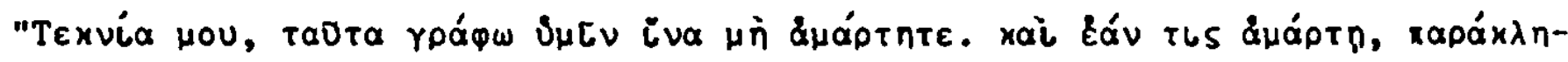

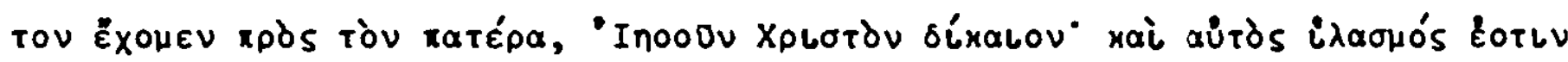

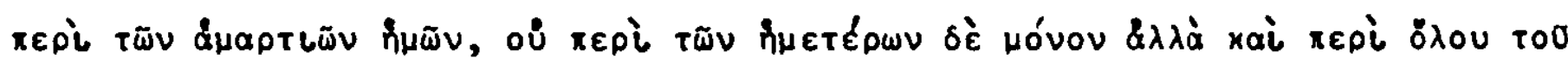
xóohou."

Das Wortverstăndnis des zentralen Begriffs 'rapáxintos' wird durch "das Bild einer Aktion vor dem Forum Gottes bestimmt". " Wie erstaunlich die Botschaft von dem 'ходатай' ist, bringt Tred. durch die Frage zum Ausdruck, welches Geschöpf denn imstande sei, 'die erregte (Rache)' zu besăftigen. Dem 'Fuxsprecher' gebührt gottliche Verehrung:

VI,606f. Кая * тварь ту упросить может раздраженну? Се ходатам долг быть точно обоженну.

Im folgenden stützt sich Tred. auf Grundgedanken der Theologie des Apostels Paulus: unsere 'Rechtfertigung', so sagt er, stamt aus dem Mysterium des stellvertretenden Suhnopfers des 'Sundlosen', der 'uns ahnlich, zur sünde gemacht' wurde, 'damit wir durch inn gottliche Gerechtigkeit' würden:

$$
\begin{aligned}
& \text { VI,608ff. Tем то нужно стало, чтоб безтрешна самого } \\
& \text { В нас грехом соделать, да ми правдой ирез него } \\
& \text { Боммех будем все: - }
\end{aligned}
$$

Deutlich klingt II.Kor.5,21 an:

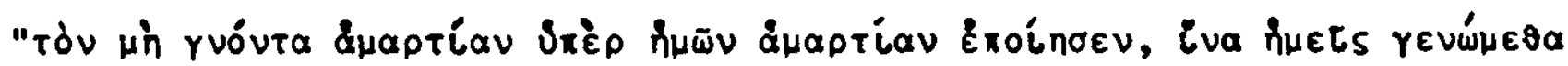




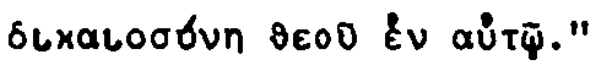

Feierlich hebt dex Autor hervor, daß 'das Wort Gottes' den 'Sündlosen', dex unsere 'Rechtfertigung so erfolgreich' herbeigefuhrt hat, als Christus, dun 'Sohn des ewigen Gottes' bezeuge, der 'durch das Kreuz die Menschen mit Gott versolhnt hat' :

$$
\text { vI,610ff. - a cero 6eзгрешна, }
$$

K оправданио всех нас бывша толь успешна,

Объявляет быти слово божие Христа,

Примиривши богу человеков со креста,

Сына божия того и превечна бога.

Die Verse sind mit neutestamentlichen Vorstellungen gefült. Das Stichwort

'примирить' erinnert z.B. an II.Kor.5,18:

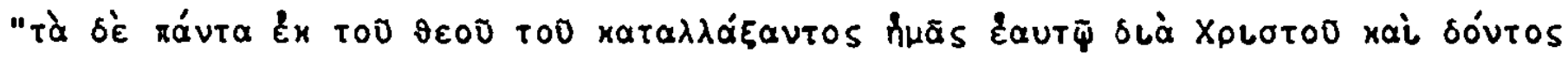

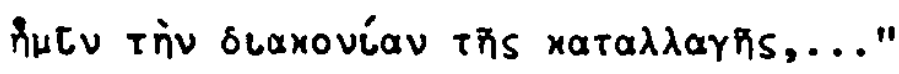

Bei 'co креста' ist u.a. an Kol.1,20 zu denken:

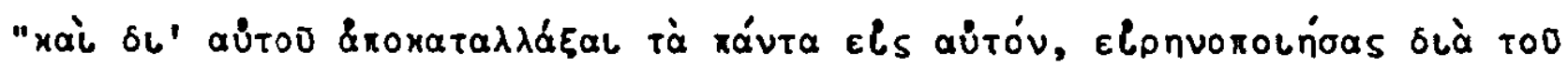
aíhatos roo otuupoo dútoó,..."

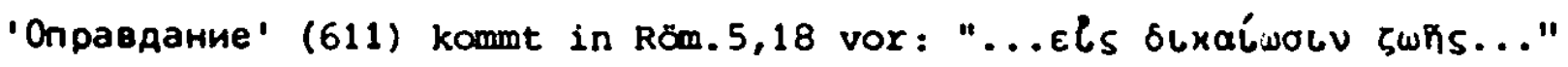

'СЫн божий' (614) ist einer der hăufigsten christologischen Titel im NT.

'Cлово божие' (612) gehort als Bezeichnung der Bibel zum kirchlichen Sprachgebrauch. Er findet sich auch in zahlreichen Bibelstellen, meint aber dort vorwiegend das einzelne, konkrete Gotteswort.

Tred. schlieBt den Abschnitt über die 'npaspa', dessen Hohepunkt die Grundgedanken der christlichen Versóhnungslehre bilden, wit einem Lobpreis. Das Dogma wird zum Inhalt der Doxologie:

$$
\text { VI.615 0! небесная пюбовь, коль ты } к \text { нам премнога! }
$$

Die Ubereinstimmung Tred.s mit der orthodoxen Kirchenlehre, die sich in der christologischen Digression der Verse 604ff. zeigt, kommt auch in der Prosaeinleitung zur VI.Epistel deutlich zum Ausdruck. Dort beruft er sich auf die 'untrügliche Schrift', die uns lehrt, daß 'Jesus Christus Gott und Mensch' ist, und dab der Mensch inn als Füsprecher braucht. Zu unserem Heil, versichert Tred., genügt das 'natürliche Gesetz' allein nicht. Die offenbarung ist unentbehrlich. Für die Auffassung der Aufklărung bezeichnend fügt er hinzu, daß die offenbarung 'im Grunde mit dem natürlichen Gesetz übereinstimmt': "Но неложное писание и показует его, что он есть Исус Христос, бог и человек. Из сего происходит необходимость человеком в ходатае и что един естественный 
закон не доволен есть к нашему спасению, но надобен необходимо откровенний, которшй всем своим основанием согласен с естественним законом. " 58

In VI,616-621 geht es um die 'Heiligkeit' Gottes.

Als vierte 'Vollkommenheit' nennt Tred. die 'Heiligkeit' Gottes, in der nach seinen Worten die anderen drei Vollkommenheiten (Barmherzigkeit, Wahrhaftigkeit und Gerechtigkeit) vereinigt sind:

VI,616ff. Всяк, едва счетает сии совершенства три,

Поймет происшедше и четвертое без при;

То есть совершенство в нем святости всецелы, -

Durch die 'Heiligkeit' werden die anderen Attribute qualifiziert als 'heilige' Barmherzigkeit, 'heilige' Wahrhaftigkeit und 'heilige' Gerechtigkeit:

VI,619ff. Нбо тем есть бог святий, что своими делы

Он себя являет тварям, коль есть милосерд,

Коль правдив нельстивно и коль в правде есть он твера.

In VI,622-627 wird das Attribut der 'Seligkeit' Gottes umschrieben.

Wenn wir bedenken, so logt Trod. dax, daB cott im 'unaufhorlichen GanuB' aller Vollkommenheiten in ewiger Freude existiert, werden wir zugeben, daB er 'selig' ist, d.h. 'uber alle Maßen glücklich'. Der unstandlich gebaute, aus sechs Versen bestehende Satz zeichnet gewissermaßen den Aufstieg zu der 'Seligkeit' Gottes nach, die alle menschlichen vorstellungen abertrifft: VI,622ff. Ho как рассуждаем мы, что от непрерывна

Наслаждения его, ввек и не отплывна,

Всеми совершенствш невозмомно в нем не быть

Крайнейшей утехе, коей вечно ж долг пребшть,

То ум бога признаем крайно всеблаженным,

То есть в сиастии всех мер више угобженным.

Hier fallt die Neigung Tred.s zu ubertriebenen steigerungsformen besonders auf.

In VI,628-642 handelt Tred. von der 'Herrschaft' Cottes uber die Menschen.

Die 'herrscherliche Gewalt Gottes uber das Menschengeschlecht' wird in dor Einleitung zur vI.Ep. (S.304) zu den gottlichen Attributen gezahlt: "...4TO имеет $/ \overline{6}$ ог7 вседержавнуо власть над человеческим родом." Sie ist 'rechtmaBig' darin begrundet, daB er uns geschaffen hat. Darum laBt er uns auch nicht verloren gehen: 
VI,628f. Бог ная человеки праведно имеет власть;

Им мы сотворенны; не дает он нам пропасть.

Zugleich weist $r x e d$. in Form von rhetorischen Fragen auf die gottliche strafgewalt hin, die niemand 'zerstören' kann:

VI,630f. К наказанио ж в нас кто испровергнет силу?

Кто разумный утвераить может ту в нем гнилу?

Als absoluter Herrscher hat Gott den Menschen eine bestimmte Regel für ihr Tun, sein Gesetz, vorgeschrieben:

VI,632f. Человечим действам правило известно бог

(То у нас законом) верно предлисать возмог.

Ex hat auch der Vernunft 'unbestreitbar' gezeigt, was falsch ist:

VI,638 И уму, что ложно есть, показал бесспорно.

Es fållt auf, daB dieser Vers nicht zu einem Verspaar gehort. Vielleicht hat

Tred. Ihn nachtrăglich eingeschoben, um außer dem 'geoffenbarten' Gesetz auch das der Vernunft innewohnende zu erwăhnen, das ebenfalls vom Schöpfer gegeben worden ist.

Aus beidem exkennt der Autor die gnädige Absicht gottes: ex hat uns 'für das Glück' geschaf fen:

VI,634f. Ho чto tak и socхотел, от cero есть твердо,

И6о к счастио создал нас он милосердо; -

Tred. versichert, daB die Weisheit (nicht etwa die Willkür des absoluten Herrschers) Gott bewogen habe, uns seine Gebote zu geben, ohne die wir nicht 'selig' werden könnten:

$$
\begin{aligned}
& \text { VI,636f. Муарость преклонила верно правило подать, } \\
& \text { без того блаженны не могли никак мы стать. }
\end{aligned}
$$

Diese Allmacht Gottes, die zugleich im höchsten Grade gerecht ist, wird gepriesen: vI,639 Се власть преверьховна! но всеправедна она; -

Die göttliche Gerechtigkeit ist die 'vertrauenswürdige Ursache' dafür, daß in Gott 'unendliche Macht' und Gnade für immer harmonisch vereinigt sind:

VI,640ff. Божия вся правда достоверна есть вина, Что безмерна сила в нем с милостио срасно Пребывает без преки́ и всегаa corласно.

VI,643-680: Hymnus auf die Erhabenheit cottes, dem der Mensch auf jede Weise dienen soll.

In preisenden Worten wird das Thema des Abschnitts angezeigt: 'groB ist der 
Allerhöchstel Seine Eigenschaften sind grob! Darum sollen wir inm auch alle gemeinsam dienen' :

$$
\begin{aligned}
& \text { VI,6431. Велий есть всевшшншй! Свойства велие } x \text { ero! } \\
& \text { Долг да слумим богу купно все ми аля того. }
\end{aligned}
$$

Die Verse sind durch die Verwendung kirchenslavischer Worte sowie durch die doppelte exclamatio und die Wiederholungsfigur als 'hoher Stil', der dem Thema angemessen ist, gekennzeichnet.

Gott dienen heibt, ihm fur die 'empfangenen Wohltaten' zu danken. Sie legen uns 'das Werk des reinen Dienstes' auf:

VI,645f. Восприятое от нас благодейство чело

Bosnaraet вapyr на всех чисты слущбы дело; -

Daskbar bezeugt der Autor, daB Gott es ist, der uns 'erwahlt und geschaffen' hat und uns alles schenkt, was zur Erhaltung des Lebens nótig ist:

VI,647f. Он нас благосерано преднзбрал и сотворил;

Он и сохраняя челостио одарил.

Die Anapher am Anfang der beiden Verse weist nachdrucklich darauf hin, wer der Geber aller Gaben ist.

Wir sollen Gott 'Innerlich' und 'auBerlich' dienen, sagt Tred., weil Gott 'nicht umsonst Seele und Leib vereinigt hat':

VI,649f. Внутренно служить ему должны и наружно:

Aушу с телом сомзил не вотне содрумно.

Der 'Innerliche' Gottesdienst wird in einem entwickelten geistlichen Leben verwirklicht: an erster stelle steht die Liebe zu Gott:

VI,651 Долженствуем бога внутренно мы все любить: -

Wir sollen inm Gehorsam leisten:

VI,653 Послушание тому да творим все здраво: -

Ihm sollen wir als dem Herrn der Welt die Ehre geben:

VI,656 OH господь во свете; чести как не отдавать?

Gott fordert von uns Gerechtigkeit. Ferner gehoren zum 'innerlichen' Gottesdienst 'Demut' vor Gott und 'Gottesfurcht', denn er bestraft seine Feinde:

VI,657f. Правды требует от нас, да благоговеем:

Над протианиками казнь в страх нам мы имеем.

Der 'Innerliche' Gottesdienst schliebt den Glauben ein, der sich auf die Wahrhaftigkeit Gottes stüzt. Weil Gott 'auf jede Weise wahrhaftig' ist, ist auch die von inm 'erleuchtete vernunft' in uns 'nicht verlogen', sondern wahrhaftig: 


$$
\text { VI,659f. Богу ль не поверим? Всячески он есть праваив: }
$$

По сему ж и разум просвещенный в нас не лжив.

Glaube und vernunft widersprechen einander nicht. Diese Einsicht liegt auch den folgender Versen zugrunde: die Vernunft erkennt, daB im göttlichen Wesen 'Macht', 'Wohltat' und 'Weisheit' vereinigt sind. Daruw soll man inm vertrauen:

$$
\text { VI,661f. Уповать долг на него: сила и щедрота }
$$

И премуарость купно в нем, сиречь вся доброта; -

Wie des ofteren in der Feoptija wird das Wesen Gottes mit der Trias seiner wichtigsten Attribute unschrieben. Anstelle von '6raroctb' steht hier synonym 'mеapota'. Sonst, z.B. in Ep.IV,3ff., nennt Tred. 'npemyapoctb', 'благость' und 'сила' nebeneinander. Diese Trias findet sich auch in anderen physiokotheologischer. Buchtiteln. So exschien 2.B. von B.Nieuwentyt "Die Erkenntnis der Weisheit, Macht und Gute des gottlichen wesens aus dem rechten Gebrauch der Betrachtungen aller irdischen Dinge dieser Welt, zur Uberzeugung der Atheisten und Unglăubigen" (1715), verdeutscht von W.C.Baumann, mit einer vorrede von Chr. Wolff, Frankfurt 1732.

Aus der Verbindung von 'cила', 'щедрота' und 'npemyapoctb' im Wesen Gottes folgert Tred. nach scholastischem Muster: durch die erste 'kann Gott', durch die zweite 'will er', durch die dritte 'weiB er'. Seine Macht, Gute und Weisheit wendet er an, uns $z u$ helfen, 'wenn er unser bekümmertes seufzen hört':

\section{VI,663ff. Перво он может, a Аруго0 хомет он,}

Третиео знает, слыша наш печальный стон,

Помощи нам тож и как, и в какое время, -

Die scholastischen Distinktionen stehen in seltsamem, von Tred. offenbar nicht so empfundenen Kontrast $z u$ dem hymnischen Ton des Abschnitts.

In den Versen 667ff. wendet sich der Autor dem 'außeren' Gottesdienst zu, wobei vor allem an den Kultus gedacht wird.

Wir sollen zu cott im Gebet unsere zuflucht nehmen, 'zum Segen fur seele und Leib': VI,667f. Но извне взшвая прибегать нам долг $k$ нему $И$ ауше аля польз山, телу 4 аля благ всемy.

Auch das Folgende bezieht sich auf den offentlichen Gottesdienst: 'wenn wir Gott rühmen, bekunden wir offen, daB uns seine Ehre uber alles geht':

VI,669f. Долокны мы и прославлять: славя, въявь покажем, Что пречестен есть он нам, как и словом скажем.

Endlich gebuhrt es uns, Gott zu danken und dadurch den Glauben und die Liebe 
bei uns sichtbar werden zu lassen:

$$
\begin{aligned}
& \text { vI,671f. Наконец нам бога надлежит благодарить: } \\
& \text { Смм его приводим ьеру и любовь - нас зрить. }
\end{aligned}
$$

Die Verse vom gottesdienstlichen 'Beten, Loben und Danken' lassen den 11turgischen Reichtum der orthodoxen Kirche anklingen, der dem Popensohn Tred. von Kindheit an vertraut war.

In der năchsten Passage rühmt der Autor den 'закон nравшй'. Damit ist, wie der Zusamenhang zeigt, die Bibel gemeint. Der 'закон правй' lehrt uns dieses, den 'Inneren' und den 'außeren' Gottesdienst. Er 'bringt uns nichts Unziemliches zu Gehór':

VI,673f. Не сему ж ли и закон правшй научает?

Он безместного всего в слухи не внушает.

'Er gibt uns niemals verderblichen Rat' und 'predigt immer, was dem Schopfer wohlgefallt':

VI,675f. He дает совета пагубного никогда,

Что твориу приятно проповедует всегда.

Zum Runm des 'закон правый' sagt Txed.: 'er bewegt uns, gottesfürchtig zu leben' und uns 'den Menschen gegenuber als unseren Năchsten' aufrichtig und gerecht zu verhalten:

VI,677f. Преклоняет, были 6 мн к богу благочестны,

К людям же, как ближним нам, правотой нелестнш.

Das erinnert deutlich an das christliche Doppelgebot (Mc.12,30f.):

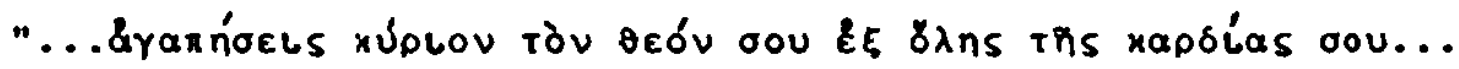

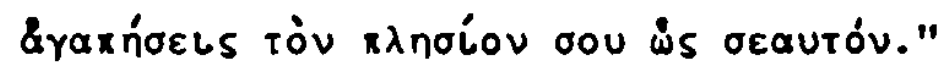

Der 'закон правшй' erscheint in der Passage personifiziert als der Prediger 'nat' \&koxh́': 'er ruft laut im Tempel und hort nicht auf, uns zu lehren, wie wir die Mittel des Heils empfangen kónnen':

VI,679f. Вопиет во храме и не престает уинть,

Как возможем средства, что5 спастись нам, получить.

VI,681-684: in Form einer Apostrophe an Evsevif wird definiert, wer ein wahrer Christ ist.

Tred. charakterisiert den 'wahren Christen' durch zwei Merkmale: er ist 'In seinem Herzen' Gottes 'wahrhaft gewiB', und er lebt 'ohne Heuchelei in der Gnade der Gotteskindschaft'. Damit soll wohl die zusamengehorigkeit von Glauben und gottesfurchtigem Leben hervorgehoben werden. Der Mensch hat allen

Grund, 'von Gott wahrhaft überzeugt' zu sein, meint der Autor. Die Grunde da- 
für sind in der Feoptija ausführlich dargelegt worden. Nun soll er der 'Sohnschaft' würdig leben. Der Mensch ist die einzige unter allen Kreaturen, die diese Auszeichnung von Gott erhalten hat. Ex soll die 'Sohnschaft' unverletzt bewahren. Der Ausdruck 'CuHoвctвo' (682) ist das Áquivalent zu gr. 'vioveoía',

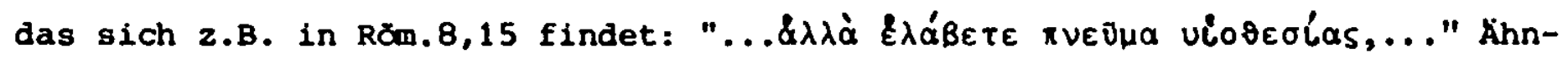

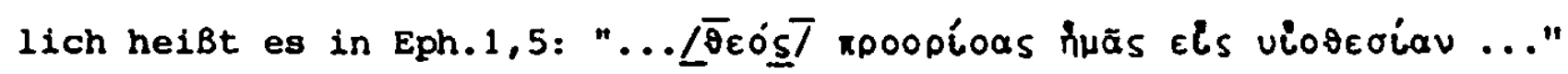

Der Apostel Paulus nennt die Christen 'sohne Gottes', 2.B. Gal.3,26:

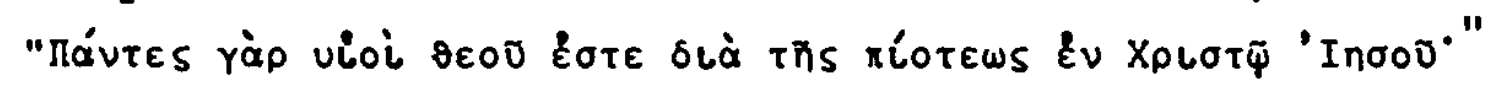

Jesus sagt von den 'Friedensstiftern' in der Bergpredigt, Matth.5,9:

"нaxáplol oi elpnvoroloí,

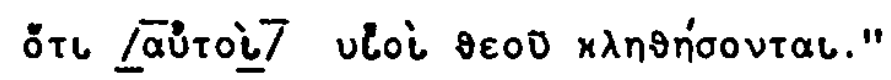

Die Feoptija schlieBt mit einer Apostrophe an Evsevij, in der der 'wahre Christ' vorgestellt wird:

VI,681f. Kто о боге сердча внутрь истинно уверен,

В благодати * сыновства цел, неличемерен,

Der Autor vervollstăndigt das Bild: der wahre Christ ist 'rechtschaffen', 'den Himmlischen ergeben' (gemeint sind wohl die himmlischen Wesen). Ex ist 'gerechtfertigt' (d.h.'er ist cott recht'), ein 'Israelit und Christ' (beide Namen geben die zugehörigkeit zum volke Gottes an). Die dreimalige Wiederholung: 'тот есть', '...тот Горним вдан', 'тот, израилтянин, христианин...' bringt die rhetorische steigerung in den SchluBversen zum Ausdruck:

VI,683f. Тот есть, о! Евсевий, правостен, тот горним вдан,
Тот, израилтянин, христианин, оправда́н.

Zusammenfassender Textvergleich

Feoptija - Démonstration

I.Epistel: Inhaltsübersicht

Motto: Röm.1,20

Thema: Philosophische Beweise für das Dasein Gottes

1-12: 'Evsevij', der fiktive Adressat, wird aufgefordert, die cottlosen $2 u$ verfluchen und den schöpfer der Welt zu verkündigen. (nicht von FëneIon abhăngig)

13-38: der physikotheologische Grundgedanke wird skizziert. Die Schöpfung im großen wie im kleinen, die Tiere und der Mensch offenbaren Gottes Herrlichkeit. 
I,39-210: Die Existenz Cottes wird mit Argumenten a priori bewiesen.

39-54: die menschliche Vernunft enthalt die Vorstellung des allervollkomensten Wesens, das 'notwendig' existiert. (nicht von Fien. abhingig)

55-74: polemische Digression, gegen die Atheisten gerichtet. (nicht abhangig) 75-88: von der Existenz der Welt wird auf ihren Urheber geschlossen. (nicht abhangig)

89-114: aus dem Begriff der absoluten Vollkommenheit, die im Menschen nicht verwirklicht 1st, wird gefolgert, daß ex nicht durch sich selbst existiert, sondern von Gott geschaffen 1st. (nicht abhangig)

115-134: die 'trage' Materie kann nicht aus sich selber geworden sein. Sie setzt eine 'tatige' Ursache voraus. (nicht abhangig)

135-160: aus der unmittelbaren GewiBheit, daB wir unser Dasein weder uns selber noch dem Nichts zuschreiben können, exgibt sich, daß uns Gott geschaffen hat. Die Eltern und Vorfahren sind Glieder einer Kette, deren Anfang bei cott ist. (nicht abhangig)

161-190: die Bewegung setzt einen 'ersten Beweger' voraus. Weder die Materie, noch der menschliche Geist, noch der zufall konnte diu weiwun Gesetze der Bewegung ausdenken.

191-200: das Kausalprinzip fuhrt auf eine 'erste Ursache', von der alle 'Zweitursachen' abhăngig sind. (nicht von Fen. abhăngig)

201-210: wegen der Kontingenz dex Welt muB ein Urheber gedacht werden, der sie nach seinem willen geschaffen hat: das ist der allweise, allgutige und allmächtige cott. (nicht abhăngig)

1,211-424: Die These, 'der Zufall sei der Schopfer aller Dinge', wird als absurd bezeichnet und mit einer Reihe von Grunden und Beispielen widerlegt.

211-232: die GroBe, Vielfalt, Schönheit und Ordnung des Universums kơnnen nicht durch Zufall entstanden sein.

233ff.: Die Meisterwerke der Menschen dienen dem AnalogieschluB, daB das Universum erst recht aus dex band des Schopfers hervorgegangen sein muB. Folgende Beispiele werden zur Begrundung herangezogen:

233-240: die Ilias des Homer

241-254: die Aineis Vergils (nicht von Fén. abhăngig)

255-258: die Annalen des Ennius

259-266: AnalogieschluB a minore ad maius

267-302: Orgelvergleich (nach einem Motiv Fén.s von Tred. ausgestaltet) 
303-312: Polemik gegen die Vertreter der Zufallstheorie (nicht abhăngig) 313-352: weitere Beispiele erweisen die Absurdităt der Zufallstheorie: Apollo von Belvedere; Venus von Medici; Herkules von Farnese. Zusatz Tred.s: die 'Statue der Vera' im Garten Peters I.

353-364: apologetische Digression. Dem Zufallsglauben wird der Glaube an den Schơpfer entgegengesetzt. (nicht von Fén. abhăngig)

365-394: das Gemălde vom Durchzug der Israeliten durch das Meer. (Tred. hat das von Fén. übernommene Bsp. teilweise verăndert)

395-404: es wird eingerăumt, daß dem Maler 'etwas Schaum' am Maul eines Pferdes 'durch Zufall' gelungen sein konnte.

405-412: etwas Ahnliches erzăhlt eine Anekdote uber das Bild 'Jalis mit dem Hunde' des griech. Malers Protogen v.Rhodos. (nicht abhängig)

413-424: 'Zufalle' dieser Art bedeuten nichts im Hinbliqk auf die Entstehung des ganzen Bildes oder gar der 'riesigen Welt'.

I,425-468: Verurteilung der Gegner, die bestreiten, daß Gott der Schópfer und Berr der Welt ist.

425-440: die Atheisten

441-454: die Deisten (Epikux)

455-468: die Pantheisten (Spinoza) - Die Passage ist nicht von Fén. abhăngig. I,469-482: Apostrophe an Evsevij, ex solle bestătigen, daß die Gegner 'nicht bestehen' kơnnen (nicht von Fén. abhăngig)

I,483-554: Wiederholung von Argumenten für die Existenz cottes

485f.: die 'Idee' eines gottlichen Wesens wohnt unserer Vernunft inne und widerspricht inr nicht

487-490: die Ordnung und Harmonie des Universums offenbaren die Macht des höchsten Wesens

491-542: die universale Verbreitung des Gottesglaubens, der consensus gentium, spricht dafür, daB cott selber allen Menschen den Glauben ins Herz gelegt hat

543-554: in Binblick auf das ewige Leben ist es 'sicherer', an Gott zu glauben, als nicht an inn zu glauben. (nicht von Fen. abhángig)

I,555-558: Lobpreisung des allweisen, allgütigen und allmăchtigen Gottes (nicht von Fén. abhăngig) 
II.Epistel: Inhaltsübersicht

Thema: Beweise für die Existenz cottes aus der Betrachtung der materiellen Natur

1-40: der zweifache Weg zur Erkenntnis cottes

a) durch begriffliches Denken

b) durch die 'Anschauung' der Natur

5-20: Apostrophe an Evsevij (nicht von Fen. abhăngig)

41-50: als Gegenstănde der Betrachtung werden genannt: Universum, Erde, Himmel, Luft, Wasser, Gestirne

51-84: der gedankenlos dahinlebende und der 'denkende' Mensch II, 85-312: Betrachtungen uber die 'Erde'

85-132: sie ist weder $2 u$ hart noch 20 weich. Sie schenkt dem Menschen nicht blOB das Notwendige, sondern Reichtum. Die Vielfalt der Landschaften gewahrt uns nicht nux Nutzen, sondern einen 'schönen Anblick'. Die Erde wird in jedem Früling neu. - Wo es Mangel gibt, ist er die Folge von menschlicher Trăgheit und von Kriegen.

103-106: Tred. beschreibt unabhangig von Fên. die far Rubland typischen Landschaften, 'Simpfe, Steppen und Urwălder'

133-144: antiheroische Digression. Nicht der kriegerische 'Held', sondern der Bauer und der Hirt nützen der Menschheit. (nicht von Fén. abhăngig)

145-164: von der 'Schónheit' und von dem 'Nutzen' der Gebirge

165-196: kein Acker bleibt ohne Extrag, wenn er bebaut wird. Selbst die Steppe bringt Heilkrăuter hervor.

197-204: die Verschiedenheit der Vegetation wird als Mittel der gottlichen Pădagogik gedeutet, die die Menschen zur Gemeinschaft exzieht: sozialethische Digression

205-244: der Kreislauf des Werdens und Vergehens in der Natur, die Fruchtbarkeit des Ackers und der Reichtum der Erde an Bodenschatzen sind Hinweise auf den Schopfer

245-302: der 'wunderbare Mechanismus' eines Baumes weist auf den 'Baume1ster' hin

257-266: erbauliche Betrachtung uber den Sinn der grũnen Farbe dex Blatter (nicht von Fén. abhăngig)

die Băume nützen dem Menschen durch das Holz zum Heizen und zum Bau von Hăusern und Schiffen. Die Obstbăume nützen und erfrouen 
den Menschen

303-312: Apostrophe an Evsevij. Das physikotheologische Credo: die Erde macht offenbar, daß der allweise, allgütige und allmächtige schöpfer als 'barmherziger vater' für uns sorgt. (nicht abhăngig)

II,313-471: Erwăgungen zum Element 'Wassex'

313-343: die 'richtige' physikalische Beschaffenheit

344-367: vom mannigfachen Nutzen des Wassers

360-367: die Verwendung des Wassers bei der Hygiene und für die Zubereitung der Speisen (nicht von Fèn, abhăngig)

368-399: vom Ursprung des Wassers. Dex Schopfex 'hăt die Wolken in dex Luft'. Er gibt Regen und Tau. 'Auf sein GeheiB tritt der Nil uber die Ufer'.

400-443: der Lauf des Wassers von der Quelle zum Meer. Das Staunen uber den 'großen Ozean', der anstatt zu trennen, uns mit der 'Neuen Welt', Amerika, verbindet. Auch an der ordnung von Ebbe und flut erkennen wir die Weisheit des Schopfers.

444-471: das fließende Wasser gefriert im winter zu Eis. In der warmen Jahreszeit wird es wieder zu Wasser und stront dem Meere $z u$. Auch das salzige Wasser des Meeres ist dem Menschen nützlich, da wir mit Salz unsexe Speisen würzen. - Lobpreis der Vorsehung, die das wassex in den wolken über uns 'aufgehăngt' hat, nicht um uns z'd 'exdrücken', sondern damit es 'von zeit zu zeit regnet und die glühenden Sonnenstrahlen sich abkühlen'.

II, 472-535: Betrachtungen über das Element 'Luft'

472-485: die Luft besteht aus 'Atherstaub'. 'Dampf' und 'Rauch'. Zeitgenơssische Theorien über das Wesen der 'elektrischen Krăfte' (nicht von Fén. abhăngig)

486-489: die 'Lichtdurchlăssigkeit der Luft

490-493: das Phãnomen des Luftarucks (nicht von F’en. abhăngigg)

494-505: hypothetische Uberlegung: was ware, wenn die Luft dichter oder dunner wäre. Die Weisheit des schopfers hat die Luft so gemacht, daß wir darin leben und atmen konnen.

506-535: die Luftbewegungen: der schopfer läbt die winde und sturme entstehen und bestimmt ihren Zweck. Die Bedeutung der Passat- und Monsunwinde für die Seeschiffahrt

II,536-593: Betrachtungen über das 'Feuer' 
536-545: es stamt von der Sonne und liegt im Inneren der Erde verborgen - das Phăncmen des Vulkanismus

546-555: der Ausbruch eines Vulkans als Gleichnis für die Auferstehung der Seele (nicht von F'en. abhăngig)

556-587: der Mensch macht sich das Feuer mannigfach zunutze

588-593: Anspielung auf den Prometheus-Mythos

II,594-869: Betrachtungen uber den 'Bimmel'

594-605: die ungeheure Grobe des Himmelsgewolbes weist auf die 'allmăchtige Hand' des Schopfers hin

606-611: Gott hat den Menschen im Unterschied zu den Tieren 'aufrecht' geschaffen, damit er mūhelos zum Himmel aufblicken kann

612-623: der Anblick des Himels am Tage

624-631: Schilderung des năchtlichen Himmels ( nicht von Fén. abhăngig)

632-667: die Tageszeiten

656-667 sind nicht von Fen. abhăngig

668-723: die Jahreszeiten

692-699: dex Zusammenhang von Ekliptik und Jahxeszeiten (nicht abhăngig)

724-763: an der Sonne wird die Macht und Weisheit des Schopfers sichtbar - Theorien uber die Bewegung des Universums

764-821: Betrachtungen über den Sternenhimmel

804-813: hymnische Verse uber die zahllosen Welten, die von der Vorsehung nach einem Plan geschaffen sind (nicht abhägig)

822-827: Lobpreisung Gottes, dessen wunder unaussprechlich groB sind (nicht von Fén. abhångig)

828-847: der Mond

837-843: die Mondphasen (nicht von Fèn. abhāngig)

848-869: gegen die Auffassung, die Gestirne bewegten sich nach autonomen Naturgesetzen wird die Theonomie der schopfung vertreten

II,870-877: Aufforderung zum Lobpreis des Schopfers (nicht von Fén. abhăngig)

III.Epistel: Inhaltsübersicht

Thema: Die Tierwelt als Spiegel der Macht und Weisheit des Schopfers

1-10: Bezeichnung des Themas und Apostrophe an Evsevif

11-20: die Fortbewegungsarten der Tiere

21-40: Vögel und Fische 
41-54: Wasser- und Tauchvð̈gel

55-74: Raubtiere und Raubvögel

75-88 Nester und Hohlen

89-94: Reptilien

95-104: die Lănge der Beine und des Halses ist den Lebensverhaltnissen der Tiere angepaßt - Beispiele: Kranich, Kamel, Elefant

III,105-268: vom Nutzen der Tiere füx den Menschen

105-152: der materielle Nutzen der Haustiere (Hund, Maulesel, Pferd, Ochse, Kuh und Schaf; anthropozentrische Deutung der Fischschwărme

153-268: die Tiere als Vorbilder und Lehxmeister des Menschen

153-178: moralisch-pådagogische Digression - nachahmenswerte und abschreckende Eigenschaften der Tiere (nicht abhăngig)

179-198: vom 'Nutzen' der Raubtiere

199-268: die Insekten als Lehrmeister des Menschen

199-220: Seidenraupen und Bienen

212-220: sozialethische Digression - der Bienenstaat (nicht abhăngig)

221-228: die Ameisen und Spinnen (nicht abhăngig)

229-238: vom Sinn der 'unnützen' Insekten

239-252: ontologische Digression - das Bild der 'Kette' (nicht von Fen. abhăngig)

253-268: vom 'Nutzen' der lastigen Fliegen (Tred. hat das von Fén. ubernommene Motiv erweitert)

III, 269-322: die Weisheit Gottes in Makro- wie im Mikrokosmos

269-292: Bewunderung der makrokosmischen Verhaltnisse

293-322: ehrfüchtige Betrachtung der Mikroorganismen

III,323-958: Tierseele und Organismus der Tiere - Auseinandersetzung mit der

'Automatentheorie' Descartes'

323-332: die 'Oreifache Ausrüstung' aller Lebewesen

333-440: Betrachtungen uber den Instinkt der Tiere

333-360: die Instinkthandlungen werden nicht vom Verstand hervorgebracht

361-366: das Gleichnis vom Selltănzer

367-420: das Instinktverhalten der Tiere wird auf die 'Kunst des Höchsten' zurückgeführt, die in ihnen wirkt 
421-428: Lobpreis der Alleinwirksamkeit Gottes (nicht abhăngig)

429-440: die Tiere sind weder 'Automaten' noch Verstandeswesen Polemik gegen das 'Uhrengleichnis' Descartes'

441-520: die Erneuerung des Organimus durch Nahrung und Schlaf

441-468: das Phănomen der Metamorphose

469-492: die Erneuerung des Organiemus durch den Schlaf

493-512: die begrenzte Fahigkeit des Organismus, sich zu erneuern, ist in der Unvollkommenheit der Geschöpe begrundet

513-520: die alleinige vollkommenheit des Schopfers (nicht von Fen. abhänig)

521-760: die Fortpflanzung der Tiere

521-538: die Entstehung und Fortdauer der Arten durch das Naturgesetz von zeugung und Geburt

539-548: die ersten jeder Art sind nicht geboren, sondern vom Schopper geschaffen worden (nicht von Fén. abhăngig)

549-608: Hymnus auf die Liebe in ihren Erscheinungsformen als Eros, Agape, 'Weltharmonie' und Elternllebe (nicht von Fen. abhångig)

609-632: die Zahl der wilden Tiere ist begrenzt, damit die anderen Tierarten erhalten bleiben

633-672: der Schópfer hat den wilden Tieren Grenzen gesetzt - sie dienen als Werkzeuge seiner strafenden Gerechtigkeit (nicht von Fen. abhangig)

673-694: die Verschiedenheit von Organismus und Mechanismus - nur die organimen können sich fortpflanzen

695-760: zeitgenössische Zeugungstheorien

761-816: das staunenswerte Verhalten der Tiere wird an einer Reihe Exempeln geschildert

763-766: der Hund spurt unermüdlich der Fahrte des wildes nach

767-770: der pfau zieht seine Jungen da auf, wo der Hund sie nicht aufspuren kann (nicht bei Fen.)

771-778: der Kampf der agyptischen storrche gegen die geflügelten Schlangen aus Libyen (nicht bel Fén.)

779-782: Anekdote vom Adler, der eine schildkrote erbeutet (nicht bei Fen.)

783-788: der 'listige' Reiher 
789-794: Beutelmeise, Maus, Holzwurm, Maulwurf und Schwalbe (nicht bei Fén.)

795-802: der Kampf des Ichneumon gegen das krokodil (nicht bel Fén.) 803-816: weitere Beispiele für die Kunst und Klugheit der Tiere Singvơgel, Papagei und Affe (nicht bei Fen.)

817-922: Erwăgungen zum Thema 'Tierseele'

817-828: aus dem staunenswerten Verhalten der Tiere folgt nicht, daB sie dem Menschen an Vernunft überlegen wären

829-838: eingeschobene Reflexion - die Irrtümer des Menschen sind in seinem freien willen begründet (nicht bel Fén.)

839-852: die Tiere sind vom Schópfer mit Klugheit ausgestattet worden, wie eine Uhr vom Meister erdacht und hergestellt worden ist

853-880: die Tiere haben eine 'gewisse Art' Denkvermögen

881-922: die Tiere haben eine Seele, die aber von der unsterblichen Seele des Menschen verschieden ist (in dieser Form nicht bei Fen.)

923-958: Polemik gegen die Matexialisten

923ff.: affektbetonte Apostrophe der materialistischen Widersacher (nicht bei Fèn.)

951-958: Aufforderung an die Materialisten, von inrem Irrglauben abzulassen (nicht bei Fen.)

III,959-1028: Berufung auf Platos und der stoa Auffassung von der Beseeltheit des Universums

981-991: Anmerkungen $2 u$ den 'Georgica' Vergils (Tred. hat den Text Fénelons erweitert

992-1008: die pantheistische Lehre in der stoa und bei Plato 1009-1028: Verurteilung des Pantheismus (z.T. anders als bei Fén.)

IV.Epistel: Inhaltsübersicht

Thema: Der menschliche Körper als Werk der Weisheit, Güte und Macht des Schöpfers

1-8: Apostrophe an Evsevij und Bezeichnung des Themas 9-20: Lobgebet (Motive des 8.Psalms) - nicht bei Fén.

21-32: die Eltern sind Werkzeuge, deren sich der Schöpfer bei der Erschaffung des menschlichen Körpers bedient 
33-48: das menschliche skelett

49-60: das Nervensystem - de Bedeutung der 'spiritus animales'

61-105: die Baut

106-121: Bemerkungen zur Physiognomik und Charakterkunde (nicht bei Fen.)

122-161: Adern und Blutkreislauf

130-161: die physiologische Bedeutung des Blutkreislaufs wird unabhangig von Fen. beschrieben

162-197: die GliedmaBen - Beine und FuBe

198-233: die Rippen und das Rückgrat

234-289: die inneren Organe - Lunge und Magen - die Funktionen der

Atmung und Verdauung

290-297: Lobpreisung des Schopfers, der die inneren organe, vor deren Anblick wir erschrecken, um so kunstvoller gemacht hat (nicht bei Fen.)

298-327: die Arme

301-307: Tred. bezeichnet sie mit Metaphern, die nicht von Fen. stammen: Querbalken, Ruder, Flügel, Zweige, Girlande

328-337: dex Bals

338-381: der Kopf - Schadel, Gehirn, Offnungen für die Sinnesorgane, Nacken, Gesicht

IV, 382-483: die fünf sinne

386-443: die Augen

404-407: Schelte der Unglaubigen, die thre Augen vor den Wundern der Schopfung verschlieBen (nicht bei Fen.)

408-413: das 'aufrechte' Sehen (nicht bei Fén.)

414-423: die Anatomie des Auges (nicht bei Fen.)

424-439: zeitgenossische Lehrmeinungen uber den Vorgang des Sehens (nicht bel Fen.)

440-443: anatomische Einzelheiten des Auges

444-453: die Ohren und das Gehơr

454-459: der Geruchssinn (von Tred. amplifiziert)

460-467: der Geschmackssinn (von Tred. amplifiziert)

468-483: der Tastsinn (nicht von Fên. abhăngig)

IV, 484-499: die würde und schonheit des menschlichen Gesichts

500-513: der Mund - Lippen, Zăhne, Zunge 
IV, 514-543: die Luftröhre

544-555: die erstaunliche Leistung der Sprech- und Hororgane (von Tred. erweitert)

556-565: physikotheologische Besinnung

566-593: das Gedãchtnis

594-599: Hinweis auf den Zweck der Epistel: der menschliche Korper sollte kurz und jedem verstăndlich als Kunstwerk des Schöpfers vorgestellt werden

600-619: die EbenmäBigkeit des menschlichen Korpers

620-629: die Uberlegenheit des Menschen über die wilden Tiere - Zähmung und Dressur

630-647: theologische Digression über das Problem des Todes - der Tod als sinnvolles, vom Schöpfer vorbestimmtes Schicksal - der Tod als Strafe für die sünde

648-661: die Vergănglichkeit des Lebens, veranschaulicht durch die Bilder des Wasserfalls und des plotzlichen Sturzes in die Tiefe 630-661 : nicht von Fén. abhängig

\section{V.Epistel: Inhaltsübersicht}

Thema: Die Psychologie in physikotheologischer sicht

1-10: Eingangspassage

11-30: die vollige Verschiedenheit von Geist und Korper (nicht von Fén. abhăngig)

31-50: das Denken wird nicht von der matexiellen Substanz hervorgebracht 51-170: Definition der wichtigsten psychologischen Begriffe (gröbtenteils nicht von Fen. abhangig)

51-76: Verstand

77-92: Vernunft

93-112: wille

114-140: Freiheit

141-148: Definition von 'навык'

149-153: Definition von 'mудpoctb'

154-158: Definition von 'АОбрый смысл'

159-162: Definition der 'Tugend'

163-166: die 'Fertigkeiten' des Körpers

167-170: die 'Fertigkeiten' der Vernunft 
V,171-202: die Vereinigung von Gelst und korper

179-190: Lehrmeinungen uber die psycho-physische Kausalitat: 'influxus physicus', 'occasio', 'prästabilierte Harmonie'

191-202: die Vereinigung von Geist und Körper ist im Plan des Schöpfers begrundet und kommt nicht durch zufall zustande

203-226: psychische Funktionen, die mit körperlichen Erscheinungen zusammenhăngen: Fủhlen, Vorstellung, Phantasie, Gedăchtnis, Erinnerung (im wesentlichen selbstandig)

227-260: Krăfe des Willens: 'Lust', 'Bewegung', Leidenschaften - Katalog dex Affekte (nicht von Fen. abhangig)

261-272: die geistigen Funktionen gehen aus der seele, nicht aus dem 'Fleisch' hervor (im wesentlichen selbstăndig)

273-322: Erwăgungen über die Möglichkeit einer 'denkenden Materie'

323-422: der Schopfer hat Geist und Korper in wechselseitiger Abhangigkeit fur das ganze Leben miteinander vereinigt

V,423-534: von der absoluten und zugleich unbewuBten Berrschaft des Geistes uber den Korper

423-452: die Berrschaft des Geistes aber den mit inm vereinigten Korper beruht in der Weisheit des Schöpers

453-534: die unbewuBten gandlungen des Geistes im Korper weisen auf den Schopfer hin

463-470: das Gleichnis von Selltănzer

471-480: das Gleichnis vom Lautenspieler

501-528: Berufung auf die Autoritat eines 'bedeutenden Lehrers' (nach Fén. handelt es sich un Augustin)

535-710: die Macht des Geistes uber den Kơrper wird am Phănomen der Vorstellungskraft aufgezeigt

537-556: das Gedăchtnis bewahrt die 'Bilder' der erlebten Wirklichkeit 557-568: das Gedăchtnis ist ohne unsere bewubte Mitwirkung entstanden 569-666: das Exinnerungsvermogen ist vom willen abhăngig

594-618: das Phăomen des Vergessens

619-666: der Inhalt der Exinnerung: Personen, Sinneseindrucke, Gemütsbewegungen

667-710: das Gedăchtnis als Beispiel fur das 'commercium mentis et corporis'

711-832: der menschliche Geist ist sowohl durch seine 'Bohe1t' als auch 
durch seine 'Schwachheit' ein Zeugnis für die Existenz cottes 711-794: die 'Boheit' des Geistes erweist sich besonders in den 'eingeborenen Ideen'

795-832: die 'Schwachheit' des Geistes bezeugt ebenfalls die Existenz des Schöpfers: wegen seiner Unvollkommenheit kann unser Geist nicht aus sich selber hervorgegangen sein

V.833-850: Apostrophe an Evsevij - Lobpreisung des Schopfers und Schelte dex Gottlosen (nicht bei F'en.)

851-870: von der Existenz Gottes und von der Unstexblichkeit der Seele (nicht bei Fén.)

871-900: die Unstexblichkeit der Seele wird aus den Attributen Gottes deduziert (nicht von F'en. abhängig)

901-912: Lobpreis der uberweltlichen Berxlichkeit Gottes, die sich in den Wundern der Schöpfung offenbart (nicht von Fén, abhăngig)

VI.Epistel: Inhaltsübersicht

Thema: Die Attribute Gottes, hergeleitet aus dem Begriff des allervollkomensten Wesens

1-6: Angabe des Themas

7-235: die 'attributa absoluta' Gottes (самостоятельне свойства 6ога) 7-17: 'Ауховность' 18-29: 'самодовольность' 30-43: aus dex Vollkommenheit cottes folgt notwendig seine Existenz 44-61: 'Бесконечность'

62-75: 'Безмерность'

76-114: die Allwissenheit Gottes (всеведение)

114b-151: die Weisheit Gottes

152-171: die Allmacht Gottes

172-197: die 'Einheit' Gottes

198-235: die Unverănderlichkeit Gottes (непременность)

236-642: die 'attributa relativa' cottes (сеойства возносительнше)

236-445: die auf die 'naturliche Welt' bezogenen Eigenschaften Gottes (естественные свойстпа)

241-325: der Schöpfex der welt

326-405: die gottliche vorsehung

406-445: die Formen der Vorsehung: 'хранение, содейство, упрапление' 
446-642: die ethischen Attribute Gottes (нравственнше свойства)

446-455: Vorbemerkungen zur Gliederung des Abschnitts

456-515: die Barmherzigke1t Gottes - Theodizeegedanken: die gottliche Barmherzigkeit wird durch das tbel in der Welt nicht aufgehoben

516-549: die Wahrhaftigkeit Gottes

550-615: die Gerechtigkeit Gottes

568-599: Bymnus auf die gottliche 'npaspa'

600-615: christologische Digression - die Vexsohnung durch Christus - der Füsprecher (ходатай)

616-621: die Heiligkeit cottes

622-627: die Seligkeit cottes

628-642: die Berrschaft Gottes Uber das Menschengeschlecht

643-680: Lobpreisung der Erhabenheit Gottes, dem der Mensch zu reinem Dienst verpflichtet ist

643-666: der 'innere cottesdienst': Gott lieben, ihm gehorchen, ihm die Ehre geben, Rechtschaffenheit, Demut vor Gott, Gottesfurcht und Glauben

667-680: der 'außere Gottesdienst': das Beten, Loben und Danken im Kultus, Dienst am Năchsten

681-684: Apostrophe an Evsevif - Kennzeichnung des 'wahren Christen' 


\section{Kapitel \\ Die Feoptija als Lehrgedicht}

\section{Einleitung}

Der Terminus Lehrgedicht bezeichnet in dex Poetik des 18.Jahrhunderts eine grundsatzlich handlungsfreie Dichtung, die die Vermittlung belehrendex Inhalte zum Gegenstand hat. Die Anerkennung der Lehrdichtung hat sich in der Thoorie gegen den lange nachwirkenden EinfluB des Aristoteles durchgesetzt, der die "Nachahmung (Mimesis) menschlichen Handelns durch Worte" ${ }^{1}$, wie er sie im Epos und Drama verwirklicht sah, der Poesie als eigentliche Aufgabe zugewiesen hatte. Die didaktische Gattung ist durch Aristoteles als 'amimetisch' von der Dichtung ausgeschlossen worden. In der Gegenuberstellung von Homer und Empedokles hat Aristoteles sein disqualifizierendes Urteil uber die Lehrdichtung prăgnant ausgesprochen: "Homer und Empedokles haben auBer dem Versmaß nichts gemein; den einen darf man mit Recht einen Dichtex nennen, für den andern paßt besser die Bezeichnung eines Naturforschers als eines Dichters." 2

Die Aufklărungspoetiker haben mit der Anerkennung der Lehrdichtung das aristotelische Mimesisprinzip relativiert. B.Fabian konstatiert in bezug auf die englische Literaturtheorie des 18. Jahrhunderts als "beceutsamste Entwicklung ...die zunehmende Vorherrschaft der horazischen Ars poetica gegenüber dem Werk des Aristoteles. " 3 Dem Leitsatz des römischen Dichters gemåB, "aut prodesse volunt aut delectare poetae", wurde die Aufgabe der Dichtung als Synthese von delectare und prodesse bestimmt, eine Aufgabe, deren Erfülung man insonderheit vom Lehrdichter erwartete. Füx das neue Dichtungsverstandnis charakteristisch sind die Sätze, die P.Hazard aus einem Brief der Lady Montague an S.Pope (1717) zitiert: "Der allein ist ein groBer Dichter, der das Nüzliche so mit dem Angenehmen $z u$ verbinden weiB, daB sein Unterricht unterhaltend und seine Unterhaltung lehrreich ist." 4

In den Jahrzehnten zwischen 1730 und 1760 ist eine Reihe von Lehrgedichten erschienen, die diesem Anspruch in hohem MaBe gerecht geworden sind. Sie haben der Anerkennung der lehrhaften Gattung den Weg gebahnt. Siegrist erklaxt: "Allein durch seine Existenz zwang das Lehrgedicht die Theorie zur Neubesinnung und damit zur Revision des Gesamtgefüges." 5

Die Renaissance des Lehrgedichts beginnt mit dem Erscheinen von A.Popes 'Essay on Man', 1733/34. Der 'Essay' wurde innerhalb weniger Jahrzehnte in 
die meisten europaischen Sprache ubersetzt. 6 Die erste franzósische Prosaubersetzung von Silhouette erschien im Jahre 1736. Sie ist spăter von dem Lomonosov-Schuler N.N.Popovskij bei seiner Versubertragung des 'Essay' ins Russische (1753) benutzt worden.?

Tred. hat den 'Essay' nach seinen worten aus einer franzósischen Ubersetzung in versen kennengelernt: "Случилось мне взять у себя в руки Французсий перевод стихами с аглинских Попповых стихов ме, а имя сей книмке есть 'Општ - человеке'." wie I.Serman anmerkt, handelt es sich um die versübersetzung von Jean-François Du Resnel, die 1737 veroffentlicht und 1738 sowie 1748 neu aufgelegt wurde. 8

Durch die Lektüre des 'Essay on Man' ist Tred. zu seinem Poem angeregt worden. Anschaulich schreibt er daruber in dem 'Predislovie' zur Feoptija: "Стал сию /п̆озму Попа] читать; читал; прочел. По прочтении спереа находился - крайнем удивлении и как бы в некотором өосторге, рассукдая, ито коль тот аетор удаленнуо материо от стихов написал, однако превосходно стихами... Начал я аумать, не можно ль чего подобного составить стихами ж. Ревнивое размышление придало мне некоторше мшсленнше крила: возлетел я ими от Поппого 'Општа о человеке' до твориа человеку. Рассуждал: понеже автор, пиша о человеке, почерпнул все свои мысли из енутренностей метафизики, то мне и приличнее еще быть имеет, чтоб мыслящему писать о боге, почерпать мои размышления из самых глубокостей тоя ж метафизики. " 9

In dem 'Predislovie' nennt Tred. weitere Gründe dafur, daß er den philosophischen Inhalt der Feoptija in der Form eines Poems dargestellt habe. Er beginnt mit einem Hinweis auf den Ursprung der Dichtung: "... поззия у Аревних была суиео их философиео и теологиео. Итак, писать философствование стихами, то возводить некак стихотворение $к$ первому его и достохвальному началу." 10 Als Beispiele werden angefunrt: die Hymnen Homers an die Gotter (noхвальныи богам Гимнн) und das Lehrgedicht des mpedokles ( 06 естестве вещей). Axistoteles hatte diesen nicht als Dichter anerkannt. Tred. nennt ferner die Theogonie Hesiods, das Lehrgedicht des Lukrez (Лукреций книги о6 естестве вещей), die Georgica Vergils (Виргилий земледельные...книги) sоwie die мetamorphosen und Fasti ovids (Оеияий слаякие Превранения и муарыи Фасты). Tred. hebt hervor, daB diese Dichtungsart weiterlebt und weist auf die Lehrgedichte G.Brunos hin: "...из новых Иордан Брун написал стихами 8 книг о множестве миров и их бесконечтости". Zu seinen Vorbildern hinsichtlich der poetischen Form der Feoptija zăhlt Tred. schlieblich den Psalter des 'Kónigs und prophe- 
ten David" urd die kirchlichen Lobgesange der frommen vater, besonders des 'ehrwïrdigen' Johannes v. Damaskus "der die tiefsinnigste Theologie auf diese weise besungen nat" ("... самую rлубокую богословио сим образом он воспел"), Die Anknüpfung an eine groBe Tradition sei aber nicht sein einziger Grund gewesen, die Feoptija in 'gebundener Rede' zu schreiben, setzt Tred. hinzu. Angeregt habe ihn die 'Kürze' und der 'sichtbare Nutzen' dex Versform: "...возбуяила меня краткость и, наконец, вияимая польза возбуяила". 12 тхед. fährt fort, daß die poetische Behandlung des stoffes auch aus pãdagogischen Gründen notwendig gewesen sei: ex habe nicht den Gelehrten, sondern der Jugend mit seinen Werk einen Dienst erweisen wollen. "Но мне надобна была краткость: я писал не яля оказания ученым словесности, но раяи услуг оношеству..." 13

Die Gesichtspunkte 'kparkoctb' und 'nonb3a' scheint Tred. bei A.Pope aufgenommen zu haben, der im Vorwort zum 'Essay on Man', "The Design", die Verwendung der versform so begründet: "This I might have done in prose; but I chose verse, and even rhyme, for two reasons. The one will appear obvious; that principles, maxims, or precepts so written, both strike the reader more strongly at first, and are more easily retained by him afterwards: The other may seem odd, but is true, I found I could express them more shortly this way than in prose itself; and nothing is more certain, than that much of the force as well as grace of arguments... depends on their conciseness." 14 Mit dieser Begründung befinden sich Pope und Tred. im Einklang mit der zeitgenösischen Poetik, die vom Gedanken der 'Wirkăsthetik' (H.-W.Jăger) bestimmt ist. 15

\section{Aufbauelemente}

Epistelform und Apostrophen

Die Feoptija ist wie der 'Essay on Man' in Episteln eingeteilt. Nach dem Beispiel der 'arguments' im Essay hat auch Tred. feder Epistel eine Zusammenfassung des Inhalts in Prosa vorangestellt. Als Vorbild der Epistelform kónnen die 'Epistulae' des Horaz gelten. B.Fabian merkt an, daB in der Dichtung des Horaz "philosophisches und popularphilosophisches Gedankengut gegenwărtig ist, .... in jener aufgelockerten Form dex Epistel, die auch das achtzehnte Jahrhundert, speziell Pope, für das didaktische Anliegen bevorzugte". 16 Die Epistelform hat für das Lehrgedicht eine mehrfache Funktion: sie rechtfertigt die Vertrautheit des Tones, die Ungezwungenheit der Sprache, die Sprünge 
in der Gedankenfolge und den assoziativen Charakter der Themenverknüpfung.

Ein typisches Mexkmal für die Epistel sind die Anreden. Wahrend im 'Essay' eine wirklich existierende Person gemelnt ist (Lord Bolingbroke) 17, sind in der Feoptija die Anreden an einen fiktiven Partner, Evsevij, gerichtet: "...все шесть эпистол адресованы определенному лицу (вимшиленному) Eecesmo..." 18 Er wird als frommer, gottesfurchtiger Mann charakterisiert

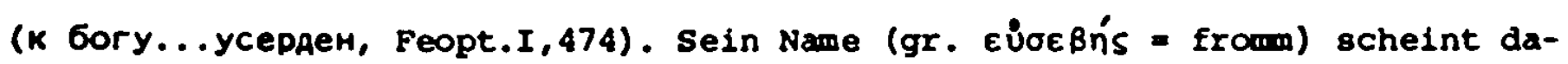
rauf anzuspielen. Der Autor nennt ihn seinen 'aufrichtigen Freund' (B Apymестве... не льстив, I,473). Evsevif wird ferner als scharfsinniger Denker apostrophiert, dessen 'aufgeklarter Verstand vor philosophischen Feinheiten nicht zuruackweicht' :

$$
\begin{aligned}
& \text { II,5f. Но твой, Евсевий смшсл толико просвещенншй } \\
& \text { От тонкости вещей не мог бшть воспяменншй. }
\end{aligned}
$$

Evsevif verkorpert den geistig ebenburtigen, gleichgesinnten Partner, tritt aber nicht als konkretes Individuum auf, mit dem der Autor unmittelbare, private Beziehungen unterhalt. Im Unterschied zur abstrakten Position des Partners in der 'Epistel' des Lehrgedichts erscheint in der im 18. Jahrhundert beliebten Spezies der 'poetischen Epistel' der 'angesprochene Partner individuell ausgeprăgt". 19

Die Apostrophen haben im Lehrgedicht einen wirkungspoetischen Zweck: Uber den angesprochenen Partner hinaus zielen sie auf den Leser. Siegrist erklät: "...der Lehrdichter bedient sich gelegentlich eines fingierten Gegenübers in Anrede, Dialog oder epistolarischem Einschub, doch wird dieses Mittel nux dort eingesetzt, wo es zur Uberwindung einer matten Stelle, zur Erregung der Aufmerksamkeit des Lesers usw. dienen soll." 20

Tred. hat dieses Mittel in der Feoptija bewuBt angewandt. So soll der Leser am Anfang des Poems aus seiner neutralen Baltung aufgeruttelt und für die Sache des Autors in Anspruch genommen werden. Dem dient der beschworende Appel1:

$$
\text { I, } 1 \text { Прокляни, Евсевий, нечестивчх слепоту, }
$$

Am SchluB soll der Leser stimuliert werden, sich mit der Uberzeugung des Autors zu identifizieren. Darauf zielt die emphatische Anrede ab:

VI,683f. Тот есть, о! Еесевий, праєостен, тот горним вдан, Тот, израилтянин, христианин, оправдан.

Des ofteren wird zu Anfang einer Epistel die Ankündigung des Themas durch eine Apostrophe des Adressaten unterstrichen, 2.B. Ep.II,1-26; III,1-10 und 
IV, 1-8.

Die Apostrophe I,469-482 folgt einer Attacke gegen die 'Atheisten'. Evsevij wird als schiedsrichter angerufen, der mit eigenen Augen gesehen hat, dab die Atheisten 'das Treffen' nicht bestanden haben. Durch den Appell an den Freund will der Autor auf den Leser einwirken, die Niederlage der Gegner zu bestătigen.

Die Aufzăhlung psychischer Funktionen in V,261-268 schlieBt mit der an Evsevij gerichteten Frage, ob denn das 'Fleisch' und nicht vielmehr die Seele der Ursprung dieser Funktionen sei. Mit der Apostrophe wird die anthropologische Bedeutung des Themas hervorgehoben.

In v,833-842 dient die Apostrophe der wirkungsvollen Verkūndigung des physikotheologischen Credo:

Не мни, Евсевий, бшть простым то любопытством, Что бога можем зреть естественным всем бытством - еtс.

Dramatische Elemente

In vielen Passagen der Feoptija setzt sich der Autor nach Art des religiosen Streitgesprăchs mit weltanschaulichen Gegnern auseinander. Er tituliert sie als Gottlose (нечестивые, I,1; безбожные пояи, I,134), unglăubige Skeptiker (сиептики неверные, 1,116 ) und Atheisten (атеисты, I,471). Mit Namen genannt werden Epikur $(I, 446)$ und Spinoza $(I, 455)$. Im 'Predislovie' erklart Tred. seine Absicht, 'den Atheisten, Deisten und Ungläubigen das Maul zu stopfen': "заграяить уста и атеистам, и деистам, и неверным". 21 I.Serman merkt an, daB Tred. die antike und moderne atheistische Philosophie gut gekannt habe. So führt Tred. im 'Predislovie' zur Feoptija eine Reihe von atheistischen Autoren aus der Antike und der Renaissance auf. Von neuzeitlichen Autoren kennt er den englischen Deisten J.Toland, dessen Schrift 'Adeisidaemon' (1709) von ihm erwăhnt wird, sowie de Lamettrie, dessen 'L'homme machine' (человек-машина) wenige Jahre vor der Feoptija verfast worden ist (1748). 22 Interessant ist, daB in dieser Aufzăhlung auch der Name des Wolffianers Matthăus Knutzen $(+1751)$ geannt wird, bei dem I.Kant Metaphysik studiert hat. 23 Im 'Predislovie' hat Tred. U.a. die Philosophie Spinozas ausfühlich kxitisiert. Er verurtellt den Pantheismus als 'listigste Form des Atheismus': "При отрицающих явно божество Спинозино злобное всебожие не токмо есть точное безбомие, но и самое тонкое и ухрищенное..., ибо он бога со всем чувствуемым естеством и с частями его сливал." 24 Annlich polemisiert 
Tred. in Ep.I,455-460 gegen Spinoza.

Die Auseinandersetzung mit den Atheisten ist keine persónliche Eigenheit Tred.s. Fä die deutschen verhältnisse stellt siegrist fest: "...der Materialist und Unglaubige bildet im Lehrgedicht eine stehende Gegenfigur". 25 $2 u$ denken ist etwa an Brockes" "Der durch sich selbst widerlegte und uberfuhrte Atheiste". 26

Tred. hat den polemischen Inhalt stellenweise dialogisiert und ihn dadurch der dramatischen Form angenahert. Den Irrlehren der Atheisten, Deisten und Materialisten tritt er als Wortführer der physikotheologischen wahrheit entgegen. Sie behaupten, 'die Materie ist ewig' und 'der zufall ist der schopfer aller Dinge'. Vorwurfsvoll fragt der Autor:

I,211f. Се уж как вам назшвать вещество всевечным, A прпадок всех вещей здателем вдруг встречным?

Darauf folgt eine gründliche Entmythologisierung des 'Zufalls'. Er ist ein blober Schemen, 'blind, taub, ohnmachtig, beinahe ein Nichts':

I,221 Cлеп, глух и бесчувствен, почитай ничто, так хил wie sollte der zufall eine so grobe, mannigfaltige und schone welt hervorbringen können. Der fiktive Dialog mündet in das Bekenntnis zum allmăchtigen, weisen und gutigen schopfer, das sich vor diesem Hintergrund um so eindrucksvoller darbietet.

Ein heftiger Wortstreit wird durch die Behauptung der Atheisten, die Welt bestehe von Ewigkeit her aus sich selbst, ausgelost. Der Autor beginnt mit zornigen vorwirfen:

I,55f. 0 ! вы, кои, буйно мчась в дерзости проклятой, Страхом совести, ниже́ правдою за пя́той, -

Dann klagt er die Atheisten an, sie stifteten Unheil mit ihrer Irrlehre: "...изрыгаете ваш яд" $(I, 58)$. Wie einen Anklagepunkt halt er ihnen ihre These vor:

$I, 59 f$.

Говорите, что сей мир, -

Вечен состонт и есть искони собом;

Der Autor zieht alle Register der Polemik. Er scheut sich nicht, die widersacher in intellektueller, moralischer und religioser Beziehung zu diffamieren: die 'Finsternis', die 'sünde', die 'Hybris', die 'Leidenschaft' habe sie 'varstockt' (I,61f.). Ex unterstellt ihnen, daB sie absichtlich die Augen vor dem 'Licht der Wahrheit' verschließen, sonst müBten sie den 'ewigen cott' erkennen: $I, 69-72$. 
Das poetische Mittel der Dialogisierung wird von der Theorie wirkungspoetisch begründet: es bringt 'Lebhaftigkeit, Personalisierung, Direktheit (Siegrist) ins Lenrgedicht. Es bildet "ein Gegengewicht zur pedantischen Gelehrsamkeit". 27 siegrist stellt fest: "...die urmerkliche Funrung des Lesers zur Erkenntnis,...die Argumentation anstelle von rhetorischer Uberwaltigung machen den Dialog zu einem bevorzugten Medium aufklarerischer Vermittlung." 28

An den fiktiven Dialogen der Feoptija fallen die emotionalen züge ins Auge. Ein weiteres Beispiel dafur ist der Disput mit den Materialisten, die das Denken als Funktion der Materie erklăren (III,923-950):

III,923f. Hо вас, у коих плоть собор только мыслит,

В презренных разум мой и в нечестивых числит.

Die motionalisierung dient der Einprăgung der Wahrheit, so lehren die Theoretiker im Einklang mit psychologischen Auffassungen der Zeit. B.Fabian zitiert den englischen Literaturkritiker Warton: "Men love to be moved, much better than to be instructed." 29 Man denkt etwa an die geschliffene Polemik Popes gegen die Vertreter der anthropozentrischen Anschauung im 'Essay on Man', Ep.I,131f. und Ep.III,45f.

In der Mischgattung des Lehrgedichts haben die dramatischen Elemente eine spezielle Funktion, die von Joh.Jac.Engel in seiner Abhandlung 'Uber Handlung, Gesprăch und Erzăhlung' (1774) so umschrieben wird: "Es ist sichtbar, daB diese Form, wo sie sich anwenden laBt, dem Vortrage ein groBes Leben geben müsse; denn sie bringt...die Gedanken uberall in Gegensatz und giebt der Rede beides mehr Ablinderung und mehr Leidenechaftliches." 30

Digressionen

Ein dem Lehrgedicht eigentümliches Aufbauelement sind die sog. 'Digressionen', der 'Abschweifung' beim Erzăhlen vergleichbar. Der Lehrdichter schmückt seine Darstellung mit Beispielen, Vergleichen, Reflexionen, Legenden, hymnischen Passagen u.a., um das Interesse des Lesers am Lehrinhalt lebendig zu erhalten und ihm auBer dem 'Nutzen' auch 'Vergnügen' zu bieten. Der Ansicht von L.L.Albertsen, solche Episoden seien im Lehrgedicht 'parasitar', ist H. -W.Jăger entgegengetreten: "Schlecht begründet und schlecht zu begründen sind die Termini 'parasităx' und 'Parasităgattung', die verwendet werden, um 'deskriptive und satirische Einschiebsel' (Albertsen, a.a.0., s.19), historische Rückblicke, eingelegte mythologische Episoden, kleine Exempel u.a. im didaktischen und beschreibenden Gedicht zu bezeichnen. " 31 Nach Meinung 
H.-W.Jaggers sind die Digressionen durchaus nicht 'parasităr', "sie schmarotzen nicht am Leben eines andern", ...sondern umgekehrt: "die Lehrstellen... erhalten durch sie Lebhaftigkeit und sinnlichkeit, die erst ein Gedicht konstituieren. Aber auch solche Prioritaten sind eigentlich falsch und unhistorisch; das Lehrgedicht als ganzes integriert gleichwertig Episode und dogmatische stelle." 32 Im Blick auf die englische Theorie ist diese Ansicht von B.Fabian bekraftigt worden. Nach ihm gründet sich die "Anerkennung der Didaktik als Dichtwerk... auf ein Element, das nach Ansicht der Kritik unabdingbar in die Methodik der Gegenstandsbehandlung hineinverwoben ist: die Episode oder 'digression'." 33 Die Digressionen dürfen Jedoch den Lehrinhalt nicht uberwuchern und die Geschlossenheit des Werkes nicht storen. Vor allem sollen sie unmittelbar mit dem Gegenstand zusammenhăngen. "Sie erhalten ihren Wert nur im Zusammenhang mit der Gedankenbildung des Gegenstandes", urteilt Fabian. 34 In der Literaturkritik ist immer wieder die Meisterschaft vergils im Gebrauch der Digressionen gelobt worden. Der englische Kritiker Newbery schreibt: " $/ \bar{V} e r g i l ' s \bar{J}$ fables, allegories, descriptions, similes, reflections, remarks,...etc. seem all to spring spontaneously out of the subject, and are so contrived that they naturally bring him to it again." 35 Im Lehrgedicht bilden die Lehrinhalte zusamen mit den Digressionen ein organisches Ganzes: "Das Ineinander von Lehrgut und dichterischer Auschmũckung, die Gliederung, Unterbrechung und Fortfuhrung des Themas ergibt sich aus dem Schaffensgesetz des Dichters, und die Verknüpfungen der einzelnen Elemente werden vom küntlexischen Empfinden vorgenommen. sie sind eher assoziativer als diskursiver Art." 36

Wie Tred. in der Feoptija Digressionen gebraucht, zeigen die folgenden Stichproben:

Zur Entkxaftung der These, die Welt sei durch Zufall entstanden, führt Trod. eine Reihe von 'Beispielen' vor, die deutlich machen, daß jedes Kunstwerk von einem Meister stammt, sei es die Ilias Homers (I,233-240) oder die Aeneis Vergils (I,241-254). 'Tausende von Beispielen' bestatigen das, sagt Tred.:

$$
\text { I,265f. Hе стихами только можно доказать все то; }
$$

Тысяни прилогов утверждарт, а не сто.

Darauf folgt eine ausfünliche, technisch zutreffende Beschreibung des zweckmaBigen und kunstvollen Mechanismus der orgel (I,267-302). Polemische Satze werden eingeschoben (I,307ff.): "To ym вam, o! мудреuн..." In I,313-352 setzt der Autor die Reihe mit Beispielen aus dem Gebiet der bildenden Kunst fort: 
das Marmorbild auf einer menschenleeren Insel, der Apollo von Belvedere, die Venus von Medici, der Herkules von Farnese, die Statue der Vera, 'die Peter in seinen Garten bringen lieB', sie alle sind von küstlerhand geschaffen worden. Die Anhānger der Zufallstheorie werden mit eingestreuten Schmahworten tituliert (сумас6род, урод, глуnue поя, 1,335f.). Eine polemische Passage schliebt sich an $(1,353-360)$. Dann kehrt der Autor zu seinem Credo zuruak:

I,361f. Всяка теарь во свете проявляет вам его /60ra] Камет всё, что стало бштием от самого.

Scheinbar am ziel, verlängert Tred. die Reihe der Beispiele durch zwei weitere: er beschreibt ein Gemalde vom Durchzug der Israeliten durch das Meex (I,365-384) und gibt eine Anekdote wieder, die sich auf den Maler Protogen von Rhodos bezieht (I,405-412). Diesem sei, heibt es, bei seinem Bilde 'Ja1 is mit dem Hund' eine Schaumflocke am Hundemaul 'durch Zufall' gelungen. Mehr bringt also der zufall nicht zustande, folgert der Autor, die Anekdote für seinen zweck auswertend:

I,413ff. Пен же ль сих примером заключить возможно нам, Что сей mир припаяком так ме саелатьси мог сам?

Коль различно то с Аругим! -

Die lose aneinandergereihten Beispiele sind zwar, wie es die Theorie fordert, dem Gedanken des Abschnitts zugeordnet. Was aber die Vielzahl angeht, wird man einwenden müssen: "Zu viele Episoden lassen die Absicht in den Hintergrund treten und heben die Einheit auf..."37

In die Ausführungen uber das Instinktverhalten der Tiere hat Tred. das Gleichnis vom Seiltănzer eingeschoben (III,361-366). Unter anderem Blickwinkel ist eine Dublette dieses Gleichnisses in die Erwăgungen zu dem ' commercium mentis et corporis' eingefügt (V,463-470). Dort schliebt sich das Gleichnis vom Leierspieler an (v,471-474). Die Gedanken uber das sterben am Ende der IV.Epistel läbt Tred. eimmünden in den Vergleich des menschlichen Lebens mit einem Wasserfall (IV,648-661).

Die physikotheologische Lehre, dab die Weisheit des Schopfers sich in den Geschopfen offenbare, hat Tred. mit zahlreichen Hinweisen auf die Klugheit und Geschicklichkeit der Tiere ausgeschmückt. Hervorzuheben sind die Legenden vam Krieg der agyptischen Störche gegen die libyschen Schlangen und vom Kampf des Ichneumon mit dem Krokodil (III,771-778 und III,795-802).

Eine weitere Digression, die Fabel vom Bienenstaat (III,210-220) gebraucht der Autor, um seine sozialethischen Reflexionen uber die ordnung des staates, 
die Arbeit des einzelnen für das allgemeine Wohl und die Beseitigung der Schmaxotzer darzutun. Wie in der Fabel erscheinen die Tiere als Lehrmeister des Menschen. Das Lamm verkorpert die Tugenden der Einfalt und Friedfertigkeit (nростота $n$ тихость, III,165f.), der sund die der Liebe und Treue ( $n_{0-}$ 6овь К...еерность, III, 167). Lówe, Wolf und Tiger dagegen geben dem Menschen ein abschreckendes Beispiel der Grausamkeit und Raubgier (хинения безмерность и лотость, III,168f.). Der Veranschaulichung von Tugenden dienen auch die Fabelmotive der 'fleiBigen Ameise' und der 'weisen Spinne' (III,221-224). Durch die 'lastigen Fliegen' wird der Mensch zu rastloser Tatigkeit aufgefordert und vor faulem Luxusleben gewarnt (III, 256-268).

In die Ausfürungen uber die Fortpflanzung der Tiere und die Dauer der Arten hat Tred. eine besondere Digression eingeschaltet, den Hymnus auf die Liebe (III,549-608). Darin preist er die Liebe in ihren Erscheinungsformen als Gatten-, Năchsten-, und Elternliebe und erkennt ihx den Rang des Weltprinzips zu, das Descartes, Newton und Plato eigentlich gemeint und mit den Begriffen Bewegung, Gravitation und Weltseele nur unvollkomen bezeichnet haben.

Eine Digression uber das ontologische Ordnungsschema der 'Kette' (III,239252), das im 'Essay on Man' zentrale Bedeutung hat (z.B. Ep.III,7ff. 'chain of Love'), ist von Tred. bei der Darstellung der unzahlbaren Arten von Lobewesen gebraucht worden.

Erwăhnenswert ist eine literaturgeschichtliche Digression Uber die Georgica Vergils, die Tred. in seine Darlegung der stoischen Logosphilosophie in Ep.III,981-991 aufgenomen hat.

Doxologien

Sie stehen meist an hervorgehobener Stelle am Anfang oder am Ende einer Epistel und haben bald gebetsartigen, bald bekenntnishaften Charakter. Nicht selten sind sie biblisch beeinfluBt.

Gebetsform haben z.B. folgende stellen:

II,823f. 01 боме, чудеса творишь един В предлог:

Нет слова, нет речей в язи́ке земнородншх, -

Der Anfang exinnert an Psalm 76,15 (LXX):

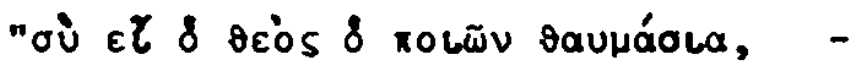

Der Lobpreis in IV,9-20 gründet sich auf Ps.8. Für die stelle sind die doxologischen Ausrufesatze charakteristisch: 
IV,9 Коль твое пречуано, боже, имя по земле!

IV,19 Господи! о! боме наш! Имя твое чуяно!

Die Credo-ahnlichen Passagen verkündigen immer wieder Gottes Weisheit, Güte und Allmacht:

\section{I,555 Есть всеведый! Всеблагий! Есть бог всемогущий!}

Von biblischem Ausdruck ist das Bekenntnis zur Majestát Gottes, dessen Thron 'über alle Himel erhaben' Ist, wo das 'Feuex schrecklicher Blitze ihn umleuchtet', so daB keiner sich ihm nahen darf:

v,903ff. Бог в мноместве земным является чудес,

Имеяй свой престол превыне всех небес,

Где грозных молний огнь весь оный освещает

И приступить К зарям собой не допущает.

Aus dem preisenden Bekenntnis zur Herrlichkeit Gottes folgt das Gebot, ihm zu dienen:

VI,643f. Велий есть всевышний! Свойства велие ж его!

Долг да служим богу купно все мы аля того.

\section{Beschreibungsformen}

Die deskriptive Darstellungsform, in dex deutschen Poetik des 18.Jahrhunderts hăufig 'mahlende' Dichtkunst genannt, zielt darauf ab, "...dem Menschen abwesende Dinge als gegenwartig vorzustellen und ihm dieselben gleichsam 24 fuhlen und $z u$ empfinden zu geben." 38 Im Unterschied zux Malerei, die auf die Darstellung sichtbaxer Gegenstände beschränkt ist, vermag die Dichtung "auch unsichtbare... uberirdische, wunderbare etc. Gegenstände anschaulich $2 u$ machen... und den inneren Aufbau, das Wesen der Phänomene zu beschreiben. "39 Solcher Beschreibung sind auBer den Gegenständen aus dem 'materialischen Reiche' auch die 'schweren metaphysicalischen Grundwahrheiten' 40 zugănglich. In seinex 'Critischen Betrachtung übex die poetischen Gemăhlde dex Dichter' (1741) unterscheidet Joh.Jac.Bodmer Gemălde aus dem 'himmlischen, menschlichen und materialischen Reich'. Gemeint sind: Astronomie, Physiologie und naturwissenschaftliche Einzelobjekte. Zux 'poetischen Malerei' zâhlt Bodmer auch 'dogmatische Beschreibungen', von denen er schreibt: "ich meine solche Gemählde, da die Absicht nicht auf die Erregung des Gemuthes gexichtet ist, damit dasselbe auf eine angenehme Weise unterhalten werde...; in denselben herrschet demnach der Unterricht, und was sie Ergetzliches mit sich füren, ist nur eine beyfallige Zugabe." 41 Als Beispiel wird neben andexen Brockes genannt. Die- 
se poetischen Gemålde sind durch eine Akribie gekennzeichnet, die der wissenschaftlicher Abhandlungen vergleichbar ist, hebt Bodmer hervor: "Man setzet sich vor, einen Gegenstand wit einem solchen genauen FleiBe zu schildern, daß kein unstand dahinten bleibt... Ihre Absicht ist eben diejenige, welche die Erforscher der Natur in ihren schriften boobachten... "42

In der Wahl seiner Gegenstande ist der Lehrdichter grundsatzlich frei. Seine Freiheit reicht "...so weit, als die Wahrheit sich sinnlich und poetisch einkleiden 1abt. "43 Dex Dichter wăhlt gewisse Wahrheiten aus. Er verfăhrt 'essayistisch und eklektisch', stellt Albertsen fest. Von Lehrdichter der Aufklärung kơnne nicht verlangt werden, "ein abgeklartes, fertiges, widerspruchsloses System in Verse zu setzen. "44 Da die Hauptaufgabe des Lehrdichters im Vermitteln besteht, "...sind es gerade die bewărten und bewahrheiteten Lehren, deren er sich annimmt." 45 Daraus erkläen sich, bemerkt siegrist, "das phănomen der thematischen Konstanz, die sich wiederholenden Titel, der Enthusiasmus, mit dem ein neues Mal eine alte Weisheit verkündet wird. "46 Die Lehrdichter werden aber auch ermuntert, neue und unverbrauchte Themen aus der Entwicklung der modernen wissenschaft zu poetisiexen. Uber das Lehrgedicht sind manche ungewohnten stoffe in die Dichtung einbezogen worden, teils 'schwierige' Wahrheiten, "die sich nicht widerstandslos poetischer Darstellung fügen wollen", teils 'gewöhnliche' Gegenstände, die als unpoetisch angesehen wurden. 47 Als besonders verdienstvoll gelten, besonders "wegen der wichtigkeit und Allgemeinheit der dargestellten wahrheiten". ${ }^{48}$ die philosophisch-religiosen Lehrgedichte, in denen neben philosophischen und moralischen Themen im engeren Sinne die Schopfungslehre, die Frage der Theodizee und der Unsterblichkeitsglaube den Ton angeben.

In der Feoptija hat sich Tred. "die künne und groBartige Aufgabe gestellt", (I.Serman) das ganze wissenschaftliche Denken der zeit in sein Poem einzubeziehen: "Он хотел вместить в позму всё содержание современной научной мшсли, всё, чего достигла наука в обияснении важнейших вопросов мироустройства." 49 Dabei hat er sich bemüht, die Inhalte (philosophisch-religióse wie auch naturwissenschaftliche) angemessen zu poetisieren. I.Serman konstatiert: "При зтом Тредиаковский понимал, что он пишет не просто философский трактат, $и$ потому стремился придать ей, насколько зто бшло...в его силах, позтическое звучание." 50 Die Einschrankung ist nach I.Serman sowohl in der begrenzten dichterischen Kraft des Autors als auch in dem teilweise schwierigen stoff der Feoptija begründet: "Но сложншй философский материал, вшбранншй им Аля 
изложения и требуощий особых терминов и оборотов, сопротивлялся этому стремлеHй автора." 51

Der kosmische Bereich

Seine Beschreibung in der Feoptija liest sich wie eine Auslegung des Psalmworts: 'die Himmel erzahlen die Ehre Gottes'(Ps,19,2), mit dem die Ir.Epistel schlieBt:

$$
\text { II,877 Вещают небеса божественнуо славу! }
$$

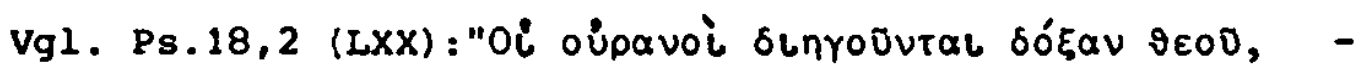

Dem Autor liegt in erster Linie am Lobpreis der Schöpfung und des Schopfers. Diesem Anliegen ist die Frage des Weltbildes untergeordnet. An manchen Stellen wird der Lobpreis durch Vorstellungen des alten und des neuen Weltbildes zugleich motiviert. Ein Beispiel dafür ist die Passage über die Sonne in Ep. II, $724 \mathrm{ff}$.

Sie wird als 'Flammenmeer' beschrieben, das durch ein festes Gesetz in seinen Grenzen gehalten wird. Die Deskription lost Fragen aus, denen die ptolemäische Anschauung zugrunde liegt:

II,730f. Кто водит шар его в порядочный толь круг?

И сбиться Кто $*$ с путей не допускает вдруг?

Die Antwort liegt im Glauben an den Schopfer.

Halt man dagegen das heliozentrische Weltbild für erwiesen, so wird das Staunen angesichts der gesetzmaBigen Bewegung der Erde um die Sonne um so gröBer:

II,740f. Но буде, напротив, мы вкруг его еертимся, Чему, поемля то, безмерно мы чудимся, -

In beiden Anschauungen wird also der Glaube an den Schopfer vorausgesetzt:

II,758ff. То больше человек есть должен познавать

Создание твориа, его разумевать

И предержавну власть в правлении всем света.

Ähnlich verhalt es sich beim Firmament. Hăufig beschreibt es Tred. in der herkömmlichen Vorstellungsweise. Er spricht von den 'blauen Gewolben', an denen die 'unzahligen sterne blitzen' (II,764f.). Ehrfurchtsvoll fragt er:

$$
\text { II,758 Кто легионам звезд места Аал пригвожденны? }
$$

Er unterscheidet zwischen den Fixsternen und den Planeten und hebt hervor, daß der Schöpfer ihre Entfernungen festgesetzt und bestimmt hat, daß 'Jene golden und diese silbern glănzen' (II,769ff.). Im Wechsel von staunenden Fragen und begeisterten Ausrufen preist der Autor die Schönheit einer stern- 
klaren Nacht. Wer kann ihren Anblick mit Worten beschreiben? Aus ihren 'scheinbar unbeweglichen Nestern' schimmern die unzahligen 'goldenen Sterne', schildert der Autor entzückt (II,624-627). Das Entzücken vom Anblick des 'bernsteinfarbenen Lichtes' der MilchstraBe auBert sich in bewegten worten:

II,628f. Ум не мятется ль наш, зря млечную дорогу,

A блеск янтарний В ней чрез искру варуг премногу?

Tred. ist jedoch nicht in den vorstellungen des alten Weltbildes befangen. In vielen Versen spiegelt sich die unendliche Grobe des Weltraums, wie sie von der neueren Astronomie seit Kopernikus aufgewiesen worden ist. So fuhrt er bei der Schilderung der 'unzăhlbaren Menge' der Sterne die Lehre Giordano Brunos an, das feder Stern die Sonne einer inm zugehorigen welt sei:

II,794ff. Мнят кажаую из звезд, дучей их no orno, Подобну солнцу бшть и сонечному анш,

А кажауо притом подобному ж светящу

Ty миру там сему и такме свой плодящу.

Die Bewunderung des Autors nimmt hymnischen Ausdruck an:

\section{II,804f. Колико зримих Солнц! Земель колико нижных! \\ Колико тварей всех! родов коль непостижншх!}

Sie steigert sich zum Lobpreis der Vorsehung, die diese vielzahl der 'Sonnen und Erden' (die kosmischen Plurale beziehen sich auf das nachkopernikanischo Weltbild) nach einem einheitlichen Plan geschaffen hat:

\section{II,808f. Всему един чертеж! но коль по виау разно! \\ 0 ! промшсл, всё ж со всем не втуне и не праздно!}

Uberwaltigt van Anblick der 'Tiefe' des Himmels bekennt der Autor, daB das 'Licht des Verstandes verlischt und nicht imstande ist, den Weltraum zu begreifen' :

\section{II,813 Темнеет свет ума: нет сил обнять пространство!}

Der Abschnitt II,790-813 ist ein Beispiel für die spezielle Art 'hymnischer Lyrik' (K.Richter), die unter dem Eindruck des neuen Weltbildes der wiseenschaft entstanden ist, und die sich, wie K.Richter ausfürt, in der deutschen Lyrik "erst im ersten Drittel des 18.Jahrhunderts, mit Brockes vor allem" 52 , entfaltet hat. "Barthold Beinrich Brockes hat die neuen kosmischen Groben und die auf sie gerichtete Ergriffenheit des Menschen als ein zentrales Thema des 'Irdischen Vergnugens in Gott' in zahllosen Versen ausgesagt. "53 Die Lyrik von Brockes ist durch ein Gott preisendes, hymnisches Sprechen charakterisiert, bei dem sich, wie K.Richter hervorhebt, "oft genug andere Gestaltungs- 
intentionen in den Vordergrund /schieben]/: Beschreibung, Betrachtung, Argumentation". 54 Die Eigenart der Gedichte von Brockes hat Richter so gekennzeichnet: "In den Formen einlaBllcher Beschreibung und begründung schliebt sich die Lyrik von Brockes auf ihre Weise an ihr wissenschaftsfreudiges Zeitalter an; aber sie bezieht auch das Ergriffensein des Menschen darauf zurück." 55

Viele Abschnitte in der Feoptija lassen sich ähnlich charakterisieren. So ist z.B. die Passage II,790ff. dem Gedicht 'Das Firmament', mit dem Brockes das erste Buch des 'Irdischen Vergnügens' eroffnet, nicht nur thematisch verwandt. Sie hat auch eine ahnliche struktur: wie das Gedicht von Brockes besteht sie aus betrachtenden, argumentierenden und hymnischen Elementen. Analog ist bei beiden Autoren auch 'die vam Blick in das All ausgelöste Erregung' (K.Richter), die 'Abfolge von Bestürzung und Beseligung'. 56

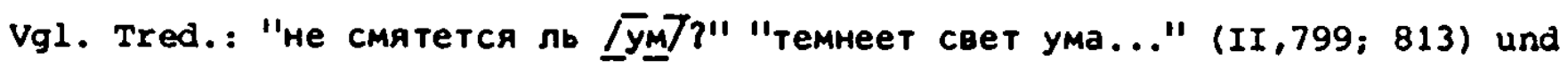
"o! nромысл..!" (809).

Brockes :

"Es schwindelte mein Aug', es stockte meine Seele Ob der unendlichen, unmäsig-tiefen Höle, -"

"Allgegenwart'ger Gott, in Dir fand ich mich wieder." 57

Im Bemühen, die Große des Universums auch 'objektiv' zu beschreiben, greift der Lehrdichter oft zum Mittel der Zahl. Siegrist erklät: "Diese abstrakte GroBe soll eine wenn auch ungenügende... Ahnung von der UnermeBlichkeit dieser Dimension vermitteln." 58 Er weist auf die Bedeutung hin, die der zahl als 'Quintessenz der Rationalităt' im Denken der Aufklărung beigemessen wird. 59 So finden sich bei Brockes in seinem Neujahrsgedicht von 1730, wie Siegrist es ausdrückt, 'Anzeichen eines Zahlenrausches'.60

Auch Tred. verwendet in der Feoptija an einigen Stellen das Mittel der Zahl bei der Beschreibung des Weltalls. 'Wieviele Millionen Werst', fragt or, mag die Sonne entfernt sein?

III,271 Мы Солнце зрим, оно (в колико ж верст мильонов?)

Er will sagen, daB bereits diese Entfernung unsere Vorstellungskraft ubersteigt. Wie steht es erst mit dem Abstand von den Sternen auBerhalb des planetarischen Raumes! Wir haben kein MaB, um diese Weiten zu messen:

III,277f. Te расстоят от нас в далекостях таких, Что меры положить не можно есть до них.

Der Verzicht auf MaB und zahl unterstreicht die Grenzenlosigkeit des Raumes. Gegenüber dem All schrumpft die Erde zu einem 'kleinen Punkt' zusammen: 
III,281 Пред всем, что зрим, земля есть точечка уже -

Die 'Gemăde des Uberirdischen' (Siegrist) wollen jedoch nicht nur für sich betrachtet und bewundert werden. Sie geben zugleich eine vorstellung von der Erhabenheit des Schópfers und rufen die Doxologie hervor, Indem sie, nach einem Wort des Kopernikus, der Aufforderung zum Lobe Gottes "das Vehikel der Anschauung an die Seite" stellen. 61 Tred.s Beschreibung der Vielzahl der Himmelskörper schließt mit dem Lobpreis:

II,822f. Кто велий толь иный, коль велий есть наш бог!

0! боже, чудеса творишь един в предлог: -

Diese Passage, die in der Démonstration keine Parallele hat, berührt sich mit dem Program des englischen Physikotheologen W.Derham, der in seiner 'Astrotheologie' (1728 von Joh.A.Fabricius erstmals ins Deutsche ubersetzt) "Anweisung zu der ErkenntniB cottes aus der Betrachtung der himmlischen Korper" gibt. Erinnert sei auch an den Lobpreis, zu dem Joh.Kepler in seiner 'Weltharmonik' hinführt: "GroB ist unser Herr und groB seine Kraft und seiner Weisheit ist keine zahl. Lobpreist ihn, ihr Himmel, lobpreist ihn, Sonne, Mond und Planeten..." 62

Bei der Beschreibung des Kosmos habt Tred. neben der Grobe besonders die ordnung, die gesetzmảBigen Bewegungen der Himmelskorper und ihre dem Menschen zugute kommenden Wirkungen auf die Erde hervor. Der Begriff 'чин' spielt in diesem zusamenhang eine entscheidende Rolle. Er bezieht sich eirmal auf die Integrităt des Kosmos, von dem nicht der geringste Teil fehlen dürte, ohne daß alles zusamenbrăche:

III,283f. Всё ж то сопряжено толь чинно меж со601, Что меньше стать в себе ни частио одноо, -

III,287 He может 6ез roro, чro6 вдpyr не сокрушился -

Zum andern wird mit 'чин' die gesetzmäige Bewegung der Himelskorper bezeichnet, bei der sich nicht die geringste Abweichung feststelien labt (II,783f). Es heiBt: II,848 Авижение планет есть чин необходимый, Auf die 'Ordnung' scheint auch die Metapher vom 'Heer' der Sterne hinzuweisen (ror Becb nonk, II, 792), das gewissermaBen in militărischer Formation dahinzieht.

In die kosmische ordnung ist auch die Erde einbezogen. Sie gehort, wie Tred. es ausdrückt, 'durch gemeinsame Gesetze' (O6ществом законов, III,272) mit dex Sonne zusammen. Eingehend beschreibt er aus der sicht des naiven Betrachters, wie der Lauf der Sonne die vier Tagezzeiten herbeifüht: II,632-667. Der 
Wechsel von Tag und Nacht wird als 'wunderbare Ordnung' beschrieben (4ин АИвный, II,632), die uns die Weisheit des Höchsten erkennen läBt. Gemütvoll schildert der Autor, unabhangig von der vorlage, die wohltat der Nacht:

I1,650f. Нощь ввоАит сладкий сон, покой и тишину,

Дает вещей забыть нам низ и вышину, -

Auch die Jahreszeiten, so führt Tred. aus, hăngen von der Sonne ab: II,668723. Ahnlich stellt er den Sachverhalt in VI,374-391 dar. Die Beschreibung zielt darauf $a b$, in der Aufeinanderfolge der vier Jahreszeiten die Fürsorge des Schöpfers für den Menschen und alle irdischen Geschöpfe sichtbar werden zu lassen:

\section{II,675 Bcerá o вcех и всём печется божество.}

Dank der Fürsorge des Schöpfers insonderheit für den Menschen rückt die Erde, die durch die unendliche Ausweitung des Weltbildes ihre Sonderstellung verloren hatte, aus neue in den Mittelpunkt. K.Richter hat die Verănderung so kommentiert: "Der wissenschaftliche Brückenschlag zwischen der Erde und den Sphăren hat das universum und einen darin wirkend gedachten cott in ein unmittelbares Gegenüber zum Menschen gebracht." Das Bewubtsein einer "grundsatzlichen Verbundenheit von Gott und Mensch" hat sich, wie Richter anmerkt, "betont an den kosmischen Bezügen" ausgesprochen. Wăhrend das dichterische "Pathos des 17.Jahrhunderts vorzugsweise an der Kluft zwischen Irdischem und Gottlichem aufbrach, konnte das 18.Jahrhundert gerade in den kosmischen Relationen die neue Harmonie von Mensch und Gott und die GewiBheit einer umgreifenden göttlichen ordnung betonen." 63

Die Vorstellung der 'prăstabilierten Harmonie' hat die kosmologischen Beschreibungen in der Feoptija beeinfluBt. So macht Tred. 2.B. an dem Verhaltnis zwischen Sonne und Mond auf ein Stück Welthamonie aufmerksam: der Mond empfängt sein Licht von der Sonne, steht mit ihr in 'freundschaftlicher Verbindung' (II,836), 'damit wir nachts nicht in völliger Finsternis sein müssen' (II,834). Kosmische Harmonie ist wohl auch in der Metapher 'Chor' der Gestirne angedeutet (коль тот непраздно хор!, II,631).

so tritt in der kosmischen wie in der irdischen ordnung (vgl. III,148f.) die unfassende göttliche Fürsorge für den Menschen zutage:

$$
\text { VI,373 Всё } \%, \text { чтоб нашей пользе не был өред здесь никакой. }
$$

\section{Der Mensch}

Das starke anthropologische Interesse der Aufklarung ist von A. Pope prăg- 
nant formuliert worden (Essay on Man, Ep.II,2):

"The proper study of Mankind is Man."

Der Unterrichturg uber den menschlichen Korper dienten im 18.Jahrhundert u.a. die anatomischen Kabinette, in denen die Anatomie des Menschen in Wachsprāparaten von kunstvoller Genauigkeit zur Schau gestellt wurde. Joh. Heinr. zedler berichtet darüber in seinem universal-Lexikon (Bd.52, 1747): "Ein dergleichen Kunst-Stück hat an.1721 der Herr P.la courege in Bamburg in unterschiedlichen Figuren sehen lassen. Die erste Figur stellete vor ein Măgen von 11 bis 12 Jahren, davon die eine Seite mit der Haut bedecket war, die andere aber also eingerichtet, daB man den Unterschied der PulB- und Blut-Adern deutlich sehen kunte. Die ersten waren mit blauen, die letzten aber mit rothen Wachs abgebildet. Man sahe auch bey dieser Figur alle inwendigen Theile in ihrer naturlichen GroBe, Farbe und Lage." 64 zedler merkt an, daB solche anatomischen Schaustellungen (theatrum anatomicum) groBen zulauf hatten. Dabei muB man bedenken, "daß die Lehrbücher der Medizin noch durchgehend lateinisch verfaBt waren,...so daB das Interesse und die Neugier auf den eigenen Korper weitgehend ungedeckt blieben. " 65

Es nimmt daher nicht wunder, daß der Mensch, seine korperlichen organe und ihxe Funktion, dazu sein geistiges Wesen in zahlreichen Lehrgedichten dargestellt worden ist. Erwăhnt seien 'Die wăchserne Anatomie' von B.H.Brockes ${ }^{66}$ und dessen Gedichtreihe 'Die füf sinne' 67 . Der Ansicht von Albertsen, die medizinischen Passagen in Ballers 'Unvollkommenem Gedicht uber die Ewigkeit' seien 'subpoetisch', widerspricht H.-W.Jăger. Nach ihm sind diese Passagen "Integrale Bestandteile des didaktischen Gedichts, in dem sie mit emphatischappellierenden,...philosophisch deutenden u.a. abwechseln. Der Begriff subpoetisch denkt gegen die Gesetzlichkeit der Gattung und impliziert historische Voreingencomenheit." 68

In dem angedeuteten Zusammenhang steht auch die Beschreibung des Menschen unter anatomischem, physiologischem und psychologischem Blickwinkel in der IV. und V.Epistel der Feoptija. Der Mensch erscheint dort in physikotheologischer sicht, die auch die Gedichte von Brockes kennzeichnet. Durch die zweckvolle Beschaffenheit aller Glieder und organe wie durch inr sinnreiches Zusammenwirken ist der Mensch ein lebendiger Beweis für die Macht, Weisheit und Gute dessen, der inn geschaffen hat. Tred. erklart in der Einleitung zur IV.Epistel: "Сео эпистоло0 доказшеаетя премудрость и благость бомия по составу человеческого тела." ${ }^{69}$ Diese Absicht fuhrt ex mit beinahe enzyklopádi- 
scher Vollstăndigkeit aus. In den 'physiologischen Gemălden' (Siegrist) dex IV.Epistel bemüht sich Tred., den anatomischen Befund wie auch die organischen Funktionen darzustellen. Damit verbinden sich die haufigen Hinweise darauf, wie wunderbar der Schópfer den menschlichen organismus eingerichtet hat.

Nehmen wir als Beispiel die Augen (IV,386-443). An ihnenwird die Erfindungskunst des Schópfers gepriesen: daB sich die Augen an der geeignetsten stelle befinden, daß sie mit 'unvergleichlicher Schönheit' ausgezeichnet sind, daB wir mit zwei Augen die Dinge nicht doppelt sehen, und daB sie uns nicht 'verkehrt', sondern 'aufrecht' erscheinen - dies alles ruft das entzückte staunen des Autors hervor (чуано!, IV,400; коль не меньше Аивно..!, IV,408; всё сие премуарость нам в здавшем изъявляает, IV,410). Tred. schmückt die Passage mit dem Vergleich, die Augen seien Spiegel (сии суть зерцала, IV,396), in denen dank gottlicher Weisheit 'jedes Bild der Natur gezeichnet wird'.

Vor diesem Hintergrund hebt sich die nüchterne Beschreibung der Anatomie des Auges un so mehr ab. Tred. gebraucht dabei Fachausdrücke wie: 'o6oлouka роговая' (IV,414), 'зрачка' (IV,415), 'зеница' (IV,417), 'влага кристальна' (IV,419) und 'сеточка тонка' (IV,422).

Darauf teilt Tred. drei Theorien uber den Sehvorgang mit, die in der Antike von Euklid und Pythagoras, in der Neuzeit von Descartes und Huygens vertreten worden sind. 70

In die minuziose schilderung der stimmorgane sind schmückende Vergleiche eingeschaltet. So heiBt es: die zunge bewegt sich so flink, wie 'klimpernde Fingex' ein Lied spielen (IV,510f.). Die stimme klingt wie eine 'Flote' (IV,524) oder wie eine 'Orgel' (IV,535). Sie ubertrifft an Vielfalt und Schönheit alle Musikinstrumente, Leiern und Trompeten (IV,540-543). Immer wieder drăngt es den Autor, das 'Wunder' zu preisen, das die göttliche Weisheit und Gute im menschlichen Organiamus geschaffen hat:

$$
\begin{aligned}
& \text { IV,536f. Мнится, что довольно муарость вышно изъявить, } \\
& \text { Смыслящего ж можно пребезмерно удивит, - } \\
& \text { IV,552 Что за чудо! - } \\
& \text { IV,556f. Не намерение ль муарое в благом творие, } \\
& \text { Смогшем всё, толико и попекшемся дельче́, - }
\end{aligned}
$$

Selbst ein so unpoetischer stoff wie die Verdauung wird im Detail beschrieben (IV, 260-275). Auch sie zăhlt der Autor zu den Wundern im menschlichen Korper : 
IV,276f. Словом, в человечем столько теле есть чудес,

Что конечно долино здатель бить от небес.

Auch das abstoBende Bild der inneren Organe, von Tred. In IV,278-297 geschildert, labt nach seiner Ansicht die weisen Absichten und die Kunst des Schöpfers erkennen. Die Beschreibung schließt doxologisch:

\section{IV,294ff. Подлинно, ито части те, в хитрости обильны, Чуаным дейстөием своим зрятся есе толь сильны, Что явить варуг могут всемогу山его твориа, И того премуара и блажайша $6 е 3$ кониа.}

Die Passage lät (wie die vom 'gehăuteten Gesicht, IV,69f.) an die in der aufklärerischen Poetik geführte Diskussion über die Darstellung des Baßlichen und AbstoBenden in der Dichtung denken. 71

Uber seine physische Art hinaus wird der Mensch im Lehrgedicht der Aufklărung vor allem als vernunftbegabtes Wesen vorgestellt. Nach Siegrist finden sich "dreierlei Aspekte des Menschen... in lehrdichterischen Gemalden artikuliert: sein Verstand, sein 'Charakter' und sein Korper". 72

Das Thema 'der Mensch als vernunftwesen' w1rd von Tred. In der V.Ep1stel entwickelt. Nach seinen Worten wird darin 'die ganze Psychologie kurz, aber deutlich' dargelegt (...еся nсихология преAлагается вкратце, но ясно). 73 Beim Ubergang zum neuen Thema unterstreicht er dessen hohere Qualitat gegenüber dem vorigen:

$$
\begin{aligned}
& \text { V,1ff. Создатель есть премуар по телу человечу. } \\
& \text { Но смысл и разум наш когда, как долг, примечу, } \\
& \text { То тело пред умом покажется ничто, - }
\end{aligned}
$$

Auf der Grundlage des von Descartes gelehrten Dualismus von Leib und Seele, der schon von Augustin vertreten wurde, ${ }^{74}$ beschreibt Tred. die Verschiedenheit der beiden substanzen (описывается...во первых, различие души с телом) 75 . Ihre Vereinigung im Menschen erscheint ihm daher als das zentrale problem der Psychologie: "...вопрошается, кто $\neq$ бы мог соединить толь твердо мыслящее суиество с немыслящим, то есть с телом..." 76 Er preist den wunderbaren, lebenslanglichen Bund von Leib und seele als das Werk des weisen schopfers:

V.193ff. Премуаршй есть сооз! и больше толь предивный, Ито в разности сунесте быть мнится сопротиеный! Hе муарого ль сие творение аельца?

Auf der Vereirigung von Geist und korper beruht ihre Wechselbeziehung im im Sinne einer vom Schópfer prăstabilierten Harmonie: 


\section{V,362ff. Взаимно другу Aруг находятся поделастны, \\ Bзаимно те do ecex cвonx qenax cornachu. \\ Лишь ум замислит, едруг приходит тело в двиг: \\ Лишь в Авиги плоть пришла, ум начал мыслить вмиг.}

Tred. betont in dem 'commercium mentis et corporis' den Primat des Geistes, von dem die intellektuellen, Gefuhls- und Willensimpulse ausgehen, die die korperlichen Bewegungen verursachen (V,261-265). Er vergleicht das Verhaltnis zwischen Geist und körper mit einem Ritter, der sein Schwert im Kampf treffsicher handhabt (V,241-244) oder mit einem Reiter, der seinem Pferd die Sporen gibt (V,365-368). Anschaulich wird geschildert, wie auf etnen Befehl des Willens die Sehnen sich straffen, alle Glieder zu arbeiten beginnen und der ganze 'Mechanismus' des Körpers gehorcht (V,429-434). Wie das vor sich geht, läbt sich mit unserer Vernunft nicht erklären, meint Tred. Er beruft sich in dieser Sache auf einen bedeutenden Lehxer (8 учителях не man, V,499), gemeint ist Augustin, der, uber das 'commercium mentis et corporis' meditierend, nur feststellen kann: wir wissen nicht, wie es zustande kanmt, nicht einmal wie es zugeht, 'wenn ich meinen Finger berähre' (V,499-534).

Das Thema der Vereinigung von seele und korrper hat Brockes in dem Gedicht 'Das menschliche Wissen' in dialogischer Form behandelt:
A. "Wie können denn der Menschen Seelen
Mit ihrem corper sich vermăhlen?
Gib mir doch davon Unterricht!
B. Das weib ich nicht. -"
Brockes ăuBert die Uberzeugung, der Mensch sei nicht dazu berufen, die Gehein nisse des Schópfers zu verstehen:

"Ex will sich hier von uns nicht fassen,

Und nur allein bewundern lassen." 77

Tred. zieht aus der Vereinigung von Geist und körper und ihrem harmonischen Zusammenwirken den SchluB auf die Existenz der gottlichen Weisheit, Güte und Allmacht, die solches 'erdacht, erwahlt und verwirklicht' hat $(v, 395-400)$.

Als ein bemerkenswertes Beispiel des 'commercium' wird das cedachtnis geschildert $(V, 535-710)$. Es hat einerseits seine korperliche Grundlage im Gehirn (образований мозг в союзе главна часть, V,536), andrerseits gehorcht es einem geistigen vermögen, dem willen (да и повелевать ей /п̆амять 7 предержавHo cmeo, V,698). Unter körperlichem Aspekt wird das Gedăchtnis mit einem groBen Buche verglichen, dessen Buchstaben nicht zu zăhlen sind $\left(V, 559 f_{.}\right)$, mit 
einem Kasten, in dem unzahlige Bilder aufbewahrt werden, deren Vollkowmenheit alle Kunst der Maler ubertrifft $\left(v, 543 f_{.}\right)$. Ohne unser bewnites zutun prăgen sich alle sinneseindrücke, Gefühle und Gemulsbewegungen in erstaunlicher ordnung dem Gedáchtnis ein. Tred. sieht darin ein Wunder, das sich nur physikotheologisch deuten laBt:

$$
\begin{aligned}
& \text { v,683f. Чья ж мудрая рука в чрежяении была, } \\
& \text { Что всё составить то способно возмогла? }
\end{aligned}
$$

Noch in anderer Hinsicht erscheint dem Autor das Gedăchtnis als 'unbegreifliches Wunder' (Ава чуда я в себе непостижимш 3р0, V,667): obwohl es nicht von uns gemacht worden ist, gehorcht es unserem willen (a воло исполнять та и cnewи mor, V,699). Anschaulich schildert Tred., wie die Erinnerungen kommen und gehen, wann immer wir wollen:

$$
\begin{aligned}
& \text { v,571f. Приходят, как зову, прочь ияут, как прочь шлю, } \\
& \text { СКршеаются, коГда им скршться повелю; - }
\end{aligned}
$$

wie sich jemand verhalt, wenn in seiner Exinnerung nicht das auftaucht, wonach er gerade sucht, zeigt das lebhafte Selbstgesprăch:

v.592f. То говорю и внутрь и вем, что не во сне:

"Прочь-прочь, я не тебя искал теперь заботно".

Die Kraft der Exinnerung, Vergangenes gegenwărtig zu machen, veranschaulicht Tred. In V,619-626: die Erinnerung stellt ihm das Bild eines Freundes in den verschiedenen Lebensjahren vor Augen, wie er ausgesehen und welche Kleidung er getragen hat. Die Beschreibung schliebt prăgnant:

$$
\text { v,625f. На том же я лице мориины образуо, }
$$

На коем красоту румянуо целую.

Nicht uberall ist das psychologische Thema von Tred. so anschaulich behandelt worden. Hăufig finden sich trockene und umstăndiche Definitionen der wichtigsten Begriffe: 'разум' (V,77-92), 'воля' (V,93-112), 'свободность' (V,113-140), 'навык' (V,141-170), 'чувствовать' (V,211-214), 'образовать' (V,215-218), 'мечтать' (V,219f.), 'памятовать' (V,221f.), 'вспоминать' (V,223226), 'охота' (v,228-236), 'страсть' (v,245-260) u.a.

Unter Hinweis auf die sehr große Verschiedenheit der menschlichen Gesichter (от Петрополя в лице разность до Пекина // толь велика, - IV, 102f.) tragt Tred. eine von Elementen des Volksaberglaubens durchsetzte Physiognomik vor, die in der Demonstration keine Parallele hat (IV,106-121). 
Die Beschreibungen in der Feoptija umfassen neben astronomischen und anthropologischen Themen eine groBe Zahl von Naturerscheinungen. Man denkt an Bodmers Unterscheidung der drei Reiche: des himmlischen, menschlichen und materialischen. 78

Tred. ordnet die Beschreibungen der irdischen Natur nach dem Schema der vier Elemente: Erde, Wasser, Luft und Feuer (II.Epistel). In der III.Epistel entwirft er ein Bild der zoologie.

Unter dem Gesichtspunkt der in der Schopfung herrschenden Teleologie beschreibt er im allgemeinen zunăchst die Beschaffenheit der Phănomene und streicht danach ihre Bedeutung fur den Menschen heraus.

Bei der Schilderung der Erde z.B. weist der Autor auf die 'richtigen' geologischen Verhăltnisse hin: sie besteht nicht nur aus stein, aber auch nicht nur aus einer zu weichen Materie. Die mannigfaltigen Landschaftsformen geben der Erde eir. abwechslungsreiches und reizvolles Aussehen:

II,105f. Всё пременяет то и скоро и чудесно, И делает уж там видение прелестно:

Immer wieder macht Tred. auf die asthetische Seite der Natur aufmerksam. Die Erde erscheint fast wie ein mythisches Wesen: sie ist die 'Mutter', die alle ihre Schătze freigebig an ihre Bewohner austeilt, sie 'verwandelt Schmutz und Staub in Reichtum' (II,97f.); sie altert nicht, ist ewig jung und lebensvoll (II,117ff.). Man hat den Eindruck einer tellurischen Gottheit; aber das Bild der Erde ist vom Schöpfungsglauben umfaßt: es offenbart uns den Schópfer, der als 'barmherziger vatex' für uns sorgt (II,311f.).

Alle Erscheinungen in der Natur sind dazu bestimnt, dem Menschen zu nützen. Tred. wird nicht mude, diese These zu illustrieren. So führt er aus, daB jede Bodenart den Menschen ihren Ertrag bringt, vorausgesetzt, sie lassen es an FleiB nicht fehlen und verwisten die Erde nicht durch Kriege (II,125-129). Nicht nux die Schwarzerde (4ернозем, II,167), auch sumpf und Sandboden lohnen dem Bauern die aufgewendete müh. Ausführlich wird beschrieben, wie damals Sumpf und Odland urbar gemacht wurden (II,171-180). Selbst die unbewohnten, scheinbar unwirtlichen Gebiete bringen dem Menschen viel Gutes: der dichte Urwald und die unfruchtbare steppe lassen 'süBe Früchte' und 'heilkräftige Pflanzen' gedeihen, die sonst nirgends zu finden sind (II,191-195). Der Nutzen der Gebirge und ihre schơnheit werden farbig geschildert: die 'herr- 
lichen Weiden für das Vieh', die 'gesunde und relne Luft', im Vorland die 'wogenden Kornfelder' und Obstbăume sowie 'die zu den Wolken ragenden Gipfel'. die den Betrachter in Bewunderung versetzen. Auch die sohlen in den Bergen sind nicht vergessen, in denen der Mensch Schutz vor Hitze und Unwetter und Zuflucht vor Feinden sucht. Die geologische Bedeutung der Gebirge wird durch den Vergleich mit dem skelett des menschlichen korpers anschaulich gemacht. Tred. schildert aber in II,145-164 nicht eine topographisch bestimmte Gebirgslandschaft. Es handelt sich vielmehr um ein typisches Landschaftsgemalde zur delectatio des Lesers, das zugleich die These der fur den Menschen segensreichen ordnung der Natur lllustrieren soll.

Als Vorlage der poetischen Malerei dient ferner der Wald. Zugunsten der Detailbeschreibung richtet der Autor den Blick auf einen einzelnen Baum (II,245296). Er schildert, wie sich die Wurzeln in eine 'unermebliche Tiefe' ausstrecken, um den Baum festen Halt zu geben. Mit seinen Wurzeln 'sucht' der Baum wie ein lebendiges Wesen unter der Erde nach saften, die fur inn taugen und 'schickt' sle durch den Stamm zum wipfel hinauf. Ein Ausdruck der Bewunderung untermalt das Blid vom steigen der safte: dieser 'wunderbare Mechanismus' zeigt uns den 'wunderbaren Mechaniker'. Auch die grune Farbe der Blatter wird physikotheologisch gedeutet: der gottliche 'Erbauer' (стронтель, II, 259) hat sie so gemacht, damit das verschiedene Grün unser Augen erquickt. Die Beschreibung ist mit schmuckenden Vergleichen versehen: der Saft fliebt im Inneren des Baumes, durch die Rinde geschutzt, 'wie in einem Leibe'; die Aste breiten sich aus und bilden dadurch 'eine Art Zelt'. Idyllische Szenen vom Ruhen im 'kuhlen Schatten' und vom Nisten der vógel in den Zweigen beleben das Bild des Baumes.

Es folgen nüchterne Ausführungen uber die Verwendung des Holzes als Brennund Baumaterial. Man braucht es als Brennholz, das uns bei 'krachendem Frost' im 'traurigen winter' wämt. Tred. gebraucht hier schmulckende Adjektive, die nach Slegrist das 'Hauptmittel' der poetischen Malerei darstellen. 79 Joh.G. Sulzer formuliert: Die "Beyworter" dienen dazu, die "Hauptvorstellungen durch Nebenbegriffe asthetisch, das 1st, sinnlicher zu machen". 80

AuBerdem verwendet man das Holz zum Bau von Băusern, Booten und Schiffen. Das lyrische Element dringt durch bei der Beschreibung der Obstbaume, die, von Früchten 'beladen', sich niederbeugen, um uns ihre Früchte zu schenken, solange sie 'frisch, reif und schmackhaft' sind (II,293-296). Alle einzelnen züge fügen sich zum Bild einer vom Schöpfer menschenfreundlich eingerichteten 
Natur.

Die Beschreibung des Wassers beginnt ebenfalls mit seiner Beschaffenheit:

$$
\text { II,315 Прозрачен жидкий сей и зыбок есть состав, }
$$

So wie es ist, ist es richtig und notwendig für alle lebewesen und bezeugt die Fürsorge des Schópfers.

Dex Nutzen des Wassers für den Menschen ist vielfălig: er loscht damit seinen Durst und braucht es fūr die zubereitung der Speisen sowie zur Reinigung und Korperpflege. Er nutzt die Kraft des Wassers. Von den vielen Anwendungsmöglichkeiten kann der Autor nur einige aufzăhlen. Er faßt zusammen:

$$
\text { II,366 Премного от воАн пособия имеем, }
$$

Ferner schildert Tred., dab das Wasser uberall in der Natur vorhanden ist. Der Schopfer hat es uber die ganze Erde fließen lassen:

\section{II,396f. Тещи пустил водам премудршй всех творец} От края по земле на самый в ней конец, -

Es komt aus den Wolken, die als riesige Gebilde, von der Vorsehung gehalten, Uber uns schweben. Der Anblick dieser Oranung weckt den Lobpreis:

$$
\text { 11,464f. 0! промшсла сего премудр толико строй: }
$$

Повесил водУ ОН, В вия ГрОзно надо мной,

Der Lauf des Wassers durch eine Ideallandschaft wird beschrieben: da gibt es 'rauschende Quellen', den 'tosenden Wasserfall', den Gebirgsbach, aus dem die Tiere trinken und die Flüsse, die an stădten vorbei dem Meere zueilen (II,400-405). Mit begeisterten Versen apostrophiert der Autor den ozean:

\section{II,406f. Великий Океан - Аивльсь, как то псемло,- 0бъемлощий вокруг и на́полы всо земло, -}

Staunend bedenkt er, daB der Ozean die Erde nicht 'zerteilt', sondern im Gegenteil die Menschheit verbindet: auf diesem Wege ist die Neue Welt, Amerika, entdeckt worden (II, 408-421).

In Verbindung mit dem Ozean spricht Tred. von den Gezeiten. Er gibt zu, daB er die Ursachen nicht kenne und deutet sie als eine wunderbare ordnung des Schopfers, der dem Ozean eine feste Grenze gesetzt hat (II,426-443).

Wie gezeigt wurde, ist die Beschreibung nach den rhetorischen Topoi aufgebaut (qualitas - cui bono - ubi) und aus einzelnen Elementen zusammengesetzt. Dieses Prinzip gilt nach Ansicht von Chr.siegrist für alle Beschreibungen der Lehrdichtung: "Die zusammenstückelung des Portrăts aus einzelnen Elementen, die enumeratio partium, durch eine mit rhetorischen Mitteln erzielte Stilisierung..., das Nebeneinander von visuellen Details und deren Deutung 
entepricht der herrschenden Auffassung von der Nützlichkelt der Dichtkunst." 81

Ahnliches labt sich bel der Beschreibung der Luft beobachten (II, 472-535). Sie besteht aus Ather, Wasserdampf und 'Rauch aus dom Inncren der Exde' (Эфир - пары - курения, извнутрь земли происходяии, II,479ff.). Von ihren Eigenschaften heift es:

II,486f. Весь воздух тонок, чист и так есть проницаем, Что шлемый от планет легко свет созерцаем, -

Zum Topos 'ubi' wird nux bemerkt, daß die Luft 'uns von allen Seiten umgibt' (II, 476).

Dagegen wird der Bezug zum Menschen (cui bono) ausfunrlichex dargestellt: die Luft lst so gemacht (nicht zu dün oder zu dicht), daß wir in lhr atmen und klar sehen konnen. Wind und Sturw haben die Aufgabe, die Luft zum Wohle des Menschen immer wieder zu relnigen. Sle vertreiben die dunklen Wolken. Die stetigen Luftstxomungen in bestimmten Regionen der Erde werden physikothoologisch erklart. Der Autor merkt an, daB 'wir erst jetzt von ihnen wissen' $(I I, 526)$. Sie sollen nach dem Willen der Vorsehung dem Menschen bei der Seeschiffahrt helfen:

II,530f. Не промшсл ли есть в сем, яля плаваний податншх, uрез полгода в страну, чрез столько ж вспять обратншх?

Bei der Beschreibung des Feuers hat Tred. zunăchst den Topos 'ubl' im Auge: es kommt von der Sonne und aus den 'feuerspeienden' Bergen. An das Stichwort 'пламенисты rops' (II,539) anknüpfend, erórtert der Autor das Phănomen des Vulkanismus, den er unbeschadet der natürlichen Kausalităt auf den Schopfer zurückfunrt:

II,546f. Огонь сей, естеству единому известный, Зиждителем зажкен и скршт как 8 ров кой тесний

Der Vulkanausbruch dient als Gleichnis fur die Himmelfahrt der 'unsterblichen seele':

\section{II,554f. Tо вспархивает светл из гроба своего, Бессмертншя ауии как образ от того.}

An zahlreichen Beispielen wird aufgezeigt, wie der Mensch gelernt hat, das 'drohende' Element zu beherrschen und für seine zwecke zu gebrauchen: zum Schmelzen, Schmleden, Leuchten, wămen u.a.m. (II,556-585). Die Unentbahrlichkeit und die Wohltaten des Feuers lassen erkennen, daB es ein Geschenk der Gottheit an uns Menschen 1st:

II,586 Премуаро нас огнем снабяило бомество: 
Tred. erinnert an den Prometheus-Mythos, in dem die Uberzeugung vom himmlischen Ursprung des Feuers greifbare Gestalt angenommen hat. Er schiebt aber diese Reminiszenz beiseite (HO 6acmb noramcka npo4b, II,592). Das soll heiBen: die heidnische Sage braucht uns nicht zu bestatigen, welch 'unvergleichlicher Schatz' in Wahrheit das Feuer fur uns ist (II,592f.).

Zoologische Beschreibungen

Im Unterschied zur Anatomie des Menschen wird die der Tiere nicht in systematischem Zusamenhang dargestellt. Statt dessen wăhlt Tred. charakteristische Merkmale aus, deren teleologische Deutung inm zwingend erscheint. Dafur einiBeispiele: die Tauchvōgel sind mit einem dichten, fettigen Gefieder ausgestattet, so daß 'keine Năsse durchoringen kann' (III,45-48). Die Raubvögel haben auf ihren Flügeln eine dicke taut, 'damit sie schnellex auf ihre Beute herabstoBen können' (III,68-70). Staunend macht der Autor darauf aufmerksam, daB 'langbeinige' Tiere auch einen langen Hals haben - Kranich und Kamel werden genannt - 'damit sie imstande sind, ihre Nahrung zu erreichen' (III,95-99). In dieser ZweckmāBigkeit erweist sich die Macht und Weisheit des Schopfers, der die Mũcke mit ihren winzigen organen nicht weniger wunderbar gemacht hat als den großen Elefanten (III, 294-298).

In vielen Bildern schildert Tred. den Nutzen der Tiere für den Menschen (III,105-268). Das Tier liefert dem Menschen Nahrung und Kleidung. Es arbeitet für den Menschen als Reit-, Trag- und zugtier. Der Nutzen ist aber nicht nur von materieller Art. So hat der Mensch z.B. eine gersónliche Beziehung zu seinem Hund. Er teilt mit seinem Herrn 'Bitze und kălte', bewacht ihn des Nachts, gehorcht seinem Befehl und apportiert das wild bei der Jagd. An ihm hat der Mensch einen treuen und uneigennutzigen Freund (III, 109-118).

Der Mensch. kann vieles von den Tieren lernen, auch darin besteht ihr Nutzen. Die Bienen führen uns ein vorbildliches Gemeinwesen vor Augen (III,209220). An der 'fleibigen' Ameise und an der 'weisen' Spinne sollen wir uns ein Beispiel nehmen. Die moralische Lehre wird sprichwortartig formuliert:

III,223f. Смотря на обои́х, труаиться 6 научились И, как на мать всех зол, на праздность ополиились. Das Lam verkorpert 'Einfachheit und Sanftmut', der Hund 'Liebe und Treus', Tugenden, nach denen der Mensch trachten soll. Sogar die Existenz der Raubtiere (ein spezielles Problem der Theodizee) bringt dem Menschen Nutzen: durch sie will der Schöpfer uns lehren, 'mablose Gier und Grausamkeit' zu 
verabscheuen (III,157-176). AuBerdem kann der Mensch, so erklart Tred., bei der Jagd auf Lowen, Wolfe und Tiger seine Tapferkeit beweisen und braucht keine 'todbringenden' Krlege zu fuhren (III,185-188). In physikotheologischem Eifer behauptet der Autor, daB 'alles, was lebt und atmet', vom Schopfer dazu gemacht ist, dem Menschen zu nützen (III,147f.).

Die weitlăufige Darlegung von Themen der Tierpsychologie (mehr als 600 Verse von insgesamt 1028 Versen der III.Ep. handeln davon) erreicht ihren Bohepunkt in der Auseinandersetzung mit der Automatentheorie Descartes'. Tred. vertritt die Auffassung, Descartes widersprechend, daB die Tiere ein 'gewisses Denken', ein 'ihnen gemaßes Wissen'. 'Trăume und Gefühle', kurz, eine Seele haben. Welcher Art die Tierseele ist, laBt sich schwer sagen, meint Tred.. Es steht fedoch fest, dab sie, anders als die menschliche Seele, nicht unsterblich ist. AuBerdem kann das Tier nicht abstrakt denken und hat kein Wissen von den 'ewigen Wahrheiten' (III,877-900).

Seine Behauptung von der Existenz der Tierseele gründet Tred. auf die allgemeine Erfahrung: 'Протие Декарта весь наш општ вопмет' (III,921). Zux Veranschaulichung reint er in III,761-814 viele Exempel staunenswerten Tiervexhaltens aneinander. Die gewöhnliche Lebensweise des Hundes, des Maulwurfs oder der Schwalbe ist genauso wunderbar wie dex legendăre Krieg der agyptischen Storche gegen die libyschen Schlangen, die Jagd des Adlers auf die Schildkrote oder der Kampf des Ichneumon mit dem Krokodil. Die Schilderung wird mehrfach von Ausrufen der Verwunderung unterbrochen: 'не Анвно ль?', III, 789, 791, 793; 'нас Аивят вельми', III,761; 'Аивятся', III,784; 'ЧуаимСя', III,805; 'предивные дела и вимшсли чудесш', III,811.

Tred. erláutert den Unterschied zwischen dem organismus der Tiere und einem seelenlosen Mechanismus. Der erste erneuert seine Krăfte durch Nahrung und Schlaf (III,440-492), vor allem ist er am Wunder der Fortpflanzung der Art beteiligt (III,521-552): 'коль Аиено как скотш сеой умножарт род!',III,521. Wo găbe es einen Mechanismus (z.B. eine Unr), der sich selbst vermehren konnte? fragt der Autor ironisch (III,679-687). In die Tiere hat der Schopfer 'diese Făhigkeit von Anfang an hineingelegt' (III,693). Darauf folgt elne, abgesehen von der Rhythmisierung, kaum poetisierte Darlegung verschiedener Zeugungstheorien, z.B. der Práformationslehre und der Theorie der ovisten sowie der 'нарочна заготовка' (III,695-728). Dieses Thema ist in den zeitgenössischen Lehrgedichten meist bei der menschlichen Physiologie behandelt worden. 82 Alles Wissen bestatigt letzten Endes den Glauben. Fur den Physikotheo- 
logen gilt:

III,729f. Hо кое мнений сих от муарых ни принять, Везде искусство долг всевинн обонять: -

\section{Bildformen}

Der Gebrauch des Bildes im Lehrgedicht der Aufklărung wird von den Theoretikern verschieden begründet:

a) Psychologisch: die Bilder wenden sich an die 'unteren Erkenntniskrafte' des Menschen, wie sich die Begriffe an seine 'oberen Erkenntniskrafte' wenden. b) Philosophisch: in der Vorstellung von der Harmonie zwischen sichtbarer und unsichtbarer Welt "liegt die Moglichkeit begründet, das eine auf das andere zu beziehen, jenes durch dieses auszudrücken; aus ihr fliebt die lizenz bilchaften Sprechens". 83

c) Sprachtheoretisch: da der Wortschatz einer Sprache nicht ausreicht, um alle Begriffe und die zwischen ihnen möglichen Beziehungen mit ebensoviel Wörtern zu benennen, wird "...die tbertragung, d.h. die mehrfache Verwendung jedes Wortes zur sprachokonomischen Notwendigkeit..." 84 Insbesondere kơnnen "...die abstrakten Begriffe nur durch einen Ubertragungsvorgang formuliert werden..." 85

d) Wirkungspoetisch: die im Lehrgedicht vorgetragenen Gedanken, Wahrheiten und Erkenntrisse würden in unanschaulicher Form den Leser schnell ermüden. Joh.Jacob Breitinger $r a ̆ t$ deshalb dem Dichter, "...seine Schriften durch eine reiche Abanderung der Bilder angenehm zu machen, und dem Leser immer neue Scenen und neue Durchblicke vor Augen zu legen, welche seine neugierige Aufmercksamkeit nicht schmachten lassen, sondern mit immer neuer Verwunderung und Lust speisen und exfrischen." 86 Nach ihxer Funktion im poetischen Kontext unterscheidet Breitinger "die erleuchtenden, auszierenden und lehrreichen Gleichnisse". 87 In der dichterischen Praxis vermischen sich diese Funktionen hăufig. Das Bild soll in erster Linie einen Gedanken 'verdeutlichen'. Deshalb muB es klar und verstehbar sein. Abgelehnt werden ratselhafte, verschlüsselte und weit hergeholte Bilder. Siegrist erklärt: "...nicht mehr die von Scharfsinn zeugende, möglichst entfernte Beziehung, sondern die naheliegende ist die bessere, da...Verdeutlichung intendiert ist". " 88 zugleich werden die Dichter aufgefordert, stănig nach neuen Bildern zu suchen, da nur so die 'delectatio' erhalten werden konne. Das Bild soll "...neu, aber nicht fremd, unerwartet, aber einsehbar" sein. 89 Als ergiebige quelle neuer Bilder wird 
den Dichtern dieser Zeit nicht die eigene Phantasie, sondern die Kunst und die wissenschaft empfohlen. J.G.Sulzer z.B. betont die Fruchtbarkeit des wissenschaftlichen fortschritts fur die Dichtung, da "In unseren zelten...bey den ...so sehr vervielfăltigten mechanischen künsten, die quelle der Metaphern weit reicher ist, als sie ehemals war". 90

Der Bildgebrauch in der Feoptija läbt sich anhand der Breitingerschen Typologie nach der Funktion der verschiedenen Bildformen spezifizieren. Aus einer groBen Zahl von Metaphern, Exempeln, Vergleichen und Gleichnissen kơnnen hier nur einige wenige ausgewahlt werden.

'Licht' wird in der Feoptija wie allgemein in den Lehrgedichten als 'Metapher der Wahrheit' (H.Blumenberg) verstanden. Die Lichtmetapher 'verdeutlicht' die Hauptbegriffe der Epoche: Vernunft, Exkenntnis und Wahrheit. DaB die geschaffene Welt den Schopfer offenbart, bezeichnet Tred. als die 'Wahrhoit, die hellex ist als die Sonne':

\section{I,20 Ясность истины сея солнца есть сөетлейша.}

Mit einer verwandten Metapher wird die Wahrheit der mathewatischen und logischen Axiome verdeutlicht:

V.775 Подобно как лучи от солнца есть светль -

Um den Begriff 'Erkenntnis' zu veranschaulichen, spricht Tred. von der ' $E x-$ leuchtung durch die Morgenrote der Wahrheit':

$$
\text { I,68 पто6 от истинных зарей в том ...просветиться: }
$$

Die Wendung 'natürliches Licht' der Vernunft entspricht dem traditionellen 'lumen naturale': 'Lразум7.... природном свете пребывающий с собой' (I,42). Den Gottlosen wirft Tred. vor, daB sie 'absichtlich die Augen der Seele vor dem Licht der wahrheit verschließen':

\section{I,69f. Pазве ош нарочно восхотите затворить}

Очи внутрь душевн, света 6 правды вам не зрить.

Der ursprünglich wohl metaphysisch gedachte Gegensatz von 'Licht und Finsternis.91 erscheint in der Feoptija als Metapher fur den Antagonismus von Vernunft und Leidenschaften, Wahrheit und Irrtum, Erkenntnis und Verblendung. Tred. spricht von der 'durch die Finsternis grober Irxtümer verblendoten Vernunft' der Gottlosen: 'LразумТ. ...ослепленншй грубых заблумдений тьмой' $(I, 41)$. Der 'Finsternis' entsprechen die 'abscheulichen Leidenschaften des Herzens',

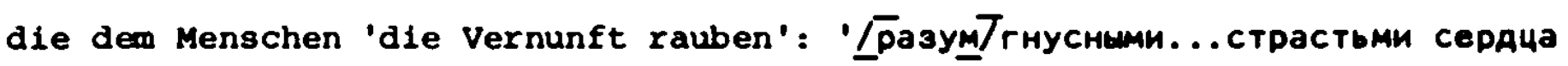
восхниенний' $(I, 43)$. Die Transposition des metaphysischen Dualismus von 'Licht' und 'Finsternis' in das Innere des Menschen scheint auf cicero zurack- 
zugehen, der auch den Begriff des 'natürlichen Lichtes' geprăgt und "die Lichtmetapher mit der inneren moralischen Evidenz verknupft" hat. 92 Zur Auffassung Cicerus schreibt H.Blumenberg: "Der Verinnerlichung des reinen Lichtes entsprechen die innerlichen Formen seiner Verdunkelung durch die Leidenschaften". 93 Das Nichtsehen wird mindestens zum Teil "auf die Trübung des Auges selbst durch die Unreinheit des Sehenden bis hin zum willentlich-schuldhaften VerschlieBen des Auges" 94 zurückgefürt. Die verschiedenen antiken, mittelalterlichen und modernen Ausprăgungen der Lichtmetapher, die H.Blumenberg in seinem Aufsatz untersucht hat, sowie die reich differenzierte 'Lichtsprache' der Bibel lassen sich im Rahmen dieser Arbeit nicht darstellen. 95 Die angefürten Stellen aus der Feoptija belegen, daß Tred. sich auf diese Uberlieferung bezogen hat.

Mit dem Lichtbereich eng verbunden ist die Vorstellung vom 'Spiegel': ex reflektiert die Lichtstrahlen. Die Entstehung der Metapher hăngt nach G.Kittel mit einem hellenistischen Zauberbrauch, der Katoptromantie, zusammen. 96 Näheres hierzu ist bei der Interpretation der Passage Ep.VI, 292-297 ausgeführt worden.

Die Physikotheologen haben die Spiegelmetapher mit vorliebe gebraucht als bildhaften Ausdruck für ihren Glaubenssatz, daß die Schöpfung die Herrlichkeit des Schöpfers offenbare. Chr.siegrist weist besonders auf das Gedicht von Brockes 'Spiegel der Gottheit' hin, in dem diese Lehre entfaltet wird: "Brockes spricht von der 'Creaturen Spiegel', vom Himmel als der cottheit Spiegel u.a.m."97 Nach siegrist ist "die physikotheologische Tradition, wonach alles Irdische cott reprăsentiert.... bei Brockes besonders ausgeprăgt".98

Auch Tred, versichert, daB die Schopfung aus vielen Gründen 'Spiegel der göttlichen Vollkommenheiten' genannt werden könne:

\section{VI,297 Божиих зерцалом совершенств быть названа́.}

Im Unterschied dazu wird die Spiegelmetapher in I.Kor.13,12 - der einzigen Belegstelle für die übertragenen Bedeutung des Wortes im $\mathrm{NT}$ - in abwertendem Sinne gebraucht. Die Aussage ' $\delta \iota^{\prime}$ '

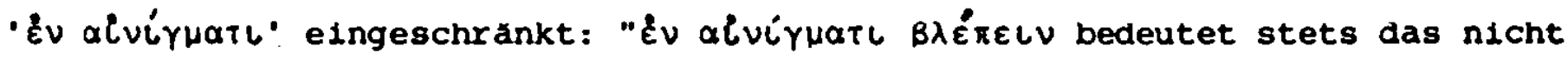
deutliche Sehen..." 99

Den kimmel nennt Tred. metaphorisch 'das Gewölbe' (СвоA сей, II,598), das die Hand des Allmăchtigen 'über unseren Hăuptern befestigt hat'. Auch vom 'Dach' (KPOвъ, II,46) des 'Weltgebăudes' (VI,312) ist die Ređe. Gott ist der 'Ertauer' des Hauses (строитель, II,33; 259). Diese zum ptolemăischen System 
passenden Metaphern, die den Kosmos als vertrautes und uberschaubares Gabilde kennzeichnen, werden in der kosmischen Lyrik des 17.Jahrhunderts, wie $K$. Richter anmerkt, noch Uberwiegend gebraucht. Erst die Dichtung des 18.Jahrhunderts findet für die kopernikanische Erkenntnis die angemessenen Ausdrucksformen. K.Richter, der die 'Kopernikanische Wende in der Lyrik von Brockes bis Klopstock' dargestellt hat, füht ein 21 tat aus den damals viel diskutierten 'Gesprăchen von mehr als einer Welt' Fontenelles an, das den 'unschlag des BewuBtseins" (K.Richter) greifbar macht: "Als ich mir eingebildet, daB der Himmel ein blaues Gewólbe wăre, woran die sternen angenagelt, schien mir die Welt klein und enge, und deuchte mich, als warde ich erdrüket; anjetzo da man diesem Gewölbe unendlich mehr an Weite und Tiefe beygeleget, indem man es in viele tausend wixbel erweitert hat, so scheint es mir, daß ich mit mehrex Freyheit Atem hole..." 100

Tred. bringt die 'Wende' u.a. durch mehrere Versionen dex Gewolbemetaphex zum Ausdruck. Er spricht vom 'xiesigen Gewolbe' (Свод огромный, II,773). Die unendiche Weite und Vielfalt des Kosmos wird auBerdem durch 'charakteristische kosmische Plurale' (K.RIChter) bezeichnet. Wir werden aufgefordert, zu den 'blauen Gewolben' aufzusehen, an denen 'Legionen von Sternen befestigt sind' (пригвожденны = angenagelt, II, 768). Mit der xămlichen Dimension wird auch die zeitliche unendich ausgedehnt:

II,45f. Воззрим вшспрь к небесам на толь далеки своди,

Которы кровом нам ирез толь премноги годн.

Die Ordnung und Harmonie des Kosmos werden durch die Metapher 'Plan' verdeutlicht: der schopfer hat die erstaunlich vielgestaltige Welt nach einem einheitlichen Plan geschaffen:

\section{II, 804f. Колико зримых Солни! Земель колико нижних! Колико тварей всех! родов коль непостижных! \\ II,808 Всему еАнн чертем! но коль по виду разно!}

In diesem Plan war eine Welt 'von solcher GröBe, Vielfalt, Pracht, Schónheit und Harmonie' (I,223-227) von Anfang an vorgesehen. Durch die Kriterien 'MaB, Zahl und Gewicht' $(I, 228 ; V, 294)$ wird schon in der Spruchweisheit des AT (Sap.Sal.XI,20 - LXX) die planvolle oxdnung der Welt als Werk des Schópfers gekennzeichnet. Sie ist von den physikotheologischen Lehrdichtern immer wieder gepriesen woxden, wie siegrist mit Versen von Brockes belegt:

"Der groBe Schopfer hat, nach Zahlen, MaB, Gewicht,

Den großen Bau der Welt besonders zugericht'." 101 
Das Bild der 'Kette' als Symbol für das 'Kontinuum der Existenzformen' (B.Fabian) und, wie Fabian anhand der Verwendung im 'Essay on Man' dargelegt hat, zugleich als "poetisches symbol für die Gravitation, für die ordnung im planetarischen Raum, ja für den gesamten Kosmos der klassischen Physik ${ }^{102}$, ist in der Textinterpretation (Ep.III,239ff. und III,576 der Feopt.) behandelt worden. Tred. hat das Bild offenbar von Pope übernommen. Es taucht Jedoch im 18.Jahrhundert bei fast allen Lehrdichtern auf. Siegrist zitiert aus der Arbeit von A.O.Lovejoy 'The great Chain of Being' die Feststellung: "It was in the 18th century, that the conception of the Universe as a chain of being.....attained their widest diffusion and acceptance..."103

Dem Bild der Kette ahnlich ist das der 'Stufenleiter', das auf eine Rangordnung hinweist. Tred. spricht von 'stufen der Vollkommenheiten':

$$
\text { III,514 Мы в совершенствах зрим степени толь различны, }
$$

Beide Metaphern enthalten die Vorstellung des lückenlosen Zusammenhangs. Alle Wesen sind unentbehrlich für die Kette oder Stufenleiter des Universums: auch die Mũcke (мшица, III,230) ist nicht 'umsonst' (втуне, III,238) auf der Welt. Kein Teilchen düfte sich von einem kimmelskörpex lusreiBen, sonst stürzte es die Erde in den Abgrund:

\section{II,866f. Хотя 6 частича гяе отторглась от wapos, Низвергла 6 Земло всо Уааром безаны в ров.}

Die Kette dient als Bild fur die Erhaltung der Welt durch Gott. Diese Vorstellung steht hinter der Frage:

\section{II,868 Хранение кому \& мы всех вещей присвоим?}

Pope hat die Metapher eindeutig in diesem Sinne gebraucht ('Essay',I,33f.):

"Is the great chain, that draws all to agree, And drawn supports, upheld by God, or thee?"

Mit den Metaphern 'Maschine', 'Mechanismus' und 'Uhr' hat Tred. 'epochenspezifische Bilder' (Siegrist) sich zu eigen gemacht, die z.B. Descartes in seiner mechanistischen Physiologie verwendet. Nach R.Specht ist der Automat Descartes" "dadurch ausgezeichnet,...daß seine sămtlichen Funktionen durch die klaren Gesetze der Dynamik erklärbar sina". ${ }^{104}$ Als Beispiele solcher Automaten nenst R.Specht: die Uhr, die orgel, die hydraulische Gartenkunstfigur, die von Descartes entworfene magnetische Seiltănzermaschine und das von ihm geplante rotierende Flugobjekt. 105

Tred. hat die Metaphern 'Maschine' und 'Mechanismus' auf verschiedenartige organismen angewendet, ohne diese aber als Automaten im Sinne Descartes' anzu- 
sehen. So nennt ex 2.B. den Saftstrom im Baum einen 'wunderbaren Mechaniamus' (предвинй механизм, II,257), der den 'wunderbaren Mechanikex' (предивнй механист, II, 258) ausweist. An die stelle der automatischen Funktion tritt die Einwirkung des Schöpfers. In dieser Undeutung steht die Mechanismus-Matapher auch fux die Korperfunktionen des Menschen und der Tiere in der Feoptija. Die Tiere sind Mechanismen, den Unren vergleichbar, erklärt Tred., denen der Schöpfer statt des Unrwerks einen 'gewissen seelischen Lebenshauch' gegeben hat:

$$
\begin{aligned}
& \text { III,688ff. Махины суть они в своем составе плотном, } \\
& \text { Подобн все часам, имеоцие в дар } \\
& \text { Внутрь, вместо всех пружин, душевный некий пар. }
\end{aligned}
$$

In ăhnlichem Sinne steht die Mechanismus-Metapher in III,417ff.:

Однак зрим механисм мы совершенный в тех,

Но в механисм какой сначала аует мех,

То первейшей вин, кроме творца, не знар,

Der Gedanke der Alleinherrschaft Gottes 'sprengt' die Metapher:

$$
\text { III,425 Самодержавный он, второе өсё есть ра6; - }
$$

In dem vom schópfer bewirkten 'commercium mentis et corporis' hat der Korper die Funktion eines dem willen des Menschen gehorchenden Mechanismus:

$$
\text { V,433 Вся ма́хина уже послушна полнить валю, - (vgl.v,470) }
$$

Die Beispiele aus dem künstlerischen Schaffen, die von Tred. in I,233-424 angeführt werden, begründen in erster Linie den AnalogieschluB: wie ein Kunstwerk den Künstler voraussetzt, so die Welt ihren Schöpfer. Zugleich gehóren diese Beispiele zu den Bildformen der Feoptija. Ihre Verwendung im Kontext soll an zwei Einzelfallen deutlich gemacht werden.

Im Orgelbeispiel (I,267-312) sind mehrere Funktionen zu erkennen. Zuerst soll daran sinnfălig werden, daB die Welt ihre Existenz nicht dem zufall, sondern dem Schopfer verdankt. Die kunstvolle Arbeit des orgelbauers wird als Analogie herangezogen. Die sinnreiche Hechanik und die besondere Schönheit der orgel sind die Vergleichspunkte. ZweckmäBigkeit und schonheit zeichnen in weit hōherem Maße auch den kosmos aus, von dem Tred. mit einer biblischen Wendung in III, 291 sagt, daß 'die Finger cottes uberall mit ihm spielen' (Prov.VIII, 31 - Mas.).

Das Orgelbeispiel hat auBerdem schmückenden Charakter. Die Beschreibung ist in einzelne szenen aufgeteilt. Man betritt eine dunkle Kirche, in der 'suB eine orgel tơnt' $(I, 267 f$.$) . Dann kommt man zum Spieltisch, an dem 'einer mit$ 
seinen Hănden die Tasten schlăgt' $(I, 273)$. 'Ein anderer tritt die Bălge', so daB sie sich auf und ab bewegen $(I, 275)$. Dex Blick fallt auf die vielen verschieden großen pfeifen, die sinnreich und schón angeordnet sind (I, 281-284).

SchlieBlich verbindet der Autor mit dem Beispiel auch eine belehrende Absicht: der Leser erfahrt, wie eine Orgel beschaffen ist und wie ihr Mechanismus arbeitet $(I, 285-294)$.

Am Beispiel des Gotzenbildes auf einer menschenleeren Insel werden ebenfalls die verschieden Möglichkeiten des Bildes im Lehrgedicht deutlich (I,313-364): die versinnlichende, schmūckende, nachdrückliche und die belehrende Funktion (nach der von Breitinger eingefürten Unterscheidung).

Zuerst veranschaulicht das Beispiel den schon genannten AnalogieschluB. Hinzu komen schmückende Elemente: das Marmorbild wird auf einer 'völlig leeren Insel' gefunden, die den Menschen 'von alters her unbekannt' gewesen ist und 'keine Spuren menschlicher Besiedlung' aufweist. Die meisterliche Arbeit des Bildhauers wird sorgfaltig beschrieben. Er hat eine statue geschaffen, die bewundernswert lebendig wirkt, und aus deren zügen 'kühnheit, würdevolle Haltung und Schönheit. sprechen (I,319-326).

Tred. benutzt das Beispiel zur 'nachdrücklichen' widerlegung der zufallsgläubigen. Sarkastisch fragt er seine widersacher, ob etwa der Sturm einen Marmorblock aus den Bergen fortgetragen und auf einen sockel gestellt habe, wobei der Stein von selbst, ohne Künstlerhand, zun Gotterbild geworden sei $(I, 331-346)$.

Auch die belehrende Absicht wird in dem Beispiel deutlich: der Autor zahlt die berühmtesten Bildwerke der Antike auf und erwăhnt darüber hinaus die statue der 'Vera', die der zar Peter in SchloBpark aufstellen lieb (I, 347-352).

Unter den Bildformen der Feoptija findet sich hăfig der 'Vergleich'. Er soll vor allem einen Inhalt 'verdeutlichen'. "Mit dex Forderung nach Deutlichkeit mag eire Vorliebe dex zeit für den Vergleich zusamenhăngen", meint siegrist. 106 wie die Beispiele sind aber auch die vergleiche oft mehrfunktional. So vergleicht Tred. die strómung des Wassers auf dem 'Erdkreis' zugleich anschaulich und nachorūcklich mit dem Blutkreislauf des korpers:

II,422fE. Разлитием своим вода в земном сем круге В подобном дейстее есть и в равной же услуге, Как в теле нашем кровь, кружащая всегда, -

Gleichzeitig treffend und schmückend ist der vergleich des GefaBsystems im menschlichen Körper mit den herabhangenden zweigen der Băume: 
IV,122f. В человечем теле суть трубочки премноги,

Схожи с ветвями аревес, также и отлоги.

Ein nachdrückliches Bild für die gehorsame Arbeit, die bestimmte Tiere dem Menschen zu leisten haben, ist der Vergleich mit dem ' $06 p o k '$, dem Exbzins der Bauern:

III, 108 И на работш нам как подданш оброчно.

Der vielseitige Gebrauch der Arme wird durch eine Reihung von Bildern aufgezeigt: sie werden mit den 'Querbalken an der Wand', mit den 'Rudern' eines Schiffes, mit 'Flügeln der vögel' und mit 'Zweigen' der Băume verglichen (IV, 301-303). Wenn ein Paar sich die tande reicht - etwa beim Menuett - so lassen sich ihre Arme mit einer 'Girlande zwischen Pfeilern' vergleichen, sagt Tred. mit einem sinnfäligen und schmúckenden Bild (как фестон межяу столпов, IV, 304).

Nach Siegrist haben die 'Bildaufzahlungen' im Lehxgedicht meist 'schmückenden Charakter'. 107 Die Theorie verlangt in diesem Falle, "das jedes Bild ein Mehr an Klarheit beitragt, so dab nicht die Emotionalitát, sondern - durch die Einbildungskxaft - der Verstand angesprochen wird". 108 Es ist kaum anzunehmen, daß Tred. alle Regeln der zeitgenössischen Poetik bewuBt beachtet hat. Die Hăufung von Bildern hangt bei ihm mit seiner Neigung zum Pleonasmus zusammen.

Das unserem Verstand unzugăngliche Geheimnis des 'commercium mentis et corporis' verdeutlicht der Autor, indem er es mit dem nachtwandlerischen Verhalten eines Seiltăners vergleicht $(v, 463-470)$.

Von den zahlreichen Vergleichen in der Feoptija, die bei der Textinterpretation behandelt worden sind, konnten hiex nur elnige proben vorgefuhrt werden.

Als beziehungsreiche Bildform erweist sich das Gleichnis, das Tred. am SchluB der IV.Epistel (648-661) auf das Menschenleben bezieht: unser Leben gleicht dem Lauf des Wassers. Das Bild wird allegorisch gedeutet: 'Ungestum', 'Aufbrausen' und 'Ruhelosigkeit' des Gebirgsbaches charakterisieren in ubertragenem Sinn auch das menschliche Leben.

Die verschiedenen Formen und Funktionen der Bildlichkeit sind im Text hăufig ineinander verflochten. Festzuhalten bleibt: das Bild ist im Lehrgedicht nicht um seiner selbst willen da, sondern hat funktionale Bedeutung. Siegrist konstatiert: "Die ornatusfunktion wird von der Wirkung her 1izensiert." 109 Für die Feoptija läbt sich sagen, daB Tred. die Bilder dem physikotheologischen zweck des Poems nutzbar gemacht hat. 


\section{Beweisformen}

Der Lehrdichter soll - so verlangt es die Theorie - die von imm vorgebrachten Wahrheiten nicht nur beschreiben und bildhaft poetisieren, er soll darüber hinaus den Leser von ihrer Gultigkeit rational überzeugen. Das geschieht durch 'poetische Beweise', die sich von den philosophischen unterscheiden. Der Unterschied wird von Siegrist, der sich dabei auf eine Definition von J.G.Sulzer beruft, so bestimmt: "Die dichterischen Beweise laufen auf 'Klarheit und Sinnlichkeit' hinaus, die philosophischen auf 'Kürze und Deutlichkeit'."110 Der poetische Beweis gründet sich daher weniger auf Begriffe als auf "jene Modi, welche grobtmögliche Anschaulichkeit verbürgen". 111 Dazu zăhlen u.a. "Erfahrungen, Inductionen, Analogien,... auffallende Schilderungen des Guten, Schónen, Ubereinstimmenden, oder des Thörichten, Hassenswürdigen..." 112

In diesem literaturgeschichtlichen Rahmen stehen auch die physikotheologischen Argumente der Feoptija. Wie der Titel des Poems anzeigt, will Tred. 'Gottes Existenz auf Grund dex Schopfung beweisen' : 'Феоптия или доказательство о Богозрении по вещам созданного естества... 113 Alle Betrachtungen Tred.s uber den Kosmos, die 'Elemente', die Pflanzen und Tiere, vor allem über die physische und psychische Natur des Menschen führen zu der einen Wahrheit, die in vielen Variationen verkünigt wird: Gott ist grob, allmăchtig, allweise und gūtig.

Wie Tred. vorgeht, wird aus folgendem deutlich. Er schildert z.B. in II,85312 eingehend die Erde: Ihre Fruchtbarkeit, den Reichtum an Bodenschatzen, de Nutzen und die Schónheit der Gebirge und wălder. Er betrachtet den Kreislauf des Werdens und Vergehens. Angesichts der natürlichen Dinge bewegt ihn ehrfurchtiges staunen, das in zahlreichen rhetorischen Fragen und enthusiastischen Ausrufen zum Ausdruck kommt. Im yinblick auf die Schatze der Erde fragt der Autor:

II,233f. Кто ж скрыл в нее то всё толикое богатство?

Кто умножает в ней сие всё толь израство, -?

Er bewundert den unaufhorlichen biologischen Kreislauf:

II,211f. Предивен есть песьма сей непрестанный круг:

Земля что нам ни даст, в себя ж приемлет вдруг, -

Er preist die gottliche ordnung, die aus Verwestem neue Pflanzen wachsen laBt II,214 А как подать? 0! чин, из сгнивших свежи злаки, Er rühmt die Vorsehung, die dafür gesorgt hat, daß in den kăltesten Regionen 
die dichtesten walder zu finden sind:

II,285f. 0! промшсл, стужа где несноснейше ярится,

В тех более странах густшх лесов и зрится.

Auf diese und viele andere 'Inductionen' (Joh.Jac.Engel) stützt sich die physikotheologische SchluBfolgerung in II,303-312, die so ausklingt:

II,303f. Прилежно рассумдай, Евсевий, и внемли,

Что вся земля собой и всё, что из земли, -

II,308fE. Показшеает всем сотворша самого,

४то он премуар, всеблаг, что всемогуи и силен,

Что по суаьбе своей нас всем снабаить обилен, -

Den Induktionen ăhnlich sind die Analogien, aus denen Tred. ebenfalls den SchluB auf die Existenz cottes ableitet. Eine zusammenhangende Kette von Analogieschlüssen bilden die 'Beispiele' in I,233-424. Die Klugheit der Tiere wird durch einen AnalogieschluB belegt, der auf dem im 18.Jahrhundert hăfig gebrauchten Bild der Uhr beruht: wie ein Unrwerk von einem Meister erdacht und in Gang gesetzt worden ist, so ist auch die Klugheit der Tiere auf den Schöpfer zurückzuführen:

III,849f. Так точно хитрость всі мивотных я скотов Твориу напредь Aам, Hе ТО что дать Готов.

Vielfach argumentiert Tred. mit dem aus der Demonstration übernomenen Gedankenexperiment: die Wohltaten der bestehenden Weltordnung werden in das rechte Licht gerückt, wenn man sich die verheerenden Folgen ausmalt, die eine andere Beschaffenheit der Dinge hatte. So bilden die hypothetischen Erwagungen (eingeleitet mit 'koraa $6 w^{\prime}$ oder 'ecли $6 w^{\prime}$ ) uber eine andere Beschaffenheit der Erde (II, 85-96), des Wassers (II, 321-343) und der Luft (II,493505) die dunkle Folie, vor der die wirkliche Welt als wunderbares Werk des Schöpfers erscheint. Die Argumentation zielt auf die Rechtfertigung des Bestehenden ab und gehort in den zusamenhang der Theodizee, auf die Tred. noch an anderen Stellen - z.B. bei der Barmherzigkeit cottes in VI,476-515 - năher eingeht. Den SchluB aus seinen hypothetischen Exwagungen zieht der Autor gern in Form von rhetorischen Fragen, die ein emotionales Element enthalten. Wiederholte rhetorische Fragen werden als affekterregendes Mittel auch im Verlauf der Argumentation eingeschoben, so etwa bel den Erwăgungen über das Wasser :

$$
\text { II,329 Kто } 2 \text { густу сотворил толь равномерно воду? }
$$


II,340ff. Кто воду так создал, что миякость, быстрина, Да и прозрачность в ней до самого есть ана? Кто твердости а себе отнодь ту не имуцу,

А бремена поянять огромные могуиу?

Zur physikotheologischen Beweisform bemerkt W.Philipp: "Das 'Beweisen' der Physikotheologen ist in Wirklichkeit ein irrationaler Bekenntnisakt." 114

Tred. argumentiert in der Feoptija nicht ausschlieblich physikotheologisch (по вещам созданного естества...), sondern bedient sich auch der apriorischen Methode, speziell der herkömmlichen Gottesbeweise. Beide Wege führen nach seiner Ansicht zur Erkenntnis der Existenz Gottes. Whahrend der erste allgemein zugänglich ist ("не должно уже употреблять великуо тонкость понятия, но токмо един простый взор на все вещи доволен..."), erfordert die apriorische Axgumentation eingeschultes Denken ("... хотя и многии находятся приобшкшии к тонкостям метафизическим, однако немало и таких, которым помянутше доказательства не без трудности будет уразумевать.", 115

Die beiden Denkweisen gehören zu verschiedenen theologischen Systemen. Die Physikotheologie schlieBt "a posteriori aus der Fülle der Welt auf Gott". Die Theologia Naturalis hingegen "will...auf dem Wege apriorischer Vernunftschlüsse Existenz und Eigenschaften Gottes erweisen". Diese Richtung wird von W.Philipp so charakterisiert: "Mit ihren begrenzten apriorischen Mitteln versuchen die Vertreter der Theologia Naturalis festzustellen, ob der Mensch aus einem angeborenen natürlichen Licht erkennen könne, dab ein Gott sei, ob man mittels vernünftiger Gründe das Dasein Gottes gegen die Atheisten erweisen könne, ob und wie die Eigenschaften Gottes durch deduktive Schlusge aus dem Gottesbegriff oder kategorischen Prămissen abzuleiten seien. "116

Dieser Denkart entsprechen die apriorischen metaphysischen Gottesbeweise, die Tred. in der I.Epistel der Feoptija nachgezeichnet hat.

Zuerst skizziert er den durch Anselm von Canterbury aufgestellten 'ontologischen Beweis', der aus dem Begriff Gottes als des 'vollkomensten Wesens' (ens perfectissimum = 'совершенств всех существо, I,49) auf die 'Notwendigkeit' seiner Existenz schließt (ens realissimum = 'өседолжно бытность купно естест80', I,50).

Auf der Grundlage Anselms hat Descartes ausgeführt, "daB wir die Idee eines vollkommensten Wesens nicht haben könnten, wenn sie nicht von einem solchen Wesen selbst in uns hervorgebracht worden wăre". 117 Das selbstbewußtsein des Menschen erkennt sich als endlich und unvollkommen, darum kann die Idee des 
vollkommensten Wesens (die Gottesidee) nicht aus uns selbst stammen. Sie ist eine uns 'eingeborene Idee' von unmittelbarer Evidenz. Tred. nimmt diesen Gedanken auf und fragt:

$$
\begin{aligned}
& \text { I,93f. От сего ль не ясно, что не от себя ум есть, } \\
& \text { И другой, сто должен в бштность оного известь? }
\end{aligned}
$$

DaB der Gottesbegriff nicht nur dem individuellen BewuBtsein, sondern der Menschheit 'eingeboren' ist, wird am 'consensus gentium' (I,491-542) dargetan. Tred. schildert die universale Verbreitung des Gottesgedankens, der Religion und des kultus und stellt fest:

$$
\text { I,534 BсNAy отдается божестеу вседолона честь. }
$$

In Form von rhetorischen Fragen wird versichert, daB Gott selbst dieses 'Gefühl' den Menschen ins Herz gelegt habe:

$$
\begin{aligned}
& \text { I,539f. Как и не от чувства внутрь в сердие поломенна } \\
& \text { И создателем его в том изобраменна? }
\end{aligned}
$$

Der 'kosmologische' Beweis ist in I,75-78 kurz dargestellt worden.

Wie Tred. das syllogistische Verfahren anwendet, wird aus folgenden Beispielen deutlich:

In I,161ff. beginnt er mit der Prämisse: die Materie ist 'trăge' und kann deshalb nicht die Ursache der Bewegung sein. Die zweite Pramisse besagt, daB die Bewegung nicht von sich aus entstehen kơnne, da sie nur eine Eigenschaft der Materie sei. Aus beiden Prămissen wird der SchluB gezogen:

$$
\text { I,165ff. Есть затем Начало, разное от вещества }
$$

И совсем аругого, нежель оное, родства,

Кое в вещество сие двиги впечатлело -

Der Syllogismus in I,201-210 beruht auf diesen Prămissen: die Welt ist ein 'Zusamengesetztes'; sie existiert nicht 'notwendig', sondern 'zufallig', d.h. sie konnte auch nicht sein oder anders sein als sie ist (I,201-203). Sie besteht zum andern aus 'trăger' Materie (I,204ff.). Folglich braucht sie eine Ursache, die sie mustergültig hervorgebracht hat, das ist Gott:

I,207ff. Слеаует, что мир винш тре6овал природно,

Aa ero так изведет, как самой угодно.

Та есть боr премуаршй,

Syllogismen dieser Art sind rein begrifflich und daher unpoetisch. DaB sie trotzdem im Lehrgedicht gebraucht werden dürfen, wird in der poetik manchmal anthropologisch begründet: 'der Vorgang des SchlieBens sei dem Menschen na- 
turlich'. 118

Die Lehre von der Unsterblichkeit wird von Tred. aus dem Begriff der 'unteilbaren' Seele und aus den Eigenschaften Gottes deduziert: v,859f. Простое, как ауша, есть без частей родство, Бессмертно есть затем Аушевно существо.

Vor allem folgt aber die Unsterblichkeit aus der Gute, Gerechtigkeit, Wahrhaftigkeit und Heiligkeit Gottes, der 'die Seele nicht vernichtet' (V,871-898).

Aus dem Begriff der Vollkommenheit Gottes leitet Tred. die 'Einheit' cottes (den Monotheismus) ab. Die Vollkommenheit bedeutet, dab cott die alles umfassende Realitát ist. Er hat nicht seinesgleichen (VI,172-181).

Eine weitere Schlubfolgerung a priori führt ebenfalls zur 'Einheit' Gottes und zur Widerlegung des Polytheismus: Zum Gottesbegriff gehoren - so Tred. Allmacht und Allwissenheit. Wenn diese Attribute einer vielzahl von Gottern beigelegt werden, geraten sie zueinander in widerspruch; denn entweder haben die Götter die Macht, ihre Gedanken voreinander zu verbergen, dann sind sie zwar măchtig, aber nicht allwissend; oder sie können ihre Gedanken nicht voreinander verbergen, dann sind sie allwissend, aber nicht allmăchtig. Tred. zieht den SchluB: in beiden Făllen sind sie keine Gotter, d.h. der Polytheismus ist logisch widerlegt (VI,182-189).

Zielt die physikotheologische Argumentation darauf ab, aus der fulle der Wirklichkeit die Existenz des allmăchtigen, gütigen und weisen Schópfers zu erweisen, so wird nun aus den Eigenschaften cottes a priori deduziert, daB die von ihm geschaffene Welt 'die beste aller möglichen Welten' sein müsse. Der weise Schópfer muB einen Grund gehabt haben, so argumentiert Tred., aus vielen möglichen Welten, die er kraft seiner Allmacht hatte verwirklichen kŏnnen, diese Welt auszuwălen. Seine Gute hat ihn zu dieser Auswahl veranlabt. Daraus folgt, daB diese Welt die beste aller möglichen welten ist:

VI,259f. Благостио сей апя тех предпочтен в уставе; Следует, что самий лучший есть из всех мир сей -

Dieses Urteil wird nicht dadurch entkraftet, daß es krankheit und sünde, d.h. physische und moralische Ubel in der Welt gibt. Vor ihrem Hintergrund hebt sich das Gute um so deutlicher ab:

VI,488f. Говоро: не пречни лучшу миру скорбь и грех, Но еще и больше можно знать добро от тех, -

Die Theodizee in der Feoptija kann hier nicht im einzelnen wiedergegeben werden. Im Grunde ist das ganze Poem eine Theodizee, eine Rechtfertigung des 
Schopfers, bei der physikotheologische Argumente und Deduktionen a priori zusammenwirken. Wo die rationale Erklarung versagt, wie angesichts der Ungleichhelt der menschlichen Schicksale, bleibt das Bekenntnis zur souveranitat Gottes, der selber 'Bitteres und subes austeilt':

$$
\text { VI,430 Вишний раздемет сам горесть нам и сладость, - }
$$

Es bleibt das Vertrauen, daß die Gute das Motiv seines Handelns ist:

VI,438f. Hо нераеенстеу почто нолжно Gwть такому?

Весно токмо самомy 6огу npe6raromy.

Darum ist der Lobpreis die angemessene Form der Rechtfertigung des Schopfers. In der Doxologie kombt die Theodizee ans ziel:

VI,444f. Тем и восклицах, умасаясь бездн сих дна:

0! премудрость, - коей неиспитна глубина.

Zahlreiche Beispiele für das scholastische Verfahren, durch das aus dem Gottesbegriff mittels logischer Analyse die gottlichen Eigenschaften ermittelt werden, liefert Tred. In der VI.Epistel. Er eruiert auf diese Weise insgesamt 23 Attribute: 'absolute' (самостоятельнше) und 'relative' (возносительmue). Bei den zuletzt genannten unterscheidet er nach scholastischem waster zwischen Eigenschaften cottes, die sich auf die 'natürlichen' Dinge (ectectвенные) und solchen, die sich auf die 'sittliche' Welt (нравственнше) beziohen. 119

Definitionen

Grundsătzlich zăhlen Definitionen zu den Beweisformen, die im Lehrgedicht angebracht sind. Siegrist erklart: "Definitionen sind der Lehrdichtung insgesamt wichtig, beim Beweisen gar unentbehrlich." 120 Der poetische Wert der Definition hangt von ihrer Form, vor allem vom Grad der Anschaulichkeit ab. Logische Begriffserklăruungen sind im Lehrgedicht fehl am Platze. Siegrist zitiert dazu den Literaturkritiker G.Friedr.Meier: "Aus allem ist klar, daB die logischen Erklarungen nicht nur asthetisch dunkle Begriffe sind, sondern daB sie auch viel zu arm, trocken und abstract sind, als daß sie schone Begriffe seyn konnten." 121 statt dessen werden besonders metaphorische Definitionen empfohlen, "die dem Gesetz maximaler Anschaulichkeit entsprechen" 122

Von den in Lehrgedichten benutzten Definitionen werden von Siegrist die wichtigsten erlautert. Die 'definitio essentialis' sucht als eigentlich philosophische Definition das Wesen einer Sache zu bestimmen. Sie muB nicht trocken und abstrakt sein. Die Lehrdichter bemuhen sich hăfig um Versinnlichung der 
'definitio essentialis' durch Bilder, Metaphern und Personifikationen. Dasselbe geschieht bei der 'definitio realis', die "eine Sache in ihrem Sosein benennt". 123 Dies kann in der form der 'enumeratio partium' exfolgen. Bei der 'definitio accidentialis' werden die zufălligen Eigenschaften der Sache herausgestellt, die dem Dichter wichtiger sein kőnnen als ihre notwendigen Merkmale. Am hăufigsten komen in den Lehrgedichten, so vermerkt siegrist, die 'definitio a simili - a contrario' und die 'definitio causalis et finalis' vor. Die exste bestimmt eine Sache mittels der Ähnlichkeit bzw. Unăhnlichkeit zu einer anderen; die zweite durch die Bezeichnung ihrer Ursache bzw. ihres Zweckes. Siegrist weist darauf hin, daB im Lehrgedicht oft mehrere Definitionsarten aneinandergereiht werden, "analog zur Metaphernkette oder Exempelreihung". 124

In der Feoptija hăfen sich die Definitionen besonders bei den psychologischen Begriffen in der V.Epistel. Aus einer groBen Anzahl nehmen wir einige Proben heraus.

Der 'Verstand' (смысл, V,51) wird zunăchst durch die Aufzăhlung seiner Tătigkeiten definiert: ex kann 'verbinden und zerlegen' (качества вещей слагать и разделять, V,52); er 'erforscht die ursachen' (разыскивает он собал все прииинш, V,54); er hat die Fảhigkeit zur Abstraktion und zur Verallgemeinerung:

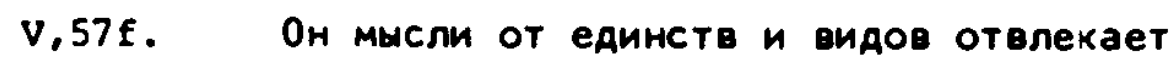

И, отвлекая так, повсемство постигает; -

Daran schliebt sich eine 'definitio a contrario':

$$
\text { V,61f. От скотского ума наш точно сим различен: }
$$

Внутрь токмо есть себя познанием тот сличен -

Mit einer 'definitio a comparatione' wird der menschliche Verstand als Mittel wesen zwischen dem der Tiere und der vollkommenen Intelligenz Gottes bestimmt $(v, 65-70)$.

'Haswk' ist nach einer 'definitio causalis' diejenige Kraft, die wir durch den stăndigen Gebrauch der Uberlegung und des willens erhalten:

V.j41ff. Tа сила навык есть, что ча́стейшим рассудком

И частейщим притом хотения побудком

Mon получаем так,

Das wird durch eine 'definitio finalis' ergănzt: alle 'навыки' tragen dazu bei, Vernunft und willen $2 u$ vervollkommen:

$$
\begin{aligned}
& \text { V,145f. Bсе навыки к тому со6со споспешахт, } \\
& \text { Что разум весь они и воло совершахт. }
\end{aligned}
$$


'Myapoctb' wird dreifach definiert. Die 'definitio essentialis' lautet: v,149f. Познавши муярость то, что праведно и ломно, Что есть Aо6ро и sло и что - ceбе возмомно, -

Eine 'definitio Einalis' wird angefügt:

v,151f. Способней момет уж суаить и предложить

Делам своим конец, а тем уму слумить;

Die Reihe schliebt mit einer 'definitio a contrario':

$$
\text { V,153 МШ буйством то зовем, что муарости противно. }
$$

Die aneinandergereihten Definitionen sind trocken und abstrakt. Durch die Zerlegung der Begriffe in Tatigkeiten und durch eine gewisse Personifikation von 'cмuсл' und 'mудрость' versucht der Autor eine, wenn auch dürtige, Poetisierung zu erreichen.

Als Beispiel einer metaphorischen Definition a simili kann das in der Textinterpretation erlăuterte Bild vom Ritter und seinem schwert gelten, das die Herrschaft des Geistes uber den korper veranschaulichen soll (V,241244).

Berufung auf Autoritaten und Lehrmeinungen

Der Lehrdichter beruft sich auf Lehrmeinungen, "welche die behandelten Wahrheiten bestătigen oder in Frage stellen". Siegrist fügt hinzu: "gerade die widerlegung einer Gegenmeinung vermag die eigene Position betrăchtilch zu stäken". 125

Die Bemühungen Tred.s, die Lehren der Atheisten, Materialisten, Deisten etc. zu widerlegen, brauchen hier nicht noch einmal dargestellt zu werden. In positivem Sinn bezieht sich Tred. in bestimmten Passagen dex Feoptija auf Plato, die Stoa, Augustin, Descartes, Newton, die neuere Naturwissenschaft und vor allem auf die Bibel.

Beim Thema 'Weltprinzip' (III,575ff.) nennt Tred. die entsprechenden Schlüsselworte Platos (Aуша естества, III,578), Descartes' (nодеижность, III, 577) und Newtons (влечениe, III,577). Zu Platos 'Weltseele' merkt er an: "Халдеи содержали, что есть симпатия между небесными вещами". 126 sie alle werden herangezogen, um die von ihm gelehrte wahrheit zu bestátigen, daB die Liebe jene 'feste Kette' sei, die alle Dinge zusamenhalt (III,575f.)

Für seine Auffassung, daB die Tiere eine Seele haben, beruft sich Tred. auf Platos Lehre vom lebendigen Wesen der Natur, auf die Logosphilosophie der stoiker und die Georgica Vergils, in denen der Dichter die 'Klugheit' 
der Bienen auf den gottlichen Geist zurückfürt (III,959-1008). Tred. vermerkt, die Lehre von der Beseeltheit der Natur sei in der Neuzeit von dem 'Italiener Giordano Bruno' vertreten worden. 127

Bei dem Problem des 'commercium mentis et corporis' läBt Tred. zur Unterstützung der eigenen Auffassung 'einen bedeutenden Lehrex' zu Wort kommen, bei dem es sich, wie die Demonstration zeigt, um Augustin handelt. Der Kirchenvater wird in V,501-516 wortlich, in den Versen 517-534 nur wenig von der Vorlage abweichend, zitiert.

Die Phănomene des 'vergessens' und des 'Sicherinnerns' beschreibt Trod. abon falls mit Worten Augustins, die aber nicht als zitat gekennzeichnet sind ( $V$, 599-613).

Die hămische Frage der Gegner, was denn Gott getan habe, bevor er die Welt erschuf, wird von Tred. mit einem Ausspruch des Kirchenvaters abgewehrt. Hier nennt er den Namen Augustins $(v, 324 \mathrm{f}$.$) .$

In der Frage des Weltbildes bezieht sich Tred. vorsichtig, in konzessiver Form, auf die neuen astronomischen Exkenntnisse. Die folgenden Verse nehmen die Erkenntnis des Kopernikus auf:

II,740f. Hо буде, напроти́в, мы вкруг ето вертимся, Чему, поемля то, безмерно мы чудимся, -

Der Streit zwischen der mechanistischen und der neuplatonischen Naturerklärung klingt in diesem Versparar an:

II,750f. Пусть будет механисм, пусть пла́стический Аух, Кой постоянно толь наш обращает круг; -

Wahrscheinlich bezieht sich Tred. dabei auf den 'Essay on Man' (Ep.III,9f.):

"See plastic Nature working to this end,

The single atoms each to other tend, -"

Die von Giordano Bruno vertretene Lehre wird in folgendem angedeutet:

II,794f. Мнят каждую из звезд, лучей их по огто,

Подобну солниу бшть и солнечному ант, -

Mit einer Folge von Konzessivsätzen referiert Tred. die zeugungstheorien dex zeitgenóssischen Biologie und Medizin:

III,695f. Пусть мноматся они Аля собственного плоду От семини, что них есть вложено по роду -

III,699 Пусть производит их нарочна заготовка, -

III,703ff. Пусть уверякт нас, что в кажром порознь звере

Припасено по их иислу, по иx и мере, 
III,705 Зародыни пред сим уг за седмь тысяч лет, -

Welcher von diesen Lehrmeinungenman auch tmmer zustimmen mag, so schliebt Tred. die Aufzălung, die Kunst des Hochsten 'ist uberall zu riechen':

III, 729f. Но кое мнений сих от муарых ни принять,

Везде искусство долг всевьшне обонять:

Die Axt, wie Tred. einzelne Punkte aus groBen zusammenhāngen herausgreift und sich aneignet, ist eklektisch und 'kompilatorisch' (Siegrist), einem Wesenszug des Lehrgedichts der Aufklaxung entsprechend.

Als oberste Alitoritat erkennt Tred. die Heilige Schrift an. Ihr unterwirft er sich, auch wenn eine ihrex Lehren,wie etwa die Trinitatslehre, der Vernunft unbegreiflich ist:

$$
\begin{aligned}
& \text { VI,190ff. Но когда святое нам слово предлагает, } \\
& \text { Что бог вынний в пресвятой тройце пребывает, } \\
& \text { То мы, упадая пред величием сим ниц, } \\
& \text { Суиества в единстве признаваем тройцу лиц, } \\
& \text { А до таинства притом разумом такова } \\
& \text { Не касаемся отнодь без писаний слова; } \\
& \text { Веры мы пленяем в послушание ум здесь, } \\
& \text { Вера в сем едина, а не слабый ум, свет весь. }
\end{aligned}
$$

Die Ubereinstimmung von Bibel und Kirchenlehre steht fur Tred. ohne weiteres fest.

Aus der Bibel stammt die Gottesvorstellung in der Feoptija. Tred. verwendet jedoch auch philosophische Bezeichnungen wie 'Gottheit' (6omect8o) und 'hochstes Wesen' (выннеe суиестөо) sowie zeittypische Gottesnamen: 'Baumeister' (строитель, II, 33; 259) und 'Konstrukteux' (механист, II,258). Im Hinblick auf die Schónheit der Welt wird Gott 'der gröBte Maler' genannt (верьховнейший 3orpaф, IV,98). Vor allem aber ist cott der schopfer der Welt (TBope4, I,13; создатель, I,540; зимдитель, I,24; здатель есего мира, I,73). Im Widerspruch gegen die deistische Position betont Tred., das Gott die Welt regiert und erhalt (верьховный царь мира, I,558; всем владыка, I, 16; самодермавный, III,425; өсё хранит, всем правит сам, I,11; правитель вышний и безмерный, I, 174). Gegen pantheistische Anschauungen wendet sich die Aussage, daB Gott der ewige, uberzeitliche und überweltliche Schöpfer ist:

$$
\begin{aligned}
& \text { I,51ff. Заклочает потому, что бог есть превечный; } \\
& \text { Что как безначальный сей, так и бесконечный, } \\
& \text { Что различен с миром, и не то что вещный свет: - }
\end{aligned}
$$


Das Universum fuhrt uns vor Augen, daß es einen uberweltlichen Schopfer hat: I.23f. Верно кажет общий круг мшслей сверьх обширншй, Что зижаитель есть ему и что сей премирнщй.

Als wichtigste Attribute cottes werden stăndig genannt: hochste Weisheit, Allgüte und Allmacht, z.B.: "...бог премудрый, всеблагий в нем произвол,// преисполнен мощи,..." (I, 209f.)

Im Verhăltnis zum Menschen werden die văterlichen züge Gottes hervorgehoben: er sorgt für uns alle $(060$ всех из нас nечется, II,311). Gott ist unser Vater (премилосеря нам в истине оте4, II,312), der seine Kinder liebt (чадолюбншй оте4, IV,6), unser Wohltăter, der uns nicht dem Verhăngnis überlaßt (6naroтворитель не оставит нас и в рок, IV,641).

Gott ist aber auch der gerechte Richter :

I,554 Бог, кой правосуанщй, не отмстит ль, ибо есть?

Die schöpfung versteht Tred., von der Bibel beeinfluBt, als 'creatio ex nihilo'. Darum lehnt er die vorstellung einer ewigen Materie ab:

VI,262 Но из ничего сие бштие всё всплыло.

VI,266f. Нет в аухах, ни в веществе такового равно,

Что показывало 6 в них вечность нам исправно;

Auf die Autorităt der Bibel stützt sich Tred. hinsichtlich des Zusammenhangs von sünde und Tod. Zunăchst erklärt er das Rătsel des Todes rationalistisch: wir müssen sterben, weil die Erde für eine unbegrenzte zahl von Menschen zu klein ist (IV,632-635). Dann greift er auf die biblische Exzahlung vom sündenfall zurück, in der der Tod als strafe Gottes erscheint (Gen. Kap.3,19). Der Apostel Paulus sagt prăgnant: 'der Tod ist der sunde sold'.

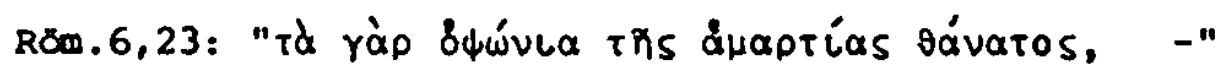

Bei Tred. klingen die biblische Geschichte und das Pauluswort an:

IV,638ff. Ha падение мое в праотце взирам:

Винный и преступник уж так я умираю.

Ведаш, что смертность наша есть греха оброк,

In VI,600-615 bezieht sich Tred. auf die neutestamentliche Lehre von der Versohnung durch das Heilswerk Christi am Kreuz. Die theologische Argumentation in diesem Abschnitt gründet sich auf verschiedene Bibelstellen.

Gott müBte gemäB seiner Gerechtigkeit den sündigen Menschen verdammen, heiBt es in VI,600-603. Dies ist auch die Auffassung des Paulus in Rŏm. 1,32:

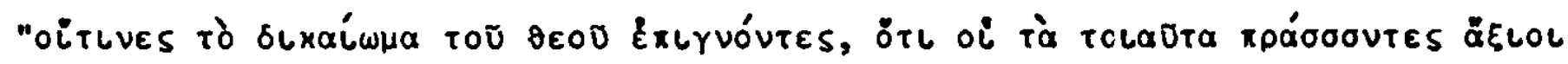
oavátou Eloív, -" 
Die Verschonung des Sünders wird in VI,604-607 mit dem Eintreten eines 'Fursprechers' (ходатай, VI,604), eines gottlichen 'Anwalts', zu seinen Gunsten begrüdet. Dahintex steht die neutestamentliche vorstellung vom 'rapa'-

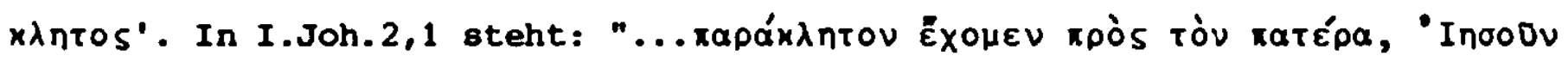
Xplotòv síxalov...."

In VI,608-610 zitiert Tred. II.Kor.5,21 (vgl. die Textinterpretation). In VI,61 s spricht Tred. von der 'Rechtfertigung' (K onpaвданиi всех нас). 'Onравдание' ist russ. Aquivalent fü das von paulus gebrauchte Wort 'olxai-

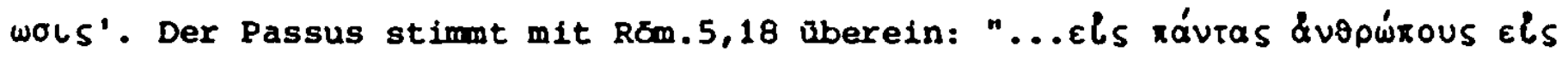

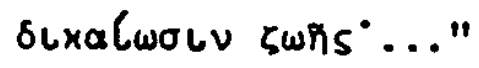

Der Vers VI,613 hat eine neutestamentliche Parallele in Kol.1,20. Vgl.: Примиривши богу человеков со креста,

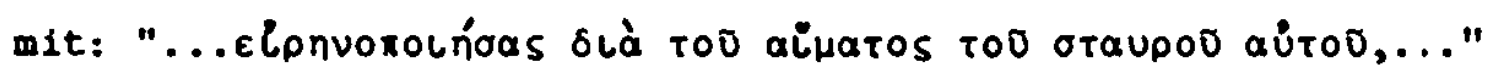

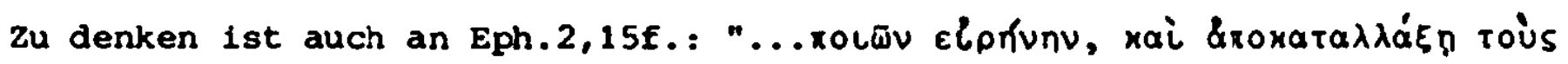

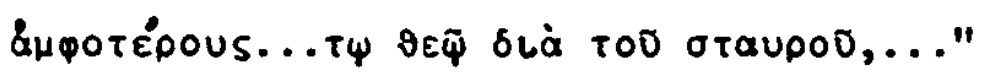

Die Passage ist bemerkenswert, da dogmatische Themen dieser Art im Lehrgedicht der Aufklarung nur selten behandelt werden. Im allgemeinen gilt, wie Siegrist vermerkt, "die Lehre von der Erbsünde und damit verbunden die Heilslehre wie die Gestalt Christi verlieren an Bedeutung". 128

Bibelzitate und biblische Anklănge

Motto der Feoptija:

"Невидимая 60 eго от создания мира твореньми помышляема, видима суть, и присносуиная сила его и божество, во еже бити им безответным." (К римлянам. Гл.1,ст.20) I,210: "содеваощий Глагол"

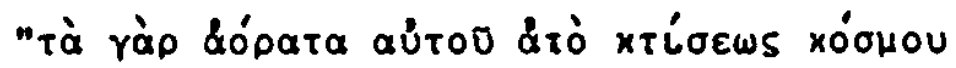

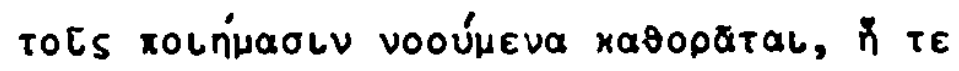

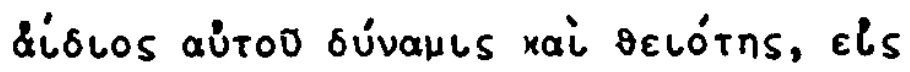
tò elval aútoìs duaxodoyńtous." Rö́m.1,20

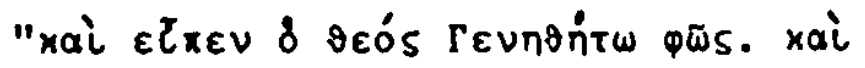
ÉYéve to ФŨS." (Gen.1,3 - LXX) "xai elx xai Éย́veto oútws." (Gen.1,6)

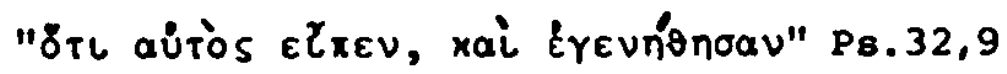

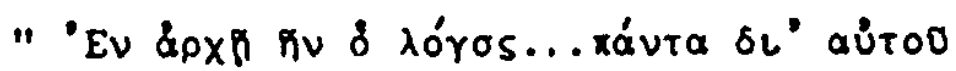
ĚÉveto..." (Joh.Ev.1,1ff.)

II, 373: "...еетров на крилах..."

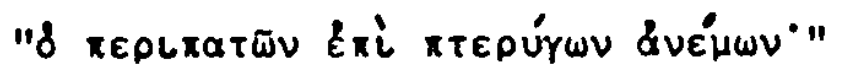
(Ps.103,3) 
II,441ff.: "Граничей Океан кто теерАой оградил,/ За кою преступить он никогда не смеет, -"

II,640: "С Полуана солнце сшеа свой Запая познавает, -"

II, 823: "0! боже, чудеса творишь

еяин 8 предлог -"

II,824: "Нет слова, нет речей в язы́ке земнородныХ -

II,877: "Вещают небеса божественную славу!"

III, 291: "Ero повс0Ay tOль в нем персты всем играют -"

III,833f.: "Так истину любло и, что Аобро, я зро,/ Но, ненавияя пожь и зло, сие творю"

III,1009f.: "Но, о! сиявши вы толь в славе муарецы,/ Вы были по своей той мудрости слепцы."

IV,7f.: "ОН, Евсевий, сотворил нас себе собразно,/ По подобию создав своему, не разно."

IV,9: "Коль твое пречуано, боже, имя по земле!"

IV, $11 \mathrm{ff."Малым} \mathrm{не́чем} \mathrm{от} \mathrm{чинов} \mathrm{умень-}$ шил небеснах,/ Зиждя и разумных нас, купно и телесных./ Славоо в отмене восхотел нас уеенчать - "

IV, 19: "Господи! о! боже haw! Имя твое иУАно!"

IV, 29f.: "От земли всё взято, но всевышний творец,/ Мнится, в том искусстео показал свое еконец." IV, 638: "Hа падение мое в праотие взирак..."

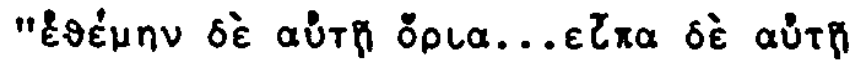

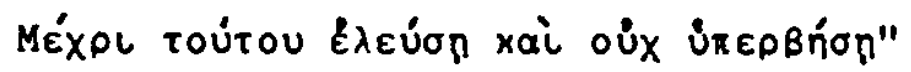
(Hiob, 38, 10f.)

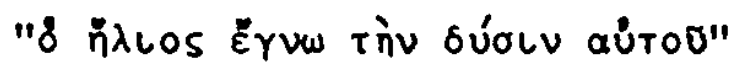

(Ps.103,19)

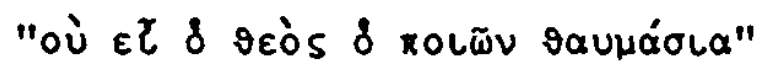

(Ps. 76, 15)

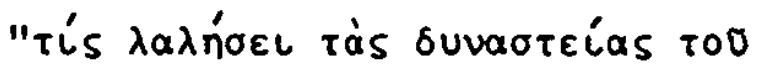
xupíou" (Ps.105,2)

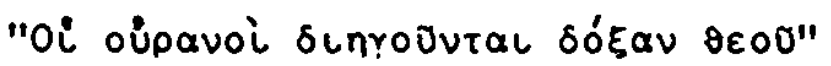

(Ps. 18,2)

"ludens in orbe terrarum" (Prov.8,31

"ŏte Évpaíveto tìv Vulg.)

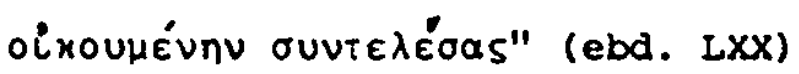

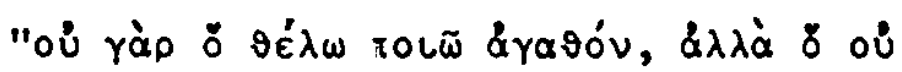

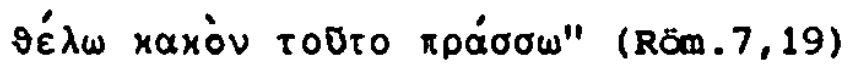

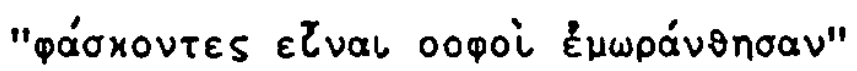

(Röm. 1,22)

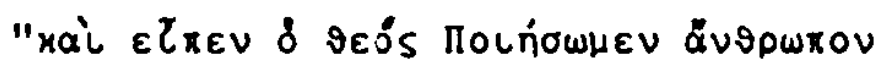

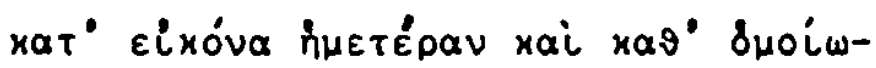
ouv"

(Gen. 1, 26)

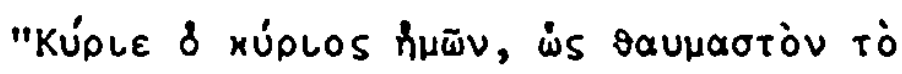

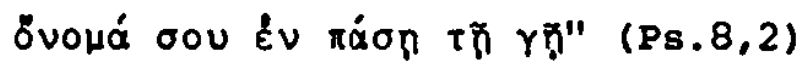

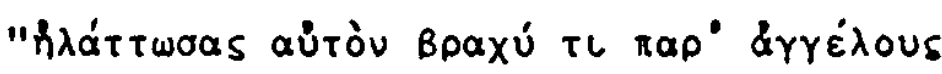

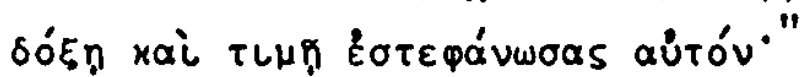

(Ps.8,6)

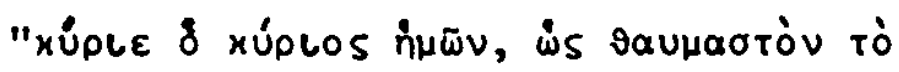

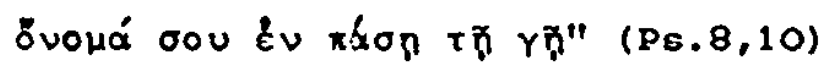

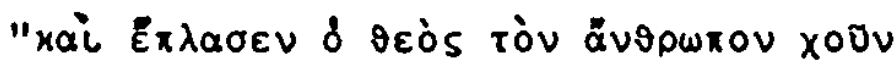

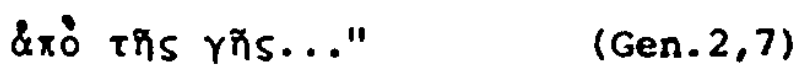

Gen.3, Geschichte vom Sündenfall 
IV,640: "Bедаw, 4то смертность наша ectb rpexa o6pok"

IV,641 : "Но благотворитель не оставит нас и в рок"

V.241: "Оанако случай $K$ ним $/ \bar{K}$ страстям7 есть уаивлений взор"

V,901: "Бог истинен, и суд его нелицемерен!"

v,904ff.: "/5ог7 Имеяй свой престол превыше всех небес,/ Где грозншх молний огнь весь оный освещает/ $И$ приступить к зарям собой не АОпушает"

V,909f.: "Пред ним сил многи тьмш сияниями блещут,/ Величества его в лоблении трелещут."

VI,196: "Верш мш пленяем в послушание ум здесь"

VI, 225: "Так как Нинивии града он нe noryбил."

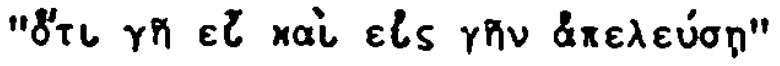

(Gen. 3,19)

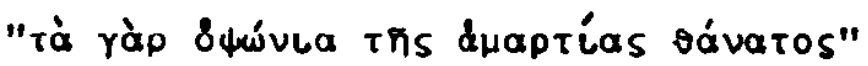

(Rōm. 6, 23)

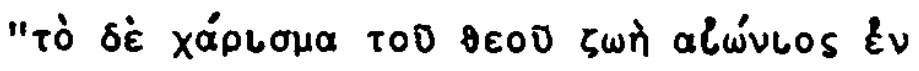

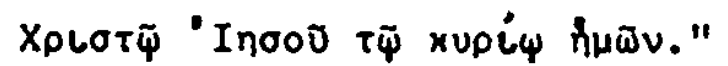

vgl. Gen. 3, 'Sündenfall', (Rסm.6,23b)

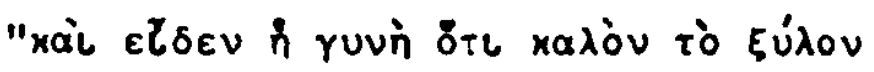

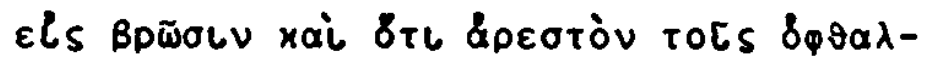

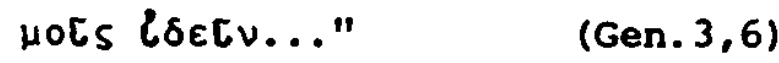

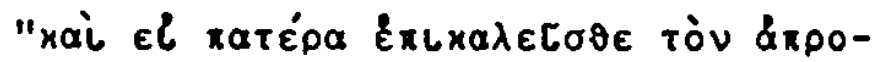

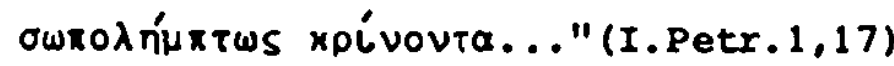

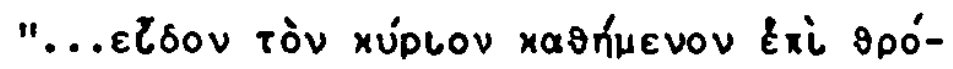

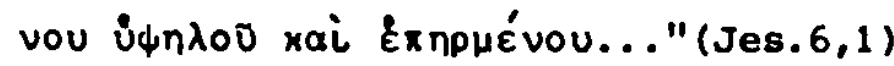

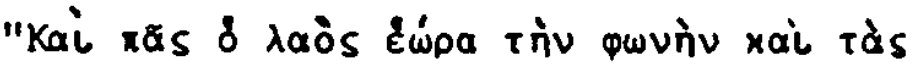

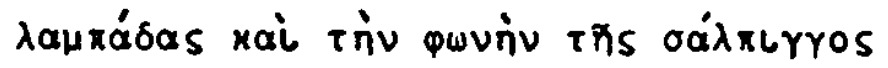

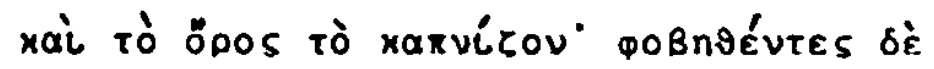

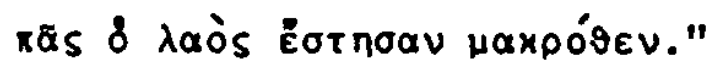

(Exod. 20, 18)

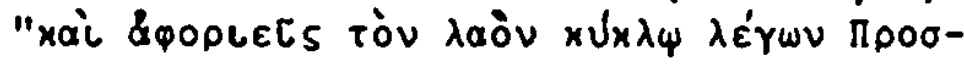

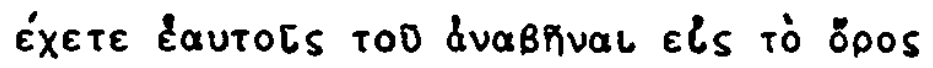

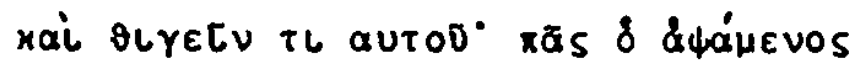

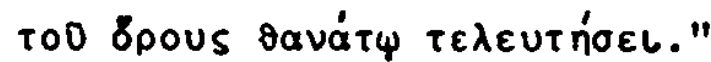

(Exod.19,12)

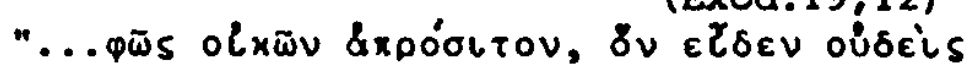

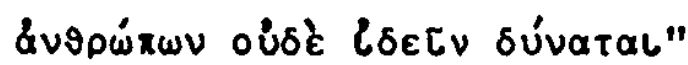

(I.Tim.6,16)

"xai Éx too opóvou Éxropevovtal dotparal xai quvai xai Bpovtai"" (Apc.Joh.4,5)

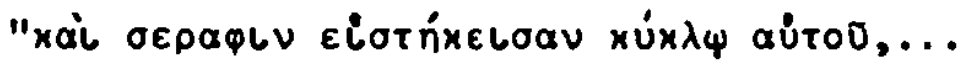
xai Exéxparov Ėtepos xoòs tòv Ëtepov xai Ẽ $\lambda \varepsilon r o v$ "Arlos árlos ärlos xúplos

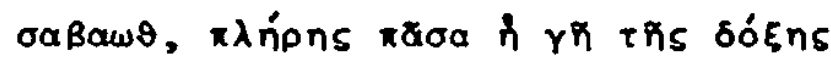
बU่To0." (Jes. 6,2f.)

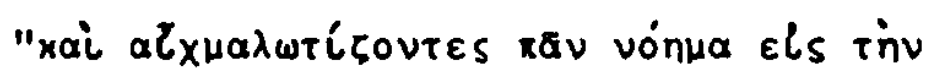
Uxaxoñv too Xplotoo" (II.Kor.10,5)

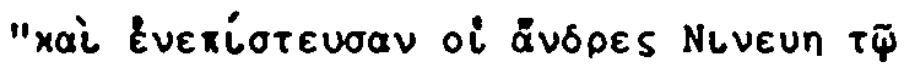

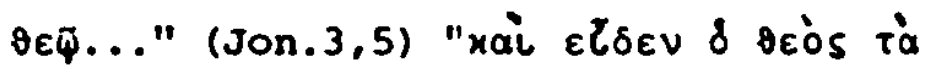


VI,445: "0! премУАрОсть, в коей неиспытна глубина."

VI,604: "Но что мы не гибнем, то ходатай њекий есть..."

VI,608ff.: "Tем то нужно стало, чтоб безгрешна самого/ В нас грехом соделать, да правдой чрез него/ Божиех будем все..."

VI,611f.: "К оправданио всех нас бывша толь успешна,/ 0бъявляет быти слово божие Христа..." VI,613f.: "Примиривши богу человеков со креста,/ Сына божия того и превечна бога."

VI,615: "0! небесная лобовь, коль ты к нам премнога!"

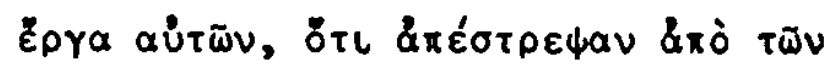

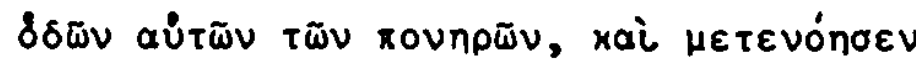

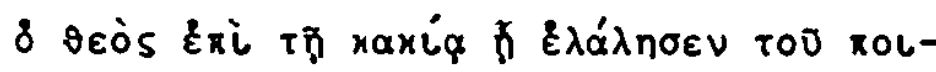

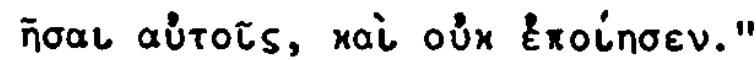

(Jon. 3, 10)

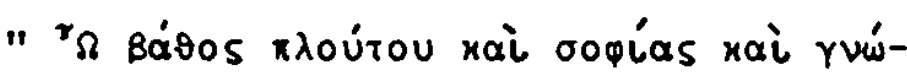

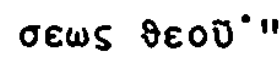
(Röm11, 33)

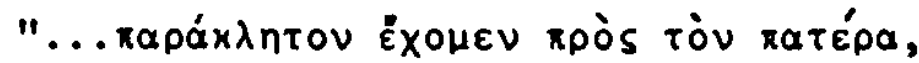
"Inaoov Xplotòv síxalov" (I.Joh. 2,1)

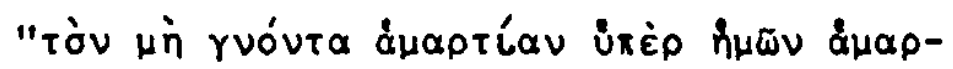

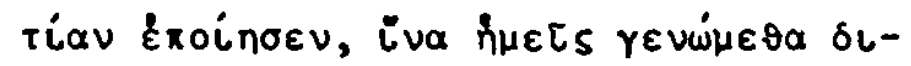

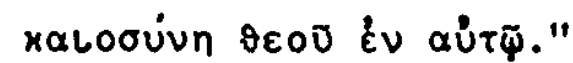

(II.Kor. 5,21 )

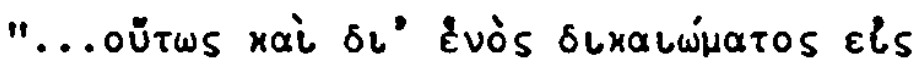

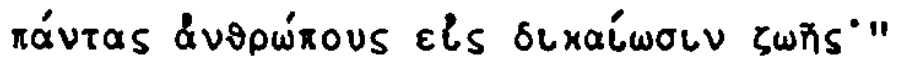

(Röm.5, 18)

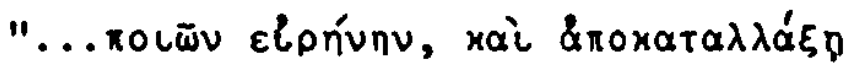

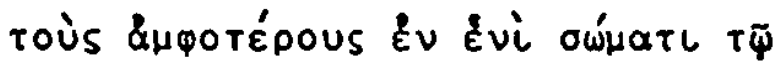

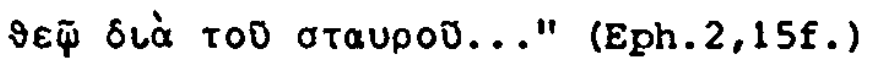

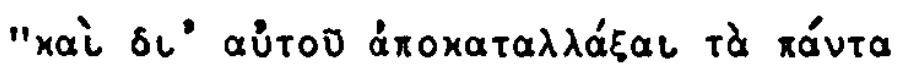
Eis aútóv, Elonuorolńoas sld rod

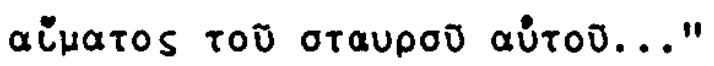

(Kol.1.20)

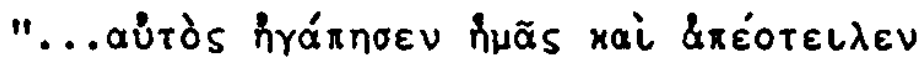

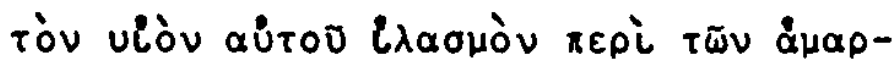

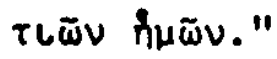
(I.Joh. 4, 10)

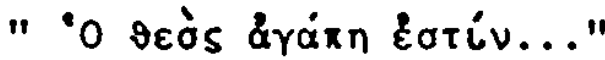

(I.Joh.4, 16) 


\section{Kapitel}

Zur Metrik und Sprache der Feoptija

Zux Metrik

Tred. hat die Verse seines Poems nach der von ihm entwickelten Verslehre gebildet. Diese war zum erstenmal im Jahre 1735 unter dem Titel "Новий n краткий способ к сложению российских стихов с определениями до сего надлежащих званий" veroffentlicht worden. Der 'Cnoco6' ist "der erste Traktat dex russischen verslehre uberhaupt". " Mit inm hat Tred., wie heute uberwiegend anerkannt wird, den entscheidenden Schritt zur Erneuerung des russischen Verses getan. O.V.orlov urteilt: "Несмотря на ограниченность, неполноту осушествленной Тредиаковским перестройки стихосложения, эта реформа имела огромное значение, явилось качественным скачком в историй русской поззии." 2 Auсh Тімоfeev wüdigt das Verdienst Tred.s für die versbildungslehre: "На доло Тредиаковского выпала честь стать реформатором ритмики русского стиха." 3

"Reformiert wurden", so konstatiert A.Adamczyk, "die sogenannten 'virsi', eine fremde rhythmische Form, wenn sie auch im Süden des Landes FuB gefaBt hatte." 4 Es handelt sich um syllabische Verse, die aus 13 bzw. 11 silben bestehen (auch 4- bis 9silbige verse kommen vor). In der Regel haben die 'virsí. weiblichen Endreim und betonen nach polnischem Vorbild die vorletzte Silbe. Tred. hat die syllabischen Verse abschătzig als 'pифмованнуо прозу' 5 und 'nрозаические строчки ${ }^{6}$ bezeichnet. Er sagt, 'sie schmeicheln sich nicht ins ohr ein': "никак не ласкают ухо" 7 . Im Gegensatz dazu entwickelt Tred. seine Gedanken im 'Cnoco6' aus der Erkenntnis, "daB russische Verse den Einklang von Hebung und Sprachton, das wăgen, verlangen". 8 Das wichtigste Element in dem von ihm reformierten Vers ist der dem natürlichen sprachton konforme, aus einer betonten und einer unbetonten Silbe bestehende 'FuB': "8 npornsosec stomy Тредиаковский выдвигает свой новый спосо6... предлагая складывать стих 'равномерными, двухслокными стопами', т.е. строить его на правильном, ритмически упорядоченном чередовании ударншх и безударных слогов." 9

Tred. hat dem 'Choreus' als VersfuB den Vorrang gegeben: "Bзsnca a вcex npewAe 3 a Crony Xopea..." 10 Das neue prinzip dex Versbildung, von ihm selber "roнический' genannt, erhielt später die genauere Bezeichnung 'syllabo-tonisch'. 1 Tatsăchlich sind im 'Cnoco6' von 1735 die Regeln für die Tonisierung des $13 s i l b i g e n$ (bzw. 11silbigen) syllabischen Verses aufgestellt worden. Der 'sprachrein wăgende' (Adamczyk) 13 silbige Vers besteht aus zwei Halbversen zu 
je 3 trochaischen, zweisilbigen FüBen. Im ersten Halbvers bildet eine zusătzliche, stets betonte Silbe, die zäsur. Im zweiten Halbvers bildet der dritte FuB den wejblichen Reim. Als den idealen GrundfuB im 'repoичecкий стих' sieht Tred. den Trochăus an, neben dem er den aus zwei unbetonten silben bestehenden Pyrrhichius und den Spondeus (zwei betonte silben) gelten labt. Dagegen halt er im heroischen Vers den Jambus für unpassend und weist ihn den 'niederen' Gattungen zu. Der mănnliche Rejm sowie mehrsilbige VersfüBe (Daktylus und Anapasst) werden im 'Cnoco6' von 1735 abgelehnt. Tred. hat in der ersten Fassung seiner versbildungslehre nux die 13- und 11silbigen syllabischen verse tonisiext. Bei den kurzen, 4-bis 9silbigen Versen schien ihm eine Aufteilung in Takte nicht notwendig zu sein.

Obwohl Tred. im 'Cnoco6' von 1735 aus seiner Entdeckung nicht alle SchluBfolgerungen gezogen hat, steht fest, daB er als erster die zentrale Bedeutung der VersfüBe für den Rhythmus des Verses erkannt und den Begriff in die russische Metrik eingeführt hat. Timofeev unterstreicht: "До Тредиаковского в русской поэзии (ни в поэтической теории, ни в поэтической практике) не существовало понятия стопы как единицы стихотворного ритма."12 Der vers unter dem im Text der Feoptija (S.320) wiedergegebenen Portrat Tred.s:

$$
\text { "Стих начавчаго стопой прежде всех в России -" } 13
$$

kennzeichnet die bahnbrechende Bedeutung des 'ersten russischen Verstheoretikers' (A.Adamczyk).

Auf die langwierigen Auseinandersetzungen zwischen Tred. und Lomonosov wegen der Priorităt und ihrer unterschiedlichen Meinungen, z.B. über den Jambus, kann hier nicht eingegangen werden. Sie haben ihr Verhăltnis zueinander zerrüttet und hatten für Tred. tragische Folgen. Festzuhalten bleibt: in diesem schmerzhaften ProzeB hat Tred. von seinem Widersacher manches gelernt und in die Neufassung seines 'Cnoco6' (1752) aufgenommen.

So hat er sich in der Neufassung der Versbildungslehre mit dem jambischen VersmaB abgefunden, obwohl er nach wie vor den 'Choreus' bevorzugt, weil er der russischen Sprache angemessener sei. Im Unterschied zur ersten Fassung wird nun auch der mănnliche Reim zugelassen. Der Reim als solcher wird aber unter Hinweis auf die Versdichtung bei den Griechen und Römern relativiert. Nach dem Muster lateinischer Verse erlaubt Tred. jetzt den 'nepenoc' (frz. enjambement), die Weiterführung eines Gedankens im folgenden Vers. Im 'Cnoco6' von 1735 hatte er den 'перенос' abgelehnt.

Für die weitere Entwicklung des russischen verses war bedeutsam, daß Trer. 
die dreisilbigen Versfüe Daktylus und Anapast in seine versbildungslehre von 1752 aufgenommen hat. Durch die Kombination von dreisilbigen und zweisilbigen versfaßen hat ex dann den "Hexameter far die russische literatur entdeckt und nachgebildet". 14 Die Zeitgenossen haben sich uber die Bexameter der 'Tilemachida' hăufig lustig gemacht. Oft wird die Episode erwăhnt, Katherina II. habe ihre Hoflinge zur strafe für kleine Verfehlungen einen Abschnitt aus der 'Tilemachida' auswendig lernen und vortragen lassen. A.Adamczyk schreibt, Tred.s 'Tilemachida' sei gewiB 'kein wunderding der Nachdichtungskunst, versgeschichtlich aber das erste und kühne Beispiel einer neuen, freieren versgestaltung. Dieser russische Bexameter ist zudem die Krönung von Trediakovskijs metrischen Lehrgebăude. "15 Radiscev und Puskin haben Tred. als bedeutenden Metriker anerkannt. Der erste schreibt in 'Putě̌estvie' (Kap. Tver'): "... Тилемахиде найдутся добрше стихи и будут в пример поставляемы." pu\&kin hat die Leistung Tred.s so gewirdigt: "Он имел в русском стихосломении обширнейшее понятие, нежели Ломоносов и Сумароков. Любовь его $к$ Фенелонову зпосу делает ему честь, а мысль перевести его стихами и самшй выбор стиха доказывает необыкновенное чувство изянного..."16

Tred. hat behauptet, seine Versbildungslehre aus der altesten russischen Volksdichtung entwickelt zu haben. Nur die Fachausdrücke habe er der franzoschen Verslehre entlehnt: "Поялинно, почти все звания при Стихе употребляемыя, занял я у Франиусской Версификации; но самое дело у самой нашей природной, наидревнейшей оных простых Людей Поззии."17 Mit dieser Erklärung haben sich die Forscher aber nicht zufriedengegeben. Timofeev weist darauf hin, daB sich eine Reform des syllabischen Verses schon lange vor Tred. angekündigt habe. Ex erwahnt, daB zu Anfang des 18.Jahrhunderts die in RuBland lebenden Deutschen Pastor Glück und Magister Paus russische Verse in Jamben gedichtet haben. Schon vorher (1672) finden sich russische Jamben in dem Theaterstück 'Aртаксерксово действо', das von dem deutschen Pastor Gregori stammt. Diesen Verfassern war das jambische Versmaß aus ihrer Muttersprache vertraut. ${ }^{18}$ ob Tred. aber diese Verse gekannt hat, ist ungewiB.

Eine differenzierte Darstellung der Faktoren, die auf die Bildung des 'Алинный стих' Tred.s eingewirkt haben können, gibt L.V.Pumpjanskij. Nach ihm hat sich Tred. bald nach seiner Rückkehr aus dem Ausland in Petersburg der dortigen 'немецкая школа разума' angeschlossen, die sich um 1700 gebildet hatte. Sie hatte sich den 'vernüntigen Stil' von Maxtin Opitz zum Vorbild genomen und vertrat inn entschieden gegen den spatbarocken schwulst der 'schlesischen 
Schule' um Hofmannswaldau. Ein Wortführer der 'немецкая школа разума' war in den areiBiger Jahren der Professor der Akademie und ihr 'Spezialpoet', Juncker, mit dem Tred. In enger verbindung stand. Unter Junckers Einfluß hat er nach Meinung von Pumpjanskij die in der 'Эпистола от российская поэзия $k$ Aполлину' aufgeführten deutschen Autoren kennengelernt, u.a.: Brockes, Günther und Opitz. ${ }^{19}$ Die metrischen Formen der deutschen Autoren haben die Versreform Tred.s wesentlich beeinfluBt, behauptet Pumpjanskij. Er stellt die Entwicklung des 'Алинный стих' Tred.s so dar:

Sein Ausgangspunkt ist der von ihm vorgefundene 13silbige syllabische Vers. Inn hat er, angeregt durch trochaische Muster in der deutschen Dichtung, tonisiert. Pumpjanskij erläutert das Vorgehen Tred.s: "Поэтому, из немецких метрических Форм ему нужна только та, которая была бы тоническим адэкватом симеоно-кантемирового стиха, а вовсе не любая (только потому, что она тоническая). Pumpjanskij unterstreicht, daB Tred. im Unterschied zu Lomonosov bei der Versreform den zusammenhang mit der Tradition wahren wollte. ${ }^{20}$ AuBerdem sei es Tred., anders als Lomonosov, zeitlebens darum gegangen, die Formen fü den 'erzălenden vers' (повествовательный стих) zu entwickeln. 21

DaB Tred. sich mit seinem trochäischen Langvers an deutschen Mustern orientiert hat, sucht Pumpjanskij an einer Variante dieser Versform nachzuweisen, die von Tred. nach 1740 hăufig angewendet wurde. Pumpjanskij nennt diese Variante 'трохаический Алинный стих...с перебоем пар'. 22 Das erste Verspaar besteht aus trochäischen Versen mit weiblichem Endreim:

"ГАе стигийску грань делмт / с полем доброзлачным Светозарнейший предел / поясом безмрачным, Im folgenden Verspaar ist die Reihenfolge der Halbverse umgekehrt; der Endreim ist mănnlich:

Где и зеленеот

8 коих арево всяко
/ всецветущие сады,

/ жизненны родит плоды." 23

Tred. hat diese charakteristische variante 'rероический эксаметр' genannt, fälschlich, wie Pumpjanskij anmerkt. Er fügt hinzu, daß viele verse in der 'Apreнияа' (1751) nach diesem 'seltsamen' Muster gebildet sind: "написаны этим курьезным вариантом трохаического стиха" und bezeichnet die variante als versgeschichtliche Raritä: "как нечто единственное (semel adhibitum)". Wenn sie in der deutschen Versdichtung vorkoment, kann als erwiesen gelten, daß Tred. sie von ihr übernommen hat: "...4то если мы найдем его в немецкой поэзии, заимствованность будет тем самым Аоказана". 24 pumpjanskij fährt fort, 
er habe das erste Beispiel dieser Versform bei Opitz gefunden, weitere Beispiele im 17.Jahrhundert und bei Gunther. Aus der Tatsache, das die bekannten Verse Trea.s zum Amtsantritt von Baron Korff (1734) - das erste syl1abo-tonische Gedicht im Russischen - von Juncker in der gezeigten Form ubersetzt worden sind, folgt nach Ansicht von Pumpjanskij 1) "что трохаический стих есть немецкий адэкват стиха Тредиаковского", 2) lät sich daraus entnehmen, "... гае Тредиаковский нашел образеи своего стиха". 25 Es leuchtet ein, daB Tred. die oben gekennzeichnete Versform erst anwenden konnte, nachdem er unter dem EinfluB Lomonosovs den mannlichen Reim anerkannt hatte. Danach erscheint bei ihm der ebenfalls von Lomonosov ubernommene 6fübige Alexandriner als jambischex Langvers. Die Bexameterformen können hier auBer acht gelassen werden, weil sie in der Feoptija nicht vorkomen. Das Poem enthalt trotzdem viele metrische Formen. Pumpjanskij spricht vom 'epischen Polymetrismus' (эпический полиметризм) Tred.s, den er dem 'Monometrismus' der ode bei Lomonosov (ояический монометризм) gegenüberstellt. 26

In der Feoptija begegnen uns zwei Grundformen des von Tred. entwickelten syllabo-tonischen Langverses: der trochäsche 'Алинный стих' in der von Pumpjanskij beschriebenen variante 'c nepeбoem nap' und der von Lomonosov übernommene Alexandriner.

Das erste Beispiel zeigt ein trochäisches Verspaar mit mánnlichem Reim: Ep.I,13f. Вся тварь возвенает / самобытного твориа, Безначальна прежде / суиа после без конца;

Der erste Halbvers in I,13 besteht aus drei 'FuBen', von denen der dritte als zăsur dient. Der zweite Halbvers besteht aus dre1 'FüBen' und hat auBerdem eine betonte Silbe, die den Reim bildet.

Das darauf folgende Reimpaar schliebt mit weiblichem Reim:

$$
\text { I,15f. } \quad \text { в себе того ж sсегда, / n преудобренна, }
$$

Всем владыку, ни чией / длани покоренна;

Hier besteht jeweils der erste halbvers aus drei 'Füßen' und einer langen silbe als zåsur. Der zweite Halbvers hat drei 'FuBe', von denen der letzte den Reim ergibt.

Zahlreiche Verse in der I., IV. und VI.Epistel sind nach diesem Muster des trochăischen 'Алинный стих с пере6оем' (Pumpjanskij) gebildet.

Dazu eine Probe aus der IV.Epistel mit parweisem Reim in der Reihenfolge mănnlich/weiblich: 
IV,9ff. Коль твое пречуано, / боже, имя по земле!

Быть земной подобным / не благоволил нам тле.

Малым ме́чем от чинов / уменьшил небесных,

Зиждя и разумных нас / купно и телесных.

Die Reimfolge ist hăufig auch umgekehrt weiblich/männlich:

vI,681ff. Кто о боге сердча внутрь / истинно уверен,

8 благодати ж сыновства / цел, нелицемерен,

Тот есть, о! Евсевий, / правостен, тот горним вдан,

Тот, израилтянин, / христианин, оправдан.

Die Form des Alexandriners begegnet in der Feoptija sowohl in Verspaaren mit männlichem wie mit weiblichem Reim.

Der Alexandriner mit männlichem Reim besteht aus zwei Halbversen mit je drei jambischen VersfüBen. Der Vers mit weiblichem Endreim hat im ersten Halbvers drei Jamben, im zweiten Halbvers auBerdem noch eine kurze silbe.

In dem folgenden Beispiel ist die Reimfolge der Verspaare weiblich/mănnlich/ weiblich:

$$
\begin{aligned}
& \text { II,257ff. Предивный механизм / сей в жилках всяка листа } \\
& \text { Предивного всем нам / являет механиста! } \\
& \text { Но и радящий сей / в строителе совет, } \\
& \text { Что на листах вобие / зеленый токмо цвет, } \\
& \text { Сей зрению очей / цвет наших споспешает, } \\
& \text { Те ж более, неж взор,/ собою утешает. }
\end{aligned}
$$

Das Verspaar II,257f. ist zugleich ein Beispiel für das Ubergreifen der grammatischen Konstruktion, den ursprünglich von Tred. abgelehnten 'nеренос'. um einen 'rексаметр иамбический' vorzustellen, zitiert Tred. in seiner Schrift 'O древнем, Среднем и Новом Стихотворении Российском' 27 die Verse II,822-827 der Feoptija:

$\begin{array}{ll}\text { Кто велий толь иный, /коль велий есть наш бог! } \\ \text { О! боже, чудеса } & \text { /творишь един в предлог: } \\ \text { Нет слова, нет речей } & \text { /в язы́ке земнородных, } \\ \text { Ни мыслей нет у нас } & \text { /пристойно благородных } \\ \text { К понятию всему } & \text { /пречудных дел твоих, } \\ \text { Дабы изобразить } & \text { /довольно силу их. }\end{array}$

Dort werden von ihm auch die Verse Feopt.I,555-558 als Beispiel für den 'rekсаметр Хореический' angeführt, der dem von Pumpjanskij beschriebenen 'трохаический длинный стих с перебоем' entspricht: 
I,555ff. Есть всеведый! Всеблагий! / Есть бог всемогуший! Без начала, без конца, / есть везде присуций!

Есть бог, о! Евсевий: / всяка проявлает тварь, Что он есть создатель / и верьховный мира царь. Die beiden stellen gehorren zu den wenigen der Feoptija, die zu Lebzeiten Tred.s gedruckt worden sind (1755).

Die III.Epistel setzt sich wie die zweite und fünfte aus Alexandrinern zusammen. Verspaare mit mănnlichem Reim wechseln mit weiblich gereimten:

$$
\begin{array}{ll}
\text { III,557ff. Какой тот полам двум } & \text { / толь пребогатый Аар, } \\
\text { Кой вспламеняет так } & \text { / К собщениь в них мар? } \\
\text { Взаимна то лобовь, } & \text { / магнит серяец небесный, } \\
\text { Не нас одних, всего } & \text { / что тварь, союз нелестный. }
\end{array}
$$

Als Beispiel aus der V.Epistel seien die Eingangsverse angefunrt: drei Verspaare, Alexandriner, mit paarweise wechselndem Reim in der Reihenfolge weiblich/mannlich/weiblich:

$\begin{array}{ll}\text { V.1ff. Создатель есть премуар / по телу человечу. } \\ \text { Но смысл и разум наш } & \text { / когда, как долг, примечу, } \\ \text { То тело пред умом } & \text { / покажется ничто, } \\ \text { И мно я, что отнодь } & \text { / не найдется никто, } \\ \text { Кой вдруг бы не сказал, / что человече тело } \\ \text { Не может никогда } & \text { / с умом сравниться в дело. }\end{array}$

Zur Sprache der Feoptija

Lexik

Die lexikalische Eigenart des Poems hat das Augenmerk der Forscher von Anfang an auf sich gezogen. I.Serman unterscheidet in seinem Aufsatz 'Неизданная Философская Позма В.Тредиаковского' (1961) zwei verschiedene Sprachschichten: "С одной стороны, это философская терминология, вновь создаваемая Тредиаковским из материала хорошо ему известного церковнослаянского языка, с Аругой - зто конкретная лексика русского быта..."28 Nach seiner Auffassung ist die heterogene Lexik in dex Feoptija in ihrem verschiedenartigen Inhalt (teils philsophisch, teils konkret) begründet. Schon vor der veroffentlichung des Poems hatte D.Blagoj in seiner 'История русской литературы XVIII B.' (1960) in den Versen Tred.s allgemein die Vermischung von Umgangssprache (просторечие) und Kirchenslavisch (церковнославянский язык), von 'lebendiger' (живое) und 'buchmăßiger' sprache (книжное) bemăngelt: "...есё зто порой при- 
дает его стихам характер какой-то языковой какофония".29 - In bezug auf die Feoptija will I.Serman diesen Tadel nicht gelten lassen: "Но в Феоптии выбор лексических средств более точно мотивирован в каждом частном случае, и потому поэма не производит впечатления стилистической какофонии." 30

Die Lexik der Feoptija hängt mit der Entwicklung der russischen Literatursprache im 18.Jahrhundert eng zusammen. Sie ist gewissermaßen eine Momentaufnahme aus einem langen ProzeB, in dem Tred. eine 'Schlusselfigur' darstellt. Nach Gerta Hüttl-Worth war Tred. "...one of the key-figures, one of the moving spirits in building up the higher lexical strata of the new litexary langrage." Tred. sei, so führt G.Hüttl-Worth aus, für diese Rolle am besten geeignet gewesen. Er war als Sohn eines orthodoxen Geistlichen mit der kirchenslavischen Sprache und Tradition aufgewachsen, hatte in der 'Slaveno-greko-latinskaja Akademija' in Moskau außer Kirchenslavisch die klassischen Sprachen und Literaturen studiert und bei einem dreijahrigen Aufenthalt in Paris ausgezeichnet Französich gelernt. Dazu kam seine vielseitige Tätigkeit als Ubersetzer, die ebenfalls der Bereicherung des russischen Wortschatzes zugute kam. Tred. hatte außerdem "eine ausgeprägte Neigung und das Talent zu lexikalischen Neuerungen". "Writing and translating was for him the same as experimenting in a laboratory", 31 erklărt G.Hütl-Worth und will mit diesem Vergleich wohl andeuten, daß Tred. mit vorhandenem sprachlichen Material gearbeitet und nicht etwa worter frei erfunden hat.

In dex Feoptija ist vor allem die 'abstrakte Terminologie' bemerkenswert. Nach Ansicht von G.Huttl-Worth hat Tred. "...zur Schaffung der 'modernen' philosophischen Terminologie...mehr beigetragen" 32 als andere Schriftsteller des 18.Jahrhunderts. Dieses Urteil stüzt sich, so merkt die Verfasserin an, auf die Untersuchung des Wortschatzes der für die abstrakte Terminologie wichtigsten Werke Tred.s: 'Слово о Премудрости, благоразумии и Аобродетели' (1752), 'Сокращение Философии Канцлера Франциска Бакона' (1760) und die 'Тилемахида' (1766). 33

Die Untersuchungen haben ergeben, daB Tred. die abstrakten Termini in exster Linie aus dem Kixchenslavischen ubernommen bzw. abgeleitet hat. In dex Feoptija wie in den anderen Werken "...überwiegen substantivische Ableitungen von älteren, meist zusammengesetzten Adjektiven", 34 stellt G.HüttlWorth fest. Mit Vorliebe hat Tred. das ksl. Suffix -octb zur Bildung von abstrakten Termini benutzt. Die zahlreichen Komposita mit 6raro-, A06po-, mнoro- und camo-, die in der Feoptija wie auch sonst bei Tred. vorkommen, 
stamen, wie D.Tschizewskij nachgewiesen hat, aus dem Kirchenslavischen und dürften kaum auf die griechische Literatur zurūckgehen. "Der Gebrauch der Komposita gehörte zu den beliebtesten Kunstgriffen der russischen dichterischen Sprache seit dem 11.Jahrhundert", 35 schreibt D.Tschizewskij. Er fügt hinzu, daB die Kcomposita in der Barockdichtung eine neue Blute erreicht hătten und bemerkt: "Trediakovskij steht auch in diesem Punkte in der Tradition der Barockdichtung des 17.Jahxhunderts." 36

Weitere abstrakte Termini hat Tred. durch Lehnubersetzung aus dem Griechischen, Lateinischen und Franzōsischen gewonnen. Als Beispiel nennt G.HüttlWorth 'Bce6omne' für franz. 'panthéisme' (seit 1712), "das auf eine Prăgung des englischen Philosophen J.Toland zurückgeht". 37 Die Herkunft von gr. "ruv

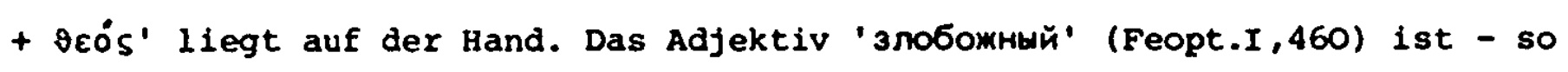
merkt G.Huttl-Worth an - vom altruss. 'зълобожныи' abgeleitet, einer Lehn-

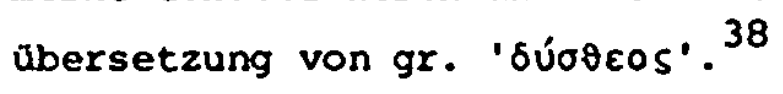

Darüber hinaus enthălt die Feoptija eine Reihe gemeineuropãischer Frendwörter, besonders wissenschaftliche Termini, die nach dem 'Словарь современного русского языка' sonst erst viel später bezeugt sind. G.Huttl-worth führt u.a. auf: 'клавитура' ('так ито тот руками не биет там клавитур', Fеорt.I, 273) statt 'клавиатура', "das nach dem (ловарь exst 1845 fur Russisch belegt ist".' zu den in der Feoptija erstmalig im Russischen gebrauchten Fremdwortern gehört nach Ansicht von G.Hütl-Worth auch 'ncихология' ('...вся психология nредлагается вкратие...', Prosaeinleitung z. V.Ep.,S.279) sowie 'naнтеист' $(I, 460)$. Das Fremdwort 'эфир' ('Эфир, тончайши те пылинки...' , II, 479) wird von G. Hüttl-Worth nicht aufgefüht. Nach I.M.Mal'ceva, 'хрон. словник', S.343 kommt die Form 'зфирны' zuerst bei V.N.Tatiscev, 'Geogr.' (1763) vor.

In seinem 'Predislovie' zur Feoptija (nicht in den 'Избранные Произведения' veroffentlicht) hat Tred. bestritten, die von ihm verwendeten Begriffe eigens neu gebildet zu haben. Sie kamen schon in kirchlichen und theologischen Büchern verstreut vor. Insonderheit beruft er sich auf die 'Heбeca' des Joh. v. Damaskus: "Впрочем, Званий Метафизических не возможно мне было не употребить в первой и последней Эпистоле; но не возможнож стало их и пременить: Они уже давно на нашем языке в употреблении, и нахояятся почитай всюлу рассеянны в церковных и Богословских книгах, а особливо в книге Преподобнаго отца Иоанна Дамаскина, прозванной НЕБЕСА..." 40

Diese Behaupting könnte nur durch einen Vergleich der abstrakten Termini der Feoptija mit einer ksl. Ubersetzung des erwahnten Werkes des Joh. Damasce- 
nus überprüt werden. Die Forscher sind jedoch der Ansicht, daB die Feoptija eine Anzahl von Neubildungen abstrakter Termini enthăl, die dort erstmalig belegt sind. Im folgenden sind Erstbelegungen zusammengestellt, die z.T. von G.Hüttl-Worth in 'Trediakovskijs Feoptija', z.T. im 'Хронологический словник' der 'Лексические новообразования в русском языке XVIII в." (1975) nachgewiesen sind. Die Verfasser des 'словник', I.M.Mal'ceva $i$ dr., weisen auf den 'выборочный характер' ihres Worterbuches hin (S.305). Demnach fehlen in inm Ableitungen, die bereits in früheren Lexikologien als Neubildungen des 18. Jahrhunderts belegt worden sind.

Hier eine Liste der als Neubildungen angesehenen Begriffe in der Feoptija: 'буйность' (Ungestüm)

II,506f. Какая сильна власть в нем бури ободряет, И буйность оных всю способно усмиряет?

Nach G.Hütl-Worth: "Ableitung von aruss. буиныи, Variante zu буйство (Igorlied, Zadonscina); буйность ist wohl im XVIII Jh. belegt, aber blieb nicht erhalten..." 41

'бездвижность' (Unbeweglichkeit)

$$
\text { II,548 Бездвижностию там покой его таит; - }
$$

Erstbelegung, nach 'хрон. словник', S.307; auch bei G.Hüttl-Worth, Tred.s Feopt. , S.969.

'благопроизвольность' , etwa 'Willenskraft', G.Hüttl-Worth, ebd.,s.969. Der Terminus steht in der Prosaeinleitung zur VI.Ep. Nach 'хрон. словник', S.307, gibt es keinen früheren Beleg für das Kompositun.

Das Adjektiv nроизвольнь ist bei Mikl. (696) mit 'spontaneus' wiedergegeben.

'вещность' (Wesenheit)

II,585f. Потребность от огня словами необъятна, Довольно, что его есть вещность всем приятна.

Erstbelegung, nach 'Хрон. словник', S.309.

'всевещность', etwa 'allesumfassende Realităt'

$$
\text { VI,179 То всевещности:s он крайно украшенный - }
$$

Nach G.Hüttl-Worth, Tred.s Feopt., S.969 gibt es keinen älteren Beleg fũr dieses Kompositum.

'зверный'

$$
\text { IV,602 Многи зверныи скотн завсе нападали }
$$

Erstbelegung, nach 'хрон. словник', S.314. 
'избранность'

II,9f. И, распростершись там, объял собой пространность,

А тем и твердость их, и видел всь избранность.

Erstbelegung, nach 'Хрон. словник', S.315.

'крумание'

II,426 Но сверх ее притом кружания обшчна, -

Erstbelegung, 'Хрон. словник', S.318.

'необходимость' etwa 'unumgangliche Notwendigkeit'

In der prosaeinleitung zur VI.Ep. heißt es: "Из самостоятельных /Свойств] присвояется именно богу: ...необходимость..."

G.Hüttl-Worth, Tred.s Feopt., S.967: "...die Ableitung wird nach dem Cлoвapb 1771 zum ersten Mal genannt".

Anders der 'хрон. словник', nach dem 'необходимость' schon zu Anfang des XVIII.Jh.s in den "Zapiski Andreja Artamonovica grafa Matveeva" zuerst belegt ist (S.351).

' незримый'

III,319f. От видимых не всех, но ведомых неложно, Незримых уж отнодь мечтать нам тьмы возможно, -

Diese Belegstelle ist alter als die für 'незримый' im 'хрон. словник', S.322 angegebene in Tilem.I,78 (1766).

'пространность' (Ausdehnung)

VI,260f. Слеаует, что самый лучший есть из есех мир сей И что ееличайший по пространности он өсей.

Nach G.Hüttl-Worth (S.967) eine Ableitung "von seit dem Aruss. belegtem пространный..."

' самодовольность' findet sich in der Prosaeinleitung zux VI.Ep. als Attribut Gottes. Der Terminus ist abgeleitet von dem bei Miklosich belegten Adj. самодовольнъ (Mikl.819).

' самоизвольность' etwa 'Willenskraft aus sich selbst' (G.Huttl-Worth,967)

VI,150f. Должно присвоять еще и самоизвольность:

К дейстөу му́арейших причин имать бог довольность.

G.Huttl-Worth weist hin auf 'Oумъ...самоизволенъ' (XV.Jh., einmal, Sreznevskij) und vermerkt: "Weder das Adjektiv, noch die Ableitung ist erhalten".

'corласность' (Harmonie)

I,274 …согласность, бемол делается сам и Аур,

Nach G.Hüttl-Worth (S.967): "Dublette zu altem cornache". 
Dem 'хрон. словник' (S.336) zufolge ist das Wort zuerst belegt in Tred.s

' сочинения и переводы', I,48 (1752).

' самолобность'

I,249 То самопобность есть, что корень меж страстями -

Hier zum ersten Mal belegt, nach 'хрон. словник', S.334.

' свойственность'

V,28 Из свойственностей тел, ни сии с теми свесть

Erstbelegung, nach 'хрон. словник', S.334.

'счетанность'

VI,250 Миром называю я всех вещей счетанность -

Erstbelegung, 'Хрон. словник', S.337.

'тленность'

VI,199 Не теряет ничего сею он ирез тленность -

G.Hüttl-Worth (S.968) verweist auf aruss. und ksl. "t'lenyi, $t$ 'lenie".

Dem 'хрон. словник' zufolge findet sich 'тленность' zuerst bei Lomonosov,

'Собрание разных сочинений' 2-е изд., I,387.

'умеренность'

II,504 Кто ж возаух весь привел в умеренность сию -?

G.Hüttl-Worth (S.968) verweist auf Polikarpov 'oymepeнne' (moderatio, temperatio).

'цельность'

VI,9 Состояния притом сущнуо и чельность -

Ableitung vom Adj. पeлъ, bei Mikl. (1107) mit 'totus' wiedergegeben.

Dieser Beleg ist alter als der im 'хрон. словник' (S.341) angegebene: danach

kommt 'чельность' zuerst in Tred.s 'Сокращение философии...Бакона', Т.I,78 (1760) vor.

Syntax

FaBt man die Syntax der Feoptija ins Auge, so fallen bestimnte Măngel auf, die von der Kritik immer wieder beanstandet worden sind: die verworrene Wortfolge, die verschachtelten satze und dic meist langen und schwerfalligen Perioden. D.Blagoj bemăngelt an der Sprache Tred.s besonders die zahlreichen Inversionen: "В соединении с искусственно затруаненным синтаксом зто делает многие его стихи почти непонятными русскому читателю." 42 wohl etwas uberspitzt urteilt Blagoj. Tred. habe die 'Erschwerung' bewuBt als sprachliches und stilistisches Mittel benutzt: "Вообще сознательное усложнение, запутанность, как 
бш намеренная затрудненность являотся отличительтыи чертами И язшка И стиля Tредиаковского." 43 Ahnlich scheint L.V.Pumpjanskij, auf den sich silbajoris beruft, uber die 'latinisierte syntax' Tred.s zu denken. Silbajoris schreibt: "L.V.Pumpjanskif thinks that Trediakovskif delibertately sought to make the reading of 'noble' poetry difficult, mostly by means of 'Latinized' syntax. " 4 Die erwăhnten Merkmale sind aber nicht auf die syntax beschrankt, sondern kennzeichnen die Sprache Tred.s im ganzen. Wahrscheinlich zeigt sich in ihnen der EinfluB des Kirchenslavischen. Speziell zur Syntax der kirchenslavischen Sprache bemerkt V.v.vinogradov in seinem Buch 'Язык Пуикина': "Порядок слов, зто был большой вопрос синтаксиса церковно-славянского языка XVIII века... Когда в начале XIX века представители новой литературы говорили о 'старом слоге', то они прежде всего ббиняли его в 'запутанной расстановке слов' и в 'затруаненном движении мысли по тягучим периодам'." 45

Die 'sапутанность слов' kann an folgenden Beispielen aus der Feoptija deutlich werden:

III, $100 \mathrm{f}$. ОАнак произведен слон инако судьбою

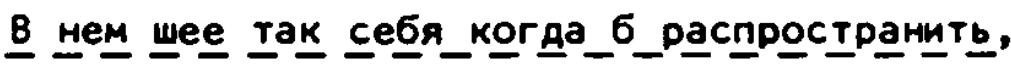

То 6 та могла собой его обременить...

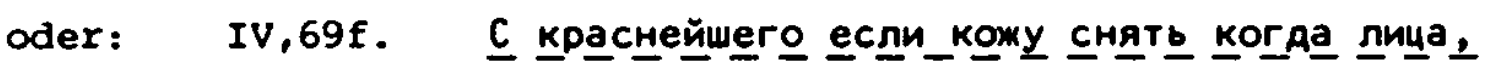
Мерзков явится красота вся до конца,...

Im allgemeinen wird die Wortfolge, wie in den zitierten Versen, durch metrische Gründe bestimnt.

Schwerfallige Satzgefüge mit Inversionen sind in der Feoptija zahlreich. Ein Beispiel dafür ist etwa die Beschreibung der Gelenkfunktion:

IV,230ff. От Аругой дабы одна возмогла скоряе

Повернуться, и чтоб быть Авигам их споряе,

Не препятствуощим прочему быть ничему

Движимому в теле, в стройном ларе, потому.

An anderer stelle sucht Tred. umstándlich zu erklăren, daB er sich nicht auf Schulmeinungen einlassen wolle, die in der Alleinwirksamkeit cottes einen Widerspruch gegen die 'cooperatio' des Menschen sehen:

VI,415ff. Но взражает школа пусть трудностей доводы:

С нас содействий правды предовольно есть сея,

Трудностей в разборы не вступаю здесь те я.

Satzbildungen dieser Art bestatigen die kritischen Urteile über die Syntax in den versen Tred.s. A.A.Iljušin vermerkt: "...ему редко удавалось простой, про- 
ясненный синтаксис...По-видимому, мешал ему и баснословный его педантизм. "46 Auch Timofeev stellt fest, daß Tred. es 'nicht vermocht hat, den Rhythmus organisch mit dem Satzbau zu verbinden': "Уловив новый тип ритма, Тредиаковский не сумел сколько-нибуаь органически связать его с новим строем Фразы, с новым порядком слов." 47

Diese Urteile sollten jedoch nicht verallgemeinert werden. In der Feoptija gibt es auch zahlreiche Passagen, die sich durch eine 'einfache und klare Syntax' auszeichnen. Dazu gehōrt z.B. die Schilderung der Gebirge:

II,145ff. Неравности Земли быть мнятся не услужны, Но те $\mathrm{k}$ ее красе, а $\mathrm{k}$ пользе нашей нужны. Где Иаут Гор Хребты, долины стольки 2 там, На пищу в них трава преславная скотам. 3 ними вкруг поля и нив бразды желтеют, Богатых класы жатв волнуются и спект.

Rhythmus und Satzbau stimmen vielfach uberein wie in den Versen vom 'Erwachen III,485ff. Потом, как пролиет заря свой яркий блеск, Встает и человек, и каждый скот и меск. Забвенны все труды, вся тяГость миновалась, Отъята сила вновь дается как давалась; -

Stil

Auf die stilistische Vielfalt der Feoptija hat I.Serman bereits in seinem Aufsatz 'Неизданная философская поэма В.Тредиаковского' (1961) aufmerksam gemacht. Er fuhrt aus, der Autor bemune sich, mit Hilfe der Epistelform 'seiner Darlegung einen gemeinverstăndichen, natürlicher. Gesprächston beizulegen': "... самом стиле поэмы заметно стремление автора придать изложению популярность и непринужденность тона, свойственного живой беседе". 48 Dieser Ton lieB sich jedoch - so I.Serman - vor allem in der I. und VI.Epistel, in denen 'auberst schwierige metaphysische probleme' erortert werden, nicht durchhalten. So ergeben sich in der Feoptija zwei verschiedene, jeweils durch den Inhalt bedingte, Stilschichten: "ОАин стилистический ряд образуот собственно философские рассуждения, Аругой - картины и примеры, особенно взятые из живой природы." 49

Timofeev spricht allgemein von der stilistischen vielfalt in der Dichtung Tred.s und stellt sie der Forderung Lomonosovs nach 'Einheit des Stils' gegen über: "В отличие от Ломоносова стремившегося К строгому единству стиля, что 
так отчетливо и сказалось в его теории трех стилей, Тредиаковский стремится к многостильности речи..." 50

A.Iljứuin unterscheidet in der Feoptija zwei gegensatzliche stilformen: die erste bestehe aus 'gereimten Erwaggungen' (рифмованные рассукдения), die 'in der Regel in einem ruhigen, leidenschaftslosen und unpoetischen stil gehalten' seien: "...выдержанные, как правило, в спокойном, основательно-бесстрастном стиле, Аалеки от поззии. Всё размерно, рассудочно... 51 - Im Gegensatz dazu wird die andere stilschicht in der Feoptija von Iljusin so charakterisiert: "Но местами... прорываются змоции, 'восторг пиитический'." 52 Als Beleg fürt er das 'kosmische Gemălde' in Feopt.II,768-771 an:

\section{Кто легионам звезд места дал пригвожденны -?}

Auch bei der Schilderung des Obstgartens in II,293ff. fallen die emotionalen züge auf. Iljusin bemerkt: "Tредиаковского волнует не только космические пейзажи, но и явления земной припоян, земного быта:

'А красный взору сад, плодом обремененный - ." 53 (II,293)

Was den stil der Feoptija angeht, ist der hăufige 'Wechsel der Tơne' (Siegrist) besonders bemerkenswert. Der Autor wechselt oft unvermittelt vom vertrauten Gesprăch zur leidenschaftlichen Polemik, von der philosophischen Argumentation zum feierlichen Bekenntnis, von der trockenen Information zu erbaulichen Betrachtungen und begeisterten Ausrufen, von der dogmatischen Belehrung zum hymnischen Lobpreis. Dabei tritt der Autor dem Leser in den verschiedensten Rollen vor Augen: als Freund des fiktiven Evsevij, als Apologet und Glaubensstreiter, als Gelehrter, Geschichten- und Legendenerzahler, als Prediger und Beter.

Woraus erklart sich diese Vielfalt? Einmal aus der Person Trediakovskijs: als Professor der Rhetorik wubte er ihr reiches Repertoire zu nutzen, als fleiBiger Ubersetzer war er an minuziōse Genauigkeit gewöhnt. Er hatte bereits Gedichte im stil der Landschaftslyrik und oden verfaBt und war auch in der dramatischen Form nicht ungeübt.

Zum andern beruht diese Vielfalt auf den stilistischen Besonderheiten des physikotheologischen Schrifttums und des Lehrgedichts. W.Philipp kennzeichnet den Stil der Physikotheologen als "affektbetont, uberladen....missionarisch drăngend, pathetisch: andererseits /äls/ genau und kleinlich, gelegentlich...trivial, utilitaristisch". ${ }^{54}$ Ferner ist stilistische vielfalt fur das Lehrgedicht als 'Mischform', die "epische, lyrische und dramatische Töne und Darstellungsmodi" enthalt, gattungstypisch: "Die Gattungsmischung, die Zusam- 
mensetzung heterogener Elemente zu einem Ganzen bedingen...den Wechsel des Tones", stellt Siegrist fest. ${ }^{55}$ Ex unterstreicht: "Da jede Gattung inren besonderen Ton hat, kann man als Merkmal des Lehrgedichtes bestimmen, daB dieses im Wechsel der Töne besteht." 56

Die Beobachtungen zum Stil dex Feoptija bestătigen noch einmal, was die Untersuchung des Ganzen erbracht hat: die Verwurzelung des Poems in der physikotheologischen Weltanschauung und seine Zugehörigkeit zu dex um die Mitte des 18.Jahrhunderts in Europa dominierenden Literaturgattung, dem Lehrgedicht. 


\section{ANMERKUNGEN}

\section{Vorwort}

1 Paul н а z a $r$ d, Die Krise des europåschen Geistes, Hamburg 1939,5.475

2 Bericht des Vf. an Prof.Dr.Gerhardt, Hamburg, vom 17.0kt.1975

3 E.N.L e b e d e v, Filosofskaja Poezija V.K.Trediakovskogo, in:Russkaja 1iteratura 1976/2, Jg.XIX,Leningrad,S.94-104

1.Kapitel: Voraussetzungen und tberlieferung der Feoptija

Leben und Werk Trediakovskijs

1 V.K.T r e d 1 a k o v s k i j, Ezda v ostrov Ljubvi, k citatelju,spb.1730 2 ebd.

3 P.P.P e k a $r$ s i j, Istorija Imperatorskoj Akademil Nauk v Peterburge, T.II, SPb.1873, S.2f.

4 P e k a r s k j, a.a.0.s.3

5 zapiski Akad.Nauk, VII, prilož.No.4, zit. P e k a r s k i j, a.a.0. s.3/4

6 P e k a s k i j, a.a.0. S.4

7 ebd., s.4/5

8 zit. P e k a s k i j, a.a.0. S.284, nach d. Materialien zur Biographie Lomonosovs, hrsg. v. Biljarskij

9 zit. P e k a $s k i j$, ebd.

10 zit. Pe k a $s k i j, a . a .0 .5 .5$, nach V.k.Tred.,Ezda v ostrov...predislovie

11 zit.p e k a s k i f, a.a.0. S.6

12 zit.p e k a s k 1 j, a.a.0. 5.7

13 P e k a s k 1 j, a.a.0. s.6

14 zit. P e k a s kij, a.a.0.,5.6/7

15 s. P.N. $B$ e $r$ k $\circ$, Tred. et l'Abbe Girard, in:Des Relations Litt. Franco-Russes, Revue des etudes Slaves 35,Paris 1958,s.11

$16 \mathrm{P}$ e $k$ a $r \mathrm{~s} k \mathrm{i} j, \mathrm{a} . \mathrm{a} .0 ., 5.7$

17 L.I. T i m of e e v, Vstupitel'naja stat'ja, S.12, in:V.K.Tred.,Izbrannye Proizvedenija,M.-L. 1963

18 P. H а z a r d, a.a.o., s.103 
19 zit. $\mathrm{p}$ e k a $x$ s k j, a.a.0.,s.8

20 P. B e $x$ k O v, a.a.0.,s.10, Anm.2

21 zit. $P$ e $k$ a $x \mathrm{~s}$ i j, a.a.o., s.8

22 zit. $P$ e $k$ a $r k i j$, ebd.

23 ebd.

24 ebd.

$25 \mathrm{ebd}$.

26 S.P.N. Berkov, a.a.O.

27 ebd.

28 L.V. P u m p j a n $s$ i j, Tred. i nemeckaja Skola razuma, in: Litera= tury Zapada. Zapadnyj sbornik p.red.V.M. Żirmunskogo,M.-L. 1937,S.157

29 zit. P u m $\mathrm{j}$ a n s kij, a.a.0., s.158

30 ebd.

31 s. P e k a r skij,a.a.0.,s.11

32 zit. P e k a $r$ ki j,a.a.0.,s.11

$33 \mathrm{~T}$ i mof e e v, a.a.o.,s.24

34 P e k a $r k i j, a . a .0 ., s .13$

35 zit. $P$ e $k$ a $r$ s $i j$, ebd.

36 zit. $P$ e $k$ a $r s k i j, a . a .0 ., s .12$ und $T i m \circ f e r v, a . a .0,, s .25$

37 s. Timof e e v, a.a.0.,s.24

38 zit. P e k a r s k j, a.a.0.,s.14

39 zit. P e k a s kij, a.a.o.,s.20

40 zit. P e k a r s k j, a.a.0.,s.20

41 s.P.N. B e $r k \circ v$, in: Wiss. Zs. d.Univ. Rostock 6,s.11

42 zit. $\mathrm{p}$ u m jans kij, a.a.0., s.176

$43 \mathrm{P}$ u m ja n s $\mathrm{ij}$, ebd.

44 s.P u m $\mathrm{p}$ a n $\mathrm{s} k \mathrm{i} j$, ebd.

45 p u m p j a skij, a.a.0., s.180

46 ebd.

47 s.P e k a r s kij, a.a.0.,s.14

$48 \mathrm{~T}$ i mo f e e v, a.a.0.,5.23

49 s. P e k a r s k j, a.a.o., s.21

50 zit. T $i$ m o f e e v, a.a.o.,s.14f. nach: A. Malein, Novye dannye dlja biografii V.K.Trediakovskogo, sbornik ORJaS,T.CI,No.3,L.1928,S.431f.

51 zit. P e k a r s k j, a.a.0.,s.30

$52 \mathrm{ebd}$. 
53 zit. P e k a $r$ s $i j, a . a .0 .5 .37$

54 L.I. T i m of e e v, a.a.o. S.23

55 zit. Pekars k 1 j, a.a.o. S.39, nach: Meloki 12 zapasa moej pamjati, M.Dmitrieva, 2-e 1zd. M.1869, str.5/6

56 zit. $T 1$ to of e e v, a.a.o. S.13

57 T i mof e e v, a.a.o. S.25

58 zit. P e k a s k 1 j, a.a.o. s.47

59 zit. $P$ e $k$ a $r$ s $k$ j, a.a.o. s.46

60 s. Barthold Beinrich B r c k e s, Auszug der vornehmsten Gedichte aus dem Irdischen Vergnügen in Gott, Stuttgart 1965, S.118

61 K. $R$ i c h t e r, D.Kopernikanische Wende in d. Lyrik von Brockes bis Klopstock, in:Jb.d.dt.Schiller-Ges. 1968,S.132-169

62 P e k a r k i j, a.a.0. S.35

$63 \mathrm{~T}$ i mof e e v, a.a.o. S.49

64 zit. P e k a s k i j, a.a.o. s.22

65 zit. P e k a s k i j, ebd.

66 Christoph $s i$ e $g$ r i s $t$, Das Lehrgedicht der Aufklărung, Stgt.1974, S. 19

67 Epigraph z. Porträt Tred.s in: Feoptija, a.a.o. S.320

68 P e k a s k 1 j, a.a.0. S.50

69 T 1 mof e e v, a.a.o. S.29

$70 \mathrm{~T}$ i mof e e v, a.a.o. S. 28

71 vgl. Günther $w$ y $t r z$ e $s, v . K$. Tred. als Etymologe, in:Wiener Slav. Jb. 21 (1975)

72 zit. P e k a s k i j, a.a.0. s.226

73 zit. T $i$ m of e e v, a.a.o. S.15/16 nach: Bibliografičeskie zapiski, 1858, Nr.18, stlb. 556

74 D.D. B 1 a $g \circ j$, Istorija Russkoj Literatury XVIII v.,Moskva $1960^{4}, 5.90$

75 T 1 mof e e v, a.a.o. S.34

76 T 1 mof e e v, a.a.o. S.34/35

77 zit. $T 1$ m of e e v, a.a.0. S.35

78 zit. P e k a s k i j, a.a.0. s.70

79 zit. P e k a s k i j, a.a.0. S.96

80 zit. T 1 m of e e v, a.a.o. S.16, nach:v.Varencov, Tred. 1 charakter nasej obscestvennoj $\mathbf{z}_{\text {izni }} v$ pervof polovine XVIII stoletija, Mosk.vedemosti, 1860,18 .fevr.str. 284 
$81 \mathrm{P}$ e k a r s k i j, a.a.0., s.107

82 ebd.

83 etrd.

84 zit. P e k a r s k i j, a.a.0., s.161

85 zit. $P$ e $k$ a $r$ s $i j, a . a .0 ., s .165$

$86 \mathrm{P}$ e k a r s k i j, a.a.0., s.173

87 ebd., S. 183

88 zit. P e k a r s k i j, a.a.0., s. 183

89-90 p e k a r s k j j, a.a.0., s.187

91 s. B 1 a goj,a.a.o., s.121

$92 \mathrm{P}$ e k a r s ki j, a.a.0., s.205 und Primečanija z. Feoptija, s.508

93 P e k a r s k j, a.a.o., s.205

94 zit. P e k a s kij, a.a.0., s.208

95 zit. p e k a r k i j, a.a.0., s.209

96-98 zit.ebd.

99 zit. $P$ e k a r s kij, a.a.0., s.210

100 P e k a s s k j, a.a.0., s.210

101 zit. P e k a s k i j, a.a.0., s.229

Der geistesgeschichtliche Hintergrund

1 Wolfgang $P$ h $i$ l $i$ p p, Das Werden der Aufklarung in theologiegeschichtlicher Sicht, Marburg 1957, S.16

2 vgl. W.W i $n$ d e $l$ b a $n d$, ed. H.H e $1 \mathrm{~m} s$ o $t h$, Lehrbuch $d$. Gesch. d. Philosophie, Tubingen 1935, S.153f.

3 н.В 1 u m e $n$ b e r g, Kopernikus im Selbstverstăndnis der Neuzeit, in: Abhdlg. d. Geistes- u. Sozialwiss. Klasse, Jg.1964 Nr.5, Mainz, S.343-45

4 w.P h i l i p p, a.a.0., s.98

5 ebd.

6 ebd.

7 H.B 1 u m e n b e r g, a.a.0., s.347

8 elua., S. 366

9 w.P h i l i p p, a.a.0., S.59

$10 \mathrm{vgl}$. E.H e i n $t$ e 1, Tierseele u. Organismusproblem im Cartesianischen System, in: Wiener Zs.f.Philosophie u.Psychologie Nr.3 (1950), S.73-120 
$11 \mathrm{vgl}$. R. S p e c h t, Commercium mentis et corporis, Uber Kausalvorstellungen im Cartesianismus, Stgt.-Bad Cannstadt,1966

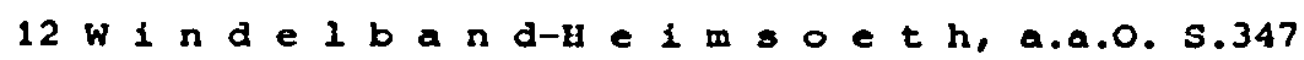

13 ebd.

14 A. P O p e, An Essay on Man, Twickenham Ed., London $1970^{2}$

15 w. P h 1 l i P P, a.a.o. 5.79

$16 \mathrm{ebd}$.

17 w. Phi l i p p, a.a.o. S.182 u.80

18 w. P h I I I p, a.a.o. S. 182

19 ebd.

20 w.P h 111 p p, a.a.0. S.66

21 W.P h 11 i p p, a.a.o.s. $44 f$.

22 w.P h 1 i i p p, a.a.0.s.155

23 zit.w.P h $i 11$ p p,a.a.0.s.61

24 zit.w.P h 1 i 1 p p, a.a.0.S. 71

25 w.P h 1 l 1 p p, a.a.0. S.103

26 zit.w.p h $i \mathrm{l}$ i p p,a.a.0. 5.65

27 zit.w.P h $i 11$ p p,a.a.o. S.155

28 w.P h 111 p p. a.a.0. S.66

29 W.P h $i$ i $i$ p. a.a.o. S.71

30 w.P h 1 i i p p,a.a.o. S.21ff.

31 w. P h 11 i p p,a.a.0.s.71

32 Titelangaben bei $P$ h 11 p p, a.a.o. S.23

33 Titelangaben ebd.

34 F $n$ e $1 \circ n$, Demonstration de $l^{\prime}$ existence de Dieu...s.8f.

35 B.H. B r o ckes, a.a.o. S.128

36 Fé n e 1 ○ n,a.a.o.s.9

37 B.H. B $r \circ c k$ e s, a.a.o. $\$ .575$

38 F e n e 1 on, a.a.o. 5.7

39 B.н.B $r \circ c k$ e s, a.a.o. 5.582

40 fe n e 1 o $n, a \cdot a \cdot 0.5 .12$

41 B.н.B r $\circ k$ e s, a.a.o.s.437f.

42 B.H.B $r$ O cke s, a.a.o. 5.453

43 H.M.W $\circ 1 \mathrm{f}$, Brockes' Religion, in:Publications of the modern language association of America (PMIA) $62,1947 \mathrm{Nr}, 4,5.1124$ 
44 B.H.B $x$ O C k e s, a.a.O. S.153

45 W. Ph 11 i p p, a.a.0. S.158

46 w. P h 11 i p p, a.a.n. S. 103

$47 \mathrm{w}$ i n d e I b a $\mathrm{nd}-\mathrm{H}$ e $1 \mathrm{~m}$ s $\circ$ e $t$ h, a.a.0. 5.353 u.357

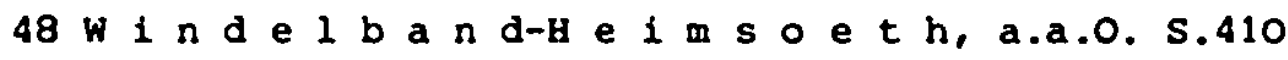

49 A. $p \circ p$ e, Essay on Man, Ep.r, $291 f$.

$50 \mathrm{w}$ i nde $\mathrm{l}$ b a $\mathrm{nd}-\mathrm{H}$ e ims o e $t \mathrm{~h}, \mathrm{a.a.0.5.412}$

51 ebd.

52 zit. P h i 1 i p p, a.a.0. S.60, nach:I.Newton, Kolner Ausg.1760,III,673

53 w.P h 1 i $i$ p p, a.a.o. S.174

54 ebd.

55 zit. P.H a z a r d, a.a.o. S.450

Die Uberlieferungsgeschichte der Feoptija

1 zit. P e k a s k i j, a.a.o. S.173

2 zit. p ka r s k $1 j, a . a .0 .5 .174$

3 zit. ebd.

4 zit. ebd.

5 zit. P e k a s k i j, a.a.o. s.174f.

6 zit. P e k r s kij, a.a.o. s.176

7 vgl. P e k a $r$ s kij, a.a.0. S.183, s.oben S.19

8 zit. P e k r s k i j, a.a.o. s.203

9 zit. ebd.

10 zit. P e k a r s i f, a.a.o. S.204

11 P e k a 8 k i j, ebd.

12 Primečanija z. Feoptija, a.a.0. S.508

13 ebd.. S. 509

14 ebd.

15 I. S e $r$ m a n,Neizdannaja filosofskaja poèma V.Treciakovskogo, in:Russk. literatura, Istoriko-1iteraturnyj Zurnal, god izd.4 No 1,Leningrad 1961

16 I. S e r ma n, a.a.0. S.160

17 zit. I. S e r m a n, a.a.0. S.160 Anm.

18 I. S e r m a n, a.a.o. S. 160

19 I. S e $r$ m a n, a.a.o. S.161 
2.Kapitel: Textbegleitende Interpretation

I.Epistel: Philosophische Beweise für die Existenz Gottes

1 Paul $A$ l $t h$ a $u$, Der Brief an die Romer, in:Das Neve Testament Deutsch, Bd.6, Gottingen 1946, S.14

2 B.H.B r O c k e s, a.a.0.,s.685

3 Chr. S i e grist, a.a.0.,S.164; vgl.A.Pope, Essay on Man,Ep.I, 1: "Awake, my St.John!"

4 E.N.L e b e d e v, Filosofskaja Poézija V.K.Trediakovskogo, in:Russk.lit. 1976/2, Jg.XIX,Leningrad, S.99,Anm.19 - und I. S e $r$ m a n,a.a.0.,S.167

5 s.Rainer $s p e c h t$, Commercium mentis et corporis, Kausalvorstellungen im Cartesianismus, Stuttgart-Bad Cannstadt, 1966,S.60f.

6 vstupitel'naja stat'ja zur Feoptija, S.511

7 W. P h i l i p p, a.a.0., 5.72

8 Windelband-H e $1 \mathrm{~ms}$ o e $\mathrm{th}, \mathrm{a} . \mathrm{a} .0 ., \mathrm{s.330}$

9 s. H.W.J $\mathrm{g}$ e $\mathrm{r}$, Zur Poetik der Lehrdichtung in Deutschland, kritische Zusatze zu L.L.Albertsens Buch 'Das Lehrgedicht'. Dtsch.Vierteljahrsschr. 44, 1970, S.552, Anm. 33

10 windelband-H e $i \mathrm{~m}$ s o e $\mathrm{h}$, a.a.0.,s.152ff.

11 ebd. .s.330f.

12 R.S p e c h t, a.a.0., s.57f.

13 windelband-H e $i$ m s o e $t h, a . a .0 ., s .342$

14 R.S p e c h t, a.a.o.,s.57f.

15 R.S p e c h t,a.a.0.,s.39f.

16 R.S p e c $h t, a . a .0 ., s .148 f$.

17 s.Windelband-H e $i \mathrm{~ms}$ e $t \mathrm{~h}, \mathrm{a} . \mathrm{a} .0 ., \mathrm{s.235}$

18 B.H.B r O c k e s, a.a.0.,S.15

19 s.chr.s i e g r is t, a.a.0.,s.74

20 s.Windelband-H e $i$ m s o e $t$ h,a.a.o.,s.153f.

21 H.P.Herrmann, Naturnachahmung und Einbildungskraft,zur Entwicklung der deutschen Poetik von 1670-1740, in:Ars poetica,Bd.8,Bad Bomburg,s.141

22 D.T $s$ c $h i z$ e $w s k i j, z u$ den Komposita in der sprache Tred.s, in: Zs.f.slav. Philologie XVII 1941, S.115

$23 \mathrm{ebd} . \mathrm{s} .114$

24 W.P h 1 i i p p, a.a.0.,s.63 (zit.) 
25 1t. Auskunft von Prof.Dr.Rudolf $R$ e $u t$ e $r$, Musikwiss.Seminar der Univers. Munster, der auch die Richtigkeit der techn. Angaben im orgelvergl. Tred.s bestatigt

26 Die russisch-orthodoxe Kirche kennt die Orgel als Kultinstrument nicht

27 Gerta $\mathrm{H}$ a $t$ t $1-w \circ r t h$, Tred.s Feopt. in:Orbis scriptus, Festschrift f.D.Tschižewskij, München 1966, S.971

28 Religion in Gesch. und Gegenwart (RGG),Bd.IV ${ }^{2}$, S.758, Artikel:orgel 29 zit.W.P h 1 i 1 p p, a.a.0.,s.155

30 Augenscheinlicher BeweiB..., Hamburg 1714,5.14

31 Primečanija zur Feopt. I, 350,s.513

32 ebd., S.513

33 E.N.L e b e d e v, a.a.0.,5.99

34 windelband-H e $i$ m s o e $t h$, a.a.0.,s.153

35 ebd., S. 142

36 Gerta H U $t$ t 1-w or $t h$, a.a.0.,s.966

37 Windelband-H e $1 \mathrm{~m} s$ or t h, a.a.0.,s.409,Anm.

38 Gerta $\mathrm{H}$ u $t \mathrm{t} 1-w \circ r t h, a . a .0 ., 5.966$

39 windelband-H e 1 m s o e $t h, a . a .0 ., 5.330$

II. Epistel: Die Beschaffenheit der Erde und der Gestirne setzt die Existenz des Schöpfers voraus

1 Windelband-H e $1 \mathrm{~m}$ s 0 e $t \mathrm{~h}, \mathrm{a} . \mathrm{a} .0 ., 5.414$

2 zit.chr. s 1 e gris t, a.a.0.,s.185

3 zit.chr. S 1 egr 1 s $t, a . a .0 ., s .283$, Anm.74

4 Theol.Wórterbuch zum Neuen Testament,hg.G.F r 1 e d r 1 c h,Bd.VIII,S.318 Art. 'hydor'

5 D. $T s c h i z$ e w $k i f$, Komposita in d. Sprache Tred.s, a.a.0.,s.116

6 D. $T s c h 1 \mathrm{z}$ e w s kij, Komposita, a.a.0.,s.114

7 s.chr.s i e grist,a.a.0.,s.217

8 B.H.B $r \circ c k$ e s, a.a.O.,s.128

9 Gerta Huttl-w $\circ$ r $h$, D.Bereicherung des russ.Wortschatzes im 18. Jhd., Wien 1956, S.96

10 B.H.B r $\circ$ cke s, a.a.0.,s.130

11 ebd., S. 453 
12 B.H.B r O C k e s, a.a.O.,S.437ff.

13 ebd. .5 .438

14 P.н а 2 a $r$ a, vie $k r i s e$ d. europ.Geistes, a.a.0.,s.32

15 Primečanija z.Feopt.II,483,S.515: "meteory'-vetry, poroždaemye skopleniem gazov".

16 ebd.,S.515, zu Feopt.II,484

17 Chr.s i e gris $t$, a.a.0.,s.132

18 B.H.B $r \circ c k$ e s, a.a.0.,s. 37

19 ebd., 5.477

20 H.B 1 u m e n b e $r$, Kopernikus im Selbstverstănanis der Neuzeit, Abhal. d.Geistes- U.Sozialw.Kl.,Jg1964 Nr.5, Mainz, S.352

21 zit.h.B 1 u m e n b e r g, a.a.0.,s.352,Anm.1

22 P.A 1 th a u s, D.christl. Wahrheit,Bd.2,S.61f., Gütersloh 1947

23 ebd., s.62

24 s.P e k a r s k i j, a.a.0.,s.8

25 A.P O $p$ e, Essay on Man, ed, by M.M a $c$ k,Twickenham Ed.,S.93,Anm.zu III,9

26 B.H.B r O cke s, a.a.0.,s.673

27 Chr.s i e gris $t, a . a .0 ., s .93$

28 ebd.

29 Chr.Huygens, zit.w. P h 1 i i p p, a.a.0.,s.61

30 Chr. s i e gr is t, a.a.o.,s.102

31 ebd.

32 I.s e r m a n, Neizdannaja filos. poèma,a.a.o.,s.165

33 R.s p e c h t, a.a.o.,s.173

III. Epistel: Macht und Weisheit Gottes werden an der Tierwelt aufgezeigt.

1 D.Ts c h 1 z e,w.skij, Komposita, a.a.o.,s.116

2 vgl. W.P h 1 i i p p, a.a.0.,s.48-50

3 D.T s C hiž e w s k i j, Komposita, a.a.o.,s.114

4 ebd., S.118

5 vgl. L.L.A 1 b e $x$ t $s$, Das Lehrgedicht, Aarhus 1967,s.243

6 H.R $0 t h$ e,Einflüsse in der russ. Lit. des 18.Jh.s, in:2tschr. f. slav. Philologie 1966, S.32 -

vgl. J.P.G 1 o c k, Die Symbolik der Bienen, Heidelberg 1891

vgl. K.K n o r $z$, Die Insekten in Sage, Sitte und Literatur, 1910 
7 B.F a b i a n, Die didakt. Dichtung in der engl. Lit.-theorie des 18.Jh.s in:Festschr. f.W.Fischer, Heidelberg 1959

B.F a b 1 a $n$, Pope und d. gold. Kette Homers, in:Angl1a 82 (1964),s.150

8 B.F a b i a n, Pope u. d. gold.Kette Homers, a.a.0.,5.150

9 ebd. S.151

10 ebd. . S. 150

11 M. Ma c k, A.Pope, Essay on Man, Anm. zu Ep.I,43-50, S.18f.

12 B. F a b i a $n$, Pope u. d.gold.Kette Homers, a.a.0.,5.152

13 M. M a c k, a.a.O., Anm. z.Ep.I,30f.,S.17

14 B. Fa b i a n, a.a.O.,S.154

15 ebd., S. 169

16 V.G i t e r m a n n, Geschichte RuBlands, Frankfurt a.Main, 1965,S.159

$17 \mathrm{chr} . \mathrm{s} i$ e gris $\mathrm{r}$, a.a.o.,s.131

18 Theol.Wb. 2.NT,Bd.VII, S.491, Art. 'sophia'

19 zit. Chr.s i e g r i s t,a.a.0.,s.124, nach:A.v.Haller, Tagebuch II,97

20 vgl. P.H a $z$ a $r$ d, a.a.O., S.355

21 vgl. W.P h 111 p p,a.a.0.,\$.105

22 zit.P.H a z a r d, a.a.O.,s.454

23 zit. ebd.

24 R.S p e c h t,a.a.o.,s.61

25 vgl. R.S p e c h t, a.a.0.,s.9

$26 \mathrm{vgl}$. E. H e in t e l, Tierseele und organismusproblem, in:wiener ztschx. f. Philosophie u. Psychologie Nr.3 (1950), s.73-120

27 zit. E.H e in t e 1, a.a.0.,s.110, nach:Descartes, Disc.v, 9

28 R.S p e c h t,a.a.o.,s.174

29 zit. E.H e i n t e l, a.a.o.,s.112

$30 \mathrm{vgl.E.H}$ e i n t e 1, a.a.0., s.110

$31 \mathrm{vgl}$. Windelband-H e $i \mathrm{~m}$ s o e $t h, a . a .0 ., 5.411 \mathrm{f}$.

32 B.F a b i a $n$, Pope u. d. gold. Kette Homers, s.153

33 v.K.T $r$ e d $i$ a $k \circ v s k i j$, Feoptija, s.250, Anm.1

34 Theol. Wb. z. NT, Bd.V, S.495f., Art. 'osphys'

$35 \mathrm{Chr} . \mathrm{s}$ i e gr is $t, a . a .0 ., 5.63$

36 ebd.

37 Theol.Wb.z.NT, Bd.II,S.624, Art. 'hepta'

38 ebd., s.625

39 ebd. , S.624 
40 Theol.Wb.z.NT, Bd.VIII, S.128, Art. 'tessares'

41 ebd. , s.130

42 ebd.

43 ebd.

44 ebd., s. 131

45 ebd., s.133

46 ebd. .S.134

47 R.s p e c h t, a.a.0.,s.171

48 Chr.G e $r$ h a $r$ d $t$, D.kxiegslist d. Pelikans, in: Zs.f.dt.Altert.,S.115ff.

49 zit. Chr.G e $\mathrm{h}$ a $r \mathrm{~d} t$, a.a.o. nach: F.wilhelm, Denkm. dt. Prosa d. 11. u. 12.Jh.s, Bd.II,S.23, München 1914-18, Nachar. München 1960

50 vgl. R.S p e c h t, a.a.0.,s.61

51 zit. E.H e i n t e 1, a.a.0.,s.110, nach:Descartes, Disc.v, 9

52 vgl.R.s p e c h $t, a . a .0 ., s .174$

53 zit.E.H e in t e 1,a.a.O.,S.84, nach:Wilh.A.J.Meyer,Descartes' Entwicklg. in d.Erklårung d.tierischen Lebenserscheinungen, GieBen 1907

54 E.H e i n e 1, a.a.0.,5.84

55 vgl.E.H e int e l, a.a.0.,S.111, Anm.74

56 E.H e i n t e 1,a.a.0.,s.113

57 E.H e $i$ n $t$ e 1,a.a.O.,S.82, nach:A.v.Berger, Hielt Desc.d.Tiere für bewuBtlos?, Wien 1892

58 zit. E.H e in t e 1, a.a.0.,s.83

59 W.P h $\mathrm{i}$ i i p p,a.a.0.,S.175

60 vgl.Windelband-H e $i$ m s o e $t$ h,a.a.o.,s.378ff.

61 Windelband-H e $i \mathrm{~m} s$ e $t h, a . a .0 ., s .383$

62 ebd. .s. 382

63 ebd.

64 ebd. . S. 383

65 ebd.

66 vgl. R.S p e cht, a.a.0.,s.60f.

67 vgl. Chr.s i e gris $t$, a.a.0., s.142ff.

68 Windelband-H e $i \mathrm{~ms}$ o e $t h, a . a .0 ., 5.155$

IV.Epistel: Das Wunder des menschlichen Organismus weist auf den Schōpfer hin

1 zit. D. Bekenntnisschriften der ev.-luth. Kirche, Gottingen 1952, S.26

2 P.A 1 t h a u s, D.christl. Wahrheit, Bd.II,S.92, Gutersloh 1948 
3 zit.P.A 1 th a u s, a.a.0.,s.100

4 P.A 1 th a u s, a.a.0., s.92

5 eba., 5.94

6 ebd. . 5.94

7 ebd.. 5.93

8 H.P.H Y $r$ m a $n$, Naturnachahmung u. Einbildungskraft, zur Entwicklung der deutschen Poetik von 1670-1740, in: Ars poetica, Bd.8, S. 205

9 Chr.s i e gris t, a.a.0., s.70

10 ders.. s.71

11 vgl. Chr.s i e g r is t, a.a.0., s.71

12 Stowasser, Lat.-deutsches Schulworterbuch, S.466, München 1969

13 vgl. Gerh.M a 1 l e $r$, D.Habliche in Poesie und Poetik, in:Die nicht mehx schónen Künste (Poetik u.Hermen. III, S.13-21), Mch.1968

14 H.P.H e r m a n n, a.a.o., s.228

15 N.B $\circ$ i l e a u, L'art poétique, ch.III, 359, hrg.A.Buck,1970, S.93

16 H.L.A I n o I d, Nachwort z.L'art poetique, Reclam, S.112

17 H.P.H e rma n n, a.a.0., s.227

18 zit. P e k a s kij,a.a.O. II, 158

19 vgl. R.s p e c h t,a.a.0., s.61

20 D.T s c h i k e w k i j, Komposita, s.115f.

21 H.P.н e r r m a $n, a . a .0 ., 5.22$

22 vgl. P e k a r s k i j, a.a.0., II, 107

23 vgl. W.P h 1 i i p p, a.a.o., s.155

24 Chr.s i g $r$ is $t$, a.a.o., s.74f.

25 H.P.H e r m a $n$, a.a.0., s.22

26 D.Ts c h 1 V e ws ki j., Komposita, s.115

27 ders., S. 117

28 B.н.B $r$ ○ c $k$ e s, a.a.o., s. 33

29 ders.. S.116

30 Chr.s i e gris $t, a . a .0 ., s .194$

31 Theol. Wb. 2. NT, Bd.I,287 Art. 'duaptávw' (G.Q u e 1 1)

32 ebd.

33 ebd.

34 ebd. S.285

35 Theol.Wb.z.NT, Bd.I, 316 Art. '\&uaprávw' (W.G r u n d m a n n) 36 ebd.. 5.313 
V.Epistel: Das Zusammenwlrken von Geist und Korper offenbart Gottes Weisheit und Gute

1 Prosaeinleitung 2.V.Ep.d. Feoptija, BP,S.279

2 G e $r$ a $H$ a $t$ t.1-Worth, Tred.s Feoptija, in:Orbis Scriptus, Festochr. f. D.Tschižewskij, München 1966, S.971

3 Windelband-H e $i \mathrm{~m} s \circ$ e $t h, a . a .0 ., s .342$

4 vgl.Chr.s i e gris $t$, a.a.o.,s.153

$5 \mathrm{vgl}$. Windelband-H e $i$ th $s$ e $t h, a . a .0 ., s .383$

6 Windelband-H e $i \mathrm{~m} \mathrm{~s} \circ$ e $t h, a . a .0 ., s .347$

7 windelband-H e $i \mathrm{~m}$ s o e $t h, a . a .0 ., s .382$

$8 \mathrm{chr}$. S 1 e gris t,a.a.o.., s.153

9 windelband-H e $i$ m s o e $t h, a . a .0 ., s .331 f$.

10 ebd., S.332, Anm. 3 u. 2

11 R.S p e c h t,a.a.0.. s.57

12 ebd. . S.64

13 ebd. . S. $39 f$.

14 ebd. . S.66

15 ebd.. S.67

16 vgl. R.s p e c h t, a.a.o., s.141

17 R.S p e c h t, a.a.0., s.68

18 Windelband-H e $1 \mathrm{~m} s$ o $t h$, a.a.o., s.347

19 R.S p e c h t, a.a.0., s.57

20 ebd. . S. 59

21 Chr.e.l u $t h$ a $r$ d t, Kompendium d.Dogmatik, Leipzig 1889, S.193f.

22 R.S p e c h t, a.a.0.. 5.9

23 ebd., Hinweis auf Descartes' 'Cogitationes privatae' X,231, Ausg.v.Adam u. Tannery

24 vgl.w.p h 1 i i p p, a.a.o., s.47ff.

25 w.P h $i$ i p p. a.a.o., S. 49

26 ebd.. S.50

27 ebd. . S.49

28 R.S p e c h t, a.a.o., s.68

$29 \mathrm{ebd}$.

30 s.Windelband-H e i m $\mathrm{s}$ e $t \mathrm{~h}$, a.a.0., $\mathbf{s . 2 3 5}$ 
31 W.P h 1 I 1 p p, a.a.o., S.102, Anm.18

32 ebd. , s.72

33 P.A I t h a u s, D.Christl. Wahrheit, Bd.2, S.488

34 ebd., S.491

VI.Epistel: Die Eigenschaften Gottes - die Notwendigkeit des 'Füsprechers'die Notwendigkeit der offenbarung durch Christus

1 K.B a $r$ t h, D.Xirchliche Dogmatik, Bd.II,1 zürich 1952-70, S.390

2 W. E 1 e $x t, D . c h r i s t l i c h e$ Glaube, Hamburg 1956, S.228 Anm.

3 ebd., S.234, Anm.

4 ebd. ,S. 234

5 ebd.

6 vgl.W.E 1 e $x$ t, a.a.O.,S.228ff.

7 Chr.E.L u $t$ h a $r$ d $t$, Kompendium der Dogmatik, Leipzig 1889, S.97

8 ebd.

9 zit.K.B a $<$ th, a.a.O. Bd.II, 1 s. 340

10 windelband-H e 1 m s o e th, a.a.o.,s.245

11 ebd.

12 K.B a $x t h, a . a .0 ., B d . I I, 15.344$

13 Windelband-H e $i$ m $s$ o $t h, a . a .0 ., s .198$

14 ebd., S. 199

15 Theol. Wb. z. NT,Bd.VII, S.617 Axt. 'otépavos' (W.Grundmann)

$16 \mathrm{G}$ e $t$ a $\mathrm{H}$ a $t \mathrm{t}$ l-Worth, D.Bexeichexung des russ. Wortschatzes im XVIII. Jh., Wien 1956, S. 184

17 K.B a $r$ t h, a.a.O. Bd.II, 15.638

18 zit. K.B a $x t$ h, a.a.o. Bd.II,1 S.639, aus:Augustin, De civitate Dei,V,9,2f.

19 G e $r$ a H a $t$ l-Worth, Tred.s Feopt., 5.969

$20 \mathrm{ebd}$.

21 K.B a $r$ th, a.a.O., Bd.I,1 S.395f.

22 Religion in Gesch. U. Gegw. ${ }^{2}$ (RGG) Bd.III, 324

23 R.S e e b e $x \mathrm{~g}$, GrundriB d.Dogmengesch., Leipzig $1934^{6}, 5.49$

24 K.B a $x$ th, a.a.O.,BD.I.1 S.396

$25 \mathrm{zit.}$ Symb. Nicaen. in: Bekenntnisschriften d.luth.Kirche, Gottingen 1952, S. 26

26 ebd.

27 windelband-H e $i$ m $s$ e $t h, a . a .0 ., 5.412$ 
28 windelband-H e im $\mathrm{s} \circ \mathrm{e} t \mathrm{~h}, \mathrm{a} . \mathrm{a} .0 ., \mathrm{s} .412$

29 zit. bei Chr.E.L u $t$ h $r d t, a . a .0 ., s .130$

30 21t. ebd. s. 130

31 zit. ebd. S. 131

32 Gerta $\mathrm{a}$ a $t$ t 1 -Worth, D.Bereicherung d.russ.Wortschatzes, $\mathbf{5 . 8 1}$

33 zit. bei Chr.E.l u $t h$ a $r$ a $t$ a.a.o., s.131

34 Theol. Wb.z.Nr, 1,177-79 Art. 'alvurua (Ěoortpov)', G.Kittel, vgl. J.Behm, R.Seeberg-Festschr.I (1929), S.315ff.

35 samtl. Zitate, G.K it $t$ e 1, a.a.0.,S.177-79

36 W.P h 11 i p p, a.a.o.,s.173

37 zit. Chr.E.L u $t$ h a r d t, a.a.o.s.131

38 zit. ebd. S. 134

39 RGG,Bd.IV, S.811ff.

40 ebd. . 5.813

41 zit. Chr.E.I u $t h$ a $r$ d $t, s .134$ (ohne Quellenangabe)

42 W.P h 1 i $i$ p p, a.a.o., s.141

43 P.A I t h a s, D. christl. Wahrheit, II,S.62 u. 63

44 zit. Chr.E.L u $t h$ a $r d t, a . a .0 ., s .134$

$44 \mathrm{a}$ ebd.

45 Gerta $H$ a $t$ t 1-Worth, Bereicherung d. russ. Wortschatzes, S.193

46 zit. I u t h a $r$ a $t, a . a .0 ., s .135$

47 Chr.E. L u th a $r$ d t, a.a.0., s.136

$48 \mathrm{ebd} . \mathrm{S} .136$

49 Th. Wb.z.NT, Bd.I.271 u.295 Art. '\&uaptávw' (Stăhlin/Grundmann)

50 zit. Chr.E. L u t h a $r$ d t, a.a.0., s.136 (quenstedt, 0.Qu.)

$51 \mathrm{vgl}$. Windelband-H e $i$ th $s$ e $t h, a . a .0 ., s .378$

52 windelband-H e $i$ m $s$ e $t h$, a.a.0., s. 366

53 M. L u t h e r, Gr.Kat., in:Bekenntnisschriften, a.a.0., S.560

54 Th. Wb.z.NT, Bd.VI,112f. Art.' 'knYr'' (W.Michaelis) - vgl. Bernh.Blume, Lebendige Quelle u. Flut des Todes, in: arcadia 1 (1966) $\$ .18 .30$

55 zit. L u $t$ h a $x$ t, a.a.0., s.102 (Hollaz, 0.Qu.)

56 zit. ebd., S. 244 (Hollaz, 0.Qu.)

57 Th. Wb.z.Nr, Bd.v, 802 Art. 'rapáxintos' (J.Behm)

58 Prosa-Einleitung z. VI.Epistel d. Feoptija, S.304 
3.Kapitel: Die Feoptija als Lehrgedicht

1 B.s $\circ w i$ n $k$, Lehrhafte Dichtung des Mittelalters, stgt.1971, $\mathbf{s . 1 4}$

2 zit. Chr.s i e g r is t, a.a.0., s.20

3 B.F a b i a n, D. didaktische Dichtung, a.a.0., S.75f.

4 zit. P.H a z a r d, a.a.0., s.399

5 chr.s i e gris t, a.a.o., s.29

6 vgl. 'Essay on Man', Twickenham ed. 1970, Introd., S.XII, Anm.1

7 s. I.S e $r$ m a $n$, Neizd. filos. poèma, a.a.o., \$.163

8 zit. I.s e r m a n, a.a.0., S.162 aus: Predislovie z.Feopt.

9-13 zit. I.S e r m a n, a.a.0.,s.162 aus: Predislovie z.Feopt.

14 A.P $\circ p$ e, Essay on Man, The Design, a.a.o., S.7f.

15 H.-W.J a g e r, Z. Poetik d. Lehrdichtung, a.a.O., S.559

vgl. B.F a b i a n, D. didakt. Dichtung, a.a.o., S.86f.

16 B.F a b i a n, D. didakt. Dichtung, a.a.0., S.69

17 A.P O p e, Essay on Man, Ep.I,1 (vgl. d. Anm.)

18 I.S e r m a n, a.a.o., S.167

19 Chr. s i e g r is t,a.a.0., s.37

$20 \mathrm{ebd}$.

21-22 zit. I.S e r m a n, a.a.0.,S.165 aus: Predislovie z. Feopt.

$23 \mathrm{vgl}$. Windelband-H e $i \mathrm{~m} s \circ \mathrm{e} t \mathrm{~h}, \mathrm{a.a.0.}, \mathrm{s.374}$ und 449

24 zit. I.s e r m a $n, a . a .0$, aus: Predislovie z. Feopt.

25 Chr.s $i$ e gris t,a.a.0., s.60

26 Chr.s $i$ e g $r i s t, a . a .0 ., s .166$

$27-28$ Chr.s $i$ e gr is $t, a . a .0 ., s .165$

29 zit. B.F a b i a n, a.a.0., s.86

30 zit. Chr.s $i$ e g r is $t$, a.a.o., s.165

31 H. - w.J a g e r, a.a.O., s.552

32 H. - W.J a g $\mathrm{r}$, a.a.O., $\$ .553$

33 B.F a b i a n, a.a.0., s.89

34 B.F a b i a n, a.a.O., s.91

35 zit. B.F a bi a n, a.a.0., s.91

36 B.F a b i a n, a.a.o.., s.91

37 Chr.s i e gris t, a.a.o., s.73

$38 \mathrm{zit.}$ Chr.s i e g r i s t, a.a.0.,s.127 aus: Joh.Jac.Breitinger, 'Crit. Dichtkunst', $1740,1,14 \mathrm{f}$. 
39 Chr.s 1 e grist,a.a.o., s.127

40 zit. Chr.s i e gris t, a.a.o., s.128 aus: Joh.Jac.Bodmer, 'Crit. Betrachtung uber die poetlschen Gemahlde, 1741, s.149f.

41-42 zit. aus Joh.Jac.Bodmer, ebd.

43 zit. Chr.s i e g r is t, a.a.0., s.54 aus: Chr.Jos.Sucro, 'Versuche in Lehrgedichten' 1747, s.6ff.

44 L.L.A 1 b e r $t s$ e $n, a . a .0, s .8$

45-46 Chr.s i e gris $t, a . a .0 ., s .54$

47 Chr.s i e gris t,a.a.0., s.57

48 Chr.s i e gris t, a.a.0., s.59

49 I.s e $x$ m a $n$, Primečanija z. Feopt. B.P., s.511

50-51 I.S e r m a $n$, Primečanija z. Feopt., 5.512

52 K.R $i \subset h t$ e $r$, D.Kopernikanische Wende in d. Lyrik v. Brockes bis Klopstock, in: Jk.d.dt. Schiller-Ges.1968, S.137

53 ebd., S.138

54 ebd., S.147

55 eba., S.158

56 ebd., S.139f.

57 zit. K.R i cht e r, a.a.O., S.139 aus: B.H.Brockes, 'D. Firmament'

58-60 Chr.s i e gris $t, a . a .0 ., s .131$

61 zit. K.R i chte r,a.a.0., s.150

62 zit. K.R i ch t e r, a.a.0., s.150

63 K.R i c h t e r,a.a.o., S.152

64 zit. Monika $s$ e $i \mathrm{n} h$ a $u$ s $r$, 'Anatomie in Lichte der Aufklärung', in: Frankfurter Allg. Ztg., Nr.204, 1977

$65 \mathrm{Chr} . \mathrm{s} i \mathrm{e} g \times$ i s $t, a . a .0 ., s .132$

66 B.H.B $r \circ \mathrm{ck}$ e s, Ird. Vergn. in Gott, a.a.0.. s.425f.

67 ebd., s.606f.

68 H. - W.J a g e r, a.a.O., s.551

69 Feoptija, Prosaeinleitung z. IV.Ep., B.P., S.261

70 I.S e $r$ m a n, Primečanija z. Feopt., Ep.IV,425-39, B.P.,S.518

71 vgl. Nic.B o i 1 e a u, L'Art Poétique, ch.III

vgl. d. Beitrăge von B.Fabian und Herb.Dieckmann in: D. nicht mehr schönen Künste, ed. H.R.Jauss, München 1968

72 Chr.si e gris t, a.a.o., s.132

73 Feoptija, Prosaeinleitung 2. V.Ep., B.P., S.279 
74 vgl. Windelband-H e $i \mathrm{~m} 8$ e $t h, a . a .0 ., s .254$

75-76 Feoptija,Prosaeinleitung z. V.Ep., B.P., S.279

77 B.E.B I O c $k$ e s, Ird. Vergn. in Gott, a.a.0., s.696f.

$78 \mathrm{vgl}$. Chr.s i e g r is t, a.a.0., s.130

79 Chr.s i e gr is t, a.a.o., s.128

80 zit. Chr.s i e g r i s t, a.a.O., s.128 aus: Joh.G.Sulzer, 'Allg. Theorie d. schönen Künste, Ipzg. 1778f., I,227

81 chr.s i e grist, a.a.0., s.135

82 vgl. Chr.s i e grist, a.a.0., s.62ff.

83-84 Chr.s 1 e g r is t, a.a.0., s.90

$85 \operatorname{chr} . s i$ e gris $t, a . a .0 ., s .91$

86 zit. Chr.s 1 e $g$ r 1 s t, a.a.0., s.92 aus: Joh.Jac.Breitinger, 'Crit. Abhandlung von der Natur...der Gleichnisse, Nachdr. d. Ausg. Zürich 1740, Stgt.1967, S.310

87 zit. Chr. S i e g r i s t,a.a.o., s.93

$88 \mathrm{chr} . s$ i e g r is $t, a . a .0 ., s .94$

89 ebd.. 5.97

90 zit. Chr.s $i$ e g r i s t, a.a.0., s.98 aus: Joh.G.Sulzer, 'Allg.Theorie d. schónen Künste, Lpzg . 1778f ., III, 239

91 vgl. B.B 1 u me $n$ b e $r$ g, Licht als Metapher d. Wahrheit, in: Studium Generale 10 (1957), 5.433

92 н.в 1 um e n b e $r$ g, a.a.0., S.435f.

93 ebd., 5.436

94 ebd., S.441

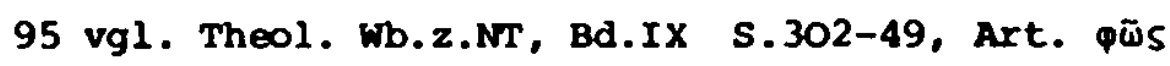

und ebd., Bd.vII s.425f. Art. oxotía

$96 \mathrm{vgl}$. Theol. Wb.z.NT, Bd.I,178, Art. alvirua (Ëooxtpov)

97-98 Chr.s i e gris $t, a . a .0 ., s .122$

99 Theol. Wb.z.NT, Bd.I,179 Art.alverua (हैбortpov)

$100 \mathrm{~K} . \mathrm{R} i \mathrm{ch}$ t $\mathrm{r}$, Kopernik. Wende in d. Lyrik, a.a.0., 5.138

101 zit. Chr. S i e g r is t, a.a.0.,s.102

102 B.F a b i a n, Pope u. d. Cold. Kette Homers, S.169

103 zit. Chr.s 1 e gris $t$, a.a.o., s.179

104 R.S $p$ e c $h t$, Commercium mentis et corporis, 5.9

105 s. R.s p e c h t, a.a.0., s.9, Hinweis auf Descartes' Cog. pivatae, Ausg. Adam u. Tannery $x, 231$ u. $x, 51$ 
106 Chr.s i e gr is t, a.a.0., s.93

107 ebd.

108 Chr.s $i$ e gris $t, a .0 .0 ., s .118$

109 ebd., S.110

110 zit. Chr.s i e gris t, a.a.o., s.155

111 Chr.s i e gris $t, a . a .0 ., s .155$

$112 \mathrm{zit}$. Chr.s i e g r is $t$, aus:Joh.Jac.Engel, Anfangsgrande einer Theorie d. Dichtungsarten, Bln. 1806, Bd.XI,196

113 zit. I.S e $r$ m $n$, 'Neiz. filos, poèma', a.a.O., s.161

114 W.P h 1 i i p, a.a.O., S.102, Anm.18

115 Feoptija, Einleitung z. II.Ep., B.P. S.211

116 w.P h 1 i i p, a.a.0., s.72

117 Windelband-H e $i \mathrm{~m}$ s o e $t \mathrm{~h}, \mathrm{a} . \mathrm{a} .0 ., \mathrm{s} .330$

$118 \mathrm{zit}$. Chr.s i e g r is t, a.a.0., s.156 aus:G.Friedr.Meier, Anfangsgründe aller schönen Wissenschaften, Halle 1748ff., III, 242

119 s. Feoptija, Einleitung z. VI.Ep., B.P. S. 304

$120 \mathrm{Chr} . s \mathrm{i}$ e gris $t$, a.a.o., s.151

121 zit. Chr.s i e gr is t, a.a.o., s.151f. aus:G.F.Meier, a.a.o., III,95ff.

122 Chr.s i e gris t, a.a.o., s.151

$123 \mathrm{ebd}$., S. 153

124 ebd., S.154

125 ebd., S.142

126 Feoptija, III.Ep.,B.P. S.250,Anm.

127 ebd., S.260,Anm.

128 Chr.s $i$ e grist, a.a.0., s.61

4. Kapitel: Zur Metrik und Sprache der Feoptija

1 A.A d a m $c z$ y k, Grundfragen d. russ. Versgesch., Tred. u. d. Reform. Eine Erorterung uber den 'Novyj 1 kratkij sposob...', Breslau 1940, S.8

2 0.V.O r $1 \circ$ v, V.K.Trediakovskij, in:Russk. 1it. XIII v., M.1973, S.66

3 L.I.T i m o f e e v, 'vstup. stat'ja' z. Feopt., B.P. S.32

4 A. A d a m $c z y k$, Russ. Verskunst, in: Mūnchener Beitrăge z. Slavenkunde, IV (1953), s.180

5 zit.D.B 1 a go j, Ist. Russk. 1it. XVIII v. M.1960, S.128

6 zit. $P$ e k a $r$ s k i j, a.a.O., II,49

7 zit. B 1 a goj, a.a.o.. s.128 
8 A.A d a m $c z y k$, Grundfragen d.rus8. Versgesch., S.35

9 D.B 1 a g O j, a.a.O., s.129

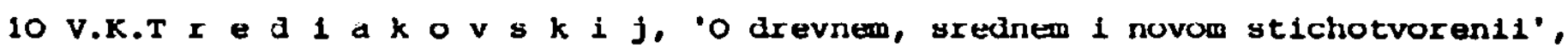
(1755) in: ezemesjacn. soc., s.496f. zit. v. Pekarskij, a.a.O., II,49

11 s. B 1 a goj,a.a.o., s.129 und $T i$ mo f e e v,a.a.o., s.32

12 T $i$ m $\circ$ e e v, 'vstup. stat'ja' z. Feopt., B.P. S.32

13 s. P e k a r s i j, a.a.o., Ir,232. Das Orig.Portrăt Tred.s befindet sich im Konferenzsaal der 'Akad. Nauk'.

14 A.A d a m c $z y$, Russ. Verskunst, a.a.0., S.181

15 ebd., S.184

16 zit. $T$ i m 0 f e e v, a.a.o., s.8 aus: Puskin, Poln. sobr. soč. XI, 253, M. - L. 1949

17 zit. P e k a s ki j, a.a.o., s.49 aus: Tred.s 'o drevnem...stichotvor.' ežemesjačn. soč. 1755, s.496f.

$18 \mathrm{vgl}$. T i m $\mathrm{f}$ e e v, 'vstup. stat'ja' z. Feopt., B.P. S.40

19 vgl. L.V.P u m p a n s k i j, a.a.0., s.173 und $177 f$.

20 ebd.. S.183

21 ebd., 5.184

22 L.V.p u m j a n s k i j, a.a.O., s.182

23 zit.p u m $\mathrm{p}$ a $\mathrm{n} s \mathrm{k}$ i j, a.a.0., s.182

24 L.V.P um $\mathrm{p}$ a n s k i j, a.a.0., s.182f.

25 ebd., S. 183

26 ebd. S. 185

27 V.K.T r e d $i$ a $k \circ v s k i j$, 'O drevnem, srednem $i$ novom stichotv.', B.P. S.447

28 I.S e $x \mathrm{~m}$ a $n$, 'Neizd. filos. poèma', S.168

29 D.B 1 a g $\circ$ j, a.a.O., S.136

30 I.s e r m a n, a.a.o., s.168

31 Gerta $H$ i $t$ l-Worth, Thoughts on the Turning Point in the History of Iiterary Russian: the Eighteenth Century, in: Intern. Journal of Slavic Linguistics and poetics, 1970, S.132

32 Gerta $\mathrm{u}$ ü $t$ t l-Worth, Tred.s Feoptija', a.a.0., S.963

33 ebd., S.964

34 ebd., 5.965

35 D.T s c h i v e w s k i j, Komposita, a.a.o., s.118

36 ebd., S.119 
37 Gerta A u $t$ t 1-Worth, Tred.s.Feopt., a.a.0., S.965

38 ebd., S.966

39 cbd., 5.971

40 zit. Gerta H a $t$ t l-Worth, a.a.O., S.964 aus: Predislovie z. Feopt.Bl.19f.

41 Gerta $\mathrm{a}$ u $t$ 1-Worth, Tred.s Feopt., a.a.0., S.966

42 D.B 1 a g $\circ$ j, a.a.o.. S.137

$43 \mathrm{eba}$.

44 R.S i l b a $j \circ x$ i s, Russian Versification, New York u. London 1968, S.32

45 zit. $T$ i m o f e e v, 'vstup. stat'ja', s.44, aus: V.Vinogradov.' Jazyk Puskkina', s.5f.

46 A.A.I l j u $\stackrel{v}{s} i \mathrm{n}$, 'O jazyke poèzil V.K.Trediakovskogo' in: Russk. jazyk $v$ skole $1969 / 4$, s.6-12

47 L.I.T 1 m o f e e v, 'vstup. stat'ja' z.Feopt., B.P. S.44

48-49 I.s e r m a n, a.a.o., S.167

50 L.I.T i m o f e e v, 'vstup. stat'ja', a.a.o., s.45

51 A.I 1 j u 8 i n, a.a.o., s.11

52 ebd.

53 ebd.

54 w.P h $i$ i i p p, a.a.0., S.140

55 Chr.s i e gris $t, a . a .0 ., s .74$

56 ebd.. s.75 
Quellen

Trediakovskij, Vasilij Kirillovič: Feoptija, in: Izbrannye Proizvedenija, Biblioteka Poeta, bol'saja serija, vtoroe izdanie, M.-L.1963, str. 196-322.

Fénelon, François de la Mothe: Traité de l'Existence de Dieu. Première Partie. Démonstration de L'Existence de Dieu, tirée du spectacle de la nature et de la connaissance de l'homme, Paris 1845.

Augenscheinlicher BeweiB/daB ein Gott sey/ Bergenommen aus der ErkantniB der Natur/ und also eingerichtet/ daB es auch die Einfaltigen begreiffen kőnnen. Nach der dritten Frantzösichen Edition ins Deutsche übersetzt. Bamburg, Verlegts Benjamin Schillers seel.Wittwe im Thum, Anno 1714. (Der Name des Ubersetzers ist nicht genannt). Geistliche Werke, Einleitung und Textauswahl v. François Varillon, Paris 1954, übersetzt v. Peter Manns, Düsseldurf 1961.

Pope, Alexander: An Essay on Man, ed. by Maynard Mack, Twickenham Edition, London 1970, 2.Auflage.

Opyt o Celoveke, übersetzt v. Nikolaj Popovskij, Moskau 1757.

Brockes, Barthold Beinrich: Auszug der vornehmsten Gedichte aus dem Irdischen Vergnugen in Gott, Faksimiledruck nach d. Ausg. v. 1738, stgt. 1965. Boileau, Nicolas: L'Art Póetique, hrsg., eingel. u. komment. v. August Buck, Studientexte 6, München 1970.

Septuaginta, ed. Alfred Rahlfs, Bd.I und II, Stuttgart, 0.J. Novum Testamentum Graece, D.E.Nestle, Stuttgart 1933. Bekenntnisschriften der evgl.-luth. Kirche, Gottingen 1952.

\section{Sekundärliteratur}

Adamczyk, Alexander: Grundfragen der russ. Versgeschichte, Trediakovskij und die Reform. Eine Erörterung über den "Novyj i kratkij sposob k složeniju rossijskich stichov" 1735, Phil. Diss., Breslau 1940. Russische Verskunst, ein geschichtlicher Uberblick, in: Münchener Beitrăge z. Slavenkunde, IV (1953) S.179-201. 
Albertsen, Leif-Ludwig: Das Lehrgedicht, Aarhus 1967.

Zur Theorie und Praxis der didaktischen Gattungen im deutschen 18. Jahrhundert, in: Dtsch.Vierteljahrsschrift 45 (1971), s.181-92.

Althaus, Paul: Der Brief an die Römer, in: Das Neue Testament Deutsch, Bd.6 Gottingen 1946.

Die Christliche Wahrheit, Bd.I und II, Gutersloh 1947.

Barth, Karl: Die Kirchliche Dogmatik, Bd.I-IV, Zürich 1952-1970.

Benz, Ernst: Theologie der Elektxizitat, in: Akademie d.Wissenschaften u.d.

Literatur, Abhdlg. d. geistes- U.sozialwiss. Klasse, Jg.1970 NK.12 Mainz 1970.

Berkov, P.N. Des Relations Litteraires Franco-Russes entre 1720 et 1730.

Trediakovskij et l'Abbe Girard, in: Rev.des ét. sl. 35 (1958),s.7ff. Blagoj, D.D.: Istorija Russkoj Literatury XVIII v., Moskva $1960^{4}$.

Blumenberg, Hans: Kopernikus im Selbstverstandnis der Neuzeit, Abhalg. der Geistes- u. Sozialwiss. Klasse, Jg.1964 Nr.5, Mainz.

Licht als Metapher der Wahrheit, in: Studium Generale 10 (1957) S. 432-447.

Die Vorbereitung der Aufklärung als Rechtfertigung der theoret. Neugiex, in: Europ. Aufklărung, Festschrift f. Herbert Dieckmann, München $1967, \mathrm{~S} .23-45$.

Pseudoplatonismen in der Naturwissenschaft dex frühen Neuzeit, Akad. d. Wissenschaften U. d. Literatur, Nr.1, Mainz 1971. Vomperskij, V.P.: ob odnof Popytke Opredelenija Individual'no-chudožestvennogo stilja. V.K.Trediakovskij i 'Avtorov Stil', in: zurnalistika i literatury, izd. Mosk. un-ta 1972, str. 66-71.

Dieckmann, Herbert: Das Abscheuliche u. Schreckliche in der Kunsttheorie des 18.Jh.s, in:Die nicht mehx schönen Künste, ed. E.R.JauB, Mchn.1968.

Eleonskaja, A.i dr.: Istorija russ. literatury XVII-XVIII vv. Trediakovskij (1703-1769), M.1969.

Elext, Werner: Der Christliche Glaube, Grundilnien der Lutherischen Dogmatik, Hambuxg 1956

Fabian, Bernhard: Die didaktische Dichtung in der engl. Literaturtheorie des achtzehnten Jahrhunderts, in:Festschrift f.W.Fischer, Heidelberg 1959, S.65-92. 
Pope und die Goldene Kette Homers, in: Anglia 82 (1964), s.150-71.

Das Lehrgedicht als Problem der Poetik, in: Die nicht mehr schōnen Künste, ed. H.R.JauB, Mũnchen 1968, S.67-89.

From, Hans: Bibliographie deutscher Ubersetzungen aus dem Franzōsischen

1700-1948, Bd.3, S.19-27 - Baden-Baden 1951.

Gitermann, Valentin: Geschichte RuBlands, Bd.I U. II, Frankfurt/Main 1965. Hazard, Paul: Die Krise des europăischen Geistes, Hamburg 1939.- Orig. Titel:

La Crise de la Conscience Europeenne 1680-1715.

Heintel, Erich: Tierseele und Organismusproblem im Cartesianischen System, in: Wiener Zs.f.Philosophie u. Psychologie, Nr.3 (1950) S.73-120. Herrmann, Hans Peter: Naturnachahmung und Einbildungskraft. Zur Entwicklung d.dtsch. Poetik von 1670-1740, in: Ars poetica, Bd.8, Bad Homburg. Huttl-Worth, Gerta: Die Bereicherung des Russ. Wortschatzes im XVIII.Jh. Wien 1956.

Trediakovskijs Feoptija, in: Orbis Scriptus, Festschrift für D.Tschižewskij, München 1966, S.963-972.

Thoughts on the Turning point in the History of literary Russian: the Eighteenth Century, in: International Journal of Slavic Linguistics and Poetics, 1970.

Iljušin, A.A.: O jazyke poèzii V.K.Trediakovskogo, in: Russk. jazyk v skole 1969/4, str. 6-12.

Jăger, Hans-Wolf: Zur Poetik der Lehrdichtung in Deutschland, kritische Zusătze zu L.L.Albertsens Buch 'Das Lehrgedicht'. Dtsch.ViertelJahrsschrift 44, 1970, S.544-576.

Küntzel, Heinrich: Essay und Aufklärung, München 1969.

Lebedev, E.N.: Filosofskaja Poézija V.K.Trediakovskogo, in: Russkaja literatura 1976/2, Jg.XIX, Leningrad.

Luthardt, Chr. Ernst: Kompendium der Dogmatik, Leipzig 1889. orlov, O.v. i dr.: V.K.Trediakovskij, in: Russk. literatura XVIII v. M. 1973, str. 63-76.

Pekarskij, Petr Petrovič Istorija Imperatorskoj Akademil Nauk v Petexburge, T.II, SPb. 1873 .

Vvedenie $v$ Istoriju Prosvjascenija v Rossii XVIII stoletija, sPb. 1862 .

Philipp, Wolfgang: Das Werden d.Aufklarung in theologiegesch. Sicht, in: Forschungen 2.Systemat. Theol. U. Religionsphilos. Bd.3,Gött.1957. 
Plett, Beinrich F.: Einführung in die rhetorische Textanalyse, Bamburg 1973. Pumpjanskij, L.V.: Trediakovskij i nemeckaja skola razuma, in: Literatury zapada. Zapadnyj sbornik p. red. V.M.Z1rmunskogo, M.-L. 1937, $3.157 f f$. Radiscev, A.N.: Putesestvie iz Peterburga v Moskvu, in: Biblioteka Skol'nika, L. 1971

Religion in Geschichte und Gegenwart (RGG), Bd.I-V, 2. Aufl., Tübingen 1927-31. Richter, Karl: Die Kopernikanische Wende in d.Lyrik von Brockes bis Klopstock, in: Jb. d. dt. Schiller-Ges. 1968, S.132-169.

Rothe, B.: Zur Frage von Einflussen in der russ. Literatur des 18.Jh.s, in: Ztschr. f. slav. Philologie 1966, s.21-68. Russ. knigi grazaanskoj pecati XVIII v. (1725-1800) I-VII, M.1962-1975. (Svodnyj katalog, II 1964).

Schweinsteiger, Heinrich: Das Echo von Pope im Ausland, (Diss.) Müchen 1912. Serman, I.: Neizdannaja filosofskaja poéma V.Trediakovskogo, in: Russk. literatura, Istoriko-literaturnyj zurnal, god izd. 4 No 1, L.1961, S. $160-168$.

Siegrist, Christoph: Das Lehrgedicht der Aufklarung, stuttgart 1974 . Silbajoris, Rimvydas: Russian Versification, New York und London 1968. Skabiceskij, A.M.: Ocerki Istoril Russkoj Cenzury (1700-1863 g.),SPb. 1892. Sowinski, Bernhard: Lehrhafte Dichtung des Mittelalters, Sammlg. Metzler, Bd.3, Stuttgart 1971 .

Specht, Rainer: Commercium mentis et corporis, Uber Kausalvorstellungen im Cartesianismus, Stuttgart-Bad Cannstadt 1966.

Striedter, Jurif: Zur unterschiedlichen Kompositionstechnik syllabischer und syllabotonischer Versionen eines Gedichtes von Trediakovskij, in: Orbis Scriptus, Festschr. f. D.Tschižewskij, Mchn.1966, S.827-34. Theologisches wörterbuch zum Neuen Testament Bd.I-X, begr. v. G.Kittel+, hrsg. Gerhard Friedrich, Stuttgart 1932-1976.

Tschizewskij, Doitrij I: Zu den Komposita in d.Sprache Trediakovskijs, in:

ztschx.f. slav.Philologie XVII 1941, S.114ff.

Unbegaun, Boris Ottokar: Russian Versification, Oxford 1956.

Veit, Walter: Toposforschung, ein Forschungsbericht, in: Dt.Vierteljahrsschr. 37 (1963), S.120-163.

Viëtor, Karl: Die Idee des Erhabenen in d.dt.Literatur, in: Geist u. Form, Bern 1952, S.234-264. 
Windelband, Wilhelm ed. Heimsoeth, Heinz: Lehrbuch der Geschichte der Philosophie, Tübingen 1935.

wolff, Hans M.: Brockes' Religion, in: Publications of the modern language association of America (PMLA) 62, 1947 Nr.4, S.1124-1152.

Wundt, Max: Die deutsche Schulmetaphysik des 17.Jh.s, Heidelberger Abhandlungen zur Philosophie u. Ihrer Geschichte (29) Tubingen 1939.

wytrzens, Günther: Vasilij Kirillovic Trediakovskij als Etymologe, in: Wiener Slavist. Jb. 21 (1975).

Lexika

Lexicon Palaeoslovenico-Graeco-Latinum, ed. Miklosich, Fr., Vindobonae 18621865.

Mal'ceva, I.M. i dr.: Leksičeskie novoobrazovanija v russkom jazyke XVIII v. chronologi ceskij slovnik, L. 1975, Akad.Nauk SSSR.

Pawlowskij, I: Russisch-Deutsches Worterbuch, dritte Aufl., Leipzig 0.J. 


\section{Whothos of}

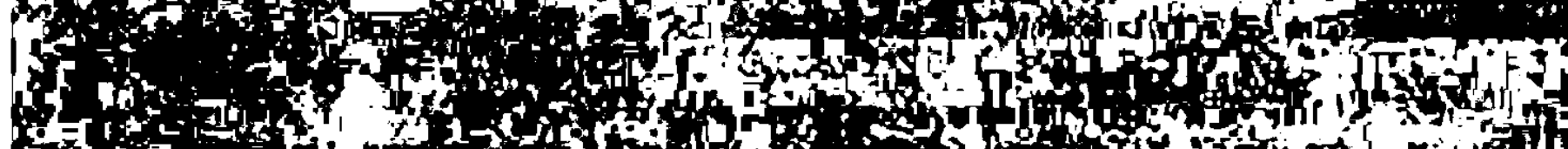

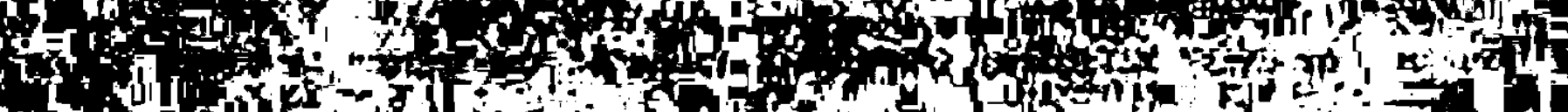
I. (1) (2)

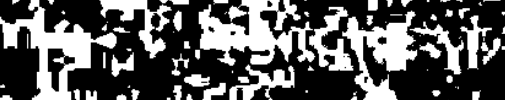

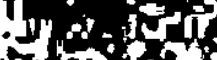 (t) 13

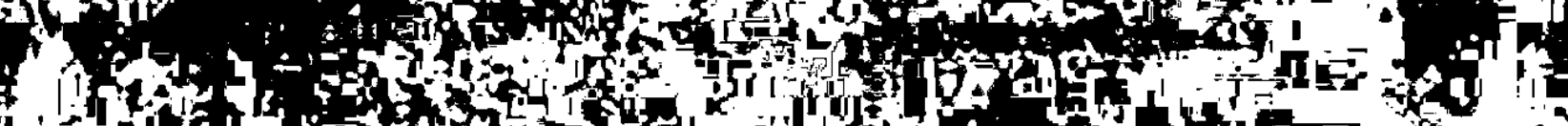

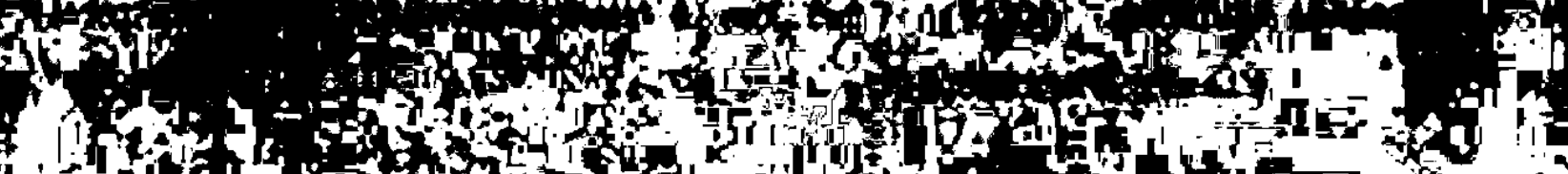
inis: The and

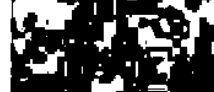
10

\section{\&} sistos

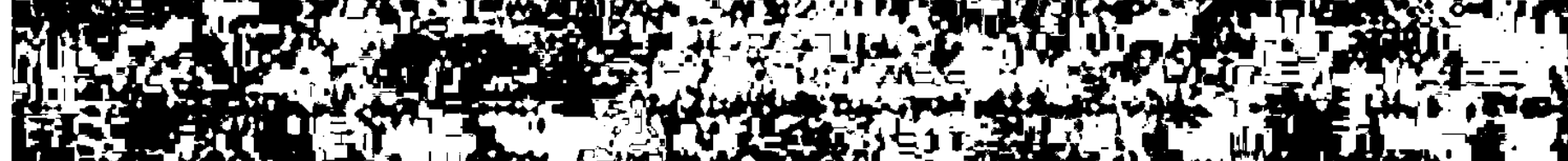

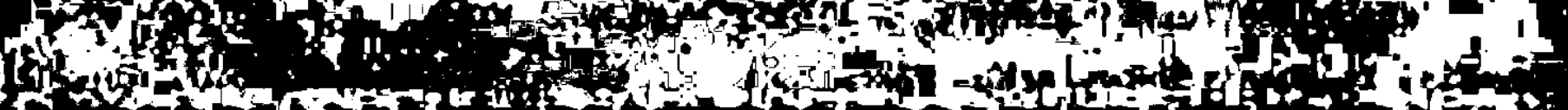

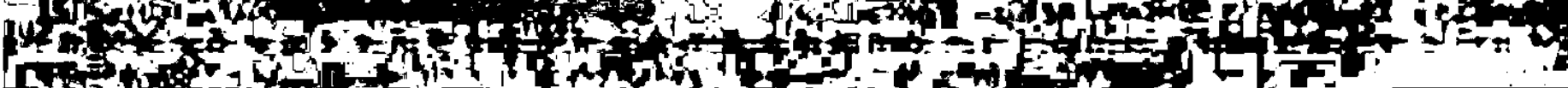

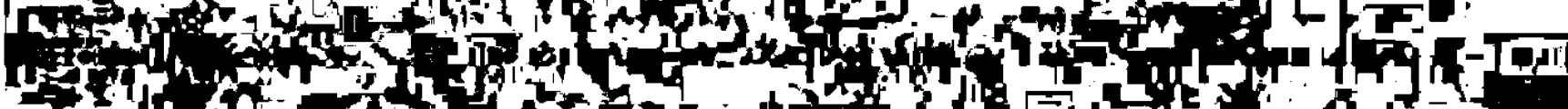

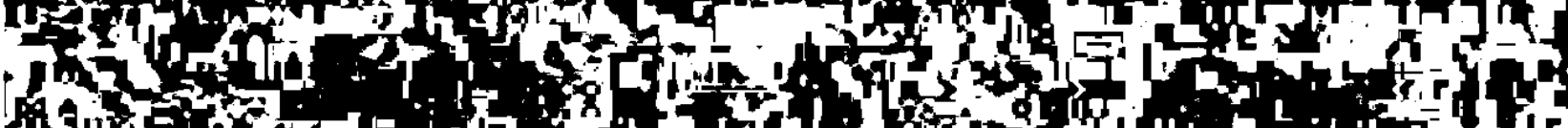
$\left\{\begin{array}{l}1 \\ 0\end{array}\right.$

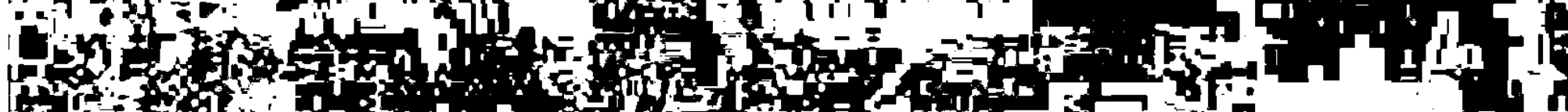

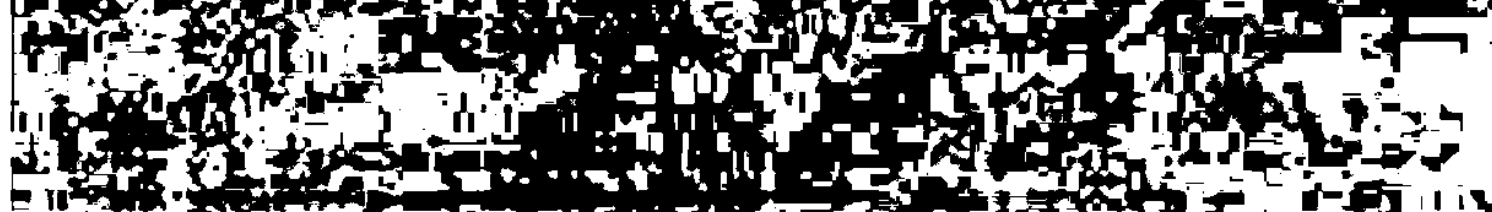
if

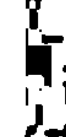

\section{ing}

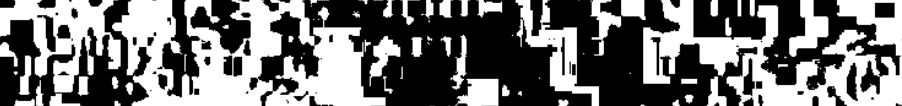

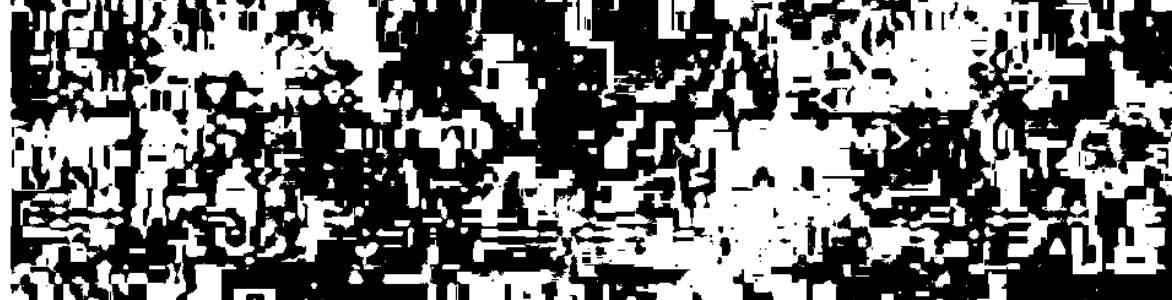

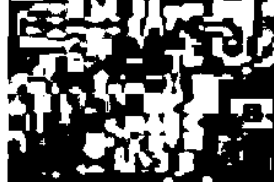

$5+20$ Sais

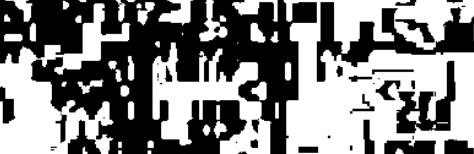




\section{SLAVISTISCHE BEITRÄGE}

91. Okuka, M.: Sava Mrkalj als Reformator der serbischen Kyrilliza. Mit einem Nachdruck des Salo debeloga jera libo Azbukoprotres. $1975.123 \mathrm{~S}$.

92. Neuhäuser, R.: The Romantic Age in Russian Literature: Poetic and Esthetic Norms. An Anthology of Original Texts (18001850) . 1975. VIII, 300 S.

93. Literaturwissenschaftliches Seminar: Zur Analyse dreier Erzählungen von Vl. I. Dal'. Redigiert und herausgegeben von $\mathrm{J}$. R. D\&ring, mit einem methodologischen Geleitwort von $\mathrm{J}$. Holthusen. 1975. $203 \mathrm{~S}$.

94. Alexander, R.: Torlak Accentuation. 1975. XVI, 806 S.

95. Schenkowitz, G.: Der Inhalt sowjetrussischer Vorlesestoffe für Vorschulkinder. Eine quantifizierende Corpusanalyse unter Benutzung eines Computers. 1976. $767 \mathrm{~S}$.

96. Kitch, F. C. M.: The Literary Style of Epifanij Premudryj. Pletenije sloves. 1976. $298 \mathrm{~S}$.

97. Eschenburg, B.: Linguistische Analyse der Ortsnamen der ehemaligen Komitate Bács und Bodrog von der ungarischen Landnahme (896) bis zur Schlacht von Mohács (1526) . 1976. $156 \mathrm{~S}$. $3 \mathrm{Kt}$.

98. Lohse, H.: Die Ikone des hl. Theodor Stratilat zu Kalbensteinberg. Eine philologisch-historische Untersuchung. 1976. XX, $242 \mathrm{~S}$.

99. Erbslöh, G.: "Pobeda nad solncem". Ein futuristisches Drama von A. KruCenych. Ubersetzung und Kommentar. (Mit einem Nachdruck der originalausgabe.) 1976. $121 \mathrm{~s}$.

100. Koszinowski, K.: Die von präfigierten Verben abgeleiteten Substantive in der modernen serbokroatischen Standardsprache. Eine Untersuchung $z u$ den Präfixen do, iz, na, za. 1976. $271 \mathrm{~S}$.

101. Leitner, A.: Die Erzählungen Fedor Sologubs . 1976. $249 \mathrm{~S}$.

102. Lenga, G.: Zur Kontextdeterminierung des Verbalaspekts im modernen Polnisch. 1976. VIII, $233 \mathrm{~S}$.

103. Zlatanova, R.: Die Struktur des zusammengesetzten Nominalprädikats im Altbulgarischen. 1976. VIII, $220 \mathrm{~S}$.

104. Krupka, P.: Der polnische Aphorismus. Die "Unfrisierten Gedanken" von Stanisław Jerzy Lec und lhr Platz in der polnischen Aphoristik. 1976. $197 \mathrm{~S}$.

105. Pogatnik, J.: Von der Dekoration zur Narration. zur Entstehungsgeschichte der slovenischen Literatur. 1977. $165 \mathrm{~S}$.

106. Bojić, V.: Jacob Grimm und Vuk Karadžić. Ein Vergleich ihrer Sprachauffassungen und ihre Zusammenarbeit auf dem Gebiet der serbischen Grammatik. 1977. 257 S.

107. Vintr, J.: Die ältesten Cechischen Evangeliare. Edition, Textund Sprachanalyse der ersten Redaktion. 1977. $367 \mathrm{~S}$.

108. Lohff, U. M.: Die Bildlichkeit in den Romanen Ivan Aleksandrovic Gončarovs (1812-1891). 1977. XVI, $244 \mathrm{~S}$.

109. Regier, Ph. R.: A Learner's Guide to the old Church slavic Language. Part 1: Grammar with Exercises. 1977. XLIV, $368 \mathrm{~S}$.

110. Worth, D. S.: On the Structure and History of Russian. Selected Essays. With a Preface by Henrik Birnbaum. 1977. X, 276 S.

111. Schulte, B.: Untersuchungen zur poetischen Struktur der Lyrik von Sima Pandurović. Posmrtne porasti.1977. $345 \mathrm{~S}$.

112. Albert, H.: Zur Metaphorik in den Epen Zivana, Medvjed Brundo, Utva und Ahasver des kroatischen Dichters Vladimir Nazor. 1977. $171 \mathrm{~s}$.

113. Slavistische Linguistik 1976. Referate des II. Konstanzer Slavistischen Arbeitstreffens (5.-7. 10. 1976). Herausgegeben von W. Girke und H. Jachnow. 1977. $261 \mathrm{~S}$.

114. Matuschek,H.: Einwortlexeme und Wortgruppenlexeme in der tech-

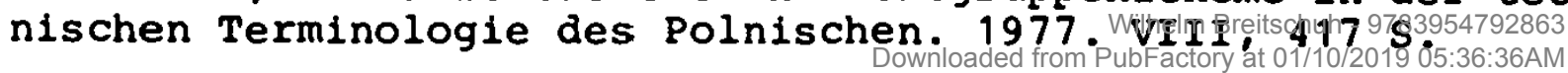


115. Schreier, H.: Gogol's religiöses Weltbild und sein literar1sches Werk. Zur Antagonie zwischen Kunst und Tendenz. 1977. $123 \mathrm{~S}$.

116. Beitrăge und Skizzen zum Werk Ivan Turgenevs. 1977. $142 \mathrm{~S}$.

117. Neureiter, F.: Geschichte der kaschubischen Iiteratur. Versuch einer zusammenfassenden Darstellung. 1978. $281 \mathrm{~s}$.

118. Russel, M.: Untersuchungen zur Theorie und Praxis der Typisierung bei I. A. Gontarov. 1978. $401 \mathrm{~s}$.

119. Referate und Beitrăge zum VIII. Internationalen slavistenkongreB Zagreb 1978. 1978. $451 \mathrm{~S}$.

120. Slavistische Linguistik 1977. Referate des III. Konstanzer Slavistischen Arbeitstreffens Bochum. 27.9.77 - 29.9.77. Herausgegeben von W. Girke und H. Jachnow. 1978. $260 \mathrm{~S}$.

121. Muller, V.: Der Poetismus. Das Programm und die Hauptverfahren der tschechischen literarischen Avantgarde der zwanziger Jahre. 1978. VI, $215 \mathrm{~S}$.

122. Pailer, W.: Die fruhen Dramen M. Gor'kijs in ihrem Verhältnis zum dramatischen Schaffen A. P. Cechovs. 1978. VIII, 210 S.

123. Thomas, G.: Middle Low German Loanwords in Russian. 1978. $269 \mathrm{~S}$.

124. Lehfeldt, W.: Formenbildung des russischen Verbs. Versuch einer analytisch-synthetisch-funktionelien Beschreibung der Prăsens- und der Präteritumflexion. 1978. $114 \mathrm{~S}$.

125. Schớn, L.: Die dichterische Symbolik V. M. Garłins. 1978. VI, $203 \mathrm{~S}$.

126. Berg, R.: Die Abstrakta auf -nie/-tie, -ka/-ok, -ost', -stvo/ -stvie, -ie/-be in den "Pis'ma 1 Bumagi" Peters des GroBen. 1978. IV, $352 \mathrm{~S}$.

127. Stricker, G.: Stilistische und verbalsyntaktische Untersuchungen zum Moskovitischen Prunkstil des 16. Jahrhunderts. 1979. XIV, 678 S., 3 Tabellen.

128. Heim, M. H.: The Russian Journey of karel Havlítek Borovský. 1979. XII, $194 \mathrm{~S}$.

129. Malingoudis, J.: Die Handwerkerbezeichnungen im Alttschechischen. 1979. IV, $221 \mathrm{~S}$.

130. Roth, J.: Die indirekten Erlebnisformen im Bulgarischen. Eine Untersuchung zu ihrem Gebrauch in der Umgangssprache. 1979. VIII, $186 \mathrm{~s}$.

131. Nitsch, E.: Thema und Anweisungsstruktur im Text. Mit einer Analyse des ersten Abschnittes aus "Noc $s$ Hamletem" von Vladimir Holan. VIII, $178 \mathrm{~s}$.

132. Höck, Ch.: Zur syntaktischen und kommunikativen struktur slavischer Partizipial- und Gerundialkonstruktionen. 1979. X, 283 S.

133. Slavistische Linguistik 1978. Referate des IV. Konstanzer Slavistischen Arbeitstreffens Tubingen 26.-29. Sept. 1978 . Herausgegeben von Jochen Raecke und Christian Sappok. 1979. $276 \mathrm{~s}$. 
Ab Jahrgang XXII (N.F. I) 1977 erscheint die Fachzeitschrift

\section{DIE WELT DER SLAVEN}

Halbjahresschrift für slavistik

Begründet von Erwin Koschmieder

Schriftleitung: Heinrich Kunstmann, Redaktion: Peter Rehder im Verlag Otto Sagner, München

Es liegen vor:

Jahrgang XXII (=N.F. I), 1977

Heft 1 und 2, 448 Seiten, DM 82.-

Jahrgang XXIII (=N.F. II), 1978

Heft 1 und 2, 448 Seiten, DM 82.-

Jahrgang $\operatorname{XXIV}(=\mathrm{N} . \mathrm{F}$. III $), 1979$

Heft 1 und 2, 448 Seiten, DM 82.- 